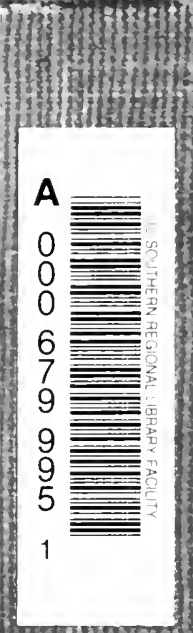


BENDER-MOSS CO. PUBLISHERS

San Francisco $\therefore \quad \therefore \quad$ Cal.

- Francisco

THE LIBRARY
OF
THE UNIVERSITY
OF CALIFORNIA
LOS ANGELES
school OF LAW
vift of
bercuer-MOSS Co.



Digitized by the Internet Archive in 2007 with funding from

Microsoft Corporation 



\title{
A Manual of
}

\section{The Federal Trade Commission}

PRESENTING

The Origin, Development and Construction of the AntiTrust Laws, with Decisions upon the Constitutional and Unfair Trade Questions Involved, together with the Rules of Practice, Forms, Texts of Statutes,

Debates in Congress

AND

Complete Memoranda of Anti-Trust Cases Instituted by the United States

\author{
By \\ RICHARD S. HARVEY \\ of the New York Bar \\ and \\ ERNEST W. BRADFORD \\ of the Washington, D. C., and Indianapolis, Ind., Bars
}

WASHINGTON, D. C.

JOHN BYRNE \& COMPANY

1916 
$T$

H2636f

1916

Copyright, 1916

by

Richard S. Harvey

and

Ernest W. Bradford 
To

HON. THOMAS EWING

this book

is respectfully dedicated

\section{7}



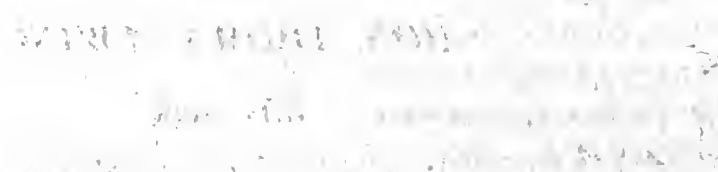

4
4
4
3
3
3
$\therefore$
3

$\operatorname{lin}^{2}$

ing

in

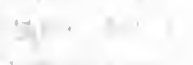

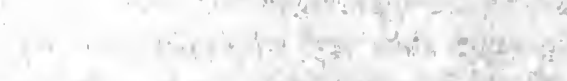

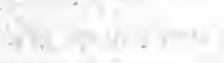

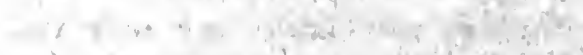

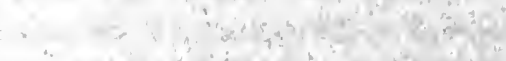

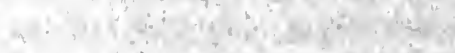

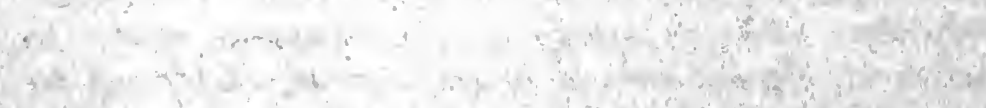

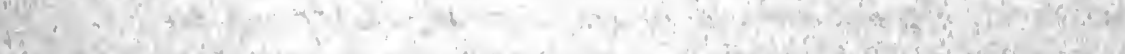

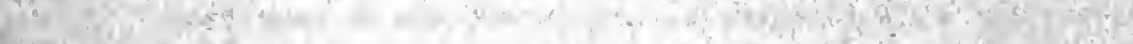

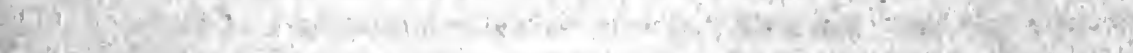

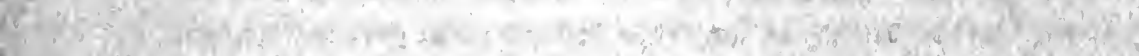
(6)

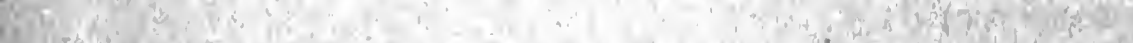

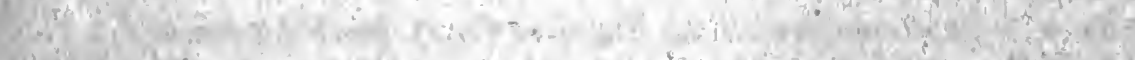

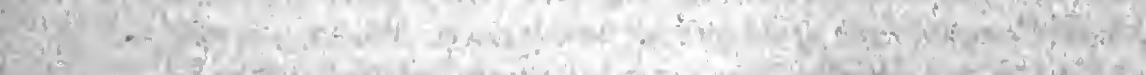

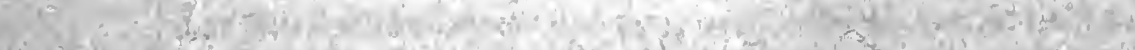

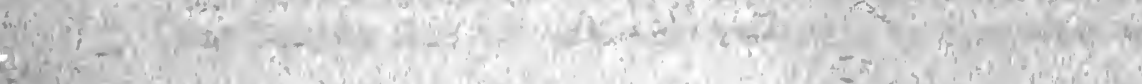




\section{PREFACE.}

If the Sherman Anti-trust Law has been properly described as a Magna Charta among the Anti-trust statutes of the United States, it appears equally proper to designate the Federal Trade Commission Act and the Clayton Law, taken together, as a Business Constitution, intended to afford fair and impartial protection to the commercial interests of the American people.

While the Sherman Law during its initial period was somewhat neglected as a weapon against the forces of trade restraint and monopoly, the sweeping nature of its constitution-like phrases gradually made it all-embracing in its prohibitions, and by its means a campaign, both offensive and defensive, was carried on in the people's behalf until at length even those giants, the Standard Oil and Tobacco trusts, were brought before the court and compelled to dismember their overgrown corporate organisms.

That there are tides in the affairs of nations as well as of men is apparent to all; and it is equally certain those tides at some seasons progress more rapidly than at others. Such a season in the Anti-trust movement was in evidence in $1889-90$, when the framing of the Sherman Law occupied the most careful attention and scrutiny of such statesmen as Senators Sherman, Edmunds, Hoar, and others.

The conscience and will of the people as condensed into the space of the eight short sections comprised in the Sherman Law have been ably and impartially interpreted and made effective by the Supreme Court; and while that tribunal has sometimes disclosed a divergency in views of its individual members, the general result has justified the confidence reposed in that court, which alone exists by warrant of a constitutional grant. In some of the Circuit Courts of Appeal a halting attitude and desire to criticise the Sherman law and to minimize its restrictive influence has been noticeable; but in the clear atmosphere of the Supreme Court the subject has been seen in plain perspective and from every angle.

Even in the disposition of the Supreme Court, however, there remained one element of doubt and uncertainty. Whereas in the latest Anti-trust decisions the issues are treated as involving only the application of established principles for their solution, and 
the rules ably and comprehensively set forth in the Standard Oil and Tobacco cases are recognized and enforced as part of the law of the nation,--still, the court reserves to itself the right and power to dispose in future of each individual case as it arises, in accordance with the measure of monopolistic tendencies therein disclosed.

The situation, therefore, was not in entire accord with a government existing under a written constitution. In conditions where Congress, the supreme legislative body, had deemed the safety and continuance of commercial freedom of the citizen at stake, it had prohibited certain acts and combinations; and the Supreme Court had decreed that in each instance it would judicially scan those single and combined acts to decide for itself whether they were such "undue restraints" as in "the light of reason" amounted to an infraction of the law. This course, it was argued in Congress, and believed by many, if continued and unrestrained, might in time grow into a system of court constructions akin to the English common law, and we should thus evolve in the United States an anomaly in the shape of an unwritten as well as a written constitution,- "a wheel within a wheel" in our governmental machine. Besides, the readjustment of certain culprit organizations had been turned over to the lower courts for their supervision of that task,-a duty which partook of ministerial rather than of judicial functions.

It was likewise brought home to the mind of the nation and in turn made known to its representatives in Congress assembled, how distracting to business was the eternal possibility and danger of a government prosecution under the Sherman Law, and that there existed a necessity for a permanent board or commission which, acting in accordance with appropriate legislation, would prevent monopolistic tendencies at their source and in cases of wilful neglect or disobedience would direct and enforce compliance with the curative decree. In brief, it was seen that the Sherman Law was inadequate to occupy the entire Antitrust field, and that something supplementary thereto was required for the adequate regulation of business.

At this juncture, and following closely upon the decisions in the Standard Oil and Tobacco cases, the Senate, July 26th, IgI I, adopted a resolution authorizing and directing the Committee on Interstate Commerce to inquire into what changes were "necessary or desirable in the laws of the United States relating to 
the creation and control of corporations engaged in interstate commerce," with directions to hold sessions and to report to the Senate at the earliest date practicable. The hearings extended from day to day over a period of three months and more than one hundred persons appeared and presented their views. The report and the extremely able debates are presented in substance in Appendix J. These debates disclose a deeper insight into Anti-trust principles and policies than can be discerned in the Sherman Law discussion in 1890 ,- which is to say that the experiences of more than twenty years had produced a riper knowledge of that department of national life. It remained, however, for the succeeding Congress to enact measures calculated to cause offending corporations and individuals to cease and desist from unfair methods of competition in commerce. This legislation is comprised in the Federal Trade Commission Act and the Clayton Law.

Already a use has been found for the supervising powers of the Federal Trade Commission. Under a Senate ResolutionSenator Gore, Oklahoma, September 28, I9I4, two days after the creating act was approved-that Commission is now engaged in an enquiry as to the manner in which the Standard Oil subsidiaries are carrying out the terms of the final decree making effective the decision of the Supreme Court handed down May I5, I9II, requiring dissolution of that trust.

Under the power to investigate trade conditions in and our commercial relations with foreign countries, sessions of the Commission have been held at various commercial centers, and these enquiries and conferences promise benefits in the way of extending our export trade.

If we are right in our view of the situation, the state trials which have marked, like battlefields, the progress of the principles exemplified in the Sherman Law, will now grow few in number. The era of preventive regulation has succeeded to the period of repression and punishment. Let us look forward with confidence to the era of prevention becoming also the era of peace and good will in the American business world. If correct principles and well thought out rules, are sensibly, impartially and promptly enforced, the average business man should now find a place for his limited capital and his activities such as has not existed since the shadow of the gigantic trusts fell across the land. 
The various Appendices are added with the purpose of brin ing the Anti-trust laws within one cover, and joining thereto convenient form access to the measures and discussions whi contain the history of that system of jurisprudence down to $t$ date of the enactment of the Federal Trade Commission A and the Clayton Law. Whether the election of Senators popular ballot will mark a change in the policy or the personn of that body, remains to be seen; but every student of the An trust laws will be thankful for and appreciative of the gre ability of the men who in the Upper Chamber took the leadi part in these debates in the Fifty-first, Sixty-second and Sixt third Congresses.

The effort to make the various Appendices disclose an epitor of the history and condition of Anti-trust legislation is due recognition of the fact that in the absence of decisions or rulin the officer of a corporation and his legal adviser must look to $t$. source of this system of laws for interpretation and guidanc It is the belief of the authors that the available material fully set forth in those Appendices.

Wherever in the general text there has appeared occasion $f$ their views, the authors have set their version forth, as in du bound. Such views are an incident to authorship. No statuto or other obligation rests upon them to produce a book; but wh written it should contain their views upon the principal poin The reader may not agree with those views, and the reades view point may be correct; but that is another story.

The forms cover the practice as laid down in the rules at will be sufficient as a guide in ordinary cases.

It has not been found practicable to include such necessari transient matter as the Terms of the Commission, but inform tion of that description can be readily secured.

The effort of preparing this work has been reduced by $t$ assistance afforded through prior labors of writers who are a thorities on the Anti-trust laws. Among these we would specif Thornton,-A Treatise on the Sherman Anti-Trust Act. Eddy,-On Combinations .

Noyes,-Intercorporate Relations.

Williams,-Laws on Trusts and Monopolies, with Authoritie (official publication).

Joyce,-On Monopolies.

Walker,-History of the Sherman Law. 
Beale and Wyman,-Article on Monopolies, 27 "Cyc."

Much useful information will also be found in: Cooke,-Combinations, Monopolies and Labor Unions, $2 \mathrm{~d}$ Edition. Ma rin,-Modern Law of Labor Unions.

Rogcrs,-Good Will, Trade Marks and Unfair Trading.

Butler and Lynde,-A Review and Interpretation of 'the Clayton and Federal Trade Commission Laws.

RICHARD S. HARVEY

and

ERNEST W. BRADFord.

January 10, 1916. 



\title{
TABLE OF CONTENTS.
}

\author{
CHAPTER I.
}

NATURE AND LIMITATIONS OF COMPETITION IN TRADE.

PAGE

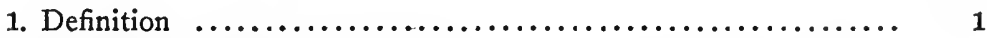

2. Benefits of Right to Compete $\ldots \ldots \ldots \ldots \ldots \ldots \ldots \ldots \ldots \ldots \ldots$. 1

3. Proper Exercise of Right ......................... 1

4. To Retain Rights, Assistance Sometimes Required .......... 3

5. Government Accords Aid to Parties Thus Situated .......... 3

6. New Measures and Methods Required .................. 4

7. Advantages of Railroad Rate Regulation ............... 5

8. Supervision of General Business Desired ................ 5

9. Purpose of Recent Legislation ...................... 7

10. Views of Leading Authorities Quoted ................. 9

11. Remarks on Field for Commission ................. 13

CHAPTER II.

MONOPOLIES AND COMBINATIONS TO PREVENT COMPETITION.

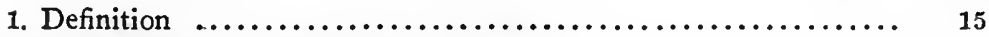

2. Development of Anti-trust Sentiment ................ 15

3. Distinction Between Exclusive Rights and Monopolies ........ 16

4. Public Interests Protected ........................ 19

5. Constitutionality of New Legislation Seems Assured ........ 21

CHAPTER III.

FEDERAL TRADE COMMISSION'S FUNCTIONS.

1. As a Board of Inquiry $. \ldots \ldots \ldots \ldots \ldots \ldots \ldots \ldots \ldots \ldots \ldots . \ldots \ldots$

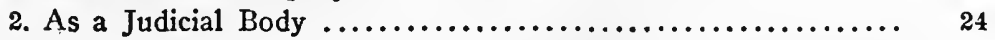

CHAPTER IV.

PROHIBITIONS UNDER THE CLAYTON LAW.

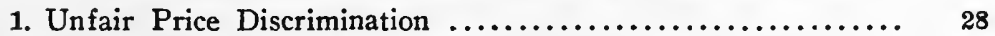

2. Conditional or "Tying" Contracts ................... 29

3. Ownership by One Corporation in the Stock of Another ..... 31

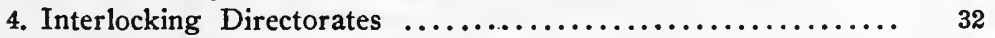

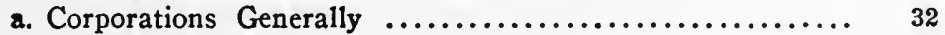


b. Provisions as to Banks .......................... 33

c. Provisions as to Common Carriers .................. 35

\section{CHAPTER V.}

PROVISIONS FOR ENFORCEMENT; PARTICULARLY, PROCEDURE UNDER SECTION 5 OF THE FEDERAL TRADE COMMISSION ACT, AND UNDER SECTION II OF THE CLAYTON LAW, TO MAKE EFFECTIVE SECTIONS 2, 3, 7, AND 8, OF SAID LAW.

1. Necessity for and Means of Enforcement ................ 37

2. Statutes Differ in Important Particular ................... 38

3. Procedure Before Commission Described ................. 39

4. Congress Prescribed Only Limited Review ............... 41

5. Commendatory Rulings Not Part of Legislative Plan ........ 42

6. Service of Process ............................... 46

CHAPTER VI.

BANKS,-PROVISIONS RELATING THERETO CONTAINED IN:

1. Federal Trade Commission Act $\ldots \ldots \ldots \ldots \ldots \ldots \ldots \ldots \ldots \ldots, \quad 47$

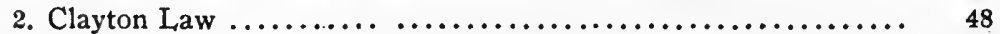

CHAPTER VII.

COMMON CARRIERS: REGULATIONS CONTAINED IN:

1. Federal Trade Commission Act $\ldots \ldots \ldots \ldots \ldots \ldots \ldots \ldots \ldots \ldots .6 \ldots$

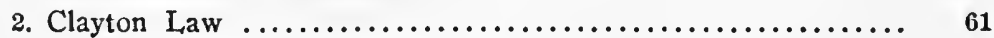

CHAPTER VIII.

THE SHERMAN ANTI-TRUST LAW; ITS ORIGIN, HISTORY AND THE LEADING CASES THEREUNDER CONSIDERED.

1. Comprehensive Language Employed ................... 70

2. Unlike Constitution,-Framers Did Not Expound Law ....... 71

3. Principles and Development .......................... 71

4. Occasion for Statutory Relief $\ldots \ldots \ldots \ldots \ldots \ldots \ldots \ldots \ldots \ldots, 7_{72}$

5. Various Drafts of Measure Considered ................. 73

6. Supporting Argument in Senate ....................... 74

7. Tentative Measures Considered...$\ldots \ldots \ldots \ldots \ldots \ldots \ldots \ldots \ldots \ldots$. 75

8. Scope and Effect of Law as Enacted ................... 77

9. Constitutional Questions Settled by Supreme Court ......... 79

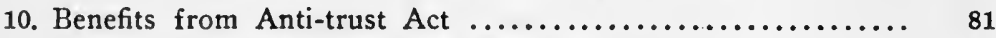

11. Foreign Anti-trust Laws Discussed $\ldots \ldots \ldots \ldots \ldots \ldots \ldots \ldots \ldots, \quad 83$ 
14. Definitions of "Commerce" ...................... 92

15. Congress Supplements Anti-trust Decisions .............. 94

CHAPTER IX.

DEFINITIONS OF PERSON AND CORPORATION AND EXTENT OF (I) INDIVIDUAI, (2) CORPORATE LIABILITY, UNDER:

1. Federal Trade Commission Act $\ldots \ldots \ldots \ldots \ldots \ldots \ldots \ldots \ldots, \quad 97$

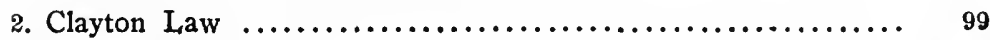

3. Sherman Law .................................. 103

\section{CHAPTER X.}

SUITS FOR INJUNCTION UNDER THE FEDERAL TRADE COMMISSION ACT AND THE CLAYTON LAW; ALSO, SPECIAL CONTEMPT PROCEEDINGS.

1. Importance of Subject Considered $\ldots \ldots \ldots \ldots \ldots \ldots \ldots \ldots \ldots, 111$

2. Notice in Equity Practice ............................ 112

3. Practice Revised ................................ 113

4. Public Interest Conserved under Commission Act ........... 114

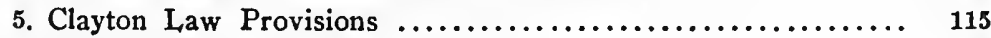

6. Application and Hearing .............................. 117

7. Order Must be Specific ............................ 118

8. Special Limitations in Trade Disputes ................. 119

9. Contempt Proceedings Where Disobedience Involves Criminal

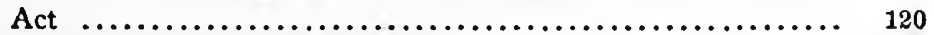

10. Old Forms of Contempt Retained ...................... 122

11. Statutory Limitation One Year; Criminal Proceedings Not Barred ....................................... 123 : : :

\section{CHAPTER XI.}

ATCIONS FOR DAMAGES UNDER THE PROVISIONS OF THE FEDERAL TRADE COMMISSION ACT AND ANTITRUST LAWS.

1. Generally as to Right to Bring Actions ................. 124

2. Right Covers All Violations of Anti-trust Laws ............ 125

3. Sherman Law Provision for Triple Damages Re-enacted ...... 126

4. Certain Judgments Prima Facie Evidence ................ 128

5. Government Suit Extends Statute of Limitations ........... 128

6. Locus of Suit ....................................... 128

7. Procedure of Service Discussed .......................... 129

8. Attendance of Witnesses Considered ................... 130 
CHAPTER XII.

\section{CRIMINAL PROVISIONS OF THE ANTI-TRUST LAWS.}

1. Federal Trade Commission Act ....................... 1

2. Clayton Law .................................... 1

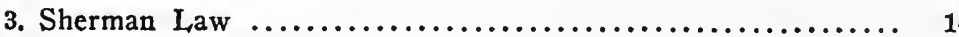

4. Wilson Tariff Law....$\ldots \ldots \ldots \ldots \ldots \ldots \ldots \ldots \ldots \ldots$

\section{CHAPTER XIII.}

IMMUNITY OF WITNESS UNDER FEDERAL TRADE CON MISSION ACT, AND THE ANTI-TRUST LAWS.

1. Immunity Proceeds from Recognition of Constitutional Rights . 1!

2. Statutes Recognize said Rights ..................... 1

3. Commission's Orders do not Confer Immunity ............. 1

4. Privilege Does Not Extend to Corporations ................ 1

5. Purpose of Privilege Stated ......................... 1

6. Actual Jeopardy Must be Shown .......................

7. Witness Must Claim Privilege ........................ 1

8. Enquiring Court or Body Must Possess Jurisdictional Powers ... 1

9. Further Consideration of Immunity Provisions ............ 1

10. Application of Principle .............................. 1

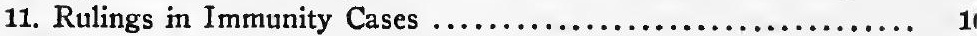

CHAPTER XIV.

HISTORY AND APPLICATION OF PROVISIONS OF CLAY TON LAW RELATING TO ENCOURAGEMENT AND PRC TECTION OF LABOR.

1. Inception of Sherman Anti-trust Act ...................

2. Question of Exempting Labor Raised ................... 1

3. Opposing Argument by Senator Edmunds ................ 1

4. Exclusion of Labor Provision from Sherman Law ..........

s. Argument Criticized ................................ 1

6. Equality of Corporation and Labor Union Noted ........... 1

7. Orderly Organized Labor Should be Encouraged ............ 1

8. Leading Decision Quoted .................................

9. "Strike"-Usual Means of Compulsion .................. 1'

10. Right to Refuse to Deal .............................. 1

11. "Boycott" ....................................... 1

12. Protection Afforded by Sections 6 and 20 of Clayton Law .....

13. Provisions Separately Examined $\ldots . \ldots \ldots \ldots \ldots \ldots \ldots \ldots \ldots$. 1

14. Rights of Labor Confirmed .......................... 1 
CHAPTER XV.

ANTI-TRUST LAWS IN THEIR RELATION TO PATENTS AND COPYRIGHTS.

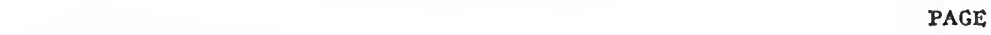

1. Origin and Purpose of Exclusive Grants ................ 185

2. Scope of Exclusive Powers Under Patent Laws ........... 187

3. Copyright Laws as Construed Under Anti-Trust Statutes ..... 193

4. Protection of Public is End Sought by Anti-Trust Laws ..... 201

CHAPTER XVI.

UNFAIR TRADING IN RELATION TO TRADE-MARKS AND TRADE NAMES.

1. An Ancient Problem ........................... 206

2. Good Will a Topic of Wide Significance ............... 207

3. Unfair Trade Methods ............................. 207

4. Deceptive Words and Emblems .................... 210

5. Imitators Display Endless Ingenuity $\ldots \ldots \ldots \ldots \ldots \ldots \ldots \ldots .218$

CHAPTER XVII.

\section{UNFAIR METHODS AS SEEN IN ABUSES OF CORPORATE CONTROL.}

1. Unfair Manipulation and Conduct .................. 222

2. Unfair Exercise of Voting Power .................. 228

Rules of Practice before the Commission ................. 232

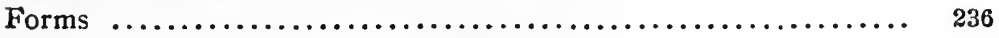

\section{APPENDIX A.}

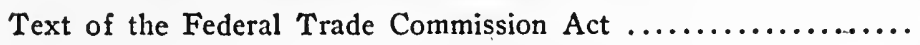

APPENDIX B.

Text of the Clayton Law or Supplemental Anti-trust Law ....... 259

\section{APPENDIX C.}

Text of the Sherman Law, or Federal Anti-Trust Law .........

$$
\text { APPENDIX D. }
$$

Portions of Wilson Tariff Law

\section{APPENDIX E.}

Statutory Provisions Creating the Bureau of Corporations 
APPENDIX F.

Provisions of Federal Constitution Applicable to Anti-trust Laws .

\section{APPENDIX G.}

Portion of Sundry Civil Act, 1914, Applicable to Restriction of Government Actions against Labor and Agricultural Organizations

APPENDIX $\mathrm{H}$.

Immunity Provisions

\section{APPENDIX I.}

Provisions of Judicial Code Referred to in the Federal Trade Commission Act, and Clayton Laws; also Provisions Abolishing the Circuit Courts of the United States .....................

\section{APPENDIX J.}

Anti-Monopoly Provisions Contained in Panama Canal Act .......

APPENDIX $K$.

Tentative Forms of Sherman Law Submitted to the Senate for the

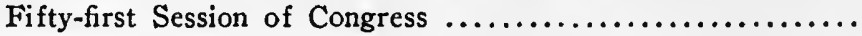

\section{APPENDIX L.}

Expediting Act of 1910

\section{APPENDIX M.}

Control of Corporations, Persons and Firms engaged in Interstate Commerce,-Senate Report No. 1326, Sixty-second Congress ..

\section{APPENDIX N.}

Regulation of Injunctions, with History of and Remarks Upon Existing Law and Practice,-Extracts from House Report No. 612, Sixty-second Congress

\section{APPENDIX O.}

An Act to Regulate Commerce,-Original Interstate Commerce Act of 1887

\section{APPENDIX P.}

Memoranda of Cases Instituted by the United States under the Antitrust Laws 


\title{
TABLE OF CASES CITED.
}

\author{
[REFERENCES ARE TO PAGES.]
}

A.

A. B. Dick Co. v. Henry (149 Fed. 424 , see also Henry v. A. B. Dick Co.), 188, 190.

Adair v. United States (208 U. S. 161), 193.

Addystone Pipe \& Steel Co.v. United States (175 U. S. 211; 20 Sup. Ct. $96 ; 44$ L. Ed. 136, affirming 85 Fed. $171 ; 29$ C. C. A. 141 ; 46 L. R. A. 122; 54 U. S. App. 723, which reversed 78 Fed. 712), 21, 80, 149, 194.

Alexander v. United States (201 U. S. 117 ; 26 Sup. Ct. 356 ; 50 L. Ed. 686), 163.

Allen v. Riley (203 U. S. 347; 27 Sup. Ct. 95 ; 51 L. Ed. 216, affirming 71 Kan. 378; 80 Pac. 952 ; 114 Am. Ct. 481), 195.

American Biscuit Co. v. Klotz (44 Fed. 721), 87, 146.

American Federation of Labor et al. v. Buck's Stove \& Range Co. (No. 1916, Cir. Ct. of App., Dist. of Columbia, decided March 11, 1909), 182.

American Soda Fountain Co. v. Green (69 Fed. 333), 21.

American Tobacco Co. v. Polacsek (170 Fed. 117), 215.

American Waltham Watch Co. v. U. S. Watch Co. (173 Mass. 85; 53 N. E. 141; 73 Am. St. Rep. 263 ; 43 L. R. A. 826), 212.

Anheuser-Busch Brewing Assoc'n v. Piza (24 Fed. 149), 212.

Arthur v. Oakes (65 Fed. 310, 317; 11 C. C. A. 209 ; 25 L. R. A. 414), 173.

\section{B.}

Barnes v. Berry (157 Fed. 883), 183.

Barnes v. Chicago Typographical Union (232 I11. $402 ; 83$ N. E. 932; 14 L. R. A. N. S. $1150 ; 122$ Am. St. Rep. 129), 183.
Bartholomew v. Austin (85 Fed. 359 ; 29 C. C. A. 568), 18.

Bauer \& Cie v. O’Donnell (229 U. S. 1 ; 33 Sup. Ct. 616 ; 57 L. Ed. -), 192, 199, 200.

Beechley v. Mulville (102 Iowa $602), 20$.

Bell v. United States (163 U. S. 662), 164.

Bennet, In re (84 Fed. 324), 164.

Berkowittz v. United States (93 Fed. 452; 35 C. C. A. 379), 164.

Blackwell v. Alibrell (3 Hughes [U. S.] $151 ; 3$ Fed. Cas. No. 1, 475 ; 14 Off. Gaz. 633), 212.

Blount Mfg. Co. v. Yale \& Towne (166 Fed. 555), 192, 194.

Bobbs-Merrill Co. v. Snellenberg (131 Fed. 530), 198.

Bobbs-Merrill Co. v. Straus (139 Fed. 155, affirmed 147 Fed. 15 ; 77 C. C. A. $407 ; 15$ L. R. A. N. S. 766 ; 210 U. S. 339 ; 28 Sup. Ct. 722 ; 52 L. Ed. 1086), 192, 196, 198, 199, 235.

\section{C.}

Carroll v. Greenwich Ins. Co. (199 U. S. 401 ; 26 Sup. Ct. 66 ; 50 L. Ed. 246, reversing 125 Fed. 121), 20.

Centaur Co. v. Killenberger ( 87 Fed. 725), 217.

Chapman, In re (166 U. S. 661), 158.

Charitable Corporations v. Sir Robert Sutton (2d Atkins 400), 125.

Charles E. Hires Co. v. George A. Hires (182 Pa. St. 346; 37 Atl. 1117), 217.

Chas. E. Hires Co. v. Consumers' Co. (100 Fed. 809), 217.

Charles River Bridge v. Warren River Bridge (11 Pet. 420; 9 L. Ed. 773, 938, affirming 7 Beck 344), 18. 


\section{[REFERENCES ARE TO PAGES.]}

Chesapeake \& Ohio Fuel Co. v. United States (115 Fed. 610, 623; 53 C. C. 256, affirming 105 Fed. 93), 19.

Chicago Wall Paper Mills Co. v. General Paper Co. (147 Fed. 491; 78 C. C. A. 607), 20.

Collier v. Jones (66 Misc. [N. Y.] 97 ; 120 N. Y. Suppl. 991, modified in 140 N. Y. App. Div. 911; 125 N. Y. Suppl. 1116), 217.

Colman v. Crump (70 N. Y. 573, 217.

Columbian Wire Co. v. Freeman Wire Co. (71 Fed. 306), 21, 190.

Com. v. Zacharias (181 Pa. St. 126, affirming $5 \mathrm{~Pa}$. Dist. 475), 17.

Counselman v. Hitchcock (142 U. S. 547; 12 Sup. Ct. 195 ; 35 L. Ed. 1110; reversing 44 Fed. 268), 156.

"Cream of Wheat" Case (224 Fed. 566, 28, 193.

Crescent City Brewing Co. v. Flanner (44 La. Ann. 22; 10 South 384), 223.

Darcy v. Allen (11 Coke 84; Noy. 173; Moore 673; 8 Coke 125), 16, 19, 72.

\section{D.}

"Danbury Hat" Case (235 U. S. '522, see Loewe v. Lawler), 175.

Dartmouth Colleg? v. Woodward (4 Wheat [17 U. S.] 518-636; 4 L. Ed. 629), 18, 229.

"Dick" Case (149 Fed. 424; see Henry v. A. B. Dick Co.), 188, 19.

Densbey, etc., Collieries v. Yorkshire Miners' Assoc'n (75 L. J. K. B. 284), 183.

Dr. Miles Medical Co. v. John D. Park \& Sons Co. (220 U. S. 373; 31 Sup. Ct. 376 ; 55 L. Ed. 902, affirming 164 Fed. $803 ; 90$ C. C. A. 579), 192, 196.

\section{E.}

Estes v. Belford (30 Off. Gaz. 99), 217.

Estes v. Leslie (27 Fed. 22; 23 Blatch. 476 ; 29 Fed. 91), 217.

Estes v. Williams (21 Fed. 189, 190), 217.

Estes v. Worthington (22 Fed. 822; 23 Blatch. 65 ; 30 Fed. 465; 31 Fed. 154; 24 Blatch. 371), 217.
F.

Farmers' Loan \& Trust Co. v. Trustees of N. Y. \& West R. R. Co. (150 N. Y. $410 ; 44$ N. E. 1043; 34 L. R. A. 76 ; 55 Am. St. 689), 226.

Febridge v. Wells (4 Abb. Pr. N. Y. 144 ; 13 How. Pr. 385), 216, 218.

Fisher Flouring Mills Co. v. Swanson (76 Wash. 649), 28, 194.

Foot v. Buchanan (113 Fed. 156), 163.

G.

General Electric Co. v. Wise (119 Fed. 922), 21.

George v. Central R. R. Co. (101 Ala. 607; 14 South 752), 226.

Gibbs v. Consolidated Gas Co. (130 U. S. 396, 9 Sup. Ct. 553, 32 L. Ed. 979), 20.

Gildersleeve v. Lester (68 Hun [N. Y.] 532), 225.

Gorrell v. Town of Newport, (Tenn. Ch. App. 120), 18.

Great Atlantic \& Pacific Tea Co. v. Cream of Wheat Co. (224 Fed. 566), 28, 193.

Greater New York etc Co. v. Biograph Co. (203 Fed. 39), 193.

Green v. Hugo (81 Tex. 452; $17 \mathrm{~S}$. W. 79; 26 Am. St. 824), 223.

Greer, Mills \& Co. v. Stoller (77 Fed. 1), 115.

Grice, In re (79 Fed. 627), 193.

H

Haarstick v. Fox (9 Utah 110;33 Pac. 351; 156 U. S. 674), 224.

Hale v. Henkel (201 U. S. 43, 66 ; 26 Sup. Ct. 370 ; 50 L. Ed. 652, affirming 139 Fed. 496), 152, 156, 157, 159, 160, 163.

Harrison v. Maynard etc. Co. (61 Fed. 689 ; 10 C. C. A. 17 ; 26 U. S. App. 99), 199.

"Harvester" Case (214 Fed. 987), $19,79,91,93$.

Heaton-Peninsular etc. Co. v. Eureka Specialty Co. (77 Fed. 288; 25 C. C. A. 267 ; 35 L. R. A. 728; 47 U. S. App. 146, 160), 195.

Heike v. United States (227 U. S. 131 ; 33 Sup. Ct. 226 ; 57 L. Ed. 450, affirming 192 Fed. 83, $112 \mathrm{C}$. C. A. 615), $157,159$. 


\section{[REFERENCES ARE TO PAGES.]}

Henry v. A. B. Dick Co. (224 U. S. 1; 32 Sup. Ct. 364 ; 56 L. Ed. 645 ; see 149 Fed. 424$), 17,19,30$, 188, 198.

Fenry Brill Publishing Co. v. Smythe (27 Fed. 914), 199.

Higgins v. Lansingh (154 Ill. 301; 40 N. E. 362), 225.

Hires v. Consumers Co. (100 Fed. 809), 217.

Hires v. Hires (182 Pa. St. 346; 37 Atl. 1117), 217.

Hopkins v. Oxley Stove Co. (83 Fed. 912), 170.

Howe Scale Co. v. Wyckoff (198 U. S. 118, 137, 25 Sup. Ct. 609, 49 L. Ed. 972), 214.

Humphrey's Homeopathic Medicine Co. v. Wenz (14 Fed. 250), 216.

\section{I.}

Insurance Policies, In re $(7 \mathrm{~Pa}$. St. 17), 20.

"International Harvester" Case (214 Fed. 987), 79, 91, 93.

Internat. Silver Co. v. Wm. H. Rogers Corp. (66 N. J. Eq. 119; 57 Atl. 1037), 213.

Interstate Commerce Commission v. Brimson (154 U. S. $447 ; 155$ U. S. 3 ; 14 Sup. Ct. $1125 ; 15$ Sup. Ct. 19 ; 38 L. Ed. 1047; 39 L. Ed. 495; reversing 53 Fed. $476), 158$.

Interstate Commerce Commission v. Harriman (211 U. S. 407), 158.

Interstate Commerce Commission v. Illinois Central R. R. Co. (215 U. S. 452), 126.

Interstate Commerce Commission v. Humboldt Steamship Company (224 U. S. 474), 39, 98.

\section{J.}

Jacobus v. Am. Min. Water Mch. Co. (38 Mise [N. Y.] $371 ; 77 \mathrm{~N}$. Y. Supp. 898), 225.

Joffe v. Evans (70 [N. Y.] App. Div. $189 ; 75$ N. Y. Supp. 257), 216.

\section{K.}

"Knight" Case (156 U. S. 1; 15 Sup. Ct. 249 ; 39 L. Ed. 325, affirming 60 Fed. 934 ; 9 C. C. A.
297 ; 24 L. R. A. 428 ; 17 U. S. App. 466, which affirmed 60 Fed. $306), 78,82$.

Kilbourn v. Thompson (103 U. S. 168), 158.

\section{L.}

Langan v. Francklyn (29 Abb. N. C. [N. Y.] 102), 225.

Lare v. Harper (30 C. C. A. 376), 215.

Lawler v. Loewe (235 U. S. 522, see Loewe v. Lawler, "Danbury Hat" Case), 175.

Locker v. American Tobacco Co. (121 [N. Y.] App. Div. 443, 106 N. Y. Supp. 115), 173.

Loewe v. Lawler "Danbury Hat" Case (235 U. S. 522; 208 U. S. 274 ; 130 Fed. 633 ; 142 Fed. 216 ; 148 Fed. 924 ; 187 Fed. 522), 175.

Lonas v. State (3 Heisk. [Tenn.] $287), 151$.

Louisville Gas Co. v. Citizens' Gas Light Co. (115 U. S. 683; 6 Sup. Ct. 265 ; 29 L. Ed. 510, reversing $81 \mathrm{Ky} .263), 18$.

Lyons v. Wilkins (67 L. J. ch. 383), 183.

M.

McClure v. Law (161 N. Y. 78; 55 N. E. 388; 76 Am. St. 262), 226.

McCutcheon v. Merz Capsule Co. (71 Fed. 787 ; 19 C. C. A. 108 ; 31 L. R. A. 415), 20.

McGourkey v. Toledo \& O. C. Ry. Co. (146 U. S. 536), 225.

McIntire v. Ajax Mining Co. (17 Utah 213; 20 id. 323 ; 28 id. 162 ; 77 Pac. 613), 224.

Macklem v. Fales (130 Mich. 66), 226.

Martell v. White (185 Mass. 255; 69 N. E. 1085 ; 64 L. R. A. 260 ; 102 Am. St. Rep. 341), 176.

Meredith v. New Jersey Zinc, etc., Co. (41 Att. 116, affirming $55 \mathrm{~N}$. J. Eq. 211; 222, 37 Atl. 539), 1.

Merrimack Mfg. Co. v. Garner (4 E. D. Smith [N. Y.] 387; 2 Abb. Pr. 318), 216.

Mines v. Scribner (147 Fed. 927), 198.

Minnesota v. Northern Securities Co. (194 U. S. 48 ; 2 Fed. Antitrust Dec. 533; 24 Sup. Ct. 588; 


\section{[REFERFNCES ARE TO PAGES.]}

48 L. Ed. 870 ; reversing 123 Fed. 692), 87, 115, 116.

Munn v. Illinois (94 U. S. 113), 78, 81.

N.

Nathan v. Louisiana (8 How. [U. S.] 73), 47.

National Biscuit Co. v. Baker (95 Fed. 135), 215.

National Biscuit Co. v. Ohio Baking Co. (127 Fed. 127, 160; 195 U. S. 630), 215.

National Biscuit Co. v. Swick (121 Fed. 1007), 215.

National Fireproofing Company v. Mason Builders Association (169 Fed. 259 ; 94 C. C. A. 535), 87, 116, 184.

National Folding-Box, etc. Co. v. Robertson (99 Fed. 985; 43 Weekly Rep'r 156), 190.

National Harrow Co. v. Hench (76 Fed. 667, affirmed; 83 Fed. 36; 27 C. C. A. 349), 191.

National Harrow Co. v. Quick (67 Fed. 130), 21.

National Lead Co. v. Grote Paint Store Co. (80 Mo. App. 247), 20.

National Protective Assoc. v. Cumming (170 N. Y. 315, 326; $63 \mathrm{~N}$. E. 369,$371 ; 58$ S. R. A. 135,140 ; 88 Am. St. Rep. 648), 175.

Nelson v. United States (201 U. S. 92 ; 26 Sup. Ct. 358; 50 L. Ed. 773, affirming 52 Fed. 646), 152, 163.

New Orleans v. Hoyle (23 La. Ann. $740), 18$.

New Orleans Butchers' Union Slaughter House, etc., Co. v. Crescent City Livestock Landing, etc., Co. (111 U. S. 749; 4 Sup. Ct. 265 ; 28 L. Ed. 585), 18.

New Orleans Gas Light Co. v. Louisiana Light, etc., Co. (115 U. S. 650; 6 Sup. Ct. 252, 29 L. Ed. $516), 18$.

New York Life Insurance Co. v. Deer Lodge County (231 U. S. 498), 47.

Northern Securities Co. v. United States (193 U. S. 197; 24 Sup. Ct. 436 ; 48 L. Ed. 679 ; affirming 120 Fed. 721), 21, 32, 80, 149, 230.
Olsen v. Smith (195 U. S. $332 ; 25$ Sup. Ct. 52 ; 49 L. Ed. 224; affirming [Texas Civ. App.] 68 S. W. 320$), 17$.

Otis Elevator Co. v. Geiger (107 Fed. 131), 190.

Over v. Byram Foundry Co. (77 N. E. 302 [Ind. App. 1906]), 19.

Oxford University v. WilmoreAndrews Pub. Co. (101 Fed. 443), 212.

\section{P.}

Pacific Factor Co. v. Adler (90 Cal. 110; 27 Pac. 36, 25 Am. St. 102), 20.

Pacific Railways Commission, In re (32 Fed. 241), 158.

Pasteur Vaccine Co. v. Burkey (22 Tex. Civ. App. 232; 54 S. W. 804), 20.

Paul v. Virginia (8 Wall. 168), 47.

People v. City Prison Warden (144 N. Y. $529 ; 30$ N. E. $686 ; 27$ L. R. A. 718), 17.

People v. North River Sugar Co. (121 N. Y. 582; 24 N. E. 834; 9 I. R. A. $33 ; 18$ Am. St. 843, affirming $2 \mathrm{Abb}$. N. C. $164 ; 54$ Hun $355 ; 3$ N. Y. Supp. 401; 2 L. R. A. 33), 81.

People v. Sheldon, 139 N. Y. 251; 54 N. Y. St. Rep'r 513; 34 N. E. 785 ; 23 L. R. A. 221 ; 36 A. St. Rep. 690), 1.

Perry v. Truefitt (6 Beav. 66), 209. Pickett v. Walsh (192 Mass. 572; 78 N. E. 753 ; 6 L. R. A. [N. S.] 1067; 116 Am. St. Rep. 272); 42 American Law Review 706), 174.

Pidding v. How (8 Sim. 477), 209.

Piddock v. Harrington (64 Fed. 821), 115.

Pillsburg-Washburn Flour Mills Co. Ltd. v. Eagle (86 Fed. 608; 30 C. C. A. 386 ; 41 I. R. A. 162 , reversing 82 Fed. 816), 212.

Poultney, ex parte (4 Peters C. C. C. 472$), 113$.

\section{Q.}

Queen Ins. Co. v. State (86 Texas 253 ; 24 S. W. 397 ; 22 L. R. A. 483 , reversing 22 S. W. 1048), 20. 


\section{[REFERENCES ARE TO PAGES.]}

\section{R.}

Reddaway v. Banham (App. Cas. 199 ; 65 L. J. Queen's Bench 381 ; 74 L. T. Rep. N. S. 289; 44 Weekly Rep. 638; 13 R. P. C. 218), 215.

Reynolds v. Davis (198 Mass. 294; 84 N. E. 457 ; 17 L. R. A. N. S. 162), 174, 183.

Royal Baking Powder Co. v. Royal (122 Fed. 337 ; 58 C. C. A. 499), 213.

\section{S.}

Scheuer v. Muller (74 Fed. 225; 20 C. C. A. 165), 215.

Singer Mfg. Co. v. June Mfg. Co. (163 U. S. 169; 16 Sup. Ct. 1002 ; 41 L. Ed. 118), 216.

Standard Oil Co. v. United States (221 U. S. 1; 31 Sup. Ct. 502 ; 55 L. Ed. 619 ; 34 L. R. A. [N. S.] 834, modifying $173 \mathrm{Fed}$. 177), 19, 93, 146, 193.

Standard Sanitary Mfg. Co. v. United States (226 U. S. 20; 33 Sup. Ct. $9 ; 57$ L. Ed., affirming 191 Fed. 172), 19, 191, 194.

State v. Armcur Packing Co. (173 Mo. $356 ; 73$ S. W. $645 ; 61$ L. R. A. $464 ; 96$ Am. St. 515), 1.

State v. Murphy (128 Wis. 201), 157.

State v. Rudolph (128 Wis. 222), 157.

State v. Wilcox (64 Kansas 789; 68 Pac. 634), 17.

Strait v. National Harrow Co. (51 Fed. 819), 21.

Straus v. American Publishing Assoc'n (177 N. Y. 473; 69 N. E. $1107 ; 64$ L. R. A. $701 ; 101$ Am. St. 819; affirming 93 N. Y. App. Div. 86, N. Y. Supp. 1091), 194, 198.

\section{T.}

Texas \& Pacific Ry Co. v. Abilene Cotton Oil Co. (204 U. S. 426), 126.

Thomas v. Cincinnati, N. O. \& $T$. P. Ry. Co. (62 Fed. 803), 174.
Tobin Canning Co. v. Frazer

Tex. 407 ; 17 S. W. 25), 223.

$(81$

Toledo, etc., Ry. Co. v. Penna. Co. (54 Fed. 730 ; 19 L. R. A. 387), 177.

\section{U.}

United Shoe Machinery Co. v. La Chapelle (212 Mass. 67; 99 N. E. 289), 187.

United States v. Addystone Pipe, etc., Co. (85 Fed. 271, 806, 814; 29 C. C. A. $141 ; 54$ U. S. App. 723 ; 46 L. R. A. 122, reversing 78 Fed. 712 ; affirmed 175 U. S. 211 ; 20 Sup. Ct. 96 ; 44 L. Ed. 136), 146, 149, 203.

United States v. American Naval Stores Co. (172 Fed. 455; 186 Fed. 592), 15.

United States v. American Tobacco Co. (221 U. S. 66 ; 31 Sup. Ct. 648 ; 55 L. Ed. 694; reversing 164 Fed. 700), 19, 93, 146.

United States v. Armour \& Co. (142 Fed. 808), 155, 157, 158, 162 , 163.

United States v. Debs (158 U. S. 564; 15 Sup. Ct. 900; 39 Fed. 1092), 175.

United States v. Heike (227 U. S. 131), 157, 159.

United States v. Hermison (26 Fed. Cas. No. 15, 308; 3 Sawyer 556), 164.

United States v. Int. Harvester Co. (214 Fed. 987), 19, 79, 91, 93.

United States v. E. C. Knight Co. (156 U. S. 1 ; 15 Sup. Ct. 249; 39 L. Ed. 325, affirming 60 Fed. $934 ; 9$ C. C. A. $297 ; 24$ L. R. A. $428 ; 17$ U. S. App. 466, which affirmed 60 Fed. 306), 78, 82.

United States v. Northern Securities Co. (193 U. S. 197; 24 Sup. Ct. 436 ; 48 L. Ed. 679 ; affirming 120 Fed. 721), 21, 32, 80, 149, 230.

Uuited States v. Standard Sanitary Mfg. Co. (187 Fed. 229; 191 Fed. 172 , affirmed 226 U. S. $20 ; 33$ Sup. Ct. 9 ; 55 L. Ed.; 57 L. Ed.) 19, 161, 191.

United States v. Swift (186 U. S. $1002), 158$. 
[REFERENCES ARE TO PAGES.]

United States v. Terminal R. Association of St. Louis, 148 Fed. 487, reversed 154 Fed. 268), 160.

United States v. Trans-Missouri Freight Assoc'n (166 U. S. 290; 17 Sup. Ct. 540; 41 L. Ed. 1007, reversing 58 Fed. $58 ; 7$ C. C. A. 15 ; 19 U. S. App. 36 ; 54 L. R. A. 73; 4 Interstate Com. Rep. 443 , which reversed 53 Fed. 440), 19, 49, 116.

United States v. Union Pacific Railroad (226 U. S. 306 ; 33 Sup. Ct. 53; 57 L. Ed., reversing 188 Fed. 116), 79, 91, 93. v.

Vegelahn v. Guntur (167 Mass. 92; 44 N. E. 1077 ; 35 L. R. A. 722; 57 Am. St. Rep. 443), 182.

\section{W.}

Walla Walla v. Walla Walla Water. Co. (192 U. S. 1; 19 Sup. Ct. 77; 43 L. Ed. 341), 18.

Waterhouse v. Comer, 55 Fed. 149; 19 L. R. A. 403), 175.

Wilbur v. Stopel (82 Mich. 344; 46 N. W. 724; 21 Am. St. 568), 224. Wood v. Whitehead Bros. (165 N. Y. 545,550$), 81$. 


\section{CHAP'TER I.}

\section{NATURE AND LIMITATIONS OF COMPETITION IN TRADE.}

I. Definition.

2. Benefits of Right to Compete.

3. Proper Exercise of Right.

4. To Retain Rights, Assistance Sometimes Required.

5. Government Accords Aid to Parties Thus Situated.

6. New Measures and Methods Required.

7. Advantages of Railroad Rate Regulation.

8. Supervision of General Business Desired.

9. Purpose of Recent Legislation.

Io. Views of Leading Authorities Quoted.

II. Remarks on Field for Commission.

\section{DEFINITION.}

Competition Judicially Defined.-The term competition in commerce or trade has been defined as that series of acts or course of conduct which is the result of the free choice of the individual and not of any legal or moral obligation or duty. ${ }^{1}$

\section{BENEFITS OF RIGHT TO COMPETE.}

Beneficial Effect in Practice.-In practice it leads to important results, because the self-interest of the individual when exercised in an untrammelled manner inures to the benefit of all. Such at least is the theory of competition; and its influence and stimulating effect have occasioned the familiar saying "competition is the life of trade." The value of competition to the state has been recognized by authority, for "the courts have acted upon and adopted this maxim [competition is the life of trade] in passing upon the validity of agreements, the design of which was to prevent competition in trade, and have held such agreements to be invalid."2

\section{PROPER EXERCISE OF RIGHT.}

Limitations of Right to Compete.-But freedom in competi-

I Meredith v. New Jersey Zinc, Etc., Co., 41 Atl. 116, affirming 55 N. J. Eq. 211; 222, 37 Atl. 539.

2 People v. Sheldon, 139 N. Y. 25I, 263, 54 N. Y. St. Rep'r 513, 34 N. E. 785, 23 L. R. A. 221 ; quoted in State v. Armour (1903), 173 Mo. 356; 73 S. W. 645,652 ; 61 L. R. A. $464 ; 96$ Am. St. 515. 
tion like other forms of liberty has limitations beyond which it degenerates into license, and unrestricted trade has brought about situations where the state has been compelled to intervene, in the public interest.

Tendency of Unrestricted Exercise of Power Shown.-Perhaps the simplest and most concrete example of the tendency of unrestricted competition to work out oppression is seen in the record of the relations of capital to labor.

With the abolition of slavery and serfdom in the first half of the nineteenth century, willing service remained as the only recognized method of employment throughout the civilized world. But with the removal of the various forms of enforced labor, no system of mutual moral obligation was substituted in their stead. Such an obligation on the part of the capitalist was habitually ignored or denied, and the laborer in his turn when so disposed by self interest entered upon each task intent upon reducing his output to prolong his work, or to minimize the fruits of a bargain he realized to be oppressive.

English Experience.-In England farm laborers breakfasting on thin broth and dining on bread and cheese, without meat more than once a week, worked from sunrise to sundown, while in the manufacturing centres the life and surroundings of workmen were more burdensome than the conditions imposed on criminals engaged upon enforced labor in prisons. Women and little children dragged loaded coal trucks along dripping tunnels in mines ten to sixteen hours a day; one quarter of the population of London lived in poverty, and public or private charity was the precarious dependence of one thirty-fourth of the entire population of England and Wales. Education of the working class was neglected, and the natural results of such an unregulated condition of competition for employment were the twin burdens of society, -pestilence and crime.

In America Similar Causes Threaten Similar Results.-In the United States, a somewhat similar condition formerly existed, excepting that the pauperism of the American poor never took on the hopeless condition which prevails in an atmosphere where the good things of life are reserved for a favored few, and artificial barriers of birth and aristocracy make it difficult to rise to a higher stratum of human life and effort.

It is hard to realize that up to sixty years ago no effort to restrict child labor had been initiated in America, and that in Penn- 
sylvania lads of fourteen years worked for nine hours each day in air so polluted with coal-dust that nature could not remove these impurities from throat and lungs for twenty-four hours thereafter. In tenements of the great cities women trod sewing machines in "sweat-shops" ten to fifteen hours at a stretch, until the exhaustion of mind and body rendered motherhood impossible. ${ }^{3}$

\section{TO RETAIN RIGHTS, ASSISTANCE SOMETIMES RE- QUIRED.}

Weaker Party Cannot Always Compete.-Of course it was theoretically possible for the employee to demand changed conditions and in default of such amelioration, to refuse to continue the engagement; but in the press of unrestricted competition, with other hands grasping for the means of subsistence, and with dependent families looking to the daily wage for their support, the workman had no actual choice but to remain at his task, trusting to the state to surround it with such conditions as would safeguard his health and prospects, in furtherance of the common good.

In Such Cases Government Must Intervene.-Modern legislation with what for lack of a better term we shall designate intelligent paternalism has obliterated or modified these hard conditions formerly prevailing between employer and employee; and competition in employment, to the permanent advantage of every interest, has now become competition as regulated and restricted by law.

Above Statement Illustrates Principle Involved.-While these remarks may be regarded by some as a digression, no apology is offered for their inclusion here. The same intrusion of social science into everyday affairs is seen in many quarters, as will abundantly hereafter appear.

\section{GOVERNMENT ACCORDS AID TO PARTIES THUS SITUATED.}

Government Intervenes against Restrictive Combinations.In the world of business, conditions similar to those existent in affairs of labor prevailed in America down to a comparatively recent period. It is true that in this coututry, in and since

3 An Industrial Revolution, by Lyman Abbott, May, 1915; The Outlook, Vol. 110, No. 4 . 
Colonial days, rigid laws have been in force against combinations and contracts in restraint of trade; but the equally deadly practices of intensive competition itself, viz: rebates, underhand methods of diverting a competitor's trade, "dumping," etc., were not within the purview of the restrictive statutes, and business became at length so honeycombed with special interests and acts of favoritism that the country rose in revolt, and the statutes creating the Interstate Commerce Commission and the Sherman Law were enacted in a determined effort to cope with this dangerous and growing evil.

These statutes have reduced to subjection to law many powerful interests and combinations which by hidden means and unfair methods were absorbing the trade of the country in their particular lines. The benefit has been apparent; but there remained a multitude of pernicious practices which the provisions for stateinstituted proceedings and the right to individuals to bring actions for three-fold damages did not and in the nature of things could not reach and obliterate.

\section{NEW MEASURES AND METHODS REQUIRED.}

Business Interests Demand That Destructive Competition Shall Also Be Restrained.-Thinking men, including our highest class of merchants and producers, have been devoting their careful attention to the situation before and about them, realizing that a contented and prosperous community can be created and maintained only upon a basis of plain dealing, and that the great body of citizens will welcome an adjustment of these problems along permanent lines. It was very natural that the study of conditions should lead them into a comparison of the situations before and after the institution of the Interstate Commerce Commission, and include a critical examination of the results which flow from competition when regulated by law.

In former times-as with labor-the railroads and other common-carriers were entirely free to compete where and when they chose, and rebates to large or favored patrons, cut-rates, free haulage at terminals, etc., were common practice. As in evolution, the survival of the fittest-and its equally inexorable counterpart, the elimination of the unfittest-led to the rapid absorption of the smaller enterprises as well as those without strategic position; and when that process had run its course, a "war of the 
Titans" brought competitive rates to a point where as was disclosed in a public examination "the freight did not pay for the axlegrease." In brief, it transpired that whereas "competition is the life of trade,"-that feature, in railroad circles as in the affairs of labor, demanded that the state, in the public interest, should intervene, and should lay down certain rules and regulations, and should in the exercise of its plenary authority under its general powers, interdict and declare illegal all competition which is $d c$ structive in its ultimate effect.

Demand Is General.-The study of conditions referred to above has progressed so rapidly and so far that the opinion has become quite general that the power to regulate competition between common carriers could and should be extended to trade and commerce in general and that an interstate board of control would create, in time, a code of business ethics that would crystallize about the restrictive statutes and in the end prevent in a large degree if not entirely the unfair methods of competition which have resulted (in the larger cases) in proceedings under the Sherman Law.

\section{ADVANTAGES OF RAILROAD RATE REGULATION.}

Benefits of Rate-Regulation Shown.-Under present. conditions, the railroads extending - to cite an instance-from Chicago to New York, New Orleans or San Francisco, must each compete under rates fixed by authority, upon a basis of the distance travelled and service performed; and rapidity and certainty of delivery and other relative advantages and conveniences to shippers are the deciding factors, in attracting business to particular lines. Here competition has a legitimate field, which in its turn, leads to improvements to retain and attract trade; and all at a rate which has been fixed at a figure intended to insure fair returns upon the investment involved, with the result that few if any railroad managers would return if they could, to the period when independent action and unrestricted competition was the prevailing rule.

\section{SUPERVISION OF GENERAL BUSINESS DESIRED.}

Evolution of Existing Sentiment.-It is true that those capitalists and persons in charge of large producing interests who are now advocating competition under provisions guaranteeing uni- 
form conditions for all concerned, have not arrived at their present view point without travelling other paths in search of an unrestricted outlet for their several products. Efforts to restrain trade and to control markets in the ' 70 s and early ' 8 os were evidenced by pools and "gentlemen's agreements"; later, the trust and then the holding company came into general use for this purpose, and with the adverse ruling in 1904 in the Northern Securities case came the era of creating vast combinations to hold the title to allied industries, at first hand. The last expedient had the advantage - or disadvantage - of placing ownership where the responsible persons could be located and reached by the state in anti-trust litigations to remove restraints of trade; and weary of seeking to combat or circumvent the popular will, the flag of truce has been raised, and peace seems at last assured.

National Commercial Conference Convened.-President Taft, in response to the sentiment of the country and with prophetic vision, early in 1912 issued a call for a National Commercial Conference to be held in Washington; and in response there assembled a gathering of six hundred delegates representing commercial bodies in all but one State in the Union, and there were present also delegates from the Philippine Islands, Porto Rico, Hawaii, and from bodies of American merchants residing in foreign cities, as well.4

The key-note in the President's call is found in the words: "How can business and the National Government be brought together in a broad national co-operation that will aid both business and the Government?"

Investigation by Congress Begun.-Congress was also alert and active, and under the resolution of July 26, I9II, the Senate Committee on Interstate Commerce was already holding that series of open hearings which continued from day to day until

4 Among the results of the Conference was the organization of The Chamber of Commerce of the United States of America. This association represents numerous interests, and by valuable addresses and published articles has done much to direct public opinion. By affording Committees of Congress the benefit of expert advice by men of standing and experience, it has been instrumental in removing prejudices and in nullifying the practice of maintaining a paid lobby at the capitol.

For useful information on anti-trust legislation, see printed Report of Speeches delivered at its Second Annual Meeting February 12, 1914, issued by the association. 
the expressions of more than one hundred representative citizens had been embodied in the record of its proceedings, culminating in the notable debate upon the proposed Interstate Trade Commission Bill, which Senator Newlands introduced in the committee's behalf."

\section{PURPOSE OF RECENT LEGISLATION.}

Policy of Regulating Competition Instead of Restraining Monopoly, Inaugurated.-Upon the advent of President Wilson's administration he seized the opportunity in January, 19I4, to send a message to Congress wherein he outlined a programme for regulating competition and urged the creation of a commission with jurisdiction over practices in this behalf extending to the fields of general trade.

Policy Outlined.-The need of the country for new means of adjusting this old difficulty is clearly and forcibly expressed in the following language:

"And the business men of the country desire something more than that the menace of legal process in these matters be made explicit and intelligible. They desire the advice, the definite guidance and information which can be supplied by an administrative body, an interstate trade commission.

"The opinion of the country would immediately approve of such a commission. It would not wish to see it empowered to make terms with monopoly or in any sort to assume control of business, as if the Government made itself responsible. It demands such a commission only as an indispensable instrument of information and publicity, as a clearing house for the facts by which both the public and the managers of great business undertakings should be guided, and as an instrumentality for doing justice to business where the processes of the courts or the natural forces of correction outside the courts are inadequate to adjust the remedy to the wrong in a way that will meet all equities and circumstances of the case."

President Commends Legislation.-That he felt the responsibility of a correct solution of this momentous question, goes with-

5 See Summary of Debate contained in Appendix M, pages 304-334, post. 
out saying. In a public statement ${ }^{6}$ made some months subsequent to the enactment of the Federal Trade Commission Act and the Clayton Law, President Wilson said:

"Enterprise has been checked in this country for almost twenty years because men were moving among a maze of interrogation points. They did not know what was going to happen them. $* * *$ It was a very great burden, let me say, to fall upon a particular adminstration of this Government to have to undertake practically the whole business of final definition. $* * *$ I feel that the mists and miasmatic airs of suspicion that have filled the world have now been blown away * * *"

Problems Involved in Solution of Difficulty.-What were the problems to which were attached the "interrogation points" mentioned in the President's address, is succinctly set forth in a list of eleven forms of "unfair competition" compiled by William S. Stevens, of Columbia University, and quoted in the debates upon the then pending Federal Trade Commission Act and Clayton Law:

I. Local price cutting.

2. Operation of bogus "independent" concerns.

3. Maintenance of "fighting ships" and "fighting brands."

4. Lease, sale, purchase, or use of certain articles as a condition of the lease, sale, purchase, or use of other required articles.

5. Exclusive sales and purchase arrangements.

6. Rebates and preferential contracts.

7. Acquisition of exclusive or dominant control of machinery or goods used in the manufacturing process.

8. Manipulation.

9. Blacklists, boycotts, white lists, etc.

10. Espionage and use of detectives.

II. Coercion, threats and intimidation. ${ }^{7}$

Reference to the text of these corrective statutes, (Appendices $A$ and $B$, pages 246-278, post,) will indicate the sincere efforts which Congress at the request of the President and with the co-

6 Address before the Conference of the American Electric Railway Association, April, 1915.

7 Cited in The Nation's Business, Washington, D. C., July 15, 1914. 
operation of the leaders in our world of business, has devoted to the solution of these questions and the removal of the "interrogation points" which have checked and bewildered the initiating force of the country "for almost twenty years."

Unfairness in Trading Has Myriad Forms.-It has from the first been realized no specific inhibitions against eleven or any number of unfair practices would or could prevent unfair dealers from finding new means to oppress their competitors, if they were so inclined. It was the intention of Congress to make the legislation so broad as to meet new devices or conditions as they arise, and to that end the words "unfair methods of competition in commerce" which contained the essential prohibitory feature of the several statutes were purposely left undefined as to their scope and meaning. In this manner the laws remain elastic, viz: like "fraud," the definition can be so extended as to meet every form which human cunning or the desire to over-reach can assume.

\section{VIEWS OF LEADING AUTHORITIES QUOTED.}

Views of Qualified Spokesmen Cited.-How complete has been the success of this supplemental legislation is a question which time alone can answer. It may, however, be at once instructive and encouraging to recite the views of others who, like President Wilson and former-President Taft, have shown a vital interest in solving the problems which long have interfered with the prosperity of the nation. It must be expected that some immediate hardships and losses will occur during the period of transition from an established though faulty system of protecting public interests, to a correct if necessarily somewhat imperfect and experimental one,and under such circumstances the promise of compensating advantages will come with welcome and heartening effect.

At a date slightly posterior to the President's Message to Congress, a gathering of distinguished men from various states and of differing political and business affiliations occurred at the City of Washington for the express purpose of discussing the various phases of the projected interstate trade commission. ${ }^{8}$

8 Second Annual Meeting of the Chamber of Commerce of the U. S. A., held February 12, 1914. References in later notes are to the reprint of speeches, issued by the association. 
Opinion of Secretary of Commerce.-Secretary of Commerce Redfield $^{\ominus}$ dwelt upon the high mortality existing among promotions which have for their object the control and exploitation of any particular line of trade. He affirmed that "the number of these gigantic organizations that have been conspicuously successful is not very large, nothing like half of those that have come into existence. *** It would be perfectly easy to take up line after line in which ten or fifteen years ago a trust dominated the whole situation and show that the independent concerns, starting since, or running independently at the time, have come to be, and are now, the more profitable." This result, he declared, was due to "a law which operates inexorably, beyond which you cannot press the production without increasing the cost of every unit of that product." In that law he saw an opposing force which would regulate those great organizations "to prevent their acquiring the dominant power which some fear."

Remarks by President of University of Wisconsin.-Charles R. Van Hise, ${ }^{10}$ president of the University of Wisconsin, affirmed that competition, when unrestricted, had failed to maintain quality or reduce prices. The waste of competitive effort was excessive. "Co-operation for all classes of business $* * *$ so far as not inimical to the general welfare," under the supervision of an appropriate commission,- -was the condition which the public interest and commerce itself demanded. He concluded: "I confidently look forward to a new era of social responsibility on the part of both the well-to-do and the poor, to a time when reason and science rather than vested interest or passion, shall control economic legislation."

\section{As Seen from the Legal View Point.-Victor Morawetz ${ }^{11}$} law writer and economist, dwelt upon the definite meaning which the Sherman Law had derived from the Standard Oil and Tobacco decisions of the Supreme Court. He deprecated, however, hasty or vindictive legislation to extend or supplement the anti-trust laws. "To hamper honest and legitimate enterprise merely to strike at those who break the law, or benefit themselves by illegitimate means, would not be enlightened and wise legislation. *** Undoubtedly, some legislation supplementary to 
the Anti-trust Act is desirable. The creation of a trade commission consisting of experienced and able men would be a wise step. It would be a step forward."

Opinion by Representative of Important Business Interests. -Frederick P. Fish, ${ }^{12}$ former president of the Amerian Telephone and Telegraph Company, asserted that- "Great business enterprises feel as never before the force of public sentiment and they are now in a chastened frame of mind which leads them to respect the universal demand that they should not deal harshly or unreasonably in their competition with those who are less strong than they." And, at an earlier place he said-"If the principles of the Sherman Law are valid some way must be found by which small concerns as well as large may be restrained from unfair competition or our whole industrial fabric may be shaken." His conclusion consisted in suggesting a preliminary commission which shall study the whole anti-trust field and recommend to Congress such supplemental legislation as will regulate all business competition, without endangering vested rights and interests.

Remarks and Suggestions by an Experienced Manufacturer. - Henry R. Towne, ${ }^{13}$ engineer and manufacturer, after a review of the existing and proposed anti-trust laws, discussed the proposed Interstate Trade Commission, and declared-"A new tribunal of this kind is unquestionably desirable, and its ultimate usefulness should equal that of the Interstate Commerce Commission. Business needs it and if it is properly constituted will welcome it. * * * The Tariff and Currency questions are disposed of. The creation of an Interstate Trade Commission, and the enactment of a clear and simple law defining its powers and duties will complete the triad by disposing of the anti-trust problem ***.

Opinion by Another Representative of Manufacturing Interests.-Guy E. Tripp, ${ }^{14}$ chairman of the Board of Directors, Westinghouse Electric and Manufacturing Company, analyzed the proposed legislation, and in the course of his remarks, said: "But I believe that our political institutions and the temper of our people [in contradistinction to those of foreign countries, particularly Germany] are not adapted to monopolistic methods that are 
in restraint of trade, and that fair competition in business will make a more contented public, a more secure government, and in the end give greater protection to property. * * * To my mind free competition is not sane competition.

"The biggest business in the country was founded almost entirely upon the principle of free competition, namely that of making prices what and when you will and of taking all the business from your competitor that you can. *** A Trade Commission seems to me to be needed in a well rounded plan of business legislation."

Criticisms and Suggestions by Professor Seager.-Henry R. Seager, ${ }^{15}$ professor of Political Economy, Columbia University, in treating of the proposed trust legislation, said: "The feature of the proposed trust legislation which I have been asked to make the starting point of my comments is the Interstate Trade Commission. In urging the creation of such a commission, President Wilson is certainly voicing the mature judgment of students of the trust problem. * * * The Newlands' bill to create an Interstate Trade Commission has received more prolonged and careful attention than any of the other three [supplemental Antitrust] measures now before Congress. $* * *$ The creation of such a commission means inevitably an extension of government by commission. I am in favor of it because I believe that with the growing complexity of business relations, it is only through the guidance of commissions of experts that we can hope to keep these relations straight and to advance sound business policy. * * * We all agree that unfair methods of competition which enable big corporations to wrest markets from their smaller rivals, not because they can produce more economically or make a profit while selling more cheaply but through the sheer force of their larger resources and the wider range of their operations, must be stopped." While affirming his belief in competition as "a dominant force in business," Professor Seager advocates the adoption of the principle that there is a higher method than the individualism which is the prevailing factor in competitive endeavors. $\mathrm{He}$ adds these words of caution: "But let us not make a fetish of competition. It also has its bad as well as its good side. While recognizing its value and making strenuous efforts to insure it a fair field for its operation, let us not ignore the fact that co-operation 
also has its legitimate place. On a higher moral plane than competition, its extension, under conditions that compel adequate regard to the public interest, must prove advantageous not only to business men but to the whole community."

The Legal View Point,-from Another Angle.-Louis D. Brandeis, ${ }^{16}$ lawyer, in treating of the pending legislation supplemental to the anti-trust laws, commented upon the general situation, as follows: "The program of President Wilson is not a program of free and unrestricted competition, but it is a program of regulating competition instead of regulating monopoly." $* * *$ I look forward to the trade commission which we are about to establish as an instrument which will be of inestimable advantage to the business and the future of America by making the common property and the common knowledge of American business men the best that has been done and is being done in every department of business throughout the world."

\section{I1. REMARKS ON FIELD FOR COMMISSION.}

General Conclusions in Aid of Subject.-In concluding these comments by experienced and keen observers of our country's affairs and interests, it may be permitted to add that cheapness in price is not the sole criterion by which to estimate the success that competition achieves. The prosperity of the average producer and merchant means prosperity in which all can and will share; and a reasonably enhanced price is a small consideration to pay for a condition which affords the customer the means to provide for his needs more readily than he could do if monopolies produced goods at prices which mean stagnation in all businesses except their ow11. For, in the words of Lincoln,-_"Cheapness is an insult to the person without the means to buy."

A commission which is ushered into being amid the favorable greetings and commendations of the business world has an incentive and advantage which is incalculable at the inception of its career. The field is wide and the mission plain. It is proper and necessary for the public to afford the Federal Trade Commission that loyal support which is at once the inspiration and the means of success in a democracy.

In the words of an able writer and recognized authority in an- 
Manual of Feneral Trade Commission.

other sphere of recent legislation: "Practical faith and mutual confidence is what we need." 17

17 F. A. Vanderlip, president of The National City Bank of New York, - "Intellectual Freedom in Currency Legislation," page 4 (1013). 
CHAPTER II.

\section{MONOPOLIES AND COMBINATIONS TO PREVENT COMPETITION.}

I. Definition.

2. Development of Anti-trust Sentiment.

3. Distinction Between Exclusive Rights and Monopolies.

4. Public Interests Protected.

5. Constitutionality of New Legislation Seems Assured.

\section{x. DEFINITION.}

r. A Monopoly Defined.-The meaning of the word "monopoly" has been expressed as the sole power (or a power largely in excess of that possessed by others) of dealing in some particular commodity, or at some particular market or place, or of carrying on some particular business. ${ }^{1}$

\section{DEVELOPMENT OF ANTI-TRUST SENTIMENT.}

Evolution of Anti-Monopoly Idea.-The granting of monopolies is a very ancient right, which is still exercised by governing bodies, though the practice is generally condemned when undertaken by individual initiative.

Thus, the state, by the patent franchise, accords sole rights to make, sell and use patented discoveries and inventions. Under the police powers of the state the marketing of liquor, tobacco, conducting of slaughter houses, and numerous other forms of human activity are confined by statute within certain prescribed limits, in the interest of the public welfare and health.

Banking, insurance and dealing in tickets are other instances of lines of business which are confined to certain persons or classes; and there are forms of semi-public institutions such as railroads, telephone and telegraph companies, which require vast aggregations of capital and are often classified as quasi-monopolies.

The existing condition which is familiar to every one has not crystallized into the shape we see about us without a history at once interesting and of service in enlightening us as to the subject in hand.

I U. S. v. American Naval Stores Co., 172 Fed. 455. 
It was from the practice of the English sovereigns in granting to favorites, or as a stimulant to good service, monopolies in the manufacture or sale of commodities, that the present manner of protecting inventions arose.

So common did this practice become in the time of the Tudors, that it led to many protests on the part of Parliament, as will be seen by reference to the history of Queen Elizabeth. Such an early authority as Sir Edward Coke, however, laid it down that while by the ancient common law the king, in aid of inventors, could grant a temporary monopoly covering the manufacture or importation of an invention, it was illegal to make grants in restraint of trade

The first recorded case, decided in 1602 , holds the same way; and while in practice the rule was frequently evaded, the decision was never overruled. ${ }^{2}$

Under the Stuarts, these abuses were not likely to grow less in number nor to become less burdensome to the people; and in fact the owners of monopolies-known generally as "purveyors" -grew so rapacious as to have a considerable influence in bringing about the death of Charles I and the flight of his son James.

In response to a widespread demand, the Statute of Monopolies was enacted by Parliament in 1623. This law was sweeping in its condemnation of the evil of favoritism in trade, and being rigidly enforced, had lasting effects; indeed, it is not too much to say that it created the rule that still prevails prohibiting restraint of trade.

In that basic enactment there appeared two exceptions, viz: That Parliament might grant legal monopolies, and that the Sovereign might exercise its ancient right for the encouragement of new manufacturers or inventions. ${ }^{3}$

On these exceptions are built up: First, the modern system of legislative grants of exclusive rights to trade in certain commodities, and second, the system of letters-patent for inventions.

\section{DISTINCTION BETWEEN EXCLUSIVE RIGHTS AND MONOPOLIES.}

Terms "Monopolies" and "Exclusive Rights" not Ident-

2 Darcy v. Allen, II Coke 84; Noy. 173; Moore 673; 8 Coke 125. Consult able discussion of principles contained in 7 Harvard Law Review, page 342. See article, "Monopoly," in Encyc. Brit., IIth Ed.

3 See Price's Eng. Patents of Monopoly. 1906. 
ical.-Obscurity and much confusion have occurred as the result of an indiscriminate use of the terms "monopoly" and "exclusive rights," regarding the privileges conferred by law upon patentees and holders of copyrights. It need hardly be said that the second term is that which correctly expresses the actual condition.

Inventors and authors are granted exclusive rights to control their creations for limited periods of time in return for and as an inducement to the disclosure of such creations and the dissemination of useful information, to the end that the public may have the free enjoyment thereof upon the expiration of such exclusive grants. ${ }^{4}$

This is something entirely different from the self-made monopolies and restraints of trade against which the Anti-trust statutes are directed. Monopoly is an abuse which for the most part has grown out of the unregulated condition of competition in commerce and trade; the exclusive rights of the inventor and author are temporary privileges which the state confers in return for permanent contributions to the advancement of the education and general welfare of the public.

The distinction between predatory interests- "trusts"-which the public in its own protection, seeks to keep within bounds, and originators of useful inventions and ideas whom the public honors and encourages by grants of limited privileges and rights, is so plain as to be apparent to all. In view, however, of the confusion of terms mentioned above, the distinction is one which has an important bearing when considering the subject in hand.

Test of Fitness not a Monopoly.-Courts have exercised their judicial powers in defining and limiting the power of the state, to give exclusive rights in trade or in various callings. Thus, doctors, ${ }^{5}$ druggists, ${ }^{8}$ pilots ${ }^{7}$ and plumbers, ${ }^{8}$ have all been held subject to the so-called police power of the state; and the rule has

4 For discussion of principle involved and for measure of protection court will afford such exclusive rights,--see Henry v. A. B. Dick Co., 224 U. S. I.

5 State v. Wilcox, 64 Kansas 789 ; 68 Pac. 634.

6 Com. v. Zacharias, 18I Pa. St. I26; affirming 5 Pa. Dist. 475.

7 Olsen v. Smith, 195 U. S. 332 ; 25 Sup. Ct. 52, 49 L. Ed. 224.

8 See People v. City Prison Warden, I44 N. Y. $529 ; 30$ N. E. 686,27 L. R. A. 718 . 
been often upheld that those who practice skilled employments must demonstrate their fitness to engage in those occupations. ${ }^{\circ}$

A Strict Construction is Applied to Chartered Rights.-All franchises are strictly construed, and since all monopolies are regarded as in derogation of common rights, they will be scrutinized with care, for there is a presumption against the extension of such rights. ${ }^{10}$

Franchise Ripens into Contract.-It is also a well-known rule that when a franchise is once accepted and acted upon, it ripens into a contract, which the state has no right to impair by revocation. ${ }^{11}$ An exception, of course, exists in those cases where the public safety or health is involved $;^{12}$ and it is now quite general for the state to expressly stipulate that it does not part with, but on the contrary continues to retain the right to revoke the charter or franchise, for causes which seem sufficient to the granting body. ${ }^{13}$

Obnoxious Monopoly Effectuates Public Injury.-But the type of monopoly which has greatly concerned the law-makers of most civilized states during recent years has not to do with any special privilege or grant from the government; the exclusive condition has been acquired by combinations between manufacturer or merchants or both, often aided by artificial manipulation of the volume of imports from foreign markets. And here as in most other cases where an offence is made criminal by statute,

9 This principle is demonstrated in State v. Wilcox, supra.

Io Charles River Bridge v. Warren River Bridge, II Pet. 420, 9 L. Ed. 773, 938; Bartholomew v. Austin, 85 Fed. 359,29 C. C. A. 568.

II Dartmouth College v. Woodward, 4 Wheat. (U. S.) 5I8, 4 L. Ed. 629. See also, New Orleans Gas Light Co. v. Louisiana Light, Etc., Co., II U. S. 650, 6 Sup. Ct. 252, 29 L. Ed. 516; Walla Walla v. Walla Walla Water Co., 192 U S. I, 19 Sup. Ct. 77, 43 L. Ed. 341; Louisville Gas Co. v. Citizens' Gas Light Co., I15 U. S. 683, 6 Sup. Ct. 265, 29 L. Ed. 510 (reversing $8 \mathrm{I} \mathrm{Ky} .263$ ). All the cases except the first relate to franchises by their terms exclusive.

12 New Orleans Butchers' Union Slaughter House, Etc., Co. v. Crescent City Livestock Landing, Etc., Co., III U. S. 749, 4 Sup. Ct. 265, 28 L. Ed. 585 .

I3 New Orleans v. Hoyle, 23 La. Ann. 740; Gorrell v. Town of Newport, Tenn. Ch. App. 120. See also Corporation Laws and Constitutions of the several States, where it is now universal to reserve the power to revoke charters. 
the intent rather than the result is the controlling element, when the person charged is put upon his trial. ${ }^{14}$

Restraint of Trade Impairs or Destroys Commerce.-The injury to the public is as disastrous in its results upon trade, as if the monopoly had been created by some favoring legislation; but the growth of monopoly by combination is frequently so slow and insidious that individual trade is dead before the people understand the nature and extent of the fatal influence.

\section{PUBLIC INTERESTS PROTECTED.}

Laws Usually Adequate, when Enforced.-In most cases, the law is adequate, when it is taken up energetically and especially, where the public authorities set the criminal law in motion. To bring a given case within the prohibited class, some degree of substantial monopolization is necessary; though it is not essential that the monopoly should be complete, or nearly so. Some control of the market is all that is called for to bring about such an infraction. And this principle extends to every variety of article that is a public necessity. Thus, machinery and tools, metals and stone, fuel, illuminating oils, drugs, together with ordinary provisions and household supplies, - have each been held to be the objects of monopolies, at various times; and such restrictions upon trade have been declared against public policy, though where latitude was left for actual competition, reasonable agreements have been tolerated by the courts. ${ }^{15}$

I4 Reasonableness or unreasonableness of the extent of restraint which is imposed upon commerce is not material, where intent or ability to create monopoly is made to appear. U. S. v. Trans-Missouri Freight Assoc., I66 U. S. 290, 17 Sup. Ct. 540, 4 I L. Ed. 1007; Chesapeake \& Ohio Fuel Co. v. U. S. II5 Fed. 610, 623. For argument opposed to above doctrine, see Over v. Byram Foundry Co., 77 N. E. 302 (Ind. App., 1906). The Standard Oil (22I U. S. I) and American Tobacco (22I U. S. 66) cases indicate an application of the common law "rule of reason" when judicially passing upon each situation. Probably the forthcoming decision by the Supreme Court in the pending appeal in the Harvester Case (2I4 Fed. 987) will have an important bearing here. For this rule in its application to right of a patentee to take his profit in whole or in part by requiring certain specified material to be employed in connection with the use of his protected device,-see Henry v. A. B. Dick Co., 224 U. S. I ; explained in Bauer et cie., 229 U. S. I. For discussion of principles involved,-see Standard Sanitary M'f'g Co. Case, 191 Fed. 172, (4 Fed. Anti-trust Dec. 395), affirmed 226 U. S. 20. For basic grounds on which monopolies are illegalized, compare generally early decision, Darcy v. Allen, page 16 , supra.

I5 Cooke's "Combinations, Monopolies," etc., sections 13, I4; "Monopolies," 27 Cyc., pages 899, 900, etc. 
Rate Fixing Falls within General Prohibition.-Generally speaking, all combinations between traders or manufacturers intended to suppress competition between themselves fall within the same class of prohibited agreements.

Rate-fixing by insurance companies or their agents when it tends to suppress competition, has been held to suffer from the same taint. ${ }^{18}$

Banks and Common Carriers under Separate Jurisdictions. -Combinations calculated to create monopolies, when undertaken on the part of transportation companies or by banks, are in general exempted from the operation of proceedings instituted under either the Federal Trade Commission Act or the Clayton Law, and they will not be considered here.

Contracts against Public Policy Usually not Enforcible.The rule seems to be that members of an agreement against public policy cannot successfully prosecute actions between themselves, where the object sought is to enforce such a contract, ${ }^{17}$ and this rule extends to affording a non-member a complete defence, when sued to compel compliance therewith. ${ }^{18}$

The rule, however, must be understood to apply only to matters directly connected with contracts in restraint of trade, collateral or independent matters being subject to the usual rights of enforcement which pertain to contracts generally. ${ }^{10}$

Equity courts will not enforce such restraining contracts by specific performance, but are somewhat more lenient in respect to compelling payment for goods or services, where there is

16 In re Insurance Policies, $7 \mathrm{~Pa}$. St. 17; Beechley v. Mulville, 102 Iowa 602; Queen Ins. Co. v. The State, 86 Texas 253, 266. Combinations to fix rates, etc., may be prohibited by State laws, without violating provisions of Fourteenth Amendment of Federal Constitution. Carroll v. Greenwich Ins. Co., 199 U. S. 401 ; Joyce on Monopolies, § 236.

17 Gibbs v. Consolidated Gas Co., 130 U. S. 396, 9 Sup. Ct. 553, 32 L. Ed. 979; McCutcheon v. Merz Capsule Co., 7I Fed. 787, ig C. C. A. 108, 31 L. R. A. 415 .

- 18 Pacific Factor Co. v. Adler, 90 Cal. 110, 27 Pac. 36, 25 Am. St. 102; McCutcheon v. Merz Capsule Co., supra.

19 Chicago Wall Paper Mills Co. v. General Paper Co., 147 Fed. 491. This principle does not apply, however, in jurisdictions where such defences are permitted by explicit statutory provisions. National Lead Co. v. Grote Paint Store Co., 80 Mo. App. 247; Pasteur Vaccine Co. v. Burkey, 22 Tex. Civ. App. 232, 54 S. W. 804. 
no mandatory statute making membership in a combination in restraint of trade a complete defence. ${ }^{20}$

New Anti-trust Laws may Establish New Rulings.-These last mentioned rules can, at first, be only an uncertain guide in actions under the Federal Trade Commission Act, or the Clayton Law, since the Commission will of necessity create its own rulings as to the extent to which it will recognize or enforce contracts of the prohibited monopolies; but nevertheless these rules and the decisions associated therewith constitute the only existing guides upon the subject in hand, and they are presented by way of suggestion, until this new legislation shall be construed and its limitations officially defined.

\section{CONSTITUTIONALITY OF NEW LEGISLATION SEEMS ASSURED.}

Test of Constitutionality Stated.-Anti-trust statutes which are not retrospective in their operation, and which do not discriminate in their application, have been usually upheld, where their constitutionality has been the subject of attack. ${ }^{21}$

The so-called police power of the state is so broad in its scope and so drastic in its compelling force that Congress can go very far in combating anything approaching the character of a monopoly, without exceeding the recognized functions of legislation. ${ }^{22}$

Federal Regulation Limited to Interstate Trading.-It need not be said, however, that the power of Congress is limited to interstate trading and business. By the nature of these statutes questions which arise from transactions carried on within the confines of a single state are relegated to the local courts $;{ }^{23}$ and those questions will not be considered here.

20 The rule does not extend to permitting defendant to interpose the defense of monopoly or restraint of trade, when sued for an infringement of patent rights. General Electric Co. v. Wise, 119 Fed. 922; Columbian Wire Co. v. Freeman Wire Co., 7r Fed. 302; American Soda Fountain Co. v. Green, 69 Fed. 333; National Harrow Co. v. Quick, 67 Fed. I30; Strait v. National Harrow Co., 51 Fed. 819. See distinction between patentee's rights and those of owner of copyright, in this particular, noted in Chapter XV, pages 185-205, post.

2I Addystone Pipe and Steel Co. v. U. S., I75 U. S. 2II, 20 Sup. Ct. 96, 44 L. Ed. 136, affirming 85 Fed. 171.

22 Northern Securities Co. v. U. S., 193 U. S. 197, 48 L. Ed. 679, 24 Sup. Ct. 436 .

23 Addystone Pipe and Steel Co. v. U. S., 175 U. S. 21r. Note portion of decision modifying the judgment of the Circuit Court of Appeals on the ground that the latter decree undertakes to regulate other than interstate trade and commerce. 


\section{CHAPTER III.}

\section{FEDERAL TRADE COMMISSION'S FUNCTIONS:}

1. As a Board of Inquiry.

2. As a Judicial Body.

General Comment.-The main functions of the Federal Trade Commission are fundamentally distinct. In the one instance it sits as a Board of Inquiry, institutes and prosecutes investigations, compiles data and reports, either at its own instance or at the request of Congress or the President. In the other capacity, it hears testimony and issues orders granting relief, which orders are reviewable and may be enforced by the Federal Courts.

The combination of powers so dissimilar, and each so far-reaching, creates a department which is unique in Federal legislation. The originality of the Congressional conception of what this body should be indicates that the abuses thereby sought to be curbed or destroyed were such as usual remedies failed to overcome. That this is so, the history of Anti-trust legislation and of the resultant litigation would seem to show. Rules were adopted which the trusts often ignored and found means to circumvent through technical points of law. This condition, as appears in Chap. VIII, Sherman Anti-trust Law, pp. 70-95, at length became intolerable. The small manufacturer or merchant existed only by sufferance, and the business world was strewn with the wreckage of battles in which the resources and acumen of the trusts destroyed the independent competitor with monotonous regularity. To end this superiority of combined wealth, and to restore the equilibrium of competition operating in accordance with law, Congress enacted various restrictive laws ending with the Federal Trade Commission Act and the Clayton Law, which are in effect a code of business ethics, fortified with provisions for carrying those rules into effect. Furthermore, since the full-grown trust has displayed a rampant energy and pugnacity which statute-laws seemed helpless to meet and overcome, Congress has sought to pursue a preventive course by prohibiting "unfair methods of competition in commerce" with the intention of guarding legitimate business against piratical and unfair methods of illegitimate combinations and powerful unprincipled competitors fraudulent 
practices generally, and thereby to preserve so far as possible equal opportunity and a fair chance for all.

This explanation is necessary before entering upon a description of the functions of the Commission itself. The functions must be viewed in connection with the situation they were intended to meet; otherwise the machinery created for that purpose cannot be appreciated or understood. If the purpose of these statutes is kept clearly in mind, numerous difficulties or uncertainties will disappear and the task of understanding their provisions will be greatly diminished.

\section{THE COMMISSION'S FUNCTIONS AS A BOARD OF INQUIRY.}

Inquisitorial Powers Enumerated.-By Section 6 of the Federal Trade Commission Act general power is vested in that Board to gather, compile and distribute information. With this object in view the Commission is given power in eight particulars,probably confined, however, to matters connected with enforcing the Anti-trust laws:

(a) To inquire into the organization, business, conduct, practice and management of any corporation engaged in commerce excepting banks and common carriers and the relation of such corporation to other corporations and to individuals, associations and partnerships.

(b) To require annual or special reports, covering the lines of inquiry named in the paragraph (a).

(c) Upon its own initiative or upon the request of AttorneyGeneral, it shall be privileged to inquire into and report upon the effectiveness of any final decree in any suit brought by the United States to prevent and restrain any violation of the Anti-trust acts.

(d) Upon the direction of the President or either House of Congress to investigate and report the facts relating to any alleged violations of the Anti-trust acts by any corporation.

(e) Upon the application of the Attorney-General, and with the obvious and laudable purpose of preventing litigation, the Commission is authorized to investigate and make recommendations for the readjustment of the business of any corporation alleged to be violating the Anti-trust laws.

(f) In the interest of the public the board is authorized and empowered in its discretion to publish the records of its investiga- 
tions, not including trade secrets and names of customers, and to publish its decisions; also to make annual and special reports to Congress, with recommendations for additional legislation.

(g) From time to time, to classify corporations and make rules and regulations for the purpose of carrying on the provisions of the act. Much discussion took place in the Congressional committees concerning the futility of compelling reports unless the Commission had previously fixed a standard of computation, so that the information thus collected and filed would be in a form convenient for reference, and by comparison of the reports definite results could be secured. The right to classify and to make suitable rules, etc., should obviate that difficulty. Doubtless, among the approximately 300,000 corporations amenable to the Federal Trade Commission, a large percentage will not afford anything of interest to the Commission, and will be excused altogether from the burden of making reports. Special reports can be demanded whenever occasion requires.

(h) Investigations are authorized into matter connected with the foreign trade of the United States and the Commission is empowered to report to Congress thereon, with recommendations. Hearings have been held at commercial centres, looking to such a report at the ensuing session of Congress.

Public Hearings Optional with Commission.-No specific provision of the Federal Trade Commission law requires it to hold public hearings or to make public its proceedings or the resultant information, except at its own volition. The Interstate Commerce Commission holds public sessions in some though not all of its investigations; the Bureau of Corporations has conducted all its hearings in private and it seems entirely optional with the Federal Trade Commission to adopt either course, as it deems fit. Probably those investigations it holds under its strictly inquisitorial powers will not be conducted publicly, and only the results will be published in annual or special reports. Where corporations neglect to file required reports, or fail to impart information duly called for, penalties are imposed by this act.

\section{THE FEDERAL TRADE COMMISSION AS A JUDICIAL $B O D Y$.}

Complaints Filed only When Violations Shown.-In the exercise of this function, the Commission is empowered to hold hearings as to particular acts and to enter orders in accord- 
ance with the facts disclosed (Federal Trade Commission Act, Section 5).

Complaints may be filed only by the Commission itself when it has reason to believe the law has been violated. This statutory interdiction against natural persons or corporations instituting proceedings, in effect simplifies the practice. When a complaint appears to the Commission to be without merit, filing thereof can be refused. Probably, in the event of a mistake, mandatory proceedings would lie in the United States District Court to compel acceptance of such a complaint. ${ }^{1}$

The absence of any absolute right by a party to file a complaint applies to both the Federal Trade Commission Act and to the Clayton Law (compare Clayton Law, Section II). It is hardly conceivable that such omission should be without some definite purpose or plan. Probably refusal to file a complaint will amount in Commission practice to the dismissal of a pleading in ordinary courts of law or equity.

Complaints under Section 5 of the Trade Commission Act have an element which distinguishes them from complaints under Sections 2, 3, 7 and 8 of the Clayton Law. In the former proceedings, the element of "public interest" must be present, whereas under the Clayton Law the disputes of private individuals are the matters required to be adjudicated. This important and farreaching distinction gives to proceedings under Section 5 of the Commission Act something of the nature and scope of state-instituted prosecutions under the provisions of Section 4 of the Sherman Law.

The whole purport and scope of the Federal Trade Commission Act lends itself readily to such an interpretation of the language of the statute. It is fitting and natural that the law which provides the means of making effective the Anti-trust laws in so far as they effect general business concerns, should in the same statute designate a class of acts and type of behavior that the Commission can take cognizance of only when the public interests are concerned. This rule in practice will emphasize such complaints, for the interest of the public therein will constitute them state trials in numerous instances; and the Attorney-General

I To this effect, see Interstate Commerce Commission v. Humboldt Steamship Co., 224 U. S. 484. 
may no doubt intervene to protect the rights of the community at large.

Provisions Analyzed and Compared.-The authorizing words of the statutes conferring power upon this Commission to hold hearings under the Federal Trade Commission Act, Section 5, and the Clayton Law, Section II, are generally the same, except that the Commission under the former law is empowered to proceed only when "it shall appear to the Commission that a proceeding by it in respect thereof would be to the interest of the public." This grant of power is in substance similar to that which the original Act to Regulate Commerce (Sections 12, I3) confers upon the Interstate Commerce Commission in respect to its rights to hold hearings and enter orders. While we find in the Act to Regulate Commerce, Section I3, a provision that "no complaint shall at any time be dismissed because of the absence of direct damage to the complainant," and while there is no positive direction to that effect in either of the statutes regulating the power and procedure of the Federal Trade Commission, it is probable that the legal result is the same. ${ }^{2}$

Under the last-named statutes it becomes the duty of the Federal Trade Commission to issue a restraining order if it shall be the opinion of the Commission that the prohibitions contained in those laws "have been or are being violated." No mention is made or anywhere suggested that proof of "direct damage to the complainant" is made the test of ability to successfully carry the proceeding to conclusion. It appears to be assumed that while such an element might be pertinent to the case, it is not an essential feature in the proceeding.

The legal questions presented by the grant of power to hold hearings and enter orders persuant to the provisions of the Federal Trade Commission Act and the Clayton Law will in due course be definitely set at rest by judicial construction.

From the wording of both these laws it seems very plain that Congress neither attempted nor intended tc institute a new branch of the legislative department of government; rather, the purport and natural inference and construction is that the Commission has been given power to act as a judicial body. In furtherance and

2 For purposes of comparison of powers, see Statute-Interstate Commerce Act (Act to Regulate Commerce, approved February 4, 1887), contained in Appendix O, pages 345, 36I. 
corroboration of this idea, attention is called to the fact that the Commission may be asked to act in conjunction with a court of equity, and as a master in chancery frame an appropriate form of decree in actions brought by the Attorney-General under the Antitrust laws (Trade Commission Act, Sec. 7). 


\section{PROHIBITIONS UNDER THE CLAYTON LAW.}

I. Unfair price discrimination.

2. Conditional or "tying" contracts.

3. Ownership by one Corporation in the stock of another.

4. Interlocking Directorates.

a. Corporations generally.

b. Provisions as to banks:

c. Provisions as to common carriers.

\section{UNFAIR PRICE DISCRIMINATION.}

Terms Originally More Severe.-This provision (section 2) was originally much more drastic, and as it came from the House, its terms made all price discrimination unlawful. The conditions which mitigate the statutes' severity were added by the Senate and in its present form no harm can be done to any person or corporation with honest intention to deal fairly. ${ }^{1}$ Indeed, this provision is more lenient than its prototype, Laws of New Jersey, Chap. 15, Session 1913, where no allowance is made for the "cost of selling," or for "discrimination in price in the same or different communities made in good faith to meet compecition," nor are the merchants to select their customers. There is no mystery about the nature, extent or reality of the "unfair methods" which is aimed at by Congress in this enactment. The record of the testimony and proceedings leading up to the decrees of dissolution of the Standard Oil Company and The American Tobacco Company show clearly how the practice of the trusts when so disposed, have worn down and crushed their competitors. Corporations, covertly controlled, were specially organized to cut prices in one community, while the price was maintained or even

I In the initial Clayton Bill decision, Great Atlantic \& Pacific Tea Co. v. Cream of Wheat Co., 224 Fed. 566, (So. Dist. of N. Y., July 20, 1915), it was held that the basic right to select customers recognized and incorporated in the provisions of Section 2 permits the defendant to refuse to sell to plaintiff.

In arriving at the general result adverse to plaintiff, the District Court relies upon the reasoning and citations contained in Fisher Flouring Mills Co. v. Swanson, 76 Wash. 649. Decision affirmed, November 9, 1915.

This Clayton Law decision is also referred to herein at pages 193, 194. 
raised elsewhere; retailers were penalized if competitors' goods were displayed; and numerous other devices resorted to in order to monopolize the business. Perhaps the extreme is shown in the record of the methods alleged to have been employed by a certain manufacturing concern, where it is charged that agents were employed to disarrange or mutilate the machines of competing concerns, in order to enhance the superiority claimed for those manufactured by the first-named concern.

Statute Ample for Purpose.-The latitude in trade permitted by the statute should be ample for those concerns intending to deal fairly; and as to the others, the severity of the law will be well employed in restraining or extinguishing their activities. The statute is well drawn to accomplish its purpose. No legitimate enterprise can suffer by compliance with its terms. The law has served due notice upon the predatory class in business, and it becomes the duty of the Federal Trade Commission to enforce the statutory requirements. Section I I vests in the Interstate Commerce Commission or the Federal Reserve Board the right to enforce Sections 2, 3, 7, and 8 where applicable respectively to common carriers or banking institutions. Section I6 further restricts to the United States government the right to apply for injunctive relief against railroads, in certain cases. Since neither banks nor railroads are dealers in commodities, it is probable Congress did not intend to include banks or transportation concerns within the scope of Section $2 .^{2}$

\section{CONDITIONAL OR "TYING" CONTRACTS.}

A Common Form of Oppression.-This practice has been common on the part of large concerns which have sought to introduce with their selling contracts a clause so "tying" up their customer that dealing with competitors was rendered almost or quite impossible. By Section 3 of the Clayton Bill, such practice is made unlawful, and the insertion of a "tying" condition is prohibited in interstate commerce, whether the articles are patented or unpatented, and whether delivery is made by sale or lease. The lawfulness is made to turn upon whether the effect of the transaction is substantially to lessen competition, or whether it tends to create a monopoly. Thus the question of fact will be the turning point in every instance, and contracts regulating

2 See Butler \& Lynde's Federal Trade Commission, pages 9 and 10. 
dealings having a legitimate and fair purpose are not likely to be disturbed. In its practical effect this clause will probably be construed to permit the patent owner to require specified material to be used in connection with his patent machine or process, as was recently permitted under then existing laws in Henry v. H. B. Dick Co., 224 U. S. I ; but it is equally probable he will not be permitted to compel the licensee to employ such material generally, regardless of its use in association with the patented invention.

The former right would seem to be in accordance with the patentee's right to exercise or transfer the privilege of "exclusive use" which letters patent confer; while the extension of that right by compelling the licensee to agree to employ such material generally would appear "to substantially lessen competition or tend to create a monopoly in any line of commerce,"-to constitute such a "tying" contract, in brief, as Section 3 was intended to prohibit in connection with patented or unpatented articles.

It may be that the Commission and the courts will construe the statute so broadly that the practice of selling patented devices under "tying" contracts will be authorized where the general volume of the material "tied" to the use of the patented machinery is not so controlled as to create a universal restraint and monopoly. in that general line of trade, for every reasonable latitude should be afforded the inventor to reap the full benefits of his discovery; but the apparent intention of the legislation is to restrict the "exclusive right" which a patent confers, to those things directly associated with the protected invention itself.

Object is Plain.-Comment seems uncalled for as the object of the statute is plain and speaks for itself. By the provisions of Section II, exclusive jurisdiction is conferred upon the Interstate Commerce Commission and the Federal Reserve Board to enforce the prohibitions contained in Sections 2, 3, 7 and 8, where applicable to common carriers or banking institutions, respectively. Probably the instances where "tying" sales or leases will occur in connection with the two last-named classes of corporations will be extremely few ; but the intent of Congress was clearly to interdict them, wherever and whenever their presence, joined to a monopolistic intent, is made to appear. 
3. OWNERSHIP OF ONE CORPORATION OF STOCK IN ANOTHER, WHERE THE EFFECT MAY BE TO RESTRAIN COMMERCE OR MAY TEND TO CREATE A MONOPOLY.

Provision Aimed at Abuse of Stock Control.-This prohibition (Sec. 7) is not directed against natural persons but relates to corporations only. It covers competing corporations actually engaged in commerce and also holding companies, whose sole function is to own and operate other incorporated enterprises.

Under Section I I the Interstate Commerce Commission or the Federal Reserve Board are specifically given power to enforce the provision of this section (7) whenever it calls for determination of the affairs of a common carrier or bank. Saving clauses are contained in the text which permits corporations to own stocks for investment, to form subsidiary corporations for non-monopolistic purposes, and which exempt stocks theretofore legally acquired. Common carriers are also permitted to own stocks in branch line companies.

Control by Holding Company Illegalized.-It will be seen that the scope and purpose of the statute is to prohibit an abuse which by degrees crept into the laws of certain jurisdictions, commonly known as "the incorporating States," and resulted in an abuse of the power to grant chartered rights. A competition in the enactment of corporation laws permitting companies to "do anything anywhere"-a maximum of powers with a minimum of responsibility and supervision-brought about an impossible situation.

Under the theory of the comity of States, these powers were accorded a measure of recognition even in jurisdictions where locally incorporated companies were denied similar privileges, and in the end confusion was sure to ensue. The corporation tax became a prize for the least conscientious in this competition in lax lawmaking, and while the fees of the Secretary of State became an Aladdin's lamp of income in numbers of instances, in one jurisdiction the salaries of the state officers and the judiciary were reputed to be met from that item alone.

Where the revenues from the trusts and large incorporated interests were so important in making up the annual budget, small concerns could not hope for equal consideration; and thus the scales of justice became suspected of being in a condition of unstable equilibrium. An aristocracy of wealth arose, which was an 
anomoly and contradiction in a republic. Fortunately, the federal court perceived the logical sequence of such overgrown powers vested in State-granted charters, and the Gordian knot was cut when those powers were refused recognition and enforcement in the Northern Securities case. ${ }^{3}$ Since that time the decline and fall of the "holding company," as a vehicle for carrying out trustcontrol, has been rapid and sure. Probably, the death-knell of that peculiar institution of vested rights in monopoly and business oppression has been sounded by the enactment of the Clayton Bill. It is, in fact, a declaration of the independence of the concern of moderate size from the domination of its overgrown rival. Even in the States where the larger portion of the tax burden was borne by favored interests "for a consideration," the return to free and fair conditions and active competition will be welcomed, when the present generation of business men have noted the freer and wider opportunities which the provisions of the Anti-trust laws afford. Perhaps it will be wise to again call attention to the fact that this provision concerns only corporations. Nothing therein contained prevents the ownership of stock of competing corporations by firms or individuals.

\section{INTERLOCKING DIRECTORATES.4}

In General.-This provision is a new development in anti-trust legislation. It is probably an outgrowth of the congressional investigation into the banking situation, instituted as an inquisition preparatory to the enactment of law creating the Federal Reserve Bank. The subject is treated under several divisions, and as our particular concern lies with business corporations, we will first take up for consideration:

\section{a. Prohibition of Directorship in Competing Companies.}

Undue Influence Gained by Official Connections.-Section 8 of the Clayton Law renders it unlawful to hold the office of director in two or more competing corporations, where one of these

3 U. S. v. Northern Securities Co., 193 U. S. 197.

4 The debates in the 6and Congress (for substance thereof, see Appendix M, pages 304,334 ) which led up to the enactment of the Clayton Law plainly indicate that this and the three preceding inhibitions were intended to go to the root of "unfair methods of competition in commerce," and to overcome these practices by attacking them at such an early stage that they should not have the opportunity to become strong and formidable. 
has assets of more than $\$ 1,000,000$, including capital, surplus and undivided profits. The evil sought to be cured is the practice of manifold directorships held by capitalists in concerns which on the surface are active competitors. As a matter of fact, the inside information and the friendly intercourse leads to a practical monopoly and kills all real competition in business. It also makes the allied interests act as a unit against any new enterprises that enter into their particular field. The "unfair methods of competition in commerce" prohibited by Section 5 of the Federal Trade Commission Act no doubt frequently have their inception in the personal dealings and private conclaves so natural in the confidential conferences of the meetings of the various boards of directorates; and of this fact and this human tendency Congress has taken notice, as shown in this prohibition of plural directorships. The assets computed as stated above exclude dividends declared but not paid at the end of the fiscal year next preceding the election of directors, and a director lawfully elected may continue to hold office for his annual term. This provision in general seems well calculated to remove, or at least to obstruct one source of monopolistic control; and later statutory amendments can strengthen the inhibition, should its avoidance in practice nullify the good intent of the law.

\section{b. Interlocking Directorates of Banking Institutions.}

Holding Plural Positions in Banks Regulated.-The provisions of Section 8 in so far as they relate to banks extend to officers and employes, as well as to directors. In that respect they differ from the corresponding regulations governing the management of common carriers and of corporations engaged in general business transactions. While the general scheme of this portion of Section 8 is so plain as to be obvious, the wording is unfortunate, and results in ambiguities and difficulties that are needless in a carefully constructed statute such as this should be.

Now as to the general scheme,-this is certainly to render unlawful community of directorates, in whole or in part, in banking institutions with large resources. As a measure of size, Congress has adopted the unit of $\$ 5,000,000$ as bringing the institution, whether organized under federal or state laws, within the class where a person must be satisfied with a seat at one directors' table. In computing the component assets,-deposits, capital, surplus and undivided profits are taken at the valuation thereon 
placed in the annual report for the fiscal year next preceding the date for the annual election of directors. The prohibition becomes effective two years from the date of the approval of the Clayton Law, i. e., October 15, 1916, and directors lawfully elected can continue to hold office for one year, notwithstanding one or more of the institutions have grown to proportions that would otherwise bring them within the prohibited class. This much of these provisions of Section 8 is plain and needs no interpretation.

Out of abundant precaution Congress has made the inhibition of interlocking bank directorates absolute in cities of more than 200,000 population, as computed in the last preceding decennial census. The period of grace which defers operation two years is not mentioned in this paragraph; but a provision excepts one institution where the entire capital stock is owned by stockholders in the other bank. Mutual savings banks not having a capital stock represented by shares are also exempted from the restrictions of this portion of Section 8. While no terms appear whereby it is expressly stated that the two years' limit is fixed for the going into effect of the prohibition relating to municipalities of more than 200,000 population, still the general intent to permit liberal time for adjustment to the circumstances ensuing from the novel environment this statute creates, seems to imply that such was the legislative intent.

Probable Modification.-Furthermore, it seems likely that prohibition against occupying a duplicate seat as director, etc., in corporations of more than $\$ 5,000,000$ of assets was intendcd to be modified by the provision as to entire stock ownership. The whole attitude of the law-making power seems to be conciliatory, outside the limits of the absolute inhibitions; and reasonable inferences as to latitude in carrying the law into effect, seems to be warranted. In fact, the Department of Justice under date of November 24, 1914, has expressed its opinion (I) that a director in a banking institution may serve in a national bank not having common ownership of stock, until the expiration of two years from the approval of the Clayton Law, and until the date thereafter when the annual election of directors is held; (2) that the right to the office of director in two institutions whose deposits, capital, etc., exceed $\$ 5,000,000$, exists where the stock of one is wholly owned by the stockholders in the other; (3) that the pro- 
visions of Section 8 as to the two-year date within which the act shall take effect, and as to mutual savings banks, common stock ownership and Federal Reserve Banks should also apply. In other words, in all cities, regardless of size, directors of banks may continue to sit at more than one board, until the period ending October 15, 1916, has expired, and until the next ensuing annual election.

As has been already explained, the Congressional intent must be gathered from the whole section construed together, and reasonable latitude as to time and method of application is implied; so that the statute will bear and should be given a liberal interpretation, in those particulars where positive prohibitions are not directly involved.

\section{c. Provisions of Section 8, Regulating Interlocking Directorates of Common Carriers.}

Exemption Covers Only Railroads.-By an express exemption common carriers subject to the Act to Regulate Commerce, approved February 4, 1887, are relieved from the restrictions contained in Section 8 of the Clayton Law; but this exception is confined to railroads only. The statute thus referred to and made controlling here, is the original act to regulate commerce, and no common carriers excepting railroads are included within the scope of that act. Hence, it is evident that no person can be at the same time a director in two corporations, including common carriers other than railroads, if elimination of competition by agreement between them would amount to a violation of any of the anti-trust laws.

Mr. Clayton, in the Report of the Judiciary Committee of the House, (printed in Senate Report No. 698, page 48) says on this point that "calamities of fire and flood" may make it sometimes necessary for a railroad to secure additional funds in the most expeditious and convenient quarter, and that accordingly railroads should be left free to have banking interests represented upon their. boards. No doubt it was also felt that the Interstate Commerce Commission had power and authority to deal with any abuse of this privilege, if such should occur.

Where common carriers are specified at other places in the Clayton Law, different language is employed so that the above deduction and inference seems abundantly supported in the text of the section itself. Thus at Section 7, paragraph 4, we find the 
words: "any common carrier subject to the laws to regulate commerce;" Section 9, paragraph I, "Every * * * corporation engaged in commerce as a common carrier;" Section I0, paragraph I, "common carrier engaged in commerce," which leads to the general conclusion that all common carriers, excepting railroads, fall within the class of corporations where interlocking directorates are prohibited.

If this construction of the statute is correct, then pipe line, express, sleeping car, telegraph and telephone companies are subject to the prohibition and are forbidden to have interlocking directors. Probably virtual control could be achieved, however, where subsidiary corporations that do not "substantially lessen competition" are concerned, by the ownership of the stock-control, permitted "by Section 7, paragraph 3; and since such cases would not "constitute a violation of any of the provisions of any of the anti-trust laws," it is probable that no charge could properly be made under the provisions of Section 8. Reverting again to Section 7, the language of paragraph 2, when read in connection with the succeeding paragraph, would appear to indicate that Congress intended to confer upon common carriers equal rights with other corporations in the matter of owning stock in subsidiary companies incorporated to carry on enterprises not otherwise declared unlawful by the anti-trust laws. 
PROVISIONS FOR ENFORCEMENT; PARTICULARLY, PROCEDURE UNDER SECTION 5 OF THE FEDERAL TRADE COMMISSION ACT, AND UNDER SECTION II OF THE CLAYTON LAW, TO MAKE EFFECTIVE SECTIONS 2, 3, 7, AND 8, OF SAID LAW.

I. Necessity For and Means of Enforcement.

2. Statutes Differ in Important Particular.

3. Procedure Before Commission Described.

4. Congress Prescribed Only Limited Review.

5. Commendatory Rulings Not Part of Legislative Plan.

6. Service of Process.

\section{NECESSITY FOR AND MEANS OF ENFORCEMENT.}

Necessity for Reform Caused Evolution of these Laws.The abuse of freedom in conducting corporate enterprises, and the practice of creating and conducting chartered bodies solely to advance some trade-restraining scheme, are subjects that have been considered by Congress for many years, and numerous corrective laws relating thereto have been added to the statute books. The Federal Trade Commission Act and the Clayton Law are but the latest in this series of Anti-trust legislation. The Commission is specially authorized to report to Congress (Commission Act, section 6, paragraph $\mathrm{f}$ ), as to the additional enactments which it may deem advisable.

Means to Enforce Required.-But laws of this nature intended to combat and destroy abuses of such long standing and affecting such powerful interests are not self-acting, and adequate provisions for the enforcement of their mandatory or prohibitory features must be carefully prepared; otherwise, the laws will be ignored or disobeyed with impunity. The procedure is contained in Section 5 of the Federal Trade Commission Act and Section I I of the Clayton Law. In terms they are practically identical, except that the Commission is only authorized by the firstnamed law to file a complaint when "it shall appear to the Com- 
mission that a proceeding by it in respect thereof would be to the interest of the public,"-Section 5, Federal Trade Commission Act. Under the Clayton Law, instances where infraction of its provisions shall be followed by proceedings, civil or criminal, are set forth specifically and in detail; whereas in the Federal Trade Commission Act the responsibility for exercising a wise discretion devolves squarely upon the Commission itself.

\section{STATUTES DIFFER IN IMPORTANT PARTICULAR.}

A Distinction Noted.-Doubtlesss there is a reason for this peculiar feature of the statute creating the Commission, and this reason probably consists in the determination by Congress that every infraction of the Clayton Law shall be considered a matter affecting "the public interest"; whereas violations of the rules established to prevent unfair methods of competition in commerce might often appear too trivial or too open to excuse or to a reasonable doubt to warrant seriously entertaining the belief that such a proceeding would be "to the interest of the public." Such seems the logical inference from the wording of these statutes,as well as from the surrounding circumstances that should always be studied and given weight when seeking to arrive at the legislative intent which is the essence of every law.

Means of Securing Information not Specified.-On one point Section 5 of the Federal Trade Commission Act is curiously deficient. It does not state how the information shall be obtained on which the Commission is to act in cases where the "public interest" is concerned. This omission was no doubt due to inadvertence on the part of the lawmakers. In actual practice, those features will, no doubt, be supplied by the Rules and Regulations which the Commission will adopt. ${ }^{1}$ A sworn affidavit or declaration would be sufficient to inform the Commission as to the specified violation of the Federal Trade Commission Act or Anti-trust laws, and this paper would form a basis on which the conscience of the Commission could rest the charge contained in the formal complaint which Section 5 prescribes for the commencement of a proceeding where the "interest of the public" is involved. While the opinion of the Commission is left by statute as the controlling element in deciding the question of recognizing or ignoring the particular charge so far as instituting a proceeding thereon is concerned, the party who feels aggrieved is not left entirely to the

I See Rules of Practice before the Commission, pages 232-235, post. 
discretion of the Commission for his right of redress. While a controversy and matter having an importance entirely personal to the parties concerned would not be entitled to attention under Section 5, yet there would be a "twilight zone" where courts might well disagree with the conclusion of the Commission and would see a public interest in having the particular matter heard and decided in due course. In brief, there must be exceptions to the rule laid down in Section 5; and some outside board or tribunal would necessarily have to act as the court of review, when such exceptional cases were shown to exist. Such a useful provision is found in practice, for mandamus proceedings would lie to compel the Commission to assume jurisdiction, in case it arbitrarily refused to take cognizance of the charge, after due compliance with the formalities required by the rules. ${ }^{1 \mathrm{a}}$

It has no doubt been abundantly shown that the element of discretion is given in large measure under the Federal Trade Commission Law, Section 5; whereas under Section II of the Clayton Law the person who alleges a grievance is in effect the moving party. With this peculiar feature of the statute disposed of, we shall pass on to consider the nature of the proceeding instituted under Section 5 of the Federal Trade Commission Act and Section II of the Clayton Law.

\section{PROCEDURE BEFORE COMMISSION DESCRIBED.}

Method of Procedure before Commission.-A proceeding of this nature is begun by the service of a complaint which has been previously issued by the Commission or Board according as the particular case relates to trade or common carriers, or banks. The complaint shall specify a date of hearing not less than 30 days after service on the defendant. Upon the return day defendant shall be entitled to appear and to show cause why an order should not be entered by the Commission or Board requiring such corporation, individual, or firm to cease and desist from the violation of the law so charged in said complaint. Since the powers required to be exercised in deciding questions of this nature are essentially judicial, it is very plain that the statute must intend that all the requirements of due process of law shall be attended to in full measure so that the terms of the Constitution

Ia Interstate Commerce Commission v. Humboldt Steamship Company, 224 U. S. 474, 484. 
shall not be impaired, but on the contrary, the parties shall have ample opportunities to present and urge their arguments and supporting cases. Express provisions in Sections 5 and II permit persons or corporations to intervene, upon due cause shown. In the vast majority of cases the persons interested in the issue raised by the complaint will be large. The result should be a thorough understanding of the situation and of the respective rights of the parties, since the subject will be presented to the Commission from every angle.

When the testimony is closed, it shall be filed in the office of the Commission. If upon such hearing the Commission shall be of the opinion that the method of competition in question is prohibited by either of these laws, it shall make a report in writing in which it shall state its findings as to the facts, and shall issue and cause to be served on such person, partnership, or corporation an order requiring such party to cease and desist from using such methods of competition. Until such order is disobeyed the Commission retains full possession and jurisdiction of the matter; but should the defendant fail to comply with the terms of the order, either that party or the Commission may file a transcript of the entire record with United States Circuit Court of Appeals which shall then assume jurisdiction as to the enforcement of the order, and by its decree affirm, modify or set it aside, as the case may require. The findings of the Commission, if supported by evidence, are binding upon the court, though it is provided that the matter may be retransferred to the Commission for further testimony if the court requires more light upon one or more aspects of the case.

Means for Review Provided.-The wording of the statute is not altogether clear as to the practice connected with the time and manner of service required to make effective the orders of the Commission; but no doubt these points are among the details that will be elaborated in the rules. As has been stated, the Commission retains full jurisdiction of the matters pending before it until such time as a transcript is filed with the United States Circuit Court of Appeals. Until such time of filing the Commission may modify or set aside in whole or in part any report or order issued under either of the Sections, 5 or II, as specified above. The nature of this review must be judicial, for the Constitution has been held to forbid the delegation to the Circuit Court of Appeal of authority of any description other than judicial. 
The scheme which the statute contemplates is quite obvious. The Congressional intent is that the Circuit Court of Appeals shall constitute a reviewing commission, which has ample authority to cancel, alter or confirm the original ruling. The court, as wc have seen, must act only upon the testimony or proceedings before the original Commission or Board; it has no right to add to or change the record, excepting the resultant order.

\section{CONGRESS PRESCRIBED ONLY LIMITED REVIEW.}

Procedure Affords a Limited Review.-This subject was debated before Congressional committees and a diversity of opinion as to the nature and extent of the review of the Commission's rulings developed at those sessions. After much argument, the consensus of opinion was that a "limited review" was called for, viz: that the Appellate Court should have no right to introduce new evidence, while retaining full power to revise the Commission's order in the premises. ${ }^{2}$

This view prevailed in the final draft, and it is now incorporated in the statute that where the Circuit Court of Appeals sees that further evidence is called for in the protection of the rights of any party, it may send the matter back to the Commission, with orders to take additional testimony upon such terms as seem equitable and fair. The Commission thereupon resumes jurisdiction and may recommend to the Circuit Court of Appeals to revise or revoke its former rulings when it returns such additional evidence. No doubt the court may take testimony upon the question whether the case should be returned to the Commission for further testimony, though nothing specifically appears in the law on that point.

Three Separate Opinions Provided; with Final Review by Supreme Court.-The general plan, accordingly, provides for three and under certain circumstances four opinions before the final decree becomes effective in a given case: (a) The Federal Trade Commission or Interstate Commerce Commission, as the situation calls for, files its complaint, hears the testimony and enters its order. (b) Upon a proceeding to enforce said order or upon an appeal by any defendant the Circuit Court of Appeals has authority to review the order and to enter its own decree, canceling, changing, or affirming said mandate, but only on the

2 For substance of the discussion of the proposed Interstate Trade Commission bill, in the Senate, in 1912, see Appendix M, pages 304-334. 
original record. (c) Where the Circuit Court of Appeals requires further testimony, it can return the matter to the Commission, or Board, and said body may make recommendation as to the form of the findings which it thinks proper after taking such additional evidence. (d) As a final precaution and safeguard, the judgment and decree of the Circuit Court of Appeals is by special provision made subject to review by the Supreme Court upon certiorari, as provided in Sec. 240 of the Judicial Code. ${ }^{3}$

It must be apparent that the legislative bodies have devoted exceptional thought and care to the preparation of these statutes, seeking to throw about the business affairs of the country an atmosphere of conservatism that would allay and remove any just occasion for fear or alarm. Certainly an abundant opportunity is provided for discussion and review before the order or decree of the supervising commission, board or court becomes effective and binding.

\section{COMMENDATORY RULINGS NOT PART OF LEGISLA- TIVE PLAN.}

No Commendatory Ruling Authorized.-One other feature was taken up in the debates upon this measure and while it is not incorporated in the statute, some mention thereof may be useful as well as interesting in this connection and at this time. We refer to the proposal to make it lawful for the Commission or Board to enter an order approving the conduct of a given individual, partnership or corporation, in the premises, thereby fixing a standard and setting its official seal of approbation upon good behavior in contradistinction to issuing mandates to restrain evil doing. While it would no doubt be sufficient to say that this provision was not retained in the final draft of the organic statutes creating this new departure and new department in Federal affairs, still it seems to us that the elimination of this power to approve contains a somewhat deeper significance than attaches to the removal of any other proposed change.

The words of the President's message delivered before Congress January 20, 1914, wherein he dealt with trusts and monopolies and urged legislation to create a trade commission,-contained the expression, "the opinion of the country would instantly approve such a commission." The whole tenor of this

3 See Code provisions contained in Appendix I, pages 29I-293. 
message shows he intended and expected that the commission should have advisory and commendatory powers, in addition to its administrative and judicial functions; and that the firstnamed powers would receive public approbation.

The Committee on Interstate Commerce, in its report on the proposed Trade Relations Bill (one of the five measures comprised in substance in the terms of the Federal Trade Commission Act and the Clayton Law), set forth the committee's views on this important topic in the following words: "There ought to be a way in which men in such a venture could submit their plan to the government and inquiry made as to the legality of such a transaction; and, if the government was of the opinion that competitive conditions would not be substantially impaired, there should be an approval, and in so far as the lawfulness of the exact thing proposed is concerned there should be a decision, and if favorable to the proposal there should be an end to that particular controversy for all time."

It is an old saying that republics are ungrateful ; and certainly where political pressure has not fortified the claims of the petitioning party, history records much to be regretted in that respect. The unpaid French spoliation claims, dating back more than a century, constitute a case in point. But this conduct is due as we believe, more to defects in political viewpoint and scheme of government, than to delinquency in morals. In brief, republics do not lend themselves readily to commendatory legislation, and bureaucratic ideas are permitted to obscure the essential equities of the case. That this is a defect may readily be shown by argument or by reflection.

Monarchial institutions on the contrary, in this particular, provide a more elastic means for administering things political. There an actual person and not an intangible ideal entity-the public-rules the state; and human needs, limitations and likewise their demerits or rights to receive rewards can all be brought forward, urged and passed upon in an atmosphere of practical requirements and human sympathy. The eye of the master is ever present in theory at least; it scans the patient labors in the inventor's laboratory; attends the explorer upon his adventures; marks with approval the results of the painter's brush, or the engraver's tool; and it commends the merchant who through years of fair dealing has established a reputation which is a standard of honesty throughout the seven seas. Upon the latter knighthood 
or higher titles are conferred and the state marks him by public acts and in effect says: "Thus shall it be done to the man whom the king delighteth to honor."

Nothing of this nature is practical, hardly possible, in a republic. It is true the "Legion of Honor" has been established in France; and the "Thanks of Congress" confer some mild form of favor for those who have done deeds of exceptional patriotism or prowess. This attempt at conferring distinction where merit exists is some evidence that the people of the United States recognize the existence of a plane of equity which statutes and court decisions do not attain unto. They indicate that the citizens of the American Republic realize the defects of their qualities and are ready and willing to supplement and build up the weak places in the scheme of government we inherit from our forefathers. Perhaps at some future time, and in some effectual way the two schemes of government may be winnowed over, and the best combined in one. Certainly, there could be no harm and much good in permitting the Commission, Board or Court to mark with approval a record of business affairs where the competition has been fair and the rewards won have been gained without fear or favor. Such commendation could and should be confined to the particular matter in hand and relate solely to the past. Future acts would call for future scrutiny. Perhaps this digression may seem to some uncalled for; to others we trust "the right to commend" will seem to be a useful adjunct to a governing Commission, Board or Court.

Procedures under these Statutes Stated and Compared.-In concluding this chapter upon enforcement it may be well briefly to point out again the classes of cases to which the procedure applies. In Section 5 of the Federal Trade Commission Act the statute empowers the Commission to prevent unfair methods of competition in commerce; and to effectuate that purpose, directs said body to issue and serve a summons with a notice of a hearing upon any such person, partnership or corporation whenever it shall have reason to believe said individual, firm or corporation has been engaged in said unlawful practices. It is apparent that a considerable degree of latitude and discretion is lodged in the Commission, since the statute further provides that such process shall be issued and served only when "it shall appear to the Commission that a proceeding by it in respect thereof would be to the 
interest of the public"; but as we have dwelt upon that qualification quite fully in the preceding pages of this chapter, that particular phase of the subject will not be treated of further in this place.

By reference to Section I I of the Clayton Law, two points of difference will be noticed: ( $I$ ) the fact that the item of public interest is presumed; (2) the violation of Sections $2,3,7$, and 8 of that law constitute the occasion for issuing and serving the complaint and notice. Referring to the provisions of the Clayton Law, it there appears that Section 2 relates to price discrimination; Section 3 to conditional or tying contracts; Section 7 to corporate stock ownership in a competing corporation or holding company, and Section 8 to interlocking directorates.

These four sections taken together comprise all the formative features of the Clayton Law and the procedure for their enforcement vitalizes the entire statute. Consequently, it is extremely necessary to those brought into those proceedings or practicing before that body that the subject should be thoroughly understood. The plan is simple and direct, and careful reading of the statute in conjunction with these comments and suggestions should and we believe will remove any existing doubts or uncertainties.

No Express Provision to Review Court Ruling as to Resubmission.-Returning to the express provisions of these statutes, it should be noted that Congress has not in terms provided for any review in cases where the party has applied for and has been refused the right to have the matter returned to the Commission or Board for further testimony. It may be that the legislative intent was that the decision of the Circuit Court of Appeals should be final; but it is to be noted that this phase of these litigations was left for the final consideration of the Supreme Court on application to review the judgment obtained, as provided in Section 240 of the Judicial Code, ${ }^{4}$ under express permission conferred by the. Federal Trade Commission Act, Section 5, paragraph 4.

In corresponding Sections 5 and I of the respective statutes it is directed that the Circuit Court of Appeals shall expedite these proceedings by giving them preference over other cases; also, that no order of the Commission or judgment of the court to enforce the same shall in any wise relieve or absolve any person, 
partnership, or corporation from any liability under the Antitrust acts.

\section{SERVICE OF PROCESS.}

Method of Service.-It is also provided in what manner orders or other process of the Commission or Board shall be served. Such service may be made by any one duly authorized by the Commission, as follows: (1) by delivering a copy thereof to the person to be served, or to a member of the partnership to be served, or to the president, secretary or other executive officer or a director of the corporation to be served; or (2) by leaving a copy thereof at the principal office or place of business of such person, partnership, or corporation; or (3) by registering and mailing a copy thereof addressed to such person, partnership, or corporation at his or its principal place of business. The means of proof of such service are also specified in the statute, (Federal Trade Commission Act, Sec. 5, page 252, post; Clayton Law, Sec. I I, pages 270, 27I, post. 


\section{BANKS,-PROVISIONS RELATING THERETO CON- TAINED IN :}

I. Federal Trade Commission Act.

2. Clayton Law.

\section{BANK REGULATIONS UNDER TRADE COMMISSION $A C T$.}

A New Federal Policy.-The new legislative standard-the declaration of a new Federal policy contained in the words prohibiting "unfair methods of competition in commerce"-constitutes the backbone of the Trade Commission Act.

Twofold Reason for Exemption of Banks.-The definition of the power conferred is very broad and its application so universal as to cover individuals, partnerships and corporations doing business in interstate or foreign trade; but no right is given to enforce the provisions as against banks and common carriers. The distinction is specially mentioned in Section 6, where banks and common carriers are expressly exempted from the investigating powers of the Commission, and from the obligation to make reports. Probably these exceptions only occur when the bank attends strictly to financial business and does not undertake promotions or matters outside of banking affairs, and the same rule applies to common carriers. Each of these forms of business activity has its own Commission or Board to check off its behavior and to prescribe rules and regulations therefor. Accordingly it would be a duplication of liability to place them within the jurisdiction of the Federal Trade Commission, provided, of course, that they each confine themselves to their usual lines.

Furthermore, early decisions by the Supreme Court held banking to be outside of the commerce clause of the Constitution, and hence State legislatives were given permission to assess local taxes thereon. But the refusal of the court to permit Congress to assume exclusive jurisdiction of banking, on the score that engaging in finance is not "commerce," did more than decide the bare question at issue. These decisions ${ }^{1}$ made it of doubtful legality to in-

I Nathan v. Louisiana, 8 How. (U. S.), 73, (1850); Paul v. Virginia, 8 Wall 168 (1868); see also New York Life Insurance Co. v. Deer Lodge County, 23I U. S. 498 (1913). 
clude banking in any statute regulatory of commerce. For one or both of these reasons, therefore, the control of banking is left with the Federal Reserve Board, instead of adding it to the duties already appertaining to the Federal Trade Commission.

\section{BANK REGULATIONS, UNDER THE CLAYTON LAW.}

General Remarks.-While it may appear to some persons that the previous remarks about the provisions as to banks and banking contained in the Federal Trade Commission Act suggest the famous essay on the snakes of Ireland,- "There are no snakes in Ireland,"-still it should be borne in mind that the machinery for carrying out the provisions of the Clayton Law are provided by the earlier act; also, that it is only by exemption from rules otherwise general in their application that banks are relieved from such business regulations, or rather regulations from that quarter instead of or in addition to very minute scrutiny on the part of the Federal Reserve Board.

Principal Functions of Clayton Law, in their Relation to Banks.-The principal functions of the Clayton Law are to regulate or prohibit-(I) Price Discrimination; (2) "Tying" or Conditional Contracts; (3) Ownership by One Corporation in the Stock of Another; (4) Interlocking Directorates.

Judicial Construction does Not Include Banking as Commerce.-From what has been said about the Supreme Court decisions holding that banking is not commerce, it will be readily observed that the Federal Trade Commission is not the proper tribunal where such questions as are involved in ( 1 ) Price Discrimination, or (2) Tying Contracts, can be adjudicated. Its very existence was intended to be a protest against certain "unfair methods of competition in commerce," and to attempt to regulate matters definitely excluded from the "commerce clause" of the Constitution by judicial construction, would be to invite rulings which would undo and render useless all the labor involved. Where a bank or common carrier engages in merchandising transactions, directly or indirectly, however, the Federal Reserve Board or the Interstate Commerce Commission are respectively given full power and authority to enforce these provisions, by Section II of said act; and the procedure for the orderly conducting of such matters is therein fully set forth.

The same reasoning, however, leads us to conclude that func- 
tions 3 and 4, to wit: Stock Ownership and Interlocking Directorates, are provisions of the Clayton Law which apply with full force or effect to banks, the same as to other kinds of corporations. We have seen that whereas in the Federal Trade Commission Act unfair methods of competition are declared illegal and those provisions are made equally operative against individuals, firms or corporations, there is no provision therein for the enforcement of that rule against banks or common carriers. This omission could not have been accidental; it must have resulted from a serious doubt in the Congressional mind as to whether "banking" was included within its powers to legislate, as provided in the "Commerce Clause" of the Constitution." If not so included (and the decisions mentioned and cited on page 47 indicate a negative view by the court), the insertion of such a regulation in the Federal Trade Commission Act would be simply vain repetition and surplusage. This manner of reading the statute in the light of attendant circumstances and of translating its novel terms and expressions into words of known significance, conforms to the requirements of reason as well as to the dictum by Mr. Justice Peckham, in United States v. Trans-Missouri Freight Association, I66 U. S. 290 ( $\left.3^{18}\right)$ : “The only proper way to construe a legislative act is from the language used in the act, and, upon occasion, by a resort to the history of the times when it was passed."

But while the Federal Trade Commission Act does not undertake anything approaching a general regulation of the affairs of banks, it does provide the machinery for enforcing certain provisions of the Clayton Law in relation thereto. The constitutional limitation which prevents Congress from so legislating as to include banks within the scope of the statutes which govern "commerce" has its effect in placing financial institutions outside the provisions against price discrimination and tying contracts; but this does not appear to be any reason why the other two main features of the Clayton Law, viz: Inter-corporation Stockownership and Interlocking Directorates, should not be esteemed functions that are in full force and operation in matters pertaining to bank management.

Stock Ownership by Corporations Regulated.-Assuming, therefore, that such is the case, it should be noted, that the first of

2 For constitutional provisions relevant to the general subject, see Appendix F, pages 286,287 , post. 
these two inhibitions, viz: as to stock ownership, applies only to corporations. The second paragraph of Section 7 of the Clayton Law contains the following:

"No corporation shall acquire, directly or indirectly, the whole or any part of the stock or other share capital of two or more corporations engaged in commerce where the effect of such acquisition, or the use of such stock by the voting or granting proxies or otherwise, may be to substantially lessen competition, between such corporations, or any of them, whose stock or other capital is so acquired, or to restrain such commerce in any section or community, or tend to create a monopoly of any line of commerce."

The intent of the foregoing is clearly to prevent banks-necessarily within the scope of the prohibitive words "no corporations" -from becoming central stations for trust-control; or in other words, to prohibit the turning of banks into "holding companies" of the familiar type.

Purchasers of shares of stock for investment, or the formation of subsidiary corporations are acts which are specially exempted from the legislative prohibition; while broad as are the indicting words, they do not condemn stock-ownership by individuals to any extent in any corporation,- - such prohibition as exists must be found elsewhere in the statutes.

Special Regulations Affecting Corporations Engaged in Banking.-The next provision, Section 8, of the Clayton Law, directly concerns not only directors but officers and employees of banks, in common with common carriers and other corporations, subject to certain limitations, as will be hereafter mentioned. In the case of provisions regulating other classes of corporations, the law concerns itself only with the doings of the members of the directing board. The obvious intent of Congress was to prevent the accumulation of too great financial power in the hands of any individual, or of any group of men, and with that end in view the legislative prohibition extends the scope of the interdicting power to the interlocking of boards of directors in official positions or even in positions of employment, in certain banking institutions. These requirements are so unusual as to be an anomaly in our laws, and to partake to some extent of the paternalism so familiar in continental Europe. 
However strange or unusual these provisions may appear to the citizen unaccustomed to foreign institutions and methods, he will certainly maintain that authority should be found in the Constitution for every precaution requisite to the careful supervision as well as the instituting of banking enterprises. Section 6 thereof confers upon Congress the power:

"To borrow money on the credit of the United States * * * To coin money, regulate the value thereof $* * *$ To make all laws which shall be necessary and proper for carrying into execution the foregoing powers."

While these powers are not explicit, they have sufficed to meet the nation's needs to the present time; and their general terms, no doubt, clothe Congress with the requisite authority.

Since the State, according to Edmund Burke, is "a partnership in all science, a partnership in all art, a partnership in every virtue and in all perfection," it is certainly incumbent upon such a corporate entity to see to it that bank-funds are not employed for the ulterior purposes and profits of the managing directors and officers. Nothing so discourages thrift and saving as to permit institutions to display the sign "Bank" and to use all the insignia of a government-controlled place of deposit for citizens, whereas in point of fact the State is a deficient guardian,-at most a stepparent,-and takes no deep concern in the actual employment or safety of the moneys which were deposited on its implied promise to exercise a watchful and supervising care and to see to it that reasonable prudence is exercised and the depositor's interest protected and conserved. To do less is to default in one of the plain duties of a civilized government. Our faults of omission have been numerous and frequent in the past, and the volume of foreign money orders transferring funds to government-controlled savings banks abroad, has been in like proportion. But with the inauguration of the postal savings bank and with the supervising as well as the ministerial powers conferred upon the Federal Reserve Bank, it seems probable a new era has begun; and that exploitations of the many by the few,--to the extent that the financial preferences growing out of interlocking bank directorates afford,-will not be easy of accomplishment in banking circles hereafter.

These provisions at first or even second reading seem curious enough; but upon reflection it will probably appear evident that 
Congress has builded wisely,-perchance better than it knew,-in erecting the present defences against monopoly in banking. It must be admitted that the language of the first and second paragraphs is ambiguous, and that it is not aided by paragraph four of the same section. Still the general meaning is plain, and no doubt the doubtful passages will in future receive an official construction by the Commission or the court. It was the evident purpose of Congress to prohibit dual or plural (interlocking) representation, upon the board of directors in banking institutions of large resources; and like inhibitions exist as to officials and employees.

The unit of size adopted for the purpose is where a fund of assets of various descriptions amounting to more than $\$ 5,000,000$ of actual value exists in the aggregate.

After two years from the date of approval of the Clayton Law, to wit, after October I5, 1916, "no person shall at the same time be a director or other officer or employee of more than one bank, banking association or trust company, organized or operating under the laws of the United States, either of which has deposits, surplus or undivided profits aggregating more than $\$ 5,000,000$ "; and it is further provided that "no private banker or person who is a director in any bank or trust company, organized and operating under the laws of a State, having deposits, capital, surplus and undivided profits aggregating more than $\$ 5,000,000$, shall be eligible to be a director in any bank or banking association organized or operating under the laws of the United States,"-(Section 8).

The annual returns or reports of the preceding fiscal year shall govern in estimating the resources of the bank; and a director, officer or employee lawfully appointed may continue for one year under said engagement.

Consideration of the terms of the foregoing provisions will disclose that no person can be an officer or employee in more than one national bank of $\$ 5,000,000$ resources; and that the same limitations attaches in the case of a private banker with equal means, or of a director in a State bank with assets to bring it into the same class.

Furthermore, out of abundant caution, Congress has made it unlawful for any individual to accept office as a director or officer or employee in a national bank in a city of more than 200,000 inhabitants, provided he already acts as director upon the board of any other national or State bank located at the same place, or 
is an officer or employee thereof. This prohibition also extends to private bankers, residing in cities of the size specified above. These provisions are certainly novel; but upon the whole they seem calculated to eliminate the factor of a "money-trust," if such exists.

Certain Exceptions Noted.-There are certain exceptions to the rule, which must be mentioned before we proceed further in our general subject. Thus, savings banks not having a stock capital represented by shares are exempted; also, one additional banking institution where all the stock of the second company is owned by shareholders of the first; and there is a further proviso that a director of Class $A$ of a Federal Reserve Bank may be an officer or director, or both an officer and director in one member bank. No doubt ample precautions are provided in the Federal Reserve Bank Act for safe-guarding public interests, and cumulative means of protection are neither necessary nor desirable. Among the ambiguous provisions of Section 8 is one that no person shall at the same time be a director in two or more competing corporations, any one of which has assets of more than $\$ 1,000,000$, engaged in whole or in part in commerce; but while the paragraph does not further define or limit the activities of the corporations of the type described, the lawmakers excepted from the operation of the statute corporations engaged in banking and doing business as common carriers. This express exemption of banks removes the foregoing paragraph from the number of those that relate to and govern this phase of financial business.

As already stated at page 52 hereof, directors, officers and employees remain eligible to election until the expiration of two years from the passage of the Clayton Law, i. e., until October 15, 1916, and until the term of one year thereafter has passed. This comparatively long period preliminary to the enforcement of the law was no doubt intended to afford the public ample time in which to adjust its affairs to the code of procedure involved in carrying out this statutory plan. Much depends upon the installation of the Federal Reserve Banking System; with that scheme of public finance in full operation these requirements should become effective as mere operative details.

Provisions Applicable to Dealings with Common Carriers.Since private banking houses and to some extent banking corporations have dealings in securities with common carriers engaged 
in commerce, the provisions of Section 10 of the Clayton Law have their importance to the banking world.

The definition "common carriers engaged in commerce" would no doubt include telephone and telegraph companies and palace or sleeping car corporations, as well as railroad and steamship lines, and other classes of concerns engaged in transport service; so that the field is very wide. The purport of the provision in question is that where two corporations are respectively a common carrier and a company supplying or dealing in securities or equipment and business relations have existed to the extent of more than $\$ 50,000$ in any year, -

"when the said common carrier shall have upon its board of directors or as its president, manager, or as its purchasing or selling officer or agent in the particular transactions, any person who is at the time a director, manager, or purchasing or selling officer or agent of, or who has any substantial interest in, such other corporation, firm, partnership or association"-

then and thereafter contracts shall be made with the second company only upon competitive bids. The Interstate Commerce Board shall prescribe the regulations governing said competitive bidding; the names, etc., of the officers, directors and general manager of the bidder, if a corporation, shall be given with the bid; or if it be a partnership or firm, then the names of the partners must appear. Violation of this provision is penalized at $\$ 25,000$ for the common carrier; while the consenting director, agent, manager or officer thereof who shall knowingly have voted for or directed the prohibited act is liable to a fine of $\$ 5,000$ and imprisonment in jail not exceeding one year, or both, in the discretion of the court. Any person, directly or indirectly, doing or attempting to do-

"anything to prevent anyone from bidding or shall do any act to prevent free and fair competition among the bidders or those desiring to bid shall be punished as prescribed in this section [10] in the case of an officer or director."

In furtherance of the supervision of this procedure in bidding, and the enforcement of the requirements of penalties therein prescribed, every common carrier thus circumstanced is required 
within 30 days to file with the Interstate Commerce Commission a full and detailed statement of the transaction; and if after investigation or hearing the Interstate Commerce Commission shall

"have reason to believe the law has been violated in and about the said purchases or transactions it shall transmit all papers and documents and its own views or findings to the Attorney-General." (Section Io.)

Regulation Demanded in Public Interest.-No doubt the severity which exudes from the statute will impress some persons as extreme, and as extending the punishment beyond the point where it fits the crime. Much might be said on that theme and many people might be convinced; but it would be hardly possible to retain their support when the history of the abuse thereby sought to be cured was laid bare.

Occasion for Such Regulation Stated.-The public is the ultimate paymaster in all enterprises conducted by a common carrier, and any waste or fictitious items of expense means a larger aggregate sum to be met. Those who ride upon railroads, for instance, are frequently obliged to endure discomforts by way of ill-constructed or ill-cared-for coaches, antiquated stations, or infrequent trains; whereas, on an adjoining system extending through a similar territory, exactly the opposite state of affairs will prevail. No surface reason will suggest itself why such a contrast should exist; and yet the difference is obvious and is a well-known feature of the territory which each or both supply. Upon investigation, however, the source of their varying fortunes will in most cases be found very quickly. In the first-mentioned class the most frequent cause of depression is exploitation on the part of the original promoters or disloyal officers, who have issued securities without due regard to the true interests of the system, being moved thereto by secret profits in the various undertakings. In the other instance, the fair dealing of promoters and officers has resulted in real value for every dollar expended, and these results, comforting and generally satisfactory alike to stockholders and the public, have been the outcome of an honest policy. Like Hogarth's prints, no words are required,-the things speak for themselves. Who will say, after reflecting upon such a contrasting spectacle in corporate management, that the public is not a party to every contract made by or on behalf of a common 
carrier or other enterprise engaged in public service? Even though they do not sign the instrument or add their seal thereto, the people are parties,-and deeply interested parties,-since upon them will fall the burden of meeting the upkeep and dividends, which must precede and accompany really efficient service. It is no wonder, then, that safeguards are thrown about the fountain-heads of extravagant or corrupt practices; and though late in the day, that the responsible executive heads with the board of directors are held liable for transactions that savor of unfairness or waste. With these protective and reformative features in full force and effect, the people are likely in future to gain the advantage of the increments which arise from their employment of public utilities. At the very least, it seems probable that unconscionable "commissions" and "watered stocks" will not figure so largely in future as in the past in the business affairs of public service corporations; and that improved facilities together with comforts, conveniences and safety appliances, will not be deferred until the exchequer has recovered from the drain occasioned by the outcome of false or faulty methods of finance. While it might with some degree of reasonableness be contended that these remarks would appear more appropriately under succeeding chapters, their occurrence as an explanation why officials of public utility corporations should not be directly or indirectly concerned in the profits from sales of securities or from the purchase of supplies, is not without a certain logical sequence here. As it is, the foregoing statement without doubt presents with substantial correctness the intention of Congress in creating these several Commissions, and endowing them with authority and powers commensurate with the importance of the tasks before them. If its presentation here will have served a useful purpose, -that is all the justification we ask or expect.

In closing, attention is again called to the fact that Section ro includes within its scope "dealings in securities"; hence, bankers and banking institutions are or may be directly concerned. 
COMMON CARRIERS: REGULATIONS CONTAINED IN :

1. Federal Trade Commission Act.

2. Clayton Law.

\section{PROVISIONS OF THE FEDERAL TRADE COMMISSION $A C T$.}

Banks and Common Carriers Generally Excepted from Jurisdiction.-As in the case of banks, ordinary transactions pertaining to the business and management of common carriers are expressly taken out of the jurisdiction of the Federal Trade Commission, as conferred by Section 5 of said law; and they are also excepted from the requirements as to inspection and annual or special reports, contained in Section 6 . These exceptions are due to no favoritism or undue advantage accorded to financial institutions, or common carriers ; such omission is merely an acknowledgment of the minute inspection and detailed reports required of these two branches of business by other departments, boards or commissions. In brief, it may have been thought that if such exactions were duplicated, no time would be left to run trains or to make bank-loans. To that extent, the statute is merciful to the classes of corporations concerned.

Such Exemptions Strictly Construed.-It should be repeated, however, here as elsewhere, that where curative statutes are enacted to reach and obliterate a long-standing abuse, the excepting clauses will without doubt be strictly and even narrowly construed by the Commission and by, in a less degree, the courts. This principle of the applications of such specific legislation is due to human nature rather than to any recognized rule of statutory construction. Every newly created member of the governmental body is bound to justify its right to exist; and the most obvious means at command is for it to assume jurisdiction in doubtful or border-line cases. Thus Congress has often found in experience that it has builded wider if not better than it knew. The early decisions of Chief Justice Marshall are replete with holdings that widened the scope of the powers of the Supreme Court; and while it was no doubt to the advantage of the country 
at large that there should be no twilight-zone or no-man's land in that sphere of government, still the fact remains that the history of that court illustrates the human tendency of institutions to retain or enlarge their rights and influence, when their own voice is potent in the demarcation of their powers. Edmund Burke said: "The speculative line of demarcation, where obedience ought to end and resistance must begin, is faint, obscure and not easily definable," and the practical line in legal construction is often as thin and hazy. This being so, the omission of excepting clauses will without question be construed to leave the business concerned within the statute, under the broad definitions of corporations, etc., therein contained. Thus where a bank or common carrier goes out of its ordinary and special field and enters upon any enterprise that involves general merchandising, it will as a matter of course become amenable to every requirement of the Federal Trade Commission Act, and of the Clayton Law as well.

Right to Inquire and Recommend, in Certain Instances.But while by express exception, Section 6 of the first-named law exempts common carriers from inspection and the burden of making reports to that body, there are certain requirements that apply to common carriers, since they are directed to "any defendant corporation," or "any corporation." These requirements are contained in subdivision (c) authorizing the Commission to investigate the manner in which any decree is being carried out, in any suit brought by the United States to prevent and restrain any violation of the Anti-trust acts; subdivision (d) upon the direction of the President or either House of Congress empowering the Commission to investigate and report the facts relating to any alleged violations of the Anti-trust acts by any corporation; subdivision (e) upon the application of the Attorney-General like power is conferred to investigate and make recommendations for the readjustment of the business of any corporation alleged to be violating the Anti-trust acts, in order that the corporation may thereafter maintain its organization, management and conduct of business in accordance with law; subdivision (f) whereby the Commission is likewise empowered to make public information thereby secured, in its discretion, except trade secrets and names of customers; make annual and special reports to the Congress and to submit therewith recommendations for additional legislation and to provide for the publication of its reports and de- 
cisions; subdivision (g) containing the important power from time to time to classify corporations and make rules and regulations for the purpose of carrying out the provisions of the Federal Trade Commission Act; subdivision ( $h$ ) establishing a new field of endeavor, by conferring authority to investigate from time to time, trade conditions in and with foreign countries where associations, conditions or practices of manufacturers, merchants or traders or other conditions may affect the foreign trade of the United States, and to report to Congress thereon, with such recommendations as it deems advisable.

The above provisions have been inserted at length and practically in the words of the statute, because it will appear upon a general view thereof that there are conditions, including the entrance upon matters of merchandising where the regulations of the Federal Trade Commission Act would apply. The right to investigate alleged infractions of the Anti-trust laws and to enquire into the effectiveness of decrees entered in actions by the government to enforce the provisions thereof, and to make recommendations as to the readjustment of the corporate affairs of a company charged with such violations-are all phases of the statute that do affect common carriers along with other incorporated concerns. Whether the right to classify corporations under subdivision $(\mathrm{g})$ relates to common carriers, or not, certainly they must, so far as concerned, conform to the rules and regulations which the Federal Trade Commission thereby is empowered to make; and it may be that steamship trusts and special rates, singly or combined, upon foreign railroads and steamship lines, or in conjunction with traffic corporations in the United States, would make the terms of subdivision (h) very important in its regulating effect upon common carriers, and make its influence felt abroad as well as within the limits of the United States and its dependencies.

Debates in Congress have developed a disposition to regard the Commission, acting under subdivision $(h)$, as constituting a convenient and permanent substitute for a Tariff Revisional Commission. What effect this aspect of its powers will produce cannot be estimated in advance; but this proposal indicates the unusual nature and far-reaching extent of the jurisdiction these statutes confer.

The right to compel access to books and papers is conferred by Section 9 , together with the usual power to subpœna wit- 
nesses; and by Section ro failure to attend and testify, or to produce documentary evidence is made a criminal offense; also, the mutilation of or making false entries in corporate papers and records, is likewise prohibited under penalty of fine and imprisonment. To secure privacy, acts of employees resulting in unauthorized publicity are penalized, and the fine of $\$ 5,000$ or imprisonment for not exceeding one year, or in the discretion of the court, the imposition of both said imprisonment and fine, indicate the intent of the statute makers that Section ro should prevent unauthorized disclosures during the progress of investigations of this nature.

Reverting to subdivision (e) which confers the power to make recommendations to the Attorney-General, this feature seems to supply the ounce of prevention that will in practice obviate pounds of cure, when the corporation concerned is ready to shape its course to the law's requirements without recourse to long and expensive litigation to determine the legal status of its acts. In effect, this provision may do much to occupy the place of the power to commend which was advocated by persons experienced in corporate management, as appears in the reports of the Congressional committees and the discussions connected with the enactment of the Trade Commission Act and the Clayton Law. The right to "investigate and make recommendations" might almost be said to imply the power to "make commendations."

Power to Investigate Foreign Trade Conditions.-Another point should not be passed by without some further consideration. Under subdivision ( $h$ ) of Section 6 the right to investigate foreign conditions is made a feature of the Federal Trade Commission's powers. Such investigation might likely enough disclose combinations by state-owned railroads and steamship lines operating under governmental control, wherein and whereby shipping of goods is permitted at such nominal traffic rates as to seriously handicap our public service corporations of similar kinds in maintaining competition upon anything resembling a fair basis of transportation cost. In that event, it would appear equitable and right to mitigate or temporarily remove altogether the restrictions of the Anti-trust statutes so far as they affect the articles of trade concerned by those practices, in foreign commerce. These are considerations which will arise from time to time, when the condition of our foreign trade is productive of situations such 
as are referred to above. As we have seen, the requirements of Section 5, regulating "unfair methods of competition in commerce" do not apply to common carriers, since they are specifically excepted therefrom. Likewise they are not liable to be investigated and common carriers are not compelled to file reports under the general provisions of Section 6. This exemption however, would not extend to matters of business outside of the right to conduct railroads, pipe lines, telephone, or telegraph systems, and similar auxiliary enterprises. Upon the whole, the provisions of the Federal Trade Commission Act cannot be said to be burdensome to common carriers. When construed in a spirit of friendly consideration,- -as we have every reason to believe is and will be the constant attitude of the Commission,- - the law will prove a shield to protect common carriers from needless interference and litigation; in brief, it guarantees them "equality under the law."

\section{PROVISIONS OF THE CLAYTON LAW.}

Certain Common Carrier Provisions Apparently Unrelated. -Although certain of the provisions affecting common carriers appear quite unrelated in the two statutes, it seems proper and necessary to collate and discuss them in one chapter, where the points of similarity and divergence can best be noted and compared as they occur in the text of the several statutes.

Extent to Which Law Applies.-It is possible that Section 2, relating to price discrimination, and Section 3, prohibiting "tying" agreements, do not relate to common carriers in so far as those corporations confine their transactions to normal operations within the scope of their business; indeed, such outside lines of business are pro tanto forbidden by the Act to Regulate Commerce, as amended, Section $I,{ }^{1}$ which prohibits any common carrier from transporting any article or commodity manufactured, mined or produced by it or under its authority, or in which it may have any interest, except those intended for its use in its transportation business, and further excepting timber and products manufactured therefrom. Doubtless the number and extent of the land grants bestowed upon railroads to encourage construction made it unjust to interfere with their ability to cut and market lumber derived from their own domains.

There are, moreover, types of common carriers that are not

I See Appendix O, pages 345-36I, for original Act, with amendatory laws cited. 
enumerated among the list set forth in the amended Act to Regulate Commerce, ${ }^{2}$ as subject thereto, and as to those, it might be held that they are subject to the provisions of the Clayton Bill. Indeed, no convincing reason appears why non-enumerated common carriers should not be regarded as concerns engaged in commercial pursuits.

In so far as common carrier corporations come within Section 2 (price discrimination), Section 3 (tying contracts), or are concerned with the enforcement of Section 7 (stock ownership in competing corporations), and Section 8 (interlocking directorates), the jurisdiction to enforce those provisions is vested in the Interstate Commerce Commission and not in the body created by the Federal Trade Commission Act. It is so enacted by Section I I of the Clayton Law and the term there employed is very broad. No qualification whatever is used; "common carriers" are the words employed in the clause giving authority to the Interstate Commission to enforce compliance with Sections $2,3,7$, and 8 of the Clayton Law. Under this broad characterization of the corporations affected thereby, all common law common carriers may be affected by these four sections even though they are not otherwise subject to the jurisdiction of the Interstate Commerce Commission. The fact that Section 2, price discrimination, and Section 3, tying contracts, are here mentioned, tends to confirm the belief elsewhere expressed that under some circumstances common carriers are subject to those provisions as well as to the regulations contained in Section 7, stock ownership in competing corporations, and Section 8, interlocking directorates.

Methods of Enforcement Compared.-The manner of enforcement of Sections 2, 3, 7, and 8 of the Clayton Law is fully provided in Section II, and the provisions are tantamount to the procedure laid down in Section 5 of the Federal Trade Commission Act for carrying out of the prohibition of "unfair methods of competition in commerce." Upon consulting the statutory requirements it will be seen that the Interstate Commerce Commission is constituted the tribunal before which the matter must be presented in the place of the Federal Commerce Commission, in any case where a complaint is lodged against a common carrier. This fact should be borne in mind, as otherwise confusion might not unnaturally arise from the requirement that Sections 2, 3, 7,

2 See note I, page 61, supra. 
and 8 are enforcible before the Interstate Commerce Commission and not before the Federal Trade Commission,- which in other respects is the companion, guardian and complement of the Clayton Law. One other like exception to the general rule occurs in that infractions of these sections by banks are made triable before the Federal Reserve Board. ${ }^{3}$

It is not specifically stated that the Commerce Commission or the Board shall have at its command the machinery for the service of process, etc., expressly provided in the Trade Commission Act ; but the powers essential to make the Clayton Law provisions effective will no doubt be implied, when those provisions are construed by the courts.

Ownership of Stock in Competing Corporation Regulated.Returning to the provisions of the Clayton Law as they affect common carriers, Section 7 expressly forbids the destruction of competition by means of stock ownership by one corporation in a competing corporation; or by one "holding company" in two or more corporations which compete among themselves. There can be no doubt that this section applies to common carriers. The section expressly states that its provisions do not prevent the ownership of stock for investment purposes and not to secure the voting power; nor do those provisions prohibit the creation of subsidiary corporations and the partial or entire ownership of the stock thereof, where competition is not substantially lessened thereby. Such minor corporation, however, must be formed only to carry on the immediate lawful business of the parent company; or must constitute a natural and legitimate branch or extension thereof.

Section 7 also provides in substance that "any common carrier subject to the laws to regulate commerce" may similarly build, aid in building, or own by stock-control one or more branch or short lines; and the Section further permits the parent company to extend any of its lines "through the medium of the acquisition of stock or otherwise of any other and common carrier" where there is no substantial competition. There is some uncertainty in the

3 Particulars of the practice in filing complaints, etc., are set forth in Chapter III, Federal Trade Commission's Functions, pages 24-27; Chapter V, Provisions for Enforcement, pages 39, 40. To avoid repetition, reference is made to those chapters for further information on these points; see also, Rules and Forms. 
statute as to whether the provision conferring right to form subsidiary corporations relates to common carriers, though it seems probable the language will be construed to that effect. Such a privilege would be useful in many ways, and when exercised under the scrutiny of the Interstate Commerce Commission as provided in Sections ro and II, it seems highly improbable any harm can ensue. The Clayton Law expressly refers to common carriers in the paragraph relating to the construction or acquisition of branch or short lines, so the uncertainty mentioned above does not extend to that very important right. Indeed, every transportation company and many public service corporations would be seriously hindered if not altogether stunted in their growth, if shorn of the right to expand as new business opportunities occurred in regular course.

Meaning and Scope Defined.-The technical expression granting this privilege to "any common carrier subject to the laws to regulate commerce" requires some explanation to define its exact meaning and scope. The reference is to the text of the Interstate Commerce Act as amended June 29, 1906," where by specific provisions the original jurisdiction over railways acquired by the Act of $I 887$ is extended to pipe lines and express companies. Telegraph and telephone companies are also included by later amendment. Accordingly, each and all these classes of corporations can avail themselves of this right to extend their systems, under the conditions already mentioned. In brief, the words "common carrier" no longer signify railroads alone; the term has become modernized and broadened into an expression which includes almost every company that affords transportation facilities of a public nature.

The provisions of Section 8 relate to interlocking directorates in so far as they include dealings between two common carriers; while similar dealings between corporations, one or more of which supply securities or articles of commerce, are regulated by corresponding rules set forth in Section ro, to which reference is made for the purposes of the following remarks. While this topic has been discussed at considerable length in Chapter IV, under the general heading "Prohibitions under the Clayton Law," it does not follow that further comments will not be of service here, or that we will not be justified in again inquiring into the 
general nature of those regulations and rules and studying their probable efficacy in combating the very real abuse they are intended to overcome.

Purpose of Provisions Discussed.-Without engaging in personalities or charging individuals with responsibilities for acts which were customary among their business associates of former days, the fact remains that very many large fortunes were accumulated in a brief period by high officials of the principal railroad companies. Some portion of this increment, earned or unearned, was no doubt secured through stock market manipulation, while opportunities in picking out choice tracts of real estate where town sites and machine shops would quadruple the investment, were no doubt instrumental in swelling the flood of dollars flowing into private bank accounts. These sources of wealth were somewhat easy of concealment through the use of deeds to third parties, dummy brokers' accounts and other familiar methods which even though ferreted out, might be claimed to be the result of activity and business acumen. In the matter of stock dealings it has been suggested that a sworn statement of such transactions attached to the annual report might check the desire of executive officers to speculate in the shares of corporations they were employed to superintend; certainly "bear campaigns" in which the officers profited by the misfortunes of the company would not inspire confidence when spread upon the yearly record. The principal Canadian railway has made public announcement that the persons selected to compose its managing board are required to forego speculating in its shares, and that this standard has been steadfastly maintained. Be that as it may, the law has not taken cognizance of these doings; and it will perhaps be left for the conscience of the business world to frame a code of ethics that will cover such situations, when more conservative ideas and ideals prevail.

There is a source of accumulation by officers, however, which the lawmakers determined to eliminate without more delay. The evils of the holding company to a large extent evaporated with the decision in the Northern Securities case; it remained for Congress to proceed a step further in the direction indicated in that far-reaching decision of the Supreme Court.

Dealings With Supply, Construction and Financial Concerns Regulated.-This legislation concerns the favored con- 
tractor plan, whereby the officers of the purchasing company made contracts for funds and supplies from banks and manufacturing concerns which they controlled and practically owned. The result was the complete destruction of anything resembling competition, and this in turn entailed advances in price, with a corresponding excessive profit to the parties in command of the situation. Section 8 provides that after two years from the passage of this law, to wit, from October I5, I916,- no person shall at the same time hold the office of director in two corporations, where the elimination of competition by agreement between them would constitute a violation of any of the Anti-trust laws. While the statute provides that this provision shall not apply to those "common carriers subject to the Act to Regulate Commerce, approved February $4,1887, " 3$ it should be carefully noted that the act thus specifically named relates solely to railroads. This statute was the original act to regulate commerce, and the inclusion of express and sleeping-car companies, pipe lines, etc., thereunder was the outcome of later amendment.

The purpose to exempt only railroads from the prohibition of interlocking directorates is shown even more conclusively by the fact that in other places where the word "common carrier" is employed in the Clayton Law to signify the enlarged list of transportation companies, the language is quite different. Thus, at Section 7, paragraph 4, the common carriers there referred to are stated to be those "subject to the laws to regulate commerce"; at Section 9, paragraph $\mathrm{I}$, they are described as "every *** corporation engaged in commerce as a common carrier"; while at still another place Section Io, paragraph $\mathrm{r}$, the expression is "common carrier engaged in commerce." It is submitted, therefore, that in view of the language employed in Section 8 , as above noted, the conclusion is natural that the prohibition against interlocking directorates is in full force and effect as to every class of common carriers engaged in interstate commerce, with the single exception of railway corporations.

This provision of Section 8 was not considered requisite to the proper conducting of corporations of small or moderate dimensions; at least the prohibition is made to apply only to companies with aggregate assets exceeding one million dollars of actual capital.

5 See original powers set forth in Appendix O, pages 345-36r. 
Our remarks upon interlocking directorates, Section 8, are as fully applicable and perhaps will appear even more pertinent to Section IO. In fact, Section Io enters directly into the preventive plan directed against secret and indirect profits in dealings by corporations engaged in public transportation, and condemns and interdicts such practices where the transactions amount to more than $\$ 50,000$ in any one year.

New Method of Regulation Prescribed by Section 10.-The statute contemplates a new angle of attack upon an old evil, and whatever we think of its potential force, and independently of whether we agree with the scheme of the legislative campaign, still the effort is interesting in itself as a study in law-making. The language of this Clayton Law provision is too compact to admit of further condensation, and we accordingly present the passage in question:

"Sec. Io, par. I, That after two years from the approval of this act [i. e., after October 15, 1916] no common carrier engaged in commerce shall have any dealings in securities, supplies or other articles of commerce, or shall make or have any contracts for construction or maintenance of any kind, to the amount of more than $\$ 50,000$ in the aggregate, in any one year, with another corporation, firm, partnership or association when the said common carrier shall have upon its board of directors or as its president, manager, or as its purchasing or selling officer, or agent in the particular transaction, any person who is at the same time a director, manager, or purchasing or selling officer of, or who has any substantial interest in, such other corporation, firm, partnership, or association, unless and except such purchases shall be made from, or such dealings shall be with, the bidder whose bid is the most favorable to such common carrier, to be ascertained by competitive bidding under regulations to be prescribed by rule or otherwise by the Interstate Commerce Commission. No bid shall be received unless the name and address of the bidder or the names and addresses of the officers, directors and general managers thereof, if the bidder be a corporation, or of the members, if it be a partnership or firm, be given with the bid." 
Then follows a provision that any person aiding or abetting in such dealings otherwise than as above prescribed shall be subject to the same penalties fixed for violations of this prohibition on the part of the officers, directors or agents.

The seriousness of the violations of the statute may be measured by the fact that the common carrier is subjected to a fine of $\$ 25,000$; while the officers, directors, and agents shall be deemed guilty of a misdemeanor, carrying with it individual fines up to $\$ 5,000$, and imprisonment in jail not exceeding one year, or both, in the discretion of the court.

The liability to personal punishment incurred on the part of the offending officers, directors and agents marks a course as logical as it is severe. Former enactments whereby the incorporated body which had already suffered by the depletion of its exchequer because of secret profits and swollen commissions, was forced to endure a further loss by means of a fine, did not and could not appeal to the good sense of judges, jurors or the general public. Fines of this description in the ultimate result fell upon the shareholders, whose assets were reduced or whose dividends were cut down, to meet the payment of the fine, in addition to the expenses of the litigation. The injustice is apparent when it is realized that most of these acts originated in the inner official circles and were concealed from the stockholders.

Under the new regime of corporate scrutiny and control these leakages in corporate finances should be curtailed; and may at length be stopped at their source. Certainly, the provisions of Sections 8 and Io comprise an earnest and intelligent effort by Congress to provide adequate measures to accomplish this longcalled-for reform.

At the conclusion of any business dealings within the scope of Section I0, the common carrier is required to file with the Interstate Commerce Commission a full and detailed statement of the transaction. If that body after investigation or hearing, finds that there is reason to believe the law has been violated in or about those particular purchases or transactions, the board of commissioners shall transmit all papers and documents and its own views or findings regarding the transaction, to the AttorneyGeneral. ${ }^{\circ}$

It cannot be denied that there is a certain grimness in the absence of direct reference to the criminal prosecutions which under circumstances indicative of guilt would be sure to follow. In no 
instance in corporation law, however, can the terrors of the law to evildoers be more usefully employed than in overcoming the practices aimed at. Inside influences and special interests have for years, yes, decades, been potent in and about the financing, equipping and management in general of common carriers and the other classes of the larger corporations engaged in public transportation and service. These special interests will see nothing except interference and unwarranted assumption of power in these restrictive Anti-trust laws. To do less would be more than human, and whatever comment has been made upon those interests and corporate influences, no one conversant with their history and methods has ever denied that the individuals concerned were extremely human. Sources of wealth will be dried up and many officials and agents will find it an irksome task to confine their outgo to their stated salaries and regular commissions. That there will be indignant protests must be expected, and no doubt these will occur in full measure.

But the public at large is certain to benefit,-and that is surely the ultimate object of legislation in a free republic. Improvements in public conveyances, reduced rates in communications by telegraph and telephone, equal or enhanced returns to investorsthese are results far more desirable than "the thrift that follows fawning." Without fear of contradiction it may be said that the deterrent effects of the Anti-trust laws alone are worth many times the cost of the public managing boards which have been created; in fact, insistence that unearned increments shall cease and those sources of revenue shall be restored to the coffers of transportation companies marks a new era in the management of corporate affairs.

Enforcement of Section ro Committed to Commerce Commission.-In concluding these references to the regulations prescribed by Section to for the guidance of common carriers with common or interlocking members upon the boards of directors of construction, supply or financial concerns, we desire to call attention to the fact that enforcement thereof rests with the Interstate Commerce Commission. This jurisdiction is in addition to the provision of Section II, which relegates to the Interstate Commerce Commission and Federal Reserve Board respectively the authority to enforce Sections $2,3,7$, and 8 of the Clayton Law, in so far as they relate to transactions by common carriers and banks. 


\section{CHAPTER VIII.}

\section{THE SHERMAN ANTI-TRUST LAW; ITS ORIGIN, HISTORY AND THE LEADING CASES THERE- UNDER CONSIDERED. ${ }^{1}$}

I. Comprehensive Language Employed.

2. Unlike Constitution,-Framers Did Not Expound Law.

3. Principles and Development.

4. Occasion for Statutory Relief.

5. Various Drafts of Measure Considered.

6. Supporting Argument in Senate.

7. Tentative Measures Considered.

8. Scope and Effect of Law as Enacted.

9. Constitutional Questions Settled by Supreme Court.

10. Benefits from Anti-trust Act.

II. Foreign Anti-trust Laws Discussed.

12. Commission Law and Clayton Law Broaden Means of Relief.

13. Narrowing Argument Examined.

14. Definitions of "Commerce."

15. Congress Supplements Anti-trust Decisions.

\section{COMPREHENSIVE LANGUAGE EMPLOYED.}

Language of Statute Very Comprehensive.-The Sherman Law, when it received the approval of President Harrison in 1890 , closely resembled the Constitution of the United States when it was framed in 1787 , in that the enactment was couched in tęrse, general and comprehensive language, calling for construction and application in numerous diversified cases to insure the incorporation thereof into the great and generally recognized body of statutory provisions seasoned by court rulings, which taken together constitute the law of the land.

Early Application of Constitution and Sherman Law Compared.-Very fortunately for the early development of our Federal government, the statesmen who framed the Constitution of the United States did not permit their interest to cease at its birth, but continued their ministrations through a series of years. While realizing that judicial development and application would continue into remote periods, they also understood that the most precarious stage would be when it was necessary to apply re-

1 For text of Sherman Law, see Appendix C, pages 279-281, post. 
straints or enforce positive requirements upon the original States which had until a then recent time acted as colonies independent of all restraint which was not exercised from a central government sometimes lenient and often forgetful of everything that did not directly concern English trade or interests.

\section{UNLIKE CONSTITUTION-FRAMERS DID NOT EX- POUND LAW.}

Principles of Constitution Explained by Its Framers.-This patriotic duty led the "fathers of the Constitution" to set forth their understanding of its meaning and practical workings in those able papers which when collected were known as the "Federalist"; and our obligations to Hamilton and Madison and Jay are largely enhanced by their voluntary act.

No Similar Interpretation of Sherman Law Exists.-Unfortunately, no publications of a similar nature and authority accompanied the enactment of the Sherman Law; and it may be for that reason the statute for a time was not rigidly enforced or at least was applied in an ineffectual way; and it may also have resulted from the same cause that only in matters of great moment has it been utilized, for, like impeachment for high treason, only formidable offenders have been thought worthy of a prosecution which arose in effect to the dignity of a state trial.

Absence of Exposition Delayed Enforcement.-Had such an authoritative explanation followed the enactment of this epochmaking statute, and had the law itself contained a provision whereby the injured citizen could register his complaint and and be heard without the intermediation of government functionaries, the era of delay, uncertainty and difficulties that has beset its enforcement might have been obviated, and a whole generation of predatory trusts and monopolies might have perished unborn.

\section{PRINCIPLES AND DEVELOPMENT.}

Development of Sherman Law Described.-Perhaps it is not too late in this connection to describe the genesis and de. velopment of this law, even though with the advent of the Clayton Law, and its enabling act, the Federal Trade Commission Law, some measure of the immediate necessity for and importance of the broad and sweeping denunciations of the Sherman Law may have passed out of our system of jurisprudence. 
Authoritative explanations of its terms will be found scattered through the debates in Congress preceding its passage. These opinions are useful, especially when considered in connection with the exigencies from which the statute arose. ${ }^{2}$

The public life of John Sherman-originator and sponsor of this law-was particularly distinguished. Beginning as a member of Congress in 1855 , his public career occupied forty-three years to the date of his retirement from the office of Secretary of State in 1898 . His record of public service in the Senate includes two periods of sixteen years each, interrupted by four years of incumbency of the Secretaryship of the Treasury under President Hayes, at which time resumption of specie payment was carried into effect at his instance and under his direction. During the whole of those thirty-two years of service in the Senate this recognized authority on monetary subjects was a member of the Committee on Finance, and during numerous years officiated as its chairman.

General Principles Involved.-Ever since and before the decision of the earliest reported Anti-trust case, ${ }^{3}$ decided in 1602 , there has existed an ingrained opposition to monopolies and traderestraining agreements, which has grown into one of the characteristic features of the Anglo-Saxon race.

This feeling was and is born of an innate sense of the principles that enter into successful self-government by freemen, and is founded upon the realization of the dual results that flow from such centralization of trade. These results are:

First, the impairment of the efficiency of the citizen, with the risk that he will be reduced to poverty and made an object of charity and an expense to the community;

Second, the enhancement of price, which results naturally and almost necessarily in the centralized commodity, which in turn, seriously affects the cost of living and is a matter that concerns adversely every individual except the owner of the right to monopolize.

\section{OCCASION FOR STATUTORY RELIEF.}

Centralization of Business Recognized and Regulated.-In the years 1889 and 1890 , a rising storm of indignation and pro-

2 For able discussion of the principles and attendant circumstances of this enactment, see Report of Senate Committee, Appendix M, pages 304334. For tentative forms of measure, see Appendix K, pages 297-30r.

3 Darcy v. Allen, II Coke 84; see 7 Harvard Law Review, p. 324. 
test was evident throughout the United States. Unrestricted competition had ceased to work out equality in service, or price, or of opportunity for the average citizen to pursue his accustomed calling,-at least in numerous departments of trade. Vast combinations of originally independent interests had placed it within the power of a comparatively small number of magnates or "captains of industry," to fence in areas of trade activity, and to make them exclusively their own. Particular attention was devoted to acquiring control of railroads (often richly endowed with public lands), and when secured, such control was misused to harass and destroy neighboring roads and competing water routes by favoring rates which were given to large patrons, usually those identical trusts. Those interests sought and obtained seats upon the boards of directors where the main contention became not the prosperity of the common carrier, but the exchange of special privileges.

The Standard Oil Company was reputed to be the worst, or at least the most subtle and far-extended offender; but profiting by its example, the Sugar Trust, the Beef Trust, the Tobacco Trust, and numerous other virtual monopolies were growing to a colossal size where, by sheer strength or weight, they could at will strangle or crush their lesser competitors. Oftentimes the independent producer or trader did not wish to adopt simliar methods and for a time engaged in a valiant battle for the retention of its own accustomed field; but as in the case of the Pratts with their recognized and favorably known product, "Astral Oil," the result was certain to occur with monotonous regularity, viz: they gave over the fight against superior numbers, capital and efficiency in trade, and by amalgamation became an integral part of the trust. Years before, the Standard Oil Company had compelled the Pennsylvania Railroad to surrender upon ignominious terms.

In despair at this perversion of public utilities and at the rapidly increasing centralization of business, with the equally rapid dwindling of opportunities for a prosperous career on the part of enterprising, industrious and ambitious men of ordinary resources, the nation turned to Congress for relief. And their appeal was not in vain.

\section{VARIOUS DRAFTS OF MEASURE CONSIDERED.}

Measure for Relief Introduced.-In December, I889, at the instance of Senator Sherman, the Senate bill, drafted by him was 
introduced, intended to meet, curb and cure the monopolistic tendency displayed by the predatory interests of that period. His bill as originally presented contains much that in the session of the following year was merged into the existing Sherman Act,the main distinguishing point being that the earlier law did not confine itself to prohibiting monopolies in restraint of commerce. Since the right to so legislate must rest for its constitutionality upon the clause, "Congress shall have power to regulate commerce with foreign nations and among the several States and with the Indian tribes," it was felt that the measure should be redrafted; and in consequence it was returned to the Judiciary Committee, where after various experiences the existing law was drawn by Senator George F. Hoar. It was submitted impersonally as the committee's substitute for the earlier bill. Not until thirteen years had passed did it become known whose hand prepared this now celebrated statute.

\section{SUPPORTING ARGUMENT IN SENATE.}

Its Enactment Urged.-When the original bill was before Congress, Senator Sherman made an earnest plea for its favorable reception. He spoke as the advocate of the people whose prosperity as individuals and as a public body was so largely at stake. He insisted that the word "commerce" as employed in the Constitution is an expression of widest scope,-

"It means the exchange of all commodities between different places or communities. It includes all trade and traffic, all modes of transportation by land or sea, all kinds of navigation * * * every mode of transit. * * * The power of Congress extends to all this commerce, except only that limited within the bounds of a State."

"Many of these powers," he continued, "have remained dormant, unused, but plainly there, awaiting the growth and progress of our country, and when the time comes, we find in that instrument provided for thirteen States,* ** all the powers necessary to govern a continental empire.",

Argument Continued.-Feeling thus assured that the inherent power which Congress possessed under its right to "regulate commerce" carried with it the authority to destroy absorption or interference therewith by monopolies and trusts,- Senator Sherman 
dwelt with great earnestness upon the necessity for immediate legislation commensurate with the object to be attained. He said:

"Associated enterprise and capital are not satisfied with partnerships and corporations competing with each other, and have invented a new form of combination commonly called 'trusts,' that seeks to avoid competition by combining the controlling corporations, partnerships, and individuals engaged in the same business, and placing the power and property of the combination under the government of a few individuals, and often under the control of a single man called a trustee, a chairman, or a president. The sole object of such a combination is to make competition impossible. It can control the market, raise or lower prices as will best promote its selfish interests $* * *$. The law of selfishness uncontrolled by competition, compels it to disregard the interest of the consumer. It dictates terms to transportation ***. Such a combination is far more dangerous than any heretofore invented $* * *$. It is a substantial monopoly injurious to the public, and by the rule of both the common law and the civil law is null and void and the just subject of restraint by the courts; of forfeiture of corporate rights and privileges and, in some cases, should be denounced as a crime, and the individuals engaged in it should be punished as criminals. It is this kind of a combination we have to deal with now."

In that spirit and with words of ringing force and no uncertain sound, Senator Sherman brought the full impact of his weighty and powerful mind and influence to bear upon the subject before him.

\section{TENTATIVE MEASURES CONSIDERED.}

Drafts of Measure Express its Intent.-The earlier drafts and amendments all bear witness to the intention to include interference with full and free competition as well as entire or partial monopoly, among the prohibited class. This appears in the title of the original act,- - "A bill to declare unlawful trusts and combinations in restraint of trade and production," which in the bill as passed was amended so as to conform to its narrowed scope, and to read, "A bill to protect trade and commerce against un- 
lawful restraints and monopolies." In the debate preceding the final vote-unanimous in the Senate except for one uncelebrated Senator from New Jersey, and unanimous in the House-Senator Hoar enunciated the official definition of "monopoly" agreed upon by the Senate Judiciary Committee as "the sole engrossing to a man's self, by means which prevent other men from engaging in fair competition with him."

Definition Suggestive of Anti-trust Term.-Perhaps this definition is the genesis-the originating germ-from which springs the term "unfair methods of competition in commerce." The effort to retain the essence of the original idea, while at the same time linking it closely with the "commerce" clause of the Constitution, is too obvious for comment. As in the case of the originators of the Sherman Law, the sponsors of the modernized Anti-trust legislation realized that it must pass through the severities of an "acid test." In that historic debate in 1890 , Senator Vest of Missouri, exclaimed: "This bill, if it becomes a law, must go through the crucible of a legal criticism which will avail itself of the highest legal talent throughout the entire Union. It will go through a furnace not seven times, but seventy-seven times heated."

Wider Scope of Proposed Law.-It is not given to the mind of man to deduce what would have occurred, if non-existent facts had existed in a given situation; but it is possible to assume that if the Sherman Act had retained the words of the original draft, "That all arrangements, contracts, agreements, trusts, or combinations between persons or corporations made with a view to prevent full and free competition in the importation, transportation, or sale of articles imported into the United States, or in the production, manufacture, or sale of articles of domestic growth or production $* * *$ designed or which tend to advance the cost to the consumer of any such articles, are hereby declared against public policy, unlawful and void,"-the growth of tradedomination by "unfair methods of competition in commerce" would not have reached a point requiring a supplementary law and an act creating the Federal Trade Commission to regulate, control and apply reforming measures to the interstate business of the nation."

4 For a résumé of this memorable debate and for the original drafts of the Sherman Law, see Appendix M, pages 304-334; also see Walker's History of the Sherman Law, pages I to 54; Thornton, "The Sherman Antitrust Act," Chapter I. 
Constitutionality thereof Considered.-Perhaps in that event the Supreme Court would have applied a different rule in the Knight case, and the right to regulate production and manufacture would have been declared within the constitutional authority to legislate conferred by the "Commerce" clause. The Sherman Law has exercised a salutary influence in a wide field; but much territory it could not or at least did not reach, and in that unregulated zone conditions that cause and attend unrestricted trusts and monopolies have had opportunities to produce their logical results.

\section{SCOPE AND EFFECT OF LAW AS ENACTED.}

Consideration from General View Point, Continued.Those who wish to study the conditions from which the Sherman Law evolved will find the essential facts set forth in an interesting and reliable form in Walker's History of the Sherman Law; while reference to Appendix M, page 304, post, will disclose the source of the Acts to Regulate Commerce, which, beginning with the original law of 1887 instituting the Interstate Commerce Commission, ${ }^{4 \mathrm{a}}$ have since broadened out in various particulars. While these laws are not technically included in the list of Anti-trust laws contained in Section I of the Clayton Law, 一the Interstate Commerce Commission is referred to at various places in that statute and in its attendant law, the Federal Trade Commission Act. The form and procedure of the Interstate Commerce Commission have been copied so closely that attention to the terms of the Acts to Regulate Commerce will be of great service towards a clear understanding of the subject of Anti-trust legislation,including the Sherman Law, which followed in 1890 , only three years later than the enactment of the creating act.

As has been stated, the Acts to Regulate Commerce, like the Federal Trade Commission Act, are not enumerated among the Anti-trust laws; but they are all correlated, and at the very least should be regarded as attendant enactments which are vital and necessary to complete the scheme and make it effectual.

In an instructive contribution on the subject in hand, ${ }^{5}$ a recent writer has indicated that in his opinion the provision of the Constitution empowering Congress to regulate commerce was first in-

4a For text of statute, see Appendix O, pages 345-36r.

5 James A. Fayne: "The Federal Trade Commission; The Development of the Law which Led to Its Enactment,"-The American Political Science Review, February, 1915. 
terpreted in 1876 in such a way as to charge business with a public interest. The case he quotes is Munn v. Illinois, 94 U. S. II3, and the issue involved therein grew out of the assertion by certain elevator owners of the right to collect discriminatory charges for storing grain.

The Supreme Court held in accordance with an English authority, Lord Chief Justice Hale, in De Portibus Maris,-

"looking then to the common law, from whence came the rights which the Constitution protects, we find that when private property is 'affected with a public interest, it ceases to be private property only." "

In finding that the warehouse of the appealing party was so charged with a public interest, the Supreme Court stated-

"while the rights of property which have been created by the common law cannot be taken away without due process" * * * due process can be altered at the will of the legislators within constitutional limitations, and it is the province and function of that department of government to remedy defects in the common law as they are developed and adapt it to the changes of time and circumstances."

Such being the rule when the enactments of a State legislature are concerned, the rule in matters within the power of Congress is still broader and less circumscribed, seeing that the common law as such does not enter directly into Federal jurisprudence, leaving the legislative rights untrammeled except by boundaries which the Constitution itself prescribes. It is not difficult from this beginning (if it be the fountain head), to follow the flow of the stream through intermediate holdings including the Standard Oil and the Tobacco cases down to the natural outlet in an interstate trade commission equipped to enforce conditions of equality in right to trade, by the abolition of illegal restraints and combinations.

In contradistinction to the narrowing tendency shown in the Knight case, - -holding that manufacture is not "commerce," (see page 77), it may be pointed out that the courts have of late held the ownership of forty-six per cent. without the employment of

6 U. S. v. E. C. Knight, 156 U. S. I. 
an intermediary holding company, is a prohibited act where the servient company is a potential competitor." Even when "an absence $* * *$ of all the elements of undue injury to the public and undue restraint of trade" is shown to exist, there is still a violation of the second section of the Sherman Law where the tendency of the combination was to destroy competition and create and maintain a monopoly. ${ }^{8}$ This is the latest authoritative decision; and it seems to prepare the way for the Federal Trade Commission with its prime purpose of overcoming the twin obstacles-undue combinations and unfair competition.

This decision (the Harvester Case) is by the United States Circuit Court of Appeals. It has yet to stand the test of scrutiny and review in the appeal now pending in the Supreme Court; but until the decision is modified or reversed, it constitutes the latest authoritative judicial version of the doctrines which have grown to be controlling in Anti-trust proceedings. The decision goes very far, and while logical in its reasoning, it may well be that the Supreme Court will regard the requirements impossible of performance, under actual business conditions in the world of large finance.

Whatever the outcome of this important appeal, it is not at all probable the rules controlling in Anti-trust litigations will experience any radical change, for those principles are now established firmly as a part of our jurisprudence, and as is noted by the author of the valuable article referred to on page 77 , "in both [the Union Pacific merger and the Harvester] cases no new expressions of opinion were recorded." In brief, recent decisions have turned upon how far or in what manner principles now recognized as established shall be applied.

\section{CONSTITUTIONAL QUESTIONS SETTLED BY SU. PREME COURT.}

Judicial Construction Appears Settled.-Even though the Supreme Court does not affirm the Harvester decision, the legal aspect may be considered a closed incident, for (as has been mentioned), in neither of these important decisions is there a new expression of opinion on the substantive Anti-trust laws. After the tumultous legal proceedings wherein the Standard Oil Com-

7 U. S. v. Union Pacific Railroad, 226 U. S. 306.

8 U. S. v. Int. Harvester Co., 214 Fed. 987. 
pany was fined $\$ 26,000,000$ in the lower courts, and the American Tobacco Company had damages enforced against it under the treble damage clause of the Sherman Act, this condition appears like a halcyon period indeed, wherein the new Commission can begin the performance of its duties, with a confidence based upon results that a long and hard fought litigation has produced.

Constitutional Question.-The question of the constitutionality of the Sherman Law having been thus disposed of, with it are adjusted problems that might otherwise come up in reference to the statutes not within the list of Anti-trust laws, as strictly enumerated in the statutes themselves.

The Sherman Law is within the enumerated class; but the decisions relating thereto are for the most part applicable to all. In the Northern Securities case, ${ }^{9}$ it was held that a large discretion pertains to Congress when it is performing its legislative duties, and that a sound construction allows great latitude "with respect to the means by which the powers it confers are to be carried into execution, which enable that body to perform the high duties assigned to it, in the manner most beneficial to the people."

Under a case of equal authority, ${ }^{10}$ the Supreme Court held in applying the "commerce" clause of the Constitution in its relation to the Sherman Law:

"Under this grant of power to Congress, that body, in our judgment, may enact such legislation as shall declare void and prohibit the performance of any contract between individuals or corporations where the natural and direct effect of such a contract will be, when carried out, to directly and not as a mere incident to other and innocent purposes, regulate, to any substantial effect, interstate commerce."

The above case as to its facts disclosed an ingenious device whereby manufacturers of pipe within a certain district joined a combination and every member agreed under penalty to sell only subject to its rules. Each contract was submitted to competition within the combination, and the successful bidder was then free to undertake the work at the best terms he could obtain, without competition from his associate members. This plan in-

9 U. S. v. Northern Securities Co., 193 U. S. 197.

10 Addystone Pipe \& Steel Co. v. U. S., 175 U. S. 21 . 
sured some profit to all, but at an additional cost to the public.

To the same effect upon the constitutional question involved, is a State court decision:

"The State has a right to limit individual rights when their exercises touches the public, and, if unrestrained, would be prejudicial to order or to progress."11

In the same court it had already been held and declared that a trust is illegal under the common law. ${ }^{12}$

\section{BENEFITS FROM ANTI-TRUST ACT.}

Interpretation and Application of Act.-The object sought to be accomplished by the Sherman Act is to afford a remedy for the injurious effect of unrestrained competition. Like most principles of wide application in the personal or business affairs of men, competition ceases to be an advantage - far less an infallible panacea-when applied without limit or modification to many tangible and concrete situations. Competition then becomes a "glittering generality" and is only too likely to mislead the confiding individual or nation. Just as it has been held "the great office of the statutes is to remedy defects in the common law as they are developed and to adapt it to the changes of time and circumstances" (Munn v. Ililnois, 94 U. S. II3), socialism has entered into the everyday problems of modern society and has endeavored to solve them to the end that the ordinary citizen shall not find existence too hard or too complex to be borne. The saying attributed to Lincoln, "God loved the common people-he made so many of them," has an application here, for the State must concern itself with the welfare of its individual citizens, since in times of peace their composite condition and wealth is the measure-the sum total - of its prosperity and material resources; and from their numbers must be gathered the lists that elect public officials and supply jurors; while in seasons of war their courage and patriotism are its sure defense.

Socialistic Influences are Apparent.-Socialism, unconsciously to most of the persons concerned, enters into the make up of political life and affairs. Thus, the childless pay their full proportion of the tax for maintaining schools in recognition of the

II Wood v. Whitehead Bros., I65 N. Y. $545,550$.

12 People v. North River Sugar Co., I2I N. Y. 582. 
direct benefit which intelligence and mental discipline on the part of the general public confer upon every resident and owner of property; while the transfer tax in a more radical manner appropriates a portion of the unearned increment which inures to heirs, and applies it to the common fund comprised in the budget required to meet the expenses of government.

Unregulated Competition Effectuates Trusts.-It is too late in the day to feel required to dilate upon the injuries that resulted from the unwillingness of the State to divorce itself from the vague generality that unlimited and unrestrained competition is a blessing and advantage in every situation and under all circumstances. The chapter in our national life that is inscribed with the record of Standard Oil, the Beef Trust and kindred combinations is written too plainly and is too recent for more than passing notice by way of illustration; fortunately these situations so inimical to general social and economic progress, are at last in a fair way to be relegated to the sphere of history; and whatever problems the Republic shall be called upon in future to face in working out the practical application of its career and aims in national life, the vital questions of the prevention and control of predatory trusts seem well in hand and in a fair way to be solved through preventive and curative legislation well adapted to achieve that end. At least, as we have seen, such was the Congressional purpose, when enacting the Clayton Law; and also when providing the machinery of the Federal Trade Commission to carry into effect that supplement to the Anti-trust laws.

Limitation of Relief to Results Obtained by Suits Solely Instituted by Government,-A Grave Question.-It has been shown (pages 77,78 ), that much retracing of steps along the pathway leading to the restraint and control of illicit monopolies and restraints of trade became necessary because of the narrow definition of "commerce" adopted and applied by the Supreme Court in the Knight case. ${ }^{13}$ That there was some doubt as to the extent to which the courts would go in applying the statute, and that it was fully recognized that a narrow and technical construction might nullify its terms, is apparent in the record of the discussion which attended the passage of the Sherman Law.

After it had received, with the exception of one vote, the

13 U. S. v. E. C. Knight Co., 156 U. S. 1. 
unanimous approval of the Senate, the proposed measure was taken up by the House, May I, 1890, and the debate became general. In the course of his defense of its provisions, Mr. Culberson, of Texas, while speaking for the Judiciary Committee, was interrogated by Mr. Henderson, of Iowa, as to whether in view of the market-control secured by the trusts- "this bill, in his judgment, reaches that difficulty or not." To this question Mr. Culberson replied by saying: "I believe it will if it is construed as we think it ought to be construed by the courts." $\mathrm{Mr}$. Henderson then continued his enquiry by asking: "Does the bill go as far as Congress has power to go to strike at that damnable system?" To which Mr. Culberson replied: "That is the opinion of the committee."14

In the first particular, the courts have justified the confidence reposed in their wisdom and acumen through a later virtual reversal of the attitude adopted in the Knight case; but it is now apparent that Congress "had power to go" several steps further by: (I) assuming a broader definition of "commerce" and so enlarging the scope of the law as to include interferences therewith as well as restraints and monopolies, among the prohibited acts; and (2) granting specifically and beyond question to individuals the power to invoke its aid.

It is certain that failure to include any right of individual initiative had much to do with limiting the usefulness of the statute and deferring the date of its active employment in the protection of public interests.

\section{FOREIGN ANTI-TRUST LAWS DISCUSSED.}

Canadian Anti-Trust Law Considered.-That wisdom is not confined to any land-is not the perquisite of any race or government-is shown by the provisions existing in the neighboring Canadian jurisdiction.

In contradistinction to the distrust of individual action and the preference for bureaucratic ideas and methods displayed by the Federal party at the inception of our government, leaving some trace thereof discernable in the attitude of Senators Sherman, Hoar and Edmunds and others of that school of thought a century later,-it is refreshing to see democratic ideals success-

14 Congressional Record, 51st Congress, first session, pages 4090-4091. 
fully put in force and practice, even though under a government which is monarchial in name.

In Canada, as mentioned above, anti-trust regulations are not left to be enforced solely by public officials, for the citizens-or subjects-who have been injured or fear injury are presumed to possess the intelligence, foresight and courage to defend their rights, when the weapon is placed in their hands or within their reach.

Thus, it is provided in the Canadian laws ${ }^{15}$ that-

"Where six or more persons, British subjects resident in Canada and of full age, are of opinion that a combine exists, and that prices have been enhanced or competition restricted by reason of such combine, to the detriment of consumers or producers, such persons may make an application to a judge for an order directing an investigation into such alleged combine." Upon receiving the petition, the judge within ten days must appoint a time and place for an investigation, with full power to summon witnesses, grant adjournments, and to enquire into every essential fact.

The statute then proceeds:

"If upon such hearing the judge is satisfied there is reasonable ground for believing that a combine exists which is injurious to trade, or has operated to the detriment of consumers or producers, and that it is in the public interest that an investigation should be held, the judge shall direct an investigation under the provisions of this act."

The complainant and the defending party are each entitled to nominate a member of the statutory board of enquiry, and these members are empowered to select a judge, who shall sit as the third member of the board, and shall preside at its meetings.

Full publicity for their report is provided. The penalty for disobedience, if the charge is sustained, consists of $\$ 1,000$ for each day of continued trade-restraint after the date set for cessation of the prohibited acts; and the import laws may be so modified

15 Combines Investigation Act (1910), 9-10 Edward VII, Chap. 9; An Act to Amend Inland Revenue Act, 4 Edward VII, Chap. 17; Canadian legislation concerning patents, -Revised Statutes of Canada, Vol. III, Chap. 146, Sections 496-498. For Anti-trust measure antedating Sherman Law and containing provision prohibiting undue restraints of production, etc.,see Stat. of Canada, I889, Chap. 4I. 
as to permit free importation of the monopolized articles, or an invention may be removed from the protection of letters patent,as the particular situation requires. In addition, the person"who thereafter continues so to offend, is guilty of an indictable offense."

The proceeding throughout is summary; and the enforcement is at no stage hampered by undue delay:

"The governor in council may make such regulations not inconsistent with this act, as to him seem necessary for carrying out the provisions of this act and for the efficient administration thereof."

Within fifteen days after any of the steps thus authorized are taken by the governor, he is required to transmit the regulations for consideration by the provincial parliament if in session, or at the next session of that legislative body.

Plan Apparenty Offers Immediate Effective Relief.-Here we have in effect a complete plan for immediate effective checking of monopolistic tendencies "where six or more persons" feel themselves aggrieved.

United States and Canadian Procedure Compared.-When these provisions combining simplicity of method with the promise of prompt and efficacious results are read in parallel columns with the tedious and cumbersome chancery practice provided under the Sherman Anti-trust statute, it is readily seen that benefits of free institutions may exist in superior form under a monarchial government. In brief, the changes embodied in the Clayton Law and the Federal Trade Commission Act consist of a necessary though belated modernization of our Anti-trust laws.

Return to Normal Conditions Indicated.-It is fortunate that trusts and monopolies have been to so considerable an extent removed or curbed under laws in which distrust of citizeninitiative constituted a predominant feature; but it would have been folly to longer delay the enactment of laws which will expedite the return of conditions of normal and healthy competition in business, extending throughout the general field of commerce, and reaching into every department of national life.

Further Consideration of Foreign Anti-trust Regulations. -Other foreign jurisdictions have provided other means of enforcement for measures intended to meet and overcome monopolies and restraints of trade. 
In Great Britain ${ }^{16}$ the solution of this problem has been sought through enforced publicity and the agency of boards of trade. In Australia $^{17}$ and New Zealand ${ }^{18}$ their protective statutes bear a general resemblance to the Anti-trust laws which we have seen are in force in the Dominion of Canada. The Colony of the Cape of Good Hope has in force and effect an "Act to Prevent a Monopoly of the Meat Trade,"19 which operates by means of a registered license. When arbitrary price-fixing or other unfair methods in restraint of traffic are shown, the license may be withdrawn and the party guilty of the prohibited practices is prevented from again engaging in that line of business for the space of two years.

Under the laws of Japan, if a company does acts contrary to the public welfare or to good morals, the court may on the application of a public procurator or of its own motion order its dissolution. ${ }^{20}$

"Unfair competition" as a term relating to statutes and regulations that concern restraints of trade, is an expression which appears to have been coined in Australia; and the revision of our Anti-trust laws owes much of its form and presumptive efficiency to the intelligent ideas which the dependencies of Great Britain have contributed to this department of Anglo-Saxon jurisprudence.

\section{COMMISSION LAW AND CLAYTON LAW BROADEN MEANS OF RELIEF.}

Section 16 of the Clayton Law Supplies Adequate Means of Relief.-Fortunately we no longer find it requisite to wander afield in foreign jurisdictions or to search the statutes of our several States for means to enable individual citizens to initiate methods of relief when beset by restraining or monopolistic conditions in trade; speedy and adequate relief may now be secured

16 Companies (Consolidation) Act, 1908, 25 and 26 Vict., Chap. 96, Sec. 84. See Chitty's Digest of the Laws of England; also Encyc. of the Laws of England, 2d Ed., Vol. II.

17 The Australian Industries Preservation Act, 1906; the Excise Tariff (No. 16 of 1906); the Patent Act of 1903.

18 Acts for Repression of Monopolies in Trade or Commerce, New Zealand Consol. Statutes, Vol. IV, Appendix D, Act I40, Sec. 28 (1910).

19 No. 15 of Laws of 1907.

20 Commercial Code of Japan, Book II, Chap. 48 (Loenholm). 
under the right to injunctions contained in Section I6 of the Clayton Law.

Governmental Initiative No Longer Required.-Every citizen may now apply for a restraining order where the injury disclosed in his complaint shows a violation of the provisions relating to price discrimination, "tying" contracts, or abuses of corporate methods by stock-ownership or control of the board of directors. Such injunctive relief may be sued for "in any court of the United States having jurisdiction over the parties."

Whereas even a State could not procure an injunction under Section 4 of the Sherman Law, ${ }^{21}$ (such relief being reserved for use in proceedings instituted by or at the instance of the Attorney-General in the government's behalf,) the modern doctrine enforced by positive statutory provisions opens the door to every aggrieved person, in the field which covers every usual form adopted by trusts or monopolies in their efforts to retain or exploit a given line of trade.

Earliest Anti-trust Decision under Sherman Law.-The earliest reported decision construing Sections I and 2 of the Sherman Law arose upon an application for the appointment of a receiver in connection with the enforcement of a sale which the defendant claimed to be void because intended to create a restraint of trade and virtual monopoly. The court says, per curiam, $^{22}$

"Now it is to be observed that these statutes [Sections I and 2, aforesaid; also, corresponding provisions in the Anti-trust Law of the State of Louisiana] outline an offence, but require for its complete submission no ulterior motive, such as to defraud, etc.; and further that the language is altogether silent as to what means must be used to constitute the offence. *** To compass either of these things [restraint of trade or monopoly], with no other motive than to compass them, and by any means, constitutes the offence."

In reaching its conclusion, adverse to the application, the court notes the inversion of the usual order, in that the statutory provi-

2I Minnesota v. Northern Securities Co., 194 U. S. 48 . See also, National Fire-Proofing Co. v. Mason Builders Association, I69 Fed. 259.

22 American Biscuit and Mfg. Co. v. Klotz, 44 Fed. 721. 
sion is used as a defence in meeting an alleged effort to monopolize; then, commenting upon the general object of the statute, the decision continues:

"The attempt to accumulate in the hands of a single organization the business [concerned in the application] should not be favored by a court of equity. It carries with it too much of danger of excluding healthy competition, thereby increasing the difficulty to the general public of participating in a most useful business [maintenance of bakeries] as well as adding to the possibility of multitudes of citizens being temporarily, at least, compelled to pay an arbitrary and high price for daily bread."

Reasoning in Early English Case Sustained.-It is curious and interesting to note that after more than three centuries, the identical defences interposed in Darcy v. Allen (pages 16, 19, ante), is again regarded with favor by a court of equity jurisdiction, i. e., the loss of opportunity to the individual and the presence of an indirect but measurable damage to the public-at-large,which, taken together, create a situation where public policy prohibits tribunals from compelling compliance with trade-restraining contracts.

\section{NARROWING ARGUMENT EXAMINED.}

An Analysis of Sections I and 2.-An ingenious writer, ${ }^{23}$ has devoted attention and skill to an analysis of "The Face of the Sherman Law," and in that connection has dissected each of the first two sections. He concludes that the meaning of Section I is-

"clear, precise and undebatable in all its words except two. Those two words are 'restraint' and 'commerce.' * * *

To construe those two words is to construe that sentence.

And to construe that sentence is to take the first and only really difficult step toward construing the whole statute."

It is then pointed out that "restraint" has a threefold aspect:

(a) It relates to and was intended to prohibit restraints both of international and interstate commerce; to 59 .

23 Albert H. Walker in "A History of the Sherman Law," pages 48 
(b) The meaning "is confined to direct restraint and is not aimed at indirect restraint of interstate or international commerce."

(c) "* * * when Congress in Section I of the Sherman Law prohibited combinations in restraint of interstate and international commerce, it did not intend to make that law the foundation for trivial and vexatious suits,"-whence he concludes that the acts complained of must be "extensive enough to be materially injurious to public or private welfare."

Perhaps without such intention, it may be that the authority quoted is in part responsible for the situation out of which Antitrust provisions have taken shape in the Clayton Law and its corollary, the Federal Trade Commission Act, providing the legal machinery for the enforcement thereof. Certain it is that "direct restraint" would preclude the prosecution of holding companies and other intermediary forms; while the third aspect would leave it to a court to classify wrongs which might appear trivial to a judge, whereas they might well be entirely destructive of the business interests of the complainant.

It is entirely possible that this construction too frequently has led to a tendency to look upon a prosecution under the Sherman Act as constituting a species of state trial, and is responsible for the tendency to avoid the responsibility thereof,-a condition that prevailed during the administration of President Harrison. Usually only affairs of a public or semi-public nature have been considered worthy of such deliberation or action. Something of this is noticeable in the prevailing note in the Standard Oil and other leading cases; while no doubt unconscious it is to a certain extent discouraging if not a deterrent to an injured person seeking redress.

Arbitrary classifications are part and parcel of the social and legal systems in force in a kingdom or aristocracy; equality be fore the law is the touchstone best suited to the administration of justice in a republic. The question of relative size is always ungracious, and it is one that should be avoided where the statute itself does not make the sum involved the test of right to litigate.

The point raised in (b) of the passage quoted is answered by the enactment of Sections 3, 7, and 8 of the Clayton Law, wherein and whereby conditional or "tying" contracts; stock ownership 
in competing concerns direct, or through the medium of a holding company; and interlocking directorates-each of these devices being an indirect means of exercising restraint-are all declared unlaw ful where the acquisition of stock tends to restrain competition in the community or to create a monopoly of any line of trade.

In so far as the limitation of jurisdiction by excluding trivial or unimportant cases is suggested by division (c) of said passage as the true construction of the word "restraint" in Section I of the Sherman Law, - the total ignoring of the amount at stake fixes an entirely different standard for proceedings instituted under the Federal Trade Commission and Clayton laws. Under the Federal Trade Commission Act the sole criterion is whether "a proceeding by it [the Commission] in respect thereof would be to the interest of the public"; in the latter the Commission or Board has the right to set its restraining or curative machinery in motion whenever, at the instance of an individual feeling himself aggrieved, it "shall have reason to believe that any person is violating or has violated any of the provisions," etc.; and the right to proceed independently to obtain injunctive relief against "threatened loss or damage" by violation of its essential prohibitions is accorded by Section I6 of the same law.

Nothing can be more certain than that the legislation embodied in these last-mentioned statutes is purposed to nullify a property valuation, if such a classification could ever be properly read into the words of Section I of the Sherman Law. Congress has decreed that in future the enforcement of Anti-trust laws should be effected by means as simple and direct as the practice in Justice's Court,- "the poor man's court."

Reverting to the arguments advanced by the able author mentioned on page 88 , the word "monopolize" which is there stated to occupy a debatable ground as its specific meaning-seems twisted out of its ordinary signification. After referring to the Senate committee's definition of "monopolize," which appears on page 76 , supra, the author argues that-

"Section two of the Sherman Law does not prohibit a complete acquirement of the whole or any part of interstate or international commerce, except where that complete acquirement results from efforts of the monopolizer 
to prevent other parties from competing with him in achieving that complete acquirement.

*

But it also follows that where a particular monopolizer does or does not possess or use superior skill and superior facilities for doing the work monopolized, but does attain a monopoly of that work by the aid of impediments placed by him in the path of his competitors, that monopolizer violates Section 2 of the Sherman Law.

Reason for Presenting foregoing Analysis.-This view has been set out somewhat at length because of the clearness of the expressing words and because similar ideas have been repeated from time to time in certain decisions under the Sherman Law. But the argument is believed to be fallacious; whatever force it may possess in academic discussion, this narrow construction has been specifically repudiated, voided and set at rest by the decisions in the Southern Pacific Railroad case and to a large extent in the International Harvester case, ${ }^{24}$ as well (see pages 19, 79, ante). While the terms of the existing decision in the Harvester Case may be modified or its application limited in the appeal now pending in the Supreme Court, it is improbable that any basic principle of Sherman Law construction will be disturbed.

Writer Above Quoted Now Controverted by Controlling Decisions.-The judicial determination of the vexatious problem which has so long troubled courts and counsel now bids fair to remain established as the law of the land in cases of this description. It will no doubt be observed how this result presents an example of the tendency in legal affairs to hark back to the mental point of view originally reasoned out by the courts. In this instance the reference is to the per curiam opinion in the first Sherman Law decision, American Biscuit and Mfg. Co. v. Klotz, quoted at page 87 , where a literal construction is deduced and applied.

Advantage Definite Ruling Affords.-The constitutionality of the Sherman Law is now firmly established; and it is fortunate that this question of constitutionality should have reached a definite conclusion and the old order should have changed and moved off the stage before the advent of the Federal Trade Com-

24 U. S. v. Union Pacific Rd., 226 U. S. 306; U. S. v. Int. Harvester Co., 214 Fed. 987. 
mission. That body in consequence can exert its important powers under a new dispensation-untrammelled by the necessity for carrying through a long and complicated series of litigations The solution of this difficult and intricate question would otherwise necessarily involve uncertainty; whereas its whole attention henceforth can be devoted to the settlement of new problems, and to the administrative duties it is called upon by law to perform.

\section{DEFINITIONS OF "COMMERCE."}

Anti-trust Definitions of "Commerce" Compared.-While reference is being made to "commerce" as regulated by the Sherman Law, it may be useful to turn aside for a moment to notice the defining words contained in the more recent Anti-trust legislation. In Section 4, of the Federal Trade Commission Act, there appears an official designation of the meaning of that word, when found in this particular statute:

"Commerce means commerce among the several States or with foreign nations, or in any Territory of the United States or in the District of Columbia, or between any such Territory and another or between any such Territory and any State or foreign nation, or between the District of Columbia and any State or Territory or foreign nation."

The definition in Section I of the Clayton Law is of the same tenor, excepting that it includes "trade or commerce," and the scope of commerce involved in the regulating statute is extended to "any insular possession or other places under the jurisdiction of the United States * * * Provided that nothing in this Act shall apply to the Philippine Islands."

Comparison of these provisions with the terms of Sections I, 2 , and 3 of the Sherman Law, discloses at a glance that the jurisdiction under the Federal Trade Commission Act is tantamount to that under the Sherman Law, so that the preventive statute covers the same area as the punitive law; whereas protection against price discrimination, "tying" or conditional contracts, control of competing corporations by stock-ownership, and the various other features of the Clayton Law extend to the limits of the entire region under protection of our flag, excepting only the Philippine Islands. What significance this distinction in jur- 
isdiction was intended to possess, or whether it was merely desired to restrict the extent to which the administrative duties of the Commission should be exercised at the inception of the plan embodied in the creating act, will appear when its policy is developed in practice. As the limits of these statutes are the same, it may also have been intended to utilize the Commission to preclude the necessity for future litigations under the Sherman Law; certainly the issuance of restraining orders requiring the defendant to cease and desist from "unfair methods of competition in commerce $* * *$ if it shall appear to the Commission that a proceeding in respect thereof would be to the interest of the public," appears to fit in well with this theory,-due regard being had to the well-defined policy of treating as state trials previous prosecutions under the Sherman Law.

Sections I and 2 of Sherman Law are Generally Construed together.-In those prosecutions, Sections $I$ and 2 are very generally regarded as dual only to the extent that Section I relates to individual attempts to restrain trade, etc., whereas combinations of two or more persons, firms or corporations are covered by the ensuing section. The distinction is obvious and is repeatedly noticed in the decisions, where these sections are usually construed together so as to include infractions of the statute by either method.

Construction and Application now Settled Law.-The law in connection with the enforcement of Sections $I$ and 2 of the Sherman Law has been so completely settled by the Northern Securities case, the Standard Oil and Tobacco prosecutions and by the success of the government in proceedings against the Union Pacific Railroad and International Harvester Company ${ }^{25}$ (the last-named decision, however, being subject to review by the Supreme Court in the pending appeal), that discussion of the rulings upon those provisions does not seem warranted. Suffice it to say that trusts, monopolies and combinations in restraint of trade or commerce have been adjudged unlawful, when the effect is to restrict the flow of traffic and trading which normal conditions of competition would otherwise create and maintain.

25 Standard Oil Co. v. U. S. 22I U. S. I; U. S. v. American Tobacco Co., 221 U. S. 66 U. S. v. Union Pacific Rd., 226 U. S. 306; U. S. v. Int. Harvester Co., 214 Fed. 987. 
15. CONGRESS SUPPLEMENTS ANTI-TRUST DECISIONS.

Purpose in Strengthening Anti-trust Laws.-Attention is again directed to the controlling purpose in the strengthening of Anti-trust legislation through the enactment of the Federal Trade Commission Act and Clayton Law. That purpose can be none other than to prevent, rather than to combat, the evils growing out of monopolistic conditions. The long warfare waged by the government against the skillfully entrenched forces of trustsgrown strong and self-endowed with resources of wealth and talent-has been a feature in the history of our times. The remark by Mr. Culberson, a leading member of the House of Representatives, during the able debate that preceded the enactment of the Sherman Law: "I believe it will [afford adequate relief], if it is construed as we think it ought to be construed by the courts"-stands justified by the outcome thus far in the progress of Anti-trust affairs.

Legislation-Supplements, Court Rulings.-The result has been, on the whole, favorable to the people; and Congress has seen fit to supplement this success by laws that by positive enactments extend Anti-trust influence and regulation into fields preventive as well as curative. These appear in the chapters already devoted to the Federal Trade Commission Act, and Clayton Law.

The debates that attended the passage of the Sherman Act are worthy of careful study in this connection. ${ }^{28}$ Many features are explained in the debates in the Sixty-second Congress in connection with the proposed Interstate Trade Commission Law of I912. This is presented very fully in Appendix M, pages 304-334.

Sections 4 to 8 Considered.-Sections 4 and 5 of the Sherman Law confer jurisdiction in equity upon the several circuit courts (since succeeded by the district courts), in government suits brought to enforce the statutory provisions.

Section 6 provides for forfeiture of goods which are concerned in such infractions, when in transit from one State to another, or to a foreign country.

Section 7 affords threefold damages for any person injured in his business and property, and grants in addition the costs of court and a reasonable attorney's fee.

26 For account of this notable discussion, occurring at the inception of Anti-trust legislation, see pages 74-77, ante. 
Section 8 provides that 'the words 'person' or 'persons' whereever used in this act shall be deemed to include corporations and associations existing under or authorized by the laws of either the United States, the laws of any of the Territories, the laws of any State, or the laws of any foreign nation." This section is very comprehensive and the definition includes firms, individuals and associations, together with corporations of every description.

With the exception of Sections I and 2, these provisions are self-explanatory and will not receive attention which should be reserved for those topics which still require our careful consideration. 


\section{DEFINITIONS OF PERSON AND CORPORATION AND EXTENT OF (I) INDIVIDUAL, (2) CORPORATE LIABILITY, UNDER:}
I. Federal Trade Commission Act.
2. Clayton Law.
3. Sherman Law.

General Comment.-In way of introduction to this department of our subject, it may be well to note that the Federal Trade Commission Act is not enumerated in the list of the Anti-trust acts. Section 4 enumerates the Sherman Anti-trust Law, ${ }^{1}$ and sections 73 to 77 , as amended, of the Wilson Tariff Law; ${ }^{2}$ while Section I of the Clayton Law adds that statute to the number. By reasonable deduction it seems to have been the legislative intent to create the Federal Trade Commission with its distinctive functions of enforcing the Anti-trust laws in their application to general business, and to some phases of the matters connected with common carriers and banks; and to accomplish this purpose, the Federal Trade Commission has been endowed with judicial powers and duties, suited to the task before it. This law, accordingly, is not an Anti-trust law; and the Commission is an instrument provided by law and superimposed upon that legislation, to render effective the preventive, administrative and curative features of the Anti-trust laws.

In exact accord with and in furtherance of this policy the definition of "corporation" in Section 4 of the Federal Trade Commission Act is given a very wide signification, which includes every form of combination except partnerships. The still broader definition of "corporation" contained in the Sherman Law, Section 8, reappears in the Clayton Law, Section 1, - -doubtless because the Clayton Law is in effect and in legislative intent an amendment of the Sherman Law. At the very least it is as the title states a "supplement" thereof. This definition appears in both statutes, under the word "person," and is as follows:

"The word 'person' or 'persons' wherever used in this act shall be deemed to include corporations and associa-

I For text, see Appendix C, pages 279-281.

2 See Appendix D, pages $282,283$. 
tions existing under or authorized by the laws of either the United States, the laws of any of the Territories, the laws of any State, or the laws of any foreign country.

It therefore will appear plainly that while the definition under the Federal Trade Commission Act is broad, the limits contained in the wording of the Sherman Law and Clayton Law present a still wider circle of meaning. There can be no doubt as to the signification of the language in the Sherman Law, for the word "corporation" occurs only in the definition itself.

The distinction in meaning is important, and must be constantly borne in mind. In the Clayton Law and the Sherman Law "person" equals and includes "corporation," as well as individuals. On the other hand, the Federal Trade Commission Act, by giving a distinctive definition to the word "corporation," wherein no mention is made of "person," and wherein partnerships are specifically excepted-confines its verbal circumference to the usual and customary scope of the word "corporation" in other connections.

In brief, in the Clayton Law and Sherman Law "person" includes "corporation," unless the application is limited elsewhere in the former statute; whereas, in the Federal Trade Commission Act "person" is distinct from and does not include "corporation," but on the contrary retains the accustomed meaning of an individual entity in contradistinction to an associated or aggregate body.

\section{FEDERAL TRADE COMMISSION ACT.}

a. Individual Liability.

Nature of Statute, Described.-Under the provisions of Section 5 of this statute, the Commission is empowered to prevent "persons, partnerships, or corporations, except banks and common carriers" from using unfair methods of competition. In this connection there should again be noted the use of the word "persons" as distinct from "corporations"; for under the definitions in the Sherman Law, and, unless qualified, in the Clayton Bill as well, the word "persons" is inclusive of "corporation." Since corporated bodies can act only through their officers or agents, contempts and penalties are prescribed and directed against those individuals, to make that power effective. But, as has already been stated, Chapter III, the Federal Trade Commission in the 
main is directed toward the establishment of a court or tribunal for correcting abuses growing out of unfair trade. In this respect it differs from the Clayton Law. The courts can enforce the rights conferred on the Commission by the former act; but those rights can be exercised and the corresponding proceedings initiated only by the Commission, in the first instance. Its visitorial powers extend only to corporations. Accordingly, obedience to "cease and desist" orders and to directions to testify, etc., is the essential liability individuals incur thereunder.

\section{b. Corporate Liability.}

Corporate Responsibility Incurred in Connection With Investigations and Reports.-In the Federal Trade Commission Act (Section 4, paragraph 2), corporation is defined as any company or association, incorporated or unincorporated, and with or without shares, which is organized to carry on business for profit, except partnerships. As has been specifically pointed out in Chapter V, the distinctive feature of the rights of the Commission under its creating act, is the limitation to the exercise of those rights only by "a proceeding * * * to the interest of the public." The Commission will necessarily require some written or sworn statement as the foundation for setting its powers in motion; and while the courts would not assume the responsibility of directing favorable or unfavorable action, it is altogether probable the courts by mandamus would compel it to exercise its discretion and elect whether it will become active in a given instance. ${ }^{3}$ Acts of individual initiative are permitted by the provisions of the Clayton Law, whereas administrative control is the dominant factor of the Federal Trade Commission Act. Careful inspection of Section 5 of the Federal Trade Commission Act will, it is believed, be convincing on this point; although the rules and procedure adopted by the Commission may modify or enlarge this section in practice.

The general investigating power over corporations, excepting banks and common carriers, expressed in Section 6, contains the essential feature of the act, aside from the definition and declaration of its powers and the measures for their enforcement, con-

3 The requirements of application to institute a proceeding appear in Rule II, p. 232. For ruling that courts will compel a statutory board or commission to pass upon questions within its jurisdiction duly submitted to it for the exercise of its discretional powers, - - see Interstate Commerce Commission v. Humboldt Steamship Co., 224 U. S. 474. 
tained in Section 5 thereof. In brief, Sections 5 and 6 contain the picture; the remainder is mostly framework and setting. One prominent element in this somewhat novel phase of legislation is the fact that all the inquisitorial powers of the Trade Commission enumerated particularly in Section 6 are directed against corporations and not against persons, which under the definition in this law comprise only individuals. The right to proceed against persons as authorized in the statute seems in the main intended to provide the requisite machinery to reach and inspect such books, papers and records as those corporate inquiries of necessity entail. Cases may and no doubt will arise where disputes will occur respecting the ownership and legal custody of those documents; and in those instances the constitutional limitations contained in the fourth amendment regarding searches and seizures, and in the fifth amendment covering self-incrimination would of course apply.

Taken broadly, and considered as a whole, the Federal Trade Commission appears to have been intended by Congress to succeed the Bureau of Corporations ${ }^{4}$ so far as its powers of inquisition are concerned, but joined with an affirmative right to initiate court proceedings, such as the Bureau never possessed; and the authority to demand and compel the production of documents and papers is an incident to those powers.

\section{THE CLAYTON LAW.}

\section{a. Individual Liability.}

Measure Fills a Dual Capacity.-This statute must be regarded as occupying to some extent a dual position. As an amendment of or supplement to the Sherman Law, it partakes of that brevity which is the soul of drastic legislation as well as of wit. The earlier constitutions, both Federal and State, set forth rules of a general nature, for the guidance of the citizens, leaving to the courts or the several legislative bodies the functions of limiting, amplifying, or applying the rights, powers and duties therein enumerated and defined. In the later constitutions the tendency has been to leave less latitude to the institution and discretion of courts or legislatures. The details and limitations are self-contained; and the only functions remaining is to apply the constitutional decree. Both influences are traceable in the Clayton Law.

4 For text of creating provisions, see Appendix E, pages 284, 285 . 
The Sherman Law is distinctly of the former class. The language is tense with meaning; words of widest scope have been chosen throughout, with deliberate intent, and to a certain degree the Clayton Law partakes of that quality. But as a medium of practical use and application, as well as to avoid the charge of presenting merely a counsel of perfection, it was seen that due regard must be had to the means at command to make its legal machinery effective. Thus, while the very and perhaps excessively comprehensive definition of "person" contained in the Sherman Law is retained in the Clayton Law, there are places where the word is utilized in connections that cannot possibly refer to other than individual human entities.

Certain Provisions Specifically Considered.-Section 2 of the Clayton Law declares price discrimination unlawful, and this practice no doubt is designated as one instance of the unfair competition prohibited by Section 5 of the Federal Trade-Commission - Law; construing the two statutes together, there can be no reasonable doubt that persons and partnerships are included in the inhibition.

The provision of Section 8 of the Clayton Law relates to interlocking directorates of two or more corporations. The word "person" is employed, but it can have no possible meaning here except that of a human individual. This dual meaning is in some places implied rather than set forth in distinct phraseology. No doubt there will be rulings by the Commission or courts which will differentiate, distinguish and point out the true significance, when opportunities for adjustment of disputed meanings shall arise.

The provisions contained in Sections $2,3,7$, and 8 of the Clayton Law are not punishable in criminal proceedings. The statute, Section II, affords the usual means of enforcement by applications to courts, where "contempt" can be shown.

Statute Creates Personal Liability for Individuals Concerned in Corporate Crimes.-Any violation of the penal provisions of the Anti-trust laws (which includes this bill, see Section I) are by Section 14 declared to be deemed the deeds of the individual directors, officers, or agents who shall have participated therein; and violations of Section Io, regulating interlocking directorates between common carriers and construction, supply or financial

5 For text, see Appendix C, pages 279-28r. 
concerns, are likewise freighted with trouble for the individuals taking part therein, with the additional feature that "any person who shall, directly or indirectly, do or attempt to do anything" along the prohibited lines, shall be equally culpable. In this instance, the word "person" is doubtless mainly directed at individuals acting in some accessory capacity; and doubtless there are other places where a similar signification will be noted when the Clayton Law comes to be enforced in connection with its companion statute, the Federal Trade Commission Act. Of this much we may be certain,- - that all the prohibitions against interlocking directorates are of necessity applicable to individuals, although in terms directed against certain classes of incorporated bodies.

\section{b. Corporate Liability.}

Responsible for Illegalized Stock-Ownership.-In Section 7 it is made unlawful for one corporation to own stock in a competing concern, or to own shares in two or more competing companies. This prohibition of stock-ownership applies only to corporations. In contradistinction to Section 7, however, the provisions of Section 2, Price Discrimination; Section 3, Tying Contracts, and Section 8, Interlocking Directorates, apply to both individuals and corporations; but no criminal penalties are provided for violations of any of these four sections.

Acts in Violation of Anti-trust Laws Carry Triple Damages.-Outside of and beyond the deterring influence of the contempt proceeding which we have seen may be instituted in cases of infraction of Sections 2, 3, 7, and 8, there exists the liability for three-fold damages. Pursuant to the provisions of Section 4, the person injured may sue for such damages in any district court where the defendant resides or has an agent, and may recover "threefold the damages by him sustained, and the costs of suit, including a reasonable attorney's fee."

Ownership in Non-Competitive Stock Company Allowed.Stock-ownership by corporations for investments, or in subsidiary companies, if for branches or extensions, is permitted, where the object is not merely to gain control and where the purpose is not otherwise unlaw ful or tending to substantially lessen competition. Further provisions of section 7 allow common carriers to own stock in branch line companies upon practically similar conditions; also, do not make unlawful any stock ownership that existed at the time when the statute went into effect. 
Final Adjudication in Government Proceeding Prima Facie Evidence; Statute of Limitations Suspended.-Under the terms of Section 5, a final decree in any criminal prosecution or suit in equity brought by or on behalf of the United States under the Anti-trust laws shall be prima facie evidence against the defendant, in any suit or proceeding brought by another party against the defendant under said laws, provided the contention of the government was successful in the prior action. In addition, this section declares the statute of limitations inoperative against private claims pending government suit to prevent, restrain or punish violations of any of the Anti-trust laws.

Interdiction of Joint Interests Between Common Carriers and Supply, Etc., Concerns.-Common carriers interlocking in their boards of directors with supply, construction and financial companies with which they do more than $\$ 50,000$ in volume of business in any one year are by Section ro rendered amenable to regulation by the Interstate Commerce Commission, and infraction of this statutory provision is made punishable by criminal proceedings, which may be instituted against the common carrier corporation as well as against its directors, agents, managers or officers. The fine against the corporation is fixed at $\$ 25,000$, while the maximum penalty for the individual directors, etc., is $\$ 5,000$ fine with imprisonment for one year. By Section 14, the provision that authorizing directors, officers or agents are liable for unlawful corporate acts and may be punished in criminal proceedings, is decreed to apply generally in all violations of any of the penal provisions of the Anti-trust laws.

Enforcement Proceedings Regulated by Section Ir.-Corporations are subject to the powers and process of the respective commissions and the Federal Reserve Board; and the specific enactments as to their several powers and authorities and the means provided for the orderly application and enforcement thereof will in general be found in Section I I of the Clayton Law The procedure is set forth in Chapters IV and V, to which reference is made for particular information. The Rules contained in pages 232 to 235 , and the forms appearing in pages 236 to 245 should also be consulted.

Under Sections 21 to 24, Court's Direction Involves Liability to Contempt Proceedings.-While the district courts are authorized by Section 9 of the Commission Act to issue writs of 
mandamus commanding and compelling any person or corporation to comply with any provisions of that statute or to obey the Commission's orders, there is no equivalent provision in the Clayton Law. Perhaps the fact that the latter law is included in the Anti-trust legislation and has the severe penal provisions associated with laws to reach misdemeanors and other crimes, may explain the discrepancy. Instead of the civil writ of mandamus we find substituted very broad provisions contained in Sections 2 I to 24 inclusive, authorizing proceedings for semi-criminal contempt. The power to punish covers wilful disobedience of "any lawful writ, process, order, rule, decree or command of any district court of the United States or any court of the District of Columbia by doing any act or thing therein or thereby forbidden to be done by him, if the act or thing so done by him be of such a character as to constitute also a criminal offence under any statute of the United States, or under the laws of any State in which the act was committed"; such offender shall be "proceeded against for his said contempt as hereinafter provided." The defendant is entitled to notice, and to a jury trial, if demanded by him; a review, with reasonable bail, is another provision of the statute. This proceeding, however, must not be confounded with the right to enforce obedience in suits or actions instituted by the United States; or to contempts committed in the presence of the court or so near thereto as to amount to an obstruction of the administration of justice. Pursuant to Section 24, these offences continue punishable in summary manner in conformity to the usages at law and in equity.

Any corporation which fears a threatened loss or darnage by any violation of the Anti-trust laws may have injunctive relief, in a proper case (Sections 16 to 20 , inclusive). What constitutes a proper case with the particulars of procedure the law prescribes will appear in Chapter $\mathrm{X}$, which is devoted to a discussion of "Injunctions and Contempt Proceedings Under the Federal Trade Commission Act and Clayton Law."

\section{LIABILITY UNDER THE SHERMAN LAW.}

In General.-While it is not intended at this place to enter fully into the discussion of the scope and effectiveness of the Sherman Law, since it has received particular attention at another place (Chapter VIII), still some remarks will without doubt be 
useful in regard to the question of where and when the liability for prohibited acts ensues.

In this connection, it may be well to call attention to the fact that the Clayton Law is in effect an amendment of the Sherman Law, and is by its terms as expressed in its title, declared to be supplementary to the "existing laws against unlawful restraint and monopolies," i. e., to the laws commonly known and occasionally described in the statute themselves (see Clayton Law, Section I) as the Anti-trust acts.

It is one feature of the history of legislation in a republic that laws of a nature declarative of individual rights, with the avowed intention of protecting the ordinary citizen in his business or profession, are always progressive; and later statutes explain, apply and generally broaden out the application of the initial enactment. In a monarchy or autocracy, the powers of the Duma or other legislative body may be seriously curtailed, or the semi-independent constitutional rights of Finland or other principality may be cut down; but under a democracy the people are granted or rather demand and take over additional powers and interests in the government, until what at first was esteemed a privilege has grown into an acknowledged right. The saying of Jefferson, "The cure for the ills of democracy is found in more democracy," may not appeal to statesmen and it may be opposed in party platforms and ideals; but the fact remains that the wheels of the political machine appear to revolve only in one direction in a republic.

\section{a. Individual Liability.}

Language of Sherman Law Extremely Condensed.-Applying the principles enumerated above to the work at hand, it may be said without fear of serious contradiction that nowhere in the Revised Statutes at Large is there more condensed meaning than is contained in the eight brief sections that together make up the Sherman Law. It seems to have been the Congressional intent to weigh every word, and to give every portion of the law the same attention and thought which would ordinarily be reserved for a provision of the Constitution itself.

Joint Restraints of Trade Illegal.-For statute in full, see pages 279-28I. Section I deals with contracts, combinations and conspiracies in restraint of trade or commerce. It relates to and declares illegal every form of executory agreement and under- 
standing, and it is especially aimed at industrial trusts and trade agreements between independent concerns, or competitive interests.

Sherman Law Reinforced by Clayton Law.-The prohibition, however, is directed solely against acts "in restraint of trade"; it is plain that acts of competition in aid of securing or enlarging trade or commerce-short of a monopoly-are not intended to be proscribed. This fact is ably presented in Thornton's work, "The Sherman Anti-trust Act," pages 308-9; but much of the reasoning and necessarily a portion of the deductions drawn are rendered obsolete in view of the preventive legislation contained in Sections 2, 3, 7 and 8 of the Clayton Law, wherein and whereby price discrimination, tying contracts, corporate stock ownership in competing corporations, and interlocking directorates are declared to be unlawful acts. This interdiction of "the very appearance of evil" is specific, and therefore outside the scope of judicial rulings and the deliberations of text-writers upon the matter and measure of the nature and the class of acts intended to be interdicted by the Anti-trust laws. Reaching back of and beneath the physical results of the desire to deal unfairly, the new legislation seeks to remove the condition out of which the occasions for such unfair actions would flow. Such is the intent of Congress; as to its practical effects or the manner and extent to which it is applied by the Federal Trade Commission or construed by the courts, - these are matters that rest as yet in the lap of the gods.

There can be no question that Section I-and the supplementary matter contained in Sections 2, 3, 7, and 8 of the Clayton Law-involve the fullest degree of personal liability, except in so far as Section 7 of the Clayton Law refers exclusively to corporate acts.

Monopolies, Whether by Combinations or Individuals, Prohibited.-Section 2 of the Sherman Law is directed especially at monopolies, which may be conducted by single persons, or corporations, or firms; whereas the provisions of Section I require a combination or conspiracy, and this of course involves joint action by two or more persons or concerns. So that while one person may offend against the second section by monopolizing acts, the first section contemplates and is directed against conduct of two or more. The comments upon the occasion for and the objects sought to be accomplished by the provisions of Section I apply with equal force here. 
Section 3 specifies Territories, etc., as localities where the act applies, and declares illegal every contract, combination or trust in the prohibited class.

The provisions of Section 4 confer jurisdiction for enforcement upon the United States circuit courts,-now merged in the district courts, -and Section 5 extends to every district the right to serve summons and subpœnas.

The right to condemn property in course of transportation, owned in violation of Section 1 , is contained in Section 6.

Criminal Jurisdiction Extended by Clayton Law.-This section concludes the penal provisions of the Sherman Law. Their application to individuals has been very much extended by Section 14 of the Clayton Law which makes a violation by a corporation also the act of its directors, officers and agents consenting thereto. This enlargement applies to any penal provision of the Anti-trust laws. The somewhat familiar spectacle of an infraction of these laws followed by a fine imposed upon the perhaps already injured or impaired corporate body, is not henceforth to constitute the only penalty. These penal features, however, have their own allotted place, Chapter XII, and only brief mention will be made of them in passing.

Word "person" has Wide Application here.-It should be remembered that under the Sherman Law a very broad definition of the word "person" applies, and that wherever that word is found it must be deemed to include not only individuals and firms, but also corporations and associations under the laws of the United States, or of any Territory, State or foreign country.

Enforcement by Contempt Proceedings Allowed.-Contempt proceedings are permitted under Section 2I of the Clayton Law, wherever the disobedience of the order constitutes a criminal offence under the laws of the United States, or of any State. Such designation, of course, includes infractions of the Sherman Law. Such contempt actions are subject to jury trial; and must be instituted within one year. Construing Section I4 of the Clayton Law in connection with the penal provisions of the Sherman Law, it seems probable that contempt actions would lie against directors of corporations charged with violations thereof, or with similar infractions of any penal provision of the Anti-trust laws.

Some Compensating Rights Are Conferred.-As some compensation for these increased severities, the amendatory features 
of the Clayton Law enlarge the scope of the rights of individuals, under the Sherman Law. Injunctions under Section 4 of the Sherman Law may be granted by a United States court of equity as the suit of the government; and a similar right exists under Section 15 of the Clayton Law. But in addition thereto, any person, firm, corporation, or association has like rights, provided an injunction bond is filed and the requirements of Sections 16 to 20 are complied with. The right to enforce the provisions of the Clayton Law contained in Section 2, price discrimination, Section 3 , tying contracts, Section 7, corporate stock ownership, and Section 8, interlocking directorates, under Section II thereof, also extends individual rights of initiative into the jurisdictions of the Interstate Commerce Commission and the Federal Reserve Board.

Right to Litigate Enlarged.-On the other hand this enlarged capacity to sue carries with it an enlarged field of litigation wherein the allegations of the complaining parties must be met and combatted; and to this extent the Clayton Law may be said to have increased the liability of individuals under the Sherman Law and the other Anti-trust statutes. The phraseology of the Sherman Law is so condensed that it seems more satisfactory to quote than to attempt to abbreviate it. Section 7 is as follows:

"Any person who shall be injured in his business or property by any other person or corporation by reason of anything forbidden or declared to be unlawful by this act may sue therefor in any circuit [district] court of the United States in the district in which the defendant resides or is found, without respect to the amount in controversy, and shall recover threefold the damages by him sustained, and the cost of suit, including a reasonable attorney's fee."

It is incorporated in almost exact words in Section 4 of the Clayton Law.

The right to pursue a defendant into another district than that in which he or it resides, permitted at the instance of the government in Section 5 of the Sherman Law, is granted to every litigant when the defendant is a corporation, provided it can be found or transacts business therein. The rule $e^{6}$ that Section 5 of the Sherman Law does not apply to actions to recover damages

6 Greer, Mills \& Co. v. Stoller, 77 Fed. I. 
under Section 7 thereof, is continued in the Clayton Law; and Section 13 accordingly permits subpœnas to run into any district only where the United States is the moving party under the Antitrust law.

Triple Damage Rights Also Enlarged.-In one particular the liability of the Sherman Law is largely increased for individuals. The threefold measure of damages is extended by the inclusion in the Clayton Law of the acts prohibited by Section 2, price discrimination, Section 3, tying contracts, Section 7, corporate stock ownership, and Section 8, interlocking directorates. Probably Section 4 of the Clayton Law includes rights of actions for damages arising from interlocking directorates between common carriers and financial or supply houses, in the improbable event that such damages can be legally proven; for Section 4 covers injuries "by reason of anything forbidden in the Anti-trust laws."

Definitions of "Person" Compared.-The final provision of the Sherman Law, Section 8, is as follows:

"The word "person" or "persons" used in this act shall be deemed to include corporations and associations existing under or authorized by the laws of either the United States or the laws of any of the Territories, the laws of any State or the laws of any foreign country."

Attention has been already called to the use of similar defining words in the equivalent provision contained in Section I of the Clayton Law; though in the latter statute the word "person" is necessarily confined to individuals where it is employed in provisions which prescribe the rights or duties of members of boards of directors, or incumbents of other offices.

The definition of "corporation" in Section 4 of the Federal Trade Commission Law is an effort to unload from the word "person" some portion of this burden of meaning which overweights it in the Sherman and Clayton Laws. Like the distances between the fixed stars,- - the extent of space involved is almost too great for human comprehension. As it stands, "person" when employed in the Sherman Law and Clayton Law includes partnerships and unincorporated associations in addition to bodies corporate, and every class of individual human beings.

\section{b. Liability of Corporations}

Subject Matter Treated in Last Paragraph.-The principal 
phases of this department of our topic have come up incidentally in writing of individual liability.

Scope of Liability Enlarged.-The liability to prosecution has now been extended by removal of the limitations prescribed in the leading decision upon that point $;^{7}$ and individuals as well as the government may now, by virtue of Section 16 of the Clayton Law, institute proceedings in equity against corporate as well as other defendants, praying for injunctive relief against "threatened loss or damage by a violation of the anti-trust laws, including Sections 2, 3, 7 and 8 of this [Clayton] Act."

Upon the law side of the court, the extent of the liability for three-fold damages recoverable under Section 7 of the Sherman Law, has been greatly increased by the more comprehensive terms of Section 4 of the Clayton Law.

Individual Responsibility for Corporate Acts.-Beside the responsibility of defending its property and other interests along a more extended line-a responsibility that devolves upon the corporation as a whole-the individual officer, director and agent must respond where his acts are the subject of complaint under Section I4 of the Clayton Law.

Thus it is apparent that under this new legislation a revision of former methods of regulating incorporated bodies is intended, and that both the material and the personal sides are involved. In brief, this new dispensation extends in manifold directions; and in each quarter there is need for study by those who have their own interests and those of the corporation at stake, when seeking the correct solution of the difficulty that confronts them.

Abuse of Chartered Powers. - The powers of joint contribution, and of concealment, so readily at command under the legal fiction of an artificial entity, and which it must be admitted in the last analysis supply the foundation for criticism of many corporate practices, have compelled Congress to take notice of this opportunity for abuse of chartered powers.

Old Remedies Applied by New Methods.-In brief, the Antitrust laws as amended and supplemented supply a new method for the enforcement of old doctrines, - a method which looks behind the form and regards mainly the substance, and places the

7 Minnesota v. Northern Securities Co., 194 U. S. 48; Thornton's Sherman Anti-trust Act, § 35r. 
penal and civil liability upon the officer, or agent, or member of the directing board.

General Result Beneficial to Individuals.-To this extent the Federal Trade Commission Act and the Clayton Law have amended and supplemented the Sherman Law and the Anti-trust laws in general, and to this extent the liability of the individual has been increased. But it is requisite to say in this connection that whatever that burden may prove to be in practice, there are reasons to believe that the dignities and rights of citizenship have been enhanced in far greater measure and that the public at large will benefit in futture by its ability to work under a coherent and efficient plan, provided with a supervising board fully empowered to protect the individual in his right to demand and require fair methods of competition in commerce. 


\section{SUITS FOR INJUNCTION UNDER THE FEDERAL} TRADE COMMISSION ACT AND THE CLAYTON LAW; ALSO, SPECIAL CONTEMPT PROCEEDINGS.

I. Importance of Subject Considered.

2. Notice in Equity Practice.

3. Practice Revised.

4. Public Interest Conserved under Commission Act.

5. Clayton Law Provisions.

6. Application and Hearing.

7. Order Must be Specific.

8. Special Limitations in Trade Disputes.

9. Contempt Proceedings Where Disobedience Involves Criminal Act. 10. Old Forms of Contempt Retained.

II. Statutory Limitation One Year; Criminal Proceedings Not Barred.

\section{IMPORTANCE OF SUBJECT CONSIDERED.}

I. Right to Injunctive Relief Retained and Enlarged.Despite the danger of appearing to state a mere truism, it is necessary to call attention to the extreme importance of the subject of injunctive relief. Particularly is this required concerning a newly created administrative body equipped with judicial functions that call for the employment of restraining orders in the performance of the duties committed to it by direct legislation or naturally associated with its allotted sphere of action.

While in numerous directions the new legislation comprised in the Commission Act and the Clayton Law has safe-guarded public interests and extended the right of the individual manufacturer, trader or consumer to demand fair treatment in business, in no quarter is this considerate treatment by Congress more plainly evident than in the enlargement of the individual's right to seek injunctive relief. By certain important decisions construing Section 4 of the Sherman Law, ${ }^{1}$ the Supreme Court confined to

I See matters referred to and authorities cited in Notes 3, 4 and 5. For extracts from interesting and able report of the Senate Judiciary Committee submitted prior to the enactment of the Federal Trade Commission Act and Clayton Law,-with particular reference to the history and nature of injunctions, and the practice in application to courts of equity when injunctive relief is sought, - see Appendix N, pages 335-344, post. 
the United States represented by the Attorney General the exclusive province of preventing and restraining violations of the Anti-trust laws, to the complete elimination of individuals and even States as suitors seeking to correct abuses and to assert the right to immediate redress through proceedings in equity.

In view of the infrequency of the instances where popular rights, once extended, have afterward been withdrawn or even curtailed,-it seems unlikely that the right to enforce the Antitrust laws through suits in equity will be again confined to government control. The general tenor of recent legislation on this subject is opposed to that feature of Sherman Law practice; and whatever the result may be, the road to redress by personal initiative remains open to every real or artificial person who feels that he or it is or may be oppressed by trade-restraint or some other "unfair method of competition in commerce." Whether the shorter road is also quicker and better, is something which the future must disclose.

Certain other modifications of equity practice should now receive attention.

\section{NOTICE IN EQUITY PRACTICE.}

Extent of Notice Courts of Equity Require.-At the inception of our judiciary system, Congress passed the Judiciary Act of 1789, containing the plan outlined by Chief Justice Ellsworth, whereby power was conferred upon the courts to issue injunctive writs, including writs of ne exeat in accordance to legal usages and practice.

This statute was revised in 1793 , and the foregoing power was confirmed, but with the limitation: "No injunction shall be issued in any case without reasonable previous notice to the adverse party or his attorney."

The intent of the law was plain; but like many general statutes its terms were too sweeping to permit of complete justice in all cases. In practice the rule was substantially modified by judicial constructions holding that the statutory provision did not cover situations where an irreparable injury was threatened. In a leading case the court said:

"Every court of equity possesses the power to mold its rules in relation to the time of appearing and answering so as to prevent the rule from working injustice, and it is 
not only in the power of the court, but it is its duty to exercise a sound discretion upon this subject."2

In brief, the spirit of equity jurisprudence rendered it incompatible for the court to issue writs or orders which were idle when the adverse party had notice and an opportunity to change the situation before the hearing; and therefore, in compliance with substantial justice, the court exercised its discretionary power in respect to requiring prior notice, notwithstanding the restrictive nature of the prohibiting words.

In this manner the practice became less broad than the law; and matters continued in that condition down to the general revision of 1873 . The clause containing the provision as to notice in respect to injunctions is therein made to conform to the practice, as follows:

"Whenever notice is given of a motion for an injunction out of a district court, the court or judge thereof may, if there appears to be danger of irreparable injury from delay, grant an order restraining the act sought to be enjoined until the decision upon the motion; and such order may be granted with or without security, in the discretion of the judge or court."

\section{PRACTICE REVISED.}

Practice Regulated by Clayton Law.-This provision is specifically repealed by paragraph 3 of Section 17 of the Clayton Law. In its place an amplified system of injunctive relief is set forth in Sections 15 to 19 , inclusive, with a further provision in Section 20, restricting the granting of injunctive relief in disputes concerning terms or conditions of employment.

The Federal courts are also granted jurisdiction to enforce the provisions of the Sherman Law, by Section 4 thereof; and a like authority is conferred by Section 74 of the Wilson Tariff Law, ${ }^{5}$ in relation to combinations and contracts in restraint of im-

2 Ex parte Poultnoy, 4 Peters C. C. C. 472.

3 Section 263 of the Judiciary Code, revision of 1873 ; continued in effect by the Judiciary Act of I9II; repealed by Clayton Law, Section 17, paragraph 3.

4 For text, see Appendix C, pages 279-28I.

5 See Appendix D, pages 282-3. 
port trade. While it will be noted that such writs do not require security and are not circumscribed as to the prior notice required for the issuance of a temporary restraining order, those statutes can be invoked only by and through the several district attorneys under the direction of the Attorney-General; and such proceedings accordingly do not come within the scope of the subject of personally conducted actions, but rather pertain to administrative prosecutions on behalf of the government.

Restraining Orders Will be Issued in the Public Interest.Section 5 of the Federal Trade Commission Law confers powers somewhat similar, in that in proceedings instituted by the Commission in accordance with the purposes of its creation, that body is authorized to issue and cause to be served an order requiring the defendant "to cease and desist from using such methods of competition," i. e., unfair methods of competition in commerce. Any person, firm, or partnership may upon application be permitted to intervene; but it will be noted that this law does not permit any private party to become the complainant in the proceeding, which is to be instituted only when the decision of the question at issue "would be to the interest of the public."

The ultimate relief is, of course, an order of an injunctive nature, and is reviewable by the courts upon the record upon which the original order was granted. It is probable that the power to apply for mandamus, contained in paragraph 4 of Section 9 , relates to these orders as well as to the production of books, papers, etc., required in the course of investigations by the Commission.

\section{PUBLIC INTERESTS CONSERVED UNDER COMMIS- SION ACT.}

No Preliminary Injunction Provided for under Federal Trade Commission Act.-The fact that these proceedings are only instituted by the Commission itself, and then only in matters where the public interest is concerned, prepare us for the absence of any provision for preliminary injunctions or restraining orders. No such power exists under the Federal Trade Commission Act. The láw creates an instrument for a state trial, to correct a public wrong, with the right on the Commission's part to admit private parties as interveners, in its discretion. The minimum of time fixed by the statute, thirty days (Section 5), of itself prevents any summary steps to restrain an existing or threatened injury. 
In this respect the Federal Trade Commission Act is in accord with the practice laid down by the courts in their construction of Section 4 of the Sherman Law. No private person is authorized to bring an action for injunctive relief under that section. Even a State cannot intrude in that field of litigation reserved exclusively for the Federal government. ${ }^{\circ}$

No doubt it was the legislative intent to leave actions of that nature to be instituted by the persons concerned, under the individual rights conferred in and by the Clayton Law, whenever individual rights under the protection of the Anti-trust acts are invaded.

\section{CLAYTON LAW PROVISIONS.}

Injunctive Relief under Clayton Law.-Returning to our consideration of the provisions for injunctive relief substituted in the place of Section 263 of the Judicial Code, ${ }^{7}$ we find that Section I 5 of the Clayton Law confers jurisdiction upon the United States government acting by the several district attorneys, to obtain complete injunctive relief, including temporary orders of a restraining nature. Section 16 empowers private parties-

"to sue for and have injunctive relief, in any court of the United States having jurisdiction over the parties, against threatened loss or damage, by a violation of the Anti-trust laws, including Sections 2 [Price Discrimination], 3 [Conditional on "Tying" Contracts], 7 [Stock Ownership in Competing Corporations], and 8, [Stock Ownership by Holding Companies] of this act, when and under the same conditions and principles as injunctive relief against threatened conduct that will cause loss or damage is granted by courts of equity, under the rules governing such proceedings, and upon the execution of proper bond against damages for an injunction improvidently granted and a showing that the danger of irreparable loss or damage is immediate, a preliminary injunction may issue."

6 Piddock v. Harrington, 64 Fed. 821 ; Greer, Mills \& Co. v. Stoller, 77 Fed. 1. Minnesota v. Northern Securities Co., I94 U. S. 48, 2 Fed. Antitrust Dec., 533. Also see Thornton's Sherman Anti-trust Act, § 35I, page 694, etc.

7 See Appendix I, pages 29I-3. 
The ensuing portion of the section prohibits bringing any injunctive suit against a railroad in matters under the authority and supervision of the Interstate Commerce Commission. Infraction of the Sherman Law by railroads and other common carriers generally, are not within the jurisdiction of the Interstate Commerce Commission; and hence such combination in restraint of trade as were held unlawful by the Supreme Court in the TransMissouri Freight Association case, ${ }^{8}$ would be subject to restraint by injunction by private parties; and railroads and other common carriers could presumably be enjoined from filing with the Interstate Commerce Commission rates in accordance with such unlawful agreement. In the above-cited case it was squarely held that where railroads associated themselves together for the purpose of making rates by agreement, those combinations were in restraint of trade, and constituted violations of the. Sherman Act.

The words, "Anti-trust laws," contained in the foregoing statutory provision (Clayton Law, Section I6), are defined in Section I of said law. They include the Sherman Act; Sections 73 to 77, inclusive, of the Wilson Tariff Law, as amended; and the Clayton Law itself.

Under the provisions of Section 16, Congress has extended to individuals the right to bring actions to restrain violations of the Sherman Law. No doubt this broadening of the means for enforcing the Anti-trust statute was intended to nullify the rule resulting from certain decisions ${ }^{9}$ and authorities cited, restricting to the Attorney-General the right to bring suits in equity to enjoin violations thereof.

In addition to or in substitution for such government-brought suits, there exists the right of the Federal Trade Commission to proceed under Section 5 of the creating act, whenever it deems the public interests will be conserved; and power to admit private individuals to intervene in such governmental proceedings should and no doubt will in practice inure to the benefit of private parties, especially since by Section 5 of the Clayton Law, every final judgment or decree in any criminal prosecution or suit in equity brought by the government under the Anti-trust Laws becomes

8166 U. S. 290.

9 National Fireproofing Company v. Mason Builders Association, 169 Fed. 259. Even a state cannot institute such a suit. Minnesota v. Northern Securities Co., 194 U. S. 48, decided in 1904. 
prima facie evidence in a proceeding instituted by any other party against the same defendant under those statutes.

\section{APPLICATION AND HEARING.}

Requirements as to Notice.-The practice with regard to notice to adverse parties is in substantial accordance with the recommendations by President Taft, contained in his message to Congress, dated December 7, 1909, to the effect that positive enactments should be passed regulating the issuing of injunctions, and requiring them to be granted only on notice,-

"unless it shall appear to the satisfaction of the court that the delay necessary to give such notice and hearing would result in irreparable injury to the complainant, and unless, also, the court shall from the evidence make a written finding, which shall be spread upon the court minutes, that immediate and irreparable injury is likely to ensue to the complainant, and shall define the injury, state why it is irreparable, and shall also endorse on the order issued the date and the hour of the issuance of the order. * * * My judgment is that the passage of such an act, which really embodies the best practice in equity and is very likely the rule now in force in some courts, will prevent the issuing of ill-advised orders of injunction without notice and will render such orders, when issued, much less objectionable by the short time in which they remain effective."

The final recommendation refers to the suggestion previously occurring in said message, that the injunction or restraining order, when granted without notice or hearing, should expire by statutory limitation within not to exceed seven days, unless the court should, upon notice and hearing, within said time extend the injunction or order.

Recommendations from a person so well qualified to speak authoritatively were entitled to respect; and the requirements of the Clayton Law were drawn in accordance with those suggestions.

By the provisions of Section $17,-$

"No temporary restraining order shall be granted without notice to the opposite party unless it shall clearly appear from specific facts shown by affidavit or by verified bill 
that immediate and irreparable injury, loss or damage will result to the applicant before notice can be served and a hearing had thereon."

Such order shall be indorsed with the date and hour of issuance and filed forthwith in the clerk's office and entered of record. It-

"shall define the injury and state why it is irreparable and why the order was granted without notice, and shall by its terms expire within such time after entry, not to exceed ten days, as the court or judge may fix, unless within the time so fixed the order is extended for a like period for good cause shown, and the reasons for such extension shall be entered of record."

Practice Upon Hearing.-The hearing upon the application for the preliminary injunction shall be advanced before all other matters excepting prior applications of a like nature; and the temporary restraining order shall be disssolved, unless the applicant for the temporary injunction proceeds with the hearing.

The opposite party upon two days' notice to the applicant may appear and move to dissolve or modify the temporary restraining order, and "in that event the court or judge shall proceed to hear and determine the motion as expeditiously as the ends of justice may require."

Security in the usual terms is required by Section 18, unless some ground of exception specified in Section 16 is made to appear. No class of applications for injunctions is relieved from the necessity of a bond by the provisions of Section 16 , but it is there set forth that applications are governed by the rules of equity courts regulating such proceedings. In effect, therefore, the court or judge may exercise discretion regarding security only to the extent that the practice in equity permits.

\section{ORDER MUST BE SPECIFIC.}

Injunction Order Must be Specific in Terms.-In another particular also, the Clayton Law is explicit as to the requirements of the reformed practice in injunction suits. It is decreed that henceforth injunction orders shall be specific. Section ig enunciates the rule as follows:

"That every order of injunction or restraining order shall set forth the reasons for the issuance of the same, 
shall be specific in terms, and shall describe in reasonable detail, and not by reference to the bill of complaint or other document, the act or acts sought to be restrained, and shall be binding only upon the parties to the suit, their officers, agents, servants, employees, and attorneys, or those in active concert or participating with them, and who shall by personal service or otherwise, have received actual notice of the same."

This statutory regulation makes specific and obligatory a requirement which every well-equipped equity practitioner observes. Under nebulous rules of practice inconceivably lax methods have prevailed. Injunctions against assemblages of strikers have contained restrictive provisions forbidding them to congregate at a spot named in the order "or elsewhere"; indeed under orders thus drawn, assemblages in Europe, Australia, or Japan, or in any other inhabited or uninhabited portion of our globe would fall equally within the prohibited zone.

To instance every type of looseness or deficiency in drafting would require thought and attention to a prohibitory extent; like proving a negative, the task is theoretically possible but impracticable in application. It will no doubt suffice in this connection to state that the rule enunciated above is in accordance with the procedure in force in those courts of equity which stand highest in that department of law.

\section{SPECIAL LIMITATIONS IN TRADE DISPUTES.}

When Injunction Orders in Trade Disputes Allowed.-The leading cases were studied and followed by the Congressional committees engaged in drafting the Clayton Law, with the result that the substance of those decisions is incorporated in the section relating to injunctions, so far as applicable. The authorities followed are valuable and form a useful guide to the legislative intent. $^{10}$

The Clayton Law enters fully into the question of the nature and extent of injunctive relief permissible in cases between employer and employees. When disputes arise concerning terms or conditions of employment, unless such relief is necessary "to pre-

Io For extracts from Report of Senate Committee on the Judiciary, with authorities, see Appendix N, pages 335-344. 
vent irreparable injury to property, or to a property right, of the party making the application, for which injury there is no adequate remedy at law"-the application will be denied.

This provision is contained in Section 20, which includes within said limitation cases of persons seeking employment, as well as employees.

That section further requires that when an injunctive order is issued in a case of dispute between employer and employees, there must appear in the moving papers a statement of the right or property jeopardized, which right or property "must be described with particularity"; and it is also provided in said section that the application "must be in writing and sworn to by the applicant or by his agent or attorney."

The second paragraph is drawn to cover a variety of instances where courts have seemed to over-extend their powers in the protection of "property or property rights," when granting injunctions against acts of employees; and the law in effect now requires that employees shall not be enjoined when they seek to terminate any relation or employment, singly or in concert; or when they seek to peacefully persuade others to join them in such acts, or engage in kindred lawful conduct connected with labor disputes.

Peaceful behavior or persuasion under such circumstances is expressly permitted and removed from the liability to restraining orders; for the statute goes very far in the way of protecting labor and holding above it the aegis of the law. ${ }^{11}$ The section concludes with the general phrase-

"nor shall any of the acts specified in this paragraph be considered or held to be violations of any law of the United States."

\section{CONTEMPT PROCEEDINGS WHERE DISOBEDIENCE INVOLVES CRIMINAL ACT.}

Special Contempt Proceedings Authorized Where Criminal Conduct is Shown.-Presumably to differentiate between liberty and license, and to repress at the inception the use of violence,

II See Senate Report, No. 698, July 22, 1914, for a full statement of the reasons leading to the enactment of the various restrictions upon injunctions in labor disputes. The extracts referred to in note 10, page 119, supra, relate solely to general history and practice. 
more particularly in strikes and in other situations where force might be employed to resist the enforcement of the orders and decrees of the court,--disobedience of court writs, process, orders, etc., are made punishable by a proceeding for contempt, when such disobedience consists in doing a criminal act. Any offence against any criminal statute of the United States or against the penal laws of any State where the act was committed, is included in the general inhibition; and the provision likewise applies to the District of Columbia.

This enactment and the procedure pertaining thereto are comprised in Sections 21 to 25, inclusive, of the Clayton Law. The proceeding is instituted by an order to show cause, with right to attach the person, if the defendant is an individual, or to sequestrate the property if the charge is made against a corporation, and the defendant neglects or refuses to appear.

If good cause is shown, however, by affidavit or proof taken in open court or before a judge and filed with the papers in the case, the court or judge may dispense with the order to show cause, and issue a warrant for the summary arrest of defendant.

The person so charged with contempt shall be brought before the court without unnecessary delay when he is apprehended, and shall be admitted to bail in a reasonable amount. Thereafter he shall be brought to trial for the contempt, and the subsequent proceedings shall be the same as are provided in cases where an order to show cause has issued in the first instance.

Defendant May Demand Jury Trial; is Entitled to Release upon Reasonable Bail.-The defendant under the practice in contempt proceedings of this nature is entitled of right to a jury trial, if demanded, and the trial shall be conducted as is usual in criminal prosecutions.

The punishment consists of imprisonment for a term not to exceed six months, and a fine. The amount is not fixed, except that the sum paid to the United States shall not exceed $\$ 1,000$ where the defendant is a natural person. The fine shall be paid to the government or to defendant or defendants, in the discretion of the court; and the court has a like discretion to distribute the fine, where one or more of the complainants or other parties to the proceeding have been injured by the act constituting the contempt.

Appeals may be taken as provided by law in criminal cases, and 
the judgment may be affirmed, reversed or modified as justice may require.

Reasonable bail may be fixed and the defendant admitted to bail after the appeal has been consummated, by any justice, or any judge of any district court of the United States, or any court of the District of Columbia.

Intent and Scope of Contempt Proceedings Considered.The existence of these provisions of the Clayton Law in the sections immediately following those which regulate the practice upon applications for injunctions in disputes between employer and employees, seems to indicate that the purpose of Sections 21 to 24 , inclusive, is to provide a ready means of meeting and overcoming violence in labor troubles, if and when they arise. The words of the statute in this connection are not special but general, and in terms include every form of disobedience to the writ, process, order or other command of a United States court, where any infraction of a Federal or State statute creating a crime, is involved. No doubt other situations will occur where this enactment will be operative and its powers invoked, in cases outside of labor disputes; but while these cases are possible, the vast majority of proceedings of this description will, it is believed, be of the class mentioned above. If this view is correct, the general purport of those provisions is to remove from labor the fear of interference with their peaceful efforts to adjust questions or disputes connected with their divers callings; but if they overstep the boundaries which the law circumscribes and seek to promote their interests or to propagate their ideas by illicit means or measures, then these proceedings provide a ready and powerful method for the judicial control and correction of the situation.

\section{OLD FORMS OF CONTEMPT RETAINED.}

Familiar Forms of Contempt Proceedings Retained.-Further corroboration of these views is contained in the provisions of Section 24. It is therein set forth that the contempt proceedings provided for in the prior sections of the Clayton Law shall not be construed to relate to "contempts committed in the presence of the court, or so near thereto as to obstruct the administration of justice"; nor shall the existing practice or usages at law or in equity be superseded in connection with contempt proceedings instituted to punish disobedience of any lawful writ, process, rule, 
decree or command entered in any suit or action brought or prosecuted in the name of, or on behalf of, the United States. In short, the old practice for the punishment of contempts is left intact, excepting that special provision is made for the prosecution of resistence accompanied by violence, with indications that this proceeding is intended as a precautionary measure directed especially at labor disputes and other situations where the interests of numerous persons are involved.

The final regulation of the practice in contempt actions appears in Section 25, where the limitation for prosecution is fixed at one year from the date of the act complained of. The provision is unqualified, and includes all contempt of every name and nature.

\section{STATUTORY LIMITATION ONE YEAR; CRIMINAL PROCEEDINGS NOT BARRED.}

Contempt Proceedings do not Bar Criminal Prosecution.In addition to limiting the period of prosecution, Section 25 further enacts that the proceeding to punish a contempt shall not be a bar to any criminal prosecution for the same act or acts, and that nothing therein contained shall affect any proceedings in contempt pending at the time of the passage of this act.

The relationship between the right to injunctive relief and the right to enforce it through proceedings in contempt for infractions thereof, is so intimate and natural that we have not sought to introduce them in separate chapters. Their juxtaposition in the statute is some indication that they should not be separated here. 


\section{ACTIONS FOR DAMAGES UNDER THE PROVISIONS OF THE FEDERAL TRADE COMMISSION ACT AND ANTI-TRUST LAWS.}

I. Generally as to Right to Bring Actions.

2. Right Covers All Violations of Anti-trust Laws.

3. Sherman Law Provision for Triple Damages Re-enacted.

4. Certain Judgments Prima Facie Evidence.

5. Government Suit Extends Statute of Limitations.

6. Locus of Suit.

7. Procedure of Service Discussed.

8. Attendance of Witnesses Considered.

\section{GENERALLY AS TO RIGHT TO BRING ACTIONS.}

General Remarks.-Among the anomalous features of the new legislation comprised in the Federal Trade Commission Act and the Clayton Law must be included the absence of provision for any description of individual initiative under the first-named statute. Even the means to be availed of by the Commission in instituting proceedings and setting in motion its machinery is left in uncertainty by the law-makers.

Whether the Commission is authorized to exercise the powers granted by Section 5 of the creating act upon the basis of a sworn affidavit or verified complaint, or by testimony secured at a preliminary hearing or investigation, or whether it was intended that that body shall take judicial notice of facts within its official knowledge and proceed accordingly to hear and determine, are elements of the actual procedure we can only surmise, until this and similar questions have been made the object of decisions by the Commission, and have been reviewed by the courts.

It seems so probable, however, that the Commission will continue to accept and act upon verified charges in affidavits or in a formal complaint, that such procedure may be assumed for the present, and until the problem is settled in due course. ${ }^{1}$

I On this point, Rule II prescribes that "the application shall be in writing, signed by or in behalf of the applicant." Some phases of the jurisdictional question involved will no doubt be the subject of adjudications, when they come up in due course. For provisions of Rules generally,-see pages 23I-235, post. 
The question of the right of an individual to sue for damages for infractions is in a similarly uncertain state. Indeed, this condition of doubt takes on a twofold aspect: (a) has he a right to sue at all; (b) does such right as exists arise prior to an actual adjudication by the Commission upon the legality of the alleged wrongful act.

Upon the ancient pronouncement by Lord Hardwicke: "There can be no injury but there must be a remedy,"2 it is obvious that redress must somewhere and by some means be found for the private injury involved in the "unfair methods of competition in commerce," the punishment and prevention of which was the very essence of the legislative idea in creating the Federal Trade Commission and endowing it with wide and compelling powers.

Of course, the general purpose of the creating act is to provide a continuing body with administrative and judicial powers, which shall oversee the business situation of the country at large, and will as if from a watchtower, behold the conflagration at its start, and overcome it before the difficulty has passed beyond control. To observe, control and correct,-these are the three main factors in the official life and duties of the Federal Trade Commission. But while it is fully-even exclusively-empowered to act, it does not follow that a private person does not obtain derivative rights.

\section{RIGHT COVERS ALL VIOLATIONS OF ANTI-TRUST LAWS.}

Laws Imply Rights and Liabilities Through Actions.-The power to sue for injuries to business or property "by reason of anything forbidden in the Anti-trust laws," and to recover threefold damages, conferred by Section 4 of the Clayton Law, the privilege to depend upon the final decree in a government suit or action as prima facie evidence in a similar proceeding brought against the same defendant by a private party granted by Section 5 of said law; and the important provision in paragraph 2 thereof, wherein and whereby the three year statute of limitation is suspended for private parties during the pendency of such government suit or action, or criminal proceeding,--are all features which, taken together, seem pro tanto to indicate and recognize a

2 Charitable Corporations v. Sir Robert Sutton, 2 d Atkins 400, decided in 1742 . 
right that must extend into the provisions of the Federal Trade Commission Act although the statute itself is not enumerated among and technically is outside of the Anti-trust laws.

At the very least, these elements in an associated statute enacted almost simultaneously with that law, encourage the injured party in the belief that "unfair methods of competition in commerce" assure and carry with them the right to sue for the damage that the person has sustained in his business or property.

These Implied Rights Present Question for Supreme Court. -The question is one which must be passed upon by the Supreme Court, unless Congress, acting upon the "recommendations for additional legislation" permitted by paragraph (f), Section 6 of the creating act, or legislating upon its own initiative,the meantime enlarge the right to sue under authority of Section 4 of the Clayton Law, and shall in specific terms authorize recoveries for injuries inflicted by "unfair methods of competition in commerce."3

\section{SHERMAN LAW PROVISION FOR TRIPLE DAMAGES RE-ENACTED.}

Right to Recover Threefold Damages.-As has already been mentioned in the foregoing discussion of particular phases of the Federal Trade Commission Act, there is no uncertain sound to the phraseology employed in the Clayton Law in connection with the right of an individual to sue for and recover damages sustained under any infraction of the Anti-trust laws. In fact, the threefold damage clause of the Sherman Law and the Wilson Tariff Act, is repeated and embodied in Section 4 of the Clayton Law."

Probably all actions of that nature in future will be brought under the authority of the later statute, though in its terms it is

3 As the matter stands, such a right must be deduced from the legislative acts; and leading cases under the Interstate Commerce Act,- "Act to Regulate Commerce" (24 Stat. 382), as amended,-have held that in a similar situation the Commerce Commission must take the primary step, in order that private rights may accrue. Texas and Pacific Ry. Co. v. Abilene Cotton Oil Co., 204 U. S. 426; Interstate Commerce Commission v. Illinois Central R. R. Co., 215 U. S. 452.

4 For text of Sherman Law, see Appendix C, pages 279-28I ; for Wilson Tariff Act, Sections 73 to 77, inclusive, see Appendix D, pages 282-3. 
not exclusive, and the right to sue thereunder is cumulative and not due to any repealing of the prior laws, in that particular.

Section 4 is as follows:

"That any person who shall be injured in his business or property by reason of anything forbidden in the Anti-trust laws may sue therefor in any district court of the United States in which the defendant resides or is found or has an agent, without respect to the amount in controversy, and shall recover threefold the damages by him sustained, and the cost of suit, including a reasonable attorney's fee."

As stated above, this language is identical with Section 7 of the Sherman Law, and Section 77 of the Wilson Tariff Law, except that the scope is here broadened to include the whole range of the Anti-trust laws.

The Definition of "Person" in Clayton Law.-In view of the importance of the rights conferred by Section 4 of the Clayton Law, it is necessary as well as useful to note that the "person," to whom that right pertains, includes corporations and associations anywhere authorized or existing; also that this definition, contained in paragraph 3 , Section I of the Clayton Law, is copied from Section 8 of the Sherman Law; consequently, not only private individuals but associations of every form, whether chartered or unincorporated, provided only they "exist" anywhere, may avail themselves of this right to bring suit.

Additions to Injuries that Will Sustain Action.-Persons injured by price discrimination, conditional or "tying" contracts, stock ownership or interlocking directorates, henceforth may sue for and recover threefold the damages they have suffered therefrom.

Since the Sherman Law and the Wilson Tariff Law also fall within the list of Anti-trust legislation, enumerated in paragraph I, Section I of the Clayton Law,-injuries to business or property sustained by reason of contracts in restraint of trade, monopolies or attempts to monopolize, or conspiracies, as well as contracts in restraint of import trade, carry with them a like privilege.

Whether actions under the provisions of the Clayton Law will lie, before the Federal Trade Commission has passed upon the alleged violation, is a question for the courts to determine. In this respect, the situation somewhat resembles the problem presented by the want of completeness in the wording of the Federal Trade 
Commission Act in marking out the extent of the right to litigate, (see pages 125, 126, supra). Perhaps amendments will be made which will clear up both of these questions.

\section{CERTAIN JUDGMENTS PRIMA FACIE EVIDENCE.}

Former Judgment or Decree Prima Facie Evidence.-Section 5 of the Clayton Law affords the person bringing an action under the Anti-trust laws the advantage of introducing as prima facie evidence the final decree in any civil or criminal proceeding which the government has instituted against the same defendant under said laws. Notwithstanding this privilege, the plaintiff, in order to recover damages, would still have to show that he had suffered injury from the wrongful act.

\section{GOVERNMENT SUIT EXTENDS STATUTE OF LIMITA- TIONS.}

Extension of Time in Which to Sue.-By paragraph 2 of Section 5, the statute of limitations is made inoperative against private claims during the pendency of a government suit, either civil or criminal; and in many cases the three year limit will thereby be materially extended. In brief, since the extension springs from any inclusion whatever and is "in respect of each and every private right of action arising under said [Anti-trust] laws and based in whole or in part on any matter complained of in said suit or proceedings," it is difficult to conceive how language of broader import could have been employed.

\section{LOCUS OF SUIT.}

Corporate Defendant May be Sued Wherever Found.-The remaining provision of the Anti-trust laws which interests and concerns us at this time and in this connection, is contained in Section 12 of the Clayton Law. Owing to its brevity we present it in its entirety:

"That any suit, action, or proceeding under the Antitrust laws against a corporation may be brought not only in the judicial district whereof it is an inhabitant, but also in any district wherein it may be found or transacts business; and all process in such cases may be served in the district of which it is an inhabitant, or wherever it may be found." 
No definition of the word "process" appears in any place in the Anti-trust laws.

\section{PROCEDURE OF SERVICE OF PROCESS DISCUSSED.}

Service of Process.-From the context in paragraph 8 of the Federal Trade Commission Act, and the corresponding provision (paragraph 7, Section II) of the Clayton Law, it appears that other legal papers beside complaints and orders are included. Probably the term covers writs, warrants of arrest and every species of mandate requiring the authority and signature of the court, excepting subpœnas. This species of mandatory direction to appear is issued in many State courts by the attorney, although such is not the practice in the Federal courts. Separate provisions governing the service, etc., of subpœnas are found in Section 12 of the Clayton Law, but it applies only to actions brought by or on behalf of the government.

But outside of and beyond the matter of inference that may be drawn from the separate mention of subpœnas in that section, it presents a matter of interest here. Subpœnas in any action brought by or on behalf of the United States under the Antitrust Laws-whether such matter is civil or criminal-may run into another judicial district than that in which the trial is held; but witnesses shall not be summoned from a place more distant than one hundred miles from the point of trial without the permission of the trial court upon proper application and cause shown.

It is believed that the statute might well extend this rule to every litigant under the Anti-trust laws. The method of taking testimony by Commission de bene esse, i. e., subject to exception upon the trial,-is both expensive and unsatisfactory. No good reason is apparent why the government with its vast machinery of salaried officials should be exempt from the hardships and inconveniences of this rule, while it is continued in full operation to vex and discourage private parties in point of both time and expense.

Anti-trust Actions Semi-public Matters.-All Anti-trust actions are in their nature semi-public, since they serve to deter as well as to punish wrong-doing in quarters where trusts and monopolies were the controlling factors in business, up to a comparatively recent time. To bring about a reform and to inculcate 
new ideals in business is the rvident purpose of Anti-trust legislation.

\section{ATTENDANCE OF WITNESSES CONSIDERED.}

Witnesses.-The danger of calling the witness a great distance from home to harass him is prevented by the necessity of obtaining leave of the court, when the resulting journey would exceed one hundred miles.

Arguments of weight may no doubt be advanced against the extension of the right to compel witnesses in ordinary actions to attend before the Federal courts; but in Anti-trust cases, we repeat, latitude might well be afforded to treat the States as counties are regarded in State courts, and to compel attendance within a radius of five hundred miles, or such maximum distance as Congress shall see fit to fix; reserving each particular exceptional instance to be passed upon by the trial court,--the subpona to be effectual therein only when officially indorsed.

The actions for damages brought by "persons" under the Antitrust laws, except as above specified, are subject to the usual rules and regulations applicable to other litigations of that nature. 


\section{CHAPTER XII.}

\section{CRIMINAL PROVISIONS OF THE ANTI-TRUST LAWS.}

1. Federal Trade Commission Act.

2. Clayton Law.

3. Sherman Law.

4. Wilson Tariff Law.

General Consideration of Subject Essential.-In treating of the criminal features of the Anti-trust laws, and more particularly of those contained in the latest enactments, viz., the Federal Trade Commission Act, and the Clayton Law, it is essential that certain facts and circumstances shall be clearly understood and constantly borne in mind; otherwise the true basis for construing these legislative provisions will be lost sight of and perhaps entirely passed by.

Nature of First Named Two Statutes Civil rather than Criminal.-In the first place, the first named two statutes are curative and administrative rather than penal in their inception. The Sherman Law ${ }^{1}$ is drastic, and the penalties vary from restraint by injunction, and sequestration and condemnation of property, to fines and imprisonment,-all comprised within the space of eight brief sections.

The Wilson Law ${ }^{2}$ applies the same rules and penalties to the prohibited acts when committed in connection with import trade.

It remained for the Federal Trade Commission Act and the Clayton Law to propose some scheme of conduct which would amplify the legislative plan and present it as a rounded and completed whole.

Operation Postponed in Some Instances.-Realizing that the business interests of the country at large must adjust themselves to the situation which these new regulations created, Congress deferred the actual operation of certain provisions for the space of two years; and has confined the punitive features to restraining orders and threefold damages in numerous instances where the

1 For text, see Appendix C, pages 279-28r.

2 For text of Sections 73-77, inclusive, see Appendix D, pages 282, 283. 
original drafts of the laws show beyond discussion that the proposers of this legislation had in mind measures which would mete out retributive justice to an extent elsewhere imposed only upon high crimes and misdemeanors. Even the milder type of procedure implied in the arbitrary power to fix prices or to appoint supervisors has been eliminated in the laws as actually passed, and the harshness approaching a state of vindictiveness so apparent in the Sherman Law, is altogether wanting here. In a report by a Committee of Congress, the language employed is :

"* * * it was thought best, especially in view of the experimental state of this legislation, that the harshness of the criminal law should not be applied, but the enforcement * * * should be given to the Federal Trade Commission."

While the passage quoted is specially directed to one class of provisions of the Clayton Law, the attitude is that adopted by Congress when approaching the subject as a whole.

It must be understood, however, that this attitude was not intended to produce a body which would be incapable of enforcing as well as promulgating its decrees. At another place in the record of the conferences and discussions leading up to this legislation, its purpose and purport are shown to be by no means of a passive or nugatory character:

"The trade commission would constitute what might be termed a 'commercial police,' to maintain a constant guard over our vast and complex interstate commerce. It would be a strong arm to aid the courts in the enforcement of the laws passed by Congress. The trade commission $* * *$ is just as much needed, as an aid to our national commerce, as policemen are needed in the enforcement of traffic regulations in a great city. It would be just as absurd to expect the courts to enforce adequate laws for the protection of interstate commerce against unfair competition and monopoly, without the aid of such a trade commission, as it would be to expect a police court to enforce traffic laws without the aid of policemen-policemen, too, with power

3 Report No. 698, 63d Congress, 2d Session,-Senate Committee on Judiciary, July 22, 1914 . 
to make and enforce traffic rules, and not merely power to 'investigate and report." "4

Merger of Bureau of Corporations Considered.-Perhaps sonie color might be lent to the suggestion that the power of the Commission is mainly ministerial by the fact of the merging therewith of the Bureau of Corporations. The latter body was created under Act of February I4, 1903. Its powers were rather extensive within its own sphere, i. e., the investigations of the organization and management of corporations, to the end that the President might make recommendations to Congress for new legislation. The great defect was in the failure specifically to confer upon it power to compel annual reports from industrial corporations engaged in interstate commerce. ${ }^{5}$

In 1913, the Bureau was placed under the jurisdiction of the Department of Commerce, and by Section 3 of the Federal Trade Commission Act its powers are transferred to and merged in the jurisdiction conferred upon the Federal Trade Commission.

System of Interstate Commerce Commission Followed.In the details of organization of the Trade Commission, the provisions of the act (with its amendments) creating the Interstate Commerce Commission ${ }^{6}$ are followed wherever practicable; and the innocuousness of the limited scope of power which characterized the Bureau has ceased to pervade the legislation whereby the Anti-trust laws are now sought to be enforced.

Supplementary Legislations Suggested by Statute.-While the infliction of the usual penalties incident to criminal statutes is in general avoided, there are frequent intimations that severer measures will be resorted to, if experience proves they are required to accomplish results. In fact, the Federal Trade Commission Act, Section 6, paragraph (f), makes it obligatory upon that body when reporting to Congress, "to submit therewith recommendations for additional legislation."

With these introductory comments upon the comparative predominance of civil over criminal features in the law supple-

4 Report No. 533, 63d Congress, 2d Session,-House Committee on Interstate and Foreign Commerce, April 14, 1914.

5 See Act creating the Bureau of Corporations, Appendix E, pages 284-5.

6 Interstate Commerce Act, entitled "An Act to Regulate Commerce," approved April 4, 1887,-24 U. S. Statutes at Large 379. For text of original act, see Appendix O, pages 345-36r. 
mentary to the Anti-trust laws, and the accompanying Act which formulates the machinery for the enforcement thereof,-we now proceed with the specific consideration of the subject-matter of this chapter.

\section{FEDERAL TRADE COMMISSION ACT.}

Essential Element in Statute.-The law itself is mainly declaratory of a new ethical code in business dealings. The essential feature is contained in Section 5, paragraph I :

"That unfair methods of competition in commerce are hereby declared unlawful."

Method of Procedure.-Various steps are required, as therein provided, to bring the defendant before the Commission and after a trial, to authorize the issuance of a restraining or mandatory order, where the charge is proven to the satisfaction of the Commission by competent evidence. Until reversed or modified these orders have all the force and effect of judgments by a duly constituted court, with the exception that infractions thereof are dealt with by the Federal courts, and not by the Commission itself. So far the administration of justice is confined to the civil side of the tribunals, and the enforcement is accomplished entirely by restraining orders of the Commission or courts, with the right upon the application of the Attorney-General, at the request of the Commission, to add the compelling force of writs of mandamus, as well. ${ }^{7}$ Willful failure of witnesses to attend before the Commission and produce documents and papers, is also punishable by proceedings for civil contempt, Section 9, paragraph 2.

Right of Enquiry into Corporation's Affairs.-The right to enquire and conduct searching examinations is an essential prerogative and characterizing feature of the Commission; without it important provisions of the extensive jurisdiction conferred by Congress would accomplish no definite end. Consequently, the power to require the attendance of persons and the production of documentary evidence is not left to civil means of enforcement,willful failure to testify is by Section 10, made a criminal act, punishable as a penal offence; in this instance the maximum fine is $\$ 5,000$, while the prison term that may be imposed is one year.

7 Federal Trade Commission Act, Section 9, paragraph 4, page 256, post. 
Correctness in Corporate Records Required.-In and by the terms of paragraph 2 of Section 10, practices not altogether unknown in corporate management or preparation of documents and records for an impending investigation or suit, will in future be rendered more dangerous even if they do not become less frequent.

Presumably beneficial results will ensue. In brief, "doctoring" records, concealing or mutilating them or removing them outside of the jurisdiction, will in future be subject to a penalty more severe than in the event of mere refusal to testify or to produce documentary evidence at the Commission's command.

The essential points in this important provision are that any person who shall-

"willfully make or cause to be made, any false entry or statement of fact in any report required to be made by this Act, or who shall willfully make, or cause to be made any false entry in any account, record or memorandum kept by any corporation subject to this act, or who shall willfully neglect or fail to make, or to cause to be made, full, true and correct entries in such accounts, records, or memoranda of all facts, and transactions appertaining to the business of such corporation, or who shall willfully remove out of the jurisdiction of the United States, or willfully mutilate, alter or by any other means falsify any documentary evidence of such corporation, or who shall willfully refuse to submit to the Commission or to any of its authorized agents, for the purpose of inspection and taking copies, any documentary evidence of such corporation in his possession or within his control, shall be deemed guilty of an offence against the United States,"

is punishable by a fine of not less than $\$ 1, \infty 00$, nor more than $\$ 5,000$, and is liable to a period of imprisonment that may extend to three years. The enforcement is by criminal prosecution in any Federal court of competent jurisdiction.

This enactment creates a situation which cannot fail to result in a new era in respect to gaining public confidence for corporate records and accounts. Honest book-keeping and maintenance of records at once accurate and complete are the badges of permanent success in business. While it is true that maintenance of accurate records and accounts may not of itself imply a high 
standard in the transaction of business affairs, such a means of procedure will tend to create an atmosphere that is opposed to "unfair methods of competition in commerce." Plain dealing will be more congenial to such control and flourish far more naturally than amid an atmosphere where falsification, mutilation or removal of records and books of accounts is permitted or desired.

If Demanded, Reports by Corporations Required.-As we have seen, the right to demand the preparation of reports by corporations and the filing thereof with the Commission was specifically included within the statutory enlargement of the system of corporate control it acquired when the right to investigate corporate affairs was transferred by amalgamating the Bureau of Corporations ${ }^{8}$ with the Federal Trade Commission. This right to demand reports by corporations is not, however, enforceable by criminal proceedings. Disobedience, if continued for a period of thirty days after the date fixed for such filing, is made the basis of a civil action to recover $\$ 100$ for each day of the continuance of such failure, see Section ro, paragraph 3. In large corporations, however, this item of expense would not be very burdensome, and probably it will later be made a criminal offence.

Unauthorized Publicity Penalized.-Since the publication of the reports or other informations is made discretionary with the Commission, excepting that it is positively prohibited from disclosing trade secrets and names of customers (paragraph b, of Section 6), the ability to keep private its counsels, proceedings and records, is an important factor in the successful carrying out of the legislative scheme. Accordingly, a criminal penalty consisting of a fine not exceeding $\$ 5,000$, together with maximum imprisonment of one year, is affixed to conviction of any employee of the Commission guilty of unauthorized disclosure of information, unless thereto directed by a court.

Penalties are Cumulative.-These penalties are cumulative so far as the various Anti-trust laws and acts to regulate commerce are concerned. Section II declares that nothing contained in the Federal Trade Commission Act shall be construed to prevent or interfere with the enforcement of those laws; nor shall such construction alter, modify, or repeal those statutes or any part thereof.

8 For provisions creating Bureau of Corporations, see Appendix E, pages $284-5$. 
Powers of Bureau of Corporations Supplemented and Made Effective.-The law now under consideration so far as its inquisitorial powers are concerned, is in substance an enlargement of the Act of 1903, creating the Bureau of Corporations. The power to obtain corporate information is supplemented and rounded out by the power to require stated and special reports. Penalties of a criminal nature have been added, to compel obedience to the law. It should be noted that the Commission's jurisdiction extends only to requiring reports from corporations; therefore, the offense in that particular attaches only to neglect on the part of corporate officers and representatives.

Enforcement is by Court Proceedings.-The administrative and judicial features of the statute are so intimately connected with the creation of a supervising and directing body in the form of the Commission with its distinctly civil powers, that it was natural Congress should entrust the carrying out of said orders to the courts, which have ample power at their command and can enforce those mandates by the coercive means specially provided by this law, or by customary writs of injunction or mandamus or proceedings for contempt, or by any other form of compulsion under the general jurisdiction granted to them to that end.

\section{CLAYTON LAW.}

Supplements System of Anti-trust Laws.-As a supplement to the Anti-trust laws, the Clayton Law would naturally enter the campaign equipped with a complete armory of weapons for use in the war upon predatory monopolies and combinations in restraint of trade.

Reasons for Non-Criminal Methods of Enforcement Stated. -It should be understood and recognized, however, at the outset, that certain provisions are not made subject to enforcement by the rigors of the criminal law; and in those particulars we shall look in vain for any means at command, outside of proceedings of a civil nature, to compel obedience to the law.

This policy was deliberately adopted by Congress. As already stated, (page I 32 ), it was the legislative purpose and intent that "the harshness of the criminal law" should not be employed in haste or without impelling cause. Those requirements embraced in this legislation which are novel and to a considerable extent embody features that are experimental or foreign to our existing system of jurisprudence, are left to be enforced by civil measures. 
Clayton Law Amalgamates Five Proposed Anti-trust Laws.-The Clayton $\mathrm{L}_{\mathrm{a}} \mathrm{w}$ is composed in part of five proposed statutes $^{9}$ enlarging the series of Anti-trust laws, and features more or less unrelated except by propinquity, are therein assembled under one head. It is not surprising that the more extreme or untried among the statutory provisions should be deferred as to operation until a period of two years have elapsed; nor that they even then are made subject to the civil rather than the criminal arm of the law.

Certain Novel Provisions Considered.-Infractions of the provisions prohibiting price discrimination, conditional or "tying" contracts, stock-ownership, and interlocking directorates (Sections $2,3,7$, and 8 ), are not made criminal offences. Failure to obey an order against a defendant "requiring such person to cease and desist from such violations and divest itself of the stock held or of the directors chosen" (Section II, paragraph 2), is not made the object of penalty. Enforcement of such official mandates must be had (paragraph 3 ) through the machinery of the United States Circuit Court of Appeals.

Treating all infractions of the Anti-trust laws as tortious acts and imposing threefold damages (Section 4) does not denote all those injuries to be crimes.

It appears probable that the prohibition of contracts between corporations dealing in securities or supplies and common carriers having one or more joint directors, etc., is a requirement (Section Io) which does not take effect as to any of its provisions until two years from the passage of this law. However that may be, Section Io contains severe penalties; and its provisions are intended to work reform in dealings between a common carrier and banks and concerns that sell its securities or furnish supplies. This section was inserted in compliance with the recommendation contained in the message delivered by the President before Congress in January, I9I4, wherein he characterized existing methods as in effect-

"making those who borrow and those who lend practically one and the same, those who sell and those who buy but

9 These tentative measures were utilized in varying degrees in the preparation of the Federal Trade Commission Act and the Clayton Law. They were entitled: (I) Interstate Trade Commission Bill, (2) Interlocking Directorates Bill, (3) Sherman Law Definitions Bill, (4) Trade Relations Bill, (5) Anti Holding Company Bill. 
the same persons trading with one another under different names and in different combinations, and those who affect to compete in fact partners and masters of some whole field of business."

"Sufficient time," he continued, "should be allowed, of course, in which to effect those changes of organization without inconvenience or confusion."

The statute (Section 10) translates the President's words into the language usual in statute books. The period of grace is fixed at two years. After that date, to wit, October 15, I916, transactions between common carriers engaged in commerce and dealers in securities or supplies, or with construction companies, are regulated wherever business to the amount of more than $\$ 50,000$ has been engaged in between those concerns within any one year. The prohibitions and regulations affect only the class where the common carrier-

"shall have upon its board of directors or as its president, manager, or as its purchasing or selling officer, or agent in the particular transaction, any person who is at the same time a director, manager, or purchasing or selling officer of, or who has any substantial interest in, such other corporation, firm, partnership or association,"-

unless the transaction is conducted by competitive bidding under the direction of the Interstate Commercee Commission. The names and addresses of the bidders and of the officers, directors and general manager, if a corporation, and of the members, if it be a firm or partnership, must be given with the bid.

"Any person who shall, directly or indirectly, do or attempt to do anything to prevent anyone from bidding or shall do any act to prevent free and fair competition among the bidders or those desiring to bid shall be punished as prescribed in this section in the case of an officer or director."

Every such common carrier engaging in those transactions or purchases shall within thirty days thereafter,-

"file with the Interstate Commerce Commission a full and detailed statement of the transaction showing the manner of the competitive bidding, who were the bidders, and the 
names and addresses of the directors and officers of the corporations and the members of the firm or partnership bidding; and whenever the said Commission shall, after investigation or hearing, have reason to believe the law has been violated in and about the said purchases or transactions it shall transmit all papers and documents and its own views or findings regarding the transaction to the AttorneyGeneral."

A violation of this section will involve the corporation in a fine of $\$ 25,000$; and every such director, agent, manager or officer thereof,-

"who shall have knowingly voted for or directed the act constituting such violation or who shall have aided or abetted in such violation"

shall be adjudged guilty of a misdemeanor, with an attendant fine in the maximum sum of $\$ 5,000$, and incur in addition thereto liability to imprisonment for one year.

Specific Common Carrier Regulations Considered.-Two features of this inhibition are distinctive and invite discussion:

First-The section is inclusive of all persons who,-

"directly or indirectly, do or attempt to do, anything to prevent any one from bidding, or shall do any act to prevent free and independent competition among the bidders."

Every participant in such a transaction becomes as much concerned in way of penalty incurred, as though he were a principal.

The reason for this sweeping provision is the realization on the part of the public that waste or dishonesty in the affairs of public service corporations either cuts down efficiency and safety, or increases the cost of operation and thereby renders more burdensome charges which it necessarily devolves upon the people to pay.

In European countries the problem has been solved by government ownership. In the United States the same question is being met by permitting privately owned corporations to continue in control under supervising official boards.

This movement is a natural and intelligent use of the general laws relating to the public health, order, safety and comfort, and which, taken together, represent and embody that police power 
which is inherent in every government. It is a topic already discussed at some length,- - see remarks at page 65 , and also pages 67-9, supra.

Second-The method adopted is what may be termed indirect prosecution. Those common carriers within the prescribed class are required to sell securities or purchase supplies or deal with construction or maintenance concerns only by competitive bids, which in turn shall be accompanied by the information required to ascertain the persons composing the dealing concerns. Avoidance of this requirement by indirect means through the aid of agents or third parties, is prohibited; and persons participating in such indirection or artifice are subjected to full penalties.

A detailed statement of the particular transaction is required to be submitted to the Interstate Commerce Commission for their inspection and approval; it is only in the event the board "have reason to believe the law has been violated," that all documents and papers are directed to be filed, together with its opinion, with the Attorney-General. Thus the ultimate decision as to filing a formal complaint and instituting a criminal proceeding rests with the chief prosecuting officer of the government.

General Purpose and Scope of Section ro.-In dealing with the subject of Unlawful Restraints and Monopolies, the Senate Committee on the Judiciary, when reporting back this section in substantially its present form, stated in their report that they have-

\begin{abstract}
"recommended a substitute * * * which with the publicity, competitive bidding and the supervision of the Interstate Commerce Commission provided for, will, it is believed, minimize, if not wholly cure the evil to be reached."
\end{abstract}

The committee, as their reason for avoiding an absolute prohibition of all dealings between concerns where such entangling alliances have been consummated, set forth the argument that seasons of emergency might arise in the affairs of the common carrier when a firm or corporation having joint representatives or officers or other interests in common would be the only or the most desirable dealer, and that conflicting or incompatible positions would be rendered extremely unlikely under the safeguards which the statute, after careful revision, affords.

Since Section ro relates to "common carriers engaged in commerce," it is important to note the broad definition of "com- 
merce," appearing in paragraph 2, Section $\mathrm{r}$, of this law. The term seems to cover the whole field of common carriers recognized by the common law when engaged in interstate and foreign trade and commerce, including trade and commerce with the Insular Possessions of the United States. Section ro is not confined in its operation to incorporated bodies; the language employed apparently applies with equal force to natural persons who are common carriers.

Corporate Crime Involves Participating Officer or Agent.The principle recognized in Section 10, to the effect that the crime of a common carrier shall be deemed also that of its director, officers and agents, under Section 14 of the Clayton Law is applied to every corporation which shall commit a criminal offence against the Anti-trust laws. This section is as follows:

"That whenever a corporation shall violate any of the penal provisions of the Anti-trust laws, such violation shall be deemed to be also that of the individual directors, offcers, or agents of such corporation who shall have authorized, ordered or done any of the acts constituting in whole or in part such violation, and such violation shall be deemed a misdemeanor, and upon conviction thereof of any such director, officer, or agent he shall be punished by a fine not exceeding $\$ 5,000$, or by imprisonment not exceeding one year, or by both, in the discretion of the court."

History and Purpose of Individual Responsibility Feature Discussed.-While it is true that at first sight the legislative policy expressed in the foregoing section may appear to consist in applying new and untried measures to the suppression of longstanding abuses of corporate methods and powers, further and more complete investigation, it is believed, will show beyond question that this policy in fact is but a return to first principles.

In the early New York decisions found in Johnson's Reports the corporation was constantly referred to and dealt with as an aggregated body of individuals-a species of permanent partnership-in which the individuals and their rights could always be discerned through the transparent forms of chartered power. Again,-under the common law no corporation possesses the right to own stock in another corporation. 
It will thus be seen that instead of adverse or destructive criticism, the policy outlined above and characteristic of the entire bill really calls for appreciation and support. It was conceived and born as the result of careful deliberations extending through numerous sessions of Congress; and prior to its advent received further and as it were parental thought from committees of both the Senate and House. The statute as it now appears is the result of an evolution extending through five proposed laws, which were regularly submitted and carefully debated, to the end that the best might be selected from each.

It is, accordingly, well within the facts to state that whatever the ultimate result as disclosed in practice, (the supreme test in legislation, as elsewhere,) the Clayton Law evinces an earnest and intelligent effort to comply with the requirements of a public demand for reform in business methods withtin the limits specified therein.

Conditions exist which have been productive of trusts, monopolies and combinations in restraint of trade, and which are almost wholly the result and slow outgrowth of abuses of corporate power; and when the legislators bring forward and enact a system of Anti-trust laws to fit the situation, it is very natural they should return to first principles and treat the individuals as the substance and the corporation as form. This explains much that on the surface seems strange or radical in the Anti-trust laws and in their sister-statute, the Federal Trade Commission Act.

The traditions of the law include a period before the "wilderness of precedents" had obscured the legal horizon. At that period partial or complete stock-ownership in one or more corporations by a competing company would have been impossible; and the device of a holding company would have been unthought of,-certainly unworkable. Joint directorates could not then have grown into a system whereby as has been stated in a Congressional report, "ffifty men in the United States control, through interlocking directorates, forty per cent. of the wealth of the country"; for there was no magic or mystery in a franchise or charter that permitted individuals thus disguised to create and maintain practical monopolies in a manner and to an extent which

9 See page 5 of report on "Interstate Trade Commission," submitted by $\mathrm{Mr}$. Covington on behalf of the House Committee on Interstate and Foreign Commerce, April 14, 1914. 
the common law has always frowned upon and condemned. If these observations are in point, they will serve to indicate the logic of the legislation making it imperative upon prosecuting officers and courts to deem the crime of a corporation also that of its directors, officers and agents, when Anti-trust laws are violated.

Embezzlement by Common Carrier Officer is Made a Felony.-Section 9 consists of matter apparently foreign to the purpose and scope of the Anti-trust laws. It is out of place here, excepting in so far as it tends to emphasize and stamp with disapproval acts derogatory to or destructive of the best interests, prosperity and even existence of the common carrier by and through the persons to whom have been entrusted its affairs by confiding shareowners. Perhaps it was in the minds of the legislators that by giving it a place immediately following the sections relating to stock control and interlocking directorates, the result would be beneficial to the extent of supplying a suitable background for those regulations,-thereby impressing officers, directors and managers of common carriers and corporations with the serious nature of the improved methods which, taken together, constitute the essential principle of the Anti-trust laws.

However that may be, the text of paragraph I, of Section 9, is as follows, and speaks for itself:

"Every president, director, officer or manager of any firm, association or corporation engaged in commerce as a common carrier, who embezzles, steals, abstracts or willfully misapplies, or willfully permits to be misapplied, any of the moneys, funds, credits, securities, property or assets of such firm, association or corporation, arising or accruing from, or used in, such commerce, in whole or in part, or willfully or knowingly converts the same to his own use or to the use of another, shall be deemed guilty of a felony, and upon conviction shall be fined not less than $\$ 500$ or confined in the penitentiary not less than one year or more than ten years, or both, in the discretion of the court."

The term "commerce as a common carrier," requires reference to Section I, paragraph 2, where "commerce" is defined as constituting interstate and foreign trade or commerce; also, trade or commerce with or between any Insular Possessions, or between such Insular Possessions and any portion of the United Statesit being, however, expressly stipulated that none of the provisions 
of the Clayton Law should apply to the Philippine Islands. The words, "common carrier," when unqualified include all classes of common carriers, except those conducted by an individual. Whether by intention or oversight, or because enterprises owned or managed by a single person are usually too small to receive legislative notice in this connection, the individually owned class of common carriers has been omitted from the general prohibition. Perhaps this omission is due to a desire to avoid the absurdity of instituting a criminal charge where the proof might and in many instances would disclose the fact that the defendant was disposing of property exclusively his own.

The legislative intent is directed to making more difficult even though it cannot entirely eradicate reckless or wasteful manipulation of corporate assets by methods which yield a mysterious or secret profit to the management or their friends. Instances of such abuses of corporate power, especially in railroad affairs, are too recent and notorious to require comment here.

The language employed is exceedingly broad; and cases seem certain to arise where the government will feel justified in charging an infraction of the statute. Until those cases have been brought and defendants have sought to justify their acts, it seems useless to endeavor to explain or to limit the signification of the statute as a whole, or to anticipate the shades of meaning or the relative importance which courts will see in the individual words. Such an attempt would savor of prophecy and entirely overstep the bounds of the present work.

There is ground to question the power of Congress to legislate regarding acts which relate to no department of government and where the acts are doubtless already penalized by the laws of the several States. This doubt relates to the general subjectmatter contained in Section I0,--dealings with construction, etc., companies, - as well as to the crime defined and prohibited by Section 9. However, this right will probably be held to be similar to that lawfully exercised in connection with the creation of the Interstate Commerce Commission.

Of the severity of the penalty there can be no doubt. No maximum sum is named as to the fine, which must be at least $\$ 500$; while the prison term of from one to ten years is sufficient to give pause to predatory interests, or rather to the individuals who undertake that kind of excursions into or attempt operations of 
that description with, the assets of the enterprises committed to their charge.

Jurisdiction is conferred upon the United States District Courts of the districts where the respective offences are committed. Paragraph 2 also recognizes the jurisdictions of the several States, and conviction or acquittal on the merits therein is stated to be a bar to prosecution on the same charge in the Federal courts.

Contempt Proceedings Specified in Sections 21 to 25 NonCriminal.-In Sections 21 to 25 , inclusive, provision is made for contempt proceedings to punish disobedience of court order by criminal acts; but since Section 25 specifically prescribes that the proceeding shall not "be a bar to any criminal prosecution for the same act or acts," it follows that those sections in legal contemplation operate as a civil and not as a criminal prosecution; otherwise, the defendant would be placed twice in jeopardy.

Section 20 Suggestive of Commendatory Court Ruling.In passing it should be noted that paragraph 2 of Section 20 , contains a statement of a protective nature which closely resembles the commendatory court ruling advocated in Chapter V, pages 42-4. After declarations that peaceful persuasion by or assembling of employees shall not be enjoined, the paragraph concludes,- "nor shall any of the acts specified in this paragraph be considered or held to be violations of any law of the United States." These words certainly imply commendation or something akin thereto, since by the elimination of opposing action, the ground and occasion for any form of unfavorable notice appears to have been removed. The conclusion may be a fallacy; but the argument is interesting, even though it is not profound.

\section{THE SHERMAN LAW.}

Early Construction Reaffirmed.-This statute received a literal construction in the earlier decisions $;^{\mathbf{1 0}}$ but while the courts have since pursued different and sometimes diverging roads, they have returned to their original starting point, as appears by the judgments of dissolution in the Standard Oil and American Tobacco cases. ${ }^{11}$

10 American Biscuit and Mnfg. Co. v. Klotz, 44 Fed. 721; U. S. v. Addystone Pipe and Steel Co., 85 Fed. 271.

II Standard Oil v. U. S., 221 U. S. 1; U. S. v. American Tobacco Co., 221 U. S. 66. 
Original Anti-trust Laws in Large Degree Superseded.The Sherman Act and the Wilson Tariff Law are not, however, entitled to the same prestige which they formerly possessed as the sole exponents of Anti-trust legislation. Owing in large measure to the inclusion in party platforms of demands for enlargement of the scope of the Anti-trust laws, the second session of the Sixty-third Congress, after much agitation and the consideration of numerous laws proposed at that and previous sessions, at last yielded to the public wish by combining in one statute the distinctive features of five proposed laws. ${ }^{12}$. It was in this manner that the Clayton Law, which its title declares to be supplementary to existing laws against unlawful restraints and monopolies (Antitrust laws), came into being.

We have seen that by its terms a definition of "commerce" is established; price discrimination, conditional or "tying" contracts, stock-ownership by corporations direct or through holding companies tending to materially lessen competition, and interlocking directorates (after two years), are declared unlawful; the statute of limitations is suspended in Anti-trust actions brought by private persons, during the pendency of governmental civil or criminal prosecutions for similar acts; the crimes of corporations committed against Anti-trust laws are made offences of directors, officers and agents participating therein or consenting thereto; means are provided whereby individuals may enforce their rights thereunder by restraining orders; and the courts are clothed with ample judicial power to enforce those orders by contempt proceedings where neglect or willful disobedience can be shown.

A statute so comprehensive and apparently so well qualified to prove itself effective in operation, presents numerous advantages over the generalities of the Sherman Law, besides by direct legislation overruling certain limitations by judicial construction which have grown out of the litigations resulting therefrom. The Clayton Law, in brief, offers simple and certain means of preventive relief or recoupment of injuries where the complainant fears or experiences damage from prohibited acts of interference in business. The didactic phrasing of the Sherman Law seems calculated to challenge argument while leaving the true meaning still a doubtful matter,-a characteristic which is doubtless responsible

12 See statutes enumerated, note 9 , page 138 , supra. 
for the complicated nature of the decisions thereunder. And this feature is likewise responsible for the unwillingness and hesitation of individuals to sail upon those-in part at least-uncharted seas.

Official Body Created to Enforce Anti-trust Laws.-Preceding the Clayton Law by a matter of weeks, the Federal Trade Commission Act was passed by Congress for the avowed purpose of supplying a permanent official body whose main function should be to enforce the Anti-trust laws,-both by self-instituted investigations and by exercising its judicial functions in hearing and determining charges preferred by individuals. Where the complainant discloses a meritorious cause, it affords complete relief, subject to a court review upon the same facts educed upon the trial.

Inquiries into corporate methods at its own suggestion, or upon the direction of the President or either House of Congress, and, especially, proceedings to prevent and restrain "unfair methods of competition in commerce," are additional features of the Federal Trade Commission's power under the creating act. It is true that there is some indefiniteness in that measure which leaves it in doubt whether the last-mentioned proceedings shall be instituted solely upon information collected by the Commission, or whether complaints by individuals will be recognized and acted upon; but obviously some documentary or other satisfying basis for action must exist. The statute reads-

"Whenever the Commission has reason to believe any person, partnership, or corporation has been or is using any unfair method of competition in commerce, and it shall appear to the Commission that a proceeding by it in respect thereof would be to the interest of the public,"

it shall proceed to issue and serve a complaint upon the party charged with wrongdoing. It is the means of knowledge, the foundation for the "reason to believe" which was left indefinite by the law-makers. This point aside-and it is one which no doubt will be obviated by the Rules of Practice that the Commission shall from time to time adopt ${ }^{13}$ - the statute is filled full of promise of relief by way of prevention. With that body in com-

13 For requirements upon application for issuance of a complaint,-see Rule II, page 232, post. 
plete operation, the occasions for employing the means of relief afforded by the Sherman Law are few and probably will grow less.

Criminal Prosecutions Obviated.-The ounce of prevention has been supplied by this supplement of the Anti-trust laws-the Clayton Law-and its associate measure, the Federal Trade Commission Act. It is presumed they will fulfil their allotted purpose by stopping at the source numerous complaints that otherwise would grow into serious wrongs which in their turn would justify the bringing of criminal actions under the Sherman Law.

It may well be assumed the Sherman Act will then to a great extent become functus officio. Supplementary Anti-trust legislation has been provided by Congress to attain the desired ends by more direct or less obscure means; and the effort will be crowned with at least partial success when the necessity for construction so apparent in the Sherman Law, is obviated thereby.

However that may be and whether the old or the new lines of approach are found in practice to be preferable in a given case, litigants will perceive they still preserve all their previously existing rights under the former practice; for it is specifically stated in Section II, of the Federal Trade Commission Act, that nothing therein contained shal lbe construed to prevent, interfere with, alter, modify or repeal any portion of any Anti-trust law.

Punishment Prescribed; Rule of Construction Applicable. -Under Sections I and 2 of the Sherman Law, combinations and conspiracies in restraint of trade-also monopolies-are each liable to the same penalty, viz: a fine not exceeding $\$ 5,000$, with imprisonment for one year.

The Northern Securities and Addystone cases ${ }^{14}$ each characterizes the Sherman Law as a criminal statute, and states it creates a new offense by penalizing what was not classified among criminal acts under the common law. The former decision holds that the strict construction required in applying criminal laws does not warrant a narrow, technical or forced construction of words, to make them include or exclude particular cases; but the controlling factor must be the legislative intent.

\section{WILSON TARIFF LAW.}

Provides Anti-trust Regulation of Foreign Trade.-The pro-

I4 U. S. v. Northern Securities Co., 193 U. S. 197; U. S. v. Addystone Pipe and Steel Co., 85 Fed. 171,-affirmed 175 U. S. 21 I. 
visions of this act (28 Statutes at Large, 570) pertaining to Antitrust legislation are contained in Sections 73 as amended, 74, 75, 76 as amended, and 77 . The amendments are added by the Act of February 12, I9I3 (37 Sta. 667). For text of Sections as amended, see Appendix D, pages 282-3. The above sections contained in the Wilson Tariff Law, enacted August 4, I894, were continued by the Dingley Tariff Act, of 1897. This law relates solely to foreign trade.

Sherman Law Provisions Reappear Therein.-These provisions are in form or in substance adapted from corresponding sections of the Sherman Act. The changes are mostly verbal. Section 73, which is the essential feature of these provisions, appears never to have come before the courts. Similar requirements are embodied in an amplified form in Sections I and 2 of the Sherman Act, and all the actual cases seem to have been brought under the latter law.

Section 6 of the Sherman Act providing for forfeiture of goods, etc., reappears in substance in Section 76 .

The connection between these five sections of the Wilson Tariff Act, and the Sherman Law, is so intimate that these provisions have an important place in Anti-trust legislation, even though they have not come directly before the courts in reported cases. 


\section{IMMUNITY OF WITNESS UNDER FEDERAL TRADE COMMISSION ACT, AND THE ANTI-TRUST LAWS.}

I. Immunity Proceeds from Recognition of Constitutional Rights.

2. Statutes Recognize said Rights.

3. Commission's Orders do not Confer Immunity.

4. Privilege Does Not Extend to Corporations.

5. Purpose of Privilege Stated.

6. Actual Jeopardy Must be Shown.

7. Witness Must Claim Privilege.

8. Enquiring Court or Body Must Possess Jurisdictional Powers.

9. Further Consideration of Immunity Provisions.

10. Application of Principle.

11. Rulings in Immunity Cases.

\section{IMMUNITY PROCEEDS FROM RECOGNITION OF CONSTITUTIONAL RIGHTS.}

Freedom to Contract a Qualified Right.-Liberty of conduct and freedom to contract are qualified and not absolute rights. Those rights imply liability to reasonable regulations and only insure the citizen against restraint exercised in an arbitrary manner.

In both of these departments of life the public welfare,-represented in matters legal by the so-called "police power" of the State,-writes the supreme code; and every right short of those which are absolute must yield and take second place.

Immunity has been described as freedom from what would otherwise have been a duty or burden. ${ }^{1}$ Of course, "immunity" in the legal sense is relief from the criminal prosecution that might result from the self-incriminating testimony of a witness called at the instance of the State and in its behalf. Such testimony, however, would be privileged under the Fifth Amendment; hence the State confers "immunity" from criminal prosecution for matters thus disclosed, and by that expedient overcomes the right of the proposed witness to remain silent." ${ }^{1 *}$

Accordingly, immunity is the recognition of an existing right, -in fact is pro tanto an acknowledgment that there is a class of

I Lonas v. State, 3 Heisk., (Tenn.) 287, 306,-cited in 21 "Cyc," 1736. ra For immunity provisions generally, see Appendix H, pages 289, 290. 
rights which the State has no power to interfere with or destroy, unless it substitutes something of equal importance and value in their place and stead.

These basic rights are for the most part contained in the Constitution and the Amendments. ${ }^{2}$

Established by Constitution itself.-Without doubt those rights are so well established under Amendments IV, V, and $\mathrm{XIV}$, of the Federal Constitution that a witness would be protected against incriminating himself, even though no reference thereto appeared in any part of the Federal Trade Commission Law, or the Clayton Law. The Sherman Law, and Sections 73 to 77, inclusive, which contain the Anti-trust provisions of the Wilson Tariff Law, are silent on that point, although immunity is conferred by the Act of February 25, 1903 (32 Stat. 854, 903), making appropriations for general expenses of government. Section 860 of the Federal Revised Statutes and the Acts of February II, I893, and February 19, 1903, were also legislative provisions conferring immunity, but not to the extent of the statute of February 25, 1903, which covers examinations of witnesses before a grand jury, in addition to trials in court. The immunity laws, however, do not protect a witness before the Federal courts from subsequent prosecution in the State courts for the offence disclosed; and this construction has been held to be in accordance with the constitutional guarantee. ${ }^{3}$

Immunity Relates to Criminal Procedure only.-Immunity under the guarantees in the Constitution and in the Federal Immunity Statutes, relate exclusively to criminal proceedings, unless it is otherwise expressly stated in the legislative acts.

These general remarks are preliminary to consideration of the subject in respect to the Federal Trade Commission Act and the interpretation which will probably be extended thereto in proceedings instituted under those laws. For convenience of reference the Constitutional Amendments will be inserted in their proper place.

2 For provisions of Constitution applicable to Anti-trust matters, see Appendix F, pages 286-7.

3 See Hale v. Henkel, 20I U. S. 43; Nelson v. U. S., 201 U. S. 92, and other cases cited under "Immunity Statutes," also "Immunity," in the Index-Digest of the official Federal Anti-Trust Decision Reports, Volume IV, pages 590 and 678.

4 See note 2. 


\section{STATUTES RECOGNIZE SAID RIGHTS.}

Statutory Provisions Stated.-Section 9, paragraph 7 of the Commission Act is as follows:

"No person shall be excused from attending and testifying or from producing documentary evidence before the Commission or in obedience to the subpœna of the Commission on the ground or for reason that the testimony or evidence, documentary or otherwise, required of him may tend to criminate him or subject him to a penalty or forfeiture. But no natural person shall be prosecuted or subjected to any penalty or forfeiture for or on account of any transaction, matter, or thing concerning which he may testify, or produce evidence, documentary or otherwise, before the Commission in obedience to a subpœna issued by it. Provided, That no natural person so testifying shall be exempt from prosecution and punishment for perjury committed in so testifying."

\section{NITY. \\ 3. COMMISSION'S ORDERS DO NOT CONFER IMMU-}

Order Not Equivalent to Subpœna.-Immunity, however, does not extend its protection to persons who are directed to "cease and desist from the violation of the law," etc., under the Commission act. Such direction is not equivalent to a subpœna, in that particular.

"No order of the Commission or judgment of the court to enforce the same shall in any wise relieve or absolve any person, partnership or corporation from any liability under the antitrust acts." Federal Trade Commission Act, Section 5, paragraph 7.

The orders referred to are those instituted in proceedings where the Commission shall deem it "to the interest of the public" that it shall take steps to prevent or abate "unfair methods of competition in commerce." While the ability to serve subpœnas is a power which is very necessary, in fact absolutely required to make effective the Commission's right to examine corporate books, accounts, records, documents in proceedings upon its own initiative or in certain specified instances at the request of the President of either House of Congress, or of the Attorney- 
General-there is no authority for it to issue any order except in proceedings instituted in respect to matters "to the interest of the public."

The question of immunity, accordingly, here relates to orders that can be issued only in those semi-administrative proceedings, obedience whereof could not properly be expected to convey immunity. Immunity by exemption is essentially an incident pertaining to criminal actions; therefore where no criminal penalty attaches to disobedience of orders which are issued as an incident to distinctly civil proceedings, enforceable by civil prosecutions for contempt,--some definite legislative intent to grant immunity must be shown.

Corresponding Situation Under Clayton Bill.-A similar provision is contained in Section I I, paragraph 6 of the Clayton Law. Price discrimination, conditional or "tying" contracts, owning or controlling stock in competing corporations and interlocking directorates (Sections $2,3,7$, and 8 ), are each and all declared unlawful acts enforceable by restraining orders only, although the Circuit Court may assume jurisdiction and take all necessary steps to compel obedience thereto,--just as may be done where infractions of the orders in proceedings initiated by the Federal Trade Commission Act are made to appear.

Provisions of Section Io not Enforcible by Civil Orders under Section II.- In the case of common carriers, certain transactions with dealers in securities or supplies where a joint interest exists are prohibited after two years from the approval of the bill, under severe criminal penalties, unless competitive bidding is permitted under supervision of the Interstate Commerce Commission. This provision, contained in Section Io, is not made a subject for the Commission's orders, under Section II ; hence, obedience to those orders is not directly connected with punishment for the guilty acts prohibited by Section II, and there would not be any immunity flowing therefrom, even though such orders conferred that privilege.

A Precautionary Measure.-No doubt the specific denial of immunity as an incident to orders issued and served by the Commission or courts, pursuant to both the Federal Trade Commission Act and the Clayton Law is a precautionary measure taken by Congress for greater security and certainty. The rule as to immunity would not protect any person who performed acts of 
any description in consequence of the issuance or service of such orders; the statute merely applies to those mandates the general policy of the non-extension of the criminal law and practice, in cases where the nature of the proceeding plainly shows the matter is one for exclusive enforcement by the machinery of the civil side of the court.

\section{PRIVILEGE DOES NOT EXTEND TO CORPORATIONS.}

Immunity Confined to Natural Persons.-Reverting to the phraseology of the regulation respecting immunity contained in Section 9, paragraph 7 of the Federal Trade Commission Act, the words "natural person" relate, of course, to individuals as distinguished from corporations of every description; so that no immunity would thereby be extended to corporations, and the incorporated body can be prosecuted to the full extent of the law, regardless of subpœnas or testimony, and without any infraction of the Constitution. The use of the restrictive expression, "natural person," in the exempting words indicate plainly that Congress did not intend that corporations should even claim such a construction of the law.

Corporations did not receive the benefit of the exemption under the former immunity laws; $;$ and there is no reason for changing the rule now, when the main purpose is to reach and to cure abuses of corporate methods and power.

\section{PURPOSE OF PRIVILEGE STATED.}

Purpose of Exemption.-The object of the immunity laws is to permit courts and other judicial or administrative bodies to compel witnesses to answer questions without violating the provisions of the Constitution regarding self-convicting testimony. Without some means of withholding that privilege, accomplices and persons directly concerned as principals could always refuse to testify, and thereby the wheels of justice would, in very many cases, cease to revolve. In effect, where acts complained of carry with them a criminal liability, the court, commission or government attorney in a given case, is put to an election whether the testimony of the witness shall free him from danger of prosecution; or whether the right to institute future criminal proceed-

5 United States v. Armour \& Co., I42 Fed. 808. 
ings shall be retained and the benefit of the testimony forfeited as the consideration for that right.

Constitutional Amendments which Supply Immunity.-The Constitutional Amendments as they apply will be presented and considered.

The Fifth Amendment to the Constitution of the United States provides-

"Nor shall [any person] be compelled in any criminal case to be a witness against himself."

In a leading case the court held:

"The privilege is limited to criminal matters, but it is as broad as the mischief against which it seeks to guard."

\section{ACTUAL JEOPARDY MUST BE SHOWN.}

Only Actual Jeopardy Affords Immunity.-If the statute of limitations has run against the criminal prosecution, or for any other effectual reason the witness is in no danger of trial and conviction upon such charge, the Fifth Amendment does not apply and the testimony can be compelled. The theory, of course, under which immunity is given is that an agreement exists whereby the government agrees not to prosecute the witness criminally by reason of any facts by him disclosed, nor to use his testimony in any manner that will place him in jeopardy, - a theory which in its effect removes the possibility of conviction and negatives the right of the witness to remain silent. ${ }^{\text {? }}$

It has been held that immunity does not extend to witnesses called by the defense in a civil suit; also, that a witness cannot refuse to testify before the grand jury, when there exists a Federal statute granting immunity, notwithstanding the exemption is not so broad as to preclude a prosecution in a State court, for the Fourth Amendment is satisfied when it guards against further prosecution within the same jurisdiction and under the same sovereignty. ${ }^{8}$

6 Counselman v. Hitchcock, 142 U. S. 547, I2 Sup. Ct. 195, 35 L. Ed. II10; reversing 44 Fed. 268. For text of constitutional provisions, see Appendix $F$, pages $286-7$.

7 Hale v. Henkel, 201 U. S. 43, 66, 26 Sup. Ct. 370,50 L. Ed. 652 ; affirming 139 Fed. 496.

8 Hale v. Henkel, supra. 


\section{WITNESS MUST CLAIM PRIVILEGE.}

Government Entitled to Know Attitude of Witness.-Since the government is put to an election as to whether it will take the benefit of a witness's testimony or will preserve its right to a future criminal prosecution, the government's attorney is entitled to know: First, that the witness is unwilling to testify, and Second, that and how the desired evidence would tend to incriminate. These facts are necessary preliminaries to the decision by the government, in the premises.

It follows as a corollary to the foregoing statement that where the witness assumes the position of a mere volunteer, or where he does not fear future prosecutions and has no desire to claim exemption, he may and does waive his privilege by failure to assert it at the proper time and in the manner contemplated by the immunitizing statutes. The words "compelled in any criminal proceeding to be a witness against himself," contained in the Fifth Amendment, ${ }^{9}$ plainly imply that some protest or objection on the part of the witness himself, shall precede the insistence by the government that he shall testify; and this construction of the right to raise and enforce the immunity privilege has been generally adopted by the courts and the authorities on the subject. ${ }^{10}$

The witness alone knows his own wishes regarding the purpose of his testimony, i. e., whether it should tend to exonerate him or to confer the expected immunity. It seems, accordingly, no hardship to exact a decision, in definite form, at the time when his testimony is demanded.

\section{ENQUIRING COURT OR BODY MUST POSSESS JURIS- DICTIONAL POWERS.}

- Testimony Must be in Proceedings Relevant and Material to the Purpose for which the Enquiring Body was Created.This very natural inference from the provisions of the statutes on which the right to examine the witness are based, was drawn

9 For Fifth Amendment-see Appendix F, pages 286-7.

For immunity provisions generally, see Appendix H, pages 289, 290.

10 U. S. v. Heike, 227 U. S. 13I, holding that the Immunity Statute should be construed "coterminous" with the privilege; 175 Fed. 852. See also, State v. Murphy, I28 Wis. 20I ; Wigmore on Evidence, Vol. 5, Section 2281a.

Effect of immunity statutes has been considered in: U. S. v. Armour \& Co., I42 Fed. 808; Hale v. Henkel, 20I U. S. 43; State v. Rudolph, 128 Wis. 222. 
in the decision in Interstate Commerce Commission v. Harriman, ${ }^{11}$ where the witness was sustained in refusing to testify. It was held that there is a limit to the power of a board or commission to compel testimony, and that where the object of the examination or proceeding is not cognate to the jurisdiction of that body, its subpœna is without compelling force, and the witness may refuse to testify. In the Harriman case the Commission undertook to supplement a Senate investigation by an enquiry into the methods by which certain railroad securities had been acquired and were held, and such an enquiry was deemed by the Supreme Court outside of the quasi-judicial functions with which the Commission was endowed.

Had Harriman appeared and testified without objection, there can be no doubt he would have been a mere volunteer, and immunity would not have attached, ${ }^{12}$ for acquiescence in the assumed right to compel testimony could not have rendered him immune.

In any matter properly within the jurisdiction of a quasijudicial body, however, Congress may invest it with authority to require the attendance and testimony of witnesses, and the production of books, papers, etc. ; and in such a matter the ordinar:s rules as to immunity of course apply. ${ }^{13}$

\section{FURTHER CONSIDERATION OF IMMUNITY PRO. VISIONS.}

Immunity Provision in Act of February 25, 1903.-The immunity provision of Section 9, paragraph 7, of the Federal Trade Commission Act in general wording and effect is identical with the immunity provision contained in the Federal Appropriation Act of February $25,1903,{ }^{13^{3}}$ which law is still in effect generally, i. e., in matters not connected with the Anti-trust laws.

Immunity by Pardon.-Another form of immunity is by pardon. This method puts the offender in the same position as if he had never done the illegal act; but it cannot close the judicial eye to the fact that he was capable of performing the acts which constituted the violation of law. ${ }^{14}$

II 21 I U. S. 407.

12 See generally, In re Pacific Railways Commission, 32 Fed. 241; Kilbourn v. Thompson, 103 U. S. 168; In re Chapman, 166 U. S. 661.

13 Interstate Commerce Commission v. Brimson, 154 U. S. 447; 14 Sup. Ct. 1125 ; 15 Sup. Ct. 19; 38 L. Ed. 1047 ; reversing 53 Fed. 476.

I3a For text of this provision, see Appendix H, pages 289, 290.

14 United States v. Swift, I86 U. S. 1002; United States v. Armour \& Co., 142 U. S. 808; Thornton's Sherman's Anti-Trust Law, § $47 \mathrm{r}$. 


\section{I0. APPLICATION OF PRINCIPLE.}

Congress Exercises Jurisdiction over All Incorporated Bodies.-In vindication of its own powers, Congress possesses and asserts as to State-chartered corporations the same authority it would have if the several corporations owed their existence to the Federal laws. Neither the corporation nor an officer thereof can successfully set up an examination in litigations concerning that body as a source of immunity. Especially is this true where the act complained of was committed by the witness in an official capacity, and is not itself the subject-matter under investigation by the examination proceedings. Neither do official compilations of the corporation's records, accounts, etc., when delivered in the form of a report, amount to the giving of testimony or the production of documentary evidence specified in the Immunity Act of February 25, $1903 .^{15}$

The foregoing statutes and decisions (which are for the most part Anti-trust cases) were all enacted or decided in accordance with and to make effectual the Fifht Amendment, which prohibits legal procedure that will "subject [any person] for the same offence to be twice in jeopardy of life and limb," i. e., in a criminal action.

The Fourth Amendment Considered.-The Fourth Amendment is also in point here, and there are important decisions that concern us. That amendment is in the following words :

"The right of the people to be secure in their persons, houses, papers and effects, against unreasonable searches and seizures, shall not be violated, and no warrants shall issue, but upon probable cause, supported by oath or affirmation, and particularly describing the place to be searched, and the persons or things to be seized."

We have seen that Congress does not concern itself with the source of the legal fiction of corporate existence, but invests this of ten very un-"natural person" with the same measure of responsibilities and rights whether it is chartered by a State, or owes its franchise to creative power inherent in a Territory or in the general government. As will presently appear, this policy and prin-

I5 Hale v. Henkel, supra; Heike v. United States, 227 U. S. I3I, 33 Sup. Ct. 226, 57 L. Ed. 450; affirming 192 Fed. 83, I12 C. C. A. 615; and see also Thornton on Sherman Anti-trust Act, §§ 472-3. 
ciple of Federal law and practice likewise confers upon Stateorganized corporations the protection of the United States Constitution. Thus, the limitation to the extent of seizure and search has been held to confine the use of the subpona duces tecum to a reasonable disclosure and surrender of the corporate books, records and documents. A direction to produce all its corporate books, letters, contracts, and agreements amounts in legal effect to a search warrant unsupported by oath, is unreasonable, and need not be obeyed. ${ }^{16}$

Where the case is against a pooling combination in control of a bridge leading to a central city, and a subpcena duces tecum is issued upon a sworn application demanding in behalf of an Antitrust prosecution by the government, the production of specified records and documents of the component corporations concerned in the pool, the court said:

"The subject of transportation $* *$ * of recent
years $* * *$ to a great extent $* * *$ has become
res publice. I think the books and papers of these traffic
associations called for in this subpœna ought to be pro-
duced and that the private interests and convenience of
those associations, if any, ought in a matter of this kind to
give way to the exigencies growing out of this suit."

Immunity Conferred in Aid of Prosecution.-We have seen (p. I56) that the right to confer immunity is given by law in aid of prosecutions, and does not extend to the calling of persons as witnesses in aid of the defense; and it has also been held in the same series of litigations that the filing of a sworn answer does not create any exemption from prosecution, in favor of the answering defendants. The court intimates plainly that in such a position the defendant could lawfully refrain from filing a sworn answer, even where the bill of complaint did not waive an answer under oath. But when filed, the situation does not call for such a forced construction. "The true criterion must be the fair and reasonable meaning-the sense in which it is probable that Congress used the chosen words." The court holds that the

16 Hale v. Henkel, supra.

17 United States v. Terminal R. Association of St. Louis, 148 Fed. 487. While this subpona duces tecum was afterward quashed (154 Fed. 269), the decision to that effect turned upon the insufficiency of the originating petition, and not upon the correctness of the reasoning quoted above. 
equity practice by which the answer became evidence when filed in response to a bill of discovery, is no longer in effect; and that the answer has performed its full function and purpose when it has enabled the defendant to appear and submit himself to the jurisdiction of a duly constituted tribunal.

"Defendants under such a bill [in equity] as was filed here are not, with my construction of this immunity statute [Act of February 25, 1903, (32 St. L. 904) as amended June 30, 1906 (34 St. L. 798) ] in danger of losing any constitutional rights [prohibitory of criminal prosecution]. They may absolutely refuse to incriminate themselves by any statement, by whatever name it may be called, and with or without oath. It may not be pleasant to take this position, but such is the constitutional method of preserving a constitutional right." ${ }^{18}$

From the sense of these authorities, it may be clearly deduced that witnesses-especially co-defendants-not called by the government, or who do not furnish information at its request by compulsion, after claiming their privilege in a matter or proceeding within the legally established jurisdiction of the enquiring body and not merely within the scope of a casual investigation, are not rendered immune in any criminal prosecutions that may ensue from the facts educed upon such examination.

Immunity does not Extend to Future Acts.-It is also a natural and logical conclusion that immunity secured through disclosures of facts constituting a monopoly in existence then and prior thereto, will not afford protection for future conduct of a similar description. If this were not so, the immunity anti-toxine would so permeate the fibre of the offender that he might and probably would continue on his way rejoicing and commit a series of new offences extending through the remaining years of his natural life. This very reasonable and, in fact, obvious holding appears in United States v. Swift, cited at page 158 , supra.

Resistance by Witness not Required.-It is not requisite that the compulsion employed should be in fact irresistible, to afford immunity. In an Anti-trust case, the court held:

"The contention has been made that in order to get immunity the citizen shall wait until the compulsion becomes

18 United States v. Standard Sanitary Mfg. Co., I87 Fed. 229. 
irresistible. That is the effect of the government contention. I am not able to bring my mind to accept that doctrine. * * * The law never puts a premium on contumacy. A person does not become a favored citizen by resistance to a lawful requirement. * * * This, then, is the proposition to which we are led: When an officer has a legal right to make a demand upon a citizen, who has no legal right to refuse, and that citizen answers under such conditions, he answers under the compulsion of the law-and immunity is thereby conferred. ${ }^{19}$

It will be interesting to note that in the foregoing instance the defendants had testified before the Commissioner of Corporations in obedience to a resolution of the House of Representatives, adopted March 7, 1904, that no subpœna was issued, and no oath administered.

Right to Immunity Narrowed by Statute.-It is extremely doubtful whether the courts will not find in the later amendments a legislative intention to overrule those judicial constructions and to fix by mandatory legislation the exact limits of the right of immunity. The amendment of June 30, 1906, to the Act of February 25,1903 , provides that "immunity shall extend only to a natural person who, in obedience to a subpœna, gives testimony under oath or produces evidence, documentary, or otherwise, under oath"; and the provisions of Section 9, paragraph 7, of the Federal Trade Commission Act-with which we are especially concerned-confines the exempting right to natural persons who "testify or produce evidence, documentary or otherwise, before the Commission in obedience to a subpœna issued by it." The exemption, of course, relates only "to any penalty or forfeiture for or on account of any transaction, matter, or thing concerning which he may testify," etc.

Fair Dealing Seems to Require Broad Construction.-The older rule seems more fair, certainly more equitable; and it appears hard that under the existing condition of the rulings the Fifth Amendment does not afford protection from prosecutions under the laws of the several States, where the same act creates a double criminal liability. Of course, conviction or acquittal before one tribunal would spell out freedom from being placed in jeopardy through a second trial for the identical offence; but it

19 United States v. Armour \& Co., 142 Fed. 808. 
seems proper and almost necessary in the spirit of fair play that the citizen who secures complete protection for himself in the Federal courts should not, by the same testimony, afford means for his own conviction under the statutes of a particular State, especially where this incomplete immunity is held a privilege which takes away his right to remain silent.

Anti-trust Investigations Benefited by Complete Immunity. -Perhaps some broadening of the immunity statutes will be found to be in accordance with the true meaning of the clemency which the Fifth Amendment was created to afford to citizens. It would certainly be helpful in proceedings to discover the true conditions in respect to trusts, monopolies and other unlawful combinations repugnant to the penal Anti-trust laws. The present rule is stated at p. 156 , and is based upon the controlling decisions. ${ }^{20}$

\section{RULINGS IN IMMUNITY CASES.}

Witness Occupies Dangerous Position.-That the rights and obligations which flow from immunity are questions for the judge, would seem apparent; but in a situation where a judicial mistake might involve the defendant in most serious difficulties, it has been held: "Great latitude should be allowed to him [the witness] in judging for himself of the effect of any particular question."21 Whenever there is a serious doubt and risk as to the question being one that is within the scope of the immunity law, the witness has a right to stand on his constitutional privileges, notwithstanding the assurances of the judge as to the probable effect of the testimony.

Immateriality not Question for Witness.-Immateriality of evidence is not a complete defence, and the legal custodian of books, etc., may be punished for contempt, when his refusal to comply is based upon that ground. The order of commitment is interlocutory only; and appeal to the Supreme Court will not lie. ${ }^{22}$

The first case (Nelson v. U. S.) was an appeal from a judg-

20 Hale v. Henkel, supra; Nelson v. U. S., 20 r U. S. 920, 26 Sup. Ct. 358, 50 L. Ed. 773, affirming 52 Fed. 646; see also U. S. v. Armour \& Co., supra.

2I Foot v. Buchanan, II3 Fed. 156.

22 Nelson v. U. S., supra; Alexander v. U. S., 201 U. S. 117, 26 Sup. Ct. 356, 50 L. Ed. 686. 
ment holding the witness for contempt, and the Supreme Court entertained the appeal on the grounds: (I) that it was a final adjudication in a proceeding; (2) that a question of constitutional law under the Fourth Amendment was presented.

In the second case, (Alexander v. U. S.) the same court held that a mere order to testify without further proceedings did not carry with it the right to such review. This ruling was held to be adequate for the protection of the witness without unduly impeding the progress of the case. In an earlier case, it was held proper to release the recalcitrant witness on habeas corpus; and no doubt when the refusal is founded upon a reasonable doubt as to the legal result and is not aggravated nor wilfully contumacious and obstinate, the court will permit this means of awaiting the decision of the appeal outside of prison walls.

Certain Rulings Considered.-Before closing this chapter and departing from the subject of the immunity which testimony in behalf of the prosecution grants in Anti-trust cases, it might be said that the doctrine of former jeopardy and the constitutional guarantees are applicable to trials in which misdemeanors as well as felonies are concerned. ${ }^{23}$ An indictment or information so defective as to be unable to support a conviction has been held in England and the United States not a "proceeding" which will confer privilege against a second and further prosecution; but the Supreme Court has held that this rule does not apply where the case actually goes to the jury and a verdict of acquittal is rendered; such verdict being sufficient to constitute a bar to subsequent prosecution for the same alleged offence. ${ }^{24}$

Two criminal proceedings which are in reality two charges of the same nature-one being a larger offence-will be decided by a verdict in either; and further criminal action is barred. ${ }^{25}$

But this rule does not prevent a legislative body from carving several distinct crimes out of one single act or transaction,-in such a case conviction on one or both may be obtained. ${ }^{28}$

How, or whether, these rulings can be harmonized, time alone can disclose. ${ }^{27}$

23 Berkowittz v. U. S., 93 Fed. 452,35 C. C. A. 379.

24 Bell v. U. S., 163 U. S. 662; see 12 "Cyc," pages 261-5.

25 In re Bennet, 84 Fed. 324.

26 United States v. Hermison, 26 Fed. Cas. No. 15, 308; 3 Sawyer 556; see, generally, 12 "Cyc," pages 382-3.

27 For Immunity Statutes, see Appendix H, pages 289, 290. 


\section{CHAPTER XIV.}

\section{HISTORY AND APPLICATION OF PROVISIONS OF CLAYTON LAW RELATING TO ENCOURAGE- MENT AND PROTECTION OF LABOR.}

1. Inception of Sherman Anti-trust Act.

2. Question of Exempting Labor Raised.

3. Opposing Argument by Senator Edmunds.

4. Exclusion of Labor Provision from Sherman Law.

5. Argument Criticized.

6. Equality of Corporation and Labor Union Noted.

7. Lawful Organized Labor Should be Encouraged.

8. Leading Decision Quoted.

9. "Strike"-Usual Means of Compulsion.

10. Right to Refuse to Deal.

I. "Boycott."

I2 Protection Afforded by Sections 6 and 20 of Clayton Law.

I3. Provisions Separately Examined.

14. Rights of Labor Confirmed.

General Comments.-This subject affords another instance where the legislative mind has returned to its first estate after wandering far afield. As in spelling, first instincts are often more dependable than are the opinions that result from deliberate reflection; for the test of experience and mature judgment usually shows the first position to have been right.

\section{INCEPTION OF SHERMAN ANTI-TRUST ACT.}

Circumstances Attending Enactment of Sherman Law.-At the time of the debates preceding the passage of the original Antitrust act, that measure was ably presented and represented the combined labors of some of the most acute minds of that day. Senator Sherman is the author of the original draft. When the law-Senate Bill No. I, of the Fifty-first Congress-was proposed on December 4, I889, it was referred to the Senate Committee on Finance, of which Senator Morrill at that time was chairman, although Senator Sherman was the most active member.

On January 14, 1890, Senator Sherman reported the Sherman Bill to the Senate from the Finance Committee, and on February 27th, he moved the Senate to proceed to its consideration. That 
motion having been adopted, Senator George, of Mississippi, an able lawyer and member of the Judiciary Committee, entered at once upon the discussion of its salient features. In his argument the speaker pointed out the probability that the proposed statute could be successfully attacked because, (I) it assumed to regulate the production, etc., of some commodities within the limits of individual States; (2) it made possible the doing of acts outside of the United States which were prohibited within the domestic field. This argument was so persuasive that many Senators were convinced the bill required material amendment prior to its enactment into law.

Consideration was resumed on March 2Ist; whereupon Senator Sherman informed the Senate that the Committee on Finance, after conference, had decided to present a substitute for the pending measure. That substitute struck out all the bill after the enacting clause and re-stated its provisions in a form intended to strengthen the constitutionality thereof by confining its prohibitions to persons or corporations residing in different States or Territories of the United States or foreign countries. (For convenience of comparison, see the two drafts printed in full in Appendix $\mathrm{K}$, pages 297-9.)

\section{QUESTION OF EXEMPTING LABOR RAISED.}

Amendment Exempting Labor Organizations Submitted.Among various amendments one was offered to the effect that the act should not be construed to apply to any agreements or conditions among laboring men made for the purpose of lessening their hours of labor or of increasing their wages, nor to agreements or combination of persons engaged in horticulture or agriculture made with a like purpose of enhancing the prices of the articles they produce. Thus early, -in fact, at the very inception of the original Anti-trust law,- the question of the necessity for Provisions Relating to the Encouragement and Protection of Labor (the subject-matter of this chapter) was squarely presented to Congress for consideration and action. Upon that important theme the main disputant appears from the official record to have been Senator Edmunds.

\section{OPPOSING ARGUMENT BY SENATOR EDMUNDS.}

Exemption of Organized Labor Opposed in Senate.-He approached the measure as a whole in a friendly attitude and advo- 
cated its passage in substantially the form in which it was presented to the Senate; but on the subject of so delimiting its scope as to exempt organized labor from the prohibitive clauses, he declared himself strongly and unalterably opposed. He said:

"I shall be glad, within the constitutional limits, which are narrow but clear, in the regulation of commerce to go as far as Congress has the power to go in breaking up these great monopolies that exist to the detriment and injury of mankind * * * But I can go no further. I do not wish to hold out a false hope to the people of the United States, be they farmers or mere workingmen, as they are sometimes called * * * If he [the working man and wage-earner] gets that wage paid to him, the thing that he has done must be worth the money that is paid to him for doing it, or his employer will fail, and then he will have nothing to do and the business will stop. That sort of thing has happened a thousand times and is happening every day * * *."

Opposing Argument, Continued.-Throughout the discussion Senator Edmunds views it from the commercial standpoint, and founds his opposition on the supposed inequality that would ensue if capital is hampered while the activities of labor are permitted to continue unrestrained. In the course of the argument, though at an earlier place, he declares:

"The fact is that this matter of capital, as it is called, of business, and of labor is an equation, and you cannot disturb one side of the equation without disturbing the other. * * * If we are to have equality, as we ought to have, if the combination on one side is to be prohibited, the combination on the other side must be prohibited or there will be certain destruction in the end." 1

\section{EXCLUSION OF LABOR PROVISION FROM SHERMAN LAW.}

Argument Prevails; Labor Clause Ignored.-The argument thus set forth and the reasoning therein expounded met with approval; at least, no account is recorded of any effective presenta-

1 Bills and Debates on Trusts, page 290; 21 Cong. Record, page 2727; see Thornton, "Sherman Anti-Trust Act," pages $26-7$. 
tion of the matter from the position of the wage earner. The bill, on March 27th, with its proposed amendments was referred to the Judiciary Committee, of which Senator Edmunds was chairman. It was there redrafted by Senator Hoar, a member of the committee, and on April 8th the law was passed by the Senate upon the recommendation of Senator Sherman, its advocate and sponsor, with only one dissenting vote. It received the unanimous vote of the House, and upon approval by President Harrison, July 2, 1890, became of binding force and effect.

Argument Advanced not Convincing.-In the light of history and of fuller study of the principles that govern the relations of employer and employee, the reasons advanced when arguing against the exemption of labor organizations from the provisions of the Sherman Act seem rather immature in the light of subsequent developments and experience. The prevailing argument in opposition to that amendment was left without material contradiction, although the answering idea might well have occurred to the Senators engaged in that conference,-so far-reaching in its effects upon the commercial and social life of the nation.

\section{ARGUMENT CRITICIZED.}

Defect in Argument Noted.-The fact is that the "equality" and the "equation" described in the foregoing quotation do not set forth the case with the accuracy and acumen that might be expected in a quarter so distinguished. The speaker and advocate overlooked the obvious-almost self-apparent-factor that every corporation in and of itself is a legally constituted and publicly recognized combination of individuals, supplemented by the crystallized form of prior labor which we call capital. It is therefore, already a "combination"; and only awaits a predatory inclination to become by collective power and weight of numbers, a member of and perhaps an active participant in the class of restraints of trade which the Anti-trust statutes frown upon and illegalize.

Labor Should Receive Legislative Encouragement.-The training and effort involved in the creation and management of the modern business corporation is presumably much more extensive and exacting than is called for in conducting the affairs of an association of workers, and the accumulation of capital is so far greater, that Congress is warranted, in the light of experience, in placing restraints about the one that may not be applicable to the other. Legislation for the encouragement of one class may be 
justified on the principle that self-help which tends to thrift and to higher averages of citizenship is beneficial; whereas the selfish aggrandizement of capital and property in its various forms is a formidable thing of itself, although a means of advancing the nation's wealth.

\section{EQUALITY OF CORPORATION AND LABOR UNION NOTED.}

Organized Labor and Corporation on Equal Footing.-In brief, the combination of labor in the form of a trades unionnot the individual worker as a unit-meets a combination of individuals in the form of an incorporated body on equal terms, and together they constitute the "equation" referred to by Senator Edmunds. The "trust" has re-combined a number of corporations under a single control, and in consequence it is not on equal terms with the trades union, when the latter comprises only a single group of wage earners. It is only where a federation of extensive or world-wide scope occupies a vast territory that the combination of workmen becomes equalized to a trust.

\section{LAWFUL ORGANIZED LABOR SHOULD BE ENCOUR- AGED.}

Occasions for Restraint Compared.-The incorporated body, when in the hands of able, aggressive and unscrupulous individuals, has shown itself an organ of oppression, at once elusive and capable of amassing vast wealth while violating the policy of the laws, although scrupulous in matters of mere form; the combination of workmen on the contrary, has shown itself principally concerned with maintaining or enhancing the rate of wages or reducing the hours of labor,-both benefits when conditions warrant, as they tend to increase the efficiency, welfare and happiness of the general populace. ${ }^{12}$ Labor organizations have, with few exceptions, displayed a tendency to conform to the requirements of law. It is upon this record that Congress has reversed its attitude and has decreed,- "nor shall such organizations, or the members thereof, be held or construed to be illegal combinations or conspiracies in restraint of trade, under the Anti-trust laws" (Clayton Law, Section 6). However, it should be noted that the constitutional right of Congress to make this exception has not been judicially determined.

Ia Thus, combinations of workmen for their own reasonable protection as such, are excepted from the criminal provisions of the Canadian Antitrust statute. $63-64$ V, C. $46, \S 3$. 


\section{LEADING DECISION QUOTED.}

Subject as Presented in Leading Decision.-Perhaps, without justly incurring the charge of overstaying our right to dwell upon the introductory portion of the subject embraced within this chapter, it may be well to quote the able disquisition presented in the dissenting opinion of Judge Caldwell, written in the year $1897:^{2}$

"While laborers, by the application to them of the doctrine we are considering, are reduced to individual action, it is not so with the forces arrayed against them. A corporation is an association of individuals for combined action; trusts are corporations combined together for the very purpose of collective action and boycotting ; and capital, which is the product of labor, is in itself a powerful collective force. Indeed, according to this supposed rule, every corporation and trust in the country is an unlawful combination, for while its business may be of a kind that its individual members, each acting for himself, might lawfully conduct, the moment they enter into a combination to do that same thing by their combined effort, the combination becomes an unlawful conspiracy. But the rule is never so applied.

Corporations and trusts and other combinations of individuals and aggregations of capital extend themselves right and left through the entire community * * * crushing out all small dealers and producers, stifling competition, establish monopolies, reducing the wages of the laborer, raising the price of food * * * ; and all these things are justified as a legitimate result of the evolution of industries resulting from new social and economic conditions, and of the right of every man to carry on his business as he sees fit, and of lawful competition. On the other hand, when laborers combine to maintain or raise their wages or otherwise to better their condition or to protect themselves from oppression or to attempt to overcome competition with their labor or the products of their labor in order that they may continue to have employment, and live, their action, however open, peaceful and 
orderly, is branded as a 'conspiracy.' What is 'competition' when done by capital, is 'conspiracy' when done by laborers. No amount of verbal dexterity can conceal or justify this glaring discrimination. If the vast aggregation and collective action of capital is not accompanied by a corresponding organization and collective action of labor, capital will speedily become proprietor of the wage earners as well as the recipient of the profits of their labor. This result can only be averted by some sort of organization that will secure the collective action of wage earners. This is demanded, not in the interest of the wage earners alone, but by the highest considerations of public policy."

Owing to the plain statement thus afforded of the attitude which has prevailed in labor legislation as contained in the Clayton Law, it has been thought not only wise but a convenience to include an extract of some length from the foregoing decision. While it suggests the ardor of combat, it also sets forth in condensed form the rules and principles of thought which have overcome and replaced the doubt and distrust and the paternalism so apparent in the arguments advanced by Senator Edmunds, at the time when the Anti-trust laws had their inception. That Senator Edmunds was the exponent of a class is shown by the nearly unanimous approval of the bill which was prepared under his immediate scrutiny as the chairman of the Judiciary Committee, to which it was referred for its final redrafting, preparatory to actual enactment.

Useful Comparison of Contrasting Sentiments.-The speech of Senator Edmunds, in substance, so far as it is relevant to this topic, appears at page 167 ; and comparison thereof with the glowing paragraphs from Judge Caldwell's decision, may be useful in this connection. Each of these sentiments is typical of a class; and their inclusion here will avoid the necessity for presenting a cumulative weight of authorities.

Trades Unions Operate by Distinctive Methods.-Trades unions operate in ways unlike the methods of incorporated bodies; and it is not the slow increase by steady growth but the sudden display of strength through numbers and organization that has rendered the latter formidable. There is usually a sense of surprise when the trades union joins issue with a company of great resources, and the artizan through the power of combined labor 
is able to dictate terms or at least to insure respectful attention to his requests.

\section{9. "STRIKE"-USUAL MEANS OF COMPULSION.}

The Strike is the Usual Method of Attack.-The weapon of attack is almost always the same, and this brings us to the consideration of strikes and boycotts,- -acts which the courts have sometimes sought to restrain or punish by injunctions and proceedings for contempt of court.

Strike Defined.-A strike is defined as an abstaining from work by a body of workmen to compel an increase in wages or to prevent a reduction, or to require the employer to grant some other form of demand. This means of bringing pressure to bear is so well recognized and legitimatized that unless violence or some ulterior purpose is disclosed, the courts will not interfere in the dispute.

\section{I0. RIGHT TO REFUSE TO DEAL.}

Right to Refuse to Deal.-The test of liability, as has been well said in Cooke, ${ }^{3}$ turns on whether the act was the natural incident or outgrowth of some lawful relation. This lawful relation in this connection is the right to refuse to deal. The subject is a broad one and includes general commercial relations quite independent of labor questions or disputes; but both in logic and in law the nature and extent of the duty an employee owes to his employer, when a disagreement as to terms and conditions of service arises, must be measured by the latitude of lawful action that established principles allow.

While there has been a great divergence of opinion in different courts and jurisdictions, and even among individual members of the same judicial body-owing apparently to the personal attitude of the particular judge on labor questions-some uniformity is at last discernible, and general rules may now be deduced. The test of malice or malicious intent is gaining ground as a means of determining the legality of acts of labor organizations, when directed at third parties (Cooke, page 40). The same reasoning is implied to a considerable extent in the restrictive rights granted to the Federal Trade Commission covering "any unfair

3 "Combinations, Monopolies and Labor Unions," p. 15. 
method of competition in commerce" (Federal Trade Commission Act, Section 5), for the element of unfairness must consist very largely in the intent of acts which taken together grow into the dignity of a "method"; but it is seen more distinctly in the provisions of Section 3 of the Clayton Law prohibiting "tying" or conditional contracts, leases or sales, and in other sections thereof which are intended to prevent or destroy monopolies and restraints of trade.

The presence of malice, however, should not be presumed merely because workmen individually or collectively exert themselves and assert every lawful right to better the conditions of their employment; nor should courts grant restraining orders intended to compel a continuation of the relationship of employer and employee; and this principle applies with particular force in cases that arise where the dispute is confined to the original parties and no element of general public interest enters in. Judge Harlan, speaking for the court, has well said:

"It would be an invasion of one's natural liberty to compel him to work for or to remain in the personal service of another. One who is placed under such restraint is in a condition of involuntary servitude-a condition which the supreme law of the land declares shall not exist within the United States, or in any place subject to their jurisdiction. * * * Relief of that character has always been regarded as impracticable.

The provisions of Section 6 of the Clayton Law negatives the judicial attitude that labor is an "article of commerce"; and probably the old line of decisions no longer apply in full measure.

In a leading case, the modern rule-which is convincing, and should prevail-is thus set forth:

"The refusal to maintain trade relations with any individual is an inherent right which every person may exercise lawfully, for reasons he deems sufficient or for no reason whatever. ***

"It is a part of the liberty of action which the Constitutions, State and Federal, guarantee to the citizen."'

4 Arthur v. Oakes, 65 Fed. 310, 317, II C. C. A. 209,25 L. R. A. 414.

5 Locker v. American Tobacco Co., I2I N. Y. App. Div. 443, 106 N. Y. Supp. II5 (1907). 
Such is the principle as to trade relations in general; and as we have seen, it is applicable wherever the act is the natural incident or outgrowth of any lawful relation, such as that of employer and employee.

A less indulgent attitude by the courts has developed into a different though not very clearly defined rule where sympathetic strikes and boycotts are disclosed as an outgrowth of labor disputes. The extreme in this effort to confine the employment of strike methods to pressure by the employee exerted directly upon and against the employer is found in decisions by the Massachusetts courts. Thus, in 1906, it was declared:

"Organized labor's right of coercion and compulsion is limited to strikes against persons with whom the organization has a trade dispute, or to put it in another way, we are of opinion that a strike against $A$, with whom the strikers have no trade dispute, to compel $A$ to force $B$ to yield to the strikers' demands, is an unjustifiable interference with the right of A to pursue his calling as he thinks best."

In the same year that court held:

"Such a strike would be a strike in the nature of a sympathetic strike, that is to say, it is a strike not to forward the common interests of the strikers, but to forward the interests of an individual employee in respect to a grievance between him and his employer where no contract of employment exists."

A like tendency is discernable in a Federal decision :

"All the employees had a right to quit their employment, but they had no right to combine to quit in order thereby to compel their employer to withdraw from a mutually profitable relation with a third person for the purpose of injuring that third person, when the relation thus sought to be broken had no effect whatever on the character or reward of their service."8

6 Pickett v. Walsh, 192 Mass. 572,78 N. E. 753, 6 L. R. A. N. S. 1067 ; I16 Am. St. Rep. 272. See a careful discussion of this case and kindred decisions in 42 American Law Review, 1908, page 706.

7 Reynolds v. Davis, 198 Mass. 294 (1908), 84 N. E. 457, 17 L. R. A. N. S. 162.

8 Thomas v. Cincinnati, N. O. \& T. P, Ry. Co., 62 Fed. 803, 818 (1894). 
And in a leading Anti-trust decision in 1893, District Judge Speer took occasion to reflect in severe terms upon an organized body of railroad employees who repudiated their contract of employment, "because of real or alleged grievances, which some other person or corporation, not a party to the contract, inflicts or is alleged to inflict, not upon a party to the contract but upon somebody else."犯

Cases in large numbers can be found which contain the foregoing doctrine. It was not passed upon directly in the Debs case, ${ }^{10}$ since the Supreme Court was contented to base its finding therein upon the element of restraint of interstate trade appearing in that situation; and in Loewe v. Lawler, ${ }^{11}$ while the doctrine was in the main adopted and applied, it was so quickly overruled by Congress through recent Anti-trust laws that it can hardly be said to have gained a foothold in the law of the land, as acknowledged and declared by that court. The New York Court of Appeals, in a leading case where the decision, however, does not necessarily rest upon this ground, states the proposition contained in the foregoing decision and refutes it. As to the doctrine that "if the motive be unlawful or be not for the good of the organization or some of its members, but prompted wholly by malice and a desire to injure others, then an act that would be otherwise legal becomes unlawful," the court says :

"I do not assent to this proposition, although there is authority for it. It seems to me illogical and little short of absurd to say that the every day acts of the business world, apparently within the domain of competition, may be either lawful or unlawful, according to the motive of the actor." ${ }^{12}$

The fact that the treatment of this subject reflects the sentiments and no doubt indicates the environment and predelictions of the individual judge, is shown by the expression contained in a Massachusetts case where the right of an individual to pursue his calling without restriction arose:

"Speaking generally, however, competition in business

9 Waterhouse v. Comer, 55 Fed. 157.

I0 158 U. S. 564, I5 Sup. Ct. 900, 39 Fed. 1092.

II Danbury Hat Case, 235 U. S. 522.

12 National Protective Assoc. v. Cumming, 170 N. Y. 315, 326, 63 N. E. 369, 371, 58 S. R. A. 135, I40, 88 Am. St. Rep. p. 648 (1902). 
is permitted, although frequently disastrous to those engaged in it. It is always selfish, often sharp, and sometimes deadly."13

This case and doctrine is mentioned, approved and followed by Justice Holmes (now of the United States Supreme Court) in Pickett v. Walsh (192 Mass. 572). The restrictive doctrine, in opposition to that of wide latitude for action by organized labor, is in general found to prevail in the Federal courts, though their decisions are frequently based upon the public rights those tribunals undertook to enforce by way of the Anti-trust laws against restraint of trade and monopoly; and this tendency is particularly apparent where strikes by the employees of railroads are concerned. Some of the earlier of the modern cases turn upon the statutes against the obstruction of the mails; but the tendency to limit the right to refuse to deal, is apparent throughout. At least, such an impression is conveyed by perusal of the cases as a whole.

What attitude Congress assumed, and which side it undertook to defend in this conflict of judicial views upon the respective rights of parties involved in labor disputes, is indicated plainly in House Report No. 6I2, Sixty-second Congress, where Mr. Clayton, for the Committee on Judiciary, states:

"The necessity for legislation concerning them arises out of the divergent views which the courts have expressed on the subject and the difference between courts in the application of recognized views. It may be proper to notice, in passing, that the State courts furnish precedents frequently for action by the Federal courts, and vice versa, so that a pernicious rule or an error in one jurisdiction is quickly adopted by the other. It is not contended that either the Federal or the State courts have stood alone in any of the precedents which are disapproved."

The provisions suggested to overcome this "pernicious rule" (which term is applied to the doctrine limiting the right of organized labor to "refuse to deal"), are embodied in those sections of the Clayton Law we shall later consider in detail. It will there appear that Congress has spoken in the statute as plainly as the committee has recorded its mind in the report.

13 Martell v. White, I85 Mass. 255, 260, 69 N. E. 1085, 64 L. R. A. 260, 102 Am. St. Rep. 34I (1904). 


\section{II. "BOYCOTT."}

Boycott Defined and Considered.-Boycotts are in their nature a species of sympathetic strike. Their origin can be traced in McCarthy's "England Under Gladstone," and it is generally supposed the idea had its inspiration in the proceedings of excommunication practiced in ecclesiastical courts. Judge Taft has presented a definition of the boycott as seen in actual operation in the United States:

"As usually understood, a boycott is a combination of many to cause a loss to one person by coercing others against their will to withdraw from him their beneficial business intercourse through threats that, unless those others do so, the many will cause similar loss to them."14

This definition perhaps assumes too much, since the use of the word "coerce" and "threats" indicate a measure of physical force or at least the introduction of fear of such active aggression. Acts or threats of that character of course, are prohibited by the criminal laws, and such a method would render the organization and the members participating therein subjects for fines and penalties of various kinds.

But where moral suasion alone is resorted to and the business of the employer or even of third parties suffers thereby or therefrom, it is an injury that is incidental to the right to refuse to deal, and there exists no means for obtaining damages or other redress, since no legally recognized injury can result therefrom. In brief, it is an instance of damnum absque injuria. It is the natural outgrowth or incident of some lawful relation, i. e., that of employer and employee, and under such circumstances the former test of malice or malicious intent, recognized and applied in some jurisdictions, no longer controls.

12. PROTECTION AFFORDED BY SECTIONS 6 AND 20 OF CLAYTON LAW.

Toleration and Protection Assured by Clayton Law.-By an affirmative enactment the Clayton Law, Section 6, specifically exempts labor organizations from any construction of the Antitrust laws that will forbid their existence and lawful operation;

14 Toledo, etc., Ry. Co. v. Penna. Co., 54 Fed. 730, I9 L. R. A. 387, 395. 
and it is therein equally forbidden to regard them as illegal combinations or conspiracies in restraint of trade, under those laws. The subject of the revision of the method of granting and applying injunctive relief in labor disputes is treated at pages I I9, I20, so that we may now devote our attention to the clauses that contain the legislatively promulgated method of dealing with disputes between employers and employees.

\section{PROVISIONS SEPARATELY EXAMINED.}

Restrictive Regulations Applicable to Injunctive Orders.Section 20 prohibits restraining orders or injunctions unless necessary to prevent irreparable injury to property, or to a property right, of the party making the application, for which injury there is no adequate remedy at law. In addition, the property or property right must be described with particularity in the application, which must be in writing and sworn to by the applicant or his agent or attorney.

With these introductory special requirements complied with, the applicant will find further and important restrictions, which are in reality declarations of the independence of organized labor, so far as regulation of their lawful acts by courts or court proceedings is concerned. The effect of the several clauses of the second paragraph is and was intended to be so comprehensive as to definitely preclude the courts from rulings unfriendly and adverse to organized labor as such; indeed, these clauses are so fundamental and so thoroughgoing as to approach the dignity of a revolution or at least of a reform in the legal aspect of this department of social science. It, therefore, is not only useful but necessary to devote space to their proper and orderly consideration.

\section{First: The Right to Strike.}

Right to Strike Recognized.-This right is affirmed in the following words :

"And no such restraining order or injunction shall prohibit any person or persons, whether singly or in concert, from terminating any relation of employment, or from ceasing to perform any work or labor, or from recommending, advising or persuading others by peaceful means so to do." 
The reasoning which prevailed and brought about this provision is so generally covered in the authorities already referred to and discussed in this chapter that it seems unnecessary to treat of those matters again in this place. It must suffice to say that while the evils which are or may be incident to labor agitation and management oftentimes bear very harshly on those interested, yet in spite of those evils organized labor is necessary to the welfare of the community as it exists to-day.

\section{Second: Peaceful Picketing.}

Peaceful Promoting of Strikers' Interests Permitted.Paragraph second further provides that such organizations or their members shall not be restrained or enjoined by courts-

"Or from attending at any place where such person or persons may lawfully be, for the purpose of peacefully obtaining or communicating information, or from peacefully persuading any person to work or to abstain from working."

This language is taken from the British trades disputes act, the second section of which is as follows:

"It shall be lawful for one or more persons acting on their own behalf or on behalf of an individual, corporation or firm in contemplation or furtherance of a trade dispute to attend at or near a house or place where a person resides or works or carries on business or happens to be if they so attend merely for the purpose of peacefully obtaining or communicating information or of peacefully persuading any person to work or abstain from work."

This section from the British act, it has been said,-

"might well be termed a codification of the law relating to peaceful picketing as laid down by a majority of the American courts."15

The same authority affirms that while-

"there are some decisions that all picketing is unlawful, * * * yet the view taken by the majority of decisions

* * * is best supported by reason."

15 Martin's Modern Law of Labor Unions, Sec. 173. 
Since it is a lawful right to persuade others, the incidental right to establish pickets to meet and argue with other workmen and to induce them to aid the cause of the strikers cannot well be gainsaid. Peaceful persuasion is obviously a feature that pertains to citizenship; when force or intimidating threats of bodily harm are employed, the statutory authorization should not and does not apply.

Unlawful Acts Subject Offender to Contempt Proceedings. -That this clause of Section 20, paragraph 2, is not intended to encourage acts of violence is evident from its terms; and when such conduct exceeds the limits of "peacefully persuading," the benefit of the exemption from restraining orders or injunctions is forfeited. Infractions of such restraining order or injunction when issued will necessarily come within the scope of the proceedings for contempt provided by Section $2 \mathrm{I}$, since acts of that description involve violations of the laws which everywhere prohibit breaches of the peace. This provision, Section 21, applies only to contempts committed without the presence of the court, where a criminal act is involved.

While this method of compelling obedience is very frequently employed by courts, Sections 21 to 25 , inclusive-governing that method of judicial coercion for acts committed without the presence of the court-contain no express provision referring to labor. The statute applies to any disobedience to "any lawful writ, process, order, rule, decree or command" by any Federal court, where the act complained of is in violation of any of the criminal laws of the United States, or of any individual State in which the act was committed. The main distinction is the right to trial by jury, and to obtain release upon bail pending appeal.

These features, and others of minor importance, are referred to and commented on in Chapter X, pages I20-2.

\section{Third: Boycott in Aid of Cause Legalized.}

Right to Withdraw Patronage.-The third clause is:

"Or from ceasing to patronize or to employ any party to such dispute, or from recommending, advising, or persuading others by peaceful and lawful means so to do."

The court opinions on this matter are conflicting, and some attention has been already devoted thereto, at pages i70-7, supra. The most recent text-book on the subject sums up the sense of 
the most thoughtful and convincing authorities on this vexed topic, as follows :

"A combination between persons merely to regulate their own conduct and affairs is allowable, and a lawful combination though others may be affected thereby. And the fact that the execution of the agreement may tend to diminish the profits of the party against whom such act is aimed does not render the participants liable to a prosecution for a criminal conspiracy or to a suit for injunction. Even though he sustain financial loss, he will be without remedy, either in a court of law or a court of equity. So long as the primary object of the combination is to advocate its own interests and not to inflict harm on the person against whom it is directed, it is not possible to see how any claim of illegality could be sustained."16

This useful "conclusion of the whole matter" leaves it a question of fact to be determined from the proof whether the "primary object of the combination is to advance its own interests and not to inflict injury on the person against whom it is directed" ; and with this inquiry answered in the affirmative and in the absence of violence or threat thereof, the boycott or secondary strike (by whatever name it may be termed), becomes a weapon which may be lawfully employed.

Labor Organizations May Assert Every Right.-As has been stated above, the best authorities give their support to this attitude toward the efforts of organized labor, whether acting upon the defensive or when asserting its power to advance its own interests. Mr. Justice Van Orsdel in his concurring opinion in the Court of Appeals of the District of Columbia says:

"Applying the same principle, I conceive it to be the privilege of one man, or a number of men, to individually conclude not to patronize a certain person or corporation. It is also the right of these men to agree together, and to advise others, not to extend such patronage. That advice may be given by direct communication or through the medium of the press, so long as it is neither in the nature of coercion or a threat. 
"As long as the actions of this combination of individuals are lawful to this point it is not clear how they can become unlawful because of their subsequent acts directed against the same person or corporation." 17

In Massachusetts, where the tide of judicial rulings flowed most strongly in the opposite direction, a counter current is disclosed in the following expression of Mr. Justice Holmes, now of the Supreme Court of the United States:

"It is plain from the slightest consideration of practical affairs, or the most superficial reading of industrial history, that free competition means combination, and that the organization of the world, now going on so fast, means an ever-increasing might and scope of combination. It seems to me futile to set our faces against this tendency. * * * If it be true that workingmen may combine with a view, among other things, to getting as much as they can for their labor, just as capital may combine with a view to getting the greatest possible return, it must be true that when combined they have the same liberty that combined capital has, to support their interest by argument, persuasion, and the bestowal or refusal of those advantages which they otherwise lawfully control.",18

Congress Overrules Restrictive Decisions.-To whatever degree Lawler v. Loewe (the Danbury Hat case), 235 U. S. 522 , has altered or expressly opposed this view, it is itself overruled by Congress, which, if within the limits of the Constitution, is the supreme authority, empowered to fix and establish the principles, policy and measures which together constitute the law of the nation.

\section{Fourth: Labor Organizations, May Grant Financial Aid.}

Strike Benefit Fund is Private Property.-The fourth clause is as follows:

"Or from paying or giving to, or withholding from, any

17 American Federation of Labor et al. v. Buck's Stove \& Range Co., Cir. Ct. of App., Dist. of Columbia, No. 1916 (decided March II, 1909).

I8 Vegelahn v. Gunter, 167 Mass. 92,44 N. E. 1077, 35 L. R. A. $722 ; 57$ Am. St. Rep. 443 ( 1896$)$. 
person engaged in such dispute, any strike benefits or other moneys or things of value."

Two leading cases in State courts ${ }^{10}$ have held that if the strike is intended to accomplish an unlawful purpose, strike benefits in aid thereof will be enjoined. But in the only case of this description disposed of in a Federal court, the opposite conclusion was reached, and the reason assigned was-

"the strike benefit fund is created by moneys deposited by the men with the general officers for the support of themselves and families in times of strike, and the court has no more control of it than it would have over deposits made by them in the banks." 20

Two leading cases recently decided in the English courts, bear out the correctness of this view. ${ }^{21}$

\section{Fifth: Right to Peaceably Assemble Established.}

Existence of Dispute does not Illegalize Otherwise Lawful Act.-The fifth and sixth clauses of this paragraph-and the final expression as to specified particular rights-are contained in the following words :

"Or from peaceably assembling in a lawful manner, and for lawful purposes; or from doing any act or thing which might lawfully be done in the absence of such dispute by any party thereto."

The conduct described in these sections is so obviously proper and is so far removed from any just ground of attack that it would appear a useless expenditure of attention-a work of supererogation-to attempt to give reasons or enter upon any argument in support thereof.

The doctrine is generally stated as a legal proposition in the able decision by Judge Noyes in a leading case :

"A laborer, as well as a builder, trader, or manufacturer, has the right to conduct his affairs in any lawful manner,

19 Reynolds v. Davis, 198 Mass. 294,84 N. E. 457 , 17 L. R. A. N. S. 162 (1908) ; A. S. Barnes \& Co. v. Chicago Typographical Union, 232 Ill. 402, 83 N. E. 932, 14 L. R. A. N. S. 1150,122 Am. St. Rep. 129 (1908).

20 A. S. Barnes v. Berry, 157 Fed. R. 883.

2I Densbey, etc., Collieries v. Yorkshire Miners' Assoc'n, 75 L. J. K. B. 284; Lyons v. Wilkins, 67 L. J. ch. 383. 
even though he may thereby injure others. $* * *$ The damage is present, but the unlawful object is absent. And so the essential question must always be, whether the object of a combination is to harm others or to exercise the rights of the parties for their own benefit." 22

These clauses, 5 and 6 , constitute a corollary of the preceding provisions of this paragraph. The reasoning is the same, only less radical than is required to support the second clause, which governs picketing.

\section{RIGHTS OF LABOR CONFIRMED.}

General Policy Declared.-The concluding words of this important paragraph are:

"Nor shall any of the acts specified in this paragraph be considered or held to be violations of any law of the United States."

This omnibus provision is declaratory of an attitude by Congress with regard to organized labor, which makes it mandatory upon the Federal courts to recognize their rights as declared in this law. It is an evolution from long and varied discussions before legislative councils and in courts.

22 National Fire Proofing Co. v. Mason Builders' Assoc'n, I69 Fed. 260,265 . 


\section{CHAPTER XV.}

\section{ANTI-TRUST LAWS IN THEIR RELATION TO PAT- ENTS AND COPYRIGHTS.}

I. Origin and Purpose of Exclusive Grants.

2. Scope of Exclusive Powers under Patent Laws.

3. Copyright Laws as Construed under Anti-Trust Statutes.

4. Protection of Public is End Sought by Anti-Trust Laws.

\section{ORIGIN AND PURPOSE OF EXCLUSIVE GRANTS.}

Power is Conferred by Constitution.-The narrative of the origin and early history of the power whereby Congress confers exclusive rights upon authors and inventors can be compressed within the space of annals at once both short and simple. Article I of the Constitution contains the basic grant:

"Section 8. The Congress shall have power *** To promote the Progress of Science and useful Arts, by securing for limited Times to Authors and Inventors the exclusive Right to their respective Writings and Discoveries."

Early Action by Congress.-This power was exercised by Congress among the first after the organization of our government. The subject was taken up at the second session of the First Congress, and a law was enacted authorizing a patent to be issued to the inventor of any useful art, etc., upon his petition-

"granting to such petitioner, his heirs, administrators or assigns, for any term not exceeding fourteen years, the sole and exclusive right and liberty of making, using and vending to others to be used, the said invention or discovery."

Such patent, the statute further declares, "shall be good and available to the grantee or grantees by force of this act, to all and every intent and purpose herein contained." The amendatory act of I793 contains the same language; and the whole indicates the legislative intent to carry out the power to that end conferred upon Congress under the Constitution. 
The exclusive powers under copyright are contained in $\mathrm{Re}$ vised Statutes, Section 4952; see also, 2 Federal Statutes Annotated, pages 255 et seq. Under the common law, authors always retained the right to control or restrain the publication of their works by others; but if they exercised the right of publication themselves, they dedicated their work and had no further control in the matter. Thus the constitutional and legislative grant is in effect an extension of the ancient common law right, and this is performed by removal of the former rule of law that publication means dedication. Thenceforth, upon complying with certain prescribed regulations as to filing, etc., the author is empowered to issue his literary productions by the thousand instead of handing about his original work, which was the extent to which his rights could be exercised with safety to his power of ownership or control, under the common law.

Relative Extent of these Exclusive Rights.-Patents are granted for inventions or discoveries in mechanisms, processes and compositions of matter which contribute to the progress of the "useful" arts and sciences. Such inventions or discoveries frequently involve broadly new principles and work revolutions in entire lines of industrial and scientific endeavor. Inventors are therefore, entitled to grants of a scope commensurate with the scope of their inventions, determined, however, by the language of the patent claim. In the cases of patents for such broadly new and useful inventions the courts are disposed to give as broad and liberal a construction to the grant as possible under the language used and give the inventor the benefit of what he has discovered. This line of judicial reasoning proceeds upon the theory that the object and purpose of the patent laws are to induce the inventor to disclose for the ultimate public benefit a discovery which he might otherwise utilize for his sole advantage and enrichment by practicing it in secret; hence, it is to the public interest that a monopoly for seventeen years shall be conferred in return for a full disclosure of his invention so that the public may have the benefit of its free enjoyment when the term of grant expires.

So, too, in the case of copyright, the statute contemplates that authors shall be encouraged in their work by the grant of exclusive rights to publish and sell the fruits of their labors for limited periods. These periods are much more liberal than in the case of patents, however, for the original copyright runs for 
twenty-eight years and may be renewed for another twenty-eight years, giving the author fifty-six years of exclusive enjoyment of his work, whereas all patented inventions must pass into the public domain at the end of seventeen years and can never thereafter be sequestrated from public enjoyment. But while the copyright law is based on the same beneficent purpose of promoting the public welfare, in this case by encouraging advancement in literary, musical and artistic achievement, yet the scope of the work of the author or the composer, or the artist must of necessity be limited to the very work he produces. It is, therefore, apparent that the grant must be different in character and in scope from a patent grant. The copyright prohibits copying, it vests in the author the exclusive right to reproduce, to publish his work. The scope of the patent is determined, as before explained, by the scope of the language used in the patent claim to define the invention, and should be co-extensive with the scope of the invention. In the case of patents the courts are disposed to construe the patents as nearly as possible under the conditions of the case to afford the inventor or patent owner that measure of protection to which he is entitled, and in the case of copyrights they are most vigorous in the enforcement of the exclusive rights of the author to the reproduction of his copyrighted work.

\section{SCOPE OF EXCLUSIVE RIGHTS UNDER PATENT LAWS.}

Restrictions on Future Inventions.-Where it was sought to require an employee to sign away his right to make any useful invention by way of improvements connected with the subject of his employment, the Massachusetts Supreme Court held that the inclusion of a term reaching ten years beyond termination of the contract of employment was in aid of monopoly of interstate trade and commerce. The contract was declared void under the Sherman Law. ${ }^{1}$

Decision Defines Scope of Patentee's Rights.-In a relatively recent decision by the Supreme Court it was held that a patentee without exceeding his exclusive right to "make, use and vend," could stipulate that certain unpatented articles should be employed in a specified manner in connection with his patented

I United Shoe Machinery Co. v. La Chapelle, 212 Mass. 67, 99 N. E. 289, cited in Thornton, "Sherman Anti-trust Act," page 652. 
machine, and that violation of that covenant should constitute a contributory infringement. ${ }^{2}$

Conditional or "Tying" Contracts.-The wide publicity given to a very forcefully expressed dissenting opinion by the chief justice attracted unusual attention to this decision, although it announced no new doctrine and went no further than to reaffirm what has been the settled law relating to these questions from the foundation of the patent system. The views expressed in the dissenting opinion, both because of the eminent authority that uttered them and because of the somewhat radical form of the dissent, attracted wide attention to the case and resulted in great divergence of opinion as to the correctness of the interpretation of the law, or the fairness of the law to the public if its interpretation by the majority of the court is correct. The element partial to the views expressed in the dissenting opinion found a considerable representation in Congress, with the result that this decision of the court played a considerable part in the framing and discussion of the Clayton Law, particularly that portion which resulted in Section 3 of the bill as enacted. Certain members of the judiciary committees advocated radical provisions prohibiting all "tying" clauses in contracts relating to patented inventions, and a number of different forms of provisions were presented to the committees, both of the House and the Senate, for consideration and much of the discussion and interest in this bill centered around the provisions of this section. The advocates of a radical prohibitory provision believed that the decision of the Supreme Court in Henry v. Dick to be an unjustifiable enlargement of rights under a patent grant, i. e., the inclusion therein of elements of control not contemplated in the patent laws and outside the scope of the grant as stated in the words of the grant itself. The consideration of this subject eventually resulted in Section 3 of the Clayton Act, which contains a provision prohibiting conditional or "tying" contracts, leases, and sales affecting articles "whether patented or unpatented, * * * where the effect may be to substantially lessen competition or tend to create a monopoly in any line of commerce."

This is the only direct reference to patents contained in the Anti-trust laws; but it was no doubt intended at once to dis-

2 Henry v. A. B. Dick Co., 224 U. S. 1, 32 Sup. Ct. 364,56 L. Ed. 645 ; see 149 Fed. 424. 
play and exercise the powers which Congress retains over limited as well as other classes of monopolies, for it is provided that this prohibition of "tying" contracts, etc., extends not only to the several States and Territories, but to "any insular possession or other place under the jurisdiction of the United States."

Owner of Patent Entitled to Select his Source of Profit.The doctrine as last announced in Henry v. Dick has been referred to as constituting the occasion for the provision-Clayton Law, Section 3-of the supplementary Anti-trust legislation intended to prevent an over-extension of the patentee's rights through "tying" agreements, leases or sales.

The prohibition, however, does not appear to be vital; and this new legislation would seem only to make clear the limitations of the doctrine and surround it with "Thou shalt not" declarations to prevent its extension beyond a fair recognition of the rights under a patent grant, recognition both fair to the owner of the patent and consistent with the rights of the public. If the owner of the patent chooses to require that the consideration for the use of the patented invention shall take the form of profits derived from the sale of material used in the course of the employment of the invention and to require, by contract with the user, that he shall purchase from him such material for such use, such an election seems justified from every point of view and within his legal rights. Such a contract can hardly be termed a contract to "substantially lessen competition or tend to create a monopoly in any line of commerce," for it would only affect the use of the patented invention, which the owner of the patent, under the specific terms of the patent grant is given the exclusive right to control during the life of the patent. It would not create a monopoly in the material, for the material would be free to the use of everyone for all purposes except to use on the patented invention in question, and the user of the patented invention would be free to use any material to his advantage for any other purpose than with the patented invention. It is only where the owner of a patent may undertake by a contract to require the person using his patented invention to purchase material for general use, outside the scope of the patented invention, and without regard to its direct connection with the utilization of the invention, that a violation of the provisions of the anti-trust laws and, in particular, the limitations upon conditional agreements, etc., contained in Section 3 of the Clayton Law, would result. Thus it 
would seem that after due consideration the Congress has substantially recognized the soundness of the doctrine of the decision of the court in Henry v. Dick, but sought to profit by the prophetic warning in the dissenting opinion and encompassed the doctrine with statutory limitations, lest it might be extended to an infringement of inherent public rights.

No doubt instances occur where the success of the patented machine or process depends upon the quality of the material used; and in such cases an additional reason exists for permitting the patentee to require such quality to be maintained and to supply the demand which his inventive skill creates.

Violation of Sherman Law not a Defence to Infringement Suit.-Important decisions have held that violations of the Sherman Law do not constitute matters for defence in actions for infringement. The ruling is in some degree akin to the doctrine that a tenant cannot dispute the title of his landlord. If there is an illegal monopoly or an unlawful restraint of trade, it must be taken up and disposed of as a separate question. In effect, these decisions leave the enforcement of the Anti-trust statute to an injunction suit at the instance of the United States government. $^{3}$

The court says :

"Such a combination may be an odious and wicked one, but the proposition that the plaintiff, while infringing the rights vested in the defendant under letters patent of the United States, is entitled to stop the defendant from bringing or prosecuting any suit therefor because the defendant is an obnoxious corporation, and is seeking to perpetuate the monopoly which is conferred upon it by its title to the letters patent is a novel one, and entirely unwarranted. * * * it is immaterial whether his [defendant's] motives are good or bad, and he is not required to give his reasons for the attempt to assert his legal rights."4

Under Section 16 of the Clayton Law, individuals are now empowered to bring suits that formerly could be brought only by

3 Otis Elevator Co. v. Geiger, I07 Fed. 131; National Folding-Box Paper Co. v. Robertson, 99 Fed. 985; Columbian Wire Co. v. Freeman Wire Co., 71 Fed. 306; Thornton, "Sherman Anti-trust Act," Section 453.

4 Strait v. National Harrow Co., 51 Fed. 819. See also Continental Wall Paper Co. v. Voight, 212 U. S. 227; D. R. Wilder Mfg. Co. v. Corn Products Co., 236 U. S. 165; also, text and authorities at page 198, post. 
the government under Section 4 of the Sherman Law; but no inherent reason appears why the doctrine enunciated above should not continue in effect and the interposing of Anti-trust defenses be barred in actions to enforce the exclusive rights which the patent laws confer.

Enlarging Patent Rights by Combinations.-It is apparent that when a number of patentees pool their respective ownerships, and proceed as a unit, it is quite possible to piece together an enlarged right-an artificial monopoly-such as was never contemplated under the patent laws. Of such a combination the Supreme Court says :

"The agreements clearly, therefore, transcend what was necessary to protect the use of the patent or the monopoly which the law conferred upon it. They passed to the pur. pose and accomplished a restraint of trade condemned by the Sherman law. ${ }^{5}$

A similar ruling by the Federal courts is found in a case where patentees based their combination on the common and natural wish to avoid infringement suits. In dealing with this contention (which the court held to be a mere cloak), it was said:

"The fact that the property involved is covered by letters patent is urged as a justification; but we do not see how any importance can be attributed to this fact. Patents confer a monopoly as respects the property covered by them, but they confer no right upon the owners of several distinct patents to combine for the purpose of restraining competition and trade. Patented property does not differ in this respect from any other. ${ }^{\circ}$

These decisions indicate the high-water mark which was reached under the Sherman Law, and supply a useful standard in their clear intention to enforce it in spirit as well as in form.

Agreeing to Suppress Invention.-Where the inventor has entered into a contract not to use his invention, such agreement has been held to be against public policy and in restraint of trade. The following brief extract contains the salient points of the leading decision which establishes this doctrine:

"It [patentee's right] is an assignable and heritable ex-

5 Standard Sanitary Mfg. Co. v. U. S., 226 U. S. 20, 33 Sup. Ct. 9, 57 L. Ed. 107; affirming 19I Fed. 172.

6 National Harrow Co. v. Hench, 76 Fed. 667 , affirmed 83 Fed. 36,27 C. C. A. 349 . 
clusive right to make, use and vend. * * * A patentee who agrees to suppress his [invention] is not promoting it. $\mathrm{He}$ is not deriving his profit from its promotion, but from the manipulation of the market. It is no part of the constitutional scheme, or of the scheme of the patent laws, to secure to inventors a profit from the suppression of their creations. * * * The reasons for enacting the Sherman Law seem quite as applicable to articles of this character as to articles having no connection with patents."

Requiring Vendee to Maintain Retail Price of Patented Article.-After some variation in judicial holdings as to the right of the patentee to fix the continuing re-sale price of patented goods, such practices were declared illegal in Bauer \& Cie v. O'Donnell. This case ${ }^{8}$ holds to the effect that where the owner of the patent has sold the product, he cannot control the re-sale price further than as to his immediate vendee, i. e., the price more than once removed or after the goods pass into the channels of trade.

"The right to vend conferred by the patent law has been exercised, and the added restriction is beyond the protection and purpose of the act."

Accordingly, a notice that a sale of the patented thing by a party not under contract with the patent owner at less than the fixed price shall constitute an infringement of the patent is brutum fulmen, and need excite no apprehension. The question seems settled in accordance with the dictates of reason and sound principles of law.

Prohibition Extends to Copyrighted and Unpatented Wares. -In another recent case the same rule as to re-sales has been applied to unpatented articles, and the cases have been construed together in an official publication:

"These last three cases (Bobbs-Merrill Co. v. Strauss, 2 ro U. S. 339; Dr. Miles Medical Co. v. Park \& Sons Co., 220 U. S. 373, and Bauer v. O'Donnell, 229 U. S. I) form a distinct trinity and express the views of the Supreme Court of the United States under existing law on the subject or re-sale and price-fixing and price-maintenance con- 
tracts. The Bobbs-Merrill case relates to copyrighted articles, while the Dr. Miles case relates to unpatented articles entering into interstate commerce, and the O'Donnell case applies to patented articles. These cases cover the whole subject of price-fixing contracts."

Clayton Act Applied.-In a recent decision by a federal court, ${ }^{10}$ a restraining order was refused where the defendant declined to sell its product direct to a customer, who, because of the magnitude of its business, through the medium of an extensive chain of stores, had been accustomed to purchase in car-lots and take advantage of special car-lot prices and, in retailing, had cut prices below the price at which small retailers were accustomed to sell and were obliged to sell in order to make a profit on the product. The decision is based upon the rights of defendant to control its trade name "Cream of Wheat" as well as upon the inherent right to select customers or refuse to deal. The decision is justified in recognizing the right to refuse to deal by reference to various court decisions, ${ }^{11}$ and by the court's interpretation of the language of Section 2 of the Clayton Act, providing that "nothing herein contained shall prevent persons engaged in selling goods, wares, or merchandise in commerce from selecting their own customers in bona fide transactions and not in restrain of trade."

Decision Recognizes Right of Dealer to Protect Trade.This decision recognizes the right of a manufacturer to refuse to place in the hands of one large customer the means of destroying the business and trade of a multitude of other customers, thus recognizing the right of every man to carry on his own business

9 "Laws on Trusts and Monopolies with Authorities," compiled by Nathan B. Williams in connection with the enquiry conducted by the House Committee on Judiciary,-at page 36. This work contains in compact and convenient form a valuable collection of Anti-trust laws, domestic and foreign.

Io Great Atlantic \& Pacific Tea Co. v. Cream of Wheat Co., 224 Fed. 566. See note containing matter pertaining to this decision, page 28 , supra.

II This right is referred to in connection with labor disputes,-Chapter XIV, pages 164-184, supra.

The following decisions recognize the inherent right of refusing business, but bear no relation to the facts herein: In re Grice, 79 Fed. Rep. 627; Greater New York, Etc., Co. v. Biograph Co., 203 Fed. Rep. 39; Adair v. United States, 208 U. S. I6I ; Standard Oil Co. v. U. S., 22I U. S. at p. 56. 
by such methods as, in his own judgment, will be to the best advantage of the business, so long as he does not adopt methods prohibited by law or contrary to public policy. The court adopts the reasoning advanced by the Supreme Court of the State of Washington in a recent decision. ${ }^{12}$

"Price-Discrimination" Section Construed.-Section 2 of the Clayton Law forbids price discrimination, with the exception among others that persons are not prevented thereby "from selecting their own customers in bona fide transactions, and not in restraint of trade." It was this provision of the Clayton Law which came up for construction. ${ }^{2 \mathrm{a}}$

Combinations by Patentees Subject to Anti-trust Laws.Authorities cited and before quoted show clearly that while a patentee may receive a grant of a limited exclusive enjoyment in return for the disclosure of his invention, he must conduct his business thereunder in conformity to law. Combinations of independent patents by their owners,-

"whereby as part of a plan to monopolize the commercial field, competition is eliminated, are within the Sherman Law, for the reason that the restraint of trade or monopoly arises from combination, and not from the exercise of rights granted by letters patent." 13

In consequence of this ruling, agreements between owners of distinct patents limiting and restraining the interstate trade of each, were declared void under the Sherman Anti-trust Act.

As has been mentioned already (page 19I, supra), combinations by owners of patents may in effect result in an enlargement of patent-rights beyond anything contemplated by law, and thereby accomplish ends that would fail if attempted through the ordinary channel of a petition for original patent-rights. In brief, it may

I2 Fisher Flour Mills Co. v. Swanson, 76 Wash. 649.

12a It may be contended, however, in opposition to this judicial construction and application of Section 2, that the Clayton Law, like the Sherman Law, is a criminal statute creating new conditions (page I49, supra) and that intent and motive are controlling factors in proceedings thereunder; also, that whereas common law rights of property may not be taken away, due process, i. e., the "rules of the road," may be changed, if public exigencies so require. (See pages 77-81, supra; also, generally, Addystone Case, 175 U. S. 21 I, affirming 85 Fed. I7I, and Straus Case, 231 U. S. 222.)

13 Blount Mfg. Co. v. Yale \& Towne, I66 Fed. 555, 562; Standard Sanitary Mfg. Co. v. U. S., 226 U. S. 20,33 Sup. Ct. 9, 57 L. Ed. I07; affirming 191 Fed. 172. 
be said that if the combining or restraining contract operates in direct restraint of interstate commerce the statutes are violated.

Right to Exclude is Distinct from Right to Sell.-There is a basic difference between these several rights. The "exclusive right to their respective writings and discoveries" which Congress, under Article I, Section 8, of the Constitution, is empowered to secure to inventors "to promote the progress of science and the useful arts," if taken literally, means the power to exclude others from interfering with profitable exploitation thereof. Congress translated this power into a statutory grant of "the sole and exclusive right and liberty of making, using and vending to others." (See page 185 , supra.)

Thoughtful consideration of the subject must make it apparent that the word "exclusive" contains the only right which the Constitution and the resultant statutes confer upon authors and inventors. The power to make, use and vend was theirs already, under the common law, and could not be taken away by any government authority, State or national, even under that most elastic function-the exercise of police powers. ${ }^{14}$

The ability to exclude others is the measure of the new power given them by the patent law, and is confined to and regulated by the provisions thereof, and as a portion of the grant thus circumstanced and limited the right to sell is subject to such requirements and terms as the legislating body has seen fit to provide. Hence it will be seen that the Anti-trust laws are applicable in the case of patented as of unpatented articles, and that the provisions intended to prevent or overcome restraints of interstate trade and monopolies are of universal application.

It follows that within the monopoly conferred by the patent law, the patentee is absolute dictator. He may refuse to utilize it at all, or he may reserve its use absolutely to himself, at his sole election. Even where he suppresses the device by refusing to employ it himself or to permit others to use it, he is but suppressing his own. "A suppression can endure but for the life of the patent, and the disclosure he has made will enable all to enjoy the fruit of his genius."15 But he cannot lawfully enter into a contract to suppress his discovery (p. I9I, supra).

The inventor may make or use his discovery under his grant of monopoly; but if he sells his product, it passes into the general

14 Allen v. Riley, 203 U. S. 347.

I5 Heaton-Peninsular, Etc., Co. v. Eureka Specialty Co., 77 Fed. 288, 25 C. C. A. 267,35 L. R. A. $728 ; 47$ U. S. App. $146,160$. 
channels of trade and the ordinary rules and regulations common to commercial affairs apply.

Medical Compounds. - The rules generally applicable to articles protected by letters patent are in like force and effect as to proprietary medicines. The discussions of that subject are for the most part contained in cases which turned upon the right of the manufacturer to prevent cut-rate prices by fixing the charge which the retailer shall make to the consumer. It has uniformly been held in the leading decisions that such regulation of re-sales was in restraint of trade and therefore void. ${ }^{16}$

Secret Concoctions Not Favored.-In some instances the medical preparations are made by secret formulas and are outside of the protection of the patent laws. In these cases there is discernible a distinct tendency to restrict the proprietor to his common law rights.

"The owner of the trade secret gives nothing to the public, the value of his property being dependent upon its secrecy. Hence public policy, as expressed in statutes or decisions, favors the statutory and opposes the natural monopoly."18

See also the "trinity of decisions" covering the subject of pricefixing contracts, mentioned at pages I92-3, supra.

Extent of Exclusive Rights Fixed.-It is fortunate that the nature and extent of the patentee's exclusive right to "make, use and vend," have been considered and fixed by the courts. The task of the Federal Trade Commission will be much lessened by rulings which mark out the extent to which that board can properly exercise its powers when seeking to prevent or restrain abuses which relate to patented articles in commerce.

\section{COPYRIGHT LAWS AS CONSTRUED UNDER ANTI- TRUST STATUTES.}

Source of Power.-As has been shown at a former place in this chapter (page 185 , supra), the laws conferring exclusive rights upon authors and upon inventors result from the same constitutional grant of power.

Great Benefits Derived.-No other feature of our national life outside of agriculture and mining has proved so productive as the

16 Dr. Miles Medical Co. v. John D. Park \& Sons Co., 220 U. S. 373, 3 I Sup. Ct. 376, 55 L. Ed. 902 ; affirming 164 Fed. 803.

17 William J. Shroder, in 25 Harvard Law Review, p. 59, etc. (Nov., 1911). 
creative power thus nurtured and stimulated; and it might appear upon fuller investigation that the resultant material and intellectual effects of this ability to originate have a value in excess of either of those two fields of profitable labors. Certain it is that such American inventions as sowing and reaping machinery, telegraphs, telephones, kodaks, and sewing-machines are coextensive with civilization and even seem to form a part thereof; while the works of Emerson, Longfellow, Holmes and Irving are a complete answer to the remark- "Who reads an American book?" -attributed to the oracular Dr. Johnson.

In numerous fields the inventive genius of America has outstripped its competitors and impressed the effect of new world conditions and exigencies upon old world training and methods of thought. If an equal pinnacle has not been attained in things literary, such conditions may be attributed to the immaturity of youth; and in the words of Lord Chatham, this is "a defect which age will cure."

The copyright laws have for their purpose the stimulation of talent for creating work in literary and artistic lines and the advancement of literature and art, while the patent laws seek to promote the advancement of the liberal arts and sciences.

Distinction Noted.-The philosophy and reasoning back of the exclusive grant to authors is somewhat different from that which has produced the system of patent laws. Whether rightly or wrongly, the public looks upon the latter as essentially an inducement to the inventor to disclose some discovery what might otherwise remain indefinitely hidden beneath the protection of a secret process.

Rights of Author and Patentee Distinguished.-In the nature of things, it is not the manufacture or individual use by the creator of copyrighted books, etc., which is the essential element of value; in this particular the copyright is different from the right of monopoly which the patentee obtains. On the other hand, it is the exclusive right to publish and circulate which is the particular privilege sought by the author and which constitutes the essential feature and source of profit of his monopoly.

Anti-trust Laws Govern Methods of Selling Copyrighted Articles.-When the publication has begun and the goods are placed on sale the author or owner of copyright exceeds his powers thereunder if he enters a combination to fix prices at which the retailer shall sell and otherwise regulate the extent and manner in which the protected articles shall be marketed after 
they have passed into the channels of general trade. Especially is this true where the resultant restraint is country-wide and no purchaser can obtain the books, etc., except upon terms imposed by this arbitrary and artificial system of price-fixing:

"As the combination extends throughout the United States by the very terms of the agreement, interstate commerce is necessarily restrained." ${ }^{\prime 18}$

Infractors Not Entitled to Relief.-Authors and owners of copyrights will be refused the aid of equity courts when it is sought to compel the contracting party to carry out the agreed terms of his stipulation, and it appears that they are parties to such combinations.

"The complainant confessedly is a party to the combination and the agreement, and cannot, if it be illegal, have a standing in a court of equity to enforce any part of it, directly or indirectly. When the complainant comes into court, asking equity, it must come with clean hands, as far as the transaction involved is concerned." 19

Violation of Printed Notice is not Infringement.-In this case, which is the principal authority upon certain phases of copyright law, the court held it was not an infringement of the copyright law to sell books for less than one dollar per volume, where the title had passed to the retailer by absolute purchase and sale, notwithstanding a signed prohibition printed on the reverse of the title page, that-"The price of this book at retail is one dollar net. No dealer is licensed to sell it at a less price, and a sale at a less price will be treated as an infringement of the copyright."

Before arriving at this conclusion, the court holds that an infringement consists solely in selling or importing without authority, one or more copies of an unauthorized edition of the work in

18 Bobbs-Merrill Co. v. Straus, 139 Fed. 155; affirmed, 147 Fed. 15, 77 C. C A.. 407, 15 L. R. A. N. S. 766, 210 U. S. 339, 28 Sup. Ct. 722, 52 L. Ed. 1086. See also, Bobbs-Merrill Co. v. Snellenberg, 13I Fed. 530, and Straus v. American Publishing Assoc'n, I77 N. Y. 473, 69 N. E. I107, 64 L. R. A. 701 ; affirming 93 N. Y. App. Div. 86, N. Y. Supp. I09I, also, 231 U. S. 222, where the Supreme Court holds that the Sherman Law interdiction applies to copyrighted as well as to uncopyrighted books; Mines v. Scribner, I47 Fed. 927; Bobbs-Merrill Co. v. Straus, supra, distinguished in Henry v. Dick Co., 224 U. S. I, 43, 32 Sup. Ct. 364, 56 L. Ed. Also, consult, generally, Thornton, "Sherman Anti-trust Act,"-Chapter XVII, "Copyrighted Books."

19 Bobbs-Merrill Co. v. Straus, 139 Fed. I55. 
question; hence the use of such term in connection with authorized publications was misleading because unwarranted in law. Such act is at most a violation of contract; and under that phase no right to recovery can be shown.

"If the publisher of the book, being the proprietor of the copyright, parts with the title to such book, either a single copy or a number of copies, and receives his pay therefor, he has voluntarily parted with all control over that or those particular books. $* * *$ the absolute ownership of an article of personal property carries with it the right to give away or sell for such consideration as the owner sees fit to impose, prescribe, or demand, so long as he violates no law."

So in the leading case before noted relating to a patented article, the Supreme Court held ${ }^{21}$ to the same effect; and as matters stand it seems to be settled law that neither the patentee nor the holder of a copyright can fix the retail price, after the goods have passed into the absolute ownership and possession of an owner not under valid contract with the owner of the patent or the copyright. Furthermore, the same ruling has been applied to like practices in connection with wares which do not come within either of the protected classes. ${ }^{22}$

Retaining Title in Property, Owner Preserves Right to Fix Price.-The converse of the legal proposition last stated makes price-fixing proper and valid where the retailer operates only under a license, and the ownership of the book remains in the holder of the copyright. Whether the business of book-selling can be conducted under a system of licensing so broad as to include the entire retail trade remains to be seen; but if such a course is practicable there is no apparent reason why the sales could not be dominated in that way. ${ }^{23}$

This ruling appears sound in the forum of logic and patent and copyright law; but the further question as to whether such a situation discloses a restraint of trade or a monopoly, will remain to be tried out according to the then existing provisions of the

20 Bobbs-Merrill Co. v. Straus, 139 Fed. I55. See authorities cited under footnote 18 , supra.

2I Bauer \& Cie v. O’Donnell, 229 U. S. I.

22 Dr. Miles Medical Co. v. Park \& Sons Co., 220 U. S. 373.

23 Such is the trend of the ruling in Henry Brill Publishing Co. v. Smythe, 27 Fed. 914; and this authority is quoted with approval in Harrison v. Maynard, etc., Co., 61 Fed. 689, 10 C. C. A. 17, 26 U. S. App. 99. 
Anti-trust statutes when that as yet hypothetical case takes on actual substance and form.

Comparison of Privileges under Patent and Copyright Laws. -As has been said (pages 186-7, supra), the construction of the patentee's rights is accorded a latitude which does not extend to the holder of copyright privileges. This attitude is felt rather than seen upon the face of the reports; but there are two instances which should be noticed and discussed:

First: Patent Rights Rest upon a Broader Grant, and ACCORDINGLY COVER A MORE EXTENSIVE FiELD.

This interesting topic has been quite fully dwelt upon and analyzed in the leading patent case, (Bauer \& Cie v. O'Donnell, 229 U. S. I,) where the distinction is noted and reason therefor stated:

"This grant [to the inventor] as defined in Bloomer v. McQuewan, I4 How. 539, 549, consists altogether in the right to exclude every one from making, using or vending the thing patented. Thus, there are several substantive rights, and each is the subject of subdivision, so that one person may be permitted to make, but neither to sell or use the patented thing. To another may be conveyed the right to sell, but within a limited area, or for a particular use, while to another the patentee may grant only the right to make and use, or to use only for specific purposes."

The court then passes to-

"the differences in the terms of the copyright and the patent statutes, the patent act conferring not only the right to make and sell, but the exclusive right to use the subject matter of the patent." (The italics appear in the original opinion.)

Therefore, it is officially stated by thc Supreme Court that the right to make and sell is the extent of the right conferred under the copyright law ; whereas the patent laws contain the additional exclusive right to use - a grant materially broader in its practical effect.

Second: Rule that Anti-trust Defences Cannot be InterPOSED TO SUITS FOR INFRINGEMENT OF PATENT Rights, is not Applied in Similar Copyright Cases.

In the leading case under copyright law (Bobbs-Merrill Co. v. 
Straus, page 199, supra), the fact is noted that violations of Antitrust laws cannot be set up in actions for impairment of patentee's rights through infringement; but it is stated that such ruling does not apply in copyright cases of that description. Section 4964, of the Revised Statutes, as amended, defines infringement of copyright as printing, publishing, etc., the protected work or selling the same without the written consent of the holder of the copyright. Thus the field for infringement of a copyright is narrower and quite different from the infringement of the patentee's device, and a moment's reflection will be sufficient to show that whereas the defence of restraint of trade or monopoly might well be interposed in proceedings under the former, it could not be employed with equal force when the suit was based upon the right which a patent confers. In brief, the "exclusive right of making, using and vending" is a very broad grant, and affords a wider scope of franchise than that which the exclusive right to make and vend confers on the holder of a copy-right.

The statement in Strait v. National Harrow Co., 5I Fed. 819: "Such a monopoly may be an odious and wicked one, but the proposition that the plaintiff while infringing the rights vested in the defendant under letters patent of the United States is entitled to stop the defendant from bringing or prosecuting any suit therefor because the defendant is an obnoxious corporation * * * is a novel one and entirely unwarranted," (page Igo, supra), closes the door to further discussion of the claim that proof of monopoly can operate as a bar in disputes concerning the infringement or priority of inventions; and the opposite ruling as to Anti-trust defences in copyright cases seems equally established.

\section{PROTECTION OF PUBLIC IS END SOUGHT. BY ANTI- TRUST LAWS.}

Author and Inventor also Concerned.-When considering matters connected with the enactment and enforcing of the Antitrust laws it frequently transpires that the interests of the originator of the patented or copyrighted device, process or work are much more at stake than the interests of the community that uses the device, process or work or by its use renders profitable the property in question. In fact, it often occurs that whereas unfair and unrestricted competition would for the moment benefit the public through a rapid and radical reduction in price, such 
practices in the end would spell destruction to the author or inventor.

Combinations may be formed to overcome or undersell useful inventions or other new productions and to crowd them out of the market by means which involve unfair or underhand dealings; and where wealth and business ability are allied against him, the originator has often been compelled to submit to the loss of years of earnest effort along useful lines. Thus it very frequently happens that the inventor and the author are concerned at least in equal measure with the public in the prohibition of those "unfair methods of competition in commerce" which it is the purpose, province and function of the Federal Trade Commission to prevent, in protection of public interests.

These methods have been in evidence in every State and Territory, not to mention the Insular Possessions and the other places under the jurisdiction of the United States, and the necessity for reforming and curative measures has not passed unnoticed by writers of authority upon the subject.

A recent writer, when discussing broadly the effect of such practices upon the rights of proprietors of trade-marks and tradenames, has treated the subject in a manner that appears equally applicable to those interests concerned in the ownership of patents and copyrights:

"Unfair competition is not confined to acts directed against the owners of trade-marks or trade-names, but exists wherever unfair means are used in trade rivalry. Equity looks not at what business the parties before the court are engaged in, but at the honesty or dishonesty of their acts. It is unfair to pass off one's goods as those of another person; it is unfair to imitate a rival's trade name or label; but he who seeks to win trade by fair means or foul is not limited to those methods. He may copy or imitate the actual goods made or sold by a competitor * * * thus producing confusion in the minds of purchasers, which enables him to purloin his rivals' trade, and in a hundred other unfair ways secure another's trade. All acts done in business competition are either fair or fraudulent, equitable or inequitable, whether they relate to marks or not; and it is believed that the question of trade-marks will soon be lost sight of in discussing un- 
fair competition, in the problem of securing, through the principles of equity, full protection to every merchant against unfair business methods." ${ }^{24}$

The same author traces the source of the term "fair competition" or "unfair competition" to a decision by Lord Elden in $1803,{ }^{25}$ and concludes: "It is, then, in reality the name, unfair competition, that is new, not the theory bearing the name; and relief formerly given $* * *$ was relief based on the principles of unfair competition." 26

Genesis of Application of Anti-trust Ideas to General Business Methods.-Perhaps it may be permitted to deal briefly with the origin of the inclusion of unfair trade methods within the Anti-trust prohibitions, - a cause which was not without able advocates, as appears from the extracts contained in the preceding paragraph.

The history of the movement to protect business good-will controverts the charge that the administration of President Wilson was anti-corporation in establishing the Trade Commission. In this connection it is interesting and instructive to note that it was William Howard Taft, sitting as a member of the Circuit Court of Appeals, Sixth District, in 1898 , who first applied the Sherman Act to the ordinary industrial combination. His definition of interstate commerce is very inclusive, viz:

"* * * the soliciting of orders for, and the sale of goods in one State, to be delivered from another State, is interstate commerce in its strictest and highest sense. * * * If this extends Federal jurisdiction into fields not before occupied by the general government, it is not because such jurisdiction is not within the limits allowed by the Constitution of the United States." ${ }^{27}$

Ex-President Taft has confirmed those early expressions in the following words:

"It is hard to reach any other conclusion, after consideration of the old legislation and the new, than that unfair

24 Nims, Unfair Business Competition, 2.

25 Hogg v. Kirby, 8 Vesey 215.

26 Nims, Unfair Business Competition, 13.

27 U. S. v. Addystone Pipe, etc., Co., 85 Fed. 27I, 806, 814; affirmed, 175 U. S. 211 . 
competition only includes those methods and practices in interstate trade the effect and intent of which would bring them within the scope and condemnation of the first and second sections of the Sherman Act."

The public sentiment thus voiced by authority found its way into the platforms of the respective political parties, and the Baltimore platform promised relief in the declaration-

"A private monopoly is indefensible and intolerable."

It was to effectuate this pledge that President Wilson urged upon Congress the enactment of legislation supplementing the Sherman Act and making its principles of broader application, in the hope and expectation that this course would reduce rather than enlarge the volume of prosecutions required to protect honest business from encroachment through unfair means.

Referring to the situation prior and subsequent to the passage and approval of the Federal Trade Commission Act and Clayton Law, President Wilson has said:

“* * * there was no law to check the practices by which monopoly was built up until the tree was full grown and its fruit developed, or, at any rate, until the full opportunity for monopoly had been created. With this new legislation there is clear and sufficient law to check and destroy the noxious growth in its infancy."

Ability and Prestige of Sponsors of Legislation Reinforcing and Enlarging Anti-trust Laws.-These sentiments represent more than mere opinions of citizens of highest repute and ability; they stand out in bold relief as sentiments of typical members of opposing parties who have joined in a common expression of the needs of the business interests in furtherance of the common good. One is a spokesman of the legal profession who adorned a judicial position of great importance and subsequently was elevated to the office of chief magistrate; the other has received equal honors after service as Governor of a State and as presiding officer of a university.

The Federal Trade Commission is the outcome of mature deliberation by Congress, aided and approved by citizens who individually and officially are the exponents of the progressive spirit of the times. 
It is hoped and believer that the Commission will be mindful of the mandate it has received from the people and of the sterling qualities of its sponsors, and that this semi-judicial body will justify the deliberations and the judgment of those who are responsible for acceding to an awakened public conscience by this reinforcement and enlargement of the Anti-trust laws. That a movement so broad and so deep will include benefits to numerous interests, is assured; and the rights of authors and inventors will be certain to share in the equal protection which the Anti-trust laws, thus supplemented, provide for every citizen. 


\section{CHAP'TER XVI.}

\section{UNFAIR TRADING IN RELATION TO TRADE- MARKS AND TRADE NAMES.}

I. An Ancient Problem.

2. Good Will a Topic of Wide Significance.

3. Unfair Trade Methods.

4. Deceptive Words and Emblems.

5. Imitators Display Endless Ingenuity.

\section{AN ANCIENT PROBLEM.}

Experience Adjusts Problems.-It is one of the fortunateor unfortunate-features of older social organizations and governments that certain questions of necessity have been worked out, reduced to a system and filed away in the pigeonholes of things accomplished, before corresponding problems arise to vex the mind in jurisdictions instituted at a later date.

Monopoly an Incident to Chartered Companies.-Thus, the trust question with its various ramifications of monopolistic tendencies in business had been met and to a considerable degree conquered during the period when the chartered companies of England and Holland flourished and were in possession of by far the greater portion of this continent. In fact, the rights conferred by King Charles the Second, in 1670 , were so extensive that the Hudson Bay Company claimed title in fee to territories equal to the whole expanse of Europe. That those rights were no empty grant is seen by their commutation for a one-twentieth interest in the Canadian public lands under a compromise effected in 1870 , and confirmed by the Parliament of that Dominion, thereby terminating a tenure extending through two centuries. It is true this phase of history has no direct connection with the topic before us, but it is nevertheless of some service in pointing out and emphasizing the fact that at a period when bison-trails were the only roads and savage tribes the only inhabitants of western plains destined to become great and powerful States-in Europe the forces of organized society were slowly but surely evolving solutions for the intricate questions that form an integral pa: $t$ of or at least are incident to existence under the forms of modern civilized life. 


\section{GOOD WILL A TOPIC OF WIDE SIGNIFICANCE.}

Good Will Defined.-The subject of good will may properly be defined so broadly as to include the right of the individual to the patronage flowing out of his enterprise, skill and approved methods in commerce.

Government Offers Monopoly to Induce Disclosure.-Where a person has developed something new, the State, by its patent and copyright laws, offers an inducement for the disclosure of his invention or writing; and grants him exclusive rights therein for a limited number of years, upon condition that his contribution to progress shall become public property at the end of that period. Usually that offer is accepted; and the limited monopolies pertaining to patents and copyrights are conditions which flow from such grants. Sometimes the proffer of the governme.st is ineffectual, and the inventor prefers to keep his own counsels and to put his confidence in the loyalty of his employees or the difficulty of duplicating his discovery; and in those instances his product is made under a secret process. Perhaps the most notable example of this retention of inventor's rights is seen in the manufacture of powdered metal by Sir Henry Bessemer, under a method never disclosed. This reticence is said to be due to a sense of inadequacy of reward from patents involving disclosures of discoveries connected with the manufacture of steel; and thus society is in danger of losing the benefit which would ultimately follow if the secret were divulged in exchange for conventional patent-rights.

Attacks on Originator's Rights Considered-Good will in business, as we have seen, is protected by grants in various forms, in conformity to the rights of the individual applicant; and while the subject is not necessarily confined to traders' rights which are recognized and confirmed by statutes, our attention will be directed mostly to such rights and to the efforts to destroy or impair the patronage and profits resulting therefrom

\section{UNFAIR TRADE METHODS.}

Unfair Trading Includes Unfair Copying.-The genesis of the term "unfair methods of competition in commerce," contained in Section 5 of the Federal Trade Commission Act, and Section II of the Clayton Law, is found in the desire to unduly benefit by 
the labor of others, - a desire not limited to any period or clime. The term "unfair trading," or "unfair competition," is recognized in Great Britain under the words, "passing off"; in France the language is "concurrence deloyale"; while in Germany the term employed is, "unlauter Wettbewerb." It was a known practice in the Middle Ages, and we find a decree of the council of Nuremberg in the year 1512 , providing:

"Whereas, a certain foreigner, who sells engravings under the council chamber, has, among others, certain ones bearing the signatures of Albrecht Dürer, therefore, it is ordered that he shall obliterate all such signatures, and keep no more such engravings in future, and if he shall neglect so to do, he shall be brought before the council of fraud."

Ancient Penalty Severe.-As early as the thirteenth century, copying of trade-marks was made a felony in France and elsewhere; and during that period the Elector Palatine hanged innkeepers who sold spurious wines labelled Rudesheimer.

Law of Infringement a Slow Development.-In England the courts were slow to recognize private rights in trade names and trade-marks. Lord Hardwicke in 1742 , refused to enjoin a trader from using a mark previously appropriated by another trader, and it was not until a century later, in 1842 , that Lord Langdale laid down the correct rule in a suit to restrain the use of an imitative label. He said:

"I think the principle on which the courts both of law and of equity proceed, in granting relief and protection in cases of this sort, is very well understood. A man is not to sell his own goods under the pretence that they are the goods of another man; he cannot be permitted to practice such a deception, nor to use the means that contribute to that end. He cannot, therefore, be allowed to use names, marks, letters, or other indicia, by which he may induce purchasers to believe that the goods which he is selling are the manufacture of another person. I own it does not seem to me that a man can acquire a property merely in a name or mark; but whether he has or not a property in the name or mark, I have no doubt that another person has not a right to use that name or mark for the purpose of 
deception, and in order to attract to himself that course of trade, or that custom which, without that improper act, would have flowed to the person who first used, or was alone in the habit of using, the particular name or mark."'

The question turned upon the right to employ the mellifluent title, "Medicated Mexican Balm," and the case is interesting because Lord Langdale was in advance of his times; and while the application was denied upon the ground that petitioner had made a false statement of fact in respect to the origin of the formula, the true basis on which such relief will be granted in a proper case, is clearly and correctly set forth. The establishment of the general rule that no one has a right to pass off his wares as the goods of another, involved much labor by the courts; and it was not finally so determined until 1896 .

Trade Protection in United States.-In the United States the question of trade protection was also receiving consideration during the same period. In I79I, Samuel Breck, of Boston, petitioned Congress for permission to designate and mark his sailcloth by a registered trade-mark. The petition was referred to Jefferson, at that time Secretary of State; and in his report he said favorable action would, in his opinion-

"contribute to fidelity in the execution of manufacturing, to secure to every manufacturer an exclusive right to some mark on its wares, proper to itself.

"That this should be done by general laws, extending equal rights to every case to which the authority of Congress should be competent."

Long Delay Required.-The nation, however, was obliged to wait seventy-nine years for the partial fulfilment of this recommendation; and it was not until 1905, that really adequate provisions were made effective. In New York a law against "fraud in the use of false stamps and labels," was enacted in 1845, and in the interval between that year and 1866, similar laws were provided in Connecticut ( 1847 ), Pennsylvania ( 1847 ), Massachusetts (1850), Ohio (1859), Iowa ( I860), Michigan (1863), Oregon (1864), Nevada (1865), Kansas, Maine and Missouri (1866). All these statutes looked to the protection of the public against

I Perry v. Truefitt, 6 Beav. 66, citing with approval Pidding v. How, 8 Sim. 477 ( 1837 ). 
adulterated and spurious goods, however, rather than to the acknowledgment and safeguarding of individual rights resulting from excellence in quality and established reputation in trade. It is only since 1890 , that cases in the United States based upon trade-marks and kindred rights have been at all numerous. Up to and including 1870 , only sixty-two such cases appear in the reports.

General Requisites for Protection.-Advertising has injected value into many of these badges of origin and proprietorship, and the very natural desire to reap the full benefits from expensive campaigns of publicity has led to repeated appeals to courts for the establishment and protection of the resultant property rights. It should be noted that where the complainant is shown to be guilty of similar acts, he for like reasons is barred from redress.

Since the public in selecting between competitive articles or commodities is usually influenced by one of four factors, viz: the person who manufactures it, the place where it is made, the material of which it is composed, and the purpose it is intended to accomplish, it may be stated generally that assertions as to any of these four elements of trading are material, and if false, will disqualify the guilty party from obtaining redress or protection in courts of equity.

A favorite method of unfair trading has consisted of singling out one competitor and cutting prices as to him, while maintaining the regular price elsewhere in the trade. Probably a rule that cutting must be general, would obviate this difficulty. Another unfair practice consists in buying a few special articles with a fixed price and drawing the intending purchasers by this attraction, and then selling them something else at a less price.

In view of the endless variety and ceaseless procession of cases which are constantly arising in the conflict between unfair trading and the provisions and doctrines of the statutes and the common law, it will be advisable to forego dwelling longer upon the generalities of this contest between restrictive laws and commercial cunning, and to devote our immediate attention to specific instances of unfair methods of business dealings in their relation to trade-marks and trade names.

\section{DECEPTIVE WORDS AND EMBLEMS.}

Misuse of Names of Places.-This abuse of language is difficult to combat, for it would seem at first sight that it Smith es- 
tablished a cannery of shrimp at Barataria Bay and styled his wares, "Barataria Shrimp," Jones would have an equal right to locate on an adjoining site and to employ a similar name-a title which would appear to be honestly descriptive and naturally appurtenant to such proprietorship. No doubt there are very numerous instances and indeed, whole classes of situations where no legal right to redress would exist although the confusion and disarrangement or even loss of trade would amount to a considerable element of damage. Thus, a store-keeper might lawfully open an adjoining store dealing in goods identical with those of a liberal advertiser, and so long as no effort was made to counterfeit the name or to mislead the public as to their identity, no legal damage could be shown, although trade was diverted and lower prices (because of the saving in advertising expenditures) were offered to customers.

Long Use Pre-empts Name.-Reverting to our first example, however, the rights of the first comer as to name and distinctive marks, are recognized when seasoned and established in the public mind. This privilege is an incident to fair trade and of course, crowds out the opposite contention, relegating it to the region of practices constituting "unfair competition." A celebrated American case consisted in an application to restrain a rival concern from employing the word "Waltham" as a trade name for watches. The competitor was actually located in that city and its wares were produced there; nevertheless Justice Holmes (now of the United States Supreme Court) issued an injunctive orderqualified, however, by the right of the defendant to continue such designation, if coupled therewith there appeared the explanatory statement, "not manufactured by the original Waltham Watch Company."

This action on the part of the Supreme Court of Massachusetts was based upon the theory that the name "Waltham" watches had come to have a meaning that stood for style and quality, rather than place of origin; and that the latter significance had become a matter of minor importance. The learned Justice approaches and deals with the subject convincingly:

“* * * we think that now it is pretty well settled that the plaintiff, merely on the strength of having been first in the field, may put later comers to the trouble of taking such reasonable precautions as are commercially 
practicable to prevent their lawful names and advertisements from deceitfully diverting the plaintiff's custom. * * * It is desirable that the plaintiff should not lose custom by reason of the public mistaking another manufacturer for it. It is desirable that the defendant should be free to manufacture watches at Waltham and to tell the world that it does so. The two desiderata cannot both be had to their full extent, and we have to fix the boundaries as best we can. On the one hand the defendant must be allowed to accomplish its desideratum in some way, whatever the loss to the plaintiff. On the other, we think the cases show that the defendant fairly may be required to avoid deceiving the public to the plaintiff's harm, so far as is practicable in a commercial sense."2

False Use of Name Illicit.-That prior and long continued use of a geographical name ripens into a property right which confers privileges upon the owner, is now too well settled for more extended discussion; and the right of course, includes protection against pretenders who are located elsewhere. Thus, the Anheuser-Busch Brewing Company prevented another brewer from using the word "St. Louis," on beer brewed in another city ; similar action was taken with respect to a brand of Durham Smoking Tobacco, ${ }^{4}$ and the most famous case of all resulted in restraining a Chicago firm from selling flour made in Milwaukee, under the trade name, "Best Minnesota Patent, Minneapolis, Minn."5 Upon the application of Oxford University the same principle was applied to unauthorized editions of "Oxford" Bibles, printed in the United States. ${ }^{\circ}$

Right to Protection Established.-Perhaps it is safe to assert as settled law that where a person starts a competing business and undertakes to appropriate without agreement or compensation the benefit of a name which represents a reputation it

2 American Waltham Watch Co. v. U. S. Watch Co., 173 Mass. 85, 53 N. E. 14I ; 73 Am. St. Rep. 263, 43 L. R. A. 826.

3 Anheuser-Busch Brewing Assoc'n v. Piza, 24 Fed. 149-50-51 (1885); cited in Nims, "Unfair Business Competition," page 243.

4 Blackwell v. Alibrell, 3 Hughes (U. S.), 15I, 3 Fed. Cas. No. I, 475, 14 Off. Gaz. 633.

5 Pillsbury-Washburn Flour Mills Co., Ltd., v. Eagle, 86 Fed. 608, 30 C. C. A. 386,4 I L. R. A. 162.

6 Oxford University v. Wilmore-Andrews Pub. Co., Ior Fed. 443. 
has taken years of fair dealing, or much advertising, or both, to establish on a firm basis, he engages in a practice the law will not countenance or tolerate, and he thereby becomes amenable to those provisions intended to preserve fair play in business and to prevent such unfair methods. This item is an asset-a species of good will-and where it attaches to a geographical name that in effect stands for the manufacturer or the wares, the courts will prevent the appropriation thereof by a new comer.

Misuse of Names of Persons.-While it is true that an individual has proprietary rights in his name and may employ it in connection with any honest trade or calling, these rights, like most other personal attributes must be employed in a manner that will not injure his business neighbor. Especially is this true where the use is plainly intended to gain an unfair advantage. The instances afforded in the reported cases are interesting and instructive.

Recent Rulings Incline to Lenity.-The courts, however, have in a number of decisions recognized the right of the fortunate possessors of names well and favorably known in commercial circles, to use them with certain restrictions designed to avoid confusion between their wares and the advertised products. The situation may be said to have reached a point where the unfair trade cases are so conflicting that each case stands on its own individual merits and facts. Thus when Royal, a citizen of Louisville, entered the business field as a manufacturer, and offered his product under the name "Royal Baking Powder," the court recognized his legal right to make this article, but required him to confine his name to the back label of his cans. ${ }^{7}$ In a State court, a bicycle repairman who engaged in the manufacture of silverplated ware was compelled to use his full name"William H. Rogers," or "W. H. Rogers," joined with the words, "not connected with the original Rogers," displayed in type of at least equal size and distinctness, for-"the court, in this class of cases, interferes only to the extent of preventing the defendant company from passing off its goods as complainant's goods."s

The chocolate business of Walter Baker \& Co. was begun in 1780 , at Worcester, Mass., and for more than fifty years had been conducted under its present name, when, in 1894, a com-

7 Royal Baking Powder Co. v. Royal, I22 Fed. 337, 58 C. C. A. 499.

8 Internat. Silver Co. v. Wm. H. Rogers Corp., 66 N. J. Eq. 119, 139, 57 Atl. 1037. 
peting product was marketed by William $\mathrm{H}$. Baker, of Winchester, Va. To avoid confusion and loss, the court compelled the selling agent of the new concern to place in prominent type upon every package: "W. H. Baker is distinct from and has no connection with the old chocolate manufactory of Walter Baker and Company."9

In a recent decision, the United States Circuit Court of Appeals for the Fourth District has confirmed this doctrine governing the right to use one's own name as a trade name. ${ }^{10}$

Relief Should Fit Individual Needs.-In brief, whereas the use of the name of a person cannot be absolutely enjoined, nevertheless the manner of such use and exploitation may be regulated to suit the peculiar requirements of the case in hand. The rule is stated by the United States Supreme Court in a leading decision, in the following words:

"A person is not obliged to abandon the use of his name or to unreasonably restrict it. The question is whether his use is reasonable and honest, or is calculated to deceive."11

It appears that something approaching fraud must be shown in the use of personal names, to entitle a competitor to relief; but where that element is present the situation discloses what is held to be an instance of "unfair trade," and the injured person may look to the courts for redress.

Misuse of Descriptive Terms.-In England a large trade had been developed in the "Camel" brand of "Camel Hair Belting" used as a substitute for leather belting in tropical countries. A former salesman adopted the title and attempted to divert the business to himself. The proprietor of the original article brought suit for an injuriction upon the ground that the substitute was an inferior article and that long use had so identified his name with the goods that persons purchasing wares under that particular brand believed them to be exclusively of his manufacture. The lower courts held for the defendants upon the ground that putting out goods under a fancy title did not warrant protection to the

9 Walter Baker \& Co. v. Sauders, 80 Fed. 889. For decisions in other "Baker Chocolate" cases,-see 77 Fed. 18I; 87 Fed. 209; 97 Fed. 948; II 5 Fed. 297; 130 Fed. 514.

10 Guth v. Guth Chocolate Co., 224 Fed. 932; see cases there cited.

II Howe Scale Co. v. Wyckoff, I98 U. S. 118, 137, 25 Sup. Ct. 609, 49 L. Ed. 972. 
owner, in a court of equity. Upon appeal to the House of Lords, the case was reversed upon the grounds-(I) that the proprietor had acquired a valuable asset in the nature of a good will, and (2) that the public should be made certain that their purchases were manufactured by the firm identified with the trade name. One of the Law Lords thus expressed his views:

"But fraud is infinite in its variety; sometimes it is audacious and unblushing; sometimes it pays a sort of homage to virtue, and then it is modest and retiring; it would be honesty itself if it could only afford it. But fraud is fraud all the same; and it is the fraud, not the manner of it, which calls for the interpretation of the court." 12

English Rule now Recognized and Enforced in United States.-Misleading purchasers into the belief that they are buying the goods of another manufacturer has been held unlawful in the United States; and the rule stated in Reddaway v. Banham, is now equally in effect in our courts. ${ }^{13}$

Deceptive Labels and Packages. - That more or less mythical person the "unwary purchaser," is not without his friends and protectors, as the decisions abundantly show. In fact, efforts to divert his attention and patronage are among the most common forms of unfair competition.

Unfair Substitution.-The difficulty really consists in the ability of the dealer to substitute the counterfeit article and to prevent any opportunity for comparison. If the purchaser had actually before his eyes and subject to his inspection, packages labelled respectively "Iwanta Biscuit" and "Uneeda Biscuit,"14 there is little likelihood he would prove himself "unwary," but on the contrary, it is almost certain he would select the familiar brand. Where only the first (substituted) package is shown him, he does not think so quickly or deeply as to detect the subterfuge; and provided the quality and amount are substantially the same, he

12 Reddaway v. Banham (1896), A. C. 199, 65 L. J. Queen's Bench 38r, 74 L. T. Rep. N. S. 289, 44 Weekly Rep. 638.

13 American Tobacco Co. v. Polacsek, 170 Fed. 117; see Coca Cola Co. v. National Syrup Co., 215 Fed. 527 (June 13, 1914), and cases therein cited, also, Penna. Rubber Co. v. Dreadnaught Fire Co., 225 Fed. 138 (July 24, I915), Wade Dist. Reporter, Nov., 1915, p. I.

14 National Biscuit Co. v. Baker, 95 Fed. I35; Id. v. Ohio Baking Co., 127 Fed. 127, 160; Id. v. Swick, I21 Fed. 1007; also, see Scheuer v. Muller, 20 C. C. A. 165 (note); Lare v. Harper, 30 C. C. A. (note). 
suffers no real damage,-it is the manufacturer who is injured. The reputation amounting to a good will which years of fair dealing and much advertising have impressed upon the public mind counts for nothing in the face of such tactics on the part of the retailer, and the courts have very promptly and properly enjoined the use of the word "Iwanta" in the biscuit trade.

Sound Sense Essential to Just Rulings.-In such cases courts are called upon to place themselves in the position of the average person who goes forth to bargain for his or her daily supply of household necessities; and we can test the judgment of the courts by our own opinion as to the fairness of the methods employed by traders, in such transactions. Sound sense is essential to just rulings in such cases and it has been well said, "a variation will be regarded as immaterial which requires a close inspection to detect."15

Leading Cases Illustrative of Above Principle.-A few illustrations will best display the principle which governs this phase of business dealings. Humphrey's Specifics are a form of homeopathic remedies which for more than a generation have been dispensed to the public under numbers " $x$ " to " 35 ." It was held that such long use of those numerals had come to indicate to the trade one particular origin and ownership, and constituted fair notice not to trespass; and the rival drug house was enjoined. ${ }^{16}$

Even when a patent has expired, and the name has become public property, such words as "Singer," when applied to an article of common domestic use, "must be accompanied with such indications as will show by whom it is made so that the public may be informed of that fact."17.

The Coleman spice house had for seventeen years supplied the trade with "Bull's Head Mustard." No other firm was employing that label, and the manufacturers considered the likelihood of any imitation so improbable that they did not take the precaution to copyright their mark, nor to register it nor in any manner to comply with the laws of the United States which relate to trademarks. When a manufacturer of labels, however, after such

15 Febridge v. Wells, 4 Abb. Pr. (N. Y.) 144, 13 How. Pr. 385. See also Merrimack Mfg. Co. v. Garner, 4 E. D. Smith (N. Y.) 387, 2 Abb. Pr. 318.

I6 Humphrey's Homeopathic Medicine Co. v. Wenz, 14 Fed. 250.

17 Singer Mfg. Co. v. June Mfg. Co., 163 U. S. 169, 16 Sup. Ct. 1002, 41 L. Ed. 118 ; cited in Joffe v. Evans, 70 (N. Y.) App. Div. 189, 75 N. Y. Supp. 257. 
long use had familiarized the public with this particular brand, began the sale of almost identical labels to other manufacturing dealers in mustard, the court did not refuse its protection to the original maker. ${ }^{18}$

As might be expected, the proprietors of "Castoria" have not retained their customers unchallenged by the swarm of imitators which surrounds a successful enterprise. In resisting such an assault (after the name had become public property), it was proven that the defendant had copied the color, type, arrangement and general appearance of complainants' wrapper. In deciding the case, the court said :

"Bearing in mind that the complainants' wrapper was well known to the trade for years before the adoption of that of the defendant, it is impossible, in view of the accumulated resemblance, to avoid the conclusion that these similarities were not the result of chance, but are chargeable to design." 19

The Federal court has well summarized the situation presented by cases to restrain unfair means of diverting trade when it said, in affording protection against imitators of Hire's Root Beer:

"An action like the present proceeds * * * upon the principle that one may not, by means lawful in themselves when devoted to a lawful end, perpetuate a fraud upon the public, or infringe the rights of another."20

That imitators are no respectors of persons but rather, mothlike, are attracted by the light of conceded excellence, is common knowledge. Literary distinction and reputation offer shining marks, as seen in efforts to duplicate "The Harvard Classics-Dr. Eliot's Five-foot Shelf of Books,"21 and in the "Chatter-Box" cases. $^{22}$ In each instance the court held that originality and use had conferred property rights.

18 Colman v. Crump, 70 N. Y. 573.

19 Centaur Co. v. Killenberger, 87 Fed. 725 ( 1898 ).

20 Chas. E. Hires Co. v. Consumers' Co., 100 Fed. 809 (1900), Id. v. George A. Hires, 182 Pa. St. 346 (1897), 37 Atl. III7.

2I Collier v. Jones, 66 Misc. (N. Y.) 97, 120 N. Y. Suppl. 991 ; modified in 140 N. Y. App. Div. 911,125 N. Y. Suppl. 1116.

22 Estes v. Williams, 21 Fed. 189, 190. Later cases in which the foregoing decision is approved and followed: Estes v. Worthington, 31 Fed. 154, 24 Blatch. 37I ; Estes v. Worthington, 30 Fed. 465; Estes v. Leslie, 27 Fed. 22, 23 Blatch. 476; Estes v. Worthington, 22 Fed. 822, 23 Blatch. 65; Estes v. Belford, 30 Off. Gaz. 99. 
Petitioners must come with "Clean Hands."-Of course, it is not every complainant that is entitled to the court's aid. Those who are seeking some unfair advantage or are engaged in working off some worthless product will not be protected from assaults by others of the same class. Indeed, the assurance of some litigants is amazing and affords a source of amusement to readers of decisions, as it no doubt did to the courts which were in duty bound to pass upon the questions thus propounded.

An instance of this assurance in its most aggravated form appears in the early decisions. The proprietor of a concoction in the form of a cosmetic rejoicing in the euphonious title, "The Balm of a Thousand Flowers," obtained a temporary injunction restraining a rival from employing the still grander name, "The Balm of Ten Thousand Flowers." ${ }^{23}$ The proofs showed it to be compounded of oil, ashes and alcohol; whereupon the judge dissolved the injunction and refused relief on the ground that an article so composed, containing no trace of elixir from any flower, was calculated to attract, deceive and impose upon the public. In its opinion the court intimated that taking the claims of such mendacious dealers at their face value, it was folly to grow old and a mistake to die. ${ }^{24}$

\section{IMITATORS DISPLAY ENDLESS INGENUITY.}

Expansive Term Required.-The framers of the Federal Trade Commission Act were wise in abiding by their determination to refrain from any definition whatever of "unfair methods of competition in commerce," recognizing that to meet and overcome new forms of deceit and unfairness as they arise, the term itself must remain elastic. That time will justify this course, there can be no doubt. As was well said by one of the Law Lords of the British court of last resort in the leading case of Reddaway v. Banham (page 215, supra): "But fraud is infinite in its variety"; and we acknowledge his wisdom by foregoing any attempt to enumerate all, or even a considerable portion of the classes of schemes predatory persons have contrived in order to

23 Fetridge v. Wells, 4 Abb. (N. Y.) 144 (1857).

24 For other illustrations of the principles applied by the courts when passing upon cases of this description, see page 247, ante; also, generally, -Nims on "Unfair Business Competition," and an article by William B. Hale on "Trade-Marks, Trade Names and Unfair Competition," in 38 "Cyc," page 674, etc. 
extract unfair profits from the efforts and investments of their competitors.

Manifold Forms of Deceit.-Appearances intended to deceive; equivalents that confuse buyers; substitution; false representations; unfair advertising; imitating the style of business names; counterfeiting the goods themselves-are a few instances of this infinite variety of subterfuges. In view of the subdivisions and re-subdivisions which are and always will be thought out and attempted while human nature remains what it is, no rational being should endeavor to compress all the types of this familiar form of chicanery into the space of a single paragraph. Nor will we attempt it here.

Principles of Fair Dealing Constitute Sole Guide.-The Federal Trade Commission like the courts when dealing with the subject of "fraud"-a term purposely left undefined in order that it may be construed to include new phases as they appear-will find that it must steer by the compass of sound judgment through applying recognized doctrines to particular cases, whenever charges of "unfair competition" are before it. The end sought to be accomplished must be what fair dealing requires.

Appropriate Judicial Ruling.-In this connection we consider ourselves fortunate to find judicial language appropriate to a condition where some novel form of unfair advantage in trade is disclosed and where the guilty party seeks to justify the fraud or imposture by sophistry in place of reason. A Federal Court of Appeals has said when passing upon an ingenious attempt to overreach and defraud:

"Property, even as distinguished from property in intellectual production, is not, in its modern sense, confined to that which may be touched by the hand, or seen by the eye. What is called tangible property has come to be, in most great enterprises, but the embodiment, physically, of an underlying life-a life that, in its contribution to success, is immeasurably more effective than the mere physical embodiment. Such, for example, are properties built upon franchises, on grants of government, on good will, or on trade names, and the like. It is needless to say, that to every ingredient of property thus made up-the intangible as well as the tangible, that which is discernible to mind only, as well as that susceptible to physical touch-equity 
extends appropriate protection. Otherwise courts of equity would be unequal to their supposed great purposes; and every day, as business life grows more complicated, such inadequacy would be increasingly felt.

"Nowhere is this recognition by courts of equity of the intangible side of property better exemplified, than in the remedies recently developed against unfair competition in trade. An unregistered trade name or mark is, in essence, nothing more than a symbol, conveying to the eye and ear. information respecting origin and identity; as if the manufacturer, present in person, and pointing to the article, were to say, 'These are mine'; and the injunctive remedy applied is simply a command that this form of speechthis method of saying, These are mine-shall not be intruded upon unfairly by a like speech of another.

"Standing apart, the symbol or speech is not property. Disconnected from the business in which it is utilized it cannot be monopolized. But used as a method of making an enterprise succeed, so that its appropriation by another would be a distinctive injury to the enterprise to which it is attached, the name, or mark, becomes at once the subject-matter of equitable protection. Here, as elsewhere, the eye of equity jurisdiction seeks out results, and though the immediate thing to be acted upon by the injunction is not itself, alone considered, property, it is enough that the act complained of will result, even though somewhat remotely, in injury to property. $* * *$ Are we to fail our plain duty for mere lack of precedent? We choose, rather, to make precedent."25

Another later decision by the same court approves the doctrine thus announced, and so far as we know it has not been questioned. This quotation from said other decision is of interest as showing the tendency of the courts to recognize and protect incorporeal rights as well as tangible rights :

"So it is apparent that something more is involved here than the question of rights flowing from the sale and purchase of original Prest-O-Lite gas packages. That something more is an incorporeal right that may best be called

25 National Tel. News Co. et al. v. Western Union Tel. Co., ing Fed. 294. 
service, the right to serve and be served without interference from outsiders. Such a right, as a species of property, has been recognized and upheld. * * * While service is not trade in articles of commerce, and while trade-marks, as such, must actually be put upon articles of commerce or their containers, we see no reason why an intending servitor may not offer his service under an arbitrary name or sign as well as under his real name. And the ultimate fact of importance is that in the automobile world Prest-O-Lite came to stand, not only for the physical article, but also for the incorporeal right to serve and be served. $* * *$ Appellee is entitled to have its lifeblood saved from leeches and its nest from cuckoos." ${ }^{26}$

Development of Unfair Competition Law.-That this wholesome view is neither new nor strange is abundantly shown by the writings of those qualified to speak on the subject. An earlier authority has thus noted and commented upon the growth of means to prevent dishonest or unfair competition: "Not yet fully adopted by all the courts, still to be developed in its application to particular circumstances and conditions, this broad principle of business integrity and common justice is the product and the triumph of the development of the law of trade-marks in the last half century, and the bulwark which makes possible and protects the world-wide business reputations common and growing more common in this new country." 27

General Conclusion Deduced from Authorities.-As deduced from the decisions and authorities generally, the rule is now quite clear that utilization of the names of persons, places, etc., and the various forms of emblems employed in trade will be restricted or prohibited where they lead to confusion or deceit, and result in the passing off of goods differing in source of manufacture, nature or quality, from those the intending purchaser purposed to acquire.

26 Searchlight Gas Co. v. Prest-o-Lite Co., 215 Fed. 692. See also other cases referred to in this decision.

27 W. K. Townsend "Two Centuries Growth of American Law,"cited in Nims" "Unfair Business Competition," page 2. 


\section{CHAPTER XVII.}

\section{UNFAIR METHODS AS SEEN IN ABUSES OF COR- PORATE CONTROL.}

I. Unfair Manipulation and Conduct.

2. Unfair Exercise of Voting Power.

Useful Comparisons.-Information useful for our purpose is contained in those reported cases that define and apply the rules and principles of equity in corporation actions which turn on the element of unfairness; and the substance of those decisions will now be shown as an aid to interpreting the phrase "unfair methods of competition in commerce" (Section 5 of Federal Trade Commission Act) which constitutes the essence of the recent enactments intended to supplement and make effective the Anti-trust laws.

Rule in Patent and Copyright Cases.-In the absence of decisions stating the position of the Federal Trade Commission in respect to delimiting the prohibitions against "unfair methods" contained in the creating statute, it is a fortunate circumstance that the corresponding expression "unfair trade" has an acknowledged and well-rounded significance in Patent and Copyright Law, and under that system of rulings which now protects the use of Trade-marks and Trade Names; and the leading cases constituting or explaining that doctrine will be found already set forth herein, in Chapters XV and XVI.

This system of interpretations and constructions may be turned to convenient and useful account when exploring and mapping out the territory which Congress, in response to a public demand, has seen fit to assign to the Federal Trade Commission for its particular jurisdiction and province.

Natural Divisions of Topic.-Matters connected with abuses of corporate control fall naturally under two heads; and we shall undertake for our immediate consideration:

I. UNFAIR MANIPULATION AND CONDUCT IN MANAGEMENT OF AND DEALINGS WITH CORPORATIONS.

Similar Principle Educed in Corporation Law.-The duty of overseeing and codifying correct methods of business pro- 
cedure should and we believe will to a considerable degree be assisted and simplified by reference to a similar line of cases construing and defining "unfair dealings," contained in corporation law. Certainly in a jurisdiction which extends throughout the confines of the United States and its various possessions and dependencies and even reaches to "commerce * * * with foreign nations" (Clayton Law, Section I, paragraph 2), no source of enlightening and useful information should be passed by or withheld.

The class of cases now referred to and considered offer decisions of greater antiquity than those comprised in Patent and Copyright law and possess at least equal authority as precedents for the Commission's guidance; they bear directly upon the subject in hand and express disapproval of "unfair" acts when these occur in connection with the affairs of incorporated bodies.

Definite Rule of Conduct Established.-In brief, this line of leading cases has established a definite rule of conduct that is enforced whenever similar situations are discovered in connection with the management of corporations.

Instances Where Rule was Applied.-Thus, sale of corporate property to pay the claim of a director, where the debt was occasioned by the mismanagement of the Board, is open to objection, and such action will be restrained ; again, authority to sell the lands of the corporation does not make legal or permit a sale to the wife of a director exercising such power, unless the consideration represents the full value. ${ }^{2}$ Where a director bought the assets of his company for a small price at sheriff's sale, he is chargeable with the profit; and a court of equity will require him to account for this profit and return such sum to the treasury of the company. ${ }^{3}$

Rule Applies Where Actual Injury Shown.-These cases are fairly illustrative of "unfair dealings" which if not unlawful per $s e$, at least are voidable upon the complaint of a creditor or fellow shareholder. Some injury, of course, must be shown to remove the case from the regions of mere theory and debate, or of objection on the part of a volunteer in the transaction; but

I Crescent City Brewing Co. v. Flanner, 44 La. Ann. 22; ro South. 384.

2 Green v. Hugo, 8I Tex. 452; 17 S. W. 79; 26 Am. St. 824.

3 Tobin Canning Co. v. Frazer, 8i Tex. 407, i7 S. W. 25. 
from the multitude of adjudicated cases there has developed a line of decisions which constitute a distinct department of equity jurisprudence and make for fair dealings within the confines of corporate management and control.

"Minority Stockholder's Rights" Explained.-This subject is known and treated of in the text books under the title "Minority Stockholder's Rights," for the reason that acts of this description almost invariably arise from abuse of power on the part of the controlling majority, or of their representatives-the officers or directors who manage the affairs and business of the corporation. A proper measure of authority, of course, is an incident and prime necessity in the management of every incorporated body; it is only the abuse of power which can be made the subject of just complaint.

Application is Reasonable.-That the rules of proper behavior in such matters are not unreasonable is instanced by the fact that stockholders may deal together regardless of whether a director is concerned in the transaction, if there is no actual misleading; and other stockholders cannot be heard to complain because such official position has clothed one of the parties with superior knowledge. ${ }^{4}$

Unfair Management of Corporation.-Instances of unfair conduct in corporate management are so largely matters of common knowledge that it will not be necessary to multiply examples, except to the extent necessary to deduce the rule resulting therefrom, in order that the instances cited may be employed in explaining or construing similar situations as and when they arise in connection with proceedings before the Federal Trade Commission.

Cases Illustrating Rule.-An agreement to pay a salary to the manager on condition that he shall buy stock, which the directors in turn engage to buy back from him at an advance, has been held voidable at the instance of a protesting stockholder, since directors have no authority in law to make a contract to give one stockholder a preference over another of the same class; even proof of good faith will not legalize such methods. Where a director serves upon two boards, and there are joint

4 Haarstick v. Fox, 9 Utah 110, 33 Pac. 35I, 156 U. S. 674; McIntire v. Ajax Mining Co., 17 Utah 213, 20 id. 323, 28 id. 162, 77 Pac. 613.

5 Wilbur v. Stopel, 82 Mich. 344, 46 N. W. 724, 21 Am. St. 568. 
dealings between the companies, he is prohibited from persuading either company to enter upon contracts where his personal interests would run counter to those of the corporation. Only confirmation by the stockholders, with full knowledge, and the absence of any impairment of the rights of creditors will legitimatize the transaction and overcome the presumption that some unfair advantage has occurred. ${ }^{\circ}$

Standard of Fair Dealing Maintained.-In so far as acts of this general description are the outcome of the fiduciary relationship growing out of the trust imposed in the governing board, decisions by the courts of highest authority insist upon a standard of fair dealing; indeed, a disinterested board is esteemed so necessary to the orderly and proper administration of the affairs of the company that in a case where a director who was receivng a profit from the particular transaction was conclusively shown to be in possession of the deciding vote, the resultant contract was adjudged unfair and set aside. ${ }^{7}$

Great Variety of Unfair Means.-Such methods are semifraudulent in their nature, and certainly resemble and perhaps equal fully matured frauds in one respect, viz.: their form and variety is endless, limited only by ingenuity of the human mind. That there exists a legion of these nefarious schemes has been shown at another place,-Chapter XVI, pages 215, 218 8.9.

Offices Exclusive Property of Corporation.-Instances have occurred where the executive officers have been shown to be likewise remiss in their dealings with the corporation. In a leading case it appeared that the president had received a sum of money for surrendering his office and contriving by his influence to secure the election of an agreed successor. A corporation entrusted to the protection and guidance of officials of this description naturally fell away, and its affairs at length came into the hands of a receiver.

In an action for restitution it was held such conduct constituted unfairness in an aggravated form; that the offices are the exclusive property of the corporation and no person will be permitted to transform them into personal gain; that defendant's

6 Langan v. Francklyn, 29 Abb. N. C. (N. Y.) IO2; McGourkey v. Toledo \& O. C. Ry. Co., I46 U. S. 536; Jacobus v. Am. Min. Water Mch. Co., 38 Mise (N. Y.) 371 ; 77 N. Y. Supp. 898.

7 Higgins v. Lansingh, I 54 Ill. zOI, 40 N. E. 362; Gildersleeve v. Lester, 68 Hun (N. Y.) 532. 
act was a perversion of the powers of office and a fraud upon the corporate body; and the court in accordance with those findings set aside the corrupt transaction and decreed that the sum involved-three thousand dollars-should be paid into the treasury of the corporation. ${ }^{8}$

Manipulation of Joint Control.-Manipulation of the control of one corporation so as to enable a rival concern to acquire the remaining shares at an inadequate price $;^{9}$ and the bringing of needless suits to waste the company's assets and destroy its business,-are other illustrations of the same unregenerate type of dealings in corporate affairs $;^{10}$ although it should be noted that in cases of this sort it is the manipulation of the combined management and stock-control rather than any individual act which constitutes the instigation and carrying through of the illicit scheme.

Redress through Court of Equity.-The means of preventing or overcoming such acts has been in most instances a representative action in equity, brought by a minority stockholder on behalf of himself and the other owners of shares who may be similarly situated. The action, in theory of law, is brought by or for the corporation; but in practice it is usual to make the corporation a party defendant, as otherwise it would be necessary to engage the services, or at least the co-operation of the officials concerned in the transaction, upon which the charge is based,- - course which would be manifestly absurd. The benefits of the litigation accrue to the corporation; although the moving parties may be allowed to retain the expenses of counsel and cther necessary outlays, in a proper case.

Results not Ideal, though often Effectual.-It must be admitted that this plan of procedure is not ideal. There is something approaching an anti-climax in the wording of a decree requiring that restitution be made by depositing a fund in the treasury of the corporation, when it is certain the major portion will in due course find its way back into the pockets of the guilty control. However, knowledge that a court will or may scrutinize the guilty transaction, and the possibility of publicity which will

8 McClure v. Law, 16I N. Y. 78,55 N. E. 388,76 Am. St. 262.

9 Farmers' Loan \& Trust Co. v. Trustees of N. Y. \& West. R. R. Co., 150 N. Y. 410, 44 N. E. 1043, 34 L. R. A. 76, 55 Am. St. 689; Macklem v. Fales, 130 Mich. 66.

so George v. Central R. R. Co., Ior Ala. 607, 14 South. 752. 
beget public disapproval and contempt,-are powerful deterrents, even though it may sometimes happen there are persons concerned who will not respond to such restraining influences when opportunities for spoliation occur. In brief, the rights of the creditor and the minority stockholder occupy a distinct and well recognized place within the precincts of corporation law and fix boundaries beyond which it is unsafe for officers and others to carry on a designing scheme or predatory campaign.

Commission's Jurisdiction Prescribed by Statute.-It does not seem likely the Commission at present will include general traffic in corporate shares for voting purposes or other matters affecting the internal workings of the company as coming within its province and particular zone of influence; its interpretation of acts included in the term "unfair methods of competition in commerce" (unless these acts are specifically pointed out by statute), can hardly be thus broad, however repugnant such conduct may appear to every person endowed with an open mind and moved by proper motives.

Has Power to Require Reports.-However that may be, there exist very wide powers to institute enquiries and to demand reports, general or special, under Section 6 of the creating act; and it may well be that the collating of the information thus obtained by the Commission and the publication thereof (in its discretion), will act as a sufficient check upon abuses of the control, thereby serving a useful purpose in ordinary cases of incipient attacks upon the property or interests of the common venture. In this event, a distinct and gratifying advance will have been accomplished without the necessity for restraining orders or other steps and proceedings directed to that end.

Commission May Recommend Additional Legislation.-But Congress has not shut the door of further legislation in case hardened offenders prove recalcitrant and refuse to recognize the handwriting upon the wall; for it requires the Commission, among its other duties, to submit to the legislating body "recommendations for further legislation" (Federal Trade Commission Act, Section 6, paragraph " $\mathrm{f}$ "), whenever that board finds the situation demands an increase of power to fully occupy its field and to bring about results in the public interest.

Corporation Decisions Useful Guide.-In the meanwhile and until Congress shall find it necessary to be its own interpreter by further supplementing of the Anti-trust laws, it is believed that the 
foregoing decisions in corporation cases taken together constitute a useful guide and criterion whenever allegations of "unfair" dealings are filed with the Federal Trade Commission for adjudication. Some method of standardizing rulings is especially needed in a jurisdiction so wide and varied as that which Congress has conferred upon this semi-judicial body; and experience may show that something worth while has been accomplished when one means of attaining that result has been pointed out.

\section{II.}

\section{UNFAIR RESTRAINT OF VOTING POWER.}

A Beneficial Result.-Although Section 7 of the Clayton Law bases its various prohibitions of stock-ownership in competing companies upon the dangers of restraints of trade and monopolies, the effect is likely to prove even more beneficial to general business interests by completing the destruction of that ingenious device known as the holding company.

Early Method of Securing Corporate Control.-In former times the control of a corporation for ulterior purposes was obtained through manipulations whereby an "inner ring" obtained possession of its directorate and thenceforth divided among themselves the resultant profits and emoluments, except as restrained through courts of equity in long and expensive litigations that were necessarily uncertain because of difficulty in gaining access to the books, documents and papers requisite to prove the corporate fraud. The entire procedure in suits of that description was cumbersome from the inception to the finish; although at times adequate relief has been secured therein, as appears by reference to quite numerous decisions in the reports of the equity courts.

Substitution of Holding Company Device.-Subsequently there flourished a new scheme whereby the control was permanently transferred to a holding company, which might become the repository of a series of stock-controls extending throughout the United States and even abroad; and control of the holding company insured the control of all.

I Enoring Constitution, Device Excludes Minority.-From the viewpoint of the ingenious manipulator this plan was a decided improvement where combinations and consolidations were desired, and altogether it marked a distinct advance in such prac- 
tices; by it the voting power of the minority was reduced to an impotent and ignorable factor notwithstanding such course contravened rights which the Constitution was calculated to secure to every citizen. As far back as the time of Chief Justice Marshall it was decided in the Dartmouth College case ${ }^{11}$ that a charter is a contract and that by the principle so established those engaged therein possess vested rights. Again, every jurisdiction provides means for the dissolution of corporations when their use or convenience as an independent and separate body corporate has ceased, and some other corporation or concern can conduct its affairs to greater advantage. To proceed otherwise is to confiscate the property of the dissenting minority "without due process of law,"-a method of taking private property which is prohibited by the Fifth Amendment.

By shifting the permanent control to a holding company, however, a new situation was created where each corporation so taken over parted with the management of its policy and business and virtual dissolution was effected without that distribution of assets a statutory dissolution necessarily requires. It follows that the "obligation of contracts" between the corporation and such of its stockholders as composed the minority was as seriously impaired as if the respective legislatures had deprived each of them of their voting power and right to require a division of the corporation's assets, from the date when the transfer of control was effectuated in binding form.

Constitutional Provision Violated.-Such conduct certainly contravenes the rights which the stockholder secured under the doctrine contained in the spirit if not in the words of the Dartmouth College case-rights which, once vested, became property that the Fifth Amendment assures him shall not be taken away "without due process of law." Both in his right to possess and retain his pro tanto share in conducting the affairs of the organization and in his right to a distributive share in the assets of his corporation whenever it shall be in fact or in effect dissolved, the minority stockholder is injured by the operation of the holding company plan; and this by a mere colorable transfer of stock-control, unsafeguarded or legitimitized by any proceedings beyond the mere act of interested persons and subse-

II Dartmouth College v. Woodward, 4 Wheat. (I7 U. S.) 518-636; 4 I. Ed. 629. 
quent ratification at meetings of the stockholders of the corporations-both dominated by the persons interested in consummating the deal.

Holding Company Creates Monopoly of Voting Power.While such acts as these may not constitute a situation where "the effect of such acquisition or the use of such stock by the voting * * * may be to * * * create a monopoly of any line of commerce" (Clayton Bill, Section 7, paragraph 2), it is certain beyond the realms of dispute that their effect is to create a permanent monopoly of the voting power, and it is equally certain these acts can never stand the test of scrutiny by courts"of equity, whenever the question is squarely presented for consideration in those tribunals.

Adverse Effects.-Complaisant legislatures, attracted by the certainty of special taxes paid in consideration for special privileges, enacted corporation laws of extraordinary latitude; and the holding company continued a favorite expedient in circles of high finance until the decision in the Northern Securities case ${ }^{12}$ swept away the foundation upon which the whole structure was based.

Means of Relief Indicated.-At a time when this corporate expedient flourished, its harmful nature was discussed and its decline and fall predicted:

"Regarding the form of the relief against the situation, it is probable that it will appear either by way of legislation confirmatory of constitutional provisions and carrying into effect their intent by specific delimitation of the right of the majority to convey and vest in a 'holding company' the corporate control; or that courts of equity will exercise their inherent powers in the premises, and cure this species of injustice by restrictive decisions aimed at the evil [control of voting power] alluded to above. Certainly relief will appear in one or the other of these forms, and it does not particularly concern the public by which road it arrives, so long as the cure is speedy and permanent." 18

12 Northern Securities Co. v. U. S., 193 U. S. 197, 24 Sup. Ct. 436, 48 L. Ed. 679 affirming 120 Fed. 721.

13 Harvey, Handbook of Corporation Law, p. 468. 


\section{Public Interests Advanced by Supplemental Anti-Trust} Laws.-The cure, even if it has not been speedy, promises to be permanent. The visitorial powers conferred upon the Federal Trade Commission by the creating statute, together with the further provisions prohibiting stock ownership in competing corporations with or without the employment of the holding company as an intermediary-when considered in connection with the interdiction of interlocking directorates and the other restraining features of the Clayton Law-foretell the complete demolition of the holding company device. This new standard of corporate methods and management does not contravene but on the contrary assists in rendering operative the principle of business dealing laid down by the Supreme Court in the Standard Oil Case"14: "The honest exertion of one's right to contract for his own benefit, unaccompanied by a wrongful motive to injure others."

Code of Business Procedure Assured.-In a quarter that so deeply concerns public interests it is well the supreme legislative authority has exercised its power by making a beginning in the establishment of a code of procedure for business dealings. It is now possible for the nation to adjust its commercial energies to conform with the system comprised within this new code of business procedure and to proceed along conservative and permanent lines, when once that system has been understood and digested by the public mind.

"Equality under the law" is a motto that inspires public confidence and in the end is productive of permanent benefits to every legitimate interest. The Anti-trust laws-altered, modified and to a certain degree softened and rendered more workable by recent enactments-should and we believe will bring about that result. Measures intended to prevent abuses of control, joined with similar restraining influences in other departments of corporate and business affairs, must establish conditions that will conduce to conservative growth, and this in turn should win the approval and confidence of investors,- - a situation which gives promise of general progress to a degree that unfair practices could never accomplish.

I4 Standard Oil Co. v. United States, 22I U. S. I; 3I Sup. Ct. 502; 55 L. Ed. 619; 34 L. R. A. (N. S.) 834 . 


\title{
FEDERAL TRADE COMMISSION.'
}

JOSEPH E. DAVIES, Chairman

\author{
EDWARD N. HURLEY, Vice Chairman \\ WILLIAM J. HARRIS \\ WILI, H. PARRY \\ GEORGE RUBLEE
}

Frank JoNes,

Acting Secretary.

\section{RULES OF PRACTICE BEFORE THE COMMISSION.}

\section{SESSIONS.}

The principal office of the commission at Washington, D. C., is open each business day from $9 \mathrm{a} . \mathrm{m}$. to $4: 30 \mathrm{p} . \mathrm{m}$. The commission may meet and exercise all its powers at any other place, and may, by one or more of its members, or by such examiners as it may designate, prosecute any inquiry necessary to its duties in any part of the United States.

Sessions of the commission for hearing contested proceedings will be held as ordered by the commission.

Sessions of the commission for the purpose of making orders and for the transaction of other business, unless otherwise ordered, will be held at the office of the commission at Washington, D. C., on each business day at $10: 30 \mathrm{a} . \mathrm{m}$. Three members of the commission shall constitute a quorum for the transaction of business.

All orders of the commission shall be signed by the secretary.

\section{COMPLAINTS.}

Any person, partnership, corporation, or association may apply to the commission to institute a proceeding in respect to any violation of law over which the commission has jurisdiction.

Such application shall be in writing, signed by or in behalf of the applicant, and shall contain a short and simple statement of the facts constituting the alleged violation of law and the name and address of the applicant and of the party complained of.

The commission shall investigate the matters complained of in such application, and if upon investigation it shall appear to the commission that there is a violation of law over which the commission has jurisdiction, the commission shall issue and serve upon the party complained of a complaint stating its charges and containing a notice of a hearing upon a day and at a place therein fixed at least forty days after the service of said complaint.

\section{ANSWERS.}

Within thirty days from the service of the complaint, unless such time be extended by order of the commission, the defendant shall file with the commission an answer to the complaint. Such answer shall contain a short and simple statement of the facts which constitute the ground of defense. It shall specifically admit or deny or explain each of the facts alleged in the complaint, unless the defendant is without knowledge, in which case he shall so state, such statement operating as a denial.

I. For membership of the other statutory bodies having jurisdictional powers under the provisions of the Clayton Law, viz., the Interstate Commerce Commission and the Federal Reserve Board,--see page 235. 
Answers in typewriting must be on one side of the paper only, on paper not more than $8 \mathrm{~s} / 2$ inches wide and not more than $I \mathrm{I}$ inches long, and weighing not less than 16 pounds to the ream, folio base, 17 by 22 inches, with left-hand margin not less than $1 \mathrm{r} / 2$ inches wide, or they may be printed in Io or 12 point type on good unglazed paper 8 inches wide by IO $1 / 2$ inches long, with inside margins not less than $I$ inch wide.

\section{SERVICE.}

Complaints, orders, and other processes of the commission may be served by anyone duly authorized by the commission, either $(a)$ by delivering a copy thereof to the person to be served, or to a member of the partnership to be served, or to the president, secretary, or other executive officer, or a director, of the corporation or association to be served; or (b) by leaving a copy thereof at the principal office or place of business of such person, partnership, corporation, or association; or $(c)$ by registering and mailing a copy thereof addressed to such person, partnership, corporation, or association at his or its principal office or place of business. The verified return by the person so serving said complaint, order or other process, setting forth the manner of said service, shall be proof of the same, and the return post-office receipt for said complaint, order, or other process, registered and mailed as aforesaid, shall be proof of the service of the same.

\section{INTERVENTION.}

Any person, partnership, corporation, or association desiring to intervene in a contested proceeding shall make application in writing, setting out the grounds on which he or it claims to be interested. The commission may, by order, permit intervention by counsel or in person to such extent and upon such terms as it shall deem just.

Applications to intervene must be on one side of the paper only, on paper not more than $8 \mathrm{r} / 2$ inches wide and not more than II inches long, and weighing not less than 16 pounds to the ream, folio base, I7 by 22 inches, with left-hand margin not less than $1 \mathrm{~T} / 2$ inches wide, or they may be printed in Io or 12 point type on good unglazed paper 8 inches wide by $10 \mathrm{t} / 2$ inches long, with inside margins not less than $I$ incin wide.

\section{CONTINUANCES AND EXTENSIONS OF TIME.}

Continuances and extensions of time will be granted at the discretion of the commission.

\section{WITNESSES AND SUBPCENAS.}

Witnesses shall be examined orally, except that for good and exceptional cause for departing from the general rule the commission may permit their testimony to be taken by deposition.

Subpcenas requiring the attendance of witnesses from any place in the United States at any designated place of hearing may be issued by any member of the commission.

Subpœnas for the production of documentary evidence (unless directed to issue by a commissioner upon his own motion) will issue only upon application in writing, which must be verified and must specify, as near as may be, the documents desired and the facts to be proved by them.

Witnesses summoned before the commission shall be paid the same fees and mileage that are paid witnesses in the courts of the United States, and witnesses whose depositions are taken, and the persons taking the same, shall severally be entitled to the same fees as are paid for like services in the courts of the United States.

\section{DEPOSITIONS IN CONTESTED PROCEEDINGS.}

The commission may order testimony to be taken by deposition in a contested proceeding. 
Depositions may be taken before any person designated by the commission and having power to administer oaths.

Any party desiring to take the deposition of a witness shall make application in writing, setting out the reasons why such deposition should be taken, and stating the time when, the place where, and the name and post-office address of the person before whom it is desired the deposition be taken, the name and post-office address of the witness, and the subject matter or matters concerning which the witness is expected to testify. If good cause be shown, the commission will make and serve upon the parties, or their attorneys, an order wherein the commission shall name the witness whose deposition is to be taken and specify the time when, the place where, and the person before whom the witness is to testify, but such time and place, and the person before whom the deposition is to be taken, so specified in the commission's order, may or may not be the same as those named in said application to the commission.

The testimony of the witness shall be reduced to writing by the officer before whom the deposition is taken, or under his direction, after which the deposition shall be subscribed by the witness and certified in usual form by the officer. After the deposition has been so certified it shall, together with a copy thereof made by such officer or under his direction, be forwarded by such officer under seal in an envelope addressed to the commission at its office in Washington, D. C. Upon receipt of the deposition and copy the commission shall file in the record in said proceedings such deposition and forward the copy to the defendant or the defendant's attorney.

Such depositions shall be typewritten on one side only of the paper, which shall be not more than $81 / 2$ inches wide and not more than II inches long and weighing not less than 16 pounds to the ream, folio base, 17 by 22 inches, with left-hand margin not less than $11 / 2$ inches wide.

No deposition shall be taken except after at least six days' notice to the parties, and where the deposition is taken in a foreign country such notice shall be at least fifteen days.

No deposition shall be taken either before the proceeding is at issue, or, unless under special circumstances and for good cause shown, within ten days prior to the date of the hearing thereof assigned by the commission, and where the deposition is taken in a foreign country it shall not be taken after thirty days prior to such date of hearing.

\section{DOCUMENTARY EVIDENCE.}

Where relevant and material matter offered in evidence is embraced in a document containing other matter not material or relevant and not intended to be put in evidence, such document will not be filed, but a copy only of such relevant and material matter shall be filed.

\section{BRIEFS.}

Unless otherwise ordered, briefs may be filed at the close of the testimony in each contested proceeding. The presiding commissioner or examiner shall fix the time within which briefs shall be filed and service thereof shall be made upon the adverse parties.

All briefs must be filed with the secretary and be accompanied by proof of service upon the adverse parties. Fifteen copies of each brief shall be furnished for the use of the commission, unless otherwise ordered.

Application for extension of time in which to file any brief shall be by petition in writing, stating the facts upon which the application rests, which must be filed with the commission at least five days before the time for filing the brief.

Every brief shall contain, in the order here stated-

(I) A concise abstract, or statement of the case.

(2) A brief of the argument, exhibiting a clear statement of the points of fact or law to be discussed, with the reference to the pages of the record and the authorities relied upon in suppose of each point. 
Every brief of more than ten pages shall contain on its top fly leaves a subject index with page references, the subject indexed to be supplemented by a list of all cases referred to, alphabetically arranged, together with references to pages where the cases are cited.

Briefs must be printed in 10 or 12 point type on good unglazed paper 8 inches by $101 / 2$ inches, with inside margins not less than $I$ inch wide, and with double-leaded text and single leaded citations.

Oral arguments will be had only as ordered by the commission.

\section{ADDRESS OF THE COMMISSION.}

All communications to the commission must be addressed to Federal Trade Commission, Washington, D. C., unless otherwise specifically directed.

\section{MEMBERSHIP OF OTHER BODIES HAVING JURIS- DICTION IN CERTAIN CASES UNDER THE PROVISIONS OF THE CLAYTON LAW.}

\section{INTERSTATE COMMERCE COMMISSION.1}

C. C. McChord, Chairman.

Commissioners.

JudSON C. CLEMENTS.

Ejgar E. Clark.

JAMES S. HARLAN.

Balthasar H. MEYER.

HenRy C. HaLL.

Winthrop M. Daniels.

GEORGE B. MCGinty, Secretary.

\section{FEDERAL RESERVE BOARD.}

Charles S. Hamlin, Governor.

Frederick A. DeLANo, Vice Governor.

Paul M. Warburg.

W. P. G. Harding.

AdolpH C. MiLLER.

H. PARKER WiLIIS, Secretary.

I For membership of Commission, as originally constituted, see page 352. 


\section{FORMS. ${ }^{1}$}

These forms are intended as precedents in cases where they are applicable. Forms Nos. I-8 inclusive may be altered to suit the circumstances of the individual case; the formalities prescribed in No. 9 demand strict compliance.

No. I.

Petition for IsSUANCE OF COMPLAint. ${ }^{2}$

FEDERAL TRADE COMMISSION.

$\left.\begin{array}{l}\text { In the MatTer of the } \\ \text { Application of A. B. }{ }^{3}\end{array}\right\}$ Petition.

The petition of the above-named applicant respectfully shows:

I. That (here state name, occupation, and address of petitioner.)

II. That (the person, partnership, corporation, or association complained of) has engaged in unlawful practices in a matter whereof the Federal Trade Commission has jurisdiction, to wit: (set forth here the section or general provision which petitioner believes has been violated; also a short and simple statement of the facts constituting the alleged violation of law, with the name and address of the party complained of. Continue numbering each succeeding paragraph-if there are others-as in Nos. I and II.)

Wherefore the petitioner prays that the defendant may be served with a complaint and may be required to answer the charges herein, and that after due hearing and investigation an order may be made commanding the defendant to cease and desist from said violations of the laws within the jurisdiction of this commission, and for such other and further order as the commission may deem necessary in the premises.

A. B.

(Signature by or in behalf of petitioner.)

I Form is omitted where the practice requires that the complaint or other process shall be prepared and served by the commission.

2 See Section 5 of Federal Trade Commission Act and Section II of Clayton Bill; also Rule II of Rules of Practice. Notice of time and place of hearing -at least forty days after date of service-will be contained in complaint, when issued.

3 Name of person, partnership, corporation, or association. 
No. 2.

ANSWER TO COMPLAINT."

FEDERAL TRADE COMMISSION.

Fedïral Trade Commission

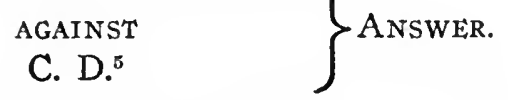

The above-named defendant for answer to the complaint in this proceeding, respectfully states-

I. That (here set forth a short and simple statement of the facts which constitute the ground of defense. Each fact alleged in the complaint must be specifically denied or explained, unless the defendant is without knowledge, when he should so state, and such averment will operate as a denial. Continue numbering each succeeding paragraph.)

Wherefore the defendant prays that the complaint in this proceeding be dismissed.

B. C.

(Signature by or in behalf of defendant.)

No. 3 .

Proof OF SERvice. 6

FEDERAL TRADE COMMISSION.

Federal, TRADE Commission AGAINST

C. D. AFFIDAVIT OF SERVICE.

$\left.\begin{array}{c}\text { STATE OF } \ldots \ldots \ldots \ldots \ldots \\ \text { COUNTY OF } \ldots \ldots \ldots \ldots\end{array}\right\}$ ss:

being duly sworn, says:

That he is more than .... years of age, and resides at $\ldots . \ldots \ldots \ldots . . .$. and is a person duly authorized by said commission to serve complaints, orders and other processes; that on the $\ldots \ldots$ day $\ldots \ldots \ldots \ldots$. r $91 .$. , at $\ldots \ldots \ldots \ldots \ldots \ldots$,

4 Answer must be filed with the commission within thirty days from service of complaint, unless time is extended. For general provisions, see Section 5 of Federal Trade Commission Act and Section II of Clayton Bill. For practice and requirements as to size of paper, etc., see Rule III.

5 Name of person, partnership, corporation, or association.

6 Requirements of proof of service are contained in Section 5 of Federal Trade Commission Act and Section II of Clayton Bill. These regulations are re-stated in Rule IV. 
he duly served the annexed (complaint or other process, specifying said paper) upon .................. by (here specify one of the three methods of service permitted by Rule IV; if service is by mail, attach return post-office receipt.) ${ }^{7}$

That he knows the person so served to be (the complainant, defendant, member of partnership, officer of corporation,-or otherwise describe person served, as occasion requires).

Sworn to before me

this.... day of ......., I9r...

(Signature of person making service.)

(Official signature of person qualified

to administer oath, with seal.)

No. 4 .

Petition for Permission to INTERvene. 8

FEDERAL TRADE COMMISSION.

Federal Trade Commission AGAINST

C. D.

\} PETITION.

The petition of $\ldots \ldots \ldots \ldots \ldots$....... respectfully shows-

I. That (set forth name and address of petitioner).

II. That there are good and substantial reasons why the abovenamed petitioner should be permitted to intervene in this proceeding, as will appear from the following facts: (Here state interest which petitioner has in the controversy, with grounds for permitting the incoming party to join in the prosecution or defense. Each succeeding paragraph should be numbered consecutively.)

Wherefore the petitioner prays that he may be permitted to intervene in the above-entitled proceeding.

\section{(Signature by or in behalf of petitioner.)}

7 The return post-office receipt is probably proof of service, without affidavit.

8 Permission to intervene and extent to which that privilege will be granted, with the terms, are discretionary matters. See Section 5 of Federal Trade Commission Act, and Section II of Clayton Bill,-also Rule V. Said rule also regulates size of paper, etc., in connection with the application. 
No. 5 .

SubPGNA. ${ }^{\circ}$

FEDERAL TRADE COMMISSION.

To

You are hereby required to appear before...$\ldots \ldots \ldots \ldots$. in the matter now pending before the Federal Trade Commission, upon the complaint of Federal Trade Commission against ...... $\ldots \ldots \ldots \ldots$, as a witness on the part of $\ldots \ldots \ldots \ldots \ldots$. on the ..... day of $\ldots . \ldots$. , I9r.., at ... o'clock in the .....noon of said day, at ...............

And for failure to attend and testify as hereby required you will be subject to such proceedings in a District Court of the United States and to such fines and penalties as are set forth in Sections 9 and Io of the Federal Trade Commission Act, to which reference is hereby made.

Dated ...............

(Seal.)

Commissioner...

No. 6.

Subpefna Duces Técum. ${ }^{10}$

FEDERAL TRADE COMMISSION.

To

You are hereby required to appear before in the matter now pending before the Federal Trade Commission upon the complaint of Federal Trade Commission against ......

9 Regulations are prescribed in Rule VII, in conformity with Sections 9 and 10 of the Federal Trade Commission Act. Fees and mileage are the same as are paid in United States courts, viz: \$1.50 for each day of attendance and five cents for each mile of the combined distance traveled going to and returning from the place of hearing. For special provisions operative in criminal and civil proceedings instituted by the United States, see Section 13 of Commission Act; for immunity provisions, see Section 9 of that statute.

Io Subponas duces tecum will be issued only when supported by a verified application, setting forth as near as may be the documents desired and the facts to be proved by them. Such subpœnas, however, may be issued by a commissioner upon his own motion. For practice generally, see Rule VII; also, matters contained in note 9, ante. 
, as a witness on the part of $\ldots \ldots \ldots \ldots \ldots \ldots$, on the... day of...$\ldots$... I9I.., at ..... o'clock in the .....noon of said day, at .............. and to bring with you then and there .............. (here designate the books, contracts or documents required to be produced, describing same with reasonable particularity.)

And for failure to attend and testify and produce the said documentary evidence you will be subject to such proceedings in a District Court of the United States and to such fines and penalties as are set forth in Sections 9 and ro of the Federal Trade Commission Act, to which reference is hereby made.

Dated ................

(Seal.)

Commissioner.

No. 7 .

Verified Application for Subpeina Duces Técum. ${ }^{11}$ FEDERAL TRADE COMMISSION.

Federal, Trade Commission AGAINST

C. D. \} VERIFIED APPLICATION.

$\left.\begin{array}{c}\text { STATE OF } \ldots \ldots \ldots \ldots \ldots \ldots \\ \text { COUNTY OF } \ldots \ldots \ldots \ldots\end{array}\right\}$ ss:

$\ldots \ldots \ldots \ldots$ being duly sworn, says:

That he is the (designate relationship to proceeding, as complainant, defendant, attorney, etc.) ; that certain documentary evidence is required in the orderly trial of this proceeding, on the part of the..$\ldots \ldots \ldots \ldots$, and that the undersigned applicant files this verified application in conformity with Rule VII of the Rules of Practice, to secure from the commission the issuance of its subpœna duces tecum to compel the production thereof upon the hearings herein; that the production of the following documents is required ............ (here specify with reasonable particularity as near as may be the documents in question, so that they may be identified and produced; care should be taken not to make a general request for all documents and papers, as such requirement might constitute an "unreasonable search", in violation of the Fourth Amendment of the Constitution); that the

II Required by Rule VII. See notes 9 and 10, ante. 
production of the said documents is necessary to the undersigned applicant for the purpose of establishing the following facts ............ (here set forth at sufficient length the facts to be proved by said documentary evidence).

Wherefore your applicant prays that a subpœna duces tecum may be duly issued on behalf of the ........... herein, directed to the said ............, requiring him to attend, testify and produce the documentary evidence hereinbefore specified.

Sworn to before me this.... day of ....., r 9 r. .

(Applicant signs here.)

(Official signature of person authorized to adininister oath, with seal.)

No. 8.

Application for Order Requiring Testimony to Be Taken BY DEPOSITION. ${ }^{12}$

FEDERAL TRADE COMMISSION.

Federal, Trade Commission

AGAINST

C. D.

Application to Take Testimo

The undersigned applicant hereby requests the commission to issue its order requiring testimony in behalf of $\ldots \ldots \ldots \ldots$. to be taken by deposition in this proceeding for the following reasons :

The witness, .............., residing at .........., has information proving (or has in his possession or under his

I2 Rule VIII follows Section 9 of the Federal Trade Commission Act in its requirements as to taking testimony by deposition. While no definite authority is given for specifically framing the questions to be propounded to the witness, it is probable the deposition could be taken in that form. Section 9 regulates the fees of the person designated to take testimony, and of the witness. Pursuant to Rule VIII the commission-if good cause be shown-prepares and serves upon the parties or their attorneys an order granting the request; but the person designated to take the testimony and the time and place of the examination may or may not be the same as are specified in the application. Size of typewritten sheet, etc., are also prescribed in said Rule. 
control documentary evidence tending to show) the following facts: (here set forth the facts in question).

That the evidence so sought to be taken is relevant and important to .......... (the complainant or defendant) upon the issues herein.

The undersigned applicant desires to take the testimony of said witness, ............... whose post-office address is .... ......... before ..............., a ............. (insert title of officer, magistrate or other person empowered to administer oaths), whose post-office address is ............. at ............, on the .... day of ........ I9I.., as a witness for the above-named (complainant or defendant, as the case may $b e$ ), and requests the commission to issue an order to the above effect.

Dated ..........., r 9 I..

(Applicant signs here.)

No. 9.

Directions for Taking Testimony by Deposition in a ConTESTED PROCEEDING. ${ }^{13}$

I. The general style or title of the depositions should be drawn up in substantially the following manner:

"Deposition of witnesses, produced, sworn or (affirmed), and examined the .... day of ......... in the year one thousand nine hundred and ........., at ..........., under and by virtue of an order issued by the Federal Trade Commission in a certain contested proceeding therein depending and at issue between Federal Trade Commission, complainant, and ......... defendant, as follows:

A. B. of (insert his place of residence and occupation), aged

13 The examination is conducted under the authority of an order prepared, issued and served by the commission. The practice is specified in Section 9 of the Trade Commission Act and in Rule VIII. These proceedings seem to contemplate an open commission, but there is no express prohibition of the method of proceeding by interrogatories and cross-interrogatories. Rule VIII also regulates size of paper, etc., and the notice of hearing required. Rule VII fixes the fees of witnesses, and compensation of officer taking deposition, see note 9 , page 239, ante.

It is prescribed in Rule VIII that "the deposition shall be $*^{*} *$ certified in the usual form"; and the examining party should insist upon strict regularity in this and every other essential particular. 
.... years and upwards, being duly and publicly sworn (or affirmed) pursuant to the terms of said order, and examined on the part of the ........... doth depose and say as follows:

[If the deposition is in the form of interrogatories and crossinterrogatories, proceed, First, To the first interrogatory, he saith, etc. (Insert the witness's answer.) Second, To the second interrogatory, he saith, etc., and so on throughout. If he cannot answer, let him say that he knoweth not. If there be any cross-interrogatories, the witness will go on thus: First, To the first cross-interrogatory, he saith, etc., and so on throughout.]

At the termination of the examination, the officer before whom one or more depositions are taken, must subscribe, and annex to each deposition, a certificate, substantially in the following form, the blanks being properly filled up:

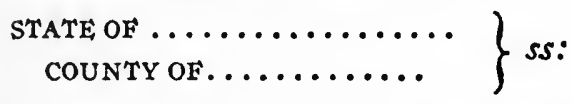

"I, .............., do certify that .............., a witness named in the annexed order to take testimony in this contested proceeding, personally appeared before me, the person designated therein to take said testimony, on the...... day of $\ldots \ldots \ldots$, at $\ldots \ldots$ o'clock in the .....noon, ............ at the..$\ldots \ldots \ldots$, in the State of...$\ldots \ldots \ldots$, and after being sworn (or 'affirmed,' as the case may be), to testify the truth, the whole truth, and nothing but the truth, did depose to the matters contained in the foregoing deposition, and did, in my presence, subscribe the same, and indorse the exhibits annexed thereto. And I further certify that I have subscribed my name to each half sheet thereof, and to each exhibit. And I further certify that ............... appeared in behalf of the .... $\ldots \ldots \ldots$ and that $\ldots \ldots \ldots \ldots \ldots$ appeared in behalf of the

(Official Signature.)

The officer should make return on the back of the order by endorsement, thus:

"The execution of this order appears in certain schedules hereto annexed.

(Official Signature.)

II. If any exhibit is produced and proved, the exhibit, or if 
the witness or other person having it in his custody does not surrender it, a copy thereof should be annexed to the deposition to which it relates, and be subscribed by the witness proving it, and be endorsed by the officer taking the deposition, in substantially the following manner:

"At the execution of an order to take testimony by deposition in a contested proceeding before the Federal Trade Commission, between Federal Trade Commission, complainant, and ........ ......, defendant, this exhibit numbered .... and hereto annexed, was produced and shown to (insert witness name) and by him deposed unto, and subscribed by him at the time of his examination before the undersigned.

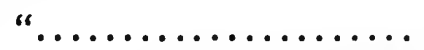

(Official Signature.)

III. The officer appointed to take the testimony by deposition should sign his name to each half sheet of the depositions and to each exhibit.

IV. If an interpreter is employed, the officer before whom the deposition is taken should administer an oath in substantially the following form, and certify thereto:

"You do solemnly swear, or affirm, that you will truly and faithfully interpret the oath to be administered unto and the questions about to be directed to............... a witness now to be examined, out of the English language into the ........ language, and that you will truly and faithfully interpret the answers of the said ................ thereto, out of the $\ldots \ldots$. language into the English language."

The deposition should be subscribed by the interpreter as well as by witness, and certified by the officer taking the depositions as in No. I hereof.

V. All the depositions and exhibits must be annexed to the order for taking the deposition, or to a certified copy thereof, and then the order (the directions, if any, together with the interrogatories and cross-interrogatories, if the testimony is taken by that method), the depositions, and exhibits, should be folded into a packet and bound with tape. The officer taking the deposition should then set his seal at the several meetings or crossings of the tape, endorse his name on the outside, and direct it thus:

To the Federal Trade Commission, Washington, D. C. 
(If taken in a foreign country, the letters U. S. A. should be added to the direction.)

VI. When the deposition has been thus taken, made up and directed, it should be returned in the manner specified in the order, if there be any such requirement.

VII. In case of returning the deposition by mail, it should be deposited by the officer taking same, in the nearest post-office, with the following endorsement by him thereon:

"Deposited in the post-office at ............. this ..... day of ........., igr.., by me.

\section{(Official Signature.)}

In case of returning the deposition by a vessel, it should be deposited by the said officer in the letter bag of such vessel, with the following endorsement by him thereon:

"Deposited in the letter bag of the ..........., now lying at .........., and bound for the port of $\ldots \ldots \ldots \ldots$, this $\ldots$... day of $\ldots \ldots \ldots$. I $191 .$. , by me.

\section{(Official Signature.)}

VIII. It is essential that officers appointed to take testimony by deposition should exercise extreme care and attention to accurately carry out the foregoing formalities, as a variance therefrom may vitiate the execution of the order. 


\section{APPENDIX A.}

\section{TEXT OF THE FEDERAL TRADE COMMISSION ACT.}

[PUBlic-No. 203-63D CoNGREss.]

[H. R. I56r3.]

An act to create a Federal Trade Commission, to define its powers and duties, and for other purposes.

\section{FEDERAL TRADE COMMISSION CREATED.}

SEC. I. Be it enacted by the Senate and House of Representatives of the United States of America in Congress assembled, That a Commission is hereby created and established, to be known as the Federal Trade Commission (hereinafter referred to as the Commission), which shall be composed of five commissioners, who shall be appointed by the President, by and with the advice and consent of the Senate. Not more than three of the commissioners shall be members of the same political party. The first commissioners appointed shall continue in office for terms of three, four, five, six, and seven years, respectively, from the date of the taking effect of this act, the term of each to be designated by the President, but their successors shall be appointed for terms of seven years, except that any person chosen to fill a vacancy shall be appointed only for the unexpired term of the commissioner whom he shall succeed. The Commission shall choose a chairman from its own membership. No commissioner shall engage in any other business, vocation, or employment. Any commissioner may be removed by the President for inefficiency, neglect of duty, or malfeasance in office. A vacancy in the Commission shall not impair the right of the remaining commissioners to exercise all the powers of the Commission.

The Commission shall have an official seal, which shall be judicially noticed.

\section{SALARIES-SECRETARY AND EMPLOYEES.}

SEc. 2. That each commissioner shall receive a salary of $\$ 10,000$ a year, payable in the same manner as the salaries of the 
judges of the courts of the United States. The Commission shall appoint a secretary, who shall receive a salary of $\$ 5,000$ a year, payable in like manner, and it shall have authority to employ and fix the compensation of such attorneys, special experts, examiners, clerks and other employees as it may from time to time find necessary for the proper performance of its duties and as may be from time to time appropriated for by Congress.

\section{APPOINTMENTS UNDER CIVIL SERVICE AND EXCEP. TIONS.}

With the exception of the secretary, a clerk to each Commissioner, the attorneys, and such special experts and examiners as the Commission may from time to time find necessary for the conduct of its work, all employees of the Commission shall be a part of the classified civil service, and shall enter the service under such rules and regulations as may be prescribed by the Commission and by the Civil Service Commission.

All of the expenses of the Commission, including all necessary expenses for transportation incurred by the commissioners or by their employees under their orders, in making any investigation, or upon official business in any other places than in the city of Washington, shall be allowed and paid on the presentation of itemized vouchers therefor approved by the Commission.

Until otherwise provided by law, the Commission may rent suitable offices for its use.

The auditor for the State and other departments shall receive and examine all accounts of expenditures of the Commission.

\section{BUREAU OF CORPORATIONS MERGED IN COMMIS- SION.}

SEC. 3. That upon the organization of the Commission and election of its chairman, the Bureau of Corporations and the offices of Commissioner and Deputy Commissioner of Corporations shall cease to exist; and all pending investigations and proceedings of the Bureau of Corporations shall be continued by the Commission.

All clerks and employees of the said bureau shall be transferred to and become clerks and employees of the Commission at their present grades and salaries. All records, papers, and property of the said bureau shall become records, papers and prop- 
erty of the Commission, and all unexpended funds and appropriations for the use and maintenance of the said bureau, including any allotment already made to it by the Secretary of Commerce from the contingent appropriation for the Department of Commerce for the fiscal year nineteen hundred and fifteen, or from the departmental printing fund for the fiscal year nineteen hundred and fifteen, shall become funds and appropriations available to be expended by the Commission in the exercise of the powers, authority, and duties conferred on it by this act.

\section{OFFICE IN WASHINGTON-MAY ACT ELSEWHERE.}

The principal office of the Commission shall be in the city of Washington, but it may meet and exercise all its powers at any other place. The Commission may, by one or more of its members, or by such examiners as it may designate, prosecute any inquiry necessary to its duties in any part of the United States.

\section{COMMERCE DEFINED.}

SEC. 4. That the words defined in this section shall have the following meaning when found in this act, to-wit:

"Commerce" means commerce among the several States or with foreign nations, or in any Territory of the United States or in the District of Columbia, or between any such Territory and another or between any such Territory and any State or foreign nation, or between the District of Columbia and any State or Territory or foreign nation.

\section{CORPORATION DEFINED.}

"Corporation" means any company or association incorporated or unincorporated, which is organized to carry on business for profit and has shares of capital or capital stock, and any company or association, incorporated or unincorporated, without shares of capital or capital stock, except partnerships, which is organized to carry on business for its own profit or that of its members.

\section{DOCUMENTARY EVIDENCE DEFINED.}

"Documentary evidence" means all documents, papers, and correspondence in existence at and after the passage of this act. 


\section{ACTS TO REGULATE COMMERCE DEFINED.}

"Acts to regulate commerce" means the act entitled "An act to regulate commerce," approved February fourteenth, eighteen hundred and eighty-seven, and all acts amendatory thereof and supplementary thereto.

\section{ANTI-TRUST ACTS DEFINED.}

"Anti-trust acts" means the act entitled "An act to protect trade and commerce against unlawful restraints and monopolies," approved July second, eighteen hundred and ninety; also the sections seventy-three to seventy-seven, inclusive, of an act entitled "An act to reduce taxation, to provide revenue for the government, and for other purposes," approved August twenty-seventh, eighteen hundred and ninety-four; and also the act entitled "An act to amend sections seventy-three and seventy-six of the act of August twenty-seventh, eighteen hundred and ninety-four, entitled 'An act to reduce taxation, to provide revenue for the government, and for other purposes," " approved February twelfth, nineteen hundred and thirteen.

UNFAIR METHODS OF COMPETITION ARE UNLAWFUL.

SEC. 5. That unfair methods of competition in commerce are hereby declared unlawful.

\section{COMMISSION EMPOWERED TO PREVENT USE OF UN- FAIR METHODS.}

The Commission is hereby empowered and directed to prevent persons, partnerships, or corporations, except banks, ${ }^{1}$ and common carriers subject to the acts to regulate commerce, from using unfair methods of competition in commerce.

I The insertion of a comma after the word "banks" is a clerical error. If the intent of the law were solely determined by punctuation, the exempting clause would not include common carriers, and they would thus be left subject to the jurisdiction of the Federal Trade Commission. This is controverted by the context and by the general purpose and provisions of the statute.

Attention was drawn to the error previous to the passage of the bill, but it remains uncorrected. 


\section{PROCEDURE BEFORE COMMISSION AND IN COURT TO ENFORCE COMMISSION'S ORDER.}

Whenever the Commission shall have reason to believe that any such person, partnership, or corporation has been or is using any unfair method of competition in commerce, and if it shall appear to the Commission that a proceeding by it in respect thereof would be to the interest of the public, it shall issue and serve upon such person, partnership, or corporation a complaint stating its charges in that respect, and containing a notice of a hearing upon a day and at a place therein fixed at least thirty days after the service of said complaint. The person, partnership, or corporation so complained of shall have the right to appear at the place and time so fixed and show cause why an order should not be entered by the Commission requiring such person, partnership, or corporation to cease and desist from the violation of the law so charged in said complaint. Any person; partnership, or corporation may make application, and upon good cause shown may be allowed by the Commission, to intervene and appear in said proceeding by counsel or in person. The testimony in any such proceeding shall be reduced to writing and filed in the office of the Commission. If upon such hearing the Commission shall be of the opinion that the method of competition in question is prohibited by this act, it shall make a report in writing in which it shall state its findings as to the facts, and shall issue and cause to be served on such person, partnership, or corporation an order requiring such person, partnership, or corporation to cease and desist from using such method of competition. Until a transcript of the record in such hearing shall have been filed in a circuit court of appeals of the United States, as hereinafter provided, the Commission may at any time, upon such notice and in such manner as it shall deem proper, modify or set aside, in whole or in part, any report or any order made or issued by it under this section.

If such person, partnership, or corporation fails or neglects to obey such order of the Commission while the same is in effect, the Commission may apply to the Circuit Court of Appeals of the United States, within any circuit where the method of competition in question was used or where such person, partnership, or corporation resides or carries on business, for the enforcement of its order, and shall certify and file with its application a transcript 
of the entire record in the proceeding, including all the testimony taken and the report and order of the Commission. Upon such filing of the application and transcript the court shall cause notice thereof to be served upon such person, partnership, or corporation and thereupon shall have jurisdiction of the proceeding and of the question determined therein, and shall have power to make and enter upon the pleadings, testimony, and proceedings set forth in such transcript a decree affirming, modifying, or setting aside the order of the Commission. The findings of the Commission as to the facts, if supported by testimony, shall be conclusive. If either party shall apply to the court for leave to adduce additional evidence, and shall show to the satisfaction of the court that such additional evidence is material and that there were reasonable grounds for the failure to adduce such evidence in the proceeding before the Commission, the court may order such additional evidence to be taken before the Commission and to be adduced upon the hearing in such manner and upon such terms and conditions as to the court may seem proper. The Commission may modify its findings as to the facts, or make new findings, by reason of the additional evidence so taken, and it shall file such modified or new findings, which, if supported by testimony, shall be conclusive, and its recommendation, if any, for the modification or setting aside of its original order, with the return of such additional evidence. The judgment and decree of the court shall be final, except that the same shall be subject to review by the Supreme Court upon certiorari as provided in section two hundred and forty of the Judicial Code.

\section{PROCEDURE IN COURT TO SET ASIDE COMMISSION'S ORDER.}

Any party required by such order of the Commission to cease and desist from using such method of competition may obtain a review of such order in said Circuit Court of Appeals by filing in the court a written petition praying that the order of the Commission be set aside. A copy of such petition shall be forthwith served upon the Commission, and thereupon the Commission forthwith shall certify and file in the court a transcript of the record as hereinbefore provided. Upon the filing of the transcript the court shall have the same jurisdiction to affirm, set aside, or modify the order of the Commission as in the case of an appli- 
cation by the Commission for the enforcement of its order, and the findings of the Commission as to the facts, if supported by testimony, shall in like manner be conclusive.

\section{CIRCUIT COURT OF APPEALS EXCLUSIVE JURISDIC- TION.}

The jurisdiction of the Circuit Court of Appeals of the United States to enforce, set aside, or modify orders of the Commission shall be exclusive.

EXPEDITION OF COURT PROCEEDINGS. NO ORDER OR JUDGMENT TO RELIEVE FROM LIABILITY.

Such proceedings in the Circuit Court of Appeals shall be given precedence over other cases pending therein, and shall be in every way expedited. No order of the Commission or judgment of the court to enforce the same shall in any wise relieve or absolve any person, partnership, or corporation from any liability under the Anti-trust acts.

\section{SERVICE OF PROCESS.}

Complaints, orders, and other processes of the Commission under this section may be served by anyone duly authorized by the Commission, either (a) by delivering a copy thereof to the person to be served, or to a member of the partnership to be served, or to the president, secretary, or other executive officer or a director of the corporation to be served; or (b) by leaving a copy thereof at the principal office or place of business of such person, partnership, or corporation; or (c) by registering and mailing a copy thereof addressed to such person, partnership, or corporation at his or its principal office or place of business. The verified return by the person so serving said complaint, order, or other process setting forth the manner of said service shall be proof of the same, and the return post office receipt for said complaint, order, or other process registered and mailed as aforesaid shall be proof of the service of the same.

GENERAL INVESTIGATING POWER OVER CORPORATIONS EXCEPT BANKS AND COMMON CARRIERS.

SEC. 6. That the Commission shall also have power-

(a) To gather and compile information concerning, and to investigate from time to time the organization, business, conduct, 
practices, and management of any corporation engaged in commerce, excepting banks and common carriers subject to the act to regulate commerce, and its relation to other corporations and to individuals, associations, and partnerships.

\section{POWER TO REQUIRE REPORTS.}

(b) To require, by general or special orders, corporations engaged in commerce, excepting banks, and common carriers subject to the act to regulate commerce, or any class of them, or any of them, respectively, to file with the Commission in such form as the Commission may prescribe annual or special, or both annual and special, reports or answers in writing to specific questions, furnishing to the Commission such information as it may require as to the organization, business, conduct, practices, management, and relation to other corporations, partnerships, and individuals of the respective corporations filing such reports or answers in writing. Such reports and answers shall be made under oath, or otherwise, as the Commission may prescribe, and shall be filed with the Commission within such reasonable period as the Commission may prescribe, unless additional time be granted in any case by the Commission.

\section{POWER TO INVESTIGATE CARRYING OUT OF ANTI- TRUST DECREES.}

(c) Whenever a final decree has been entered against any defendant corporation in any suit brought by the United States to prevent and restrain any violation of the Anti-trust acts, to make investigation, upon its own initiative, of the manner in which the decree has been or is being carried out, and upon the application of the Attorney General it shall be its duty to make such investigation. It shall transmit to the Attorney General a report embodying its findings and recommendations as a result of any such investigation, and the report shall be made public in the discretion of the Commission.

\section{INVESTIGATION OF VIOLATIONS OF ANTI-TRUST LAWS.}

(d) Upon the direction of the President or either House of Congress to investigate and report the facts relating to any alleged violations of the Anti-trust acts by any corporation. 
POWER TO RECOMMEND READJUSTMENT OF BUSINESS.

(e) Upon the application of the Attorney General to investigate and make recommendations for the readjustment of the business of any corporation alleged to be violating the Anti-trust acts in order that the corporation may thereafter maintain its organization, management, and conduct of business in accordance with law.

\section{POWER TO MAKE REPORTS.}

(f) To make public from time to time such portions of the information obtained by it hereunder, except trade secrets and names of customers, as it shall deem expedient in the public interest; and to make annual and special reports to the Congress and to submit therewith recommendations for additional legislation; and to provide for the publication of its reports and decisions in such form and manner as may be best adapted for public information and use.

\section{POWER TO CLASSIFY CORPORATIONS.}

(g) From time to time to classify corporations and to make rules and regulations for the purpose of carrying out the provisions of this act.

POWER TO INVESTIGATE FOREIGN TRADE CONDITIONS.

(h) To investigate, from time to time, trade conditions in and with foreign countries where associations, combinations, or practices of manufacturers, merchants, or traders, or other conditions, may affect the foreign trade of the United States, and to report to Congress thereon, with such recommendations as it deems advisable.

\section{COMMISSION TO ACT AS MASTER IN CHANCERY.}

SEC. 7. That in any suit in equity brought by or under the direction of the Attorney General as provided in the Anti-trust acts, the court may, upon the conclusion of the testimony therein, if it shall be then of opinion that the complainant is entitled to relief, refer said suit to the Commission, as a master in chancery, to ascer- 
tain and report an appropriate form of decree therein. The Commission shall proceed upon such notice to the parties and under such rules of procedure as the court may prescribe, and upon the coming in of such report such exceptions may be filed and such proceedings had in relation thereto as upon the report of a master in other equity causes, but the court may adopt or reject such report, in whole or in part, and enter such decree as the nature of the case may in its judgment require.

\section{GOVERNMENT RECORDS AVAILABLE TO COMMISSION.}

SEC. 8. That the several departments and bureaus of the government when directed by the President shall furnish the Commission, upon its request, all records, papers, and information in their possession relating to any corporation subject to any of the provisions of this act, and shall detail from time to time such officials and employees to the Commission as he may direct.

\section{COMMISSION TO HAVE ACCESS TO CORPORATE RECORDS.}

SEC. 9. That for the purposes of this act the Commission, or its duly authorized agent or agents, shall at all reasonable times have access to, for the purpose of examination, and the right to copy any documentary evidence of any corporation being investigated or proceeded against; and the Commission shall have power to require by subpœna the attendance and testimony of witnesses and the production of all such documentary evidence relating to any matter under investigation. Any member of the Commission may sign subpœnas, and members and examiners of the Commission may administer oaths and affirmations, examine witnesses, and receive evidence.

\section{COMMISSION MAY REQUIRE ATTENDANCE OF WIT- NESSES AND PRODUCTION OF DOCUMENTARY EVI- DENCE.}

Such attendance of witnesses, and the production of such documentary evidence, may be required from any place in the United States, at any designated place of hearing. And in case of disobedience to a subpœna the Commission may invoke the aid of any court of the United States in requiring the attendance and testimony of witnesses and the production of documentary evidence. 


\section{DISTRICT COURTS MAY ENFORCE ABOVE REQUIRE- MENTS.}

Any of the district courts of the United States within the jurisdiction of which such inquiry is carried on may, in case of contumacy or refusal to obey a subpœna issued to any corporation or other person, issue an order requiring such corporation or other person to appear before the Commission, or to produce documentary evidence if so ordered, or to give evidence touching the matter in question; and any failure to obey such order of the court may be punished by such court as a contempt thereof.

\section{MANDAMUS PROCEEDINGS AUTHORIZED.}

Upon the application of the Attorney General of the United States, at the request of the Commission, the district courts of the United States shall have jurisdiction to issue writs of mandamus commanding any person or corporation to comply with the provisions of this act or any order of the Commission made in pursuance thereof.

\section{TESTIMONY MAY BE TAKEN BY DEPOSITION.}

The Commission may order testimony to be taken by deposition in any proceeding or investigation pending under this act at any stage of such proceeding or investigation. Such depositions may be taken before any person designated by the Commission and having power to administer oaths. Such testimony shall be reduced to writing by the person taking the deposition, or under lis direction, and shall then be subscribed by the deponent. Any person may be compelled to appear and depose and to produce documentary evidence in the same manner as witnesses may be compelled to appear and testify and produce documentary evidence before the Commission as hereinbefore provided.

\section{WITNESS FEES.}

Witnesses summoned before the Commission shall be paid the same fees and mileage that are paid witnesses in the courts of the United States, and witnesses whose depositions are taken and the persons taking the same shall severally be entitled to the same fees as are paid for like services in the courts of the United States. 


\section{IMMUNITY.}

No person shall be excused from attending and testifying or from producing documentary evidence before the Commission or in obedience to the subpœna of the Commission on the ground or for the reason that the testimony or evidence, documentary or otherwise, required of him may tend to criminate him or subject him to a penalty or forfeiture. But no natural person shall be prosecuted or subjected to any penalty or forfeiture for or on account of any transaction, matter, or thing concerning which he may testify, or produce evidence, documentary or otherwise, before the Commission in obedience to a subpœna issued by it: Provided, That no natural person so testifying shall be exempt from prosecution and punishment for perjury committed in so testifying.

\section{FAILURE TO TESTIFY CRIMINAL OFFENCE.}

SEC. IO. That any person who shall neglect or refuse to attend and testify, or to answer any lawful inquiry, or to produce documentary evidence, if in his power to do so, in obedience to the subpœna or lawful requirement of the Commission, shall be guilty of an offence and upon conviction thereof by a court of competent jurisdiction shall be punished by a fine of not less than $\$ 1,000$ nor more than $\$ 5,000$, or by imprisonment for not more than one year, or by both such fine and imprisonment.

\section{FALSIFICATION, ETC., OF CORPORATE RECORDS A} CRIMINAL OFFENCE.

Any person who shall willfully make, or cause to be made, any false entry or statement of fact in any report required to be made under this act, or who shall willfully make, or cause to be made, any false entry in any account, record, or memorandum kept by any corporation subject to this act, or who shall willfully neglect or fail to make, or to cause to be made, full, true, and correct entries in such accounts, records, or memoranda of all facts, and transactions appertaining to the business of such corporation, or who shall willfully remove out of the jurisdiction of the United States, or willfully mutilate, alter, or by any other means falsify any documentary evidence of such corporation, or who shall willfully refuse to submit to the Commission or to any of its authorized agents, for the purpose of inspection and taking copies, any documentary evidence of such corporation in his possession or 
within his control, shall be deemed guilty of an offence against the United States, and shall be subject, upon conviction in any court of the United States of competent jurisdiction, to a fine of not less than $\$ 1,000$ nor more than $\$ 5,000$, or to imprisonment for a term of not more than three years, or to both such fine and imprisonment.

\section{PENALTY FOR FAILURE TO FILE REPORTS.}

If any corporation required by this act to file any annual or special report shall fail so to do within the time fixed by the Commission for filing the same, and such failure shall continue for thirty days after notice of such default, the corporation shall forfeit to the United States the sum of \$100 for each and every day of the continuance of such failure, which forfeiture shall be payable into the Treasury of the United States, and shall be recoverable in a civil suit in the name of the United States brought in the district where the corporation has its principal office or in any district in which it shall do business. It shall be the duty of the various district attorneys, under the direction of the Attorney General of the United States, to prosecute for the recovery of forfeitures. The costs and expenses of such prosecution shall be paid out of the appropriation for the expenses of the courts of the United States.

\section{UNAUTHORIZED PUBLICITY BY EMPLOYEE OF COM- MISSION AN OFFENCE.}

Any officer or employee of the Commission who shall make public any information obtained by the Commission without its authority, unless directed by a court, shall be deemed guilty of a misdemeanor, and, upon conviction thereof, shall be punished by a fine not exceeding $\$ 5,000$, or by imprisonment not exceeding one year, or by fine and imprisonment, in the discretion of the court.

\section{ANTI-TRUST ACTS AND ACTS TO REGULATE COM- MERCE NOT MODIFIED.}

SEC. II. Nothing contained in this act shall be construed to prevent or interfere with the enforcement of the provision of the Anti-trust acts or the acts to regulate commerce, nor shall anything contained in the act be construed to alter, modify, or repeal the said Anti-trust acts or the acts to regulate commerce or any part or parts theerof.

Approved, September 26, I9I4. 


\title{
APPENDIX B.
}

\section{TEXT OF THE CLAYTON LAW OR SUPPLEMENTAL ANTI-TRUST LAW.}

\author{
[Public-No. 212-63D Congress.] \\ [H. R. 15657.$]$
}

An act to supplement existing laws against unlawful restraints and monopolies, and for other purposes.

\section{ANTI-TRUST LAWS DEFINED.}

SEc. I. Be it enacted by the Senate and House of Representatives of the United States of America in Congress assembled, That "Anti-trust laws," as used herein, includes the act entitled "An act to protect trade and commerce against unlawful restraints and monopolies," approved July second, eighteen hundred and ninety; Sections seventy-three to seventy-seven, inclusive, of an act entitled "An act to reduce taxation, to provide revenue for the government, and for other purposes," of August twenty-seventh, eighteen hundred and ninety-four; an act entitled "An act to amend Sections seventy-three and seventy-six of the act of August twenty-seventh, eighteen hundred and ninetyfour, entitled 'An act to reduce taxation, to provide revenue for the government, and for other purposes," " approved February twelfth, nineteen hundred and thirteen; and also this act.

\section{COMMERCE DEFINED.}

"Commerce," as used herein, means trade or commerce among the several States and with foreign nations, or between the District of Columbia or any Territory of the United States and any State, Territory, or foreign nation, or between any insular possessions or other places under the jurisdiction of the United States, or between any such possession or place and any State or Territory of the United States or the District of Columbia or any foreign nation, or within the District of Columbia or any Territory or any insular possession or other place under the jurisdiction of the United States: Provided, That nothing in this act contained shall apply to the Philippine Islands. 


\section{PERSON DEFINED.}

The word "person" or "persons" wherever used in this act shall be deemed to include corporations and associations existing under or authorized by the laws of either the United States, the laws of any of the Territories, the laws of any State, or the laws of any foreign country.

\section{PRICE DISCRIMINATION.}

SEC. 2. That it shall be unlawful for any person engaged in commerce, in the course of such commerce, either directly or indirectly to discriminate in price between different purchasers of commodities, which commodities are sold for use, consumption, or resale within the United States or any Territory thereof or the District of Columbia or any insular possession or other place under the jurisdiction of the United States, where the effect of such discrimination may be to substantially lessen competition or tend to create a monopoly in any line of commerce: Provided, That nothing herein contained shall prevent discrimination in prices between purchasers of commodities on account of differences in the grade, quality, or quantity of the commodity sold, or that makes only due allowance for difference in the cost of selling or transportation, or discrimination in price in the same or different communities made in good faith to meet competition: And provided further, That nothing herein contained shall prevent persons engaged in selling goods, wares, or merchandise in commerce from selecting their own customersi in bona fide transactions and not in restraint of trade.

\section{TYING LEASES, SALES AND CONTRACTS.}

SEC. 3. That it shall be unlawful for any person engaged in commerce, in the course of such commerce, to lease or make a sale or contract for sale of goods, wares, merchandise, machinery, supplies or other commodities, whether patented or unpatented, for use, consumption or resale within the United States or any Territory thereof or the District of Columbia or any insular possession or other place under the jurisdiction of the United States, or fix a price charged therefor, or discount from, or rebate upon, such price, on the condition, agreement or understanding that the lessee or purchaser thereof shall not use or deal in the goods, wares, merchandise, machinery, supplies or other com- 
modities of a competitor or competitors of the lessor or sellor, where the effect of such lease, sale, or contract for sale or such condition, agreement or understanding may be to substantially lessen competition or tend to create a monopoly in any line of commerce.

\section{THREE-FOLD DAMAGES RECOVERABLE BY PERSON INJURED.}

SEC. 4. That any person who shall be injured in his business or property by reason of anything forbidden in the Anti-trust laws may sue therefor in any district court of the United States in the district in which the defendant resides or is found or has an agent, without respect to the amount in controversy, and shall recover threefold the damages by him sustained, and the cost of suit, including $a_{1}$ reasonable attorney's fee.

\section{FINAL DECREE PRIMA FACIE EVIDENCE IN ANOTHER} PROCEEDING.

SEC. 5. That a final judgment or decree hereafter rendered in any criminal prosecution or in any suit or proceeding in equity brought by or on behalf of the United States under the Anti-trust laws to the effect that a defendant has violated said laws shall be prima facie evidence against such defendant in any suit or proceeding brought by any other party against such defendant under said laws as to all matters respecting which said judgment or decree would be an estoppel as between the parties thereto: Provided, This section shall not apply to consent judgments or decrees entered before any testimony has been taken: Provided further, This section shall not apply to consent judgments or decrees rendered in criminal proceedings or suits in equity, now pending, in which the taking of testimony has been commenced but has not been concluded, provided such judgments or decrees are rendered before any further testimony is taken.

\section{STATUTE OF LIMITATIONS INOPERATIVE AGAINST PRIVATE CLAIMS PENDING GOVERNMENT SUIT.}

Whenever any suit or proceeding in equity or criminal prosecution is instituted by the United States to prevent, restrain or punish violations of any of the Anti-trust laws, the running of the statute of limitations in respect of each and every private 
right of action arising under said laws and based in whole or in part on any matter complained of in said suit or proceeding shall be suspended during the pendency thereof.

EXEMPTION OF LABOR, HORTICULTURAL AND AGRICULTURAL ORGANIZATIONS AND MEMBERS.

SEC. 6. That the labor of a human being is not a commodity or article of commerce. Nothing contained in the Anti-trust laws shall be construed to forbid the existence and operation of labor, agricultural, or horticultural organizations, instituted for the purposes of mutual help, and not having capital stock or conducted for profit, or to forbid or restrain individual members of such organizations from lawfully carrying out the legitimate objects thereof; nor shall such organizations, or the members thereof, be held or construed to be illegal combinations or conspiracies in restraint of trade, under the Anti-trust laws.

\section{CORPORATE STOCK OWNERSHIP IN COMPETING COR- PORATION UNLAWFUL.}

SEC. 7. That no corporation engaged in commerce shall acquire, directly or indirectly, the whole or any part of the stock or other share capital of another corporation engaged also in commerce, where the effect of such acquisition may be to substantially lessen competition between the corporation whose stock is so acquired and the corporation making the acquisition, or to restrain such commerce in any section or community, or tend to create a monopoly of any line of commerce.

\section{HOLDING COMPANY OWNING STOCK OF COMPETING CORPORATIONS UNLAWFUL.}

No corporation shall acquire, directly or indirectly, the whole or any part of the stock or other share capital of two or more corporations engaged in commerce where the effect of such acquisition, or the use of such stock by the voting or granting of proxies or otherwise, may be to substantially lessen competition between such corporations, or any of them, whose stock or other share capital is so acquired, or to restrain such commerce in any section or community, or tend to create a monopoly of any line of commerce. 


\section{OWNERSHIP OF STOCK FOR INVESTMENT ONLY, PERMITTED.}

This section shall not apply to corporations purchasing such stock solely for investment and not using the same by voting or otherwise to bring about, or in attempting to bring about, the substantial lessening of competition. Nor shall anything contained in this section prevent a corporation engaged in commerce from causing the formation of subsidiary corporations for the actual carrying on of their immediate lawful business, or the natural and legitimate branches or extensions thereof, or from owning and holding all or a part of the stock of such subsidiary corporations, when the effect of such formation is not to substantially lessen competition.

\section{COMMON CARRIERS PERMITTED TO OWN STOCK IN BRANCH LINE COMPANIES.}

Nor shall anything herein contained be construed to prohibit any common carrier subject to the laws to regulate commerce from aiding in the construction of branches or short lines so located as to become feeders to the main line of the company so aiding in such construction or from acquiring or owning all or any part of the stock of such branch lines, nor to prevent any such common carrier from acquiring and owning all or any part of the stock of a branch or short line constructed by an independent company where there is no substantial competition between the company owning the branch line so constructed and the company owning the main line acquiring the property or an interest therein, nor to prevent such common carrier from extending any of its lines through the medium of the acquisition of stock or otherwise of any other such common carrier where there is no substantial competition between the company extending its lines and the company whose stock, property, or an interest therein is so acquired.

\section{LAWFUL STOCK OWNERSHIP NOT IMPAIRED.}

Nothing contained in this section shall be held to affect or impair any right heretofore legally acquired: Provided, That nothing in this section shall be held or construed to authorize or make lawful anything heretofore prohibited or made illegal by the Anti-trust laws, nor to exempt any person from the penal provisions thereof or the civil remedies therein provided. 


\section{INTERLOCKING BETWEEN BANKS, ONE OF WHICH HAS \$5,000,000 RESOURCES, UNLAWFUL.}

SEC. 8. That from and after two years from the date of the approval of this act no person shall at the same time be a director or other officer or employee of more than one bank, banking association or trust company, organized or operating under the laws of the United States, either of which has deposits, capital, surplus, and undivided profits aggregating more than $\$ 5,000,000$; and no private banker or person who is a director in any bank or trust company, organized and operating under the laws of a State, having deposits, capital, surplus, and undivided profits aggregating more than $\$ 5, \infty 00,000$, shall be eligible to be a director in any bank or banking association organized or operating under the laws of the United States. The eligibility of a director, officer, or employee under the foregoing provisions shall be determined by the average amount of deposits, capital, surplus, and undivided profits as shown in the official statements of such bank, banking association, or trust company filed as provided by law during the fiscal year next preceding the date set for the annual election of directors, and when a director, officer, or employee has been elected or selected in accordance with the provisions of this act it shall be lawful for him to continue as such for one year thereafter under said election or employment.

\section{INTERLOCKING BETWEEN BANKS IN CITIES OF OVER 200,000 POPULATION PROHIBITED.}

No bank, banking association or trust company, organized or operating under the laws of the United States, in any city or incorporated town or village of more than two hundred thousand inhabitants, as shown by the last preceding decennial census of the United States, shall have as a director or other officer or employee of any other bank, banking association or trust company located in the same place: Provided, That nothing in this section shall apply to mutual savings banks not having a capital stock represented by shares: Provided further, That a director or other officer or employee of such bank, banking association, or trust company may be a director or other officer or employee of not more than one other bank or trust company organized under the laws of the United States or any State where the entire capital stock of one is owned by stockholders in the other: And 
provided further, That nothing contained in this section shall forbid a director of class A of the Federal reserve bank, as defined in the Federal Reserve Act from being an officer or director or both an officer and director in one member bank.

\section{INTERLOCKING BETWEEN COMPETING CORPORA- TIONS OF MORE THAN \$I,000,000 RESOURCES UNLAWFUL.}

That from and after two years from the date of the approval of this act no person at the same time shall be a director in any two or more corporations, any one of which has capital, surplus, and undivided profits aggregating more than $\$ 1,000,000$, engaged in whole or in part in commerce, other than banks, banking associations, trust companies and common carriers subject to the act to regulate commerce, approved February fourth, eighteen hundred and eighty-seven, if such corporations are or shall have been theretofore, by virtue of their business and location of operation, competitors, so that the elimination of competition by agreement between them would constitute a violation of any of the provisions of any of the Anti-trust laws. The eligibility of a director under the foregoing provision shall be determined by the aggregate amount of the capital, surplus, and undivided profits, exclusive of dividends declared but not paid to stockholders, at the end of the fiscal year of said corporation next preceding the election of directors, and when a director has been elected in accordance with the provisions of this act it shall be lawful for him to continue as such for one year thereafter.

\section{ELIGIBILITY OF INTERLOCKING DIRECTORS.}

When any person elected or chosen as a director or officer or selected as an employee of any bank or other corporation subject to the provisions of this act is eligible at the time of his election or selection to act for such bank or other corporation in such capacity his eligibility to act in such capacity shall not be affected and he shall not become or be deemed amenable to any of the provisions hereof by reason of any change in the affairs of such bank or other corporation from whatsoever cause, whether specifically excepted by any of the provisions hereof or not, until the expiration of one year from the date of his election or employment. 


\section{EMBEZZLEMENT BY COMMON CARRIER OFFICER A FELONY.}

SEc. 9. Every president, director, officer, or manager of any firm, association or corporation engaged in commerce as a common carrier, who embezzles, steals, abstracts, or willfully misapplies, or willfully permits to be misapplied, any of the moneys, funds, credits, securities, property or assets of such firm, association or corporation, arising or accruing from, or used in, such commerce, in whole or in part, or willfully or knowingly converts the same to his own use or to the use of another, shall be deemed guilty of a felony and upon conviction shall be fined not less than $\$ 500$ or confined in the penitentiary not less than one year nor more than ten years, or both, in the discretion of the court.

\section{CONVICTION OR ACQUITTAL IN STATE COURT ON SAME OFFENSE BARS PROSECUTION IN FEDERAL COURT.}

Prosecutions hereunder may be in the district court of the United States for the district wherein the offence may have been committed.

That nothing in this section shall be held to take away or impair the jurisdiction of the courts of the several States under the laws thereof; and a judgment of conviction or acquittal on the merits under the laws of any State shall be a bar to any prosecution hereunder for the same act or acts.

REGULATION PRESCRIBED FOR COMMON CARRIER INTERLOCKING WITH CONSTRUCTION, SUPPLY OR FINANCIAL CONCERNS.

SEC. IO. That after two years from the approval of this act no common carrier engaged in commerce shall have any dealings in securities, supplies or other articles of commerce, or shall make or have any contracts for construction or maintenance of any kind, to the amount of more than $\$ 50,000$, in the aggregate, in any one year, with another corporation, firm, partnership or association when the said common carrier shall have upon its board of directors or as its president, manager or as its purchasing or selling officer, or agent in the particular transaction, any person who is at the same time a director, manager, or purchasing or selling officer of, or who has any substantial interest in, such other corporation, firm, partnership or association, unless and 
except such purchases shall be made from, or such dealings shall be with, the bidder whose bid is the most favorable to such common carrier, to be ascertained by competitive bidding under regulations to be prescribed by rule or otherwise by the Interstate Commerce Commission. No bid shall be received unless the name and address of the bidder or the names and addresses of the officers, directors and general managers thereof, if the bidder be a corporation, or of the members, if it be a partnership or firm, be given with the bid.

\section{PENALTY FOR AVOIDING REGULATIONS.}

Any person who shall, directly or indirectly, do or attempt to do anything to prevent anyone from bidding or shall do any act to prevent free and fair competition among the bidders or those desiring to bid shall be punished as prescribed in this section in the case of an officer or director.

\section{FURTHER REGULATIONS PRESCRIBED.}

Every such common carrier having any such transactions or making any such purchases shall within thirty days after making the same file with the Interstate Commerce Commission a full and detailed statement of the transaction showing the manner of the competitive bidding, who were the bidders, and the names and addresses of the directors and officers of the corporations and the members of the firm or partnership bidding; and whenever the said Commission shall, after investigation or hearing, have reason to believe that the law has been violated in and about the said purchases or transactions it shall transmit all papers and documents and its own views or findings regarding the transaction to the Attorney-General.

\section{VIOLATION OF REGULATING PROVISIONS A MISDE- MEANOR.}

If any common carrier shall violate this section it shall be fined not exceeding $\$ 25,000$; and every such director, agent, manager or officer thereof who shall have knowingly voted for or directed the act constituting such violation or who shall have aided or abetted in such violation shall be deemed guilty of a misdemeanor and shall be fined not exceeding $\$ 5,000$, or confined in jail not exceeding one year, or both, in the discretion of the court. 
AUTHORITY TO ENFORCE LAW VESTED IN FEDERAL TRADE COMMISSION, INTERSTATE COMMERCE COMMISSION AND FEDERAL RESERVE BOARD.

SEC. II. That authority to enforce compliance with Sections two, three, seven and eight of this act by the persons respectively subject thereto is hereby vested: in the Interstate Commerce Commission where applicable to common carriers, in the Federal Reserve Board where applicable to banks, banking associations and trust companies, and in the Federal Trade Commission where applicable to all other character of commerce, to be exercised as follows:

\section{PROCEDURE BEFORE COMMISSION OR BOARD.}

Whenever the Commission or Board vested with jurisdiction thereof shall have reason to believe that any person is violating or has violated any of the provisions of Sections two, three, seven and eight of this act, it shall issue and serve upon such person a complaint stating its charges in that respect, and containing a notice of a hearing upon a day and at a place therein fixed at least thirty days after the service of said complaint. The person so complained of shall have the right to appear at the place and time so fixed and show cause why an order should not be entered by the Commission or Board requiring such person to cease and desist from the violation of the law so charged in said complaint. Any person may make application, and upon good cause shown may be allowed by the Commission or Board, to intervene and appear in said proceeding by counsel or in person. The testimony in any such proceeding shall be reduced to writing and filed in the office of the Commission or Board. If upon such hearing the Commission or Board, as the case may be, shall be of the opinion that any of the provisions of said sections have been or are being violated, it shall make a report in writing in which it shall state its findings as to the facts, and shall issue and cause to be served on such person an order requiring such person to cease and desist from such violations, and divest itself of the stock held or rid itself of the directors chosen contrary to the provisions of Sections seven and eight of this act, if any there be, in the manner and within the time fixed by said order. Until a transcript of the record in such hearing shall have been filed in a Circuit Court of Appeals of the United States, as hereinafter provided, 
the Commission or Board may at any time, upon such notice and in such manner as it shall deem proper, modify or set aside, in whole or in part, any report or any order made or issued by it under this section.

\section{PROCEDURE IN COURT TO ENFORCE COMMISSION'S $O R$ BOARD'S ORDER.}

If such person fails or neglects to obey such order of the Commission or Board while the same is in effect, the Commission or Board may apply to the Circuit Court of Appeals of the United States, within any circuit where the violation complained of was or is being committed or where such person resides or carries on business, for the enforcement of its order, and shall certify and file with its application a transcript of the entire record in the proceeding, including all the testimony taken and the report and order of the Commission or Board. Upon such filing of the application and transcript the court shall cause notice thereof to be served upon such person and thereupon shall have jurisdiction of the proceeding and of the question determined therein, and shall have power to make and enter upon the pleadings, testimony, and proceedings set forth in such transcript a decree affirming, modifying, or setting aside the order of the Commission or Board. The findings of the Commission or Board as to the facts, if supported by testimony, shall be conclusive. If either party shall apply to the court for leave to adduce additional evidence, and shall show to the satisfaction of the court that such additional evidence is material and that there were reasonable grounds for the failure to adduce such evidence in the proceeding before the Commission or Board, the court may order such additional evidence to be taken before the Commission or Board and to be adduced upon the hearing in such manner and upon such terms and conditions as to the court may seem proper. The Commission or Board may modify its findings as to the facts, or make new findings, by reason of the additional evidence so taken, and it shall file such modified or new findings, which, if supported by testimony, shall be conclusive, and its recommendation, if any, for the modification or setting aside of its original order, with the return of such additional evidence. The judgment and decree of the court shall be final, except that the same shall be subject to review by the Supreme Court upon certiorari as provided in Section two hundred and forty of the Judicial Code. 


\section{PROCEDURE IN COURT TO SET ASIDE COMMISSION'S OR BOARD'S ORDER.}

Any party required by such order of the Commission or Board to cease and desist from a violation charged may obtain a review of such order in said Circuit Court of Appeals by filing in the court a written petition praying that the order of the Commission or Board be set aside. A copy of such petition shall be forthwith served upon the Commission or Board, and thereupon the Commission or Board forthwith shall certify and file in the court a transcript of the record as hereinbefore provided. Upon the filing of the transcript the court shall have the same jurisdiction to affirm, set aside, or modify the order of the Commission or Board as in the case of an application by the Commission or Board for the enforcement of its order, and the findings of the Commission or Board as to the facts, if supported by testimony, shall in like manner be conclusive.

\section{CIRCUIT COURT OF APPEALS JURISDICTION EX- CLUSIVE.}

The jurisdiction of the Circuit Court of Appeals of the United States to enforce, set aside, or modify orders of the Commission or Board shall be exclusive.

\section{EXPEDITION OF COURT PROCEEDINGS-NO ORDER OR JUDGMENT TO RELIEVE FROM LIABILITY.}

Such proceedings in the Circuit Court of Appeals shall be given precedence over other cases pending therein, and shall be in every way expedited. No order of the Commission or Board or the judgment of the court to enforce the same shall in any wise relieve or absolve any person from any liability under the Anti-trust acts.

\section{SERVICE OF PROCESS.}

Complaints, orders, and other processes of the Commission or Board under this section may be served by anyone duly authorized by the Commission or Board, either (a) by delivering a copy thereof to the person to be served, or to a member of the partnership to be served, or to the president, secretary, or other executive officer, or a director of the corporation to be served; or (b) by leaving a copy thereof at the principal office or place of 
business of such person; or (c) by registering and mailing a copy thereof addressed to such person at his principal office or place of business. The verified return by the person so serving said complaint, order, or other process setting forth the manner of said service shall be proof of the same, and the return postoffice receipt for said complaint, order, or other process registered and mailed as aforesaid shall be proof of the service of the same.

\section{VENUE OF SUITS AGAINST CORPORATIONS.}

SEC. 12. That any suit, action, or proceeding under the Antitrust laws against a corporation may be brought not only in the judicial district whereof it is an inhabitant, but also in any district wherein it may be found or transacts business; and all process in such cases may be served in the district of which it is an inhabitant, or wherever it may be found.

\section{SUBPCENAS MAY RUN INTO ANY DISTRICT.}

SEC. 13. That in any suit, action, or proceeding brought by or on behalf of the United States subpœnas for witnesses who are required to attend a court of the United States in any judicial district in any case, civil or criminal, arising under the Anti-trust laws may run into any other district: Provided, That in civil cases no writ of subpœna shall issue for witnesses living out of the district in which the court is held at a greater distance than one hundred miles from the place of holding the same without the permission of the trial court being first had upon proper application and cause shown.

\section{CRIME OF CORPORATION ALSO THAT OF ITS DIREC. TORS, OFFICERS AND AGENTS.}

SEC. I4. That whenever a corporation shall violate any of the penal provisions of the Anti-trust laws, such violation shall be deemed to be also that of the individual directors, officers, or agents of such corporation who shall have authorized, ordered, or done any of the acts constituting in whole or in part such violation, and such violation shall be deemed a misdemeanor, and upon conviction therefor of any such director, officer, or agent he shall be punished by a fine of not exceeding $\$ 5,000$ or by imprisonment for not exceeding one year, or by both, in the discretion of the court. 


\section{SUITS IN EQUITY BY UNITED STATES AUTHORIZED TO RESTRAIN VIOLATIONS.}

SEC. 15. That the several district courts of the United States are hereby invested with jurisdiction to prevent and restrain violations of this act, and it shall be the duty of the several district attorneys of the United States, in their respective districts, under the direction of the Attorney General, to institute proceedings in equity to prevent and restrain such violations. Such proceedings may be by way of petition setting forth the case and praying that such violation shall be enjoined or otherwise prohibited. When the parties complained of shall have been duly notified of such petition, the court shall proceed, as soon as may be, to the hearing and determination of the case; and pending such petition, and before final decree, the court may at any time make such temporary restraining order or prohibition as shall be deemed just in the premises. Whenever it shall appear to the court before which any such proceeding may be pending that the ends of justice require that other parties should be brought before the court, the court may cause them to be summoned whether they reside in the district in which the court is held or not, and subpœenas to that end may be served in any district by the marshal thereof.

\section{PERSON MAY ENJOIN THREATENED DAMAGES BY VIO. LATIONS.}

SEC. I6. That any person, firm, corporation, or association shall be entitled to sue for and have injunctive relief, in any court of the United States having jurisdiction over the parties, against threatened loss or damage by a violation of the Anti-trust laws, including Sections two, three, seven and eight of this act, when and under the same conditions and principles as injunctive relief against threatened conduct that will cause loss or damage is granted by courts of equity, under the rules governing such proceedings, and upon the execution of proper bond against damages for an injunction improvidently granted and a showing that the danger of irreparable loss or damage is immediate, a preliminary injunction may issue: Provided, That nothing herein contained shall be construed to entitle any person, firm, corporation, or association, except the United States, to bring suit in equity for injunctive relief against any common carrier subject to the 
provisions of the act to regulate commerce, approved February fourth, eighteen hundred and eighty-seven, in respect of any matter subject to the regulation, supervision, or other jurisdiction of the Interstate Commerce Commission.

\section{NO PRELIMINARY INJUNCTION WITHOUT NOTICE.}

SEC. 17. That no preliminary injunction shall be issued without notice to the opposite party.

\section{NO TEMPORARY RESTRAINING ORDER WITHOUT NO. TICE UNLESS IRREPARABLE INJURY SHOWN.}

No temporary restraining order shall be granted without notice to the opposite party unless it shall clearly appear from specific facts shown by affidavit or by the verified bill that immediate and irreparable injury, loss, or damage will result to the applicant before notice can be served and a hearing had thereon. Every such temporary restraining order shall be indorsed with the date and hour of issuance, shall be forthwith filed in the clerk's office and entered of record, shall define the injury and state why it is irreparable and why the order was granted without notice, and shall by its terms expire within such time after entry, not to exceed ten days, as the court or judge may fix, unless within the time so fixed the order is extended for a like period for good cause shown, and the reasons for such extension shall be entered of record. In case a temporary restraining order shall be granted without notice in the contingency specified, the matter of the issuance of a preliminary injunction shall be set down for a hearing at the earliest possible time and shall take precedence of all matters except older matters of the same character; and when the same comes up for hearing the party obtaining the temporary restraining order shall proceed with the application for a preliminary injunction, and if he does not do so the court shall dissolve the temporary restraining order. Upon two days notice to the party obtaining such temporary restraining order the opposite party may appear and move the dissolution or modification of the order, and in that event the court or judge shall proceed to hear and determine the motion as expeditiously as the ends of justice may require. 
SECTION 263 OF JUDICIARY ACT REPEALED.

Section two hundred and sixty-three of an act entitled "An act to codify, revise, and amend the laws relating to the judiciary," approved March third, nineteen hundred and eleven, is hereby repealed.

\section{SECTION 266 OF JUDICIARY ACT NOT AMENDED.}

Nothing in this section contained shall be deemed to alter, repeal, or amend Section two hundred and sixty-six of an act entitled "An act to codify, revise, and amend the laws relating to the judiciary," approved March third, nineteen hundred and eleven.

\section{INJUNCTION BOND REQUIRED.}

SEC. 18 . That, except as otherwise provided in Section 16 of this act, no restraining order or interlocutory order of injunction shall issue, except upon the giving of security by the applicant in such sum as the court or judge may deem proper, conditioned upon the payment of such costs and damages as may be incurred or suffered by any party who may be found to have been wrongfully enjoined or restrained thereby.

\section{INJUNCTION ORDER SHALL BE SPECIFIC.}

SEC. 19. That every order of injunction or restraining order shall set forth the reasons for the issuance of the same, shall be specific in terms, and shall describe in reasonable detail, and not by reference to the bill of complaint or other document, the act or acts sought to be restrained, and shall be binding only upon the parties to the suit, their officers, agents, servants, employees, and attorneys, or those in active concert or participating with them, and who shall, by personal service or otherwise, have received actual notice of the same.

NO INJUNCTION ORDER PERMITTED IN CASES BETWEEN EMPLOYER AND EMPLOYEES, ETC.

SEC. 20. That no restraining order or injunction shall be granted by any court of the United States, or a judge or the judges thereof, in any case between an employer and employees, or between employers and employees, or between employees, or between persons employed and persons seeking employment, in- 
volving, or growing out of, a dispute concerning terms or conditions of employment, unless necessary to prevent irreparable injury to property, or to a property right, of the party making the application, for which injury there is no adequate remedy at law, and such property or property right must be described with particularity in the application, which must be in writing and sworn to by the applicant or by his agent or attorney.

\section{PEACEFUL PERSUASION OF EMPLOYEES NOT TO BE ENJOINED.}

And no such restraining order or injunction shall prohibit any person or persons, whether singly or in concert, from terminating any relation of employment, or from ceasing to perform any work or labor, or from recommending, advising, or persuading others by peaceful means, so to do; or from attending at any place where any such person or persons may lawfully be, for the purpose of peacefully obtaining or communicating information, or from peacefully persuading any person to work or to abstain from working; or from ceasing to patronize or to employ any party to such dispute, or from recommending, advising, or persuading others by peaceful and lawful means so to do; or from paying or giving to, or withholding from, any person engaged in such dispute, any strike benefits or other moneys or things of value; or from peaceably assembling in a lawful manner, and for lawful purposes; or from doing any act or thing which might lawfully be done in the absence of such dispute by any party thereto; nor shall any of the acts specified in this paragraph be considered or held to be violations of any law of the United States.

\section{DISOBEDIENCE OF COURT ORDER BY CRIMINAL ACT PUNISHABLE.}

SEC. 2I. That any person who shall willfully disobey any lawful writ, process, order, rule, decree, or command of any district court of the United States or any court of the District of Columbia by doing any act or thing therein, or thereby forbidden to be done by him, if the act or thing so done by him be of such character as to constitute also a criminal offence under any statute of the United States, or under the laws of any State in which the act was committed, shall be proceeded against for his said contempt as hereinafter provided. 


\section{PROCEEDINGS IN CONTEMPT CASES.}

SEc. 22. That whenever it shall be made to appear to any district court or judge thereof, or to any judge therein sitting, by the return of a proper officer on lawful process, or upon the affidavit of some credible person, or by information filed by any district attorney, that there is reasonable ground to believe that any person has been guilty of such contempt, the court or judge thereof, or any judge therein sitting, may issue a rule requiring the said person so charged to show cause upon a day certain why he should not be punished therefor, which rule, together with a copy of the affidavit or information, shall be served upon the person charged, with sufficient promptness to enable him to prepare for and make return to the order at the time fixed therein. If upon or by such return, in the judgment of the court, the alleged contempt be not sufficiently purged, a trial shall be directed at a time and place fixed by the court: Provided, however, That if the accused, being a natural person, fail or refuse to make return to the rule to show cause, an attachment may issue against his person to compel an answer, and in case of his continued failure or refusal, or if for any reason it be impracticable to dispose of the matter on the return day, he may be required to give reasonable bail for his attendance at the trial and his submission to the final judgment of the court. Where the accused is a body corporate, an attachment for the sequestration of its property may be issued upon like refusal or failure to answer.

\section{JURY TRIAL IF DEMANDED.}

In all cases within the purview of this act such trial may be by the court, or, upon demand of the accused, by a jury; in which latter event the court may impanel a jury from the jurors then in attendance, or the court or the judge thereof in chambers, may cause a sufficient number of jurors to be selected and summoned, as provided by law, to attend at the time and place of trial, at which time a jury shall be selected and impaneled as upon a trial for misdemeanor; and such trial shall conform, as near as may be, to the practice in criminal cases prosecuted by indictment or upon information.

\section{PUNISHMENT-DISTRIBUTION OF FINE.}

If the accused be found guilty, judgment shall be entered accordingly, prescribing the punishment, either by fine or imprison- 
ment, or both, in the discretion of the court. Such fine shall be paid to the United States or to the complainant or other party injured by the act constituting the contempt, or may, where more than one is so damaged, be divided or apportioned among them as the court may direct, but in no case shall the fine to be paid to the United States exceed, in case the accused is a natural person, the sum of $\$ 1,000$, nor shall such imprisonment exceed the term of six months: Provided, That in any case the court or a judge thereof may, for good cause shown, by affidavit or proof taken in open court or before such judge and filed with the papers in the case, dispense with the rule to show cause, and may issue an attachment for the arrest of the person charged with contempt; in which event such person, when arrested, shall be brought before such court or a judge thereof without unnecessary delay and shall be admitted to bail in a reasonable penalty for his appearance to answer to the charge or for trial for the contempt; and thereafter the proceedings shall be the same as provided herein in case the rule had issued in the first instance.

\section{REVIEW PROVIDED FOR CONTEMPT PROCEEDINGS- BAIL.}

SEC. 23. That the evidence taken upon the trial of any persons so accused may be preserved by bill of exceptions, and any judgment of conviction may be reviewed upon writ of error in all respects as now provided by law in criminal cases, and may be affirmed, reversed, or modified as justice may require. Upon the granting of such writ of error, execution of judgment shall be stayed, and the accused, if thereby sentenced to imprisonment, shall be admitted to bail in such reasonable sum as may be required by the court, or by any justice, or any judge of any district court of the United States or any court of the District of Columbia.

\section{CONTEMPT PROCEEDINGS NOT APPLICABLE IN CER- TAIN CASES.}

SEC. 24. That nothing herein contained shall be construed to relate to contempts committed in the presence of the court, or so near thereto as to obstruct the administration of justice, nor to contempts committed in disobedience of any lawful writ, process, order, rule decree or command entered in any suit or ac- 
tion brought or prosecuted in the name of, or on behalf of, the United States but the same, and all other cases of contempt not specifically embraced within Section twenty-one of this act, may be punished in conformity to the usages at law and in equity now prevailing.

\section{LIMITATIONS IN CONTEMPT ACTIONS ONE YEAR.}

SEC. 25. That no proceeding for contempt shall be instituted against any person unless begun within one year from the date of the act complained of; nor shall any such proceeding be a bar to any criminal prosecution for the same act or acts; but nothing herein contained shall affect any proceedings in contempt pending at the time of the passage of this act.

\section{CONSTITUTIONAL SAVING CLAUSE.}

SEC. 26. If any clause, sentence, paragraph, or part of this act shall for any reason be adjudged by any court of competent jurisdiction to be invalid, such judgment shall not effect, impair, or invalidate the remainder thereof, but shall be confined in its operation to the clause, sentence, paragraph, or part thereof directly involved in the controversy in which such judgment shall have been rendered.

Approved, October I5, I9I4. 


\section{APPENDIX C.}

\section{SHERMAN LAW, OR FEDERAL ANTI-TRUST LAW.}

$$
\text { (Act of July 2, 1890; } 26 \text { Stat. 209.) }
$$

An act to protect trade and commerce against unlawful restraints and monopolies.

CONTRACTS, COMBINATIONS OR CONSPIRACIES IN RESTRAINT OF TRADE ILLEGAL.

SEc. I. Be it enacted by the Senate and House of Representatives of the United States of America in Congress assembled. Every contract combination in the form of a trust or otherwise, or conspiracy, in restraint of trade or commerce among the several States, or with foreign nations, is hereby declared to be illegal. Every person who shall make any such contract or engage in any such combination or conspiracy, shall be deemed guilty of a misdemeanor, and, on conviction thereof, shall be punished by fine not exceeding five thousand dollars, or by imprisonment not exceeding one year, or by both said punishments, in the discretion of the court.

\section{MONOPOLIZING OR ATTEMPTING TO MONOPOLIZE TRADE A MISDEMEANOR.}

SEC. 2. Every person who shall monopolize, or attempt to monopolize, or combine or conspire with any other person or persons, to monopolize any part of the trade or commerce among the several States, or with foreign nations, shall be deemed guilty of a misdemeanor, and, on conviction thereof, shall be punished by fine not exceeding five thousand dollars, or by imprisonment not exceeding one year, or by both said punishments, in the discretion of the court.

CONTRACTS, ETC., IN RESTRAINT OF TRADE ILLEGAL.

SEC. 3. Every contract, combination in form of trust or otherwise, or conspiracy, in restraint of trade or commerce in any Territory of the United States or of the District of Columbia, or in restraint of trade or commerce between any such Territory and 
another, or between any such Territory or Territories and any State or States or the District of Columbia, or with foreign nations, or between the District of Columbia and any State or States or foreign nations, is hereby declared illegal. Every person who shall make any such contract or engage in any such combination or conspiracy, shall be deemed guilty of a misdemeanor, and, on conviction thereof shall be punished by fine not exceeding five thousand dollars, or by imprisonment not exceeding one year, or by both said punishments, in the discretion of the court.

\section{JURISDICTION TO RESTRAIN VIOLATIONS.}

SEC. 4. That several circuit courts of the United States are hereby invested with jurisdiction to prevent and restrain violations of this act; and it shall be the duty of the several district attorneys of the United States, in their respective districts, under the direction of the Attorney General, to institute proceedings in equity to prevent and restrain such violations. Such proceedings may be by way of petition setting forth the case and praying that such violation shall be enjoined or otherwise prohibited. When the parties complained of shall have been duly notified of such petition the court shall proceed, as soon as may be, to the hearing and determination of the case; and pending such petition and before final decree, the court may at any time make such temporary restraining order or prohibition as shall be deemed just in the premises.

\section{OTHER PARTIES MAY BE SUMMONED.}

SEC. 5. Whenever it shall appear to the court before which any proceeding under section four of this act may be pending, that the ends of justice require that other parties should be brought before the court, the court may cause them to be summoned, whether they reside in the district in which the court is held or not; and subponas to that end may be served in any district by the marshal thereof.

\section{PROPERTY OWNED IN VIOLATION OF LAW MAY BE CONDEMNED.}

SEC. 6. Any property owned under any contract or by any combination, or pursuant to any conspiracy (and being the subject thereof) mentioned in section one of this act, and being in 
the course of transportation from one State to another, or to a foreign country, shall be forfeited to the United States, and may be seized and condemned by like proceedings as those provided by law for the forfeiture, seizure, and condemnation of property imported into the United States contrary to law.

INJURED PERSON GIVEN RIGHT TO RECOVER THREE. FOLD DAMAGES.

SEC. 7. Any person who shall be injured in his business or property by any other person or corporation by reason of anything forbidden or declared to be unlawful by this act, may sue therefor in an circuit court of the United States in the district in which the defendant resides or is found, without respect to the amount in controversy, and shall recover threefold the damages by him sustained, and the costs of suit, including a reasonable attorney's fee.

\section{PERSON DEFINED.}

SEC. 8. That the word "person," or "persons" wherever used in this act shall be deemed to include corporations and associations existing under or authorized by the laws of either the United States, the laws of any of the Territories, the laws of any State, or the laws of any foreign country. 


\section{APPENDIX D.}

\section{PORTIONS OF WILSON TARIFF LAW.}

[Act of August 27, 1894 (28 Stat. 570) as amended by Act of February I2, 1913 (37 Stat. 667).]

Applicable to regulation of import trade only, being Sections 73 as amended, $74,75,76$ as amended, and 77 .

CONTRACTS, ETC., IN RESTRAINT OF IMPORT TRADE ILLEGAL.

SEC. 73. That every combination, conspiracy, trust, agreement, or contract, is hereby declared to be contrary to public policy, illegal, and void when the same is made by or between two or more persons or corporations either of whom, as agent or principal, is engaged in importing any article from any foreign country into the United States, and when such combination, conspiracy, trust, agreement, or contract is intended to operate in restraint of lawful trade, or free competition in lawful trade or commerce, or to increase the market price in any part of the United States of any article or articles imported or intended to be imported into the United States, or of any manufacture into which such imported article enters or is intended to enter. Every person who is or shall hereafter be engaged in the importation of goods or any commodity from any foreign country in violation of this section of this act, or who shall combine or conspire with another to violate the same, is guilty of a misdemeanor, and on conviction thereof in any court of the United States such person shall be fined in a sum not less than one hundred dollars and not exceeding five thousand dollars, and shall be further punished by imprisonment, in the discretion of the court, for a term not less than three months nor exceeding twelve months.

\section{JURISDICTION TO RESTRAIN VIOLATIONS.}

SEC. 74. That the several circuit courts of the United States are hereby invested with jurisdiction to prevent and restrain violations of Section seventy-three of this act; and it shall be the duty of the several district attorneys of the United States, in their respective districts, under the direction of the AttorneyGeneral, to institute proceedings in equity to prevent and restrain 
such violations. Such proceedings may be by way of petitions setting forth the case and praying that such violations shall be enjoined or otherwise prohibited. When the parties complained of shall have been duly notified of such petition the court shall proceed, as soon as may be, to the hearing and determination of the case; and pending such petition and before final decree, the court may at any time make such temporary restraining order or prohibition as shall be deemed just in the premises.

\section{ADDITIONAL PARTIES MAY BE SUMMONED FROM OTHER DISTRICTS.}

SEc. 75. That whenever it shall appear to the court before which any proceeding under the Seventy-fourth section of this act may be pending that the ends of justice require that other parties should be brought before the court, the court may cause them to be summoned, whether they reside in the district in which the court is held or not; and subpœnas to that end may be served in any district by the marshal thereof.

\section{PROPERTY OWNED IN VIOLATION OF LAW MAY BE CONDEMNED.}

SEC. 76. That any property owned under any contract or by any combination, or pursuant to any conspiracy, and being the subject thereof, mentioned in Section seventy-three of this act, imported into and being within the United States or being in the course of transportation from one State to another, or to or from a Territory or the District of Columbia, shall be forfeited to the United States, and may be seized and condemned by like proceedings as those provided by law for the forfeiture, seizure, and condemnation of property imported into the United States contrary to law.

\section{INJURED PERSON GIVEN RIGHT TO RECOVER THREE. FOLD DAMAGES.}

SEC. 77. That any person who shall be injured in his business or property by any other person or corporation by reason of anything forbidden or declared to be unlawful by this act, may sue therefor in any circuit court of the United States in the district in which the defendant resides or is found, without respect to the amount in controversy, and shall recover threefold the damages by him sustained, and the cost of suit, including a reasonable attorney's fee. 


\title{
APPENDIX E.
}

\section{STATUTORY PROVISIONS CREATING THE BUREAU OF CORPORATIONS.}

\author{
[32 Stat., 825, 827.]
}

AN ACT to establish the Department of Commerce and Labor. * * * * * * *

SEC. 6. That there shall be in the Department of Commerce and Labor a bureau to be called the Bureau of Corporations, and a Commissioner of Corporations who shall be the head of said bureau, to be appointed by the President, who shall receive a salary of five thousand dollars per annum. There shall also be in said bureau a deputy commissioner, who shall receive a salary of three thousand five hundred dollars per annum and who shall in the absence of the commissioner, act as and perform the duties of the Commissioner of Corporations, and who shall also perform such other duties as may be assigned to him by the Secretary of Commerce and Labor or by the said commissioner. There shall also be in the said bureau a chief clerk and such special agents, clerks, and other employees as may be authorized by law.

The said commissioner shall have power and authority to make, under the direction and control of the Secretary of Commerce and Labor, diligent investigation into the organization, conduct, and management of the business of any corporation, joint stock company, or corporate combination engaged in commerce among the several States and with foreign nations, excepting common carriers subject to "An act to regulate commerce," approved February fourth, eighteen hundred and eighty-seven, and to gather such information and data as will enable the President of the United States to make recommendations to Congress for legislation for the regulation of such commerce, and to report such data to the President from time to time as he shall require; and the information so obtained, or ai much thereof as the President may direct, shall be made public.

In order to accomplish the purposes declared in the foregoing part of this section, the said commissioner shall have and exer- 
cise the same power and authority in respect to corporations, joint-stock companies, and combinations subject to the provisions hereof as is conferred on the Interstate Commerce Commission in said "act to regulate commerce" and the amendments thereto in respect to common carriers, so far as the same may be applicable, including the right to subpona and compel the attendance and testimony of witnesses and the production of documentary evidence and to administer oaths. All the requirements, obligations, liabilities, and immunities imposed or conferred by said "act to regulate commerce" and by "An act in relation to testimony before the Interstate Commerce Commission," and so forth, approved February eleventh, eighteen hundred and ninety-three, supplemental to said "act to regulate commerce," shall also apply to $a^{1 l}$ persons who may be subpœnaed to testify as witnesses or to produce documentary evidence in pursuance of the authority conferred by this section.

It shall also be the province and duty of said bureau, under the direction of the Secretary of Commerce and Labor, to gather, compile, publish, and supply useful information concerning corporations doing business within the limits of the United States as shall engage in interstate commerce or in commerce between the United States and any foreign country, including corporations engaged in insurance, and to attend to such other duties as may be hereafter provided by law.

*

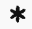

*

Approved, February 14, 1903. 
APPENDIX F.

\section{PROVISIONS OF FEDERAL CONSTITUTION APPLI- CABLE TO ANTI-TRUST LAWS.}

ARTICLE I.

SEC. 8. The Congress shall have Power To $* * *$ regulate Commerce with foreign Nations, and among the several States, and with the Indian Tribes.

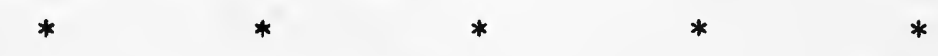

\section{ARTICLE VI.}

* * * This Constitution, and the Laws of the United States which shall be made in Pursuance thereof; and all Treaties made, or which shall be made, under the Authority of the United States, shall be the Supreme Law of the Land; and the Judges in every State shall be bound thereby, anything in the Constitution or Laws of any State to the contrary notwithstanding.

*

*

*

*

*

\section{AMENDMENTS.}

\section{[ARTICLE IV.]}

The right of the people to be secure in their persons, houses, papers, and effects, against unreasonable searches and seizures, shall not be violated, and no warrants shall issue, but upon probable cause, supported by oath or affirmation, and particularly describing the place to be searched, and the persons or things to be seized.

\section{[ARTICLE V.]}

No person shall be held to answer for a capital, or otherwise infamous crime, unless on a presentment or indictment of a grand jury, except in cases arising in the land or naval forces, or in the militia, when in actual service in time of war or public danger; nor shall any person be subject for the same offence to be twice put in jeopardy of life or limb; nor shall be compelled in any criminal case to be a witness against himself, nor be deprived of life, liberty, or property, without due process of law ; nor shall 
private property be taken for public use, without just compensation.

$$
\text { [ARTICLE XIV.] }
$$

SEC. I. * * * No State shall make or enforce any law which shall abridge the privileges or immunities of citizens of the United States; nor shall any State deprive any person of life, liberty, or property, without due process of law ; nor deny to any person within its jurisdiction the equal protection of the laws. 


\section{APPENDIX G.}

PORTION OF SUNDRY CIVIL ACT, 1914, APPLICABLE TO RESTRICTION OF GOVERNMENT ACTIONS AGAINST LABOR AND AGRICULTURAL ORGANIZATIONS.

AN ACT making appropriations for sundry civil expenses of the Government for the fiscal year ending June thirtieth, nineteen hundred and fourteen, and for other purposes.

* * * * * * *

Enforcement of Anti-trust laws, including not exceeding \$10,$\infty 0$ for salaries of necessary employees at the seat of government, $\$ 300,000$ : Provided, however, That no part of this money shall be spent in the prosecution of any organization or individual for entering into any combination or agreement having in view the increasing of wages, shortening of hours, or bettering the conditions of labor, or for any act done in furtherance thereof not in itself unlawful: Provided further, That no part of this appropriation shall be expended for the prosecution of producers of farm products and associations of farmers who co-operate and organize in an effort to and for the purpose to obtain and maintain a fair and reasonable price for their products. $* * *$

Approved, June 23, I9I3. 


\title{
APPENDIX H.
}

\section{IMMUNITY PROVISIONS.}

\section{EXTRACT FROM APPROPRIATION ACT OF 1903.}

\author{
[32 Stat., 854, 903.]
}

AN ACT making appropriations for the legislative, executive, and judicial expenses of the government for the fiscal year ending June thirtieth, nineteen hundred and four, and for other purposes.

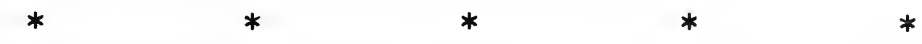

That for the enforcement of the provisions of the act entitled "An act to regulate commerce," approved February fourth, eighteen hundred and eighty-seven, and all acts amendatory thereof or supplemental thereto, and of the act entitled "An act to protect trade and commerce against unlawful restraints and monopolies," approved July second, eighteen hundred and ninety, and all acts amendatory thereof or supplemental thereto, and Sections seventy-three, seventy-four, seventy-five, and seventy-six of the act entitled "An act to reduce taxation, to provide revenue for the government, and other purposes," approved August twentyseventh, eighteen hundred and ninety-four, the sum of five hundred thousand dollars, to be immediately available, is hereby appropriated, out of any money in the treasury not heretofore appropriated, to be expended under the direction of the AttorneyGeneral in the employment of special counsel and agents of the Department of Justice to conduct proceedings, suits, and prosecutions under said acts in the courts of the United States: Provided, That no person shall be prosecuted or be subjected to any penalty or forfeiture for or on account of any transaction, matter, or thing concerning which he may testify or produce evidence, documentary or otherwise, in any proceeding, suit, or prosecution under said acts: Provided further, That no person so testifying shall be exempt from prosecution or punishment for perjury committed in so testifying.

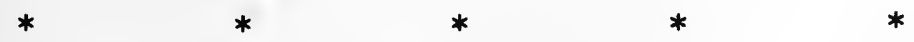

Approved, February 25, 1903. 


\section{ACT DEFINING RIGHT OF IMMUNITY.}

\section{[34 Stat., 798.]}

AN ACT defining the right of immunity of witnesses under the act, entitled "An act in relation to testimony before the Interstate Commerce Commission," and so forth, approved February eleventh, eighteen hundred and ninety-three, and an act, entitled "An act to establish the Department of Commerce and Labor," approved February fourteenth, nineteen hundred and three, and an act, entitled "An act to further regulate commerce with foreign nations and among the states," approved February nineteenth, nineteen hundred and three, and an act, entitled "An act making appropriations for the legislative, executive, and judicial expenses of the government for the fiscal year ending June thirtieth, nineteen hundred and four, and for othr purposes," approved February twenty-fifth, nineteen hundred and three.

Be it enacted by the Senate and House of Representatives of the United States of America in Congress assembled, That under the immunity provisions in the act entitled "An act in relation to testimony before the Interstate Commerce Commission," and so forth, approved February eleventh, eighteen hundred and ninetythree, in Section six of the act entitled "An act to establish the Department of Commerce and Labor," approved February fourteenth, nineteen hundred and three, and in the act entitled "An act to further regulate commerce with foreign nations and among the States," approved February nineteenth, nineteen hundred and three, and in the act entitled "An act making appropriations for the legislative, executive, and judicial expenses of the government for the fiscal year ending June thirtieth, nineteen hundred and four, and for other purposes," approved February twentyfifth, nineteen hundred and three, immunity shall extend only to a natural person who, in obedience to a subpœna, gives testimony under oath or produces evidence, documentary or otherwise, under oath.

Ápproved, June 30, 1906. 


\section{APPENDIX I.}

PROVISIONS OF JUDICIAL CODE REFERRED TO IN THE FEDERAL TRADE COMMISSION ACT, AND CLAYTON LAW; ALSO, PROVISIONS ABOLISHING THE CIRCUIT COURTS OF THE UNITED STATES.

Section 240, Containing Authority for Review by the Supreme Court upon Certiorari.-

[Referred to in Section 5 of the Federal Trade Commission Act, and in Section II of the Clayton Law.]

"In any case, civil or criminal, in which the judgment or decree of the Circuit Court of Appeals is made final by the provisions of this title, it shall be competent for the Supreme Court to require, by certiorari or otherwise, upon the petition of any party thereto, any such case to be certified to the Supreme Court for its review and determination, with the same power and authority in the case as if it had been carried by appeal or writ of error to the Supreme Court."

Section 263.-

[Repealed by Section 17 of Clayton Law.]

"Whenever notice is given of a motion for an injunction out of a district court, the court or judge thereof may, if there appears to be danger of irreparable danger from delay, grant an order restraining the act sought to be enjoined until the decision of the motion; and such order may be granted with or without security, in the discretion of the court or judge."

Section 266.-

[Approved, ratified and continued by Section I7 of Clayton Law.]

"No interlocutory injunction suspending the enforcement, operation, or execution of any statute of a State by restraining the action of any office of such State in the enforcement or execution of such statute, shall be issued or granted by any justice of the Supreme Court, or by any district court of the United States, or by any judge thereof, or by any circuit judge acting as district judge, upon the ground of the unconstitutionality of such statute, unless the application of the same shall be presented to a justice 
of the Supreme Court of the United States, or to a circuit or district judge, and shall be heard and determined by three judges, of whom at least one shall be a justice of the Supreme Court, or a circuit judge, and the other two may be either circuit or district judges, and unless a majority of said three judges shall concur in granting such application.

Whenever such application as aforesaid is presented to a justice of the Supreme Court, or to a judge, he shall immediately call to his assistance to hear and determine the application two other judges: Provided, however, That one of such three judges shall be a justice of the Supreme Court, or a circuit judge.

Said application shall not be heard or determined before at least five days' notice of the hearing has been given to the Governor and to the Attorney-General of the State, and to stich other persons as may be defendants in the suit: Provided, That if of opinion that irreparable loss or damage would result to the complainant unless a temporary restraining order is granted, any justice of the Supreme Court, or any circuit or district judge, may grant such temporary restraining order at any time before such hearing and determination of the application for an interlocutory injunction, but such temporary restraining order shall remain in force only until the hearing and determination of the application for an interlocutory injunction upon notice as aforesaid. The hearing upon such application for an interlocutory injunction shall be given preference and shall be in every way expedited and be assigned for a hearing at the earliest practicable day after the expiration of the notice hereinbefore provided for. An appeal may be taken direct to the Supreme Court of the United States from the order granting or denying, after hearing, an interlocutory injunction in such case."

Sections 289, 290 and 291, Abolishing the Circuit Courts of the United States, and Substituting the District Courts Therefor.-

(Approved March 3, I9I I in effect January I, I9I2, 36 Stat. 1087.)

SEC. 289. The circuit courts of the United States, upon the taking effect of this act, shall be and hereby are abolished. ***

SEC. 290. All suits and proceedings pending in said circuit courts on the date of the taking effect of this act, whether originally brought therein or certified thereto from the district courts, 
shall thereupon and thereafter be proceeded with and disposed of in the same manner and with the effect as if originally begun therein. $* * *$

SEC. 291. Wherever, in any law not embraced within this act, any reference is made to, or any power or duty is conferred or imposed upon, the circuit courts, such reference shall, upon the taking effect of this act, be deemed and held to refer to, and to confer such power and impose such duty upon, the district courts. 
APPENDIX J.

\title{
ANTI-MONOPOLY PROVISIONS CONTAINED IN PANAMA CANAL ACT.
}

\author{
[Act of March 4, 1913, (37 Stat., 560).]
}

AN ACT to provide for the opening, maintenance, protection and operation of the Panama Canal, and the sanitation and government of the Canal Zone.

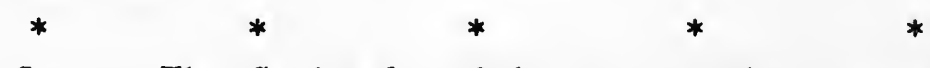

SEC. II. That Section five of the act to regulate commerce, approved February fourth, eighteen hundred and eighty-seven, as heretofore amended, is hereby amended by adding thereto a new paragraph at the end thereof, as follows:

"From and after the first day of July, nineteen hundred and fourteen, it shall be unlawful for any railroad company or other common carrier subject to the act to regulate commerce to own, lease, operate, control, or have any interest whatsoever (by stock ownership or otherwise, either directly, indirectly, through any holding company, or by stockholders or directors in common, or in any other manner) in any common carrier by water operated through the Panama Canal or elsewhere with which said railroad or other carrier aforesaid does or may compete for traffic or any vessel carrying freight or passengers upon said water route or elsewhere with which said railroad or other carrier aforesaid does or may compete for traffic; and in case of the violation of this provision each day in which such violation continues shall be deemed a separate offence."

Jurisdiction is hereby conferred on the Interstate Commerce Commission to determine questions of fact as to the competition or possibility of competition, after full hearing, on the application of any railroad company or other carrier. Such application may be filed for the purpose of determining whether any existing service is in violation of this section and pray for an order permitting the continuance of any vessel or vessels already in operation, or for the purpose of asking an order to install new service not in conflict with the provisions of this paragraph. The Commission may on its own motion or the application of any shipper 
institute proceedings to inquire into the operation of any vessel in use by any railroad or other carrier which has not applied to the Commission and had the question of competition or the possibility of competition determined as herein provided. In all such cases the order of said Commission shall be final.

If the Interstate Commerce Commission shall be of the opinion that any such existing specified service by water other than through the Panama Canal is being operated in the interest of the public and is of advantage to the convenience and commerce of the people and that such extension will neither exclude, prevent, nor reduce competition on the route by water under consideration, the Interstate Commerce Commission may, by order, extend the time during which such service by water may continue to be operated beyond July first, nineteen hundred and fourteen. In every case of such extension the rates, schedules, and practices of such water carrier shall be filed with the Interstate Commerce Commission and shall be subject to the act to regulate commerce and all amendments thereto in the same manner and to the same extent as is the railroad or other common carrier controlling such water carrier or interested in any manner in its operation: Provided, Any application for extension under the terms of this provision filed with the Interstate Commerce Commission prior to Iuly first, nineteen hundred and fourteen, but for any reason not heard and disposed of before said date, may be considered and granted thereafter.

No vessel permitted to engage in the coastwise or foreign trade of the United States shall be permitted to enter or pass through said canal if such ship is owned, chartered, operated, or controlled by any person or company which is doing business in violation of the provisions of the act of Congress approved July second, eighteen hundred and ninety, entitled "An act to protect trade and commerce against unlawful restraints and monopolies," or the provisions of Sections seventy-three to seventy-seven, both inclusive, of an act approved August twenty-seventh, eighteen hundred and ninety-four, entitled "An act to reduce taxation, to provide revenue for the government, and for other purposes," or the provisions of any other act of Congress amending or supplementing the said Act of July second, eighteen hundred and ninety, commonly known as the Sherman Anti-trust Act, and amendments thereto, or said sections of the Act of August twenty- 
seventh, eighteen hundred and ninety-four. The question of fact may be determined by the judgment of any court of the United States of competent jurisdiction in any cause pending before it to which the owners or operators of such ships are parties. Suit may be brought by any shipper or by the Attorney-General of the United States.

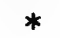




\section{APPENDIX K.}

\section{TENTATIVE FORMS OF SHERMAN LAW SUBMIT- TED TO THE SENATE FOR THE FIFTY-FIRST SESSION OF CONGRESS.}

I.

I. SHERMAN ANTI-TRUST BILL INTRODUCED DECEMBER 4, I889, DESIGNATED "SENATE BILL NO. I."

\section{A BILL}

[Referred to Finance Committee of Senate; reported back by Senator Sherman with certain amendments January I4, I890. See, Bills and Debates on Trusts, pages 69-71.]

To declare unlawful trusts and combinations in restrain of trade and Production.

Be it enacted by the Senate and House of Representatives of the United States of America in Congress assembled:

Sec. I. That all arrangements, contracts, agreements, trusts, 4 or combinations between persons or corporations made 5 with a view or which tends to prevent full and free com6 petition in the importation, transportation or sale of ar7 ticles imported into the United States, or in the produc8 tion, manufacture or sale of articles of domestic growth 9 or production, or domestic raw material that competes Io with any similar article upon which a duty is levied by I I the United States, or which shall be transported from 12 one State or Territory to another, and all arrangements, I3 contracts, agreements, trusts or combinations between perI4 sons or corporations designed, or which tend, to advance I5 the cost to the consumer of any such articles, are hereby I6 declared to be against public policy, unlawful and void.

I SEC. 2. That any person or corporation injured or 2 damnified by such arrangement, contract, agreement, 3 trust or combination may sue for and recover, in any court 4 of the United States of competent jurisdiction of any per5 son or corporation a party to a combination described in 
6 the first section of this act, the full consideration or sum 7 paid by him for any goods, wares and merchandise included 8 in or advanced in price by said combination.

I SEC. 3. That all persons entering into any such arrange2 ment, contract, agreement, trust or combination described 3 in Section one of this act, either on his own account or as 4 agent or attorney for another, or as an officer, agent or 5 stockholder of any corporation, or as a trustee, committee, 6 or in any capacity whatever, shall be guilty of a high 7 misdemeanor, and on conviction thereof in any district or 8 circuit court of the United States, shall be subject to a

9 fine of not more than ten thousand dollars or to imprison10 ment in the penitentiary for a term of not more than five II years, or to both such fine and imprisonment in the dis12 cretion of the court. And it shall be the duty of the 13 district attorney of the United States of the district in I4 which such persons reside to institute the proper proceedI5 ings to enforce the provisions of this act.

II.

2. SHERMAN ANTI-TRUST SUBSTITUTED BILL, REPORTED BY SENATOR SHERMAN FROM THE COMMITTEE ON FINANCE, MARCH $18,1890$.

[Referred to Committee on Judiciary, March 27, I890; redrafted by Senator Hoar and reported back, April 23, 1890. Bills and Debates on Trusts, pages $89,306,324,326$.

\section{AMENDMENT}

Reported by Mr. Sherman from the Committee on Finance, and intended to be proposed to the bill (S. I) to declare unlawful trusts and combinations in restraint of trade and production, viz: Strike out all after the enacting clause and insert the following:

3 That all arrangements, contracts, agreements, trusts, or 4 combinations between two or more citizens or corporations, 5 or both, of different States, or between two or more citi-

6 zens or corporations, or both, of the United States and

7 foreign States, or citizens or corporations thereof, made 
8 with a view or which tend to prevent full and free com-t 9 petition in the importation, transportation, or sale of arIo ticles imported into the United States, or with a view or II which tend to prevent full and free competition in articles I2 of growth, production, or manufacture of any State or I3 Territory of the United States, with similar articles of the I4 growth, production or manufacture of any other State or 15 Territory, or in the transportation or sale of like articles, I6 the production of any State or Territory of the United 17 States into or within any other State or Territory of the I8 United States; and all arrangements, trusts or combinaI9 tions between such citizens or corporations, made with a 20 view or which tend to advance the cost to the consumer 2I of any such articles, are hereby declared to be against 22 public policy, unlawful and void. And the circuit court 23 of the United States shall have original jurisdiction of all 24 suits of a civil nature at common law or in equity arising 25 under this section, and to issue all remedial process, orders, 26 or writs proper and necessary to enforce its provisions. 27 And the Attorney-General and the several district attor28 neys are hereby directed, in the name of the United States, 29 to commence and prosecute all such cases to final judg30 ment and execution.

I SEC. 2. That any person or corporation injured or 2 damnified by such arrangement, contract, agreement, trust 3 or combination defined in the first section of this act may 4 sue for and recover, in any court of the United States of 5 competent jurisdiction, without respect to the amount in6 volved, of any person or corporation a party to a combina7 tion described in the first section of this act, twice the 8 amount of damages sustained and the costs of the suit, 9 together with a reasonable attorney's fee.

\section{III.}

3. ON MARCH 2T, I890, SENATOR REAGAN, OF TEXAS, INTRODUCED THE FOLLOWING SUBSTITUTE BILL:

[Referred to Committee on Judiciary, with other proposed amendments, March 27, 1890. Bills and Debates on Trusts, page 306.] 


\section{SUBSTITUTE BILL.}

SEC. 3. "That all persons engaged in the creation of any trust, or as owner or part owner, agent or manager of any trust, employed in any business carried on with any foreign country, or between the States or between any State and the District of Columbia, or between any State and any Territory of the United States, or any owner or part owner, agent or manager of any corporation using its powers for either of the purposes specified in the second section of this act, shall be deemed guilty of a high misdemeanor, and on conviction thereof, shall be fined in a sum not exceeding $\$ 10,000$, or imprisonment at hard labor in the penitentiary not exceeding five years, or by both of said penalties, in the discretion of the court trying the same.

SEC. 4. That a trust is a combination of capital, skill or acts by two or more persons, firms, corporations or associations of persons, or of any two or more of them for either, any or all of the following purposes:

First. To create or carry out any restrictions in trade.

Second. To limit or reduce the production or to increase or reduce the price of merchandise or commodities.

Third. To prevent competition in the manufacture, making, purchase, sale or transportation of merchandise, produce or commodities.

Fourth. To fix a standard or figure whereby the price to the public shall be in any manner controlled or established of any article, commodity, merchandise, produce or commerce intended for sale, use or consumption.

Fifth. To create a monopoly in the making, manufacture, purchase, sale or transportation of any merchandise, article, produce or commodity.

Sixth. To make or enter into or execute or carry out any contract, obligation or agreement of any kind or description by which they shall bind or shall have bound themselves not to manufacture, sell, dispose of or transport any article or commodity or article of trade, use, merchandise or consumption below a common standard figure, or by which they shall agree, in any manner, to keep the price of such article, commodity or transportation at a fixed or graduated figure, or by which they shall, in any manner, establish or settle the price of any article, commodity or transportation between themselves and others so as to preclude 
free and unrestricted competition among themselves and others in the sale and transportation of any such article or commodity, or by which they shall agree to pool, combine or unite in any interest they may have in connection with the same or transportation of any such article or commodity that its price may, in any manner, be so affected.

SEc. 5. That each day any of the persons, associations or corporations aforesaid shall be engaged in violating the provisions of this act shall be held to be a separate offence. 


\title{
APPENDIX L. \\ EXPEDITING ACT OF IgIO.
}

\author{
[36 Stat., 854.]
}

\begin{abstract}
AN ACT to amend an act, entitled "An act to expedite the hearing and determination of suits in equity pending or hereafter brought under the Act of July second, eighteen hundred and ninety, entitled 'An act to protect trade and commerce against unlawful restraints and monopolies,' 'An act to regulate commerce,' approved February fourth, eighteen hundred and eighty-seven, or any other acts having a like purpose that may be hereafter enacted," approved February eleventh, nineteen hundred and three.
\end{abstract}

Be it enacted by the Senate and House of Representatives of the United States of America in Congress assembled, That Section one of the act entitled "An act to expedite the hearing and determination of suits in equity pending or hereafter brought under the Act of July second, eighteen hundred and ninety, entitled 'An act to protect trade and commerce against unlawful restraints and monopolies,' 'An act to regulate commerce,' approved February fourth, eighteen hundred and eighty-seven, or any other acts having a like purpose that may be hereafter enacted," approved February eleventh, nineteen hundred and three, be, and the same is hereby amended so as to read as follows:

"That in any suit in equity pending or hereafter brought in any circuit court of the United States under the act entitled 'An act to protect trade and commerce against unlawful restraints and monopolies,' approved July second, eighteen hundred and ninety, 'An act to regulate commerce, approved February fourth, eighteen hundred and eighty-seven, or any other acts having a like purpose that hereafter may be enacted, wherein the United States is complainant, the Attorney General may file with the clerk of such court a certificate that, in his opinion, the case is of general public importance, a copy of which shall be immediately furnished by such clerk to each of the circuit judges of the circuit in which the case is pending. Thereupon such case shall be given precedence over others and in every way expedited, and be assigned for hearing at the earliest practicable day, before not less than three of the circuit judges of said court, if there be 
three or more; and if there be not more than two circuit judges, then before them and such district judge as they may select; or, in case the full court shall not at any time be made up by reason of the necessary absence or disqualification of one or more of the said circuit judges, the justice of the Supreme Court assigned to that circuit or the other circuit judge or judges may designate a district judge or judges within the circuit who shall be competent to sit in said court at the hearing of said suit. In the event the judges sitting in such case shall be equally divided in opinion as to the decision or disposition of said cause, or in the event that a majority of said judges shall be unable to agree upon the judgment, order, or decree finally disposing of said case in said court which should be entered in said cause, then they shall immediately certify that fact to the Chief Justice of the United States, who shall at once designate and appoint some circuit judge to sit with said judges and to assist in determining said cause. Such order of the chief justice shall be immediately transmitted to the clerk of the circuit court in which said cause is pending, and shall be entered upon the minutes of said court. Thereupon said cause shall at once be set down for reargument and the parties thereto notified in writing by the clerk of said court of the action of the court and the date fixed for the reargument thereof. The provisions of this section shall apply to all causes and proceedings in all courts now pending, or which may hereafter be brought.

Approved, June 25, 1910. 


\section{APPENDIX M.}

\section{CONTROL OF CORPORATIONS, PERSONS, AND FIRMS ENGAGED IN INTERSTATE COMMERCE.}

[Senate Report No. I326, Sixty-second Congress, third session; ordered to be printed, February 26, 1913.]

Mr. Cummins, from the Committee on Interstate Commerce, submitted the following report of the committee:

The Committee on Interstate Commerce, to which was referred the following resolution:

Resolved, That the Committee on Interstate Commerce is hereby authorized and directed, by subcommittee or otherwise, to inquire into and report to the Senate at the earliest date practicable what changes are necessary or desirable in the laws of the United States relating to the creation and control of corporations engaged in interstate commerce, and what changes are necessary or desirable in the laws of the United States relating to persons or firms engaged in interstate commerce, and for this purpose they are authorized to sit during the sessions or recesses of Congress, at such times and places as they may deem desirable or practicable; to send for persons and papers, to administer oaths, to summon and compel the attendance of witnesses, to conduct hearings and have reports of same printed for use, and to employ such clerks, stenographers, and other assistants as shall be necessary, and any expense in connection with such inquiry shall be paid out of the contingent fund of the Senate upon vouchers to be approved by the chairman of the committee.

begs leave to make the following report:

On the 26th day of July, I9II, the Senate adopted the foregoing resolution, and acting under the authority and in pursuance thereof the Committee on Interstate Commerce provided for open hearings upon the subject matter of the resolution. The hearings began on the I5th day of November, I9II, and were continued from day to day for more than three months, during which time IO3 men appeared before the committee, and their statements, together with the exhibits and documents submitted by them, fill 2,799 printed pages. A printed copy of these statements, exhibits, and documents, including an index, laws and reference concerning industrial combinations in foreign countries and a collection of judicial decisions touching the power of Congress in the regu- 
lation of commerce among the States, in all, five volumes, is herewith presented to the Senate.

While the committee is conscious that some of the matter adduced at the hearings and submitted as a part of this report is not relevant to the questions under consideration and of little worth, it believes that, upon the whole, the hearings have furnished one of the most valuable contributions that can be found in the literature of the subject. It is not yet ready to report any of the bills which are now before it, and which propose specific modifications of or additions to the existing statute; nor is it prepared at this time to report a substitute for them. It hopes that it may be able before the close of the present session to act finally upon these bills and recommend in definite form the legislation which it may think necessary or wise to meet modern business conditions. It is, however, prepared to answer the general inquiries propounded in the resolution, and in view of the overwhelming importance of the subject it ventures to add to the direct response some observations upon the origin, purpose, and effect of the enactment commonly known as the Anti-trust law, to indicate wherein it is inadequate, and to suggest the general scope of further regulation.

The committee is of the opinion:

First. That the statute should stand as the fundamental law upon the subject, and that any supplemental legislation for more effectual control and regulation of interstate and foreign commerce should be in harmony with the purpose of the existing statute.

Second. That whatever may be our views respecting the power of Congress to enact a general Federal incorporation law, it is neither necessary nor desirable at this time to provide for the organization under act of Congress of industrial corporations which propose to engage in commerce among the States and with foreign nations.

Third. That it is desirable to impose upon corporations now or hereafter organized under State law, and engaged or proposing to engage in such commerce, further conditions or regulations affecting both their organization and the conduct of their business, and also to impose further conditions or regulations upon persons, copartnerships, and other associations now engaged, or hereafter engaging, in such commerce, the general character of 
such regulation to be the same as those laid upon corporations, except such conditions or regulations as are in their very nature peculiar to the corporate form of commercial activity.

It is plain that the first question to be answered in considering what additional legislation upon the subject is necessary or desirable is a vital one, it is this: Should Congress attempt to maintain competitive conditions in the general interstate commerce of the country, where they still exist, and to restore such conditions where they have been destroyed, or should it accept the complete or partial overthrow of competition and resort to some other method of protecting the people against the power of combination and monopoly?

Without doubt the chief if not the only object in mind, when the Anti-trust law was passed, was to maintain competition as an effective regulating force in business by making it unlawful to enter into any contract or combination in restraint of trade or commerce among the States or with foreign nations, or to monopolize, or attempt to monopolize, such trade or commerce. The bill introduced by Senator Sherman, out of which the present statute grew, was in terms directed against the suppression of competition. After a long debate and much reflection the Judiciary Committee of the Senate reported a substitute in which "restraint of trade" was the thing forbidden instead of interference with competition. This was accepted not because there was any abandonment of the desire to preserve competition, but because there was a common law on the subject well established and carefully elucidated in the English decisions. The common law was that both contracts and acts in restraint of trade were injurious to the public welfare and therefore opposed to public policy. The Congress of $1890^{\circ}$ very wisely borrowed the language of the common law and with it came the learning of the judges, who had from time to time declared and expounded it. It is not the purpose of the committee to recite the development of the English doctrine. It was not always stated with exact accuracy and there is some inharmony of expression, but it may be said with confidence that a restraint of trade consisted of such unreasonable restriction of competition as impaired substantially, and to the public injury, the freedom of trade or the freedom to trade. Interference with free competition was generally but not necessarily a restraint of trade, for there were some restrictions 
that could be put upon competition and upon competitors that left the competitive force as an adequate protection to the people. Hence the common law was that unreasonable, unfair, undue restraint upon or interference with competition or competitive conditions constituted a restraint of trade.

The committee has made this comment upon the common law, and pointed out the distinction between "restraint of competition" and "restraint of trade" in order that it may be fully understood in its analysis of the conflict between the earlier and later opinions of the Supreme Court of the United States relating to the construction and application of the Anti-trust statute.

The committee will not at this time enter upon an extended argument respecting the policy of maintaining competition or competitive conditions in the business of the country. It is well understood that there are many distinguished students and highly trained thinkers who believe that the age of competition is past, and that for the struggle which competition involves there should be substituted combination and co-operation, under such regulation and supervision as will protect the people from the oppression of monopolistic power, and added to the students and thinkers who have reached this conclusion through mere observation and investigation there are many men engaged in commerce, and who therefore speak from a practical standpoint, who have also concluded that some form of regulated monopoly or concentration should be adopted. All these men, whether theorists or otherwise, admit that if we abandon the effort to maintain competition the government must undertake, directly or indirectly, to fix prices for the combinations or monopolies. The committee feels that the time has not yet come for so radical a departure from the long-established policy of the country, and it hopes that the time may never come when it will be necessary for the government to assume the task of establishing prices for general commodities. It believes that the progress of the world depends in a large measure upon that fair, reasonable rivalry among men which has hitherto characterized the advances of civilization.

It is frequently declared that the law can not compel men employed in like business to compete with each other. There is a sense in which this is true, but it is only technically true. What is meant when we use the phrase "maintaining competition" is maintaining competitive conditions. We can both create and 
maintain competitive conditions, and, until human nature is revolutionized, when competitive conditions exist there will be actual competition; but if for some extraordinary reason that should fail there will be, at least, a potential competition tending to prevent undue prices and unfair practices. Without going further into the issue between regulated competition and regulated monopoly, the committee reiterates its finding that the Anti-trust statute should stand and that every possible effort to create and preserve competitive conditions should be made.

Assuming, therefore, that Congress should maintain the policy established by the Anti-trust law and should make it more effective by additional legislation, if it be within our power to do so, the committee calls attention to the interpretation which the Supreme Court has given to the statute and to the application of its provisions which that tribunal has made in cases which have come before it for decision. It is not the intent of the committee, in this report, to review the opinions of the Supreme Court one by one, but rather to select certain types which will either demonstrate the wisdom of additional legislation or show that the law is adequate as it is.

The committee selects for the purpose indicated the following cases, all of which arose under the statute now being considered:

United States v. E. C. Knight Co. (156 U. S. 1).

United States v. Trans-Missouri Freight Association (166 U. S. 290).

United States v. Joint Traffic Association (17I U. S. 505).

Hopkins v. United States (171 U. S. 578).

Northern Securities Company v. United States (193 U. S. 197).

Standard Oil Co. v. United States (22I U. S. I).

United States v. American Tobacco Company, (22I U. S. 106).

United States v. Union Pacific Railroad Co. (not yet reported, opinjon delivered Dec. 2, 1912).

The committee does not give a statement of the facts in each of these cases, for to do so would greatly prolong the report, and it will be taken for granted that those who are interested in the subject are already familiar with the facts as they appear in the Supreme Court reports.

The rule of law announced in United States v. Knight Co. and in Hopkins v. United States is that a restraint of trade however unreasonable is not prohibited by the Anti-trust statute, no matter how general or disastrous the interference or restraint may be upon commerce among the States unless it directly affects such 
commerce. There is a general understanding among the judges and lawyers of the country that the Knight case has bcen overruled or modified in subsequent decisions. Undoubtedly it can be fairly inferred from the recent opinions of the court in like cases that, if the facts of the case were now presented, it would be held that the restraint was direct; but the rule of law established has never been questioned by the court and has been emphatically reasserted in every prominent opinion hitherto rendered. The committee does not bring these cases forward for the purpose of disputing the soundness of the rule under existing legislation. Its object is to disclose, as clearly as possible, the scope of judicial discretion, and therefore of business uncertainty which it creates. In every prosecution under the act wherein there is proven or admitted a contract or combination which restrains trade among the States, the first thing that the court must ascertain and declare is whether the restraint is direct or indirect. In the Knight and Hopkins cases, and others of that type, it was held to be indirect. In the Northern Securities Co., Standard Oil Co., and American Tobacco Co. cases it was held to be direct. It is obvious that the opinion of any given man in any given case upon this question, whether he be judge or not, must depend largely, not upon his learning in the law but upon his training and bent in the economy of commerce. The result has been, and necessarily will be, that the law officer of the government before he institutes a prosecution must determine whether the restraint is direct and immediate, and the court in order to decide the issue must employ the functions of the legislator rather than the lawyer.

The consequence is twofold: First, the Department of Justice will ignore a great many unlawful transactions because there will be doubt as to whether the interference with interstate or international trade is direct or indirect; second, the business community has found itself, and will find itself in a state of uncertainty as to whether a particular transaction is to be judged by the law of the State or the law of the Nation. It is not claimed that this undefined and undefinable field of judicial discretion can be wholly occupied by legislation, but it is manifest that it is the duty of the legislative branch of the government to circumscribe it within the closest practicable bounds. The committee will recur to this subject in connection with another aspect of the judicial power, and contents itself now with a statement of its 
conclusion that there should be further legislation specifically prohibiting certain forms of association, combination, or monopoly which admittedly restrain trade and commerce among the States and with foreign nations, but which may be held by the courts to be indirect or remote interferences.

The committee has first referred to the point just mentioned, not because it is first in importance, but because it first arose. It now passes to another and more serious weakness in the law as now interpreted.

In the Trans-Missouri Freight Association case there developed a controversy among the members of the Supreme Court that was carried on with unabated vigor through the ${ }_{5} 5$ years intervening between the opinion in the Freight Association case and the opinion in the Standard Oil Co. case. In this period the vicissitudes of life and the changes upon the bench which necessarily ensued converted the opinion of the court in the Freight Association case into a single dissenting opinion in the Standard Oil Co. case, and the dissenting opinion in the former case into the opinion of the court in the latter case. In the Freight Association case Mr. Justice Peckham, in delivering the opinion of the court, said :

Second. The next question to be discussed is as to what is the true construction of the statute, assuming that it applies to common carriers by railroad. What is the meaning of the language as used in the statute that "every contract, combination in the form of trust or otherwise, or conspiracy in restraint of trade or commerce among the several States or with foreign nations, is hereby declared to be illegal"? Is it confined to a contract or combination which is only in unreasonable restraint of trade or commerce, or does it include what the language of the act plainly and in terms covers, all contracts of that nature (p. 327)?

The learned justice answered the question thus propounded many times and in great variety of phrase in the course of the opinion, and the committee quotes some of these answers.

When, therefore, the body of an act pronounces as illegal every contract or combination in restraint of trade or commerce among the several States, etc., the plain and ordinary meaning of such language is not limited to that kind of contract alone which is in unreasonable restraint of trade, but all contracts are included in such language, and no exception or limitation can be added without placing in the act that which has been omitted by Congress (p. 328).

But we can not see how the statute can be limited, as it has been by the courts below, without reading into its text an exception which alters the 
natural meaning of the language used, and that, too, upon a most material point, and where no sufficient reason is shown for believing that such alteration would make the statute more in accord with the intent of the lawmaking body that enacted it (p. 329).

"The arguments which have been addressed to us against the inclusion of all contracts in restraint of trade, as provided for by the language of the act, have been based upon the alleged presumption that Congress, notwithstanding the language of the act, could not have intended to embrace all contracts, but only such contracts as were in unreasonable restraint of trade. Under these circumstances we are, therefore, asked to hold that the act of Congress excepts contracts which are not in unreasonable restraint of trade, and which only keep rates up to a reasonable price, notwithstanding the language of the act makes no such exception. In other words, we are asked to read into the act by way of judicial legislation an exception that is not placed there by the law-making branch of the government, and this is to be done upon the theory that the impolicy of such legislation is so clear that it can not be supposed that Congress intended the natural import of the language used. This we can not and ought not to do (p. 340).

"The conclusion which we have drawn from the examination above made into the question before us is that the Anti-trust act applies to railroads, and that it renders illegal all agreements which are in restraint of trade or commerce as we have above defined that expression, and the question then arises whether the agreement before us is of that nature" (p. 34I).

The issue was clearly joined by Mr. Justice White (now Chief Justice), who in his dissenting opinion, in which Justices Field, Gray, and Shiras concurred, thus stated the question:

"To state the proposition in the form in which it was earnestly pressed in the argument at bar, it is as follows: Congress has said every contract in restraint of trade is illegal. When the law says every, there is no power in the courts, if they correctly interpret and apply the statute, to substitute the word 'some' for the word 'every.' If Congress had meant to forbid only restraints of trade which were unreasonable it would have said so; instead of doing this it has said 'every,' and this word of universality embraces both contracts which are reasonable and unreasonable" (p. 345).

The distinguished justice begins his answer to the proposition just quoted as follows:

I commence, then, with these two conceded propositions, one of law and the other of fact, first that only such contracts as unreasonably restrain trade are violative of the general law, and, second, that the particular contract here under consideration is reasonable, and therefore not unlawful if the general principles of law are to be applied to it (p. 344). 


\section{Again :}

Its title is "An act to protect trade and commerce against unlawful restraints and monopolies." The word "unlawful" clearly distinguishes between contracts in restraint of trade which are lawful and those which are not. In other words, between those which are unreasonably in restraint of trade, and consequently invalid, and those which are reasonable and hence lawful (p. 352).

\section{Again :}

If these obvious rules of interpretation be applied, it seems to me they render it impossible to construe the words "every restraint of trade" used in the act in any other sense than as excluding reasonable contracts, as the fact that such contracts were not considered to be within the rule of contracts in restraint of trade was thoroughly established both in England and in this country at the time the act was adopted (p. 354).

\section{Again:}

Indeed, it seems to me there can be no doubt that reasonable contracts can not be embraced within the provisions of the statute if it be interpreted by the light of the supreme command that the intention of the law must be carried out, and it must be so construed as to afford the remedy and frustrate the wrong contemplated by its enactment (p. 355).

It will be noted that but once in the dissenting opinions is the word "unreasonable" used to qualify the phrase "in restraint of trade." It is generally employed to qualify the word "contract." There is some difference between saying that there may be a reasonable interference with competition or freedom in trade or freedom to trade which did not, at the common law, constitute a restraint of trade, and saying that there can be, under our statute, a reasonable restraint of trade. But this was only the beginning.

Two years later the suit of the United States v. Joint Traffic Association came on for decision. Again Mr. Justice Peckham delivered the opinion of the court, and upon the point we are considering there seems to have been no change in the attitude of the members of the court toward it. It is instructive to observe, however, that in referring to Hopkins v. The United States, in which the opinion was handed down at the same term, the learned justice said:

In Hopkins v. The United States, decided at this term, post 578 , we say that the statute applies only to those contracts whose direct and immediate effect is a restraint upon interstate commerce *** the effect upon interstate commerce must not be indirect or incidental only (p. 568). 
Five years thereafter the well-known Northern Securities case was decided, and the struggle was renewed with intense earnestness. Mr. Justice Harlan rendered the opinion of the court, and this is the way he stated the question:

Is the act to be construed as forbidding every combination or conspiracy in restraint of trade or commerce among the States or with foreign nations? Or does it embrace only such restraints as are unreasonable in their nature? Is the motive with which a forbidden combination or conspiracy is formed at all material when it appears that the necessary tendency of that particular combination or conspiracy in question is to restrict or suppress free competition between competing railroads engaged in commerce among the States? Does the act of Congress prescribe, as a rule for interstate or international commerce, that the operation of the natural laws of competition between those engaged in such commerce shall not be restricted or interfered with by any contract, combination, or conspiracy (p. 328)?

In answering the question he probably goes a little further than Justice Peckham. He states as the conclusion to be drawn from former opinions of the courts :

That the act is not limited to restraints of interstate and international trade or commerce that are unreasonable in their nature, but embraces all direct restraints imposed by any combination, conspiracy, or monopoly upon such trade or commerce; ***. That every combination or conspiracy which would extinguish competition between otherwise competing railroads engaged in interstate trade or commerce, and which would in that way restrain such trade or commerce, is made illegal by the act; $* * *$. That to vitiate the combination, such as the act of Congress condemns, it need not be shown that the combination in fact results or will result in a total suppression of trade or in a complete monopoly, but it is only essential to show that by its necessary operation it tends to restrain interstate or international trade or commerce or tends to create a monopoly in such trade or commerce and to deprive the public of the advantages that flow from free competition (p. 331).

Whether the free operation of the normal laws of competition is a wise and wholesome rule for trade and commerce is an economic question which this court need not consider or determine. Undoubtedly there are those who think that the general business interest and prosperity of the country will be best promoted if the rule of competition is not applied. But there are others who believe that such a rule is more necessary in these days of enormous wealth than it ever was in any former period of our history. Be all this as it may, Congress has in effect recognized the rule of free competition by declaring illegal every combination or conspiracy in restraint of interstate and international commerce (p. 337).

Mr. Justice Brewer was with the majority of the court in the Trans-Missouri Association case, and he concurred in the de- 
cision in the Northern Securities Co. case; but upon the question we are discussing he rejected the reasoning of Justice Harlan and adopted the views expressed by Justice White in the former case. He said :

Instead of holding that the Anti-trust act includes all contracts, reasonable or unreasonable, in restraint of interstate trade, the ruling should have been that the contracts there presented were unreasonable restraints of interstate trade, and as such within the scope of the act. That act, as it appears from its title, was leveled at only "unlawful restraints and monopolies." Congress did not intend to reach and destroy those minor contracts in partial restraint of trade which the long course of decision at common law had affirmed were reasonable and ought to be upheld. The purpose rather was to place a statutory prohibition with prescribed penalties and remedies upon those contracts which were in direct restraint of trade, unreasonable, and against public policy. Whenever a departure from common-law rules and definitions is claimed, the purpose to make the departure should be clearly shown. Such a purpose does not appear and such a departure was not intended (p. 361).

The Chief Justice and Justices White, Peckham, and Holmes dissented. Justice White, while discussing many phases of the relation between the general and the State governments, finally rested his opinion upon the Knight case, holding that there was no direct restraint of interstate commerce. Justice Holmes, while concurring with Justice White, took occasion to say, in substance, that the method adopted by the defendants for the suppression of competition did not constitute a restraint of trade in the sense of the Anti-trust law.

With the Northern Securities case there terminated one distinct, striking period in the interpretation and application of the Anti-trust statute. It is needless to inquire at length whether or not the views of the court, as expressed in the opinions of Justices Peckham and Harlan, were in exact harmony with the common law as to the meaning or definition of the phrase "restraint of trade." Even if these learned judges were not quite successful in distinguishing the difference, at the common law, between a restraint of competition and a restraint of trade, it still remains true that for more than 13 years repeated decisions of the highest tribunal of the country had declared that every contract or combination which prevented free competition was a restraint of trade, and that, if the restraint directly affected commerce among the States, then the contract or combination was unlawful, under the first section of the act. 
Inasmuch as the committee is of opinion that legislation should be so clear in its terms as not to admit of unlimited judicial discretion, it pauses here a moment to point out just what the range of discretion was under the decisions ending with the Northern Securities case. It is manifest that the inquiry that the court was then required to make in each case was this: Has the evidence established a restraint of trade; that is to say, has the evidence established a contract or combination which interfered with free competition?

There was some, but not great latitude for difference of opinion upon such an inquiry, and the uncertainty in the application of the law was reduced to a minimum; nor would the uncertainty have been much increased if the inquiry had been as to an unreasonable interference with free competition, which would have been the inquiry had the common-law understanding been strictly adopted by the Supreme Court.

If the more recent construction of the statute were in harmony with the earlier decisions, further legislation might nevertheless be required; but it is unnecessary to make the inquiry. That question is purely academic, for the later rulings have completely reversed the former ones, in so far as the phase of the subject now being discussed is concerned.

On the I5th day of May, I9II, the case of the Standard Oil Co. v. The United States was passed upon by the Supreme Court. Chief Justice White (formerly Justice White) delivered the opinion and reiterated, as the conclusion of the court, the views that he had so forcibly urged as a dissenter I 5 years before. It was not necessary for the court to deal with the question at all, inasmuch as it found the defendants guilty of a restraint of tradc under any and every meaning of the term, but for the very purpose, the committee assumes, of advising the country that a new rule had been adopted so that business might be guided by it, it was stated in the most emphatic way imaginable that the statute which declares that "Every contract, combination in the form of trust or otherwise, or conspiracy in restraint of trade or commerce among the several States or with foreign nations is hereby declared to be illegal" means that a contract or combination in order to be illegal must cause an undue restraint of trade. The following quotations from the opinion will need no comment:

That in view of the many new forms of contracts and combinations which were being evolved from existing economic conditions, it was 
deemed essential by an all-embracing enumeration to make sure that no form of contract or combination by which an undue restraint of interstate or foreign commerce was brought about could save such restraint from condemnation. The statute under this view evidenced the intent not to restrain the right to make and enforce contracts, whether resulting from combination or otherwise, which did not unduly restrain interstate or foreign commerce, but to protect that commerce from being restrained by methods, whether old or new, which would constitute an interference that is an undue restraint (pp. 59,60).

\section{Again :}

In other words, having by the first section forbidden all means of monopolizing trade-that is, unduly restraining it by means of every contract, combination, etc.-the second section seeks, if possible, to make the prohibitions of the act all the more complete and perfect by embracing all attempts to reach the end prohibited by the first section (p. 6I).

That the Chief Justice intended to announce a rule at variance with the declarations of Justice Peckham and Justice Harlan in the Trans-Missouri Freight Association and Northern Securities cases is made clear in the following extracts:

The question is pertinent and must be fully and frankly met, for if it be now deemed that the Freight Association case was mistakenly decided or too broadly stated, the doctrine which it announced should be either expressly overruled or limited. * * * And in order not in the slightest degree to be wanting in frankness, we say that in so far, however, as by separating the general language used in the opinion in the Freight Association and Joint Traffic cases from the context and the subject and parties with which the cases were concerned, it may be conceived that the referred to conflicts with the construction which we give the statute, they are necessarily now limited and qualified (pp. 68, 69).

The learned Chief Justice contends that this rule of construction, which he repeatedly calls the "rule of reason," must be applied in order to prevent the entire overthrow of the statute.

It is one of the interesting things in our judicial history that so great had been the change in the personnel of the court that when the dissenting opinion of Justice White in 1896 became the opinion of the court in I9I I Justice Harlan was the only member remaining to protest against the reversal. He recorded his dissent in one of the most vigorous opinions that can be found in the reports, but for the purposes which the committee has in view it is not necessary to do more than to mention it.

Justice Harlan has passed away, and it may be assumed that the Supreme Court is now unanimously in favor of the doctrine 
so often and so ably promulgated by Chief Justice White. The rule was reasserted in the American Tobacco Co. case and has not since been questioned by any member of the court.

It is true that in the important opinion rendered in the suit of the United States v. The Union Pacific Railroad Co., Justice Day says :

The act is intended to reach combinations and conspiracies which restrain freedom of action in interstate trade and commerce and unduly suppress or restrict the play of competition in the conduct thereof-

Citing as authority the Joint Traffic Association case.

It is true also that the court quotes, with apparent approval, the following extract from Mr. Justice Harlan in the Northern Securities case :

In all the prior cases in this court the Anti-trust act has been considered as forbidding any combination which by its necessary operation destroys or restrains free competition among those engaged in interstate commerce; in other words, that to destroy or restrict free competition in interstate commerce was to restrain such commerce.

\section{But thereafter the court says :}

In the recent discussion of the history of the meaning of the act in the Standard Oil Co. and Tobacco Co. cases this court declared that the statute should be given a reasonable construction with a view to reaching those undue restraints of interstate trade which are intended to be prohibited and punished.

The fair conclusion is that it is now the settled doctrine of the Supreme Court that only undue or unreasonable restraints of trade are made unlawful by the Anti-trust act, and that in each instance it is for the court to determine whether the established restraint of trade is a due restraint or an undue restraint.

Whatever may be the opinion of the several members of the committee with respect to the soundness of the rule as now established, the committee as a whole accepts it as the present law of the land. It is profoundly convinced that, in view of the rule and its necessary effect upon the business of the country, the inherent rights of the people, and upon the execution of the statute it has become imperative to enact additional legislation.

The committee has full confidence in the integrity, intelligence, and patriotism of the Supreme Court of the United States, but it is unwilling to repose in that court, or any other court, the vast 
and undefined power which it must exercise in the administration of the statute under the rule which it has promulgated. It substitutes the court in the place of Congress, for whenever the rule is invoked the court does not administer the law, but makes the law. If it continues in force, the Federal courts will, so far as restraint of trade is concerned, make a common law for the United States just as the English courts have made a common law for England.

The people of this country will not permit the courts to declare a policy for them with respect to this subject. If we do not promptly exercise our legislative power, the courts will suffer immeasurable injury in the loss of that respect and confidence so essential to their usefulness. It is inconceivable that in a country governed by a written Constitution and statute law the courts can be permitted to test each restraint of trade by the economic standard which the individual members of the court may happen to approve. If we do not speedily prescribe in so far as we can a legislative rule by which to measure the forms of contract and combination in restraint of trade with which we are familiar or which we can anticipate, we cease to be a government of law and become a government of men, and, moreover, of a very few men, and they appointed by the President.

It may be that the Supreme Court will be so enlightened and so alert that its opinion respecting what is due and what is undue restraint of trade will be in harmony with an awakened public conscience and a disinterested public judgment, but to fashion our conduct upon that hypothesis is to repudiate the fundamental principles of representative government.

When the commercial development of the country is considered, when the forms of industrial activity are taken into account, it must be admitted by every student of affairs that the policy of the government with respect to restraints of trade and commerce should remain a judicial question in those cases only in which Congress can not prescribe a definite rule.

In order to look at the subject in the light of illustration, it is suggested that there will presently come before the courts the combination centered in the United States Steel Corporation. In the end nine justices of the Supreme Court will be asked to say whether the restraint of trade brought about through this combination is a due or an undue restraint, and the answer which 
each justice makes to that question will depend upon his individual opinion as an economist or sociologist, the conclusion of the court being in substance an act of legislation passed by the judicial branch of the government to fit a particular case.

Further, it is believed by many thoughtful people that a substantial identity in the managing boards of competing corporations constitutes a restraint of trade and is harmful to the public interest. If such a case were brought before the court, what would be the "rule of reason"? What guide would the court have in determining whether such community of directors or managers was a due or an undue restraint of trade?

Again, suppose there were a dozen establishments in a given field of production competing with each other and six of them were to consolidate, employing half of all the capital and advancing the consolidated enterprise to a dominating position in the trade, where would the judge go for light in determining whether the restraint of trade was due or undue? These illustrations might be indefinitely extended, but it would serve no useful purpose to multiply them.

The committee does not intend in this report to indicate the terms of the act or acts that should be passed to supply the court with such legislative tests and standards as will limit the scope of judicial discretion. To do so would be to report upon the bills now before it, and that the committee is not prepared to do. It is prepared, however, to say that Congress should, in as far as is possible, specifically prescribe certain conditions upon which persons and corporations shall be permitted to engage in commerce among the States and with foreign nations. These conditions should be of a character that will tend to preserve reasonable competition, or substantially competitive conditions, and to con1pel independence in both organization and conduct. They should be so clear that the business world can understand them and go confidently forward, guided by them.

Not only should such conditions be imposed upon those who are engaged or propose to engage in commerce among the States, but our legislation should further recite certain known form of combination and declare them to be unlawful because in restraint of trade. With respect to other forms, we should declare that if restraint is established the burden of proof is upon the persons or corporations involved to show that the restraint is reasonable. 
These suggestions are not made solely for the better protection of that general body of our citizens, commonly called the people, who must deal with, buy from and sell to the combinations sought to be regulated, but are made also in the interest of safety and certainty for the men who compose what is ordinarily known as the business community.

There are many forms of combination, and many practices in business which have been so unequivocally condemned by the Supreme Court that as to them and their like the statute is so clear that no person can be in any doubt respecting what is lawful and what is unlawful; but as the statute is now construed there are many forms of organization, and many other practices that seriously interfere with competition, and are plainly opposed to the public welfare, concerning which it is impossible to predict with any certainty whether they will be held to be due or undue restraints of trade.

The committee does not conceal the difficulty of reaching an agreement concerning the details of the legislation just outlined, but it has no hesitation in reporting that legislation of the general character pointed out is both wise and necessary.

The committee further reports that if the additional legislation, the general scope of which has been pointed out, is enacted it will be very desirable to accompany such legislation with a measure establishing a commission for the better administration of the law and to aid in its enforcement. It may be fairly said that there is need of such a commission, even though the present statute is not supplemented in any manner; but it is apparent that if the new legislation is enacted the need of a commission will become more imperative.

There are three general fields in which the commission could work to the great advantage both of the people for whose protection the law exists and the people against whom it is directed.

First. If the Bureau of Corporations were converted into an independent commission composed of trained, skillful men, and clothed with adequate authority, there could be gathered more complete and accurate knowledge of the organization, management, and practices of the corporations and associations engaged in national and international commerce than we now have. In saying this the committee does not mean to disparage the work of the Bureau of Corporations as hitherto carried on, but, valuable 
as the work has been, it is believed that a greater service could be rendered by a commission with a distinct organization with adequate appropriations and added authority. Moreover, it is clear that the constant inquiry into and investigation of interstate commerce in order to ascertain whether the law is being violated should be more closely connected with prosecutions for violations, when found to exist, than at the present time.

Second. When the conditions upon the fulfillment of which persons and corporations may engage in commerce among the States and with foreign nations are imposed, as the committee has heretofore recommended, there will be some of them upon which the government must act with administrative promptness rather than with judicial deliberation and delay. For instance, suppose Congress were to declare, as the committee thinks it ought to declare, that no corporation should be permitted to engage in interstate or international commerce unless it be honestly capitalized, and that when anything but money is accepted for its stock that the value at which the property is so taken must be its fair, reasonable value. It seems clear that a corporation proposing to enter business should have an opportunity to come to some governmental tribunal and say, here is the property purposed to be taken for stock, and here is the price at which it is to be taken, and thereupon ask for approval or disapproval of the proposition. It would be most unjust in such a case to allow the corporation to go on for years and then be told that it must cease to do business because the value of the property was less than the par value of the stock issued for it.

And, again, suppose that to out of 20 manufacturing establishments heretofore in competition with each other desire to consolidate into one enterprise. There ought to be a way in which the men in such a venture could submit their plan to the government and an inquiry made as to the legality of such a transaction, and if the government was of the opinion that competitive conditions would not be substantially impaired there should be an approval, and in so far as the lawfulness of the exact thing proposed is concerned there should be a decision, and if favorable to the proposal there should be an end of that particular controversy for all time. Such results as these can be attained in no other way than through a commission which, though administrative in its character, would, in some instances, exercise quasi judicial func- 
tions. It is believed that through the intervention of such a body of men the legislative policy with respect to combinations and monopolies could be vastly more effectual than through the courts alone, which in most cases will take no cognizance of violations of the law for months or years after the violations occurred and when the difficulty of awarding reparation for the wrong is almost insurmountable.

The committee has not attempted to be comprehensive as to the usefulness of the commission in this field, and has made these suggestions only to indicate in the most general way the assistance that could be rendered in the enforcement of the law.

Third. One of the most serious problems in connection with suits brought under the Anti-trust act is to find the proper method of disintegrating combinations that have been adjudged unlawful. The dissolution of a corporation or a series of associated corporations must often involve the consideration of plans for reorganization in order that the property which has been unlawfully employed may thereafter be lawfully used in commerce. The courts are not fitted for the work of reconstruction, and whatever jurisdiction they now have, or that may hereafter be conferred upon them with respect to such matters, it can not be gainsaid that a commission, the members of which are in close touch with business affairs, and who are intimately acquainted with the commercial situation, might be extremely helpful in the required readjustment.

\section{ADDITIONAL VIEWS OF MR. POMERENE.}

With the report in general I am in accord. But there is one feature of it about which I desire to be more explicit, and that is the paragraph discussing the certainty of the provisions of the Sherman law as applicable to certain cases and its uncertainty as applicable to others.

I approve the view that-

There are many forms of combination and many practices in business which have been so unequivocally condemned by the Supreme Court that as to them and their like the statute is so clear that no person can be in any doubt respecting what is lawful and what is unlawful.

There are other forms of organization and acts which seriously interfere with competition, such as interlocking directories, watering of stock, selling of merchandise in one locality at a less 
price than in another, and other practices which are so contrary to sound business principles and good morals that they can and should be specifically controlled or prohibited by statute. As to these, in the interest of certainty, there should be other and further legislation. But, whatever may be the additional legislation, there will be many other contracts, combinations, and practices in "undue and unreasonable restraint of trade," which it is impossible for Congress to define by statute, because any attempt to so define them will, in practice, be found to exclude many other contracts, combinations, and practices which are equally inimical to the public good. As to these, we must always depend upon the sound wisdom and discretion of courts and juries for relief, just as in the past we have been obliged to trust to their judicial administration.

To illustrate: We know that legislatures and courts have constantly refused to define fraud because the multiplicity of acts and circumstances involved in human affairs make it impossible of definition.

The same may be said with equal truth as to what constitutes "undue or unreasonable restraint of trade."

It is said with a great deal of force that men are not always able to tell in advance whether certain acts are in "undue or unreasonable restraint of trade." But however difficult this may be, it is no reason why they should be left for decision to the selfishness of interested parties uncontrolled by judicial decision under the principles of the common law or under the broad provisions of the Sherman law.

In criminal cases it is often difficult to say in advance whether a given state of facts constitutes a reasonable doubt. But is that a reason why courts and juries should not attempt to say in a specific case whether there was, in fact, a reasonable doubt or not?

In negligence cases it is equally difficult to say whether a given state of facts constitutes contributory negligence on the part of the plaintiff or reasonable care on the part of the defendant. But can this be urged as a reason for not leaving special cases to the judgment of the court and jury?

In my judgment, what is "undue or unreasonable restraint of trade" must, in many cases if not in most cases, be left largely for judicial determination and sound judgment and good morals 
will be a sufficient guide for those who are actuated by a proper public spirit rather than by selfish motives.

While I believe there can be some additional legislation along the lines indicated, I am firmly of the opinion that the Sherman Law is a clear and certain guide for reasonable men who desire to comply with the law and do not exert themselves to evade its provisions.

AtLeE POMERENe.

\section{ADDITIONAL VIEWS OF MR. TILLMAN.}

The undersigned, after carefully considering the Anti-trust statute or Sherman Law, agrees to the first proposition laid down by the committee contained on the second page of this report, and to that portion of the second proposition beginning with the words, "it is neither necessary nor desirable at this time to provide for the organization under act of Congress of industrial corporations which propose to engage in commerce among the States and with foreign nations." It would be unwise for Congress to interfere by Federal corporation acts, and he believes it wiser to leave such things where they now are, to the States.

With the third proposition the undersigned is not now prepared to express concurrence, preferring to wait until the specific conditions and regulations contemplated are presented for decision.

$\mathrm{He}$ assents to the lucid and masterly exposition in the report of the vacillation of the Supreme Court of the United States, which has made the minority opinions of 15 years ago become the majority opinions now. That powerful tribunal has thus reversed the law on a most important question relative to crimes in connection with trusts and monopolies, and instead of a congressional statute we have judge-made law. These opinions ivere rendered in lawsuits of all sorts; and thus made by piecemeal, instead of properly explaining and defining the scope of the Antitrust law, have made it a judicial question to be decided by the judges trying the case, whether a proven destruction of competition operating as a restraint of trade is to be prohibited and punished because contrary to law, or is to be allowed to go unwhipped of justice because the judges think it is not an "unreasonable" crime, but one which may be permitted.

The undersigned agrees that Congress should legislate so as to destroy any such preposterous and dangerous judicial discretion, because such discretion was never contemplated by the Constitution. 
The undersigned is not now prepared to say that a new national commission should be established for the better administration of the Anti-trust law. $\mathrm{He}$ is inclined to believe that we have too many commissions now, composed largely of so-called "lame ducks," both Democrats and Republicans, who have been defeated at the polls and are given these places mainly as a compensation and means of support. He thinks Congress ought to perform its own functions rather than surrender them to commissions thus created by Executive appointment.

$\mathrm{He}$ does not assent to the particular language used on any point in the report of the committee, except where he has specifically so stated.

As the committee is not now ready to propose specific measures of legislation, he prefers to wait and to listen to the recommendations of the incoming President of the United States.

B. R. Tiliman.

\section{ADDITIONAL VIEWS OF MR. GORE.}

I concur in the main body of the report and in the conclusions arrived at, except as to the specific recommendation looking to the establishment of a commission. Upon that recommendation I reserve my judgment for the present. I could not yield my assent to this proposition without first considering both the principles and details of any measure proposing such a commission. My ultimate assent would depend upon the constitution and character of the commission and upon the extent and limitation of its powers and purposes. It may be possible that a commission could with propriety be vested with power to pass upon the form of a proposed organization, but no commission should have authority to grant indulgences as to the methods, conduct, and operations of any such organization.

T. P. GORE.

\section{ADDITIONAL VIEWS OF MR. NEWLANDS.}

Whilst I agree with the general conclusion reached by $\mathrm{Mr}$. Cummins in his report, I have not been able to study with sufficient care the decisions of the Supreme Court relating to the trusts to enable me to form an independent opinion as to his analysis of them. For years I have contended that if at the time the Sherman Act was passed (the date of its passage being almost 
contemporaneous with that of the interstate commerce act regarding the railroads) we had organized an interstate trade commission similar to the Interstate Commerce Commission, and with somewhat similar powers of investigation and correction, we would have prevented or remedied many of the abuses which have since grown up, and that we would have gradually evolved a system of commercial law, through administrative process, as complete as that which has been built up regarding our system of transportation.

I presented my views relating to this matter at the first hearing of this committee regarding the control of corporations on the $4^{\text {th }}$ day of August, I9I I, and on the I6th of November, I9I I (hearings, pp. I to 26, inclusive). I then discussed a bill for the organization of an interstate trade commission (Senate bill No. 294I), which was introduced by me on the $5^{\text {th }}$ of July, I9I I, and a substitute bill of the same number, introduced by 'me August 2I, I9I I

As a result of the additional light shed upon this stubject by the hearings, I introduced in the Senate, on February 26, I912, a bill (Senate bill 5485, 62d Cong., 2d sess.) entitled " $A$ bill to create an Interstate Trade Commission," etc.

Later on, as a result of subsequent consideration, this bill has been amended and $I$ present it with the alterations as a tentative proposal for criticism and suggestion. The bill as amended is annexed hereto.

Whilst I believe that the Sherman Anti-trust Act should not be altered, I believe that it should be supplemented by such legislation as is shown to be necessary by the experience of the time. Such variety of view exists as to what this supplementary legislation shall be that I do not believe early legislation on this line is practicable. But I do believe that all can agree upon an Interstate Trade Commission with powers of investigation and correction, and with the power to aid the courts in the administration of the Sherman Act and other supplementary legislation; and 1 believe that such a commission should be organized immediately, so that Congress can soon have the benefit of the recommendations which it will make as the result of its experience.

I shall not enter into any labored argument upon this question. I shall simply content myself with quoting from previous utterances in the Senate. 
In the Senate, January II, I9I I;

Mr. Neglands. * * * The Railroad Commission bill furnishes a model for the action of Congress upon matters involving minute and scientific investigation. Had we followed the same method regarding trusts that we followed regarding railroads, we would have made much better progress in trust regulation. The Anti-trust act was passed 2I years ago, about the same time that the Railroad Commission was organized. The railroad question is practically settled; the settlement of the trust question has hardly been commenced. Had we submitted the administration of the Anti-trust act to an impartial quasi judicial tribunal similar to the Interstate Commerce Commission instead of to the AttorneyGeneral's office, with its shifting officials, its varying policies, its lack of tradition, record, and precedent, we would by this time have made gratifying progress in the regulation and control of trusts, through the quasi judicial investigations of a competent commission and through legislation based upon its recommendations. As it is with the evasive and shifting incumbency and administration of the Attorney-General's office, oftentimes purely political in character, we find that the trusts are more powerful to-day than when the Anti-trust act was passed, and that evils have grown up so interwoven with the general business of the country as to make men tremble at the consequence of their disruption.

\section{In the Senate, May 16, I9I I :}

Mr. NEWLANdS. Mr. President, whilst I was addresisng the Senate yesterday upon the importance of taking up immediately certain questions upon which public opinion has been formed, and crystallizing them into legislation, I referred, among others, to the great questions of the combinations of capital called trusts which have assumed of late years so powerful and menacing an aspect.

The Supreme Court yesterday acted upon this matter with reference to one of the great trusts in a decision which applies to them all, and, as the result probably of the inertia and the inaction of Congress, has taken upon itself what the dissenting member of that court, Mr. Justice Harlan, declared to be judicial legislation, and has written into the statute words which Congress never put there; and so to-day we have a decision upholding the Anti-trust act so far as it applies to unreasonable restraint of trade.

The question, therefore, presents itself to us whether we are to permit in the future the administration regarding these great combinations to drift practically into the hands of the courts and subject the question as to the reasonableness or unreasonableness of any restraint upon trade imposed by these corporations now existing and to be brought into existence in the future to the varying judgments of different courts upon the facts and the law, or whether we will organize, as the servant of Congress, an administrative tribunal similar to the Interstate Commerce Commission, with powers of recommendation, with powers of condemnation, with 
powers of correction similar to those enjoyed by the Interstate Commerce Commis sion over interstate transportation.

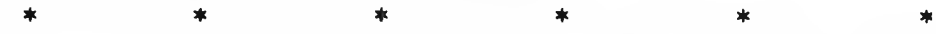

* * * What has been our experience regarding that branch of interstate commerce which covers transportation? Our experience has been that 20 years ago, just about the time the Anti-trust act was passed, Congress passed the Interstate Commerce Act, creating a Commission as its servant to attend to its duties under rules prescribed by Congress. The regulation of interstate commerce belonged to Congress. Congress wisely saw that it could not undertake that regulation in all its details; that it could not pass rate bills which would be satisfactory to every section of the country; that it could not reduce rates that were claimed to be excessive and increase rates that were claimed to be too low; that it could not correct the varying abuses which creep into the administration of every great enterprise. Therefore it created this Commission as its servant, to carry out its will under rules established by it.

The history of the last 23 years proves the wisdom of our action. By a gradual process of evolution this Commission, as the result of gradual improvements in legislation and as the result of constantly increasing powers recommended by it and affirmed by Congress, has become a tribunal second in importance only to the Supreme Court of the land. It has made transportation a science. It has studied all the intricate questions relating to it, and in a recent illuminating decision has formulated a great State paper that has impressed the country and the world with its wisdom.

Now, contrast that action with other action taken by Congress regarding the trusts. It would have been possible 23 years ago, when the Interstate Commerce Act was passed, with reference to interstate trade, to have established an industrial or trade commission or board similar to the Interstate Commerce Commission with reference to transportation. If we had done so and had put upon that Commission the same class of men who have been appointed upon the Interstate Commerce Commission, we would have had the constant corrective power of that Commission applied both to the existing trade corporations and to the trade corporation afterwards created. Many abuses would have been prevented. Many abuses would have been corrected. As a result of the constant study and inquiry of a competent board engaged in this work as a specialization recommendations would have been made to Congress which would have been accepted, as were those recommendations made with reference to interstate transportation, and a great body of administrative law would have been built up and combinations of capital would have been effected without the abuses which have existed during the past 23 years. ***

\section{In the Senate, June 22, I9I I :}

Mr. NEWLANDS. What is the second one which I suggested? I suggested legislation providing, in connection with the Bureau of Corporations, for a board of interstate trade, with powers of examination, correction, and recommendation with regard to interstate trade similar to those conferred upon the Interstate Commerce Commission regarding in- 
terstate transportation. This resolution was offered before the recent decision of the Supreme Court regarding the trusts, and I then declared that, whatever might be the decision of that court, the creation of such a Commission was essential. Interstate trade is just as much a part of interstate commerce as interstate transportation. The abuses of interstate trade have become just as great as the abuses of interstate transportation in the past have been. Obviously the teachings of experience lead us to the organization of a Commission or board similar to the Interstate Commerce Commission, with a view of taking hold of the great combinations of capital and making them obedient to the law, giving such a Commission powers of examination, recommendation, and condemnation similar to those enjoyed by the Interstate Commerce Commission.

Since that decision the trust managers themselves have seen a great light, and in public examinations have stated that in their judgment the time has come for as complete regulation of corporations engaged in interstate trade as of corporations engaged in interstate transportation. Whether that regulation will ever extend so far as the regulation of the price itself is a matter to be determined in the future, for Congress will be called upon to decide how great these corporations shall be, what the extent of their capital shall be, what number of plants they shall own, and what shall be the extent of their operations. If they conclude to maintain the principle of competition, even though it leads to destruction, there will then, of course, be no necessity of regulating prices. But if they recognize the principle of helpful co-operation instead of destructive competition, then it will be necessary for them in extreme cases to face the question of the regulation of prices just as the prices of any public utility are regulated.

I do not venture to express an opinion now as to what course should be pursued with reference to this great question, but it is time that the Interstate Commerce Committee of the Senate were entering upon an inquiry of the most important question in economics that has engaged the attention of the country since the railroad question was first presented to it.

Quotation from Mr. Newlands's statement before the committee on the I $5^{\text {th }}$ day of November, I9I I (hearings, P. 25) :

I may later on have something further to lay before this committee regarding this bill; but I wish to state at present that since the bill was introduced there has been a wide discussion throughout the country upon two divergent lines of thought, one insisting upon absolutely free and unrestricted competition as the regulator of corporate business, and the other inclining toward allowing large combinations of capital and applying thereto government supervision and direction as the prime regulator. It is difficult to say now which of these opposing tendencies should or will ultimately prevail. The bill which I have introduced is, in my judgment, adapted to this undeveloped situation. It will help us to determine which of these theories is the correct one; it will furnish to Congress and to the public the accurate and broad information on corporate conditions that is 
necessary to determine the line of further advance. It does not affect the operation or the enforcement of the Sherman Law; its work of publicity and supervision will tend to promote fair competition and keep equally open to all the highways of commerce. On the other hand, it takes the situation as it is, recognizes that there is a large degree of combination already existing, and makes that condition a subject for supervision, study, and report to Congress. Its frankly tentative character and its moderation recommend it as a step upon which all can unite in doing what is imperatively needed for the present, without prejudicing the future.

I trust that the committee will see the wisdom, without waiting for the end of this investigation, of recommending this tentative measure, which will aid in the final solution of all the pressing questions relating to trade corporations.

\section{APPENDIX TO REPORT OF COMMITTEE.}

The following is the Interstate Trade Commission bill as introduced by Senator Newlands and tentatively amended by the Senate Committee on Interstate Commerce:

\section{[S. 5485, Sixty-second Congress, second session.]}

A BIL, To create an Interstate Trade Commission, to define its powers and duties, and for other purposes.

Be it enacted by the Senate and House of Representative of the United States of America in Congress assembled, That this act shall be referred to and cited as the Interstate Trade Commission Act. Corporations a majority of whose voting securities is held or owned by any corporation subject to the terms of this act are referred to herein as subsidiaries of such holding or owning corporation.

SEc. 2. That there is hereby created a body to be known as the Interstate Trade Commission, which shall consist of three members, of whom no more than one two shall belong to the same political party. The Commission shall be appointed by the President, by and with the arvice and consent of the Senate, and the terms of such commissioners so first appointed shall be three, siz, and nine years, respectively, and shall be so designated by the President in making such appointments; and thereafter all the commissioners shall hold office for the term of nine years, and shall be appointed by the President, by and with the advice and consent of the Senate. Vacancies shall be filled by like appointment and confirmation for the unexpired term. Each member of said Commission shall receive a salary of $\$ 10,000$ a year. The office of the Commission shall be at Washington, in the District of Columbia, but the Commission may hold meetings elsewhere when necessary and convenient.

SEC. 3. That the Bureau of Corporations is hereby transferred to and merged in said Commission, and all of the powers, duties, records, papers, and funds belonging or pertaining to the Bureau of Corporations shall hereafter belong and pertain to the Interstate Trade Commission, and all 
the officers and employees of said bureau shall thereupon be officers and employees of the Interstate Trade Commission. The said Commission shall also have a secretary, a chief clerk, and such clerks, inspectors, examiners, experts, messengers, and other assistants as from time to time may be necessary and as may be appropriated for by Congress.

SEC. 4. That all corporations engaged in commerce among the several States or with foreign nations, excepting common carriers, shall from time to time furnish to the Commission such information, statement, and records of their organization, business, financial condition, conduct, and management and the organization, business, financial condition, conduct, and management of their subsidiaries at such time, to such degree and extent, and in such form as may be prescribed by the Commission; and the Commission at all reasonable times, or its duly authorized agent or agents, shall have complete access to all records, accounts, minutes, books, and papers of such corporations and their subsidiaries, including the records of any of their executive or other committees. Failure or neglect on the part of any corporation subject to this act, or of any of its subsidiaries, to comply with the terms of this section within such time after written demand shall have been made upon such corporation by the Commission requiring such compliance, as shall be fixed by the Commission, shall constitute a misdemeanor, and upon conviction such corporation shall be subject to a fine of not more than $\$ 1,000$ for every day of such failure or neglect.

SEC. 5. The information so obtained shall be public records, and the Commission shall from time to time make public such information in such form and to such extent as it may deem necessary.

SEC. 6. That the district courts of the United States, upon the application of the Commission alleging a failure to comply with any order of the Commission or alleging a failure to comply with or a violation of any of the provisions of this act by any corporation subject thereto, shall have jurisdiction to issue a writ or writs of mandamus or injunction or other order enforcing such order of the Commission or commanding such corporation, its officers and employees, to comply with the provisions of this act.

SEC. 7. That for the purposes of this act the Commission shall have the power to require by subpœna the attendance and testimony of witnesses and the production of all books, papers, contracts, agreements, documents, or other things of every kind and nature whatsoever relating to any matter under investigation by the Commission. Such attendance of witnesses and the production of such documentary evidence may be required from any place in the United States at any designated place of hearing, and in case of disobedience to a subpœna the Commission, or any party to a proceeding before the Commission, may invoke the aid of any court of the United States in requiring the attendance and testimony of witnesses and the production of books, papers, and documents under the provisions of this section.

And any of the circuit courts of the United States within the jurisdiction of which such inquiry is carried on may, in case of contumacy or refusal to obey a subpona issued to any corporation subject to the pro- 
visions of this act, or other person, issue an order requiring such corporation, or other person, to appear before said Commission (and produce books, documents, and papers, if so ordered) and give evidence touching the matter in question, and any failure to obey such order of the court may be punished by such court as a contempt thereof. The claim that any such testimony or evidence may tend to criminate the person giving such evidence shall not excuse such witness from testifying.

The testimony of any witness may be taken at the instance of a party in any proceeding or investigation pending before the Commission by deposition at any time after the inquiry is instituted. The Commission may also order testimony to be taken by deposition in any proceeding or investigation pending before it at any stage of such proceeding or investigation. Such deposition may be taken before any person authorized so to do by the the Commission and who has power to administer oaths.

Any person may be compelled to appear and depose, and to produce documentary evidence, in the same manner as witnesses may be compelled to appear and testify and produce documentary evidence before the Commission as hereinbefore provided. Such testimony shall be reduced to writing.

Witnesses whose testimony is taken under the provisions of this act shall severally be entitled to the same fees as are paid for like service in the courts of the United States.

No person shall be excused from attending and testifying, or from producing books, papers, documents, or other things before this Commission or in obedience to the subpœna of the Commission whether such subpona be signed or issued by one or more of the commissioners on the ground or for the reason that the testimony or evidence, documentary or otherwise, required of him may tend to criminate him or subject him to a penalty or forfeiture. But no natural person shall be prosecuted or subjected to any penalty or forfeiture for or on account of any transaction, matter, or thing concerning which he may testify under oath or produce evidence, documentary or otherwise, before said Commission in obedience to a subpœna issued by it in a proceeding instituted upon its own initiative: Provided, That no person so testifying shall be exempt from prosecution and punishment for perjury committed in so testifying. The purpose of this provision is to give immunity only to natural persons who under oath testify in response to a subpœna of the Commission in an inquiry instituted by the Commission.

SEC. 8. That the said Commission shall, on or before the first day of January in each year, make a report, which shall be transmitted to Congress. This report shall contain such information and data collected by the Commission as it may deem of value in the determination of questions connected with the regulation of commerce, together with such recommendations as to additional legislation relating thereto as the Commission may deem necessary.

SEC. 9. That any person willfully making or furnishing to said Commission any statement, return, or record required by this act, when knowing such statement, return, or record to be false in any material particular, 
shall be guilty of a misdemeanor, and upon conviction shall be fined not more than $\$ 1,000$ or imprisoned not more than one year, or both.

SEC. IO. That in case a final decree shall be issued against any corporation under the act entitled "An act to protect trade and commerce against unlawful restraints and monopolies," approved July second, eighteen hundred and ninety, or under Sections seventy-three to seventy-seven, inclusive, of "An act to reduce taxation, to provide revenue for the government, and for other purposes," which became a law August twenty-seventh, eighteen hundred and ninety-four, the court entering such decree may, in its discretion, refer to the Commission its decree, with instructions to take evidence, consider such facts, and report to the court the findings as to method of dissolution or reorganization as the Commission shall consider best fitted to carry out such decree; if a reorganization takes place under a decree, the Commission shall inform itself respecting the reorganization, and if it is of the opinion that it is not in harmony with the decree it shall, through counsel, inform the court for such action as the court may take.

SEC. II. That the said Commission may at any time, upon complaint of any person or corporation, or upon its own initiative, or upon the request of the Attorney-General, or of the corporation affected, investigate any corporation subject to the provisions of this act for the purpose of determining whether such corporation has been guilty of a violation of the act entitled "An act to protect trade and commerce against unlawful restraints and monopolies," approved July second, eighteen hundred and ninety, or under Sections seventy-three to seventy-seven, inclusive, of an "Act to reduce taxation," and so forth, which became a law August twenty-seventh, eighteen hundred and ninety-four, or of any of the provisions of this act, and may hold such hearings and take such evidence as it may deem necessary; and in case the Commission shall find that such corporation has been guilty of a violation of the provisions of said acts or of this act it shall make a finding, stating the facts, and prescribing the acts, transactions, and readjustments necessary in order that said corporation may thereafter comply with the terms of said acts and of this act, and shall transmit a copy of the said finding in full to such corporation. If within sixty days after transmitting said finding, or such extension thereof as shall be given by the Commission, the corporation shall not have complied with the terms of the finding, and shall not have performed the acts prescribed as necessary to make it comply with the said acts or with this act, the Commission shall report the fact of noncompliance to the Attorney-General, together with a copy of such finding, for his action under the said acts or of this act. But the Commission may, if it deems it proper, report the facts to the Attorney General without calling upon such corporation for compliance with said acts or with this act.

Nothing contained in this act shall be construed to prevent or interfere with the Attorney-General in enforcing the provisions of the act to protect commerce, and so forth, approved July second, eighteen hundred and ninety. 


\title{
MINORITY VIEWS.
}

The undersigned members of the Senate Committee on Intertate Commerce are unable to agree to the report of the majority of the committee on Senate resolution 98, as to "what changes are necessary or desirable in the laws of the United States relating to the creation and control of corporations engaged in interstate commerce and what changes are necessary or desirable in the laws of the United States relating to persons or firms engaged in interstate commerce."

While certain features of the report are commendable, there are several conclusions therein which do not accord with our views, and therefore we are prevented from approving the report as a whole.

\author{
W. M. Crane. \\ Frank B. BrandegeE. \\ Gérge T. Oliver. \\ HENRY F. LIPPITT.
}

\section{MEMBERSHIP OF THE SENATE COMMITTEE ON IN- TERSTATE COMMERCE.}

Moses E. Clapp, of Minnesota, Chairman; Shelby M. Cullom, of Illinois; W. Murray Crane, of Massachusetts; George S. Nixon, of Nevada; Albert B. Cummins, of Iowa; Frank B. Brandegee, of Connecticut; George T. Oliver, of Pennsylvania; Henry F. Lippitt, of Rhode Island; Charles E. Townsend, of Michigan; Benjamin R. Tillman, of South Carolina; Murphy J. Foster, of Louisiana; Francis G. Newlands, of Nevada; James P. Clarke, of Arkansas; Thomas P. Gore, of Oklahoma; Clarence W. Watson, of West Virginia; Atlee Pomerene, of Ohio.

Lee F. Warner, Clerk; G. B. Spaulding and R. J. McNeil, Assistant Clerks. 


\section{APPENDIX N.}

\section{REGULATION OF INJUNCTIONS; WITH HISTORY OF AND REMARKS UPON EXISTING LAW AND PRACTICE. ${ }^{1}$}

[Extracts from House Report No. 612, Sixty-second Congress, second session, April 26, 1912, submitted by Mr. Clayton; contained in Senate Report No. 698, (Committee on the Judiciary), Sixty-third Congress, second session, July 22, 19I4, submitted by Mr. Culbertson, pages 18 to 23, inclusive.]

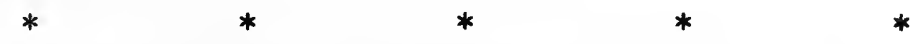

The too ready issuance of injunctions or the issuance without proper precautions or safeguards has been called to the attention of the Congress session after session for many years. The bill now reported [House Committee's draft of Clayton Bill] seeks to remedy the evils complained of by legislation directed to those specific matters which have given rise to most criticism. These matters are so segregated in various sections of the bill that they may be separately discussed.

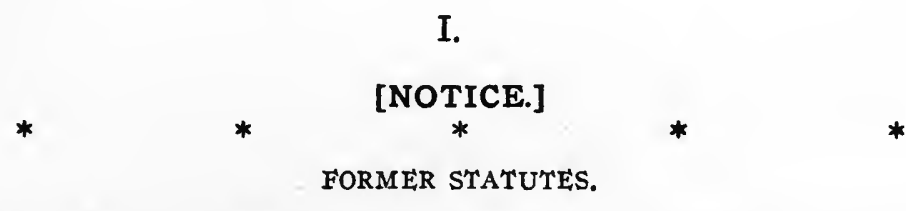

In order to fully understand the subject of notice in injunction cases it is necessary to give an historical resume of the subject. In the judiciary act of 1789 which was passed during the first session of that year, Congress having created the different courts according to the scheme outlined by Chief Justice Ellsworth, conferred upon the courts power to issue all writs, including writs of ne exeat (a form of injunction), according to legal usages and practice. In 1793, however, there was a revision of that statute, and among other things the same powers, substantially, were conferred upon the judges as before; but at the

I These extracts present only such portions of the report as relate to the general subject of injunctive relief. For the able discussion of the right to injunctive relief in labor disputes appearing at pages 25-35 and $5 \mathrm{I}$ thereof, and for discussions of other special phases, reference must be had to the report. 
end of the section authorizing the issuance of injunctions, was this language: "No injunction shall be issued in any case without reasonable previous notice to the adverse party or his attorney."

The law stood thus until the general revision of 1873 , during which period the law expressly required reasonable notice to be given in all cases. But the will of Congress as thus expressed was completely thwarted and the statute nullified by the peculiar construction placed upon it by the courts. The question frequently arose. The courts got around it in various ways, but usually by holding that it did not apply to a case of threatened irreparable injury, notwithstanding that its language was broad and sweeping, plainly covering all cases. Another form of expression often used is found in Ex parte Poultney (4 Peters C. C. C., 472):

Every court of equity possesses the power to mold its rules in relation to the time of appearing and answering so as to prevent the rule from working injustice, and it is not only in the power of the court, but it is its duty to exercise a sound discretion upon this subject.

The court found a similar method of evading the sweeping prohibition of the revision of 1793 , with respect to notice in Lawrence v. Bowman (I U. S. C. C., Alester, 230).

But the earliest provision requiring notice came before the Supreme Court in I799, in New York v. Connecticut (4 Dall., I). Its constitutionality was not questioned. The only issue was as to the sufficiency of the notice, Chief Justice Ellsworth, for the court, saying: "The prohibition contained in the statute that writs of injunction shall not be granted without reasonable notice to the adverse party or his attorney, extends to injunctions granted by the Supreme Court or the circuit court as well as to those that may be granted by a single judge. The design and effect, however, of injunctions must render a shorter notice, reasonable notice, in the case of an application to a court than would be so construed in most cases of an application to a single judge, and until a general rule shall be settled the particular circumstances of each case must also be regarded."

Here was a case in which, although no point was made by counsel on any question of constitutionality, the Supreme Court accepted the comprehensive requirement of the act of 1793 as binding on all the Federal courts. 
Now we come to the present law, found in section 263 [ro pealed by Section 17 of Clayton Law] of the Judicial Code, and reading thus:

Whenever notice is given of a motion for an injunction out of a district court, the court or judge thereof may, if there appears to be danger of irreparable injury from delay, grant an order restraining the act sought to be enjoined until the decision upon the motion; and such order may be granted with or without security, in the discretion of the court or judge.

This was the law as contained in section 718 of the Revised Statutes, said section having been enacted in 1872 . It simply embodies the practice of the courts with respect to notice, a practice established notwithstanding the nonconformity of the practice to the positive requirement of the act of 1793 .

\section{PROPOSED CHANGES.}

But it will be seen that the giving of notice and requiring security, left by the present law to the discretion of the court, is by this bill a positive duty, except where irreparable and immediate injury might result from the giving of a notice or the delay incident thereto, in which case the court or judge may issue a temporary restraining order pending the giving of the notice. The concluding part of the amended section [Section 263 of the Judicial Code: repealed by Section 17 of Clayton Law] has an effect to safeguard parties from the reckless and inconsiderate issuance of restraining orders. Injuries compensable in damages recoverable in an action at law are not treated or considered by the courts as irreparable in any proper legal sense, and parties attempting to show why the injury sought to be restrained is irreparable would often disclose an adequate legal remedy. This provision requires the reason to appear in the order, but it should be read in connection with the new section $266 \mathrm{~b}$, [See Section I9 of Clayton Law] requiring the order to be made by the court or judge to be likewise specific in other essentials, and section 266 , [See Section 20 of Clayton Law] requiring that every complaint filed for the purpose of obtaining the order, in the cases there specified, shall contain a particular description of the property or property right for which the prohibitive power of the court is sought, and that such complaint shall be verified.

A valuable provision of the amendment is one that a restraining order issued without notice "shall by its terms expire within 
such time after entry, not to exceed seven days, [ten days,-see Section I7 of Clayton Law] as the court or judge may fix, unless within the time so fixed the order is extended or renewed for a like period, after notice to those previously served, if any, and for good cause shown, and the reasons for such extension shall be entered of record."

A legislative precedent for such legislation is found in the act of 1807 , wherein it was provided that injunctions granted by the district courts "shall not, unless so ordered by the circuit court, continue longer than to the circuit court next ensuing, nor shall an injunction be issued by a district judge in any case where a party has had a reasonable time to apply to the circuit for the writ." (U. S. Stat. L., vol. 2, p. 4I8.)

If the views of President Taft on this subject have not changed, [it should be noted that this report was submitted April 26 , 1912,] he will welcome an opportunity to approve a bill containing such provisions as those in the amendment governing notice, because in his message of December 7, 1909, to the regular session of the Sixty-first Congress, after a quotation from the Republican platform of I908, he said:

I recommend that in compliance with the promise thus made appropriate legislation be adopted. The ends of justice will best be met and the chief cause of complaint against ill-considered injunctions without notice will be removed by the enactment of a statute forbidding hereafter the issuing of any injunction or restraining order, whether temporary or permanent, by any Federal court without previous notice and a reasonable opportunity to be heard on behalf of the parties to be enjoined; unless it shall appear to the satisfaction of the court that the delay necessary to give such notice and hearing would result in irreparable injury to the complainant, and unless, also, the court shall from the evidence make a written finding, which shall be spread upon the court minutes, that immediate and irreparable injury is likely to ensue to the complainant, and shall define the injury, state why it is irreparable, and shall also indorse on the order issued the date and the hour of the issuance of the order. Moreover, every such injunction or restraining order issued without previous notice and opportunity by the defendant to be heard should by force of the statute expire and be of no effect after seven days from the issuance thereof or within any time less than that period which the court may fix, unless within such seven days or such less period the injunction or order is extended or renewed after previous notice and opportunity to be heard.

My judgment is that the passage of such an act, which really embodies the best practice in equity and is very likely the rule now in force in some courts, will prevent the issuing of ill-advised orders of injunction without 
notice and will render such orders, when issued, much less objectionable by the short time in which they may remain effective.

\section{II.}

\section{[SECURITY.]}

Section 266a [see Section 18 of Clayton Law] simply requires security for costs and damages in all cases, leaving it no longer within the discretion of the courts whether any such security or none shall be given.

Prior to the said act of 1872 (contained in the revision of 1873) there appears to have been no legislation on the matter of security in injunction cases; but that security was usually required is a fact well known to the legal profession. It seems clearly just and salutary that the extraordinary writ of injunction should not issue in any case until the party seeking it and for whose benefit it issues has provided the other party with all the protection which security for damages affords.

It appears by the authorities, both English and American, to have been always within the range of judicial discretion, in the absence of a statute, to waive security, though better practice has been to require security as a condition to issuing restraining orders and injunctions.

The new section 266a, [see Section I8 of Clayton Law] takes the matter of requiring security out of the category of discretionary matters, where it was found by the Committee on Revision and permitted to remain.

For a discussion of the existing law on the question of security, we refer to Russell v. Farley (105 U. S., 433).

\section{III.}

\section{[INJUNCTIVE ORDER MUST BE SPECIFIC.]}

Section 266b [see Section 19 of Clayton Law] is of general application. Defendants should never be left to guess at what they are forbidden to do, but the order "shall describe in reasonable detail, and not by reference to the bill of complaint or other document, the act or acts sought to be restrained." It also contains a safeguard against what have been heretofore known as dragnet or blanket injunctions, by which large numbers may be accused, and eventually punished, for violating injunctions in 
cases in which they were not made parties in the legal sense and of which they had only constructive notice, equivalent in most cases to none at all. Moreover, no person shall be bound by any such order without actual personal notice.

\section{EXISTING LAW AND PRACTICE.}

There was heretofore no Federal statute to govern either the matter of making or form and contents of orders for injunctions. Of course, where a restraining order is granted that performs the functions of order, process, and notice. But the writ of injunction, where temporary, is preceded by the entry of an order, and where permanent by the entry of a decree.

The whole matter appears to have been left, both by the States and the Federal Government, to the courts, which have mostly conformed to established principles.

The most important of these was that the order should be sufficiently clear and certain in its terms that the defendants could by an inspection of it readily know what they were forbidden to do.

See Arthur v. Oakes, 63 Fed. Rep., 3ro; 25 L. R. An., 414; St. Louis Min., etc., Co. v. Co. C. Montana Min. Co., 58 Fed. Rep., 129; Sweet v. Mangham, 4 Jur., 479; 9 L. J. Ch., 323, 34 Eng. Ch., 5I ; Cother v. Midland R. Co., 22 Eng. Ch., 469.

It should also be in accordance with the terms of the prayer of the bill. (State v. Rush County, 35 Kan., 150; McEldowney v. Lowther, $49 \mathrm{~W}$. Va., 348). It should not impose a greater restraint than is asked or is necessary (Shubert v. Angeles, 80 N. Y. App. Div., 625; New York Fire Dept. v. Baudet, 4. N. Y. Supp., 206), and should be specific and certain. (Orris v. National Commercial Bank, 8I N. Y. App. Div., 63I ; St. Rege's Paper Co. v. Santa Clara Lumber Co., 55 N. Y. App. Div., 225 ; Norris v. Cable, 8 Rich (S. C.), 58; Parker v. First Ave. Hotel Co., 24 Ch. Div., 282; Hackett v. Baiss, L. R., 20 Eq., 494; Dover Harbour v. London, etc., R. Co., 3 De G. F. \& J., 559; Low v. Innes, 4 De G. J. \& S., 286.)

So it appears that section $266 \mathrm{~b}$ [see Section 19 of Clayton Law] really does not change the best practice with respect to orders, but imposes the duty upon the courts, in mandatory form, to conform to correct rules, as already established by judicial precedent. 
That such provision is necessary and timely will appear upon an inspection of some orders which have issued.

For instance, take the case of Kansas \& Texas Coal Co. v. Dcnney, decided in the district court for Arkansas in 1899. And here, as in most of such cases, no full official report of the case can be obtained, but a mere memorandum. In this case the defendants (strikers) were ordered to be and were enjoined from "congregating at or near or on the premises of the property of the Kansas \& Texas Coal Co. in, about, or near the town of Huntington, Ark., or elsewhere, for the purpose of intimidating its employees or preventing said employees from rendering service to the Kansas \& Texas Coal Co. from inducing or coercing by threats, intimidation, force, or violence any of said employees to leave the employment of the said Kansas \& Texas Coal Co., or from in any manner interfering with or molesting any person or persons who may be employed or seek employment by and of the Kansas \& Texas Coal Co. in the operation of its coal mines at or near said town of Huntington, or elsewhere."

It will be observed that a defendant in that suit would render himself liable to punishment for contempt if he met a man seeking employment by the company in a foreign country and persuaded him not to enter its service.

The bill further provides that it shall be "binding only upon parties to the suit, their agents, servants, employees, and attorneys, or those in active concert with them, and who shall by personal service or otherwise have received actual notice of the same." Unquestionably this is the true rule, but unfortunately the courts have not uniformly observed it. Much of the criticism which arose from the Debs case ( 64 Fed. Rep., 724) was due to the fact that the court undertook to make the order effective not only upon the parties to the suit and those in concert with them, but upon all other persons whomsoever. In Scott v. Donald ( 165 U. S., II7), the court rebuked a violation by the lower court in the following language:

The decree is also objectionable because it enjoins persons not parties to the suit. This is not a case where the defendants named represent those not named. Nor is there alleged any conspiracy between the parties defendant and other unknown parties. The acts complained of are tortious and do not grow out of any common action or agreement between constables and sheriffs of the State of South Carolina. We have indeed a right to presume that such officers, though not named in this suit, will, 
when advised that certain provisions of the act in question have been pronounced unconstitutional by the court to which the Constitution of the United States refers such questions, voluntarily refrain from enforcing such provisions; but we do not think it comports with well-settled principles of equity procedure to include them in an injunction in a suit in which they were not heard or represented or to subject them to penalties for contempt in disregarding such an injunction. (Fellows v. Fellows, 4 John. Chan. 25, citing Iveson v. Harris, 7 Ves. 257.)

The decree of the court below should therefore be amended by being restricted to the parties named as plaintiff and defendants in the bill, and this is directed to be done, and it is otherwise.

IV.

\section{[PRACTICE IN RELATION TO INJUNCTIVE RELIEF IN TRADES DISPUTES.]"}

Section 266c [see Section 20 of Clayton Law] is concerned with cases between "employer and employees, or between employers and employees, or between employees, or between persons employed and persons seeking employment, involving or growing out of a dispute concerning terms or conditions of employment."

The first clause of the new section $266 \mathrm{c}$ relates to the contents and form of the complaint. It must disclose a threatened irreparable injury to property or to a property right of the party making the application for which there is no adequate remedy at law. And the property or property right must be described "with particularity."

These requirements are merely those of good pleading and correct practice in such cases established by a long line of precedents, well understood by the profession and which should be but perhaps have not been uniformly applied. To show this it is only necessary to briefly state the applicable rules, citing some of the numerous authorities.

As the granting of an injunction rests in some degree in the discretion of the chancellor, allegations in the complaint should show candor and frankness. (Moffatt v. Calvert County Comm'rs, 97 Md., 266; Johnston v. Glenn, 40 Md., 200; Edison Storage Battery Co. v. Edison Automobile Co., 67 N. J. Eq., 44; Sharp v. Ashton, 3 Ves. \& B., 144.)

I This portion of the report is broader than the sub-title indicates. It will be found to contain a statement of matters of general application in suits for injunctive relief. 
The omission of material facts which, in the nature of the case, must be known to the plaintiff will preclude the granting of the relief. (Sprigg v. Western Tel. Co., $46 \mathrm{Md}$., 67; Walker v. Burks, 48 Tex., 206.)

An injunction may be refused if the allegations are argumentative and inferential. (Battle v. Stevens, 32 Ga., 25; Warsop v. Hastings, 22 Minn., 437.)

The allegations of the complaint must be definite and certain. (St. Louis v. Knapp Co., I04 U. S., 658.)

The complaint must set forth the facts with particularity and minuteness (Minor v. Terry, Code Rep. N. S. (N. S.), 384), and no material fact should be left to inference. (Warsop v. Hastings, 22 Minn., 437 ; Philphower v. Todd, II N. J. Eq., 54; Perkins v. Collins, 3 N. J. Eq., 482.)

Facts, and not the conclusions or opinions of the pleader, must be stated. (McBride v. Ross (D. C.), I3 App. Cas., 576.)

An injunction should not ordinarily be granted when the material allegations are made upon information and belief. (Brooks v. O’Hara, 8 Fed. Rep., 529; In re Holmes, 3 Fed. Rep. Cases No. I, 562.)

The complaint must clearly show the threats or acts of defendant which cause him to apprehend future injury. (Mendelsohn v. McCabe, I44 Cal., 230; Ryan v. Fulghurn, 96 Ga., 234). And it is not sufficient to allege that the defendant claims the right to do an act which plaintiff believes illegal and injurious to him, since the intention to exercise the right must be alleged. (Lutman v. Lake Shore, etc., R. Co., 56 Ohio St., 433; Attorney General v. Eau Claire, 37 Wis., 400.)

The bill must allege facts which clearly show that the plaintiff will sustain substantial injury because of the acts complained of. (Home Electric Light, etc., Co. v. Gobe Tissue Paper Co., 146 Ind., 673; Boston, etc., Ry. Co. v. Sullivan, I77 Mass., 230; McGovern v. Loder (N. J. Ch., I890), 20 Atl. Rep., 209; Smith v. Lockwood, I3 Barb., 209; Jones v. Stewart (Tenn. Ch. App., I900), 6I Sev., I05; Spokane St. R. Co. v. Spokane, 5 Wash., 634; State v. Eau Claire, 40 Wis., 533. And it is not sufficient to merely allege injury without stating the facts. Giffing v. Gibb, 2 Black, 519; Spooner v. McConnell, 22 Fed. Cases No. I3245; Bowling v. Crook, I04 Ala., I30; Grant v. Cooke, 7 D. C., I65; Coast Line R. Co. v. Caben, 50 Ga., 45I; Dinwiddie v. 
Roberts, I Greene, 363; Wabaska Electric Co. v. Wymore Co., Nebr., I99; Lubrs v. Sturtevant, ro Or., I70; Farland v. Wood, 35 W. Va., 458.)

Since the jurisdiction in equity depends on the lack of an adequate remedy at law, a bill for an injunction must state facts from which the court can determine that the remedy at law is inadequate. (Pollock v. Farmers' Loan \& Tr. Co., I 57 U. S., 429; Safe-Deposit, etc., Co. v. Anniston, 96 Fed. Rep., 66r.)

If the inadequacy of the legal remedy depends upon the defendant's insolvency the fact of insolvency must be positively alleged. (Fullington v. Kyle Lumber Co., I39 Ala., 242; Graham v. Tankersley, I5 Ala., 634.)

An injunction will not be granted unless the complaint shows that a refusal to grant the writ will work irreparable injury. (California Nav. Co. v. Union Transp. Co., I22 Cal., 64r ; Cook County Brick Co., 92 Ill. App., 526; Manufacturers' Gas Co. v. Indiana Nat. Gas, etc., Co., I56 Ind., 679.) And it is not sufficient simply to allege that the injury will be irreparable, but the facts must be stated so that the court may see that the apprehension of irreparable injury is well founded. (California Nav: Co. v. Union Transp. Co., $122 \mathrm{Cal}$, 64I ; Empire Transp. Co. v. Johnson, 76 Conn., 79; Orange City v. Thayer, 45 Fla., 502.)

The plaintiff must allege that he has done or is willing to do everything which is necessary to entitle him to the relief sought. (Stanley v. Gadsley, ro Pet. (U. S.), 521 ; Elliott v. Sihley, Ior Ala., 344; Burham v. San Francisco Fuse Mfg. Co., 76 Cal. 26; Sloan v. Coolbaugh, ro Iowa, 31 ; Lewis v. Wilson, $17 \mathrm{~N}$. Y. Supp., 128; Spann v. Sterns, I8 Tex., 556.)

*

$$
\text { * }
$$

$$
\text { * }
$$

It may be proper to notice, in passing, that the State courts furnish precedents frequently for action by the Federal courts, and vice versa, so that a pernicious rule or an error in one jurisdiction is quickly adopted by the other. It is not contended that either the Federal or the State courts have stood alone in any of the precedents which are disapproved. 


\section{APPENDIX O.}

\section{AN ACT TO REGULATE COMMERCE. ${ }^{1}$}

Be it enacted by the Senate and House of Representatives of the United States of America in Congress assembled,

\section{COMMON CARRIERS SUBJECT TO ACT.}

SEC. I. That the provisions of this act shall apply to any com. mon carrier or carriers engaged in the transportation of passengers or property wholly by railroad, or partly by railroad and partly by water when both are used, under a common control, management, or arrangement, for a continuous carriage or shipment, from one State or Territory of the United States, or the District of Columbia, to any other State or Territory of the United States, or the District of Columbia, or from any place in the United States to an adjacent foreign country, or from any place in the United States through a foreign country to any other place in the United States, and also to the transportation in like manner of property shipped from any place in the United States to a foreign country and carried from such place to a port of transshipment, or shipped from a foreign country to any place in the United States and carried to such place from a port of entry either in the United States or an adjacent foreign country: Provided, however, That the provisions of this act shall not apply to the transportation of passengers or property, or to the receiving, delivering, storage, or handling of property, wholly within one State, and not shipped to or from a foreign country from or to any State or Territory as aforesaid.

I The text of the original Interstate Commerce Act of 1887 is presented for convenience of comparison with the provisions of the Federal Trade Commission Act.

The jurisdiction and powers conferred upon the Interstate Commerce Commission, as well as the procedure established in connection therewith, were used as precedents and followed in numerous instances by the framers of the Federal Trade Commission Act.

The various amendments will be found in-24 Stautes at Large, 379; 25 id., 855 ; 26 id., 743; 28 id., 643; 34 id., 584 ; 34 id., 838; 35 id., 60 ; 35 id., 648 ; 36 id., $539 ; 37$ id., $566 ; 37$ id., 70 ; 38 id., I Ig6. 


\section{Manual of Federal Tradf Commission.}

\section{TERM "RAILROAD" DEFINED.}

The term "railroad" as used in this act shall include all bridges and ferries used or operated in connection with any railroad, and also all the road in use by any corporation operating a railroad, whether owned or operated under a contract, agreement, or lease; and the term "transportation" shall include all instrumentalities of shipment or carriage.

\section{CHARGES SHALL BE REASONABLE AND JUST.}

All charges made for nay service rendered or to be rendered in the transportation of passengers or property as aforesaid, or in connection therewith, or for the receiving, delivering, storage, or handling of such property, shall be reasonable and just; and every unjust and unreasonable charge for such service is prohibited and declared to be unlawful.

\section{SPECIAL RATES AND PRIVILEGES PROHIBITED.}

SEc. 2. That if any common carrier subject to the provisions of this act shall, directly or indirectly, by any special rate, rebate, drawback, or other device, charge, demand, collect, or receive from any person or persons a greater or less compensation for any service rendered, or to be rendered, in the transportation of passengers or property, subject to the povisions of this act, than it charges, demands, collects, or receives from any other person or persons for doing for him or them a like and contemporaneous service in the transportation of a like kind of traffic under substantially similar circumstances and conditions, such common carrier shall be deemed guilty of unjust discrimination, which is hereby prohibited and declared to be unlawful.

\section{PREFERENCES ILLEGALIZED.}

SEc. 3. That it shall be unlawful for any common carrier subject to the provisions of this act to make or give any undue or unreasonable preference or advantage to any particular person, company, firm, corporation, or locality, or any particular description of traffic, in any respect whatsoever, or to subject any particular person, company, firm, corporation, or locality, or any particular description of traffic, to any undue or unreasonable prejudice or disadvantage in any respect whatsoever. 


\section{INTERCHANGE OF TRAFFIC PRESCRIBED.}

Every common carrier subject to the provisions of this act shall, according to their respective powers, afford all reasonable, proper, and equal facilities for the interchange of traffic between their respective lines, and for the receiving, forwarding, and delivering of passengers and property to and from their several lines and those connecting therewith, and shall not discriminate in their rates and charges between such connecting lines; but this shall not be construed as requiring any such common carrier to give the use of its tracks or terminal facilities to another carrier engaged in like business.

\section{LONG AND SHORT HAUL PROVISION.}

SEC. 4. That it shall be unlawful for any common carrier subject to the provisions of this act to charge or receive any greater compensation in the aggregate for the transportation of passengers or of like kind of property, under substantially similar circumstances and conditions, for a shorter than for a longer distance over the same line, in the same direction, the shorter being included within the longer distance; but this shall not be construed as authorizing any common carrier within the terms of this act to charge and receive as great compensation for a shorter as for a longer distance: Provided, however, That upon application to the commission appointed under the provisions of this act, such common carrier may, in special cases, after investigation by the commission, be authorized to charge less for longer than for shorter distances for the transportation of passengers or property; and the commission may from time to time prescribe the extent to which such designated common carrier may be relieved from the operation of this section of this act.

\section{POOLING AGREEMENTS PROHIBITED.}

SEC. 5. That it shall be unlawful for any common carrier subject to the provisions of this act to enter into any contract, agreement, or combination with any other common carrier or carriers for the pooling of freights of different and competing railroads, or to divide between them the aggregate or net proceeds of the earnings of such railroads, or any portion thereof; and in any case of an agreement for the pooling of freights as aforesaid, each day of its continuance shall be deemed a separate offense. 


\section{RATE SCHEDULES REQUIRED.}

SEc. 6. That every common carrier subject to the provisions of this act shall print and keep for public inspection schedules showing the rates and fares and charges for the transportation of passengers and property which any such common carrier has established and which are in force at the time upon its railroad, as defined by the first section of this act. The schedules printed as aforesaid by any such common carrier shall plainly state the places upon its railroad between which property and passengers will be carried, and shall contain the classification of freight in force upon such railroad, and shall also state separately the terminal charges and any rules or regulations which in any wise change, affect, or determine any part or the aggregate of such aforesaid rates and fares and charges. Such schedules shall be plainly printed in large type, of at least the size of ordinary pica, and copies for the use of the public shall be kept in every depot or station upon any such railroad, in such places and in such form that they can be conveniently inspected.

\section{PROVISION INCLUDES TRANSPORTATION THROUGH FOREIGN TERRITORY.}

Any common carrier subject to the provisions of this act receiving freight in the United States to be carried through a foreign country to any place in the United States shall also in like manner print and keep for public inspection, at every depot where such freight is received for shipment, schedules showing the through rates established and charged by such common carrier to all points in the United States beyond the foreign country to which it accepts freight for shipment; and any freight shipped from the United States through a foreign country into the United States, the through rate on which shall not have been made public as required by this act, shall, before it is admitted into the United States from said foreign country, be subject to customs duties as if said freight were of foreign production; and any law in conflict with this section is hereby repealed.

\section{NOTICE OF ADVANCE IN RATES.}

No advance shall be made in the rates, fares, and charges which have been established and published as aforesaid by any common carrier in compliance with the requirements of this section, except 
aften ten days' public notice, which shall plainly state the changes proposed to be made in the schedule then in force, and the time when the increased rates, fares, or charges will go into effect; and the proposed changes shall be shown by printing new schedules, or shall be plainly indicated upon the schedules in force at the time and kept for public inspection. Reductions in such published rates, fares, or charges may be made without previous public notice; but whenever any such reduction is made, notice of the same shall immediately be publicly posted and the changes made shall immediately be made public by printing new schedules, or shall immediately be plainly indicated upon the schedules at the time in force and kept for public inspection.

\section{ALTERATIONS OF PUBLISHED SCHEDULE PROHIB- ITED.}

And when any such common carrier shall have established and published its rates, fares, and charges in compliance with the provisions of this section, it shall be unlawful for such common carrier to charge, demand, collect, or receive from any person or persons a greater or less compensation for the transportation of passengers or property, or for any services in connection therewith, than is specified in such published schedule of rates, fares, and charges as may at the time be in force.

\section{SCHEDULES TO BE FILED WITH COMMISSION.}

Every common carrier subject to the provisions of this act shall file with the commission hereinafter provided for copies of its schedules of rates, fares, and charges which have been established and published in compliance with the requirements of this section, and shall promptly notify said commission of all changes made in the same. Every such common carrier shall also file with said commission copies of all contracts, agreements, or arrangements with other common carriers in relation to any traffic affected by the provisions of this act to which it may be a party. And in cases where passengers and freight pass over continuous lines or routes operated by more than one common carrier, and the several common carriers operating such lines or routes establish joint tariffs of rates or fares or charges for such continuous lines or routes, copies of such joint tariffs shall also, in like manner, be filed with said commission. Such joint rates, fares, and charges 
on such continuous lines so filed as aforesaid shall be made public by such common carriers when directed by said commission, in so far as may, in the judgment of the commission, be deemed practicable; and said commission shall from time to time prescribe the measure of publicity which shall be given to such rates, fares, and charges, or to such part of them as it may deem it practicable for such common carriers to publish, and the places in which they shall be published; but no common carrier party to any such joint tariff shall be liable for the failure of any other common carrier party thereto to observe and adhere to the rates, fares, or charges thus made and published.

\section{MEASURES TO COMPEL FILING AND PUBLISHING.}

If any such common carrier shall neglect or refuse to file or publish its schedules or tariffs of rates, fares, and charges as provided in this section, or any part of the same such common carrier shall, in addition to other penalties herein prescribed, be subject to a writ of mandamus, to be issued by any circuit court of the United States in the judicial district wherein the principal office of said common carrier is situated or wherein such offense may be committed, and if such common carrier be a foreign corporation, in the judicial circuit wherein such common carrier accepts traffic and has an agent to perform such service, to compel compliance with the aforesaid provisions of this section; and such writ shall issue in the name of the people of the United States, at the relation of the commissioners appointed under the provisions of this act; and failure to comply with its requirements shall be punishable as and for a contempt; and the said commissioners, as complainants, may also apply, in any such circuit court of the United States, for a writ of injunction against such common carrier, to restrain such common carrier from receiving or transporting property among the several States and Territories of the United States, or between the United States and adjacent foreign countries, or between ports of transshipment and of entry and the several States and Territories of the United States, as mentioned in the first section of this act, until such common carrier shall have complied with the aforesaid provisions of this section of this act. 


\section{EVASIONS ILLEGALIZED.}

SEC. 7. That it shall be unlawful for any common carrier subject to the provisions of this act to enter into any combination, contract, or agreement, expressed or implied, to prevent, by change of time schedule, carriage in different cars, or by other means or devices, the carriage of freights from being continuous from the place of shipment to the place of destination; and no break of bulk, stoppage, or interruption made by such common carrier shall prevent the carriage of freights from being and being treated as one continuous carriage from the place of shipment to the place of destination, unless such break, stoppage, or interruption was made in good faith for some necessary purpose, and without any intent to avoid or unnecessarily interrupt such continuous carriage or to evade any of the provisions of this act.

\section{CIVIL DAMAGES FOR VIOLATION.}

SEc. 8. That in case any common carrier subject to the provisions of this act shall do, cause to be done, or permit to be done any act, matter, or thing in this act prohibited or declared to be unlawful, or shall omit to do any act, matter, or thing in this act required to be done, such common carrier shall be liable to the person or persons injured thereby for the full amount of damages sustained in consequence of any such violation of the provisions of this act, together with a reasonable counsel or attorney's fee, to be fixed by the court in every case of recovery, which attorney's fee shall be taxed and collected as part of the costs in the case.

\section{CLAIMANT MUST ELECT BETWEEN SUIT AND COM-} PLAINT TO COMMISSION; TESTIMONY COMPELLED; IMMUNITY PROVIDED.

SEC. 9. That any person or persons claiming to be damaged by any common carrier subject to the provisions of this act may either make complaint to the commission as hereinafter provided for, or may bring suit in his or their own behalf for the recovery of the damages for which such common carrier may be liable under the provisions of this act, in any district or circuit court of the United States of competent jurisdiction; but such person or persons shall not have the right to pursue both of said remedies, and must in each case elect which one of the two methods 
of procedure herein provided for he or they will adopt. In any such action brought for the recovery of damages the court before which the same shall be pending may compel any director, officer, receiver, trustee, or agent of the corporation or company defendant in such suit to attend, appear, and testify in such case, and may compel the production of the books and papers of such corporation or company party to any such suit; the claim that any such testimony or evidence may tend to criminate the person giving such evidence shall not excuse such witness from testifying, but such evidence or testimony shall not be used against such person on the trial of any criminal proceeding.

\section{CARRIER, OR OFFICER, AGENT, ETC., OF TRANSPORTA- TION CORPORATION SUBJECT TO PROSECUTION.}

SEC. IO. That any common carrier subject to the provisions of this act, or, whenever such common carrier is a corporation, any director or officer thereof, or any receiver, trustee, lessee, agent, or person acting for or employed by such corporation, who, alone, or with any other corporation, company, person, or party, shall willfully do or cause to be done, or shall willingly suffer or permit to be done, any act, matter, or thing in this act prohibited or declared to be unlawful, or who shall aid or abet therein, or shall willfully omit or fail to do any act, matter, or thing in this act required to be done, or shall cause or willingly suffer or permit any act, matter, or thing so directed or required by this act to be done not to be so done, or shall aid or abet any such omission or failure, or shall be guilty of any infraction of this act, or shall aid or abet therein, shall be deemed guilty of a misdemeanor, and shall, upon conviction thereof in any district court of the United States within the jurisdiction of which such offense was committed, be subject to a fine of not to exceed five thousand dollars for each offense.

\section{COMMISSION CREATED AND ESTABLISHED.2}

SEC. II. That a commission is hereby created and established

2 The commission as originally organized comprised: Thomas M. Cooley, of Michigan, chairman; William E. Morrison, of Illinois; Aldace F. Walker, of Vermont; Augustus Schoonmaker, of New York; Walter L. Bragg, of Alabama.

For present membership, see page $\mathbf{2 3 5}$. 
to be known as the Inter-State Commerce Commission, which shall be composed of five commissioners, who shall be appointed by the President, by and with the advice and consent of the Senate. The commissioners first appointed under this act shall continue in office for the term of two, three, four, five, and six years, rspectively, from the first day of January, Anno Domini eighteen hundred and eighty-seven, the term of each to be designated by the President; but their successors shall be appointed for terms of six years, except that any person chosen to fill a vacancy shall be appointed only for the unexpired time of the commissioner whom he shall succeed. Any commissioner may be removed by the President for inefficiency, neglect of duty, or malfeasance in office. Not more than three of the commissioners shall be appointed from the same political party. No person in the employ of or holding any official relation to any common carrier subject to the provisions of this act, or owning stock or bonds thereof, or who is in any manner pecuniarily interested therein, shall enter upon the duties of or hold such office. Said commissioners shall not engage in any other business, vocation, or employment. No vacancy in the commission shall impair the right of the remaining commissioners to exercise all the powers of the commission.

\section{JURISDICTION AND POWERS.}

SEC. I2. That the commission hereby created shall have authority to inquire into the management of the business of all common carriers subject to the provisions of this act, and shall keep itself informed as to the manner and method in which the same is conducted, and shall have the right to obtain from such common carriers full and complete information necessary to enable the commission to perform the duties and carry out the objects for which it was created; and for the purposes of this act the commission shall have power to require the attendance and testimony of witnesses and the production of all books, papers, tariffs, contracts, agreements, and documents relating to any matter under investigation, and to that end may invoke the aid of any court of the United States in requiring the attendance and testimony of witnesses and the production of books, papers, and documents under the provisions of this section.

And any of the circuit courts of the United States within the jurisdiction of which such inquiry is carried on may, in case of 
contumacy or refusal to obey a subpœna issued to any common carrier subject to the provisions of this act, or other person, issue an order requiring such common carrier or other person to appear before said commission (and produce books and papers if so ordered) and give evidence touching the matter in question; and any failure to obey such order of the court may be punished by such court as a contempt thereof. The claim that any such testimony or evidence may tend to criminate the person giving such evidence shall not excuse such witness from testifying; but such evidence or testimony shall not be used against such person on the trial of any criminal proceeding.

\section{PROCEDURE UPON INVESTIGATION OF COMPLAINTS.}

SEC. I3. That any person, firm, corporation, or association, or any mercantile, agricultural, or manufacturing society, or any body politic or municipal organization complaining of anything done or omitted to be done by any common carrier subject to the provisions of this act in contravention of the provisions thereof, may apply to said commission by petition, which shall briefly state the facts; whereupon a statement of the charges thus made shall be forwarded by the commission to such common carrier, who shall be called upon to satisfy the complaint or to answer the same in writing within a reasonable time, to be specified by the commission. If such common carrier, within the time specified, shall make reparation for the injury alleged to have been done, said carrier shall be relieved of liability to the complainant only for the particular violation of law thus complained of. If such carrier shall not satisfy the complaint within the time specified, or there shall appear to be any reasonable ground for investigating said complaint, it shall be the duty of the commission to investigate the matters complained of in such manner and by such means as it shall deem proper.

\section{OFFICIAL COMPLAINTS; PROCEEDINGS INSTITUTED ON MOTION OF COMMISSION.}

Said commission shall in like manner investigate any complaint forwarded by the railroad commissioner or railroad commission of any State or Territory, at the request of such commissioner or commission, and may institute any inquiry on its own motion in the same manner and to the same effect as though complaint had been made. 
DIRECT DAMAGE NOT REQUIRED TO SUSTAIN COMPLAINT.

No complaint shall at any time be dismissed because of the absence of direct damage to the complainant.

\section{CONTENTS OF REPORT; SHALL BE PRIMA FACIE EVI. DENCE.}

SEc. I4. That whenever an investigation shall be made by said commission, it shall be its duty to make a report in writing in respect thereto, which shall include the findings of fact upon which the conclusions of the commission are based, together with its recommendation as to what reparation, if any, should be made by the common carrier to any party or parties who may be found to have been injured; and such findings so made shall thereafter, in all judicial proceedings, be deemed prima facie evidence as to each and every fact found.

\section{ORDER ENTERED; COPIES SUPPLIED.}

All reports of investigations made by the commission shall be entered of record, and a copy thereof shall be furnished to the party who may have complained, and to any common carrier that may have been complained of.

\section{PROCEDURE WHERE VIOLATION IS PROVEN.}

SEC. I5. That if in any case in which an investigation shall be made by said commission it shall be made to appear to the satisfaction of the commission, either by the testimony of witnesses or other evidence, that anything has been done or omitted to be done in violation of the provisions of this act, or of any law cognizable by said commission, by any common carrier, or that any injury or damage has been sustained by the party or parties complaining, or by other parties aggrieved in consequence of any such violation, it shall be the duty of the commission to forthwith cause a copy of its report in respect thereto to be delivered to such common carrier, together with a notice to said common carrier to cease and desist from such violation, or to make reparation for the injury so found to have been done, or both, within a reasonable time, to be specified by the commission; and if, within the time specified, it shall be made to appear to the commission that such common carrier has ceased from such violation of law, and 
has made reparation for the injury found to have been done, in compliance with the report and notice of the commission, or to the satisfaction of the party complaining, a statement to that effect shall be entered of record by the commission, and the said common carrier shall thereupon be relieved from further liability or penalty for such particular violation of law.

\section{ENFORCEMENT THROUGH EQUITY POWERS OF THE CIRCUIT COURTS.}

SEC. I6. That whenever any common carrier, as defined in and subject to the provisions of this act, shall violate or refuse or neglect to obey any lawful order or requirement of the commission in this act named, it shall be the duty of the commission, and lawful for any company or person interested in such order or requirement, to apply, in a summary way, by petition, to the circuit court of the United States sitting in equity in the judicial district in which the common carrier complained of has its principal office, or in which the violation or disobedience of such order or requirement shall happen, alleging such violation or disobedience, as the case may be; and the said court shall have power to hear and determine the matter, on such short notice to the common carrier complained of as the court shall deem reasonable; and such notice may be served on such common carrier, his or its officers, agents, or servants, in such manner as the court shall direct; and said court shall proceed to hear and determine the matter speedily as a court of equity, and without the formal pleadings and proceedings applicable to ordinary suits in equity, but in such manner as to do justice in the premises; and to this end such court shall have power, if it think fit, to direct and prosecute, in such mode and by such persons as it may appoint, all such inquiries as the court may think needful to enable it to form a just judgment in the matter of such petition; and on such hearing the report of said commission shall be prima facie evidence of the matters therein stated; and if it be made to appear to such court, on such hearing or on report of any such person or persons, that the lawful order or requirement of said commission drawn in question has been violated or disobeyed, it shall be lawful for such court to issue a writ of injunction or other proper process, mandatory or otherwise, to restrain such common carrier from further continuing such violation or disobedience of such order or requirement of said commission, and enjoining obedience to the 
same; and in case of any disobedience of any such writ of injunction or other proper process, mandatory or otherwise, it shall be lawful for such court to issue writs of attachment, or any other process of said court incident or applicable to writs of injunction or other proper process, mandatory or otherwise, against such common carrier, and if a corporation, against one or more of the directors, officers, or agents of the same, or against any owner, lessee, trustee, receiver, or other person failing to obey such writ of injunction or other proper process, mandatory or otherwise; and said court may, if it shall think fit, make an order directing such common carrier or other person so disobeying such writ of injunction or other proper process, mandatory or otherwise, to pay such sum of money not exceeding for each carrier or person in default the sum of five hundred dollars for every day after a day to be named in the order that such carrier or other person shall fail to obey such injunction or other proper process, mandatory or otherwise; and such moneys shall be payable as the court shall direct, either to the party complaining, or into court to abide the ultimate decision of the court, or into the treasury; and payment thereof may, without prejudice to any other mode of recovering the same, be enforced by attachment or order in the nature of a writ of execution, in like manner as if the same had been recovered by a final decree in personam in such court. When the subject shall be of the value of two thousand dollars or more, either party to such proceeding before said court may appeal to the Supreme Court of the United States, under the same regulations now provided by law in respect of security for such appeal; but such appeal shall not operate to stay or supersede the order of the court or the execution of any writ or process thereon; and such court may, in every such matter, order the payment of such costs and counsel fees as shall be deemed reasonable. Whenever any such petition shall be filed or presented by the commission it shall be the duty of the district attorney, under the direction of the Attorney-General of the United States, to prosecute the same; and the costs and expenses of such prosecution shall be paid out of the appropriation for the expenses of the courts of the United States. For the purposes of this act, excepting its penal provisions, the circuit courts of the United States, shall be deemed to be always in session. 


\section{PRACTICE REGULATIONS.}

SEC. I7. That the commission may conduct its proceedings in such manner as will best conduce to the proper dispatch of business and to the ends of justice. A majority of the commission shall constitute a quorum for the transaction of business, but no commissioner shall participate in any hearing or proceeding in which he has any pecuniary interest. Said commission may, from time to time, make or amend such general rules or orders as may be requisite for the order and regulation of proceedings before it, including forms of notices and the service thereof, which shall conform, as nearly as may be, to those in use in the courts of the United States. Any party may appear before said commission and be heard, in person or by attorney. Every vote and official act of the commission shall be entered of record, and its proceedings shall be public upon the request of either party interested. Said commission shall have an official seal, which shall be judicially noticed. Either of the members of the commission may administer oaths and affirmations.

\section{SALARIES, OFFICERS, ETC.}

SEC. 18. That each commissioner shall receive an annual salary of seven thousand five hundred dollars, payable in the same manner as the salaries of judges of the courts of the United States. The commission shall appoint a secretary, who shall receive an annual salary of three thousand five hundred dollars, payable in like manner. The commission shall have authority to employ and fix the compensation of such other employees as it may find necessary to the proper performance of its duties, subject to the approval of the Secretary of the Interior.

\section{OFFICES; WITNESS-FEES.}

The commission shall be furnished by the Secretary of the Interior with suitable offices and all necessary office supplies. Witnesses summoned before the commission shall be paid the same fees and mileage that are paid witnesses in the courts of the United States.

\section{EXPENSES PROVIDED FOR.}

All of the expenses of the commission, including all necessary expenses for transportation incurred by the commissioners, or by 
their employees under their orders, in making any investigation in any other places than in the city of Washington, shall be allowed and paid, on the presentation of itemized vouchers therefor approved by the chairman of the commission and the Secretary of the Interior.

\section{PRINCIPAL OFFICE; SESSIONS ELSEWHERE.}

SEc. I9. That the principal office of the commission shall be in the city of Washington, where its general sessions shall be held; but whenever the convenience of the public or of the parties may be promoted or delay or expense prevented thereby, the commission may hold special sessions in any part of the United States. It may, by one or more of the commissioners, prosecute any inquiry necessary to its duties, in any part of the United States, into any matter or question of fact pertaining to the business of any common carrier subject to the provisions of this act.

\section{IF REQUIRED, CARRIERS MUST FILE REPORTS.}

SEC. 20. That the commission is hereby authorized to require annual reports from all common carriers subject to the provisions of this act, to fix the time and prescribe the manner in which such reports shall be made, and to require from such carriers specific answers to all questions upon which the commission may need information. Such annual reports shall show in detail the amount of capital stock issued, the amounts paid therefor, and the manner of payment for the same; the dividends paid, the surplus fund, if any, and the number of stockholders; the funded and floating debts and the interest paid thereon; the cost and value of the carrier's property, franchises, and equipment ; the number of employees and the salaries paid each class; the amounts expended for improvements each year, how expended, and the character of such improvements; the earnings and receipts from each branch of business and from all sources; the operating and other expenses; the balances of profit and loss; and a complete exhibit of the financial operations of the carrier each year, including an annual balance-sheet. Such reports shall also contain such information in relation to rates or regulations concerning fares or freights, or agreements, arrangements, or contracts with other common carriers, as the commission may require; and the said commission may, within its discretion, for the purpose of enabling 
it the better to carry out the purposes of this act, prescribe (if in the opinion of the commission it is practicable to prescribe such uniformity and methods of keepng accounts) a period of time within which all common carriers subject to the provisions of this act stall have, as near as may be, a uniform system of accounts, and the manner in which such accounts shall be kept.

\section{ANNUAL REPORT BY COMMISSION.}

SEC. 2r. That the commission shall, on or before the first day of December in each year, make a report to the Secretary of the Interior, which shall be by him transmitted to Congress, and copies of which shall be distributed as are the other reports issued from the Interior Department. This report shall contain such information and data collected by the commission as may be considered of value in the determination of questions connected with the regulation of commerce, together with such recommendations as to additional legislation relating thereto as the commission may deem necessary.

\section{SAVING CLAUSES.}

SEC. 22. That nothing in this act shall apply to the carriage, storage, or handling of property free or at reduced rates for the United States, State, or municipal governments, or for charitable purposes, or to or from fairs and expositions for exhibition therèat, or the issuance of mileage, excursion, or commutation passenger tickets; nothing in this act shall be construed to prohibit any common carrier from giving reduced rates to ministers of religion; nothing in this act shall be construed to prevent railroads from giving free carriage to their own officers and employees, or to prevent the principal officers of any railroad company or companies from exchanging passes or tickets with other railroad conpanies for their officers and employees; and nothing in this act contained shall in any way abridge or alter the remedies now existing at common law or by statute, but the provisions of this act are in addition to such remedies. Provided, That no pending litigation shall in any way be affected by this act.

\section{APPROPRIATION.}

SEC. 23. That the sum of one hundred thousand dollars is hereby appropriated for the use and purposes of this act for the 
fiscal year ending June thirtieth, Anno Domini eighteen hundred and eighty-eight, and the intervening time anterior thereto.

\section{TIMES WHEN PROVISIONS BECOME EFFECTIVE.}

SEC. 24. That the provisions of sections eleven and eighteen of this act, relating to the appointment and organization of the commission herein provided for, shall take effect immediately, and the remaining provisions of this act shall take effect sixty days after its passage.

Approved, February 4, 1887. 


\section{APPENDIX P.}

\section{MEMORANDA OF CASES INSTITUTED BY THE UNITED STATES UNDER THE ANTI- TRUST LAWS.}

\section{(Revised to October 15, 1915.)}

United States v. Jellico Mountain Coal Company. (43 Fed. 898, 46 Fed. 432.) Suit in Circuit Court at Nashville, Tenn., October I3, I890, against the members of the "Nashville Coal Exchange," composed of various coal-mining companies operating mines in Kentucky and Tennessee and of persons and firms dealing in coal in Nashville, formed for the purpose of fixing prices and regulating the output of coal. Upon hearing the court, on June 4, r89r, held the combination to be in violation of the Anti-trust law and enjoined the further carrying out of the agreement.

United States v. Greenhut et al. (50 Fed. 469.) A proceeding by indictment in District Court, Massachusetts, May I6, 1892, against the officers of the Distilling and Cattle Feeding Co. (Whiskey Trust) for an alleged violation of the Anti-trust law. Indictment quashed, as allegations were held not to constitute an offense under the statute.

In re Corning. (5I Fed. 205.) Application to District Court, N.

D. Ohio, June II, I892, for a warrant of removal from Ohio to Massachusetts to answer to the indictment found in the Greenhut case. Application denied and prisoner discharged.

In re Terrell. (5I Fed. 2r3.) Application to Circuit Court, S. D. New York, June 28, 1892, for a writ of habeas corpus to secure a discharge from arrest and detention upon a warrant for removal from New York to Massachusetts to answer to the indictment found in the Greenhut case. Petitioner discharged. In re Greene. (52 Fed. I04.) Petition to Circuit Court, S. D. Ohio, August 4, I892, for writ of habeas corpus to secure release from the custody of the marshal, by whom he was held awaiting an order for the removal of Greene to Massachusetts to answer to the indictment in the Greenhut case. Prisoner discharged.

United States v. Nelson. ( 52 Fed. 646,201 U. S. 92.) Indictment in District Court, Minnesota, October Io, 1892, of a num- 
ber of lumber dealers for conspiring together to raise the price of lumber. Demurrer to indictment sustained.

United States v. Trans-Missouri Freight Association. (53 Fed. 440, 58 Fed. 58, 166 U. S. 290.) Petition filed January 6, I892, in Circuit Court Kansas, to enjoin the operations of a combination of railroads engaged in interstate commerce, formed for the purpose of maintaining "uniform rates," etc. Petition dismissed by Circuit Court; decree of dismissal affirmed by Circuit Court of Appeals, and reversed by the United States Supreme Court.

United States v. Workingmen's Amalgamated Council of New Orleans et al. (54 Fed. 994, 57 Fed. 85.) Suit in Circuit Court, E. D. Louisiana, March 25, 1893, to restrain defendants, a combination of workmen, from interfering with interstate and foreign commerce. An injunction was granted and the decree was affirmed by the Circuit Court of Appeals.

United States v. Patterson et al. (55 Fed. 605, 59 Fed. 280.) Indictment in Circuit Court, Massachusetts, February 28 and June 7, 1893 , of members of a combination formed for the purpose of controlling the price of cash registers. Letter of Attorney-General dated October 16,1893 , shows case was allowed to lapse because of reconciliation of complaining witness with defendants. (For summary of proceedings upon renewal of prosecution, see page 385 ; also action in equity entitled United States v. National Cash Register Co., page 382.)

United States v. E. C. Knight Company. (6o Fed. 306, 6o Fed. 934, 156 U. S. I.) Petition in Circuit Court, E. D. Pennsylvania, January 30,1894 , to enjoin the operations of an alleged Sugar Trust. The petition was dismissed January 30, I894. Appeal was taken to the Circuit Court of Appeals and the decree affirmed. From this decision an appeal was taken to the Supreme Court of the United States, where the decree of dismissal was again affirmed.

United States v. Eugene V. Debs et al. Petition filed on July 3, 1894, in the U. S. Circuit Court for the District of Indiana, seeking to restrain interference by American Railway Union and forty-nine individual defendants with mails and interstate commerce carried by all railroads operating in Indiana. An injunction was issued on July 3, 1894, which was continued in force until September I9, I898, when the case was dismissed 
at the instance of the government. (See this page, post, for other proceedings against same defendant.)

United States v. Agler. (62 Fed. 824.) Information filed in Circuit Court, Indiana, July 12, 1894, charging contempt of court in disobeying an injunction restraining Agler and others from interfering with interstate commerce and obstructing the mails. Agler was a member of the American Railway Union, the members of which order had been enjoined from interfering with the carrying of the mails and from obstructing interstate commerce. Information quashed.

United States v. Elliott. (62 Fed. 801, 64 Fed. 27.) Suit in Circuit Court, E. D. Missouri, July 6, and October 24, 1894, to restrain Elliott, Debs, and others, members of the American Railway Union, from carrying out an unlawful conspiracy to interfere with interstate commerce and to obstruct the carrying of the mails. Preliminary injunction granted. Final decree entered April 6, I896, against two hundred and ninetyfive defendants, and temporary injunction made permanent.

United States v. Debs et al. (64 Fed. 724.) Petition filed on July 2, 1894, in the Circuit Court for the Northern District of Illinois, alleging conspiracy to obstruct the mails and to interfere with interstate commerce. A temporary injunction was issued on July 2, 1894, for violation of which contempt proceedings were instituted. Original petition dismissed on July 28,1899 , at the instance of the government.

United States v. Debs et al. Proceedings in contempt in the Circuit Court, N. D. Illinois, December I4, I894, to punish Debs and others for disobeying an injunction restraining them from interfering with interstate commerce and with obstructing the mails. Defendants found guilty and punished.

In re Debs, petitioner. (I58 U. S. 564.) Application to United States Supreme Court, July 2, 1894, for a writ of habeas corpus to secure a discharge from imprisonment for disobeying an injunction of the Circuit Court for the Northern District of Illinois, restraining Debs and others from conspiring to interfere with interstate commerce. Petition for the writ denied.

United States v. Cassidy. (67 Fed. 698.) Indictment in District Court, N. D. California, April I and 2, 1895, under section 5440, Revised Statutes, for combining and conspiring to restrain trade and commerce between the States, in violation of the Anti-trust law, of which conspiracy the Pullman strike in Cali- 
fornia was a result. The trial resulted in a disagreement of the jury on April 6, I895. A nolle prosequi entered on July I, I895.

Mcore v. United States. (85 Fed. 465.) Indictment returned November 4, I895, against the members of an association of dealers in coal at Salt Lake City for entering into a conspiracy, while Utah was a territory, to regulate the price of coal. Moore was tried and convicted in the District Court of Utah. The Circuit Court of Appeals reversed the judgment of conviction, for the reason that upon the admission of Utah as a State it was no longer a "Territory" within the meaning of the Antitrust act, and the combination not being in restraint of interstate commerce, the court had no jurisdiction of the offense.

United States v. Joint Traffic Association. ( 76 Fed. 895,89 Fed. 1020, I7I U. S. 505.) Suit instituted January 8, I896, in the Circuit Court, S. D. New York, to enjoin the alleged violation of the Anti-trust law by a combination of railroads. The Circuit Court dismissed the bill, and the Court of Appeals affirmed the action of the Circuit Court. These judgments were reversed by the United States Supreme Court.

United States v. Addyston Pipe and Steel Company. (78 Fed. 712, 85 Fed. 27I, I75 U. S. 2 II.) Suit instituted December Io, I896, Circuit Court, E. D. Tennessee, to enjoin the operations of a combination of manufacturers of cast-iron pipe, by which it was attempted to control prices. The petition was dismissed by the Circuit Court. The Circuit Court of Appeals reversed the decree of the Circuit Court and remanded the case with instructions to enter a decree for the government. On appeal to the Supreme Court the action of the Circuit Court of Appeals was affirmed.

United States v. Hopkins et al. (82 Fed. 529, 84 Fed. Ior8, I7 I U. S. 578.) Suit instituted in the Circuit Court, Kansas, December $3 \mathrm{I}$, 1896 , to restrain the operations of the "Kansas City Live Stock Exchange," organized to control shipments of live stock. The injunction was granted and an appeal was taken to the Circuit Court of Appeals, from whence it was removed to the Supreme Court of the United States. By that court the decree of the Circuit Court was reversed and the case was remanded with instructions to dismiss the petition.

Anderson v. United States. (82 Fed. 998, I7 I U. S. 604.) Petition filed June 7, 1897, in the Circuit Court for the Western 
District of Missouri to restrain the operations of "The 'Traders' Live Stock Exchange," of Kansas City, an association formed for the purpose of buying cattle on the market. Decree of temporary injunction was granted and the case was appealed to the Circuit Court of Appeals for the Eighth Circuit. From there it was certified to the Supreme Court of the United States for instructions. The Supreme Court reversed the decree of the Circuit Court and remanded the case with directions to dismiss the petition.

United States v. Coal Dealers'Association. (85 Fed. 252.) Petition filed December 16, r897, in the Circuit Court, N. D. California, to restrain the operations of a combination of coal dealers. A temporary injunction was granted, from which no appeal was taken, and on May 2, r899, a final decree was ordered granting the relief prayed for.

United States v. Chesapeake and Ohio Fuel Company et al. (105 Fed. 93, Ir5 Fed. 610.) Petition filed May 8, 1899, in the Circuit Court, S. D. Ohio, to annul a contract and dissolve a combination among and between producers and shippers of coal in Ohio and West Virginia. Defendants were enjoined, contract was declared void and illegal, and the combination was dissolved.

United States v. Northern Securities Co. et al. (I20 Fed. 721 , 193 U. S. 197.) Petition filed March Io, 1902, in the Circuit Court, Minnesota, to enjoin the defendant, the Northern Securities Co., from acquiring, holding, or voting the shares of the capital stock of two competing railway companies. The Circuit Court on April 9, 1903, entered a decree in favor of the government, and this decree was, on March I4, 1904, affirmed by the Supreme Court of the United States.

United States v. Swift \& Co. et al. (122 Fed. 529, I96 U. S. 375.) Petition filed May ro, 1902, in the Circuit Court, Northern District of Illinois, to restrain the defendants, who were engaged in the buying of live stock and the selling of dressed meats, from carrying out an unlawful conspiracy entered into between themselves and the various railway companies to suppress competition and to obtain a monopoly. Demurrers to the petition were overruled on February 18, 1903, and a preliminary injunction was granted. The defendants having failed to answer, the court, on May 26,1903 , entered a final decree. 
Defendants appealed from this decree to the Supreme Court of the United States, where it was affirmed.

United States v. The Federal Salt Company et al. Petition filed October 15, 1902, in Circuit Court for the Northern District of California to restrain the defendants from combining and conspiring to suppress competition in the manufacture and sale of salt in the Western States. A temporary restraining order was issued on that date, and the court on November 10, I902, granted an injunction pendente lite, thus in effect making the restraining order perpetual.

United States v. The Federal Salt Company. Indictment returned on February 28, 1903, in the Northern District of California, against the so-called Salt Trust. On May I2, I903, a plea of guilty was entered and a fine of $\$ 1,000$ was imposed and collected.

United States v. Jacksonville Wholesale Grocers' Association. Petition filed September 12, 1903, in the Circuit Court for the Southern District of Florida, for the purpose of dissolving a combination of wholesale grocers. November I, 1907, the case was dismissed.

United States v. General Paper Co. et al. (See U.S. v. Nelson, and U. S. v. Alexander, 52 Fed. 646, 201 U. S. 92, 201 U. S. I17.) Petition filed December 27, 1904, in the Circuit Court for the District of Minnesota against the General Paper Co. and twenty-three other corporations engaged in the manufacture and sale of paper, alleging a combination and conspiracy to restrain trade and commerce. On May II, 1906, the court ordered judgment in favor of the government, dissolving the combination and granting all relief prayed for in the petition.

United States v. Armour \& Co. et al. (I42 Fed. 808.) Indictment returned on July I, 1905, in the Northern District of Illinois. Many preliminary objections were urged, and all were disposed of in favor of the government, except certain special pleas of immunity, based upon information concerning the matters for which the defendants were indicted which they had given to the Department of Commerce and Labor. On March 29, 1906, the court sustained the pleas so far as the individual defendants were concerned and overruled them with respect to the corporations. February 5, 1913, dismissed.

United States v. MacAndrewes \& Forbes Company et al. (149 Fed. 823; 149 Fed. 836, 212 U. S. 585.) Indictment returned in 
June, 1906, in the Southern District of New York charging a combination and conspiracy to regulate the interstate trade and sale in licorice paste. January 10, 1907, MacAndrews \& Forbes Co. was found guilty on first and third counts of indictment, the J. S. Young Co. was found guilty on first and third counts; and a verdict of acquittal was returned as to the individual defendants. MacAndrews \& Forbes Co. was fined $\$ 10,000$, and J. S. Young Co. $\$ 8,000$.

United States v. Metropolitan Meat Company et al. (3 Dist. Hawaii, I Io.) Petition filed in October, I905, in the Circuit Court for Hawaii, to restrain the operation of alleged unlawful combinations in restraint of trade in beef and beef products. Demurrer to bill overruled October 2, 1906.

United States v. Nome Retail Grocers' Association. Petition filed November 4, I905, in the District Court, Second Division, District of Alaska, alleging combination to fix prices and to suppress competition. With the consent of the defendant a decree was entered dissolving the combination.

United States v. Terminal Railroad Association of St. Louis et al. (I97 Fed. 446, 224 U. S. 383, 226 U. S. 420, 236 U. S. 194.) Petition filed on December I, 1905, in the Circuit Court for the Eastern District of Missouri, to enjoin the defendant railroads from continuing an unlawful combination to operate Eads Bridge and Merchams Bridge as a common agency of interstate commerce. Upon disagreement of circuit judges the case was carried to the Supreme Court but was remanded by that court for further proceedings. The petition was then dismissed by the Circuit Court, and an appeal was taken to the Supreme Court, where, on April 22, 1912, the decree of the Circuit Court was reversed, and the case remanded with directions to enter a decree in conformity with the opinion of the Supreme Court. A controversy having arisen as to whether the district judge or the three circuit judges had jurisdiction a writ of prohibition was filed against the district judge, which was sustained by the Supreme Court. A decree was thereupon entered by the circuit judges from which the government again appealed, but the decree was affirmed.

United States v. Allen \& Robinson et al. (3 Dist. Hawaii, 664.) Petition filed in October, I905, in the Circuit Court for the District of Hawaii alleging unlawful combination to control the trade in lumber in that Territory. Answers filed January 2, 
1906. Decision adverse to government and petition ordered dismissed on March 30, I9II.

United States v. Otis Elevator Co. et al. Petition filed March 7 , 1906, in the Circuit Court for the Northern District of California against the Otis Elevator Co. and a number of other corporations and individuals, in which it was alleged that they were maintaining a combination in restraint of trade in the manufacture and sale of elevators. On June I, I906, a decree was entered by consent, granting the relief prayed for.

United States v. F. A. Amsden Lumber Company et al. Indictment returned on May 4, 1906, in the District Court of Oklahoma for restricting competition and maintaining prices in the sale of lumber. September 25, 1907, pleas of guilty were entered and fines aggregating $\$ 2,000$ were imposed and collected. United States v. National Association of Retail Druggists et al. Petition filed May 9, 1906, in the Circuit Court for the District of Indiana, alleging a combination in restraint of interstate trade in the sale of drugs and proprietary medicines. On May 9, 1907, a final decree was entered by agreement, granting all the relief prayed for in the petition.

United States v. Virginia-Carolina Chemical Company et al. ( 163 Fed. 66.) Indictment returned on May 25, 1906, in the Middle District of Tennessee, against thirty-one corporations and twenty-five individuals engaged in the fertilizer business, charging a conspiracy in violation of the Federal Anti-trust act and a conspiracy to commit an offense against the United States in violation of section 5440 of the Revised Statutes. On April I7, I908, various motions, pleas in abatement, and demurrers were filed. On July 3, 1908, the motions and demurrers were overruled, and the pleas in abatement were sustained and the indictment was quashed.

United States v. American Ice Company et al. Indictment returned on July 12, 1906, in the Supreme Court of the District of Columbia, charging an unlawful agreement to control prices and restrict competition in the sale of ice. No further action taken.

United States v. Chandler Ice and Cold Storage Plant et al. Indictment returned on September 19, I906, in the District Court for the Territory of Oklahoma, charging a combination to apportion territory in the sale of ice. Demurrer overruled in May, I907. Case was ordered dismissed on April IO, I9II. 
United States v. Alfred M. Gloyd et al. Indictment returned on September 2I, I906, in the District Court for the Territory of Oklahoma, charging a combination to maintain prices and restrict competition in the sale of lumber. Dismissed.

United States v. People's Ice and Fuel Company and W. B. Lount. Indictment returned on October 23, 1906, in the District Court for the Territory of Arizona, charging a combination to control prices and restrict competition in the sale of ice. The trial resulted in a verdict of not guilty as to People's Ice and Fuel Co. Case as to W. B. Lount was continued over term, and on October I6, I907, a plea in bar was filed, which on following day was sustained.

United States v. Demund Lumber Company et al. Indictment returned on October 23, 1906, in the District Court for the Territory of Arizona, charging a combination to control prices and restrict competition in the sale of lumber. January 2, 1907, the trial was commenced and resulted in a verdict of not guilty as to Demund Lumber Co. May 9, 1907, a verdict of acquittal was directed as to remaining defendants.

United States v. Phanix Wholesale Meat and Produce Company et al. Indictment returned on October 23, 1906, in the District Court for the Territory of Arizona, charging a combination to control prices and restrict competition in the sale of meats. January 7, 1907, verdict of not guilty as to Phœnix Wholesale Meat \& Produce Co. and indictment against Hurley dismissed. Verdict of guilty as to defendant S. J. Tribolet, and fine of $\$ 1,000$ imposed. Verdict affirmed by Supreme Court of Territory.

United States v. Standard Oil Company of N. J. et al. (I52 Fed. 290, I73 Fed. I77, 221 U. S. r.) Petition filed November 15, 1906, in Circuit Court for the Eastern District of Missouri, alleging that defendants were maintaining a combination in restraint of trade in the production and sale of petroleum. Decision in favor of government on November 20, 1909. Appealed to Supreme Court, and judgment affirmed May I5, I9I I, and the combination was thereafter dissolved in accordance with the terms of the decree.

United States v. T. B. Hogg et al. Indictment returned December 8 , 1906, in the District Court for the Territory of Oklahoma, charging a combination and conspiracy in restraint of 
trade and commerce in the sale of lumber. Dismissed upon admission of Oklahoma to statehood.

United States v. Atlantic Investment Company et al. Indictment returned February II, 1907, in the District Court for the Southern District of Illinois, charging a combination in restraint of tarde and commerce in the manufacture and sale of turpentine. February 18, 1907, four corporations and two individuals entered pleas of guilty, and the court imposed fines aggregating $\$ 30,000$.

United States v. American Seating Company et al. Indictment returned March 12, 1907, in the District Court for the Northern District of Illinois, charging a combination in restraint of trade in the manufacture and sale of school and church furniture. April I, 1907, defendant corporations entered pleas of guilty, with one exception. May 20, 1907, fines aggregating $\$ 43,000$ were imposed and collected. Defendant E. H. Stafford Manufacturing Co. filed demurrer April 3, 1907. May 31 , 1907, demurrer was overruled and plea of not guilty entered. Dismissed January 27, 19r3.

United States v. American Seating Company et al. Petition filed March 12, 1907, in the Circuit Court for the Northern District of Illinois, alleging a combination in restraint of trade in the manufacture and sale of school and church furniture. August 15, 1907, decree entered granting perpetual injunction against all defendants, except E. H. Stafford Manufacturing Co., E. H. Stafford, E. M. Stafford, and E. G. Bentley. As to these defendants the case was dismissed on January 27, r9r3.

United States v. Santa Rita Mining Company and Santa Rita -Store Company. Indictment returned on April 4, 1907, in the district of New Mexico, charging a combination in restraint of trade. Demurrer was filed and overruled. Fine of $\$ r, 000$ imposed on each defendant. An appeal was taken to the Supreme Court of the Territory of New Mexico, where judgment of the lower court was reversed, and the case was subsequently dismissed.

United States v. The Reading Company et al. ( 183 Fed. 427, 226 U. S. 324, 228 U. S. 158.) Petition filed June 12, 1907, in the Circuit Court for the Eastern District of Pennsylvania, to dissolve a combination among the anthracite coal-carrying roads and others. December 8, r9ı, a decision was handed down by the Circuit Court adjudging that defendants were joined in 
a combination in restraint of trade through the instrumentality of the Temple Iron Co., but dismissing the charge of the petition as to the so-called sixty-five per cent contracts whereby it was alleged the independent output was controlled, and also the charges as to certain so-called minor combinations. Cross appeals were taken to the Supreme Court, where the decree of the lower court, in so far as it adjudged the defendants parties to a combination in restraint of trade through the instrumentality of the Temple Iron Co., was affirmed, but was reversed as to the so-called sixty-five per cent contracts with instructions to cancel them, and was further modified by dismissing the petition in other respects without prejudice, instead of absolutely. (See further proceedings against the Reading Company, page 392.)

United States v. National Umbrella Frame Company et al. Indictment returned July I, I907, in the District Court for the Eastern District of Pennsylvania, charging a conspiracy to restrain interstate trade and commerce in the manufacture and sale of umbrella material. Pleas of guilty were entered and fines aggregating $\$ 3,000$ imposed and collected.

United States v. American Tobacco Company et al. (I64 Fed. 700, 22r U. S. 106, r9r Fed. 37r.) Petition filed July 10, 1907, in the Circuit Court for the Southern District of New York, in which it was alleged that defendants were maintaining a combination in restraint of trade and commerce in the manufacture and sale of tobacco. November 7, rgo8, a decision was rendered in favor of the government, except as to individual defendants and certain foreign and other corporations. Cross appeals were taken to the Supreme Court, where, on May 29, I9II, a decision was rendered sustaining the government on every point; and the case was remanded to the Circuit Court and the unlawful combination was dissolved in accordance with the decision of the Supreme Court.

United States v. E. H. Stafford Manufacturing Company et al. Indictment returned July 10, 1907, in the District Court for the Northern District of Illinois, charging a combination in restraint of trade in the manufacture and sale of school and church furniture. Dismissed January 27, 1913.

United States v. E. I. du Pont de Nemours \& Co. et al. (I88 Fed. 127.) Petition filed July 30, 1907, in the Circuit Court for the District of Delaware, in which it is alleged that defend- 
ants were maintaining a combination in restraint of trade in the manufacture and sale of gunpowder and other explosives. On June 2I, I9I I, a decision and interlocutory decree was rendered ordering the dissolution of the combination. Final decree dissolving the combination was approved by the court on June I3, I9I2.

United States v. One Hundred and Seventy-five Cases of Cigarettes. Information filed October 28, I907, in the District Court for the Eastern District of Virginia, covering the seizure of I75 cases of cigarettes under section 6 of the Federal Antitrust act. Cigarettes subsequently released under bond. Decree of dismissal entered January 3 I, I9I3.

United States v. H. D. Corbett Stationery Company et al. Indictment returned November I, 1907, in the District Court for the District of Arizona, charging a combination in restraint of trade. November 4, 1907, demurrer filed. November 14, 1907, demurrers sustained and defendants were held to next grand jury. October 28, I908, reindicted. November 6, I908, verdict of not guilty returned.

United States v. Union Pacific Coal Company et al. (I73 Fed. 737.) Indictment returned November 20, 1907, in the District Court for the District of Utah, charging a conspiracy to maintain a monopoly in the sale of coal. January 6 , I908, demurrer filed. March 2, 1908, the demurrer was sustained as to first count and overruled as to second count. December 3, I908, verdict of guilty was returned. March 29, I909, fines aggregating \$13,000 imposed. November, 1909, judgment was reversed by Circuit Court of Appeals, and the suit was dismissed March 2I, I9Io.

United States v. Chas. L. Simmons et al. Indictment returned January 20, 1908, in the District Court for the Southern District of Alabama charging a combination in restraint of trade and commerce in the manufacture and sale of plumbers' supplies. December I, I9I0, pleas of guilty were filed, and fines aggregating $\$ 265$ were imposed.

United States v. Union Pacific Railroad Company et al. (I88 Fed. 102, 226 U. S. 61, 226 U. S. 470.) Petition filed February I, I908, in the Circuit Court for the District of Utah, charging a combination and conspiracy in violation of the Sherman Act on the part of the so-called Harriman lines. June 23, I9I I, the petition was dismissed by the Circuit Court on the ground 
that the roads involved were not competing lines and hence the combination was not a violation of law. An appeal was taken to Supreme Court, which handed down a decision reversing the lower court on December 2, 1912. Final decree entered at St. Paul, Minn., on June 30,1913 . This decree is regarded as a model on the question of dissolution.

United States v. E. J. Ray et al. Indictment returned February 14, I908, in the Circuit Court for the Eastern District of Louisiana, against seventy-two laborers, charging a combination and conspiracy in restraint of foreign trade and commerce. See following case.

United States v. E. J. Ray et al. Indictment returned February I5, 1908, in the Circuit Court for the Eastern District of Louisiana, against seventy-two laborers, charging a combination and conspiracy in restraint of interstate trade and commerce. On January $26, \mathrm{I} 9 \mathrm{Ir}$, this and the preceding case were consolidated for trial. A verdict of guilty was returned as to three defendants, and fines aggregating \$1 Io were imposed. An appeal was granted and the judgment of the lower court was affirmed by the Circuit Court of Appeals.

United States v. Joseph Stiefvater et al. Indictment returned February 15, 1908, in the Circuit Court for the Eastern District of Louisiana, charging a combination in restraint of trade and commerce in the manufacture and sale of plumbers' supplies. June 25, 1910, case was dismissed:

United States v. American Naval Stores Company et al. (172 Fed. 455, r86 Fed. 592, 229 U. S. 373.) Indictment returned April II, 1908, in the Circuit Court for the Southern District of Georgia, charging a combination in restraint of trade and commerce in the manufacture and sale of turpentine. May ro, r909, verdict of guilty was returned as to five individual defendants. Fines aggregating $\$ 17,500$ imposed and two defendants sentenced to serve three months in jail. Appeal taken to Circuit Court of Appeals and the judgment was there affirmed. Certiorari granted by Supreme Court. Judgment of lower court reversed June 9, 1913, on ground of error in judge's charge to jury. Upon the retrial defendants were acquitted.

United States v. New York, New Haven and Hartford Railroad Company et al. Petition filed May 22, 1908, in the Circuit Court for the District of Massachusetts, charging the New Haven Co. with combining under common control the steam 
and electric railway systems in New England. Dismissed June 26,1909 . (See action in equity terminating in a decree dissolving combination, page 394; also United States v. Mellen, page 388, and United States v. William Rockefeller et al., page 395.

United States v. John H. Parks et al. Indictment returned June I6, I908, in the Circuit Court for the Southern District of New York, charging a combination in restraint of trade in the manufacture and sale of paper. On June 19, 1908, defendants plead guilty and fines aggregating $\$ 50,000$ were imposed and collected.

United States v. American Sugar Refining Company et al. (I73 Fed. 823, 218 U. S. 60I.) Indictment returned July I, I909, in the Southern District of New York. A plea of the statute of limitations was interposed by the defendants Kissel and Harned, which was sustained by the Circuit Court. An appeal therefrom was taken to the Supreme Court, where the matter was decided in favor of the government. March 3I, I912, the trial of this case resulted in a disagreement of the jury.

United States v. Albia Box \& Paper Company et al. Indictment returned December 7, 1909, in the Southern District of New York charging combination in restraint of trade in paper board. February 7, r9ro, all defendants plead guilty and fines aggregating $\$ 57,000$ were imposed and collected.

United States v. John S. Steers et al. (I92 Fed. I.) Indictment returned February I7, I9I0, in Eastern District of Kentucky, charging conspiracy to restrain trade. This is the socalled "Night Rider" case. April 16, I910, a verdict of guilty was returned as to eight of twelve defendants and fines aggregating $\$ 3,500$ were imposed. The case was appealed to Circuit Court of Appeals, and the judgment was affirmed. May II, 1912, the sentences were commuted by the President to payment of costs of suit.

United States v. Imperial Window Glass Company et al. Indictment returned April 7, I9Io, in the Western District of Pennsylvania, charging combination and conspiracy to enhance the price of window glass. Demurrers to the indictment were overruled, and on November I0, I9IO, pleas of nolo contendere were entered and fines aggregating $\$ 10,000$ were imposed and collected.

United States v. National Packing Company et al. Indictment returned March 21, I9Io, in Northern District of Illinois, 
charging combination in restraint of trade in fresh meats. Demurrer to indictment was sustained June 23, I9ro.

United States v. National Packing Co. et al. Petition filed March 12, I910, in the Circuit Court for the Northern District of Illinois, charging combination in restraint of trade in fresh meats and praying for dissolution. Dismissed in order to facilitate the prosecution of criminal case.

United States v. Armour Packing Company et al. Indictment returned in April, I9Io, in the Southern District of Georgia, charging combination to control prices and restrict competition. Pending on demurrer.

United States v. Missouri Pacific Railroad Company and twentyfour other railroads. Petition filed May 31, 1910, in Circuit Court, E. D. of Missouri, to restrain violation of Sherman Law, and temporary restraining order issued on that day enjoining advances in freight rates in western trunk-line territory. Thereafter the Interstate Commerce Commission enjoined the rate advances which the temporary restraining order had prevented from going into effect, and the petition was dismissed.

United States v. Southern Wholesale Grocers' Association. Petition filed June 9, I9I0, in the Circuit Court, Northern District of Alabama, alleging combination to regulate prices and control marketing of groceries. An agreed decree was entered. The court, October I7, I9II, perpetually restraining the association, its officers and members, from doing any and all of the acts complained of. See contempt proceedings, number 79 post.

United States v. Great Lakes Towing Company et al. (208 Fed. 733, 217 Fed. 657.) Petition filed June 19, I910, in the Circuit Court Northern District of Ohio, against an alleged combination of towing facilities on the Great Lakes. A decision in favor of the government was handed down February II, I9I3. Final decree entered February I3, I9I5, from which the government appealed. Pending in U. S. Supreme Court for the reason that no provision was made for the dissolution of the corporation.

United States v. Chicago Butter \& Egg Board. Petition filed June I3, I9I0, in Circuit Court, Northern District of Illinois. A demurrer to the petition was sustained with leave to amend, and an amended petition was filed. Set for hearing on master's report on January 8, i914. Court held government to be enti- 
tled to a decree as prayed for in the petition. Final decree entered October 12, I914.

United States v. Frank Hayne, James A. Patten, et al. ( 180 Fed. 946, 187 Fed. 664, 226 U. S. 525.) Indictments returned August 4, I9Io, in Southern District of New York alleging conspiracy to run a corner in cotton. Demurrers were sutained as to certain counts of indictment and overruled as to others, and an appeal was taken by the United States to the Supreme Court. Case was argued during November, I9II, and reargued at the October term, 1912. Decision by Supreme Court January 6, 1913, sustaining indictments. Patten entered plea of guilty February Ir, 19r3, and was fined $\$ 4,000$. Indictment dismissed as to other defendants, and another indictment was returned July r, 19r3. (See United States v. Thompson et al., page 392.) United States v. Standard Sanitary Manufacturing Company et al. (187 Fed. 229, 187 Fed. 232, I9r Fed. 172, 226 U. S. 20.) Petition in equity filed July 22, 1910, in Circuit Court, District of Maryland, charging a combination, under cover of a patent licensing arrangement, to restrain competition and enhance prices of enamel ware. In a decision rendered October 13, I9I I, the court sustained all the government's contentions, and a decree was entered November 25, I911, from which an appeal was taken to the Supreme Court. Decision of lower court affirmed by Supreme Court November 18, 1913. (See criminal proceedings against the defendants, page 378 .)

United States v. Louis F. Swift et al. (I88 Fed. 92.) Indictment returned in September, 1910, in the Northern District of Illinois against ten individuals engaged in the meat-packing industry. Defendants filed numerous pleas in bar, etc., all of which were decided in favor of the government. March 27, I9I2, after a trial lasting over three months the jury returned a verdict of acquittal.

United States v. John Reardon \& Sons Company and Consolidated Rendering Co. ( $19 \mathrm{I}$ U. S. 454.) Indictment returned in October, I910, in the District of Massachusetts, charging combination in the rendering business. Demurrer to indictment was sustained June 23, I9II.

United States v. Ferdinand Sulzberger, doing business under the name of John Reardon $\mathcal{E}$ Sons Company, and Horatio $W$. Heath, of Boston, doing business as the Consolidated Renderdering Company. Indictment returned in October, I9Io, in the 
District of Massachusetts, charging a combination in the rendering business. Demurrer to indictment was sustained June 23, I9II.

United States v. Horatio $W$. Heath and Cyrus S. Hapgood. Indictment returned in October, I9Io, in the District of Massachusetts, charging a combination in the rendering business. Demurrer to indictment was sustained June 23, 191 I.

United States v. Standard Sanitary Manufacturing Company et al. In addition to the above-mentioned suit in equity (page 377, supra, indictments were returned at Detroit on December 6, I9IO, against the same corporations and individuals, charging the same acts. After a trial lasting six weeks the jury reported a disagreement on March I4, I9I2. Retrial in February, 1913, resulted in a verdict of guilty and fines aggregating $\$ 51,006$ were imposed.

United States v. American Sugar Refining Company et al. Peti.. tion filed November 28, I9I0, in the Circuit Court Southern District of New York, alleging a combination in restraint of trade and praying for its dissolution. Demurrer was overruled December II, IgII. Issues joined and taking of testimony has been concluded. Set for hearing in October, I9I5.

United States v. General Electric Company et al. Petition filed March 3, I9II, in the Northern District of Ohio, charging a combination in the manufacture of incandescent electric lamps. A decree was agreed upon between counsel, which was approved by the court October I2, I9Ix.

United States v. Purrington et al. Indictment returned September I4, 1910, in the Northern District of Illinois, charging combination to restrain trade in paving bricks and paving blocks. Demurrer was overruled November 9, I9II. Nolle prosequi entered June 3, r9r3.

United States $v$. Hamburg-Amerikanische Packetfahrt Actien Gesellschaft and others. (200 Fed. 806, 216 Fed. 971.) Petition filed January 4, I9II, in the Circuit Court for the Southern District of New York, to dissolve a combination of steamship lines regulating steerage traffic on the Atlantic Ocean. Demurrers were overruled December 20, I9Ir. Taking of testimony completed and case set for argument on April 17, 1914. Decision adverse to government handed down October 13, 1914. Appealed to Supreme Court. 
United States v. William C. Geer, President, Albia Box and Paper Company et al. Indictment returned April 28, I9II, in the Southern District of New York, alleging a combination and conspiracy in restraint of interstate commerce in paper board. Demurrer overruled May 9, 19I3. Upon the commencement of the trial in February, 1915, defendants withdraw their former pleas of not guilty and offered pleas of nolo contendere. The court accepted these pleas and imposed fines aggregating $\$ 16,000$.

United States v. Eastern States Retail Lumber Dealers Association. (20r Fed. 58r, 234 U. S. 600.) Petition filed May I9, I9r r, in Circuit Court for the Southern District of New York, charging defendants with conspiring to restrain trade through the instrumentality of black lists and trade agreements. Decision by lower court in favor of government January 9, r9r3, and a decree entered March I, I9r3, from which an appeal was taken to the Supreme Court. Decree affirmed June 22, I9r4.

United States v. Isaac Whiting et al. Indictment returned May 26, I9II, in the District of Massachusetts, charging a combination to restrain trade in milk throughout the New England States. Demurrer argued in November, 1912. March 23, ror4, demurrers overruled as to counts charging combination and sustained as to counts charging conspiracy and monopoly. United States v. Isaac Whiting et al. Indictment returned May 26, I9II, in the District of Massachusetts, charging a conspiracy to restrain trade in milk throughout the New England States. Demurrer arguel in November, r9r2. March 23, I9r4, demurrers overruled as to counts charging combination and sustained as to counts charging conspiracy and monopoly.

United States v. Holmes et al. Indictment returned June 23, I9II, in the Northern District of Illinois, charging that the secretaries of fourteen retail lumbermen's associations were in a conspiracy by means of a central bureau to control the marketing of lumber. Demurrer filed. Nolle prosequi entered June 6, I9i3.

United States v. Wm. P. Palmer and twenty-five others, constituting the Bare Copper Wire Assocaition. Indictment returned June 29, I9II, in the Southern District of New York. Defendants entered pleas of nolo contendere.

United States v. Wm. P. Palmer and thirty-three others, constituting the Weatherproof and Magnet Wire Association. Indict- 
ment returned June 29, I9II, in the Southern District of New York. Defendants entered pleas of nolo contendere.

United States v. Wm. P. Palmer and thirty-eight others, constituting the Rubber Covered Wire Association. Indictment returned June 29, 1911, in the Southern District of New York. Defendants entered pleas of nolo contendere.

United States v. F. W. Roebling and scventeen others, constituting the Fine Magnet Wire Association. Indictment returned June 29, I9II, in the Southern District of New York. Defendants entered pleas of nolo contendere.

United States v. Wm. P. Palmer and fifteen others, constituting Horse Shoe Manufacturers' Association. Indictment returned June 29, 19II, in the Southern District of New York. Defendants entered pleas of nolo contendere.

United States v. Phillip H. W. Smith and fourteen others, constituting the Underground Power Cable Association. Indictment returned June 29, I9II, in the Southern District of New York. Defendants entered pleas of nolo contendere.

United States v. Frank N. Philips and ten others, constituting the Telephone Cable Association. Indictment returned June 29, I9I I, in the Southern District of New York. Defendants entered pleas of nolo contendere.

United States v. Wm. P. Palmer and seventeen others, constituting the Lead Encased Rubber Insulated Cable Association. Indictment returned June 29, I9I I, in the Southern District of New York. Defendants entered pleas of nolo contendere.

United States v. E. E. Jackson, Jr., and seventeen others, constituting the Wire Rope Association. Indictment returned June 29, I9I I, in the Southern District of New York. In this case and the eight cases immediately preceding, the various defendants entered pleas of nolo contendere, and fines aggregating approximately $\$ 128,700$ were assessed.

United States v. Periodical Clearing House et al. Petition filed in June, I9II, in the Southern District of New York against the members of the so-called Magazine Trust. The trial resulted in an equally divided court, and an order of dismissal was entered May 29, I9r3. It appearing that defendants had abandoned their alleged unlawful practices, no further action was taken.

United States v. Jay B. Pearce et al. Indictment returned July I9, I9I I, in the Northern District of Ohio against certain man- 
ufacturers and jobbers for combination and conspiracy in the manufacture and sale of wall paper. Demurrer was overruled May 13, 1912. Trial resulted in a verdict of not guilty on May 24, I912.

United States v. Lake Shore \& Michigan Southern R. R. et al. (203 Fed. 295.) Petition filed August 4, 19Ir, in the Southern District of Ohio to enjoin combination and conspiracy whereby certain carriers of bituminous coal are held under one control. Decision of lower court in favor of government December 28, 1912. Final decree entered March 14, 1914, but matters pertaining to the enforcement thereof are being taken up with the court from time to time.

United States v. Edward E. Hartwick et al. Petition filed August 3I, I9II, in the Circuit Court, Eastern District of Michigan, alleging conspiracy and unlawful restraint of trade on the part of members of the Michigan Retail Lumber Dealers' Association, The Scout Publishing Co., and the Lumber Secretaries' Bureau of Information. Issues joined and taking of testimony completed. Awaiting decision in U.S. v. Hollis, page 382, infra.

United States v. Standard Wood Company et al. Petition filed in September, I9II, in the Circuit Court, Southern District of New York, against the members of the so-called Kindling Wood Trust. On default of answer a decree was entered against defendants March II, I9I2.

United States v. Hunter Milling Company, Blackwell Milling and Elevator Company, and Frank Foltz. Indictment returned September 10, I9II, in the Western District of Oklahoma, charging violation of section I of the Anti-trust act. Demurrer overruled December 16, 1912. Jury returned a verdict of guilty, and fines aggregating $\$ 2,000$ were imposed.

United States v. S. W. Winslow et al. (195 Fed. 578, 227 U. S. 202.) Two indictments ( $\mathrm{I} / 3$ and II 4 ) returned September I9, I9II, in the District of Massachusetts, charging combination, conspiracy, and monopoly in trade in shoe machinery. Demurrer to indictment II 3 was sustained, and demurrer to indictment II4 was overurled as to first count and sustained as to second count. An appeal was taken by the United States from decision in No. II3, which was affirmed by the Supreme Court. Pending. (See United States v. United Shoe Machinery Co. et al., 382-3; also proceeding to enforce section 3 of Clayton Law, relating to "tying" clauses, page 396.) 
United States v. The Colorado and Wyoming Lumber Dealers' Association and The Lumber Secretaries' Bureau of Information. Petition filed September 25, I9I I, in the Circuit Court, District of Colorado, for injunction against defendants for conspiracy to restrain trade in lumber and its products. The taking of testimony has been completed and further action is being deferred, awaiting decision in the following case, U.S. v. Hollis.

United States v. Willard G. Hollis et al. Petition in equity filed October, I9II, in the Circuit Court, District of Minnesota, against the Lumber Secretaries' Bureau of Information. The Lumberman Publishing Company, and certain individuals alleging conspiracy and combination in the lumber trade. Argued and submitted in December, 19I4, and decision awaited. (See action pending, United States v. Hartwick, page 38I.) United States v. United States Steel Corporation and others. (223 Fed. 55.) Petition filed October 27, 19r I, in District Court for District of New Jersey alleging a combination in restraint of interstate commerce in iron and steel and their products and an attempt to monopolize the same. Case argued before circuit judges in October, I9I4. Decision adverse to government handed down June 3, I9I 5. Attorney-General has announced that an appeal will be taken to the Supreme Court.

United States v. Joe Cotton et al. Defendants were, on November I5, I9I I, indicted in the Southern District of Mississippi for conspiring to restrain interstate commerce during course of a strike on the Illinois Central Railroad. The strike having been terminated, no further action has been taken.

United States v. National Cash Register Co. et al. Petition filed December 4, I9I I, in Circuit Court, Southern District of Ohio, alleging conspiracy and monopoly in the manufacture, sale, and shipment of cash registers and other registering devices. Issue joined and taking of testimony will shortly be commenced. Delay due to prosecution of criminal case, United States v. John H. Patterson et al.,--see page 363.

United States v. United Shoe Machinery Co. et al. (222 Fed. 349.) Petition in equity filed December I2, I9I I, in Circuit Court, District of Massachusetts, alleging combinations and conspiracies in restraint of interstate and foreign trade in shoe machinery, and praying for perpetual restraining order, dissolution of company, and restoration of normal conditions. Decision adverse to government handed down March 18, I9I5. 
An appeal has been taken to the Supreme Court. (See United States $v$. Winslow, page $38 \mathrm{I}$; and also United States v. United Shoe Machinery Co. et al., page 396. In the last-named action relief in equity is sought enforcing Section 3 of the Clayton Law.)

United States v. A. Haines et al. Two indictments returned December I6, I9I 1 , in the Southern District of Florida against members of Longshoremen's Association for combining, conspiring, and agreeing to interfere with interstate operations of the Mason Forwarding Company which had declined to recognize one of the conspirators known as the "walking delegate." See following case.

United States v. A. Haines et al. Two indictments returned December I6, I91 1 , in the Southern District of Florida for combining, conspiring, and agreeing upon rules, regulations, requirements, etc., with reference to the employment of workmen to load vessels with lumber for interstate shipment. This and preceding case were consolidated for trial. Defendants entered pleas of guilty and were sentenced each to four hours' confinement.

United States v. Pacific Coast Plumbing Supply Association et al. Petition filed December 18, 1911, in Circuit Court, Southern District of California, alleging unlawful restraint of trade and commerce in plumbing supplies on the Pacific coast. Decree enjoining defendants from further committing the acts complained of was entered January 6, I912.

United States v. The Keystone Watch Case Company et al. (2I8 Fed. 502.) Petition filed December 20, I9II, in the Circuit Court, Eastern District of Pennsylvania, alleging unlawful contracts, combinations, and conspiracies to monopolize trade in filled watch cases and watches, and praying for a permanent decree ordering the dissolution of the company and enjoining defendants from further committing the unlawful acts complained of. January 2, I9I5, decision partly favorable and partly adverse to government handed down. Decree entered June 4, I9I5, from which government has appealed to the Supreme Court.

United States v. American Naval Stores Company et al. Petition filed January 8, I9I2, in the District Court, Southern District of Georgia, alleging unlawful combination and conspiracy in restraint of interstate and foreign commerce in turpentine and resin. Demurrer overruled January 2, 19r3. Defendant sus- 
pended business in March, 1913, on account of financial difficulties, and since then no further action has been taken.

United States v. New Departure Manufacturing Company et al. (204 Fed. 107.) Indictment returned January 8, 1912, in the Western District of New York against six corporations and eighteen individual defendants, charging unlawful combination and conspiracy for the purpose of monopolizing the coasterbrake business, and fixing and maintaining prices for coaster brakes. Plea in abatement overruled April 2, 1912. Demurrer overruled March 12, I913. Defendants entered pleas of guilty and nolo contendere and fines aggregating $\$ 81,500$ were imposed in May, r9r3.

United States v. The North Pacific Wharves \& Trading Co. et al. Indictment (834-B) returned February 12, 1912, in the First Division, District of Alaska, charging defendants with conspiring to monopolize and monopolizing the coal business at Skagway. Demurrer sustained May 3, I9r2.

United States v. Pacific \& Arctic Railway \& Navigation Co. et al. Indictment (835-B) returned February 12, 1912, in the First Division, District of Alaska, charging defendants with engaging in a conspiracy to monopolize and monopolizing the transportation business between the head of Lynn Canal and the headwaters of the Yukon River. Demurrer sustained on May 3, IgI2.

United States v. The North Pacific Wharves \& Trading Co. et al. Indictment (836-B) returned February 12, 1912, in the First Division, District of Alaska, charging defendants ( 1 ) with engaging in a conspiracy and combination in restraint of trade and commerce by way of combining the four wharves at Skagway under one management, and (2) with monopolizing the wharfinger business at Skagway. Demurrer overruled on May 3, 1912. First trial resulted in disagreement of jury on January 27, rgr 3 . Corporation defendants entered pleas of guilty and on February 2, 1914, fines aggregating $\$ 19,500$ were imposed. Case dismissed as to individual defendants.

United States v. Pacific \& Arctic Railway and Navigation Co. et al. (228 U. S. 87.) Indictment (837-B) returned February 13, 1912, in the First Division, District of Alaska, charging defendants with engaging in a conspiracy to monopolize and monopolizing the steamship transportation between Puget Sound and British Columbia ports in the south and Skagway 
in the north. Demurrer sustained, except as to corporation defendants to count No. 6. Upon appeal to the Supreme Court the judgment was reversed and the case remanded for further proceedings. Corporation defendants entered pleas of guilty and on February 2, 1914, fines aggregating $\$ 8,500$ were imposed. Case dismissed as to individual defendants.

United States v. John H. Patterson et al. (201 Ficd. 697, 205 Fed. 292, 222 Fed. 599.) Indictment returned February 22, 1912, in the Southern District of Ohio, against John H. Patterson, president, and twenty-nine other officials and employees of the National Cash Register Company, alleging a conspiracy in restraint of interstate trade and commerce in cash registers, resulting in an unlawful monopoly of the industry. Demurrer overruled June 26, 1912. Trial resulted in a verdict of guilty as to twenty-nine of the thirty defendants and fines aggregating $\$ 135,000$ and jail sentences ranging from nine months to one year were imposed. Defendants appealed to the Circuit Court of Appeals. In a decision handed down March 13, I915, the judgment of conviction was reversed and the case remanded for new trial on certain counts. The government petitioned the Supreme Court for a writ of certiorari which was denied. (For previous criminal proceeding, also for suit in equity, see pages 363 and 382 .)

United States v. American-Asiatic Steamship Company et al. (220 Fed. 230.) Petition in equity filed March 30, 1912, in Southern District of New York, charging defendants with combining and conspiring, entering into unlawful contracts and pooling agreements, and allowing rebates, for the purpose of securing a monopoly of the business of transporting freight between ports on the Atlantic coast of the United States and ports in the Philippine Islands, Japan, China, and the Far East. A decision in the main adverse to the government handed down February 3, 1915. The government has appealed to the Supreme Court.

United States v. Julius F. Miller, Secretary, New York Charcoal Company et al. Indictment returned April 2, 1912, in the Eastern District of New York charging defendants with restraining interstate trade and commerce in charcoal. Demurrer sustained October 17, 1912.

United States v. International Harvester Company et al. (214 Fed. 987.) Petition filed April 30, 1912, in the District Court, 
District of Minnesota, allleging the acquisition and maintenance of a monopoly in harvesting and agricultural machinery and implements and twine. Testimony taken, expediting certificate filed, and case argued before three circuit judges at St. Paul during November, 1913. Decision in favor of the government handed down August 12, 1914. The defendants appealed to the Supreme Court where the case was argued in April, I915, June 2, I915, restored to the docket for reargument at Fall Term, I9I5.

United States v. Aluminum Company of America. Petition filed May 16, I912, in the District Court, Western District of Pennsylvania, to prevent a further monopoly of and restraint upon the interstate and foreign trade and commerce in aluminum and aluminum wares. Consent decree granting relief substantially as prayed for was entered at Pittsburgh on June 7, I9I2.

United States v. Herman Sielcken et al. Petition filed May 18, I9I2, in the District Court, Southern District of New York, alleging conspiracy to reduce the production of coffee, especially in the State of San Paulo, Brazil, and to withdraw a large per cent of coffee from the market by purchase. Motion for preliminary injunction denied. Upon the advice of the State Department that representations had been made by the Brazilian government that the entire quantity of coffee which was being withheld from market had been sold to a large number of dealers throughout the United States, an order of dismissal was entered May 29, I9I3.

United States v. Prince Line (Limited) et al. (220 Fed. 230.) Petition filed June 5, 1912, in the District Court, Southern District of New York, charging defendants, as common carriers of freight and passengers between ports of the United States and ports in the Republic of Brazil, with acquiring and maintaining a substantial monopoly by means of contracts, rebates, and other unlawful acts, and praying for an annulment of said contracts, agreements, etc. A decision in the main adverse to the government handed down February 3, 1915. The government has appealed to the Supreme Court.

United States v. Central-West Publishing Co. et al. Petition filed August 3, I9I2, in the District Court, Northern District of Illinois, charging defendants with engaging in unfair competition against each other and against others engaged in competing industries, with the intent to restrain and monopolize 
interstate trade and commerce in plate and ready-print matter. Consent decree, granting relief as prayed for, entered at Chicago on August 3, I9I2.

United States v. Associated Billposters and Distributors of the United States and Canada et al. Petition filed August 3, I9I2, in the District Court, Northern District of Illinois, charging defendants with engaging in a combination and conspiracy to place unlawful restraints upon interstate and foreign trade and commerce in posters. A demurrer to the petition having been overruled, this case was tried in open court in July, 1915, and a decision is awaited.

United States v. Motion Picture Patents Company et al. Petition filed August 15, 1912, in the District Court, Eastern District of Pennsylvania, to remove the restraints which defendants have imposed upon interstate and foreign trade and commerce in machines, appliances, and apparatus relating to the motionpicture art, and upon persons engaged in such trade and commerce. October I, 19I5, decision in favor of the government handed down.

United States v. Calvin N. Payne et al. Indictment returned August 29, 1912, in the Northern District of Texas, charging defendants with engaging in a conspiracy in restraint of interstate and foreign trade and commerce in oils and oil products. Nolle prosequi entered February 25, I913.

United States v. Consolidated Rendering Co. Indictment returned October 31, 1912, in the District of Massachusetts, charging monopoly of interstate trade and commerce in rendering materials. December I, I913, plea of nolo contendere by defendant and fine of $\$ 5,000$ imposed.

United States v. Consolidated Rendering Company et al. Indictment returned October 3I, 1912, in the District of Massachusetts, charging monopoly of interstate trade and commerce in rendering materials. December I, I9I3, plea of nolo contendere by corporation and fine of $\$ 3,000$ imposed. Indictment nolle prossed as to individual defendants.

United States v. The Master Horseshoers' National Protective Association of America and others. Petition filed December 12, 1912, in the Eastern District of Michigan, charging defendants with engaging in a combination and conspiracy in restraint of trade and commerce in drilled horseshoes, adjustable calks, and rubber hoof pads. Consent decrees entered as to certain 
defendants. April 4, I9I4, demurrers overruled. Negotiations looking to the entry of a consent decree now pending.

United States v. Philadelphia Jobbing Confectioners' Association et al. Petition filed December 13, 1912, in the Eastern District of Pennsylvania, charging defendants with unlawfully interfering with interstate commerce in candies and confections. Consent decree entered February I7, I9I3.

United States v. Elgin Board of Trade et al. Petition filed December 14, 1912, in the Northern District of Illinois, charging defendants with combining and conspiring in the interest of a number of large centralizing concerns to restrain interstate commerce in butter and butter fat, and arbitrarily fixing the price thereof to obtain throughout the United States. Issue joined and taking of testimony in open court will be commenced on January 8, I9I4, Consent decree entered April 27, I9I4.

United States v. Charles S. Mellen, Edson J. Chamberlin, and Alfred $W$. Smithers. Indictment returned December 23, I912, in the Southern District of New York, charging a combination and conspiracy to restrain interstate commerce by preventing the construction of subsidiary lines of the Central Vermont Railway Company (itself a subsidiary of the Grand Trunk Railway Company) from Palmer, Mass., to Providence, R. I.; from White River Junction, Vermont, to Boston; and from Boston to Blackstone, connecting there with the Palmer-Providence line. Case at issue awaiting trial. (For suit in equity, see pages 374-5; for criminal proceeding against individual directors and officers, see pages 388 and 395 .)

United States v. Kellogg Toasted Corn Flake Company et al. (222 Fed. 725.) Petition filed December 26, I912, in the Eastern District of Michigan, alleging that the business policy of the defendant company in fixing and enforcing resale prices on Kellogg's Toasted Corn Flakes is unlawful and tends to restrain and monopolize interstate commerce in said product. July I4, I9I4, hearing on motion to dismiss involving merits of case. April 14, I9I5, decision in favor of the government. September 20, 1915, final decree entered. This decree is regarded as a model on the question of resale price fixing.

United States v. Page et al. Indictment returned February 5, 1913, at Portland, District of Oregon, charging fifteen individuals, through the medium of the Produce Merchants' Exchange, of Portland, with unlawfully controlling the purchase, 
distribution, and sale of approximately ninety per cent of the produce, fruit, and vegetables shipped into the State of Oregon. The defendants entered pleas of guilty on February 21, 1913, and fines aggregating $\$ 8,450$ were imposed and collected.

United States v. Krentler-Arnold Hinge Last Company et al. Petition filed February 7, 1913, in the District Court, Eastern District of Michigan, alleging the unlawful control by defendant of the interstate trade and commerce in shoe and boot lasts, both patented and unpatented. Consent decree was entered at Detroit, Michigan, on February 7, 1913.

United States v. United Shoe Machinery Company of New Jersey et al. Petition filed February 8, 1913, in the District Court at Trenton, New Jersey, seeking to have annulled an alleged unlawful contract involving "inseam trimming machines." Further action in this case has been deferred awaiting final outcome of case pending against same company in Massachusetts, pages $382-3$.

United States v. The Southern Wholesale Grocers' Association et al. (207 Fed. 434.) Petition for rule to show cause why an attachment for a criminal contempt of court for alleged violation of the terms of a decree, entered October I7, I9I I (see No. 9), should not issue was filed in the District Court at Birmingham, Northern District of Alabama, on February Io, I913. The association and three individual members were adjudged guilty of contempt of court, and on July 29, 1913, fines aggregating $\$ 5,500$ were imposed.

United States v. Board of Trade of the City of Chicago et al. Petition filed February II, I9I3, in the District Court at Chicago, Illinois, attacking Rule 33 of the Chicago Board of Trade, by virtue of which it is alleged the price of all corn, oats, wheat, and rye arriving in Chicago at times when the board of trade is not in session is arbitrarily determined. Motion to strike out certain portions of defendants' answer sustained. The court announced its decision of this case in favor of the government on September 8, 1915 , and ordered the preparation of an appropriate decree. No opinion was filed.

United States v. The Cleveland Stone Company et al. Petition filed February 12, 1913, in the District Court at Cleveland, Northern District of Ohio, charging defendants with establishing and maintaining a practical monopoly of the stone business. Set for hearing at the Fall Term of Court, I9I5. 
United States v. The Delaware, Lackawanna \& Western Railroad Company and The Delaware, Lackawanna \& Western Coal Company. (213 Fed. 240, 238 U. S. 516.) Petition filed February 13, 1913, in the District Court at Trenton, New Jersey, charging defendants with transporting coal in which it had an interest in violation of the commodities clause of the interstate commerce act, and with entering into an unlawful contract whereby the coal company acquired a monopoly of the sale of anthracite coal produced along the line of the railroad company, in violation of the Anti-trust act. April 7, r914, decision adverse to the government handed down. Appealed by government to Supreme Court. June 21, I915, decree of lower court reversed. August II, I9I 5, final decree entered.

United States v. The McCaskey Register Company et al. Petition filed February 20, 1913, in the District Court at Cleveland, Northern District of Ohio, charging defendants with conspiring to restrain and monopolize the manufacture and sale of account registers and appliances. Upon a reinvestigation of the facts in this case, the department reached the conclusion that the charges against the McCaskey Company were not well founded. Accordingly the petition was dismissed without prejudice on January 7, I9I 5.

United States v. International Brotherhood of Electrical Workers, Local Unions Nos. 9 and 134 et al. Petition filed February 24, I9I3, in the District Court at Chicago, Northern District of Illinois, seeking to enjoin defendants from interfering with the interstate business of the Postal Telegraph-Cable Company. A temporary injunction was granted. Decree making temporary injunction permanent entered February 27, 1914.

United States v. Corn Products Refining Company et al. Petition filed March I, I9I3, in the District Court at New York City, charging defendants with monopolizing interstate trade and commerce in corn products, and praying for the dissolution of the combination. Issue joined. The taking of testimony has been completed and the case has been set for early hearing.

United States v. The American Thread Company et al. Petition filed March 3, 1913, in the District Court at Trenton, New Jersey, charging defendants with monopolizing the thread industry. Answers of defendants filed September I0, I9I3. Consent decree entered June 2, 1914, granting relief as prayed by the 
government. This decree is regarded as a model on questions of unfair trade methods.

United States v. The Burroughs Adding Machine Company et al. Petition filed March 3, 1913, in the District Court at Detroit, Michigan, alleging that defendants were engaged in a conspiracy to monopolize interstate trade and commerce in adding machines. A consent decree was entered at Detroit on March 3, 1913.

United States v. American Coal Products Company et al. Petition filed March 3, 1913, in the District Court at New York City, charging defendants with monopolizing the supply of coal tar and restraining the trade of competitors in the purchase of coal tar and in the manufacture and sale of tarred roofing felts, coal tar pitch, and other coal tar products. A consent decree was entered on March 4, 1913.

United States v. Terminal Railroad Association of St. Louis et al. Petition filed March 4, I9I3, in the District Court at St. Louis, Eastern District of Missouri, alleging a conspiracy on the part of the members of the St. Louis Coal Traffic Bureau to suppress and eliminate competition in various rates for the transportation of soft coal from the State of Illinois to the city of St. Louis, Missouri. The increased rates having been upheld by the Interstate Commerce Commission in a decision handed down January 29, I9I5, this case was dismissed without prejudice on September 20, 1915.

United States v. The New Departure Manufacturing Company et al. Petition filed May 27, 1913, in the District Court at Rochester, Western District of New York, alleging that defendants entered into a conspiracy and combination and devised a license agreement for the purpose of restraining and monopolizing the manufacture and sale of bicycle and motorcycle parts and coaster brakes. An agreed decree was entered at Rochester on May 27, 19r3.

United States v. White et al. Indictment returned June 7, 1913, in the District Court for the Southern District of West Virginia, against nineteen members of the United Mine Workers of America, alleging a conspiracy to interfere with interstate commerce in coal mined in West Virginia. Nolle prosequi entered June 20, I9I4.

United States v. Eastman Kodak Company et al. Petition filed June 9, 1913, in the District Court at Buffalo, Western District 
of New York, alleging that defendants have acquired a monopoly of the business of manufacturing, selling, and distributing photographic supplies. Testimony taken in open court. A decision favorable to the government was handed down on August 24, 19I5, and the form of decree to be entered is now under consideration.

United States v. The Quaker Oats Company et al. Petition filed June I I, I9I3, in the District Court at Chicago, Illinois, alleging combination to restrain and monopolize interstate trade and commerce in oatmeal products and by-products. The taking of testimony has been completed and the case is being prepared for early hearing.

United States v. Hippen et al. Indictment returned June 25, 1913, in the District Court for the Western District of Oklahoma against The Oklahoma Brokerage Company and two other corporations and the officers thereof, alleging a conspiracy to restrain and monopolize interstate trade and commerce in fruits and vegetables. Demurrer sustained October I, I9I3.

United States v. Thompson et al. Indictment returned July I, 1913, in the District Court for the Southern District of New York, alleging that the defendants conspired to run a corner in cotton on the New York Cotton Exchange. Defendants entered pleas of nolo contendere in December, 1913, and fines aggregating $\$ 18,000$ were assessed. (See United States v. Patten, page 377.$)$

United States v. American Telephone \& Telegraph Company, et al. Petition filed July 24, 1913, in the District Court at Portland, Ore., seeking to destroy a monopoly of the telephone business on the Pacific Coast. Terminated by entry of a consent decree on March 26, I9I4.

United States v. Reading Company et al. (Anthracite coal combination.) Petition in equity filed September 2, 1913, in the District Court at Philadelphia, $\mathrm{Pa}$., against a combination consisting of Reading Company and affiliated corporations, charging it with restraining and monopolizing trade in anthracite coal. Decision handed down on July 3, 1914, holding combination of competing coal companies illegal but deciding against the government on all other points. Case will be appealed. (As to earlier suit in equity, see pages 37I-2.) 
United States v. The National Wholesale Jewelers' Association et al. Petition filed November I8, I9I3, in the District Court at New York City, charging defendants with conspiring to eliminate all competition-except as between wholesalers or jobbers-for the trade of all classes of retail dealers in jewelry and jewelry products.

United States v. American Can Company et al. Petition filed November 29, I9I3, in the District Court at Baltimore, Md., alleging monopolization of the business of making tin cans. The taking of testimony has been completed and the case was argued and submitted to the court in October, 1915.

United States v. John P. White et al. Indictment returned December I, I9I3, in the District Court, Pueblo, Colo., charging officials and members of the United Mine Workers of America with monopolizing all diggers of coal and mine laborers and with restraining interstate commerce in coal. Pending. United States v. Frank J. Hayes et al. Indictment returned December I, I9I3, in the District Court, Pueblo, Colorado, charging a combination and conspiracy by mine workers to interfere with the mining of coal in Colorado and its transportation to and sale in other states. Pending.

United States v. Southern Pacific Company, Central Pacific Railway Company et al. Petition in equity filed February I I, I9I4, in the District Court at Salt Lake City, Utah, to compel the Southern Pacific to relinquish its control of the Central Pacific. The taking of testimony was commenced October 2I, I9I4, and has now been completed. Set for hearing in the District Court on December I, I9I 5 .

United States v. Lehigh Valley Railroad Company et al. Petition filed March 18, I9I4, in the District Court at New York City, New York, charging the defendants with having monopolized the production, transportation and sale of anthracite coal from mines tributary to Lehigh Valley Railroad Company in violation of the Anti-trust act, and charging the said railroad company with transporting in interstate commerce coal in which it has an interest, in violation of the Commodity Clause of the Act to Regulate Commerce. Argued in November, 1914. Opinion dismissing petition handed down December 2I, 1914. Case appealed to Supreme Court.

United States v. Knauer et al. Indictment returned June 4, I9I4, at Des Moines, Southern District of Iowa, charging defendants 
with having entered into a combination in restraint of trade in plumbing supplies. Motion to quash and demurrer overruled November 25, 1914. Trial commenced February 10, 1915, and verdict of guilty returned February 24, 1915. Four defendants fined amounts aggregating $\$ 3,000$ and writ of error granted as to them. Case to stand on motion for new trial as to thirty-one defendants pending decision or writ of error by Court of Appeals.

United States v. The American Wringer Company et al. Indictment returned May 22, 1914, in the District Court for the Western District of Pennsylvania, charging defendants with unlawfully engaging in a combination in restraint of interstate trade and commerce in clothes wringers. Pleas of nolo contendere were entered on November 13,1914 , and fines aggregating $\$ 6,000$ imposed.

United States v. Booth Fisheries Company et al. Indictment returned July 20, 1914, in the District Court at Seattle, Washington, charging defendants with entering into a combination and conspiracy in restraint of interstate trade and commerce in fresh fish. Awaiting trial.

United States v. The New York, New Haven \& Hartford Railroad Company et al. Petition filed July 23, r9r4, in the District Court for the Southern District of New York, alleging monopolization of transportation facilities in New England and praying for a dissolution thereof. Decree entered October I7, I914. (For dismissal of prior action for a dissolution, see pages 374-5; for criminal proceeding against directors and officers as individuals, see pages 388 and 395.)

United States v. Western Cantaloupe Exchange et al. Indictment returned August 7, 1914, in the District Court at Chicago, Northern District of Illinois, charging defendants with having entered into a combination to restrain and monopolize interstate trade in cantaloupes. Awaiting trial.

United States v. Collins et al. Indictment returned September 4, 1914, in the Supreme Court of the District of Columbia, against thirty-one commission merchants, charging them with engaging in a combination to fix arbitrarily and without competition the prices at which country produce is dealt in in the District of Columbia. Argued on demurrer during December, 19r4. Demurrer overruled May I, I9I5, and now awaiting trial on the merits. 
United States v. McCoach et al. Indictment returned October 5, 1914, in the District Court at Pittsburgh, Western District of Pennsylvania against thirty-three individuals, each a master plumber and retail dealer in plumbing supplies, charging them with entering into a combination to secure a monopoly of the business of selling and installing plumbing supplies. Awaiting trial.

United States v. Irving et al. Indictment returned October 31, I9I4, in the District Court at Salt Lake City, District of Utah, against fourteen individuals, each a master plumber and retail dealer in plumbing supplies, charging them with entering into a combination to secure a monopoly of the business of selling and installing plumbing supplies. Argued on demurrer in January, 1915. Demurrer overruled and motion to quash denied January 25, I9I5. Awaiting trial.

United States v. William Rockefeller et al. Indictment returned November 2, 1914, in the District Court at New York, Southern District of New York, against twenty-one individuals, each at some time a director or officer, or both, of the New York, New Haven \& Hartford Railroad Company, charging them with conspiring to monopolize the transportation facilities of New England. Numerous demurrers and pleas in abatement argued. October, 1915, on trial. Superseding indictment returned February 26, 1915. (For actions in equity for dissolution of the combination, see pages $374-5$, and 394 ; also, see United States v. Mellen, page 388.)

United States v. Isaac E. Chapman, William L. Chapman, and Merritt \& Chapman Derrick \& Wrecking Co. Indictment returned January 27, 1915, in the District Court, Southern District of New York, charging a combination and conspiracy to monopolize interstate trade and commerce in the derrick, lighterage and wrecking business in New York harbor and its environs and along the Atlantic coast of the United States. Demurrer sustained April 13, I9I 5.

United States v. Carl C. King et al. Indictment returned March 4, I9I5, in the District Court at Boston, Mass., charging defendants (Aroostook Potato Shippers Association) with entering into a conspiracy in restraint of trade in potatoes. Argued on demurrer in June, 1915, and decision of the court now awaited. 
United States v. Michael Artery et al., Northern District of Illinois. Eight indictments returned in January and April, 1915, against certain so-called business agents of Chicago labor unions, charging them with combining and conspiring to prevent the unloading in Chicago of goods shipped from other states.

United States v. Michael Boyle et al., Northern District of Illinois. Two indictments returned April 27, 1915, against certain so-called business agents of Chicago labor unions, charging them with combining and conspiring to prevent the installation in Chicago of electrical appliances and lighting fixtures manufactured in other states.

United States v. S. F. Bowser \& Company, Inc., et al., District of Indiana. Petition filed June 1o, 1915, charging defendants with combining to restrain and attempting to monopolize interstate trade and commerce in pumps, tanks and outfits for the storage and handling of gasoline and other inflammable liquids. A decree granting the relief sought by the government was entered simultaneously with the filing of the petition.

United States v. United Shoe Machinery Company et al., Eastern District of Missouri. Petition filed October 18, 1915, charging that the so-called tying clauses in the series of leases used by the defendants in the conduct of their business are in violation of section 3 of the Clayton Law. A temporary restraining order was granted at the time the petition was filed. Set for hearing on October 27, 19r5. (For decision adverse to government in action to restrain, etc., under Sherman Law, see pages 282-3 ; for criminal prosecution of individual defendants, see United States v. Winslow et al., page 381.)

[For Alphabetic List of Cases Contained in the foregoing 'Appendix,-see pages 397 to 401.$]$ 


\section{Alphabetic List of Cases Contained in Appendix P.}

Anderson v. United States (82 Fed. 998, 171 U. S. 604) ........ 365

Corning, In re (51 Fed. 205) ....................... 362

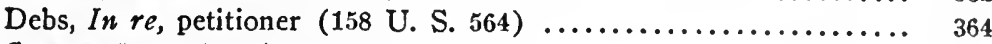

Greene, In re (52 Fed. 104) .......................... 362

Moore v. United States ( 85 Fed. 465) ................... 365

Terrell, In re (51 Fed. 213) .......................... 362

United States v. Addyston Pipe and Steel Company (78 Fed. 712,

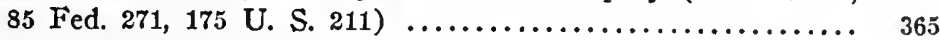

United States v. Agler (62 Fed. 824) ................... 364

United States v. Albia Box \& Paper Company et al. ............ 375

United States v. Allen \& Robinson et al. (3 Dist. Hawaii 664) .... 368

United States v. Alluminum Company of America ............. 386

United States v. American-Asiatic Steamship Company et al. (220 Fed. 230) .................................... 385

United States v. American Can Company et al. ............... 393

United States v. American Coal Products Company et al. ........ 391

United States v. American Ice Company et al. ................ 369

United States v. American Naval Stores Company et al. (172 Fed. 455, 186 Fed. 592, 229 U. S. 373) ..................... 383

United States v. American Seating Company et al. ............ 371

United States v. American Sugar Refining Company et al. (173 Fed. 823,218 U. S. 601) .................................... 378

United States v. American Telephone \& Telegraph Company et al. • 392

United States v. American Thread Company et al. ............. 390

United States v. American Tobacco Company et al. (164 Fed. 700, 221 U. S. 106, 191 Fed. 371) ...................... 372

United States v. American Wringer Company et al. ........... 394

United States v. Armour \& Co. et al. (142 Fed. 808) ........... 367

United States v. Armour Packing Company et al. .............. 376

United States v. Artery, Michael, et al ................... 396

United States v. Associated Billposters and Distributors of the

United States and Canada et al. .................... 387

United States v. Atlantic Investment Company et al. .......... 371

United States v. Board of Trade of the City of Chicago et al. .... 389

United States v. Booth Fisheries Company et al. ............... 394

United States v. Boyle, Michael, et al. .................. 396

United States v. Burroughs Adding Machine Company et al. ..... 391

United States v. Cassidy (67 Fed. 698) .................... 364

United States v. Central-West Publishing Co. et al. ............ 386

United States v. Chandler Ice and Cold Storage Plant et al. ...... 369

United States v. Chapman, Isaac E., William L. Chapman, and Merritt \& Chapman Derrick \& Wrecking Co. ................

United States v. Chesapeake and Ohio Fuel Company et al. (105 Fed. 93, 115 Fęd. 610) $\ldots \ldots \ldots \ldots \ldots \ldots \ldots \ldots \ldots \ldots \ldots \ldots$ 
United States v. Chicago Butter \& Egg Board .................

United States v. Cigarettes, One Hundred and Seventy-five Cases of

United States v. Cleveland Stone Company et al. ................

United States v. Coal Dealers' Association (85 Fed. 252) ...........

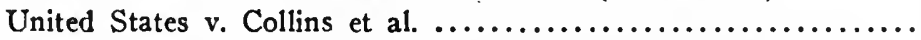

United States v. Colorado and Wyoming Lumber Dealers' Association and The Lumber Secretaries' Bureau of Information ..

United States v. Consolidated Rendering Co. ..................

United States v. Consolidated Rendering Company et al. ..........

United States v. Corn Products Refining Company et al. ..........

United States v. Cotton, Joe, et al. ...........................

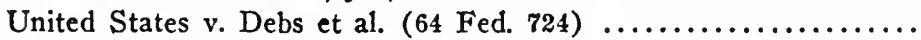

United States v. Debs et al. ..............................

United States v. Debs, Eugene V., et al. .......................

United States v. The Delaware, Lackawanna \& Western Railroad Company and The Delaware, Lackawanna \& Western Coal Company (213 Fed. 240, 238 U. S. 516) ...................

United States v. Demund Lumber Company et al. ................ United States v. Eastern States Retail Lumber Dealers' Association. (201 Fed. 581, 234 U. S. 600) .........................

United States v. Eastman Kodak Company et al. ................

United States v. E. C. Knight Company (60 Fed. 306, 60 Fed. 934,

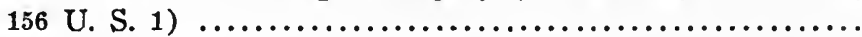

United States v. E. H. Stafford Manufacturing Company et al. ....

United States v. E. I. du Pont de Nemours \& Co. et al. (188 Fed. 127)

United States v. Elliott (62 Fed. 801, 64 Fed. 27) ................

United States v. Elgin Board of Trade et al. ...................

United States v. F. A. Amsden Lumber Company et al. ...........

United States v. Federal Salt Company .......................

United States v. Federal Salt Company et al. ...................

United States v. Geer, William C., President Albia Box and Paper

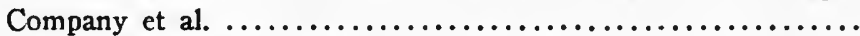

United States v. General Electric Company et al. ................

United States v. General Paper Co. et al. (See U. S. v. Nelson, and U. S. v. Alexander, (52 Fed. 646, 201 U. S. 92, 201 U. S. 117) .. United States v. Gloyd, Alfred M., et al. .....................

United States v. Great Lakes Towing Company et al (208 Fed. 733,

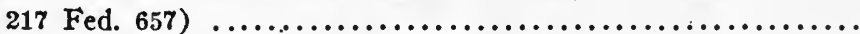

United States v. Greenhut et al (50 Fed. 469) $\ldots . \ldots \ldots \ldots \ldots . . . . .$.

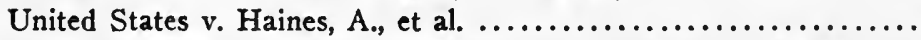
United States v. Hamburg-Amerikanische Packetfahrt Actien Gesellschaft and others (200 Fed. 806, 216 Fed. 971) ...........

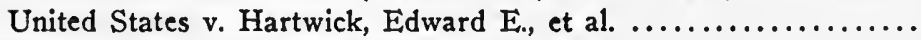

United States v. Hayes, Frank J., et al. ...................... United States v. Hayne, Frank, James A. Patten, et al. (180 Fed. 946, 187 Fed. 664, 226 U. S. 525) ....................... United States v. H. D. Corbett Stationery Company et al. ......... United States v. Heath, Horatio W., and Cyrus S. Hapgood ........ 
United States v. Hippen et al.

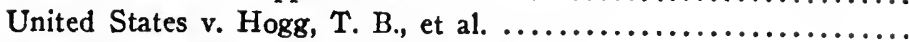

United States v. Hollis, Willard G., et al. ......................

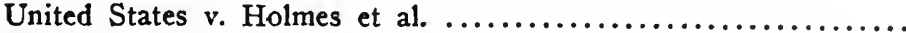

United States v. Hopkins et al. (82 Fed. 529, 84 Fed. 1018, 171 U. S. 578)

United States v. Hunter Milling Company, Blackwell Milling and Elevator Company, and Frank Foltz ....................

United States v. Imperial Window Glass Company et al. ..........

United States v. International Brotherhood of Electrical Workers, Local Unions Nos. 9 and 134 et al. .......................

United States v. International Harvester Company et al. (214 Fed. 987)

United States v. Irving et al.

United States v. Jackson, Jr., E. E., and seventeen others ..........

United States v. Jacksonville Wholesale Grocers' Association ......

United States v. Jellico Mountain Coal Company (43 Fed. 898, 46 Fed. 432)

United States v. John Reardon \& Sons Company and Consolidated

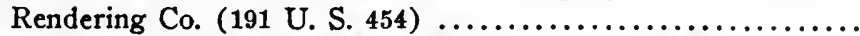

United States v. Joint Traffic Association (76 Fed. 895, 89 Fed. 1020,

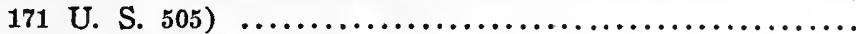

United States v. Kellogg Toasted Corn Flake Company et al. (222 Fed. 725)

United States v. Keystone Watch Case Company et al. (218 Fed. 502)

United States v. Carl C. King et al.

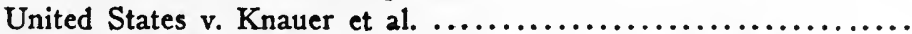

United States v. Krentler-Arnold Hinge Last Company et al. ......

United States v. Lake Shore \& Michigan Southern R. R. et al. (203 Fed. 295)

United States v. Lehigh Valley Railroad Company et al. .......... United States v. MacAndrews \& Forbes Company et al. (149 Fed.

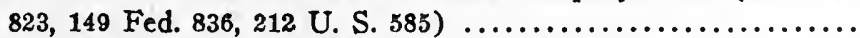

United States v. Master Horseshoers' National Protective Associa-

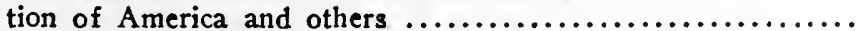

United States v. Mellen, Charles S., Edson J. Chamberlin, and Al-

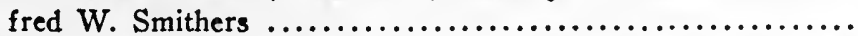

United States v. Metropolitan Meat Company et al. (3 Dist. Hawaii 110)

United States v. Miller, Julius F., Secretary, New York Charcoal Company et al.

United States v. Missouri Pacific Railroad Company and twentyfour other railroads

United States v. Motion Picture Patents Company et al. ..........

United States v. McCaskey Register Company et al. ..............

United States v. McCoach et al. ...........................

United States v. National Association of Retail Druggists et al. ... 
United States v. National Packing Co. et al. .................375, 376

United States v. National Umbrella Frame Company et al. ....... 372

United States v. National Wholesale Jewelers' Association et al. ... 393

United States v. Nelson (52 Fed. 646, 201 U. S. 92) ........... 362

United States v. New Departure Manufacturing Company et al. (204

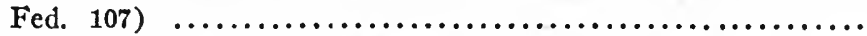

United States v. New Departure Manufacturing Company et al. ....

United States v. New York, New Haven \& Hartford Railroad Company et al. ..................................374, 394

United States v. North Pacific Wharves \& Trading Co. et al. ..... 384

United States v. Northern Securities Co. et al. (120 Fed. 721, 193 U.

S. 197)

United States v. Nome Retail Grocers' Association ...............

United States v. Otis Elevator Co. et al. ......................

United States v. Pacific \& Arctic Railway \& Navigation Co. et al. ..

United States v. Pacific \& Arctic Railway and Navigation Co. et al.

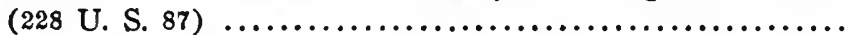

United States v. Pacific Coast Plumbing Supply Association et al. ..

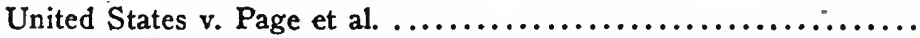

United States v. Palmer, Wm. P., and twenty-five others ..........

United States v. Palmer, Wm. P., and thirty-three others .........

United States v. Palmer, Wm. P., and seventeen others ...........

United States v. Palmer, Wm. P., and fifteen others .............

United States v. Palmer, Wm. P., and thirty-eight others .........

United States v. Parks, John H., et al. ......................

United States v. Patterson et al. (55 Fed. 605, 59 Fed. 280) ........

United States v. Patterson, John H., et al. (201 Fed. 697, 205 Fed. 292, 222 Fed. 599) ..................................

United States v. Payne, Calvin N., et al. ......................

United States v. Pearce, Jay B., et al. .......................

United States v. People's Ice and Fuel Company and W. B. Lount .

United States v. Periodical Clearing House et al. ...............

United States v. Philadelphia Jobbing Confectioners' Association et al.

United States v. Philips, Frank N., and ten others ................

United States v. Phonix Wholesale Meat and Produce Company et al. ............................................

United States v. Prince Line (Limited) et al. (220 Fed. 230) ......

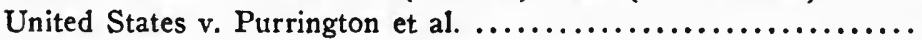

United States v. Quaker Oats Company et al. ..................

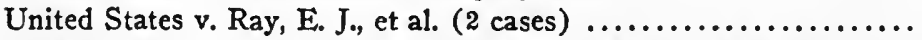

United States v. Reading Company et al. (183 Fed. 427, 226 U. S.

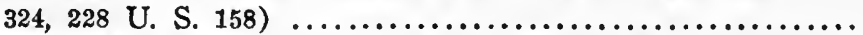

United States v. Reading Company et al. (Anthracite Coal Combination)

United States v. Rockefeller, William, et al. .................

United States v. Roebling, F. W., and seventeen others ...........

United States v. Santa Rita Mining Company and Santa Rita Store 


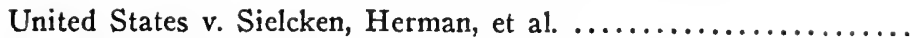

United States v. S. F. Bowser \& Company, Inc., et al. ............

United States v. Simmons, Chas. L., et al. .....................

United States v. Smith, Phillip H. W., and fourteen others ........

United States v. Southern Pacific Company, Central Pacific Railway

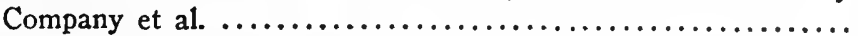

United States v. Southern Wholesale Grocers' Association ........

United States v. Southern Wholesale Grocers' Association et al.

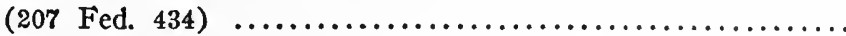

United States v. Standard Oil Company of N. J. et al. (152 Fed.

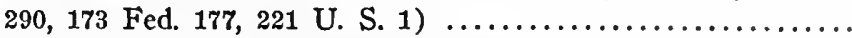

United States v. Standard Sanitary Manufacturing Company et al. (187 Fed. 229, 187 Fed. 232, 191 Fed. 172, 226 U. S. 20) ......

United States v. Standard Sanitary Manufacturing Company et al.

United States v. Standard Wood Company et al. ................

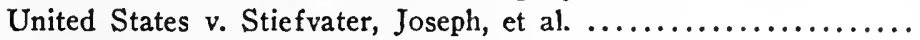

United States v. Steers, John S., et al. (192 Fed. 1) .............

United States v. Sulzberger, Ferdinand, doing business under the name of John Reardon \& Sons Company, and Horatio W. Heath, of Boston, doing business as the Consolidated Rendering

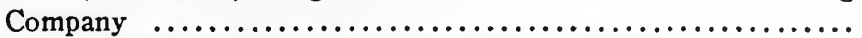

United States v. Swift \& Co. et al. (122 Fed. 529, 196 U. S. 375) ...

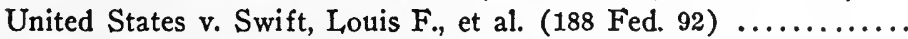

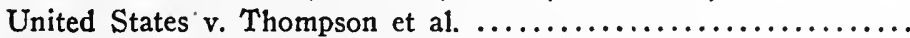

United States v. Terminal Railroad Association of St. Louis et al. (197 Fed. 446, 224 U. S. 383, 226 U. S. 420, 236 U. S. 194) .....

United States v. Terminal Railroad Association of St. Louis et al. .

United States v. Trans-Missouri Freight Association (53 Fed. 440,

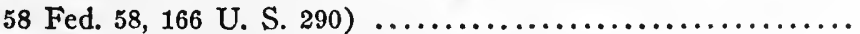

United States v. Union Pacific Coal Company et al. (173 Fed. 737) .

United States v. Union Pacific Railroad Company et al. (188 Fed.

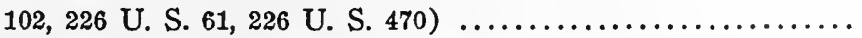

United States v. United Shoe Machinery Co. et al. (222 Fed. 349) ..

United States v. United Shoe Machinery Company et al. ..........

United States v. United Shoe Machinery Company of New Jersey

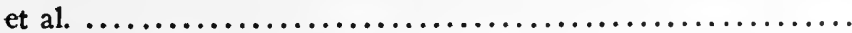

United States v. United States Steel Corporation and others (223

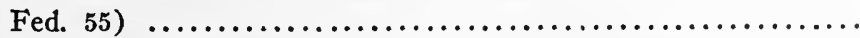

United States v. Virginia-Carolina Chemical Company et al. (163

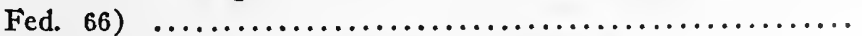

United States v. Western Cantaloupe Exchange et al. ...........

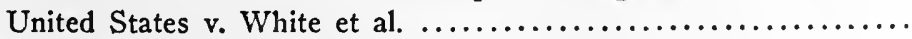

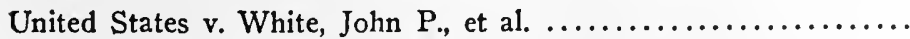

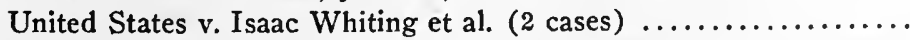

United States v. Winslow, S. W., et al. (195 Fed. 578, 227 U. S. 202) 



\section{INDEX.}

[REFERENCES ARE TO PAGES.]

ABUSE OF CHARTERED POWERS: See ABUSE OF CoRpoRATE CONTROL.

subject considered $.108,109,110$

\section{ABUSES OF CORPORATE CONTROL:}

comparisons useful $\ldots \ldots \ldots \ldots \ldots \ldots \ldots \ldots \ldots \ldots \ldots \ldots, 222$

rule as developed in patent and copyright cases ............. 222

rule in trade-marks and trade names .................... 222

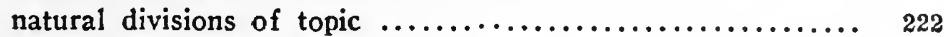

unfair manipulation and conduct in management of and dealings with corporations ................................ 222

principles of fair dealing educed in corporation law ......... 223

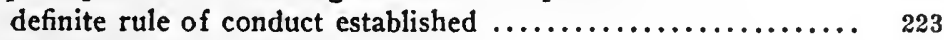

instances where rule was applied $\ldots \ldots \ldots \ldots \ldots \ldots \ldots \ldots . . .6223$

rule applies where actual injury is shown $\ldots \ldots \ldots \ldots \ldots \ldots . .223$

minority stockholders' rights explained $\ldots \ldots \ldots \ldots \ldots \ldots \ldots, 224$

application is reasonable ............................ 224

unfair management of corporation ..................... 224

cases illustrating rule $\ldots \ldots \ldots \ldots \ldots \ldots \ldots \ldots \ldots \ldots \ldots \ldots, 224$

standard of fair-dealing maintained $\ldots \ldots \ldots \ldots \ldots \ldots \ldots \ldots \ldots, 225$

great variety of unfair means ........................ $\quad 225$

offices exclusive property of corporation ................ 225

manipulation of joint control ......................... 226

redress through courts of equity $\ldots \ldots \ldots \ldots \ldots \ldots \ldots \ldots \ldots, \quad 226$

results not ideal, though often effectual ................. 226

Trade Commission's jurisdiction prescribed by statute ........ 227

Trade Commission has power to require reports ............ 227

Trade Commission may recommend additional legislation ...... 227

corporation decisions useful guide $\ldots \ldots \ldots \ldots \ldots \ldots \ldots \ldots \ldots, 227$

unfair restraint of voting power $\ldots \ldots \ldots \ldots \ldots \ldots \ldots \ldots \ldots, 228$

provisions of Section 7 of Clayton Bill promise beneficial results 228

early unfair method of securing corporate control ........... 228

substitution of holding company device $\ldots \ldots \ldots \ldots \ldots \ldots \ldots . .228$

ignoring constitution, device excludes minority ............ 228

device apparently violates Fifth Amendment .............. 229

holding company creates monopoly of voting power ......... 230

adverse effects ..................................... $\quad 230$

means of relief indicated ........................... 230

doctrine of Northern Securities Company case opposed to hold-

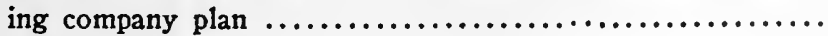


[REFERENCES ARE TO PAGES.]

public interests advanced by supplemental Anti-trust laws .... $\quad 231$

code of business procedure assured .................... 230

ACCESS BY TRADE COMMISSION TO DOCUMENTARY EVIDENCE OF CORPORATION: See DOCUMENTARY EVIDENCE.

under what circumstances permitted and how enforced ........ 255

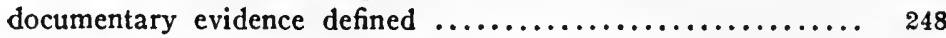

\section{ACTS TO REGULATE COMMERCE:}

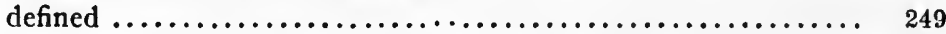

not repealed or modified by Trade Commission law .......... 258

term "any common carrier subject to," defined ............. 64

combination of manufacture and transportation of commodities,

by common carrier, forbidden by $\ldots \ldots \ldots \ldots \ldots \ldots \ldots \ldots, 61$

\section{AFFIDAVIT:}

or verified bill required to show urgent need for relief, upon application for temporary restraining order $\ldots \ldots \ldots \ldots \ldots \ldots . .$. may be filed in support of application to institute contempt proceedings under Section 21 of Clayton Law ...............

\section{AGENTS:}

criminally liable for corporations' violations ........142, 143, 144, 271 liable for violation of Wilson $\mathrm{Law}$................... 282

\section{AGREEMENT:}

in restraint of trade unlawful $\ldots \ldots \ldots \ldots \ldots \ldots \ldots \ldots \ldots \ldots . .260,279$

in restraint of import trade unlawful .................. 282

AGRICULTURAL ORGANIZATIONS NOT FOR PROFIT:

excepted from provisions of anti-trust acts ................ 262 members of, also excepted $\ldots \ldots \ldots \ldots \ldots \ldots \ldots \ldots \ldots \ldots \ldots . .262$

\section{ANSWERS TO QUESTIONS OF TRADE COMMISSION:}

to be under oath if required $\ldots \ldots \ldots \ldots \ldots \ldots \ldots \ldots \ldots \ldots, 253$

may be compelled by court order ..................... 256

criminal offense to refuse to make $\ldots \ldots \ldots \ldots \ldots \ldots \ldots \ldots .257$

\section{ANTI-HOLDING COMPANY BILL:}

one of five proposed measures utilized by Congress when preparing Trade Commission Act and Clayton Law ............

ANTI-TRUST aCtions: See Antr-Trust Laws; Damages FOR VIOLATION OF ANTI-TRUST LaWS.

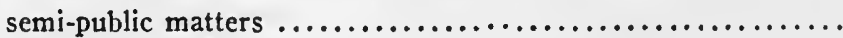


ANTI-TRUST LAWS: See Sherman Antr-Trust LaW; WiLson Tariff Law; Clayton Bili; also Foreign Anti-Trust Laws; see also Damages for Violatron of Anti-Trust LAws.

defined in Trade Commission Law to include Sherman Antitrust Law and Sections 73 to 77 as amended of the Wilson

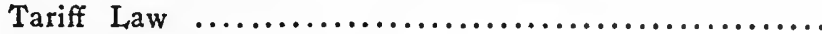
defined in Clayton Law to include:

Sherman Anti-Trust Law ..........................

Sections 73 to 77 as amended of the Wilson Tariff Law and the Clayton Law itself ......................... 259 Federal Trade Commission Act not included in ..........249, 259 not repealed or modified by Trade Commission Law ........149, 258 liability under, not relieved by Trade Commission's order ..... 252 provisions regulating foreign trade contained in Wilson Tariff

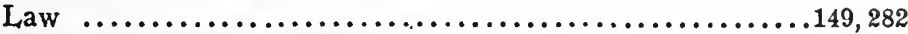

criminal provisions of Wilson Tariff Law discussed ......... 150

test of constitutionality of Anti-trust laws stated ........... 21 protection by public is end sought by ................... 201

ANTI-TRUST LAWS IN THEIR RELATION TO PATENTS AND COPYRIGHTS: See Patents and Copyrights; TradeMarks and Trade Names; Tying Clauses; Anti-Trust Laws; ANTY-TRUST PoLICY.

ANTI-TRUST POLICY:

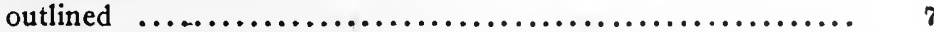

legislation carrying out, commended $\ldots \ldots \ldots \ldots \ldots \ldots \ldots \ldots \ldots, 7$

consists in regulating competition instead of regulating monop-

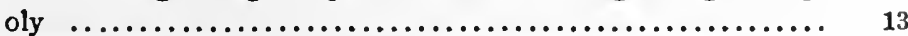
situation requires practical faith and mutual confidence ....... 14

APPEALS: See Circuit Court of Appeals; Supreme Court; REview; Contempt; Resubmission to Commission.

Congress provided only limited review ................... 41 nature and extent of review considered .................4 40,41 statute permits three separate opinions, with final Supreme Court review ...................................

no period fixed within which party must secure review of Commission's order ...............................251, 269

\section{ARTICLE OF COMMERCE:}

labor of human being declared not to be $\ldots \ldots \ldots \ldots \ldots \ldots . . . .$.

associations: See Persons; Labor; Corporation.

defined as included within word "persons" ................ Clayton Law includes all, whether for profit or not for profit .. for profit only under Trade Commission Law .............. 


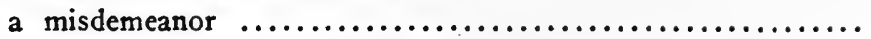

ATTENDANCE OF WITNESSES: See WitNesSES.

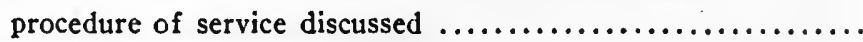

ATTORNEY GENERAL:

to direct institution of proceedings under Sherman, Wilson and Clayton Laws ...........................272, 280, 282 upon application of, Trade Commission to investigate, etc. .... 253 upon application of district courts, to issue writs of mandamus

to compel compliance with Trade Commission's order .....134, 256 to prosecute for recovery of forfeitures ............... 258 Interstate Commerce Commission to report violations of Clayton Law by common carriers to $\ldots \ldots \ldots \ldots \ldots \ldots \ldots \ldots 140,141,267$

\section{ATTORNEY'S FEES:}

recoverable for person injured under Sherman, Clayton and Wilson Laws, but not under Trade Commission Law ...261, 281, 283

\section{AUSTRALIA: See Foreign ANTi-Trust Laws.}

\section{AUTHORS:}

and inventors,--exclusive rights of, distinguished from monopoly 16, 17

\section{BAIL:}

in reasonable amount, may be required in contempt proceeding instituted under Section 22 of Clayton Law ............276, 277 person summarily arrested in such proceeding shall be admitted

to bail in reasonable amount ......................276, 277 after conviction, defendant in such proceeding shall be admitted

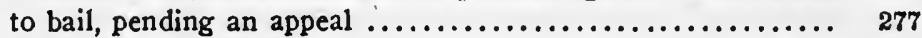

BANKS: See Corporattons; InTerLocking Directors; FederaL RESERVE BOARD.

Trade Commission has no power to prevent banks from using unfair methods of competition .....................47, 280 two-fold reasons for exemption of, stated ................ 47 clerical error in text of Trade Commission act noted ........ 249 Trade Commission act applies to banks in following particulars: Commission may investigate manner in which decree against banks in Anti-trust proceeding has been or is carried out upon the direction of the President or either house of Congress Commission may investigate and report facts relating to any alleged violation of Anti-trust laws by banks upon the application of the attorney general Commission may investigate and recommend readjustment of business of banks violating Anti-trust acts 
Commission may classify corporations $\ldots . \ldots \ldots \ldots \ldots \ldots$

Commission may investigate trade conditions with foreign countries affecting foreign trade with the United States . class A director of Federal Reserve Bank may be officer and di-

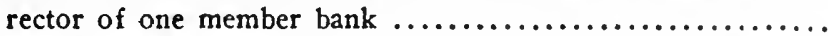
mutual banks without shares of stock not subject to interlock-

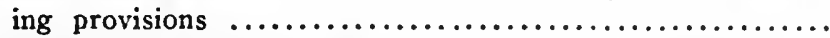
ownership of stock in other corporations for investment not

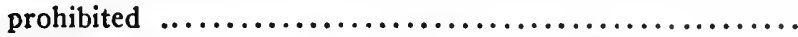
by early decisions, banking not within commerce clause of constitution $\ldots \ldots \ldots \ldots \ldots \ldots \ldots \ldots \ldots \ldots \ldots \ldots \ldots \ldots \ldots .47,48,49$ power to institute and control, contained in Section 6 of con-

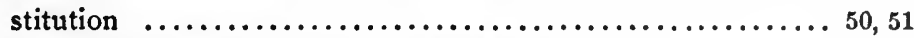

principal functions of Clayton Law respecting ........... 48

regulation of, under Clayton Law, considered ............. 48 merchandising transactions by, probably within scope of Clay-

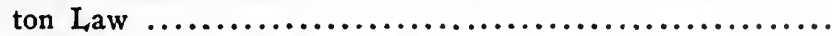
stock ownership and interlocking directorate provisions of Clayton Law probably apply to $\ldots \ldots \ldots \ldots \ldots \ldots \ldots \ldots \ldots \ldots \ldots 48,49$ statutory exceptions noted $\ldots \ldots \ldots \ldots \ldots \ldots \ldots \ldots \ldots \ldots \ldots, 53$ public interests demand careful supervision of $\ldots \ldots \ldots \ldots \ldots, 50,51$ special regulations affecting banking institutions .......... 50 intent of Congress to prevent centralization of control of .... 50 Sections 2, 3, 7, and 8 of Clayton Law enforced by Federal Reserve Board, as to $\ldots \ldots \ldots \ldots \ldots \ldots \ldots \ldots \ldots \ldots \ldots \ldots \ldots, 50,268$ interlocking directorates of, considered $\ldots \ldots \ldots \ldots \ldots \ldots \ldots, 51,52$ occasion for regulation stated $\ldots \ldots \ldots \ldots \ldots \ldots \ldots \ldots \ldots \ldots \ldots, 55$ exceptions to directorate regulations, noted $\ldots \ldots \ldots \ldots \ldots \ldots .53$ provisions applicable to dealings between, and common carriers, considered $. \ldots \ldots \ldots \ldots \ldots \ldots \ldots \ldots \ldots \ldots \ldots \ldots \ldots \ldots . \ldots \ldots, 54,55,56$ regulation or relations with common carriers under Section 10 of Clayton Law considered and occasion for requirements stated $\ldots \ldots \ldots \ldots \ldots \ldots \ldots \ldots \ldots \ldots .50,55,65,67,68,69,138,139,266$

BIDDING: See Competitive Brdding.

\section{BILL OF EXCEPTIONS:}

testimony may be preserved by, in connection with appeal from judgment in contempt proceedings instituted under Section

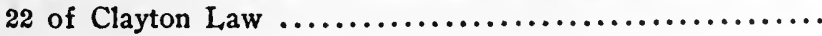

BOARD: See Commission OR Bonto.

BOARD OF INQUIRY:

Federal Trade Commission empowered to act as..22, 23, 24, 252, 253, 254 public hearings optional

BOOKS OF CORPORATIONS: See DOCUMENTARY EVIDENCE; CoMMISSION, POWERS OF. 
BOYCOTTING: See LABOR.

defined $\ldots \ldots \ldots \ldots \ldots \ldots \ldots \ldots \ldots \ldots \ldots \ldots \ldots \ldots \ldots \ldots, \quad \mathbf{1 7 7}$

power of court to enjoin, limited $\ldots \ldots \ldots \ldots \ldots \ldots \ldots \ldots \ldots . \ldots 2,83$

in effect legalized, when in aid of labor interests in trade dis-

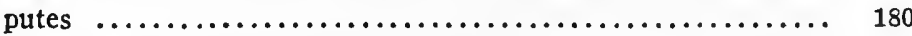

BRANCH LINES: See Common Carriers.

\section{BRANDEIS, LOUIS D.:}

views of, on need for regulation of competition .............

BRITISH TRADES DISPUTES ACT:

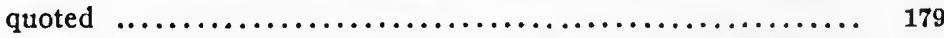

termed "a codification of the law relating to peaceful picketing" 179

BUREAU OF CORPORATIONS:

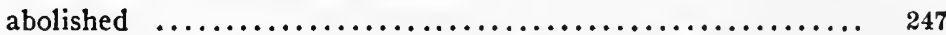

pending investigations to be continued by Trade Commission .. 247

merger of, with Trade Commission, discussed ............ 133

inability to require corporate reports, grave defect in original

authority conferred upon $\ldots \ldots \ldots \ldots \ldots \ldots \ldots \ldots \ldots \ldots \ldots, 133$

powers made effective under Trade Commission act ........136, 137

BUSINESS :

of corporation, correct entries and records required ...........

BUSINESS-INJURY TO: See DAMAGES FOR VIOLATION OF ANTI-TRUST Laws.

BUYER OR LESSEE: See Tying Clause.

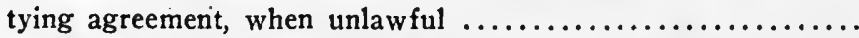

CANADIAN ANTI-TRUST LAWS: See ForFign ANTI-TrUST LAWS.

provisions of, considered $\ldots \ldots \ldots \ldots \ldots \ldots \ldots \ldots \ldots \ldots \ldots \ldots .83,84,85$

apparently offer immediate effective relief $\ldots \ldots \ldots \ldots \ldots \ldots \ldots . \quad 85$

United States and Canadian procedure compared ........... 85

CAPE OF GOOD HOPE: See Foreign Anti-Trust Laws.

"CEASE AND DESIST" ORDERS: See Federal, Trade Commission; INTerstate Commerce Commission; Federal Reserve Board; Circuit Court of Appeals; Commission.

\section{CHARTERED RIGHTS.}

ripen into contract with state $\ldots \ldots \ldots \ldots \ldots \ldots \ldots \ldots \ldots . .18$

modern grants reserve power to cancel or amend ........... 18

of monopoly, strictly construed, $\ldots \ldots \ldots \ldots \ldots \ldots \ldots \ldots \ldots .18$

\section{CIRCUIT COURT OF APPEALS:}

jurisdiction of :

to enforce provisions of Sections 2, 3, 7, and 8 of Clayton

Law $\ldots . \ldots \ldots \ldots \ldots \ldots \ldots \ldots \ldots \ldots \ldots \ldots \ldots . .268-269$ 


\section{[REFFRENCES ARE TO PAGES.]}

same jurisdiction at suit of party as in suit by commission

for enforcement of Commission's or board's order .....251, 270 may review Commission's or board's order at suit of party thereto statute fixes no limitation as to time $\ldots \ldots \ldots \ldots \ldots \ldots 251,270$ may order additional evidence to be taken before the Commission or board ............................... 269 exclusive jurisdiction to enforce; set aside or modify Commission's or board's order ..................252, 270 decree of, subject to review by Supreme Court upon certiorari ....................................... 269 no power to relieve from liability under Anti-trust laws . .252, 270 expedition of hearings to be granted ...............252, 270 no provision for taking testimony in court, except upon application for leave to adduce additional evidence before the Commission or board ..................251, 269 procedure in, by Commission or board to enforce its order ...250, 269 review of Commission's or board's order by parties as follows:

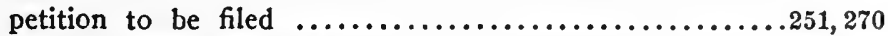
copy of petition to be served upon Commission or board . .251, 270 Commission or board then to serve and file transcript of

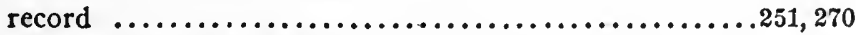
proceedings to be expedited ........................252, 270 Commission's or board's findings of facts conclusive if sup-

ported by testimony .......................251, 252, 270 subpœnas may run into any other district $\ldots \ldots \ldots \ldots \ldots \ldots 25,271$ venue:

in proceedings to enforce Commission's or board's orders, the circuit where violation is committed or where person accused resides or transacts business .............250,269 provisions as to venue in suits against corporations ........ 271

\section{CIVIL SERVICE:}

employees of Trade Commission subject to..$\ldots \ldots \ldots \ldots$

\section{CLASS A DIRECTOR OF RESERVE BANK:}

may be officer and director of one member bank ..........264, 265

\section{CLAYTON LAW; also known as SUPPLEMENTARY}

ANTI-TRUST ACT or SUPPLEMENTARY SHER-

MAN LAW: See Commission OR BoARD.

text of $.259-278$

operates in dual capacity ......................... 99

comprises provisions contained in five proposed laws ........ 138

proposed laws enumerated $\ldots . \ldots \ldots \ldots \ldots \ldots \ldots \ldots \ldots \ldots \ldots . \ldots \ldots$ novel or untried features not made subject to criminal pen-

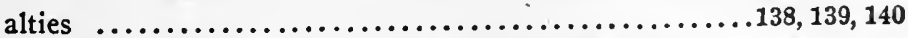
occasion for postponement of operation of novel or untried 


\section{[REFERENCES ARE TO PAGES.]}

PAGE

features, described

$.131,132$

limitation, upon right to pursue defendants, contained in Sher-

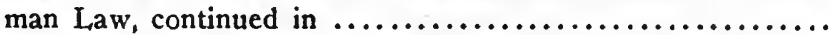
offers regulatory measures largely superseding criminal provisions of Sherman Law

compulsative provisions of Clayton Law considered .......... in pursuance of general right to recommend further legislation, scope of provisions for enforcement may be enlarged ....... offenses against regulation of relations between common carrier and supply, etc., concerns considered; and occasion for Section 10 of Clayton Law, stated ..................138, 139 provisions of Section 10 not enforcible by civil orders under

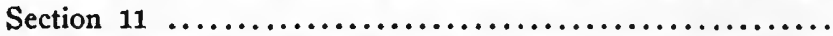

history and purpose of individual responsibility feature discussed $\ldots \ldots \ldots \ldots \ldots \ldots \ldots \ldots \ldots \ldots \ldots \ldots \ldots \ldots \ldots 99,142,143,144,271$ protection afforded organized labor by Sections 6 and 20 , considered

provisions separately examined

\section{CLERICAL ERROR:}

misplaced comma retained by mistake in Section 5 of Trade

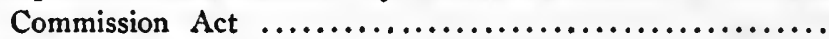

COMBINATION TO PREVENT OR RESTRAIN COMPETITION: See MoNopoly.

in restraint of import trade, unlaw ful in restraint of interstate and foreign commerce, unlaw ful ...... labor etc., organization, not conducted for profit, shall not be

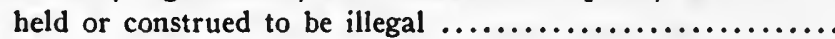

\section{COMMENDATORY RULINGS:}

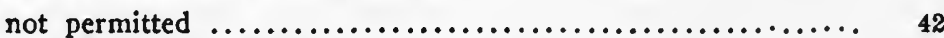

subject of, discussed $\ldots \ldots \ldots \ldots \ldots \ldots \ldots \ldots \ldots \ldots \ldots \ldots \ldots \ldots, 42$

suggested in message of President ..................... 42

advocated in Congress $\ldots \ldots \ldots \ldots \ldots \ldots \ldots \ldots \ldots \ldots \ldots \ldots . \ldots \ldots$

argument in favor of, considered $\ldots \ldots \ldots \ldots \ldots \ldots \ldots \ldots \ldots 43,44$

not authorized by measures, as enacted ................ 42

par. 2 of Section 20 of Clayton Law suggestive of .......... 146

sub-div. "e," Section 9 of Trade Commission Act, suggests .... 60 tendency toward, evidenced by Section 20 of Clayton Law ..... 184

\section{COMMERCE:}

defined under Trade Commission Act $\ldots \ldots \ldots \ldots \ldots \ldots \ldots \ldots$ 248

defined under Clayton Law ....................... 259

Anti-trust definitions of, compared ................. 92

limited to interstate and foreign commerce .............. 259

Philippine Islands excepted in Clayton Law .............. 259

"acts to regulate" enumerated ........................ 249 
no corporation engaged in, shall acquire ownership in competing

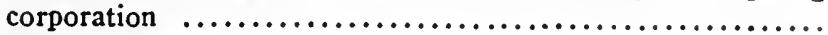

specific provisions regulating conduct of persons or corporations engaged in commercial transactions ............260, 262, 263 regulatory provisions as to corporation engaged in commerce as

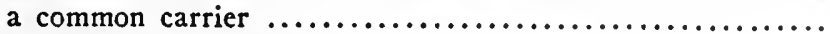

COMMERCE CLAUSE OF CONSTITUTION: See ConstiTUTION.

decisions holding banking not within provisions of $\ldots . \ldots \ldots$. considered in connection with early draft of Sherman Law . .77, 78, 79 applied in relation to Sherman Law ............... 79, 80 0. narrow construction in Knight case, considered ........... 82 early debates in Congress on subject, discussed ............ 83

COMMISSION OR BOARD-PROVISIONS COMMON TO FEDERAL TRADE COMMISSION, INTERSTATE COMMERCE COMMISSION AND FEDERAL RESERVE BOARD: See FederaI, Trade CoMmission; INTERSTATE CoMmerce CoMmission; Federal Reserve, Board; PROVISIONS FOR ENFORCEMENT.

powers and jurisdiction of commissions and board:

to order compliance with Sections $2,3,7$, and 8 of Clayton Law where applicable $\ldots \ldots \ldots \ldots \ldots \ldots \ldots \ldots \ldots \ldots$. to prevent restraint of commerce or tendency to create monopoly by stock ownership by

1. one corporation in a competing corporation ........

2. one corporation in two or more companies competing .................................

to order compliance with provisions against interlocking directors (see Interlocking Directors) $\ldots . \ldots \ldots \ldots \ldots$

to issue and serve complaint if of the opinion law has been

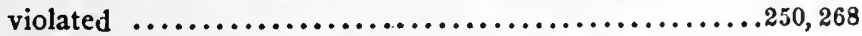
to hold hearings at least 30 days after service of com-

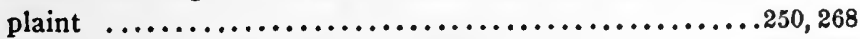
to permit intervention by third persons $\ldots \ldots \ldots \ldots \ldots \ldots \ldots 250,268$ to issue "cease and desist" orders $\ldots \ldots \ldots \ldots \ldots \ldots \ldots \ldots . \ldots 250,268$ to make findings of fact which shall be conclusive if supported by testimony $\ldots \ldots \ldots \ldots \ldots \ldots \ldots \ldots \ldots \ldots \ldots .251,269$ to institute suit in circuit court of appeals to enforce orders $\ldots \ldots \ldots \ldots \ldots \ldots \ldots \ldots \ldots \ldots \ldots \ldots \ldots . \ldots . \ldots . \ldots 250,268,269$ no power to prevent stock ownership for investment pur-

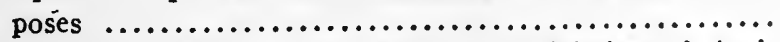

no power to relieve from liability for violation of Anti-

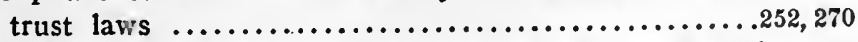
no power to prevent legitimate formation of and stock ownership in subsidiary corporations .............. 263 
has right of access to documentary evidence of corporation

means to enforce right $\ldots \ldots \ldots \ldots \ldots \ldots \ldots \ldots \ldots \ldots \ldots$

proceedings before:

Commission or board to file complaint only when it has reason to believe law has been violated. (For exceptions see heading "FEDERAL TRADE COMMISSION : Powers

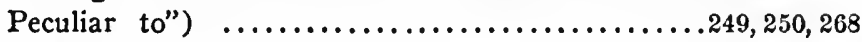

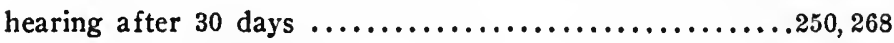

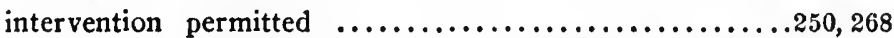

report in writing to be made if Commission or board is

of opinion law has been violated $\ldots \ldots \ldots \ldots \ldots \ldots \ldots 250,268$

findings of fact to be made as part of report .........250,268

Commission or board may modify report or order without additional testimony before transcript filed in court, or after additional hearing taken under court order .....251,269 Commission or board may issue "cease and desist" orders.250, 268 Commission or board may apply to circuit court of appeals

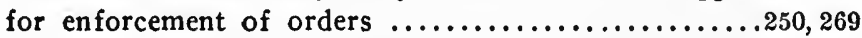
review of Commission's or board's order by party in circuit court of appeals ......................251, 270

must pass upon question involving the exercise of its discretionary powers $\ldots \ldots \ldots \ldots \ldots \ldots \ldots \ldots \ldots \ldots \ldots \ldots$

mandamus proceedings would lie to compel Commission or board to act, in proper case ................... provisions for enforcing Trade Commission Act and Clay-

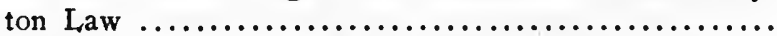

history and purpose of individual responsibility feature, discussed.$\ldots \ldots \ldots \ldots \ldots \ldots \ldots \ldots \ldots \ldots \ldots$. $142,143,144,145$

regulatory system comprised in Trade Commission statutes largely supersedes employment of criminal provisions of Sherman Law ..........................147, 149

Trade Commission exists to enforce Anti-trust laws by preventing unfair methods ................... 148

by restraining or preventive measures, obviates necessity for criminal prosecutions $\ldots \ldots \ldots \ldots \ldots \ldots \ldots \ldots \ldots 14,148,149$ definitions of "person" and "corporation" considered ..... 96 liability of individual:

under Trade Commission Act ................ 97, 98

under Clayton Law ....................99, 100, 101

liability of corporation:

under Trade Commission Act .................. 98

under Clayton Law ....................101, 102, 103

by criminal proceedings $\ldots \ldots \ldots \ldots \ldots \ldots \ldots \ldots \ldots, 102$

liability under Sherman Law ....................103-110 proof of direct damage to person injured apparently not required 
limitation upon right to pursue defendants, contained in Sherman Law, continued in Clayton Law .............

COMissioners: See Federal Trade Commission; INTerSTATE COMMERCE CoMmission.

\section{COMMODITIES:}

labor of human being declared not to be a commodity .......... discriminatory sales to different purchasers of, when unlawful 260 subject of unfair price discrimination, considered, .......28, 193, 194

COMMON CARRIERS: See INTERL,OCKING DIRECTORS; INTERSTATE CoMmerce Commission; Competition.

Trade Commission has no power to prevent common carriers from using unfair methods of competition ............... error in punctuation of Section 5 of Trade Commission Act noted .........................................

Trade Commission law appiies to common carriers in following particulars :

Commission may investigate manner in which decree against common carriers in anti-trust proceeding has been or is being carried out $\ldots \ldots \ldots \ldots \ldots \ldots \ldots \ldots \ldots \ldots \ldots \ldots, 253$

upon the direction of the President or either house of Congress Commission may investigate and report facts relating to any alleged violation of Anti-trust acts by common carriers ............................. 58,253

upon the application of the attorney general Commission may investigate and recommend readjustment of businessness of common carriers alleged to be violating Antitrust acts $. . . \ldots \ldots \ldots \ldots \ldots \ldots \ldots \ldots \ldots \ldots \ldots . . .68,254$

information so derived may be made public, except trade secrets and names of customers .................. 254

Commission may classify corporations ............... 24

common carrier corporations probably subject to classification by Trade Commission ....................... Commission may investigate trade conditions with foreign countries affecting foreign trade with the United States.. power to investigate foreign trade may have important bearing upon common carrier interests $\ldots \ldots \ldots \ldots \ldots \ldots, 60,61$

provisions of Section 6 of Trade Commission Act not bur-

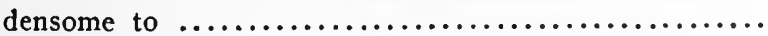
in general, common carriers exempted from Trade Commission Act provisions ............................ such exemptions strictly construed .................... Clayton Law applies to common carriers in following particulars:

elimination of competition by stock ownership prohibited . ownership of stock in competing corporations regulated ...63,64 


\section{[REFERENCES ARE TO PAGES.]}

PAGE

purpose of regulating provisions discussed $\ldots \ldots \ldots \ldots \ldots 6,66$ stock ownership in branch and construction lines permitted 263 meaning and scope of term "subject to the laws to regulate

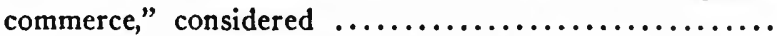

provisions applicable to dealings between, and banks, con-

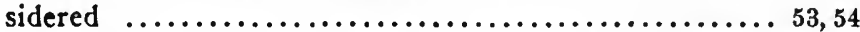
occasion for regulation of dealings in securities of, stated . 55, 56 regulation of dealings with supply, etc., concerns, considered $\ldots \ldots \ldots \ldots \ldots \ldots \ldots \ldots \ldots 53,55,65,66,67,138,139,140,141$ interlocking between common carrier corporations and supply, financial or construction companies subjects their relations to regulation, under provisions of Clayton Law .. interlocking of directors, etc., between railroad common

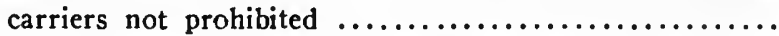

criminal liability of director, agent, manager or officer ....

regulations for interlocking with supply and other com-

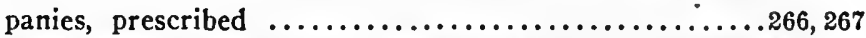
offenses against regulation of relations with such companies

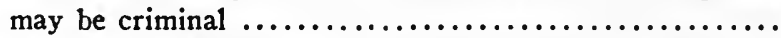

general purpose and scope of Section 10 of Clayton Law, regulating such dealings $\ldots \ldots \ldots \ldots \ldots \ldots \ldots \ldots \ldots$.

specific regulations as to competition in bidding, consid-

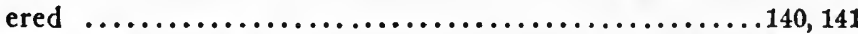

Interstate Commerce Commission empowered to enforce

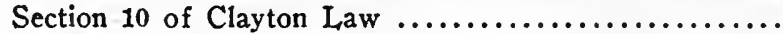
stock ownership in other corporations for investment not prohibited

embezzlement by director, officer or manager of common

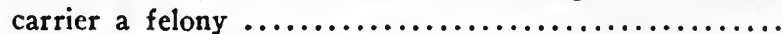
nature, extent and purpose of provision penalizing embezzlement, considered .......................144, 145 extent to which Sections $2,3,7$, and 8 of Clayton bill apply

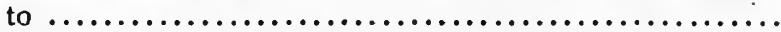

Sections 2, 3, 7, and 8 enforced by Interstate Commerce

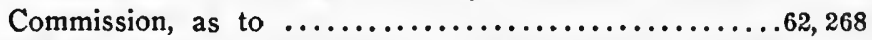
methods of enforcing Sections 2, 3, 7, and 8 of Clayton bill,

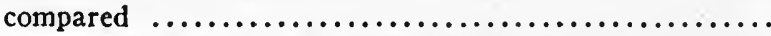

injunctive relief may be granted against any common carrier for violation of such provisions of Anti-trust laws as are not within jurisdiction of the Interstate Commerce Commission

COMPETITION: See Substantial Lessening of Comperition.

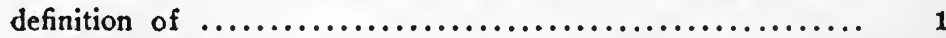

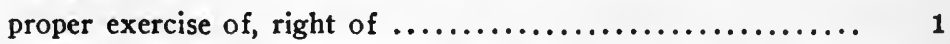

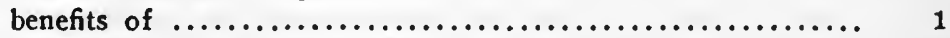

limitations of right to compete $\ldots \ldots \ldots \ldots \ldots \ldots \ldots \ldots \ldots \ldots, 2$ 
[REFERENCES ARE TO PAGES.]

weaker party cannot always compete $\ldots \ldots \ldots \ldots \ldots \ldots \ldots \ldots$

PAGE

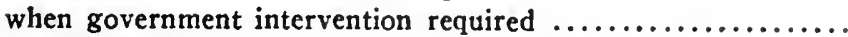

English experience in unrestricted employment of labor .......

American experience $. . . \ldots \ldots \ldots \ldots \ldots \ldots \ldots \ldots \ldots \ldots . . . \ldots \ldots$

tendency of unrestricted competition, shown $\ldots \ldots \ldots \ldots \ldots \ldots$

unregulated competition effectuates trusts $\ldots \ldots \ldots \ldots \ldots \ldots$

supervision of methods of competition employed in general

business, desired

3,4

2

2

business interests demand restraint of destructive competition . new administrative measures required $\ldots \ldots \ldots \ldots \ldots \ldots \ldots$

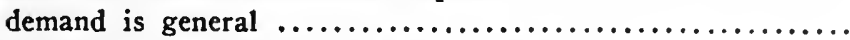

National Commercial Conference convened ............... investigation by Senate Committee on Interstate Commerce ... policy of regulating competition instead of restraining monop-

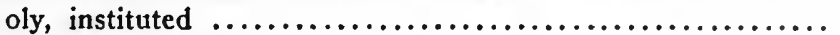

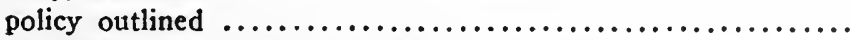

remarks of President upon need to regulate ...............

problems involved in regulation of $\ldots \ldots \ldots \ldots \ldots \ldots \ldots \ldots$

esteemed dominant force in business $\ldots . \ldots \ldots \ldots \ldots \ldots \ldots . . . \ldots$

5,6

manifold forms of unfair methods of indicated ........... $9.218,225$

views of leading authorities on necessity for regulation of ... 9-13

remarks on field for Commission ..................... 13

Commission laws supplement Sherman Law field ......... 105

price not sole criterion of success of competition ......... 13, 14

substantial lessening of competition by tying contracts de-

clared unlawful ................................ 260

elimination of, by price discrimination unlawful .......... 260

tying clause contracts, etc., unlawful ................. 260

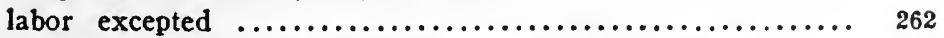

control of, by stock ownership, regulated and forbidden ..... 262

preservation of, by regulation of stock ownership, considered . 63

elimination of, by interlocking directors in corporations other

than banks and common carriers, prohibited .............

regulations concerning supply, construction and financial con-

cerns with common carriers through interlocking directors ..266, 267

purpose of requiring, in transportation business, discussed ....65, 66 power to prevent elimination of, vested in Federal Trade Com-

mission, Interstate Commerce Commission and Federal Re-

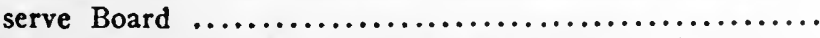

power to prevent vested in attorney general and U. S. attorneys price discrimination, unlawful $\ldots \ldots \ldots \ldots \ldots \ldots \ldots \ldots \ldots \ldots$ un fair methods of, unlaw ful $\ldots \ldots \ldots \ldots \ldots \ldots \ldots \ldots \ldots \ldots$ Trade Commission has power to prevent unfair methods of ...

COMPetitive BIDding: See Compertrion; Common Carriers.

statutory provisions require, in specified dealings between com-

mon carriers and construction concerns, etc. ..........266, 267 regulative provisions called for in public interest ......... 88,89 


\section{[REFERENCES ARE TO PAGES.]}

PAGE

COMPLaINTS: See Federal Trade Commission; Commission OR BOARD.

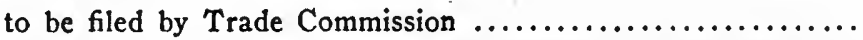

when it has reason to believe any provision of Sections 2, 3,

7 , and 8 of Clayton Law have been violated, filing required .. 268 filed only when violation is shown $\ldots \ldots \ldots \ldots \ldots \ldots \ldots \ldots .24,25,26$

\section{CONDEMNATION OF PROPERTY :}

uséd or owned in violation of Sherman and Wilson Laws 280, 281, 283

\section{CONGRESS:}

either house may direct Trade Commission to investigate al-

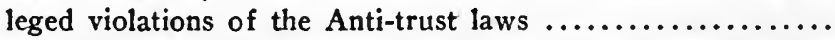
report of Trade Commission as to foreign trade, submitted to,

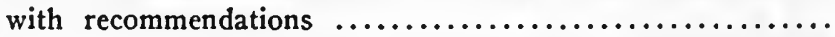
reports annual or special made to, by Trade Commission, with

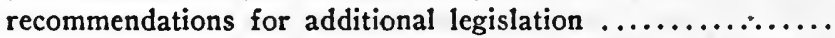
investigation of need for preventive and remedial legislation, by Senate committee under resolution of July $26,1911 . \ldots$.

CONDITIONAL CONTRACTS: See Tying Clause.

\section{CONSPIRACY:}

in restraint of interstate and foreign trade, unlawful ......279, 280 in restraint of import trade, unlawful ................ 282 to monopolize, unlawful $\ldots \ldots \ldots \ldots \ldots \ldots \ldots \ldots \ldots \ldots \ldots \ldots .279$

CONStitution: See Commerce Clause of Constirution; IMMUNITY.

text of provisions applicable to Anti-trust laws and proceedings .286, 287 constitutionality of drafts of Sherman Anti-trust Law consid-

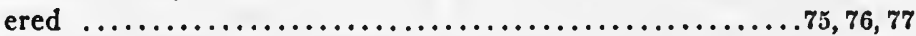
right of State under, to limit individual rights, stated ........ 81 narrow construction of commerce clause in Knight case, consid-

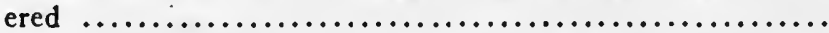
when instituting Trade Commission, Congress adopts broad

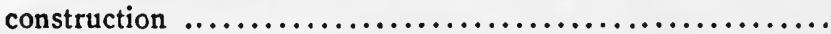

Section 6 of, empowers Congress to institute and control bank-

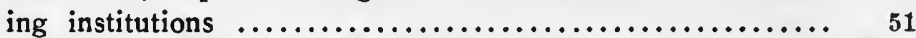
amendments which provide immunity rights $\ldots \ldots \ldots \ldots \ldots \ldots 156,159$ Fourth Amendment guarantees against unreasonable searches

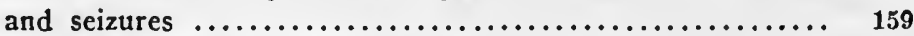

Fifth Amendment guarantees against self-incrimination ..... 152 does not apply to corporations $\ldots \ldots \ldots \ldots \ldots \ldots \ldots \ldots \ldots \ldots \ldots$

CONSTITUTIONALITY: See Constitution.

test of, concerning Anti-trust statutes, stated 


\section{CONSTRUCTION:}

rule of, applicable when construing Sherman Law as criminal statute

narrow construction of "commerce" in Knight case, considered when instituting Trade Commission Congress adopts broad con-

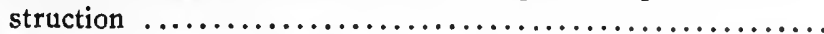
argument advocating narrow construction of Sections 1 and 2 of Sherman Law, examined

Supreme Court adopts broad construction .............. 91

of statutes, proper method stated .................. 49

\section{CONSTRUCTION COMPANIES:}

regulation of relations with common carriers under Section 10 of Clayton Law, considered, and occasion for requirements stated

CONTEMPT OF COURT: See District CoURT.

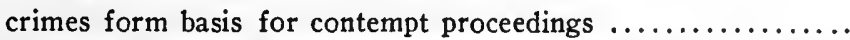
violations of orders entered in suits by United States constitute

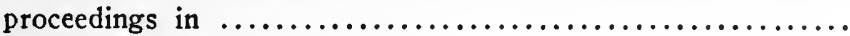
jury trial permitted $\ldots \ldots \ldots \ldots \ldots \ldots \ldots \ldots \ldots \ldots \ldots \ldots \ldots \ldots$

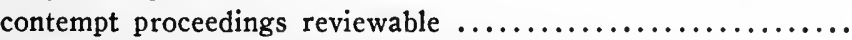
release upon reasonable bail pending appeal, provided .........

provisions of act not applicable where contempt was committed

in presence of court or in suit by the United States, or is not

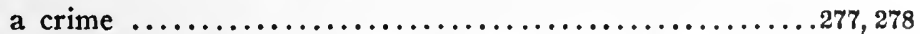
scope of proceeding in, under Sections 21 to 24 of Clayton

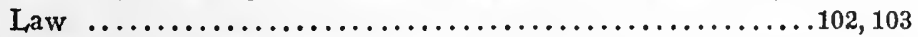

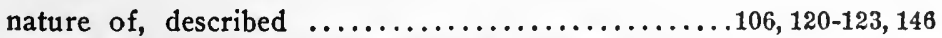
proceeding extends to infractions of Sherman Law ........ 106 statute of limitations in contempt proceedings, one year ...... 278 contempt proceedings not a bar to criminal prosecutions ...... 278 for failure to obey order of court requiring testimony, etc. ... 256

CONTRACTS IN RESTRAINT OF TRADE, ILLEGAL: See COMPETITION.

parties thereto guilty of misdemeanor $\ldots \ldots \ldots \ldots \ldots \ldots \ldots 279,280$

in restraint of import trade, unlawful ................. 282 exclusive tying contracts, unlawful when they substantially

lessen competition or tend to create a monopoly .........260,261

CONTUMACY, OR REFUSAL TO OBEY SUBPCENA:

district court may issue compelling order, and enforce same by

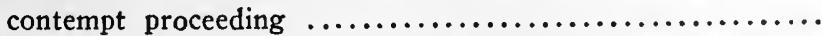

refusal to obey subpœna or produce documentary evidence, con-

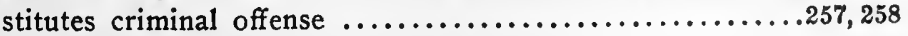

COPYRIGHTS: See Patents and Copyrights. 
[REFERENCES ARE TO PAGES.]

CORPORATE LIABILITY: See LIABILITY.

CORPORATE RECORDS: See CoRforatrons; CRIMES.

Commission has access to, for purposes of Trade Commission

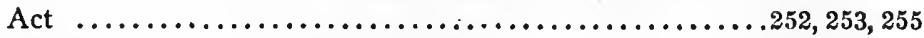

falsification, etc., of a criminal offense $\ldots \ldots \ldots \ldots \ldots \ldots 135,257,258$

CORPORATIONS: See Common Carriers; Banks; InTERlocking Directors; Abuses of Corporate Control.

definition of :

in Trade Commission Law means company or association for profit incorporated or unincorporated with or without capital shares, except partnerships ............... in Clayton Law included with associations under word per-

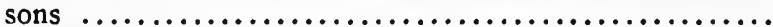

in Sherman Law included with associations under word

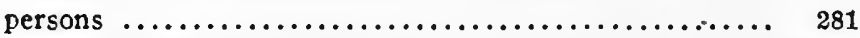
statutory definitions of, considered $\ldots \ldots \ldots \ldots \ldots \ldots \ldots \ldots, 96,97$ Congress does not concern itself with the legal fiction, when dealing with $\ldots \ldots \ldots \ldots \ldots \ldots \ldots \ldots \ldots \ldots \ldots \ldots \ldots \ldots \ldots \ldots, 159,160$

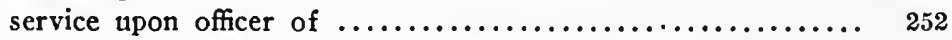
inquisitorial powers of Trade Commission as to:

Commission may investigate $\ldots \ldots \ldots \ldots \ldots \ldots \ldots \ldots \ldots 252,253$

may be required by Commission to file reports and answer

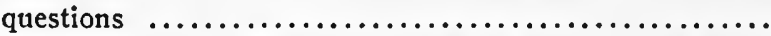

Commission may investigate manner in which corporation

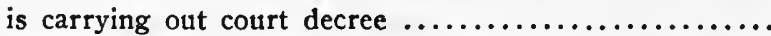
Commission may investigate any violation of Anti-trust

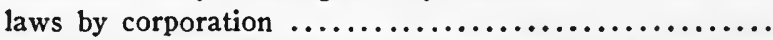

Commission may investigate and recommend readjustment of business of corporation .........................

Commission may classify corporations $\ldots \ldots \ldots \ldots \ldots \ldots . .$. inquisitorial powers under Section 6 of Trade Commission act

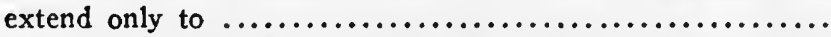
documentary evidence of corporation subject to examination by Trade Commission ........................... 255 penalties for falsifying records, etc. ................257, 258 penalties for failure to file reports $\ldots \ldots \ldots \ldots \ldots \ldots \ldots \ldots . .258$ banks and common carriers excepted from Trade Commission's power under Section 5 ...................... 249 error in punctuation of Section 5, noted ................ 249 stock ownership by one corporation in another unlawful in certain cases $\ldots \ldots \ldots \ldots \ldots \ldots \ldots \ldots \ldots \ldots \ldots \ldots \ldots . \ldots \ldots 26.263$ right to own capital stock of another corporation for investment only not prohibited $\ldots \ldots \ldots \ldots \ldots \ldots \ldots \ldots \ldots \ldots . .263$ ownership of the stock of subsidiary corporations permitted ... 263 stock ownership in branch line by common carriers permitted . 263 


\section{[REFERENCES ARE TO PAGES.]}

interlocking directors prohibited between competing corporaPAGE tions (other than railroad common carriers and banks) if one has capital and surplus of more than one million dollars director, officer or employee eligible at time of election not ineligible until one year from date of election or employment

venue in suits against:

where the violation is committed, or where corporation accused resides or carries on business ................ in district where corporation is an inhabitant or where it may be found or transacts business ................. criminal acts of, deemed also criminal acts of individual, directors, officers and agents ..........................

history and purpose of individual responsibility discussed ..... for general consideration of individual responsibility feature,

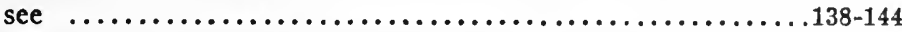
corporations not included within scope of immunity provisions 155,257 abuses of corporate control ......................... 222 unfair manipulation and management $\ldots \ldots \ldots \ldots \ldots \ldots \ldots \ldots . .222$ unfair exercise of voting power $\ldots \ldots \ldots \ldots \ldots \ldots \ldots \ldots \ldots . .228$

COSTS AND DAMAGES: See InJunction.

security conditioned upon the payment of, required upon is-

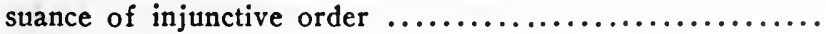

COURTS: See Circuit Court of Appeals; District Court; SuPREME COURT; DECREE OF CourT.

may adopt or reject an advisory suggestion of the Commission 254, 255 application to courts, manner and character fixed $.250,251,268,269,270$ application to, to enforce Commission's orders against a re-

calcitrant ....................................250, 269

application to, to have order Commission set aside ........251, 270 appropriate court obtains jurisdiction ...........250, 251, 269, 270 Trade Commission may investigate carrying out of final decrees issued by, in Anti-trust suits .................. 253

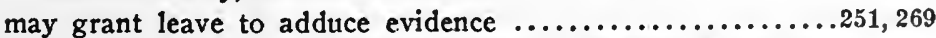
Circuit Court of Appeal's judgment and order final, except upon discretionary review by Supreme Court ..............251, 269 jurisdiction $\ldots \ldots \ldots \ldots \ldots \ldots \ldots \ldots \ldots \ldots . .252,256,266,269,270,272$ have concurrent jurisdiction to enforce Sections $2,3,7$, and 8 of Clayton Law .............................. ${ }_{272}$ judgment may be reviewed in discretion by Supreme Court ..251, 209 order admissible as evidence ........................ 261 order does not relieve from liability under Anti-trust acts 252, 258, 270 may refer an inquiry to Commission .................254, 255 duty of, to review Trade Commission's construction of term "unfair competition" 
[REFERENCES ARE TO PAGES.]

\section{COURTS OF EQUITY:}

will not enforce contracts against public policy .............

COURT OR ENQUIRING BODY: See CoURTS; Immunity.

cannot confer immunity, except when exercising jurisdictional

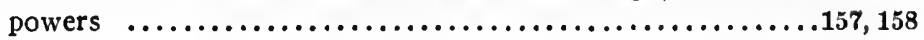

COURT REVIEW: See APPEALS.

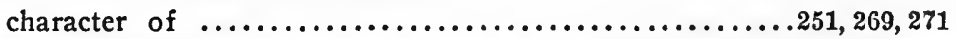

findings of Commission binding upon court ............251, 269

question of law, as distinguished from question of fact, open to

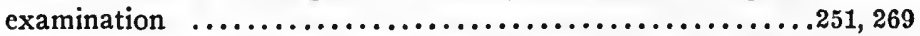

questions of sufficiency of proof and of proper construction of statutes and of Trade Commission's jurisdictional powers raised upon review of Commission's order ..........251, 269

CRIMES: See Penalties; Contempt of Court.

criminal provisions of Anti-trust laws considered ...........

nature of Trade Commission Act and Clayton Law civil rather

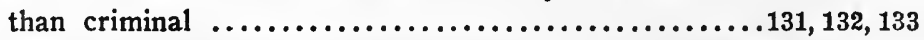

occasion for omission of criminal measures for enforcement of

certain provisions of Clayton Law, stated ............. 137

novel or untried features subject to civil penalties only $\ldots \ldots 132,137$

violations of Sections 2, 3, 7, and 8 are civil offenses ........ 138

penalties under Trade Commission Act (as under Clayton Law)

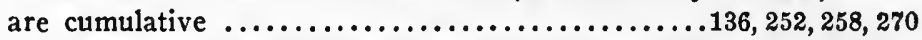

in general, intent is controling element in criminal trials ..... 18, 19

immunity granted to witnesses testifying under subpœna ..... 257

failure to attend or testify, an offense $\ldots \ldots \ldots \ldots \ldots \ldots \ldots . \ldots \ldots, 257$

wilfully making false entry or report, or wilful failure to make true entry, or wilful removal or alteration of documentary evidence, or wilful refusal to submit same for ex-

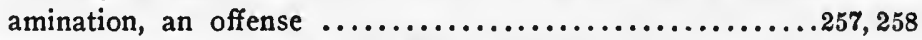

occasion for penalizing falsification, etc., of corporate records,

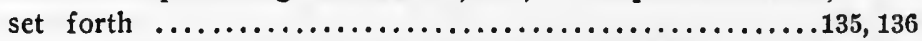

failure to file report by corporation subject to penalty ........ 258

officer or employee of Commission making public information

without authority, guilty of a misdemeanor $\ldots \ldots \ldots \ldots \ldots .136,258$

embezzlement by officer, director or manager of common car-

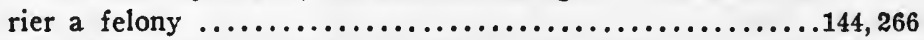

nature, extent and purpose of provision considered ......144, 145, 146

offenses against regulation of relations between common carriers and supply, financial or construction companies, criminal

general purpose and scope of Section 10 of Clayton Law ...... wilful disobedience of any order, etc., a contempt ........... contempt proceedings not bar to prosecutions for criminal of- 
[REFERENCES ARE, TO PAGES.]

officers, directors and agents criminally liable for corporate

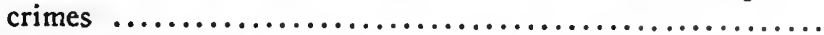

PAGE

history and purpose of individual responsibility feature discussed

director, agent, manager or officer of common carrier liable criminally

occasion for prohibitory provision contained in Section 10 of

Clayton Law, discussed ..............................

generally as to regulation of relations between common car-

riers and supply, etc., concerns ...................138-146

specific common carrier regulations considered $\ldots \ldots \ldots \ldots \ldots .140,141$

criminal provisions of Sherman Law discussed ......146, 147, 148, 149

Sherman Law declared to be a criminal statute ........... 149

creates a new offense by penalizing acts not criminal under

the common law ............................. 149

punishment prescribed in Sherman Law ................... 149

rule applicable when construing Sherman Law as criminal

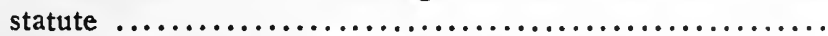

criminal jurisdiction of Sherman Law extended by Clayton Law

by preventive and restraining measures, Trade Commission

obviates criminal prosecutions ................147, 148, 149

Contempt proceedings specified in Sections 21 to 25 of Clayton

Law, non-criminal

crimes under Wilson Tariff Law relate solely to import trade. Wilson Tariff Law contains re-enactment of Sherman Law

Anti-trust provisions $\ldots \ldots \ldots \ldots \ldots \ldots \ldots \ldots \ldots \ldots \ldots \ldots$

provides Anti-trust regulation of import trade ..............

essential feature, contained in Section 73 thereof, not passed

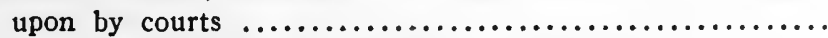

Section 6 of Trade Commission act confers authority for recommending enlargement of penal provisions, if required to make effective Anti-trust laws

\section{CRIMINAL INTENT:}

in general, is controlling element in criminal trials

\section{CUSTOMERS:}

names of, not to be divulged by Trade Commission ..........

may be selected when not in restraint of trade ........... 260

\section{DAMAGES FOR VIOLATION OF ANTI-TRUST LAWS:}

three-fold recoverable by injured persons with costs and at-

torney's fee .................................. 261, 283

right to recover three-fold damages extended by Clayton Law.. 108

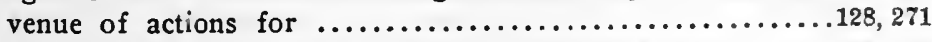

no provision as to damages in Trade Commission Act ........125, 126

generally, as to right to bring actions ................ 124 


\section{[REFERENCE,S ARE, TO PAGES.]}

right covers all violations of Anti-trust laws ............. 125

Sherman Law provision for triple damages re-enacted ....... 126 extent of actionable injuries enlarged ................ 127 liability for damages accruing under "unfair methods" de-

clared illegal by Trade Commission act, considered ........125, 126 presents question for Supreme Court ................ 126 definition of "person" in Clayton Law ................. 127 right to litigate before alleged violation has been adjudged

illegal by the Trade Commission, considered ..........127, 128 final decrees in proceedings by government, prima facie evidence 128 provision as to venue $\ldots \ldots \ldots \ldots \ldots \ldots \ldots \ldots \ldots \ldots \ldots \ldots \ldots .128,129$ procedure of service discussed $\ldots \ldots \ldots \ldots \ldots \ldots \ldots \ldots \ldots \ldots .129$ service of subpœnas $\ldots \ldots \ldots \ldots \ldots \ldots \ldots \ldots \ldots \ldots \ldots \ldots \ldots \ldots \ldots .129$ attendance of witnesses, considered .. ...............129, 130 Anti-trust actions semi-public matters ................129, 130

DEALERS IN SECURITIES AND SUPPLIES: See BANKS; Competition; Competitive Bidding; Common Carriers.

regulation of relations with common carriers under Section 10 of Clayton bill considered, and occasion for requirements stated $\ldots \ldots \ldots \ldots \ldots .53,54,55,65,66,67,138,139,140,266,267$

DEBATES IN CONGRESS: See ShERMAN LAW.

Summary of, connected with passage of Sherman Law ....74, 75, 76 committees' report, containing substance of, upon proposed supplementary Anti-trust laws, session of 1911-12 ......... tentative forms of Sherman Law submitted to the Senate for

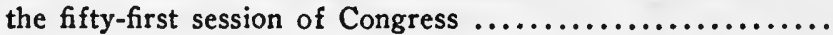

DECREE OF COURT: See CoMmission OR BOARD.

Commission may act as master in chancery to report form of court decree in proceedings by the United States under Anti-

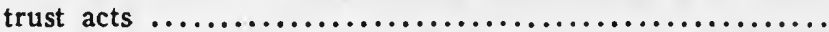

in suits by United States, shall be prima facie evidence against defendant in other suits, except consent decrees, etc. ...... 261 Trade Commission may investigate manner of carrying out ...

\section{DEFENDANT PARTY:}

appeal to court from Commission's orders ..........251, 252, 270 service of process on $\ldots \ldots \ldots \ldots \ldots \ldots \ldots \ldots \ldots \ldots \ldots \ldots \ldots . \ldots \ldots 25$ rights of, court review deals with $\ldots \ldots \ldots \ldots \ldots \ldots \ldots \ldots . \ldots \ldots \ldots \ldots$, 269 statute fixes no time limit for appeal from Commission's

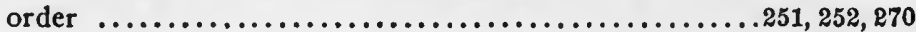

\section{DEFENSE:}

violation of Sherman Law not a defense to suit for infringement of patent rights 
[REFERENCES ARE, TO PAGES.]

DEFINITIONS OF TERMS: See TERMS, DEFINITIONS of; DEFINITIONS.

PACE

\section{DEFINITIONS: See TERMS, DeFinitions OF.}

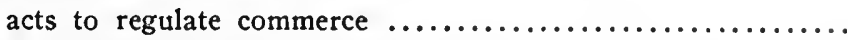

Anti-trust laws (see Anti-trust Laws) ................249, 259

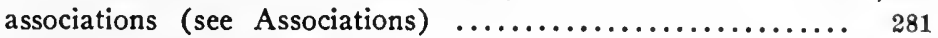

commerce (see Commerce) ....................... 259

Anti-trust definitions of commerce, compared ........... 92,93 corporations (see Corporations) .................248, 259, 281 documentary evidence (see Documentary Evidence) ........ 248 partnerships :

excepted from definition of corporations ............ 248

subject to Section 5 Trade Commission Law .......... 249

person or persons (see Person or Persons) .............260, 281 person, in Clayton Law ......................... 127 person, in Anti-trust laws ..................96, 106, 115, 116 corporation in Anti-trust laws ..................... 96

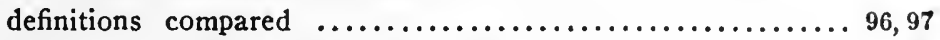
monopoly, defined by Senate committee ............... 76 monopoly, judicially defined ........................ 15 competition, judicially defined $\ldots \ldots \ldots \ldots \ldots \ldots \ldots \ldots \ldots \ldots \ldots \ldots$ embezzlement, Section 9, Clayton Law ...............144, 266 Federal Trade Commission defined as "a commercial police" .. 132 strike ................................... 172

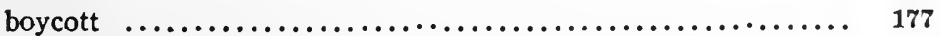

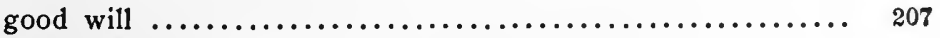
exclusive rights $\ldots \ldots \ldots \ldots \ldots \ldots \ldots \ldots \ldots \ldots \ldots \ldots \ldots \ldots \ldots, 17$

\section{DEPOSITIONS :}

testimony may be taken by deposition $\ldots \ldots \ldots \ldots \ldots \ldots \ldots \ldots .256$ manner of taking depositions ..................... 256 compelling attendance of witnesses, etc. $\ldots \ldots \ldots \ldots \ldots \ldots \ldots 256$

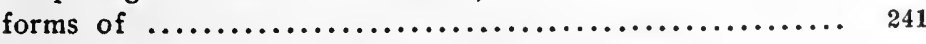

\section{DIRECT DAMAGE TO THE PERSON INJURED:}

proof of, apparently not required

DIRECTORS: See BANKS; INTERLocking Directors; CoMmon Carriers; Corporations.

with officers and agents, are personally liable for corporate crimes in which they participate .............142,143,144,271 embezzlement of property of common carrier by, a felony ..... 266 nature, extent and purpose of provision, discussed ......144,145, 146 
DIRECTORS, OFFICERS AND AGENTS OF CORPORATION CONSENTING TO VIOLATION OF PENAL PROVISIONS OF ANTI-TRUST LAWS: See DIRECtors; Anti-trust Laws; Crimes.

are individually guilty of misdemeanor $. . . \ldots \ldots \ldots \ldots \ldots . . . . . .$.

DisCRETION: See Commission or Board; Federal Trade CoMmission.

right of Commission to exercise as to instituting of proceedings under Section 5 of Trade Commission act ............. under provisions of Section 11 of Clayton Law, the person aggrieved is in effect the moving party .................... mandamus to compel Commission or board to exercise its .....

\section{DISCRIMINATION IN PRICE:}

unlawful when effect may be to substantially lessen competi-

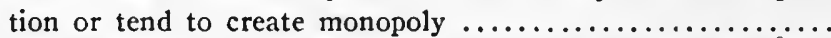
permitted when on account of differences in grade, quality or quantity sold, or because of difference in cost of selling or transportation, or when made to meet competition ........... persons may select their own customers when not in restraint

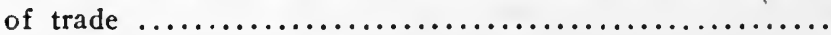

decision in first Clayton Law case, passes upon question of .28, 193, 194

DISTRICT ATTORNEYS OF UNITED STATES: See INJUNCTION.

duty, under direction of attorney general to enforce Sections $2,3,7$, and 8 , and other provisions of Clayton Law ......... may conduct contempt proceedings ......................

DISTRICT COURTS OF UNITED STATES: See INJUNCTrON.

jurisdiction to restrain violations of Clayton, Sherman and

Wilson Laws ..........................272, 280, 282 may require other parties summoned $\ldots \ldots \ldots \ldots \ldots \ldots .272,280,283$ crimes form basis for contempt proceedings ............. 275 violations of orders entered in suits by United States basis

for contempt proceedings under Clayton Law ..........277, 278 procedure in contempt cases .....................276, 277 may refer suit by government to Federal Trade Commission

as master in chancery to report form of decree ...........254,255 may enforce Trade Commission Act by mandamus ......... 256 may punish by contempt failure to obey order requiring testi-

mony, etc. ................................. 256 venue of private actions for violations of Sherman Law ...... 281 of Clayton law ............................. 261

\section{DISTRICT OF COLUMBIA, COURT OF:}

wilful disobedience of any order, etc., a contempt ........... 
DOCUMENTARY EVIDENCE: See EVIDENCE.

defined to include all papers, etc., in existence at time and after

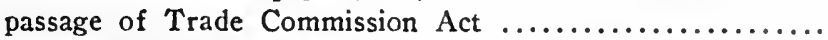
Commission shall have access to documentary evidence of corporation being investigated or proceeded against ..........

production of, may be compelled $\ldots \ldots \ldots \ldots \ldots \ldots \ldots \ldots$

\section{EDMUNDS, SENATOR:}

argument in opposition to amendment exempting labor from provisions of Sherman Law ..................166, 167

\section{ELIGIBILITY OF INTERLOCKING DIRECTORS, OFFI-}

CERS OR EMPLOYEES: See INTERLOCKINC DIRECTORS.

\section{EMBEZZLEMENT: See Crimes.}

statutory definition $\ldots \ldots \ldots \ldots \ldots \ldots \ldots \ldots \ldots \ldots \ldots \ldots, \quad 266$

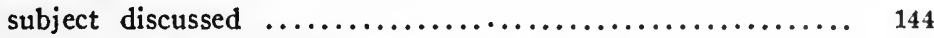

such misappropriation of property of common carrier by presi-

dent, director, officer or manager, is a felony ........... 144

nature, extent and purpose of provision, considered .....144, 145, 146

EMPLOYEES: See INTERLOCKING DiRECTORS; BANKS; CoMmon Carriers; Corporations; Crimes.

EMPLOYEES AND EMPLOYERS: See LABOR.

ENFORCEMENT: See Provisions for Enforcement.

necessity for and means of $\ldots \ldots \ldots \ldots \ldots \ldots \ldots \ldots \ldots \ldots \ldots, 37$

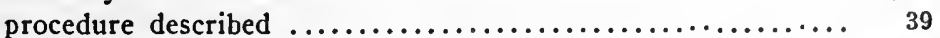

means of review $\ldots \ldots \ldots \ldots \ldots \ldots \ldots \ldots \ldots \ldots \ldots \ldots \ldots, 40,41$

methods of procedure stated and compared ............. 44

\section{EQUITY SUIT:}

Trade Commission may act as master in chancery in ......254,255 any person may apply for injunctive relief, where violation of

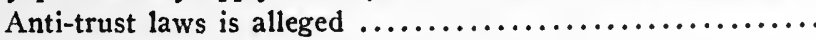

\section{ERROR:}

in Section 5, Trade Commission act $\ldots \ldots \ldots \ldots \ldots \ldots \ldots \ldots$.

evidence: See Documentary Enidence; Prima Facie EilDENCE.

Commission's findings of facts conclusive if supported by testimony, ................................................ 269 additional evidence may be ordered by court to be taken before Commission ................................ 269

Commission may require attendance of witnesses and production of documentary evidence (Query-has Federal Reserve Board such power as to enforcement of Trade Commission or Clayton Law?), - see statutory provisions ...........255, 256 
final decree of court in suit by United States prima facie evi-

dence against defendant in other suits ...............102, 261 testimony must be taken before Commission or board ......250, 268 query-whether court may hear testimony as to necessity for

adducing additional evidence before Commission or board ..251, 269

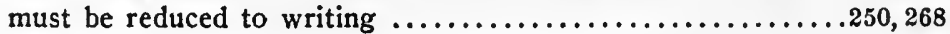

\section{EXAMINERS:}

may prosecute inquiry in any part of United States ..........

\section{EXCLUSIVE RIGHTS OF INVENTORS AND AUTHORS:}

See Patents and Copyrights.

exclusive rights as distinguished from monopolies ........ 15, 16

\section{EXEMPTION FROM PROVISIONS OF ANTI-TRUST LAWS:}

agricultural, horticultural and labor organizations and mem-

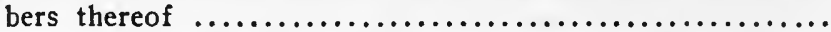
exemptions from provisions of curative statutes strictly con-

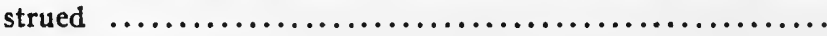

\section{EXPEDITION IN THE CIRCUIT COURT OF APPEALS:}

See Appeals; Review; Resubmission to Commission. granted to all Commission cases ...............45, 252, 270

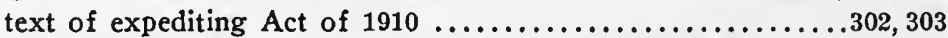

EXPORT AND IMPORT TRADE: See ForEIGN TRADE.

\section{FALSE TESTIMONY, REPORTS, ETC.:}

punishable by fine and imprisonment $\ldots \ldots \ldots \ldots \ldots \ldots \ldots .257$ importance of accuracy in reports, etc., shown .........135, 136

FARMERS EXEMPT:

farmers exempt from provisions of Anti-trust laws ......... 262 FEDERAL RESERVE BANK:

Class A director of Federal Reserve Board may be officer and director in one member bank $\ldots \ldots \ldots \ldots \ldots \ldots \ldots \ldots \ldots .264,265$

FEDERAL RESERVE BOARD: See COMMISSION OR BoARD.

for names of members of Board, see .................. 235 powers peculiar to:

to enforce provisions of Clayton Law applicable to banks.. 268

FEDERAL TRADE COMMISSION: See CoMMISSION OR BOARD.

for names of members of Commission, see ............... 232 for text of Federal Trade Commission Act, see .............259-278 definition of terms "person" and "corporation" ............. 96 
not intent of Congress to institute a legislative body ....... 26, 27 creation of :

composed of five commissioners ................ 246

appointed by the President .................... 246

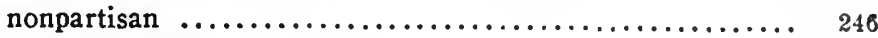

term of office seven years $\ldots \ldots \ldots \ldots \ldots \ldots \ldots \ldots \ldots \ldots . \ldots \ldots$

chairman chosen by commissioners ............... 246

in general :

official seal shall be judicially noticed $\ldots \ldots \ldots \ldots \ldots \ldots \ldots 246$

causes of removal of commissioners .............. 246

may employ attorneys, experts, etc. .............. 247

commissioner's salary $\$ 10,000 \ldots \ldots \ldots \ldots \ldots \ldots \ldots \ldots .246$

employees under civil service (except secretary, commissioners' clerks, special experts and examiners) ....... 247

principal office in Washington .................. 248

may meet and exercise powers any place ............ 248

necessary expenses provided for $\ldots \ldots \ldots \ldots \ldots \ldots \ldots \ldots 246,247$

one or more commissioners or an examiner may prosecute

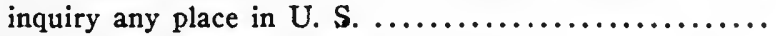

powers and duties grouped under five heads:

advisory powers of (Trade Commission Act, Sec. 6, pars. $\mathrm{f}$

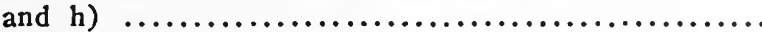

powers and duties, investigatory (Trade Commission Act,

Sec. 6, par. g, and Sec. 9) .............254, 255, 256, 257 powers and duties, power of publicity (Trade Commission

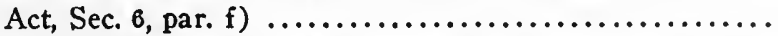
powers and duties, powers to establish procedure (Trade

Commission Act, Sec. 6, par. g, subject to the statutory provisions establishing general methods of procedure, as set forth in identical terms in Sec. 5 of act, and in Sec.

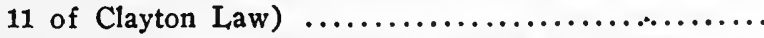
powers and duties, semi-judicial (Trade Commission Act, Sec. 5 ; Sec. 3, par. 3; Sec. 9, pars. 1 and 5 ; Sec. 10) ... .......................248, 249, 255, 256, 257, 258

powers to sit as judicial body, analyzed and compared ...... 26 powers peculiar to:

to prevent price discrimination (certain price discrimina-

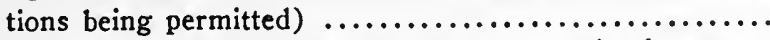
to prevent unlawful tying clause contracts (such as contracts of lease or sale binding lessee or purchaser not to use goods of competitor or sellor or lessor, if such contract substantially lessens competition or tends to create monopoly) ..........................260, 261 to conduct proceedings now pending before Bureau of Corporations 


\section{[REFERENCES ARE TO PAGES.]}

PAGE

to file complaint only if of opinion unfair methods of com-; petition have been used and that the proceeding would be "to the interest of the public".................

person, partnership or corporation complained of may show cause why order should not be entered $\ldots \ldots \ldots \ldots \ldots .250,268$

to prevent persons, partnerships or corporations, except banks and common carriers from using unfair methods

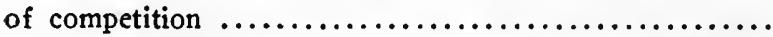

right to exercise visitorial powers over business and records of corporations ...................99, 252, 253, 255

to investigate corporations other than banks and common carriers .............................252, 253, 254

visitorial powers under Section 6 of Act extend only to

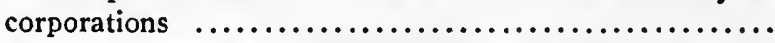

to require annual or special reports and answers to ques-

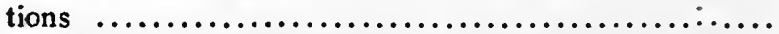

to investigate the manner in which decree against any corporation has been or is being carried out ............

under direction of President or either House of Congress to investigate and report alleged violations of Anti-trust acts by corporation $\ldots \ldots \ldots \ldots \ldots \ldots \ldots \ldots \ldots \ldots \ldots \ldots \ldots \ldots \ldots \ldots, 254$ upon application of attorney general to recommend readjustment of business of corporation $. . . \ldots \ldots \ldots \ldots . . . .$. to publish information except trade secrets and names

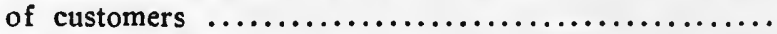

to make annual and special reports and recommendations to Congress and publish its reports ................. to classify corporations and make rules and regulations ... to investigate trade conditions with foreign countries ..... to investigate and make recommendations to Congress concerning manufacturers, merchants' or traders' relations

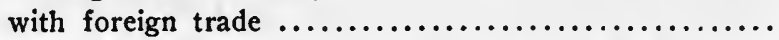

to act as master in chancery in proceedings by government under Anti-trust laws ..................254, 255

to have access to all papers, etc., in the possession of other departments and bureaus of the government .......... 255

to administer oaths, examine witnesses and receive evi-

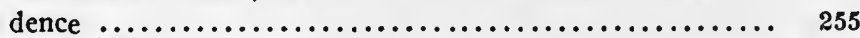

to take testimony in person or by examiners $\ldots \ldots \ldots \ldots \ldots 248,255$

to subpona witnesses and production of documentary evidence from any place in the United States to any place

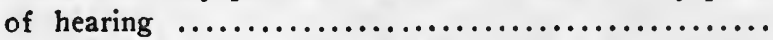

district courts may enforce attendance, etc., by contempt

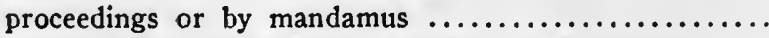
to order testimony taken by deposition (see Forms) .... 256 
to examine and copy documentary evidence of corporations

liability of individual:

under Trade Commission Act.....................

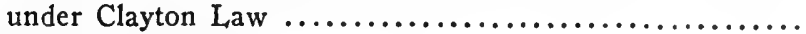

PAGE

liability of corporation:

under Trade Commission Act ...................... ${ }_{98}$

under Clayton Law ................................ 101

penalties prescribed in Act, and under Clayton Law are cumu-

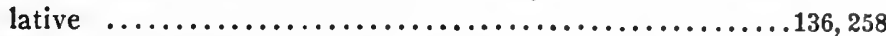

mandamus proceedings will lie to compel Commission to exer-

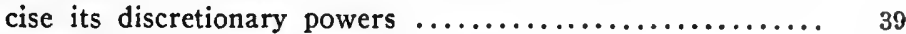

provisions for enforcing Trade Commission Act ............ 37

FEDERAL TRADE COMMISSION ACT: See FEDERAL Trade

COMMISSION; COMMISSION OR BOARD.

text of .....................................259-278

consideration of penal provisions pertaining to .............134-137

FEDERAL TRADE COMMISSION'S FUNCTIONS: See

Federal Trade Commission; Commission or Board.

for names of members of Commission, see .............. 232

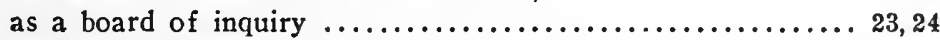

as a judicial body $\ldots \ldots \ldots \ldots \ldots \ldots \ldots \ldots \ldots \ldots \ldots \ldots \ldots \ldots \ldots \ldots \ldots \ldots \ldots \ldots, 24,25$

FELONY: See Crimes.

embezzlement by a common carrier officer a ............... 266

FINAL DECREE AGAINST DEFENDANT CORPORA-

TION: See Federal, Trade Commission.

when violation of Anti-trust acts are concerned, Trade Commission has power to investigate manner in which decree is

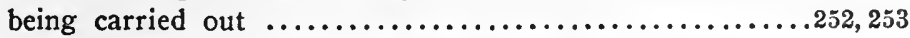

FINDINGS OF FACT BY COMMISSION OR BOARD:

conclusive if supported by testimony ..................251, 269

\section{FINES :}

penalty prescribed for failure to give testimony or produce doc-

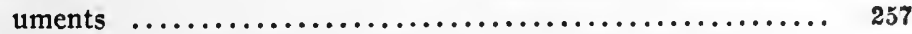

. penalty for withholding or falsifying corporate records ...... 257

penalty for failure to file reports ..................... 258

FISH, FREDERICK P.:

views of, on need for regulation of competition ..............

FOREIGN ANTI-TRUST LAWS:

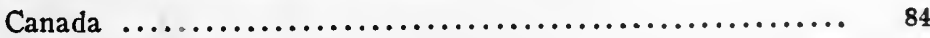

Great Britain .................................... ${ }_{86}^{86}$

Cape of Good Hope $. . . \ldots \ldots \ldots \ldots \ldots \ldots \ldots \ldots \ldots \ldots . . \quad 86$ 
Japan

Japan $\ldots \ldots \ldots \ldots \ldots \ldots \ldots \ldots \ldots \ldots \ldots \ldots \ldots \ldots \ldots \ldots \ldots,{ }_{86}$

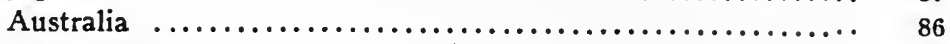

New Zealand $. . . \ldots \ldots \ldots \ldots \ldots \ldots \ldots \ldots \ldots \ldots \ldots \ldots,{ }_{86}$

FOREIGN TRADE:

both export and import trade subject to Sherman, Clayton and

Trade Commission laws .....................248, 259, 279

import trade only, subject to Wilson Tariff Law ............ 282

Philippine Islands, not subject to Clayton Law ............ 259

Trade Commission has power to investigate foreign trade con-

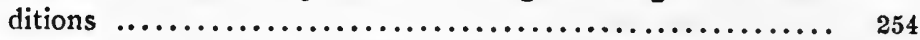

effects of right of Trade Commission to investigate .........60,61

\section{FORFEIT:}

failure by corporation to file report subjects it to $\$ 100$ per day .

FORMS:

No. 1. Petition for Issuance of Complaint ................ 236

No. 2. Answer to Complaint .......................... 237

No. 3. Affidavit of Service ........................237, 238

No. 4. Petition for Permission to Intervene .............. 238

No. 5. Subpœna ................................... $\quad 239$

No. 6. Subpœna Duces Tecum .......................239, 240

No. 7. Verified Application for Subpœna Duces Tecum ...... 240

No. 8. Application for Order Requiring Testimony to be Taken by Deposition ..........................241, 242

No. 9. Directions for Taking Testimony by Deposition in a Contested Proceeding .......................242, 243

FUNCTIONS OF FEDERAL TRADE COMMISSION: See Commission or Board; Federal, Trade, Commission; Federal Trade Commission's Functions.

\section{FRANCHISE:}

ripens into contract with state $\ldots \ldots \ldots \ldots \ldots \ldots \ldots \ldots \ldots \ldots .18$

modern franchises reserve power to cancel or amend ......... 18

GOVERNMENT RECORDS:

available to Trade Commission, upon direction by President ..

GREAT BRITAIN: See ForeIgN ANTI-Trust Laws.

GUILTY KNOWLEDGE: See OFFICERS.

joined with participation in crime of corporation, renders directors, officers and agents liable to prosecution for misde-

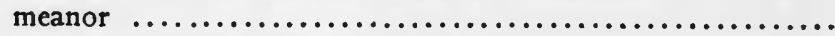

HABEAS CORPUS: See WitNESSES; ImMunIty. 
[REFERENCES ARE, TO PAGES.]

HEARINGS: See COMMISSIONER OR BOARD.

notice of, by Commission $.250,268$ place and time of hearing fixed thirty days after service of complaint .................................250, 268 record of, filed in Circuit Court of Appeals ...........250, 251, 269 further hearings by Commission permitted .............251, 269

HORTICULTURAL ORGANIZATIONS, NOT FOR PROFIT:

excepted from provisions of Anti-trust acts; members of, also

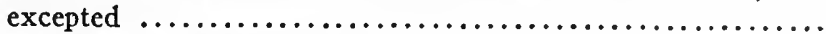

\section{ILLEGAL COMBINATION:}

labor, etc., organization shall not be held or construed to be ...

\section{IMMUNITY: See WITNESSES.}

granted to witnesses, testifying under subpona $\ldots \ldots \ldots \ldots \ldots .257$

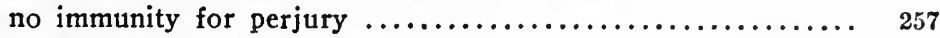

not granted by any order of Commission or board, or judgment

or decree of Circuit Court of Appeals ..............153, 252, 270

based upon rights conferred by constitution ............. 152

corporation, not entitled to $\ldots \ldots \ldots \ldots \ldots \ldots \ldots \ldots \ldots \ldots \ldots \ldots \ldots \ldots \ldots, 159,257$

purpose of immunity provisions stated .................. 155

actual jeopardy must be shown to confer ............156, 157, 161

witness must claim, in order to secure $\ldots \ldots \ldots \ldots \ldots \ldots \ldots \ldots .157$

government entitled to know attitude of witness as to claiming

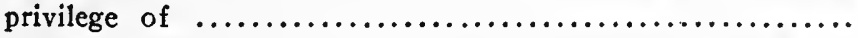

court or body acting within jurisdictional powers alone can

confer ....................................157, 158

testimony must be in proceeding relevant and material to exer-

cise of such powers ...........................157, 158

further consideration of provisions relating to ........... 158

provisions in act of February 25, $1903 \ldots \ldots \ldots \ldots \ldots \ldots \ldots .158$

text of immunity statutes .........................289, 290

by pardon $\ldots \ldots \ldots \ldots \ldots \ldots \ldots \ldots \ldots \ldots \ldots \ldots \ldots \ldots \ldots \ldots \ldots \ldots \ldots, 158$

power to exclude from, inclusive of state incorporated bodies .. 159

Fourth Amendment, as it relates to ..................159, 160

conferred in aid of prosecution $\ldots \ldots \ldots \ldots \ldots \ldots \ldots \ldots \ldots \ldots \ldots, 161$

does not extend to future acts $\ldots \ldots \ldots \ldots \ldots \ldots \ldots \ldots \ldots \ldots, 161$

resistance by witness, not required $\ldots \ldots \ldots \ldots \ldots \ldots \ldots \ldots \ldots 1,162$

exemption in federal courts does not protect from State court

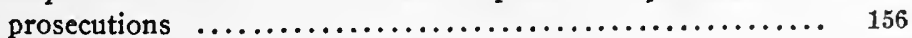

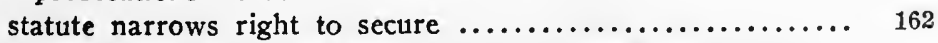

fair dealing seems to require broad construction of privilege .. 162

policy granting complete immunity would benefit Anti-trust in-

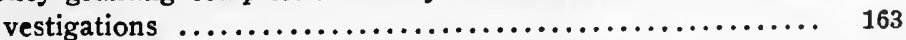

rulings in immunity cases .......................... 163

witness occupies dangerous position $\ldots \ldots \ldots \ldots \ldots \ldots \ldots \ldots . .163$

immateriality not a question for witness to decide ...........163, 164 


\section{[REFERENCES ARE TO PAGES.]}

PAGE

specific rulings considered $\ldots \ldots \ldots \ldots \ldots \ldots \ldots \ldots \ldots \ldots \ldots, 164$

relates to criminal procedure only ................... 152

immunity proceeds from recognition of constitutional rights ...

freedom to contract a qualified right $\ldots \ldots \ldots \ldots \ldots \ldots \ldots \ldots \ldots, 151$

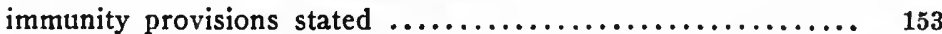

Commission's orders not equivalent to subpœna ............ 153

IMPORT AND EXPORT TRADE: See ForEIGN TRADE.

IMPRISONMENT: See CRIMES.

as punishment for violation of provisions of the Clayton Law

..........................266, 267, 271, 276, 277

\section{INDIVIDUAL LIABILITY OR RESPONSIBILITY: See LIABILITY.}

\section{INJUNCTION:}

importance of subject considered $\ldots \ldots \ldots \ldots \ldots \ldots \ldots \ldots \ldots, 111$

right to relief by, retained and enlarged $\ldots \ldots \ldots \ldots \ldots \ldots \ldots 111,112$

notice which equity courts require $\ldots \ldots \ldots \ldots \ldots \ldots \ldots \ldots \ldots .112,113$

development and establishment of practice ..............112,113

any person or corporation threatened with damage by violation

of Anti-trust laws entitled to injunction ............... 272 practice revised:

regulations under Clayton Law ................113, 114, 115 relief by, under Clayton Law:

general features, considered $\ldots \ldots \ldots \ldots \ldots \ldots \ldots \ldots \ldots \ldots, 115,116$

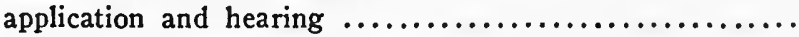

requirements as to notice $\ldots \ldots \ldots \ldots \ldots \ldots \ldots \ldots \ldots \ldots \ldots \ldots \ldots \ldots \ldots, 118$

security ................................... 118

orders must be specific .........................118, 119

special limitations, in trade disputes ................119, 120

report of Senate committee relating to (note) .......... 120

injunctive relief not authorized by Clayton Law, against common

carrier in certain cases $\ldots \ldots \ldots \ldots \ldots \ldots \ldots \ldots \ldots \ldots \ldots \ldots \ldots \ldots \ldots \ldots \ldots, 272,273$

no preliminary injunction without notice ............... 273

no temporary restraining order without notice unless imme-

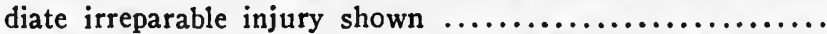
party enjoined may move dissolution of temporary restraining order upon two days' notice............................ injunction bond required ............................. 274 order of injunction shall be specific ................... 274 binding only upon parties and those receiving actual notice .... 274 injunctions not permitted between employers and employees, or between employees, or between persons employed and persons seeking employment, unless necessary to prevent an irreparable injury and no such injunction shall prohibit terminat- 
[REFERENCES ARE TO PAGES.]

PAGE

ing the employment or peacefully persuading others to do so 274,275 court may issue, to restrain violation ...........272, 280, 282, 283 public interests conserved under Trade Commisssion Act ...114, 115 restraining orders (not injunctions) issued under said Act ...114, 115 no preliminary injunctive relief provided for under Trade Com-

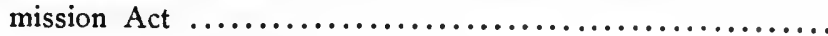

INJUNCTIVE RELIEF: See INJUNCTION.

INJURIES TO BUSINESS OR PROPERTY FROM VIOLATIONS OF ANTI-TRUST LAWS: See DAMAGES FOR Violation of Anti-Trust Laws.

compensated by threefold damages, costs and attorney's

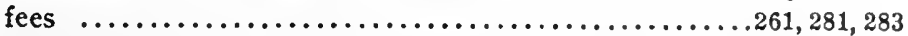
no provision as to recovery of damages in Trade Commission

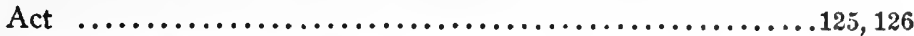

INQUISITORIAL POWERS: See Federal, TRADE Commission.

INTER-CORPORATE SHAREHOLDING: See STOCK OWNERSHIP BY ONE CORPORATION IN ANOTHER.

\section{INTERLOCKING DIRECTORS:}

prohibited after two years as follows:

as to banks:

interlocking officers, directors or employees in national banks if either one has deposits, capital, surplus and undivided profits of more than five million dollars .. private banker or director of state bank having more than five million of deposits, capital, surplus and undivided profits not eligible as director in any national bank ...............................

provisions for determining the five million dollar limitation above mentioned $. . . . \ldots \ldots \ldots \ldots \ldots . . . . .$.

a national bank in city of more than 200,000 population may have as a director, officer or employee any director, officer or employee of not more than one other national or state bank in the same place, only where the entire capital stock of one of such banks is owned by the stockholders in the other, but may not have as officer, director or employee any private banker located in the same place ..............264, 265 query: whether this provision is subject to the five million dollar limitation above mentioned ........264, 265 mutual banks without shares of capital stock not subject to interlocking provisions ...............264, 265 class "A" director of federal reserve bank may be officer or director or both in one member bank ....

director, officer or employee eligible at time of election 


\section{[REFERENCES ARE, TO PAGES.]}

does not become subject to interlocking provisions until one year from date of election or employment .

as to common carriers:

no provisions against interlocking in railroads $.35,65,266,267$

interlocking between common carrier and supply, construction or financial concern subjects transactions between them to regulation by the Interstate Commerce Commission .....................266, 267

as to corporations other than banks and railroad common carriers :

interlocking directors prohibited after two years in two or more corporations any one of which has capital, surplus and undivided profits aggregating more than one million dollars, if such companies be competitors so that elimination of competition by agreement would violate Anti-trust laws ............... director eligible at time of election not subject to interlocking provisions until one year from date of election ...................................

provisions for regulation of interlocking directors, considered generally

\section{INTERLOCKING DIRECTORATES BILL:}

one of five proposed measures utilized by Congress when preparing Trade Commission Act and Clayton Law ............

INTERSTATE COMMERCE ACTS: See Acrs To REgUlate COMMERCE.

INTERSTATE COMMERCE COMMISSION: See COMMISSION OR BOARD; COMPETITIVE Bidding; COMPETITION.

for names of members of Commission, see ............... powers peculiar to, under authority conferred by Section 11 of Clayton Law:

may determine legality of branch line construction or acquisition through stock ownership ................... may regulate relations between common carriers and supply, construction or financial concerns with interlocking directors ..................................266, 267

to report to attorney general violations by common carriers of Section 10 of Clayton Law .................. may enter cease and desist orders to prevent unlawful stock ownership by common carriers ................ no authority to prevent interlocking of directors, etc., as between common carriers .......................... empowered to enforce Section 10 of Clayton bill ............. 
[REFERENCES ARE, TO PAGES.]

uncertainty as to whether provision of Section 7 conferring right to form subsidiary corporations, includes common carriers, noted ................................6 63, 64

organization and procedure of, followed, so far as practicable, in formation of Federal Trade Commission .............77, 133 for text of original Interstate Commerce act, see Appendix "O" 345

INTERSTATE TRADE COMMISSION BILL:

one of five proposed measures utilized by Congress when preparing Federal Trade Commission Act and Clayton Law ..

INTERVENTION :

permitted by Commission or board on good cause shown (see

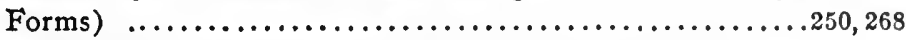

INVALIDITY OF A PORTION OF CLAYTON ACT:

shall not invalidate any other portion $\ldots \ldots \ldots \ldots \ldots \ldots \ldots \ldots$

INVENTORS:

and authors, exclusive rights of distinguished from monopoly .

INVESTIGATION: See InterLocking Directors; Common CarRIERS.

by Interstate Commerce Commission, into alleged violation of provision as to competitive bidding $\ldots \ldots \ldots \ldots \ldots \ldots \ldots \ldots$.

INVESTIGATION BY TRADE COMMISSION: See CoMMISSION.

INVESTMENT IN STOCK BY CORPORATION:

not prohibited, when for investment only ..................

JAPAN: See ForEIGN ANTI-TRUST LAWS.

JEOPARDY :

actual, must be shown to afford immunity ..................

JUDGMENT OF COURT IN SUITS BY UNITED STATES:

prima facie evidence against defendants in other suits, except consent decrees, etc. ..........................102, 261

for memoranda of Anti-trust cases instituted by the United States, (complete to October 15, 1915), -see Appendix "P" ..

JUdiciaRY: See Judicial, Body; Judicial, Code.

JUDICIAL BODY: See Courts; CourTs of Equity; CourT or Enquiring Body; Commission or Board; Feperal Trade Commission; Appeals.

Trade Commission empowered to act as ...............22, 23, 24 judicial powers of Trade Commission analysed and compared . 26, 27

JUDICIAL CODE: See REVIEW; ReVIEW OF ORDERS; APPEALS.

Section 263 repealed by Clayton Law .................113, 274 
[REFERENCES ARE TO PAGES.]

Section 266 not amended $. . . \ldots \ldots \ldots \ldots \ldots \ldots \ldots \ldots \ldots . . \ldots \ldots$

right of review by the Supreme Court upon certiorari under Section 240 of, specifically provided .................251, 269

JURISDiction: See Circuit Court of Appeals; Commission or Board; District Court; Supreme Court; Federal Trade Commission; Interstate Commerce Commission; Federal, RESERVE BOARD.

\section{KNIGHT CASE:}

narrow construction of "commerce" in, overruled ........... when instituting Trade Commission, Congress adopted and applied broad construction of power to regulate commerce .....

KNOWLEDGE: See GUILTY KNOWLEDGE.

\section{LABOR:}

labor not a commodity or article of commerce ...............

labor organizations not for profit excluded from provisions of

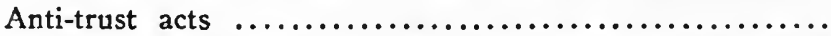
injunctions not permitted between employers and employees, or between employees, or between persons employed and persons seeking employment, unless necessary to prevent an irreparable injury and no such injunction shall prohibit terminating the employment or peacefully persuading others to do so 274,275 members of labor organizations not for profit, excluded from provisions of Anti-trust acts ......................... subject considered in connection with inception of Sherman

Law ........................................165, 166 exemption from requirements of Sherman Law, advocated and

discussed at period of enactment $\ldots \ldots \ldots \ldots \ldots \ldots \ldots \ldots \ldots \ldots \ldots$. 165,166 argument of Senator Edmunds in opposition to exemption ...166, 167 argument prevails ................................167, 168 exclusion of labor-exempting provision ................167, 168 argument criticised $\ldots \ldots \ldots \ldots \ldots \ldots \ldots \ldots \ldots \ldots \ldots \ldots, 168$

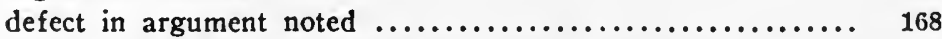
Congress should encourage lawful organized labor .......... 169 combinations of workmen for their own reasonable protection, as such, excepted from criminal provisions of Canadian Antitrust Law (note) .............................. 169 equality of corporation and organized labor, noted ......... 169

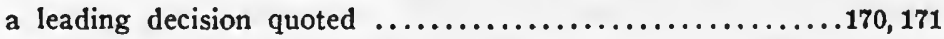
contrasting sentiments compared $\ldots \ldots \ldots \ldots \ldots \ldots \ldots \ldots \ldots, 171$ trades' unions operate by distinctive methods .............171, 172 "strike"-usual means of compulsion .................. 172 "strike" defined ....................................... 172

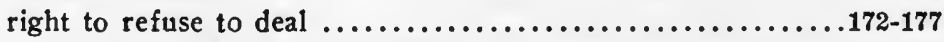
"boycott" defined and considered $\ldots \ldots \ldots \ldots \ldots \ldots \ldots \ldots \ldots .177$ 
[REFERENCES ARE TO PAGES.]

extent of rights conferred upon organized labor under Clayton

Law ........................................... provisions of Clayton Law separately examined .............. restrictive regulations applicable to injunctive orders .......... PAGE right to strike recognized ..........................178, 179 peaceful picketing legitimatized .....................179, 180 peaceful promoting of strikers' interests permitted ..........179, 180 British Trades' Disputes act, quoted .................... 179 policy indicated and embodied in Clayton Law, best supported

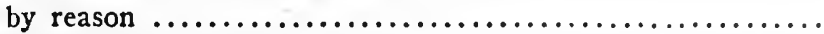

unlawful act in disobedience of court's order, subjects offender

to contempt proceedings $\ldots \ldots \ldots \ldots \ldots \ldots \ldots \ldots \ldots \ldots \ldots . .180$

boycott in aid of cause legalized .....................180, 181 right to withdraw patronage $\ldots \ldots \ldots \ldots \ldots \ldots \ldots \ldots \ldots \ldots . \ldots \ldots, 181$ labor organizations may assert every lawful right .........181, 182 labor organizations may grant financial aid $\ldots \ldots \ldots \ldots \ldots \ldots 182,183$ strike benefit fund is private property $\ldots \ldots \ldots \ldots \ldots \ldots \ldots \ldots 182,183$ Congress overrules opposing decision .................. 182 rulings cited $\ldots \ldots \ldots \ldots \ldots \ldots \ldots \ldots \ldots \ldots \ldots \ldots \ldots \ldots \ldots \ldots \ldots, 182$ right to peaceably assemble established .................183, 184 existence of dispute does not illegalize otherwise lawful act ..183, 184 supporting decision cited $\ldots \ldots \ldots \ldots \ldots \ldots \ldots \ldots \ldots \ldots \ldots \ldots \ldots \ldots \ldots, 183,184$ rights of labor confirmed $\ldots \ldots \ldots \ldots \ldots \ldots \ldots \ldots \ldots \ldots \ldots, 184$

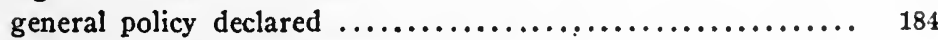

LABOR ORGANIZATIONS: See LABOR.

LEASE: See Tring $\mathrm{Cl}_{\text {LAUSE. }}$

based upon tying contract, unlawful when it substantially lessens trade, or tends to create monopoly ..................

\section{LEGISLATIVE BODY:}

Trade Commission not intended by Congress to constitute .....

\section{LEGISLATIVE STANDARD ESTABLISHED:}

"that unfair methods of competition in commerce are hereby declared unlawful"

LESSEE OR BUYER: See Tying Clause.

nature of unlaw ful agreement entered into with, considered ...188, 189

LESSENING OF COMPETITION: See CoMpetition; SubStantial, Lessening of CoMpetition.

LIABILITY: See CONTEMPT of CourT.

individual:

under Trade Commission Act 97,98

under, Clayton Law ............................ 99

under Sherman Law ..........................104-108 
corporate:

under Trade Commission Act $\ldots \ldots \ldots \ldots \ldots \ldots \ldots \ldots \ldots$ 98, 99

under Clayton Law ........................ 101

under Sherman Law .....................108, 109, 110

scope of, enlarged under Clayton Law ................ 119

limitations of earlier doctrine removed by provisions of Clay-

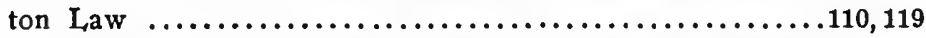

for damages accruing under "unfair methods" illegalized by

Trade Commission Act, considered ................125, 126 presents question for Supreme Court ............... 126

for actionable injuries under Sherman Law, extended ...126, 127, 128 under Anti-trust laws, not relieved by order of Commission

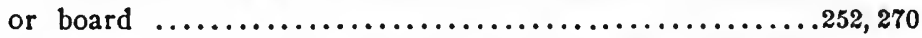

corporations (not individuals) subject to visitorial powers of

Commission under Section 6 of Act ................98, 99

to action for damages before alleged violation has been ad-

judged illegal by Trade Commission, considered ........127, 128

later amendment may confirm such tentative right ......... 128

LIABILITY UNDER ANTI-TRUST LAWS: See LIABILITY.

not relieved by Commission's orders $\ldots \ldots \ldots \ldots \ldots \ldots \ldots \ldots 252,270$

\section{LIMITATIONS, STATUTE OF:}

running of statute of limitations as to private rights suspended

during pendency of proceeding by United States .....128, 261, 262 statutory limitation, in contempt, one year $\ldots \ldots \ldots \ldots \ldots 123,278$

\section{LIMITATION UPON INDIVIDUAL INITIATIVE IN ANTI-TRUST SUITS:}

removed by provisions of Clayton Law $.107-110$

\section{LUMBER:}

not included in prohibition of transportation by common carriers of goods in which they retain interest $\ldots . . . \ldots \ldots \ldots . . .$.

\section{MANAGER:}

embezzlement of property of common carrier by, a felony ....

MANDAMUS: See District CourTs.

proceedings by, authorized only under Trade Commission Act .102, 103 right of attorney general to apply for, at request of Trade Com-

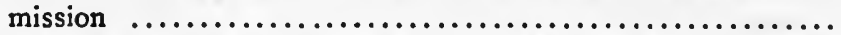
proceeding will lie, at instance of person injured, to compel Commission or board to pass upon question within its dis-

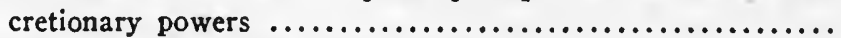


[REFERENCES ARE, TO PAGES.]

mentary evidence of corporation under examination; also, to compel obedience to Commission's subpœna ...............

MANUFACTURERS:

Trade Commission has power to investigate and make recommendations to Congress concerning foreign trade, in connection with combinations by manufacturers, etc. ..............

MASTER IN CHANCERY:

Commission may be appointed by district court as master in chancery to report form of decree $\ldots \ldots \ldots \ldots \ldots \ldots \ldots \ldots \ldots .254,255$

MEMBERS OF LABOR, AGRICULTURAL OR HORTICULTURAL ORGANIZATIONS:

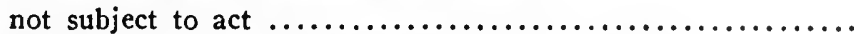

\section{MEMBERSHIP OF COMMISSION OR BOARD:}

Federal Trade Commission .......................... 232

Interstate Commerce Commission ..................... 235

Federal Reserve Board ............................ 235

\section{MERCHANTS:}

Trade Commission has power to investigate and make recommendations to Congress concerning foreign trade ..........

MISAPPLICATION OF MONEYS, FUNDS, CREDITS, ETC., OF COMMON CARRIER: See CRIMES.

by its president, director, officer or manager, is embezzlement ..

MISDEMEANOR: See CRIMES.

violation of regulation prescribed for common carrier by Section 10 of Clayton Law is .......................... violation of any penal provision of the Anti-trust laws deemed offense of consenting individual director, etc. ........... 271 false entries in corporation records ..................257, 258 false statements in reports to Commission ...............257, 258 for officer or employee of Commission to make public informa-

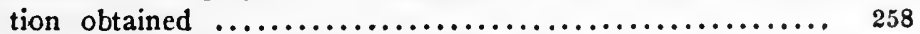
refusal to testify in response to subpona ................. 257

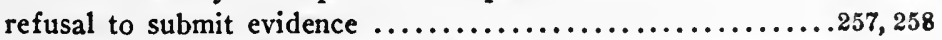
removal of documentary evidence from jurisdiction of United

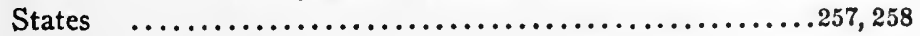

moNopoly: See Combination to Prevent or Restrain ComPETITION; TRUSTS.

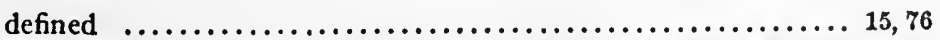
acts declared unlawful, when constituting a $\ldots . .260,261,262,279,282$ distinguished from exclusive rights of inventors and authors ..

exclusive rights of inventors and authors considered .......200, 201 


\section{[REFERENCES ARE, TO PAGES.]}

PAGE

Anti-trust laws govern method of selling copyrighted articles .. 197

public benefit is ultimate object of exclusive rights ......... 197

rights of author and patentee distinguished $\ldots \ldots \ldots \ldots \ldots \ldots .197$

development of anti-monopoly sentiment $\ldots \ldots \ldots \ldots \ldots \ldots \ldots 15,16$

doctrine of Darcy v. Allen adopted .................. 16

terms,-exclusive rights, and monopolies, - not identical .... 16, 17

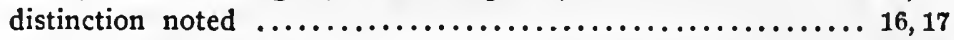

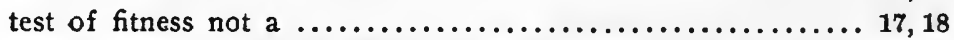

strict construction is applied to chartered rights of ......... 18

when franchise ripens into exclusive contract $\ldots \ldots \ldots \ldots \ldots .18$

unregulated condition of competition frequent source of $\ldots \ldots .18$

public injury effectuated by obnoxious ............... 18

rate or price fixing agreements fall within general prohibition .. 20

Anti-trust laws, especially criminal provisions, adequate to sup-

press ........................................ 19

commerce impaired or destroyed by restraint of trade or .... 19

banks and common carriers not within jurisdiction of Trade

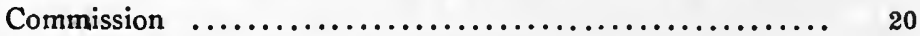

the deferise of, is not a bar to enforcement of collateral or in-

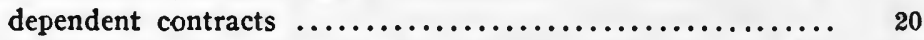

but State laws may authorize such defense (note) .......... 20

construction of Federal Trade Commission laws may change

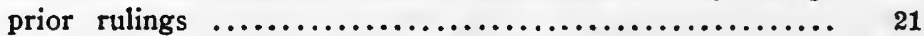

contracts of, not enforcible when against public policy ...... 20

equity courts apply similar ruling $\ldots \ldots \ldots \ldots \ldots \ldots \ldots \ldots, 21,198$

collateral or independent contracts, however, may be enforced . 20

statutory provisions may make defense general (note) ....... 20

test of constitutionality of Anti-trust statutes stated ....... 21

constitutionality of new legislation seems assured $\ldots \ldots \ldots \ldots .21$

Federal regulation of monopoly limited to interstate trade and

commerce ................................... 21

whether conducted by combination or individual, prohibited ..105-106

\section{MORAWETZ, VICTOR:}

views of, on need for regulation of competition

\section{MUTUAL BANKS:}

provisions against interlocking do not apply to mutual savings

banks without shares of capital stock .................

NAMES: See MEMBERSHIP OF COMMISSION OR BoARD.

NEW ZEALAND: See Foreign Antt-Trust Laws.

OFFENSES: See CRIMES.

OFFICERS: See INTERLOCKING DIRECTORS; CORPORATIONS;

Banks; Common Carriers; Crimes.

criminal liability of common carriers' officers ............ 267

embezzlement of property of common carrier by, a felony ... 266 
[REFERENCES ARE TO PAGES.]

PACE

nature, extent and purpose of provision considered $\ldots \ldots .144,145,146$ criminal liability of corporations' officers, directors and

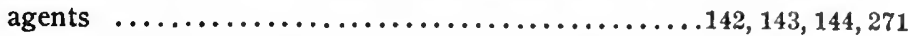
for discussion of similar provision in its application to officers of common carrier, see $\ldots \ldots \ldots \ldots \ldots \ldots \ldots \ldots \ldots \ldots \ldots \ldots \ldots, 66$

ORDERS OF COMMISSION OR BOARD: See FEDERAL Trade Commission; Interstate Commerce Commission; FEDERAL, Reserve BOARD; INTERLocking DiRECTORS. general provisions:

no provision of statute as to effective date of "cease and desist" orders against unfair methods of competition .. all other orders referred to must state the manner in which compliance with the order shall be carried out and the time therefor ..................................

Circuit Court of Appeals has exclusive jurisdiction to affirm, modify; or set aside, at suit of Commission or

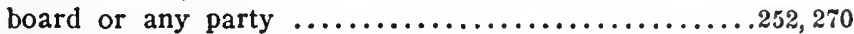
no order of Commission or board or judgment of court to enforce the same shall relieve any person from liability under Anti-trust laws .......................252, 270 person, partnership or corporation complained of may show cause why order should not be entered .........250, 268 Commission or board may modify "cease and desist" orders until record is filed in Circuit Court of Appeals ....250, 268, 269

ORDERS TO CEASE AND DESIST: See ORdERS OF CommisSION OR BOARD.

procedure upon applications for, described ........39, 40, 41, 250, 268

ORGANIZED LABOR: See LABOR.

Senate debate upon original Anti-trust law included discussion

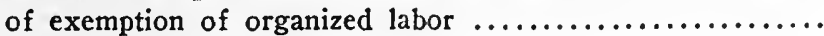

PARTNERShIPS: See Persons.

subject to Section 5 of Trade Commission Law ............. when excluded from definition of corporation in Trade Commission Act

PATENTS AND COPYRIGHTS: See Trade-Marks and Trade Names; Tying Clause; Antr-Trust Laws; Anti-Trust Pos,icy.

distinction between exclusive rights and monopolies ........ 16,17 distinction between right to exclude and right to sell ........194, 195 Anti-trust laws in their relationship to ................. 185 origin and purpose of exclusive grants to inventors and au-

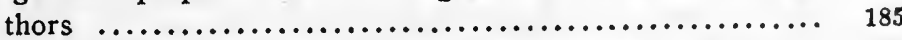
power of Congress to grant, is conferred by constitution ...... 185 


\section{[REFERENCES ARE TO PAGES.]}

early action by Congress $\ldots \ldots \ldots \ldots \ldots \ldots \ldots \ldots \ldots \ldots \ldots . \quad 185$

relative extent of these exclusive grants $\ldots \ldots \ldots \ldots \ldots \ldots \ldots, 186$

public interest is ultimate object $\ldots . \ldots \ldots \ldots \ldots \ldots \ldots \ldots \ldots . .186$

scope of exclusive rights under patent laws .............. 187

decision defines extent of patentee's rights ............... 187

occasion for and legislative intent embodied in Section 3 of

Clayton Law, described and discussed ................. 189

inventor entitled to select his source of profit ............. 189

said right of selection considered in connection with Section 3

of Clayton Law ...............................189, 190

violation of Sherman Law not a defense to infringement suit .. 190

enlarging patent rights by combination, prohibited .......... 191

agreeing to suppress invention, not permitted .............191, 192 requiring vendee to maintain the continuing re-sale price of

patented article, not within scope of grant .............. 192 remarks upon decision in "Cream of Wheat" case ..........193, 194 initial Clayton Law decision recognizes right of dealer to pro-

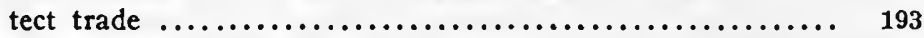

anti-discrimination (Section 3) construed ................ 194

argument opposed to above-mentioned construction of Sec-

tion 3, stated (note) ............................. 194

combinations by patentees, subject to Anti-trust laws ....... 194

right to exclude distinct from right to sell ...............195, 196

medical compounds ................................ 196

secret concoctions not favored $\ldots \ldots \ldots \ldots \ldots \ldots \ldots \ldots \ldots \ldots . .196$

extent of exclusive rights fixed $. . \ldots \ldots \ldots \ldots \ldots \ldots \ldots \ldots \ldots . \quad 196$

copyright laws as construed under Anti-trust laws ......... 196

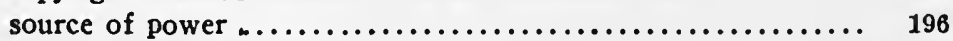

great benefit derived ..............................196, 197

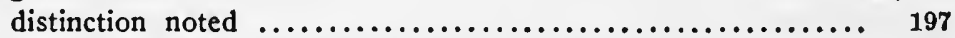

rights of author and patentee distinguished ............. 197

Anti-trust laws govern method of selling copyrighted articles .197, 198 infractors of Anti-trust laws not entitled to enforce trade-

restraining agreements, in equity courts ............... 198

violation of printed notice not an infringement ........... 198

retaining title in property, owner preserves right to fix prices. 199

comparison of privileges under patent and copyright laws .... 200

extent of exclusive rights under patent laws .............. 200

violation of Anti-trust law, is a defense in suit to enforce

copyright grant $\ldots \ldots \ldots \ldots \ldots \ldots \ldots \ldots \ldots \ldots \ldots \ldots \ldots \ldots \ldots . .200,201$

protection of public is end sought in Anti-trust laws ...... 200

author and inventor concerned in enforcement ........200, 201, 203

genesis of application of Anti-trust ideas to general business

methods .........................................

original authority for the inclusion of unfair business methods

by the ordinary industrial combination, as within the Anti-

trust prohibitions 
leaders in movement

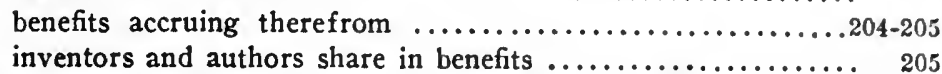

PATENTED AND UNPATENTED ARTICLES: See PATents and Copyrights; Tying Clause.

\section{PENALTIES:}

for violation of Trade Commission Law:

for neglecting or refusing:

1. to attend and testify $\ldots \ldots \ldots \ldots \ldots \ldots \ldots \ldots \ldots, 257$

2. to answer questions $\ldots \ldots \ldots \ldots \ldots \ldots \ldots \ldots \ldots, 257$

3. to produce evidence ..................... 257

for wilfully making, etc. :

1. a false entry .........................257, 258

2. a false statement of fact $\ldots \ldots \ldots \ldots \ldots \ldots \ldots \ldots . .257,258$

for wilfully removing evidence from the U. S. ........257, 258

for wilfully mutilating evidence ..................257, 258

for wilfully refusing to submit evidence to Commission ..257, 258 against officer or employee of Commission for making informa-

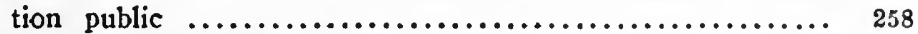

for violation of Sherman Law .....................279, 280

for violation of Wilson Law ....................... 282

for violations of Clayton Law,-embezzlement by officers of

common carrier ................................ 266

for violations of regulations based on interlocking by com-

mon carriers and other companies ..................267, 268

persons liable to, for corporate crimes ................. 271

for contempt of court .......................275, 276, 277

for failure to obey court's order to testify, etc. ........... 256

PERJURY: See CRIMES.

no person exempt from punishment for perjury .............

PETITION FOR PERMISSION TO INTERVENE, ETC.:

See Forms.

PERSON OR PERSONS: See Definitrons; Definition of

Terms; Crimes; Penalties; Damages.

definition of, considered ......................... 96,97

definition has wide application under Sherman Law ........ 96, 97

defined to include corporations and associations ............260, 281

subject to rule against unfair methods of competition ........ 249

subject to prohibitions against:

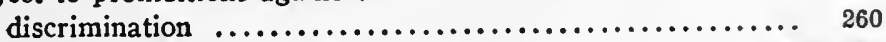

conditional or tying clause contracts .................260, 261

interlocking $. \ldots \ldots \ldots \ldots \ldots \ldots \ldots \ldots \ldots \ldots \ldots . \ldots \ldots, 265,266$

subject to estoppel of decrees in suits by United States under

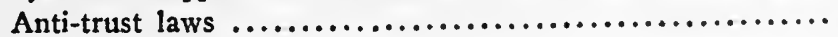


subject to authority of Trade Commission, Reserve Board, Interstate Commerce Commission to enforce Clayton Law .... 268 may have injunction to prevent violations of Anti-trust laws .. 272 subject to Wilson Law ......................... 282

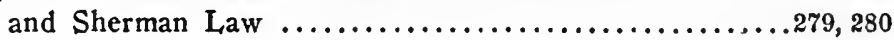

\section{PETITION TO PREVENT OR RESTRAIN VIOLATION} OF CLAYTON LAW: See COMMISSION OR BoARD.

district courts are empowered to entertain such application at the instance of the respective district attorneys, acting under the direction of the attorney general $\ldots \ldots \ldots \ldots \ldots \ldots . . . .$.

\section{PHILIPPINE ISLANDS:}

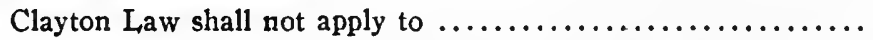

\section{POSTPONEMENT OF OPERATION OF PROVISIONS} OF SECTION 8 OF CLAYTON LAW: See BANKS;

Common Carriers; InTERLocking Directors.

occasion for postponement, considered .............131, 132, 133

PoWers: See Attorney General; Circuit Court of Appeals; District Court; Supreme Court; Federal Trade CommisSion; Federal Reserve Board; INTERstate Commerce ComMISSION; COMMISSION.

\section{PRESIDENT:}

may direct Trade Commission to investigate and report ...... may direct departments and bureaus to place all government records at disposal of Trade Commission ................

\section{PRESIDENT OF CORPORATION:}

embezzlement of property of common carrier by, a felony .... 266 nature, extent and purpose of provision considered ......144, 145, 146

PRICE DISCRIMINATION: See Discrimination in Price.

\section{PRICE OR RATE FIXING AGREEMENTS: See ClayToN} LAW; COMMISSION OR BOARD.

conditions where such agreements fall within general prohibition of monopolies $\ldots \ldots \ldots \ldots \ldots \ldots \ldots \ldots \ldots \ldots \ldots \ldots \ldots, 20,260$

PRIMA FACIE EVIDENCE: See EVIDENCE.

when final judgment or decree in action brought by government under Anti-trust laws, is ........................102, 261 privilege does not obviate proof of damages by reason of viola-

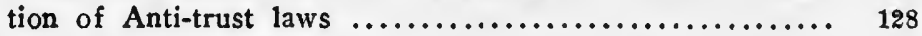

PRIVATE BANKER: See BANKS; INTERLocking DIRECTORS. regulation of dealings in securities of common carriers, dis-

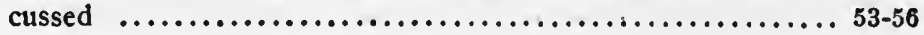


[REFERENCES ARE TO PAGES.]

PRIVATE RIGHTS OF ACTION: See Damages.

PROCEDURE: See Federal Trade Commission; Commission or Board; Circuit Court of Appeals; Contempt.

before Commission or board, described ................ 39, 40 PROCESS:

Service of

by delivering copy $\ldots \ldots \ldots \ldots \ldots \ldots \ldots \ldots \ldots \ldots \ldots \ldots \ldots \ldots \ldots 2,270,271$

by leaving copy $\ldots \ldots \ldots \ldots \ldots \ldots \ldots \ldots \ldots \ldots \ldots \ldots \ldots \ldots \ldots \ldots, 272,271$

by registered mail ........................252, 270, 271

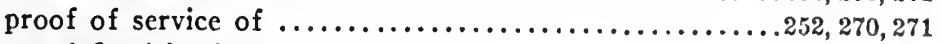

not defined in the Anti-trust laws ..................... 129

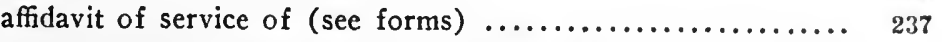

PROHIBITIONS UNDER CLAYTON LAW: See CoMmISSION OR BOARD.

for general consideration of prohibitions under Clayton Law,

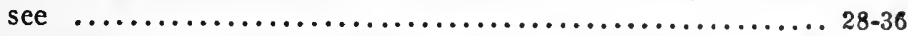
prohibitions concerning common carriers, considered ......63,64, 65

PROOF OF SERVICE: See Process.

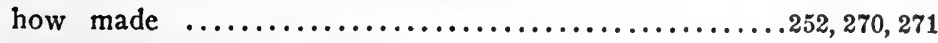

affidavit of service of (see forms) .................... 237

PROPERTY OWNED IN VIOLATION OF LAW MAY BE

CONDEMNED $\ldots \ldots \ldots \ldots \ldots \ldots \ldots \ldots \ldots \ldots \ldots \ldots \ldots .28 \mathrm{n}, 28 \mathrm{r}$

PROSECUTION OF INDIVIDUAL OFFICERS, DIRECTOR OR AGENT OF CORPORATIONS: See OFFICERS.

permitted, where they severally authorized, etc., corporate violation of any penal provision of the Anti-trust laws .........

PROVISIONS FOR ENFORCEMENT: See FEDERAL, TRADE Commission; Commission or BoArd; Prohibitions Under Clayton Law; Orders of Commission or Board; InJunction; Mandamus; Contempt; Crimes.

necessity for and means of applying, stated $\ldots \ldots \ldots \ldots \ldots \ldots, 37,38$

important distinction between the Trade Commission Act and

Clayton Law noted ............................. 38

means of securing information not specified .............. 38, 39

for prohibitions under Clayton Law and for subject generally,

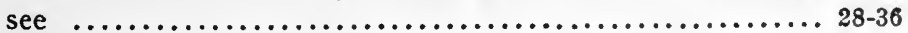

PUbLIC INTEREST: See Federal Trade Commission; Banks;

Common CarRiers; Comperition.

must appear, to justify institution of proceedings under Section

5 of Trade Commission Act ........................ 250

demands regulation of dealings by and with common carriers .. 55, 56 
[REFERENCES ARE TO PAGES.]

PUBLICATION OF COMMISSION'S REPORTS AND DECISIONS:

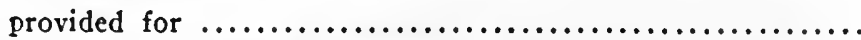

PUBLICITY OF COMMISSION'S REPORTS: See REPORTS.

Commission's reports as to manner in which court decree is being carried out may be made public in Commission's discretion

\section{PUBLICITY OF INFORMATION OBTAINED BY COM-} MISSION:

information, except trade secrets and names of customers may be made public as deemed expedient in the public interest ... unauthorized publicity by officer or employee of Commission a

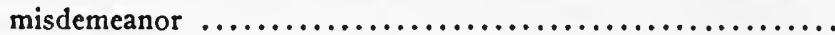

PAGE

\section{PUBLIC POLICY:}

contracts against:

not enforcible at law $\ldots \ldots \ldots \ldots \ldots \ldots \ldots \ldots \ldots \ldots \ldots, 20,21$

or in equity $\ldots \ldots \ldots \ldots \ldots \ldots \ldots \ldots \ldots \ldots \ldots \ldots \ldots \ldots \ldots \ldots \ldots \ldots \ldots \ldots, 21,198$

\section{PUBLIC UTILITIES CORPORATIONS:}

occasion for prohibiting profits to officers, from dealings with . 55, 56

RAILROADS: See Common CARRIERS.

designated by term "common carriers subject to the Act to Regulate Commerce, approved February 4, 1887" ............

Interstate Commerce Commission authorized to enforce compliance with Sections 2, 3, 7, and 8 of Clayton Law, by the persons respectively subject thereto, where applicable to .... 268 excepted from prohibition of interlocking directors $\ldots \ldots \ldots .66,265$ reason for exemption, as set forth in committee's report ...... 35 provisions regulating dealings in the supply, etc., concerns, considered $\ldots \ldots \ldots \ldots \ldots \ldots \ldots \ldots \ldots \ldots \ldots \ldots \ldots \ldots \ldots \ldots, 6,66,67$ Interstate Commerce Commission empowered to enforce Section 10 of Clayton Law, by transmitting papers and findings to attorney general $\ldots \ldots \ldots \ldots \ldots \ldots \ldots \ldots \ldots \ldots 67,68,69,266,267$

REDFIELD, WILLIAM C.: SECRETARY OF COMMERCE.

views of, on need for regulation of competition $\ldots \ldots \ldots \ldots \ldots$

REFUSAL TO OBEY SUBPCENA: See CoNTUMACY. REPORTS:

of Trade Commission:

to be published

as master in chancery not conclusive ............ 254, 255

annual and special reports to be made to Congress ....... 254

reports to Attorney General as to carrying out decrees in

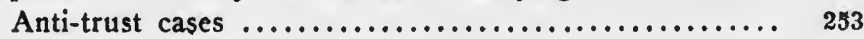


on direction of President or either branch of Congress,

Commission shall report as to alleged violations of Antitrust acts by any corperation .......................

to Trade Commission:

corporations to make annual or special reports to.........

failure by corporation to file, when required by Trade Commis-

sion, incurs penalty of $\$ 100$ per day $\ldots \ldots \ldots \ldots \ldots \ldots \ldots . .136,258$ falsification, etc., a crime ......................135, 257, 258 necessity for correctness in, considered ...............135, 136

RESTRAINT OF TRADE: See Monopoly; SHERMAN LAw.

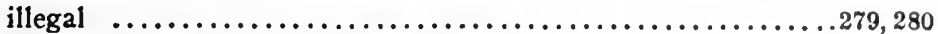

by corporate stock ownership, illegal ................262,281

illegal restraints may result from joint acts ..............104, 105

price discriminations, also tying contracts, etc., which lessen

competition, unlawful $\ldots \ldots \ldots \ldots \ldots \ldots \ldots \ldots \ldots \ldots \ldots .260,261$

\section{RESUBMISSION TO COMMISSION:}

no means of review provided, where circuit court refuses to

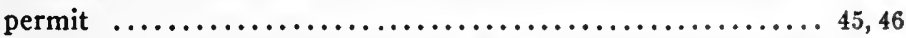

Section 240 of Judicial Code probably permits review by Supreme Court ....................................

REVIEW: See APPEALS.

means of, provided $.40,251,252,269,270$

Congress prescribed limited review (viz., only as to law) .......

three separate opinions, with final appeal to Supreme Court ... 41, 42

REVIEW OF ORDERS: See Circuit Court of Appeals; SuPREME COURT.

\section{RIGHT TO BRING ACTIONS:}

covers all violations of Anti-trust laws . ............125, 126, 261

RIGHT TO REFUSE TO DEAL: See LABOR.

subject considered in connection with labor disputes ..........172-176 principle applied in dispute concerning commercial dealings ... 193 subject considered in connection with questions involved in enforcement of Section 2 of Clayton Law .............55, 193, 194

RULES OF PRACTICE BEFORE THE FEDERAL TRADE Commission:

For text of Rules, see $232-235$

RULINGS: See COMMENDATORY RULINGS.

\section{SECRETARY OF TRADE COMMISSION:}

salary $\$ 5,000$

SEAGER, HENRY R.:

views of, on need for regulation of competition 
[REFERENCES ARE TO PAGES.]

PAGE

SEARCHES AND SEIZURES: See Constirution; IMmunity.

unreasonable, prohibited under Fourth Amendment of Constitution $\ldots \ldots \ldots \ldots \ldots \ldots \ldots \ldots \ldots \ldots \ldots \ldots \ldots \ldots \ldots \ldots \ldots \ldots \ldots \ldots \ldots, 160,286$ use of subpœna duces tecum confined to a reasonable disclosure and surrender of corporate books, records, etc. .....

SELF-INCRIMINATION: See ConstrTution; ImMUNITY.

guarantees of Fifth Amendment of constitution, respecting ....

.............................156, 157, 158, 286, 287

conditions which confer immunity under Fifth Amendment, stated $\ldots \ldots \ldots \ldots \ldots \ldots \ldots \ldots \ldots \ldots \ldots \ldots \ldots \ldots \ldots \ldots \ldots \ldots, 157,158$

SEller: See Tying Clause.

exclusive tying contracts by, when unlawful ...............

\section{SENATE COMMITTEE ON INTERSTATE COMMERCE:}

report by, on changes necessary or desirable in the laws relating to the creation and control of corporations engaged in interstate commerce, Appendix " $M$ " .....................304-334

SERVICE OF PROCESS: See Process; Forms.

method of, described $\ldots \ldots \ldots \ldots \ldots \ldots \ldots \ldots \ldots \ldots \ldots \ldots, \quad 46$

subject discussed $\ldots \ldots \ldots \ldots \ldots \ldots \ldots \ldots \ldots \ldots \ldots \ldots \ldots \ldots \ldots \ldots \ldots \ldots \ldots, 129,130$

\section{SHERMAN LAW:}

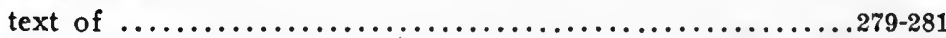

character of, described $\ldots \ldots \ldots \ldots \ldots \ldots \ldots \ldots \ldots \ldots \ldots \ldots, 131$

language constituting, commented upon ................ 100

definitions of "person" and "corporation," considered ....... 96, 97

Sherman Law declared to be a criminal statute ............ 149

creates a new offense by penalizing acts not criminal under

common law .................................. 149

criminal provisions of, discussed ...................146-149

largely superseded by regulatory features of Trade Commis-

sion Act and Clayton Law .......................147, 148

punishment prescribed under ...................... 149

rule applicable, when construing, as a criminal statute ....... 149

in effect, Clayton Law is amendment of ................ 104

language of Sherman Law characterized ................ 104

joint restraints of trade declared illegal by ............... 104

liability under Sherman Law considered:

individual .................................. 104

corporate .............................108, 109, 110

scope of liability enlarged under Clayton Law ............ 109

Sherman Law reinforced by Clayton Law .............. 105

prohibition of unfair methods of competition, added by new

legislation .................................... 105 


\section{[REFERENCES ARE TO PAGES.]}

Sections 2, 3, 7, and 8 of Clayton Law supplement Sections 1

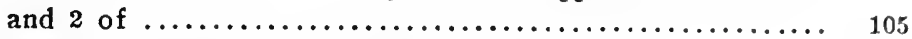
criminal jurisdiction of, extended by Clayton Law ........... 106 word "person" has wide application under .............. 106 enforcement of provisions of, by contempt proceedings, per-

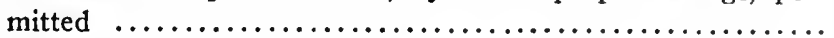
enforcement by contempt proceedings, allowed ............ right to litigate under, enlarged by Clayton Law ............ limitation upon right to pursue defendants, continued in Clay-

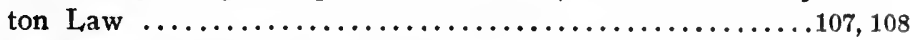
triple-damage rights, also enlarged by Clayton Law ........ 108 definitions of "person," compared ................... 108

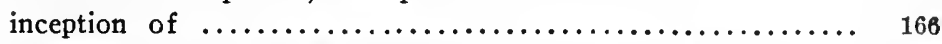
circumstances attending enactment of $\ldots \ldots \ldots \ldots \ldots \ldots \ldots . \ldots \ldots$ question of exempting labor from requirements of, raised and

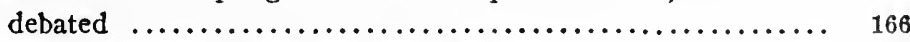

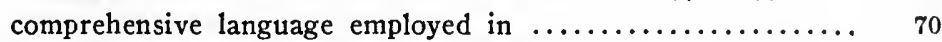
early application of constitution and Sherman Law compared .. 70 principles of constitution expounded by framers .......... 71 no similar exposition of Sherman Law $\ldots \ldots \ldots \ldots \ldots \ldots \ldots .71$ absence of exposition delayed enforcement $\ldots \ldots \ldots \ldots \ldots \ldots \ldots 71$ principles and development described $\ldots \ldots \ldots \ldots \ldots \ldots \ldots \ldots, 72$

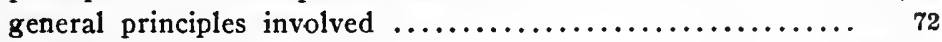
occasion for statutory relief $\ldots \ldots \ldots \ldots \ldots \ldots \ldots \ldots \ldots \ldots, 72,73$ centralization of business recognized and regulated $\ldots \ldots \ldots \ldots 72,73$ measure for relief introduced $\ldots \ldots \ldots \ldots \ldots \ldots \ldots \ldots \ldots \ldots, 73,74$ various drafts of, considered $\ldots \ldots \ldots \ldots \ldots \ldots \ldots \ldots \ldots \ldots \ldots, 74$ enactment of proposed measure, urged $\ldots \ldots \ldots \ldots \ldots \ldots \ldots \ldots .74$

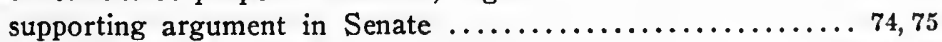
tentative measures further considered $\ldots \ldots \ldots \ldots \ldots \ldots \ldots, 75,76,77$

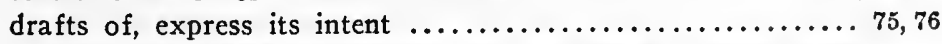
for tentative forms of Sherman Law submitted to the Senate for the fifty-first session of Congress, see Appendix "K" ...297-301 Senate committee's definition of "monopoly" ............. 76 definition suggestive of term "unfair methods of competition in

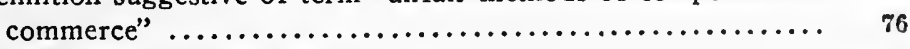

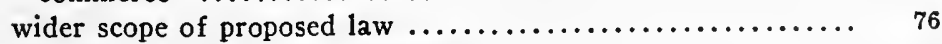

constitutionality thereof considered $\ldots \ldots \ldots \ldots \ldots \ldots \ldots \ldots \ldots, 77$

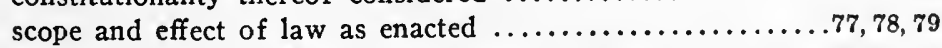
consideration from general view point, continued $\ldots \ldots \ldots .77,78,79$ constitutional questions involved in construction and application of Sherman Law have been determined by Supreme

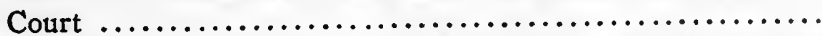

held to be in conformity with the powers vested in Congress by the commerce clause of the constitution $\ldots \ldots \ldots \ldots \ldots$. benefits derived from Sherman Law $\ldots \ldots \ldots \ldots \ldots \ldots \ldots \ldots . \ldots \ldots$ interpretation and application of $\ldots \ldots \ldots \ldots \ldots \ldots \ldots \ldots \ldots, 81$ 


\section{[REFERENCES ARE, TO PAGES.]}

PAGE

socialistic influences apparent in Anti-trust legislation ...... 81, 82

unregulated competition effectuates trusts ..................

limitation of relief to results obtained in suits instituted solely

by government, involves grave question .................

narrowing construction of commerce clause feared in debates in

Congress

decision in "Knight" case considered

wide construction applied in legislation connected with Trade

Commission .....................................

foreign Anti-trust laws discussed in connection and compari-

son with the Sherman Law .......................... 83-86

Commission Act and Clayton Law broaden means of relief ...

Section 16 of Clayton Law supplies right of individual initiative 86,87

government initiative no longer essential ...................

earliest Anti-trust decision under Sherman Law ..............

reasoning in early English case sustained ...................

ingenious analysis of Sections 1 and 2 of Sherman Law, pre-

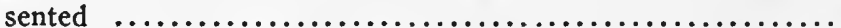

argument examined and criticized $\ldots \ldots \ldots \ldots \ldots \ldots \ldots \ldots . . . . .68$

argument now controverted by controlling decisions ..........

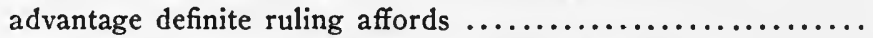

Anti-trust definitions of "commerce" compared ...............

meaning of Sections 1 and 2 discussed $\ldots . \ldots \ldots \ldots \ldots \ldots . . . . . .$.

Sections 1 and 2 generally construed together ...............

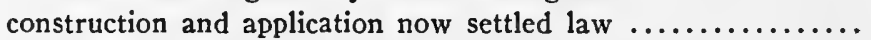

Congress supplements Anti-trust decisions .................

purpose in strengthening Anti-trust laws ...................

Sections 4 to 8 of Sherman Law considered .............. 94, 95 violation by plaintiff, of anti-monopoly provisions of, not a de-

fense to suit for infringement of patent rights ..........190, 191

enforcement of provisions of Anti-trust laws, by suits of indi-

viduals, removes the occasion for setting up defenses of this

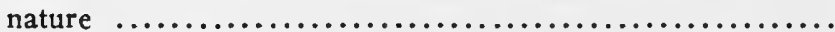

for memoranda of Anti-trust cases instituted by the United

States, (complete to October 15, 1915), see Appendix "O" ..

\section{SHERMAN LAW DEFINITIONS BILL:}

one of five proposed measures utilized by Congress when preparing Trade Commission Act and Clayton Law ............

SHERMAN, SENATOR:

argument by, in support of original Anti-trust bill

SPECIAL PROVISIONS FOR ENFORCEMENT: See Pro-

VISIONS FOR ENFORCEMENT; MANDAMUS; INJUNCTION; CONTEMPT; CRIMES.

mandamus will lie to compel Commissions or board to pass upon matter within scope of their several powers ............ 
[REFERENCES ARE, TO PAGES.]

SPECIFIC PERFORMANCE: See MONOPOLY.

enforcement by, not permitted where contract is against public

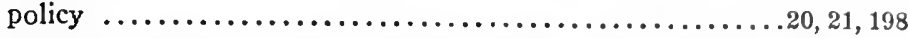

SPECIFIC PRACTICES FORBIDDEN BY CLAYTON

LAW: See Clayton LaW; CoMmission OR BoARd.

enumerated :

price discrimination $\ldots \ldots \ldots \ldots \ldots \ldots \ldots \ldots \ldots \ldots \ldots \ldots . \ldots \ldots$

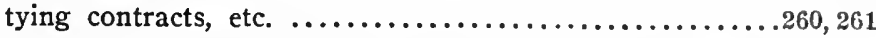

corporate stock ownership in one or more competing cor-

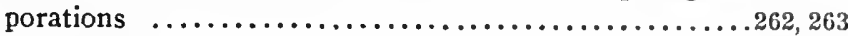

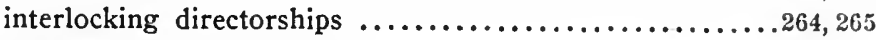

STATE LAWS: See Immunity.

disobedience of order of court constituting criminal offense under Federal or State laws, punishable by contempt ....... judgment of conviction or acquittal on the merits under state laws shall bar prosecution under Clayton Law for the same

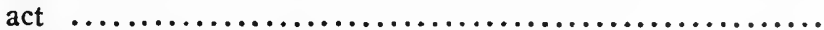

immunity in federal courts does not protect witness when prosecuted for infractions of

STATUTE OF LIMITATIONS: See LimiTATIONS.

suspended during pendency of government proceedings under

Anti-trust laws ............................ 261, 262

STATUTES: See Statute of Limitations; Construction.

STOCK OWNERSHIP BY ONE CORPORATION IN AN-

OTHER: See Banks; CoMmon Carriers; Corporations.

prohibited in whole and in part where competition is lessened,

commerce restrained, or a tendency to monopolize created ...262, 263

prohibition does not impair previously acquired rights ...... 263

for investment, not prohibited .................... 263

in subsidiary corporations, not prohibited .............. 263

in branch lines by common carriers permitted ........... 263

prohibitions and regulations of Clayton Law, considered ..... 101

violations charged with liability to actions for three-fold dam-

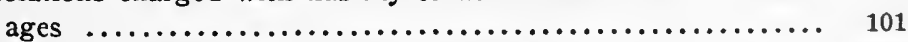

exceptions contained in prohibiting clauses ............. 101

STRICT CONSTRUCTION: See CoNSTRUCTION.

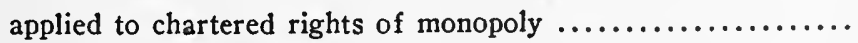

STRIKE: See LABOR.

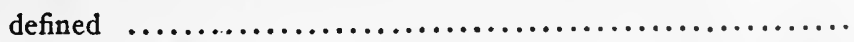

\section{SUBJECT TO ACTS:}

Clayton Law and Sherman Law:

associations existing under the laws of the United States 
[REFERENCES ARE, TO PAGES.]

PAGE

or any State or Territory or foreign country .......260, 281 corporations existing under the laws of the United States or any State or Territory or foreign country ......260, 281

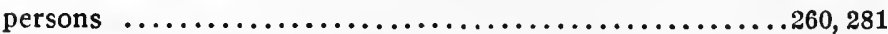

Trade Commission Act:

associations for profit incorporated or unincorporated, ex-

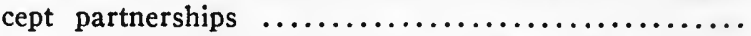
companies for profit incorporated or unincorporated, except partnerships ....................... 248

corporations for profit with or without capital shares .... 248 partnerships subject to Section $5 \ldots \ldots \ldots \ldots \ldots \ldots \ldots \ldots .249$ persons subject to Section $5 \ldots \ldots \ldots \ldots \ldots \ldots \ldots \ldots \ldots . \ldots \ldots$

Wilson Law :

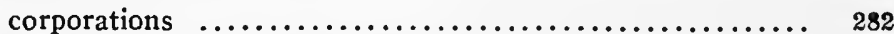

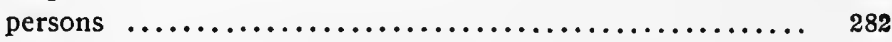

\section{SUPERVISION :}

of methods of competition in general business, desired ..... 5, 6

\section{SUPPLY, CONSTRUCTION AND FINANCIAL CON-}

CERNS: See Prohibitions of Chayton Bili; Commission of Board; Banks; Common Carriers.

regulation of dealings with common carriers considered $\ldots \ldots 65,66,67$

SUBPCENAS: See FORMS.

May be issued

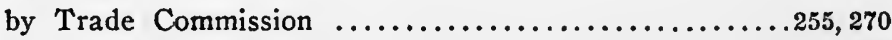

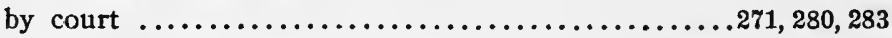

service of, discussed $\ldots \ldots \ldots \ldots \ldots \ldots \ldots \ldots \ldots \ldots \ldots \ldots \ldots .129$

attendance of witnesses, considered $\ldots \ldots \ldots \ldots \ldots \ldots \ldots \ldots .130$

\section{SUBSIDIARY CORPORATIONS:}

corporation may own stock in

SUBSTANTIAL LESSENING OF COMPETITION: See

COMPETTTION.

by price discrimination, unlawful $\ldots \ldots \ldots \ldots \ldots \ldots \ldots \ldots \ldots .260$

subject discussed ...............................28, 193, 194

by tying contracts unlawful $\ldots \ldots \ldots \ldots \ldots \ldots \ldots \ldots \ldots \ldots . .260,261$

by stock ownership by one corporation in another, unlawful ... 262

by stock ownership by "holding" companies, unlawful ....... 262

stock ownership for investment not resulting in, lawful ...... 263 stock ownership in subsidiary corporations not resulting in,

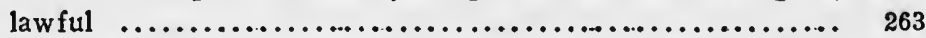
in absence of substantial competition, common carriers may own stock of branch lines ............................ 263 interlocking (other than between banks, and common car- 
[REFERE,NCES ARE, TO PAGES.]

riers) prohibited between competitors if elimination of competition by agreement would violate Anti-trust laws ........

SUPPLEMENTAL ANTI-TRUST ACT (also known as Clayton Law or Supplemental Sherman Law) .............259-278

SUPREME COURT: decree of circuit court of appeals reviewable upon certiorari ............................251, 269

for text of Section 240 of Judicial Code, containing provision authorizing such review, see Appendix "I" .............. 291

TEMPORARY RESTRAINING ORDER: See CoMmission. provisions for $\ldots \ldots \ldots \ldots \ldots \ldots \ldots \ldots . .272,273,274,275,280,282,283$

TERMS, DEFINITIONS OF: See DEFINITIONS.

inventors' and authors' exclusive rights $\ldots \ldots \ldots \ldots \ldots \ldots \ldots, 17$

"person" as defined in Clayton Law .................. 127 definitions of "person" and "corporation" considered ....... 96,97 definitions of "person" and "corporation" compared ........ 108 "engaged in commerce as a common carrier" (Section 9 of

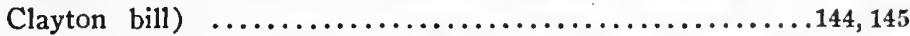

"any common carrier subject to the laws to regulate commerce,"

meaning and scope defined $\ldots \ldots \ldots \ldots \ldots \ldots \ldots \ldots \ldots \ldots, 64,65$

"common carriers subject to the act to regulate commerce, ap-

proved February 4, 1887" ........................ 66

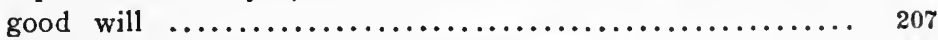

right (of State) to limit individual rights $\ldots \ldots \ldots \ldots \ldots \ldots . .61$

\section{TEST OF FITNESS:}

not a monopoly

TESTIMONY: See Evidence; Forms.

no person excused from testifying $\ldots \ldots \ldots \ldots \ldots \ldots \ldots \ldots \ldots .257$

testimony at hearing shall be taken in writing $\ldots \ldots \ldots \ldots \ldots .250,268$

THREE-FOLD DAMAGE RIGHT:

enlarged by Clayton bill ......................... 108

TOWNE, HENRY R.:

views of, on need for regulation of competition

TRADE COMMISSION: See FEDERAL TRADE COMMISSION.

TRADE COMMISSION LAW:

TRADE CONDITIONS: See Federal, TRAdE Commission.

in and with foreign countries, Trade Commission has power to

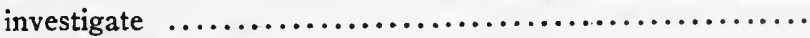

TRADE DISPUTES: See Labor; Trades Unions.

special limitations as to injunctive relief in 
[REFERENCES ARE, TO PAGES.]

PAGE

TRADE RELATIONS BILL:

one of five proposed measures utilized by Congress when preparing Trade Commission Act and Clayton Law ..........

\section{TRADERS:}

Trade Commission has power to investigate and make recommendations to Congress concerning foreign trade ..........

TRADE-MARKS AND TRADE NAMES: See PATENTS AND Copyrights; Tying Clause; Anti-Trust LaW ; AntiTrust Policy; Unfair Trading; Unfair Methods of ComPETITION :

unfair trading in relation to, an ancient problem ...........

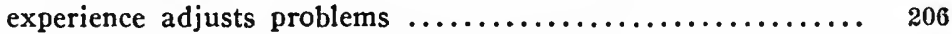

monopoly an incident to chartered companies ............ 206

good will a topic of wide significance ................. 207

good will defined $\ldots \ldots \ldots \ldots \ldots \ldots \ldots \ldots \ldots \ldots \ldots \ldots \ldots \ldots, 207$

government offers monopoly to induce disclosure $\ldots \ldots \ldots \ldots .207$

attacks on originator's rights considered $\ldots \ldots \ldots \ldots \ldots \ldots \ldots, 207$

unfair trading includes unfair copying ................ 207

foreign terms for unfair trading ..................... 208

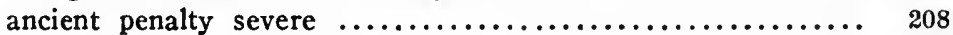

law of infringement a slow development $\ldots \ldots \ldots \ldots \ldots \ldots . . \ldots 208$

trade-protection in United States .................. 209

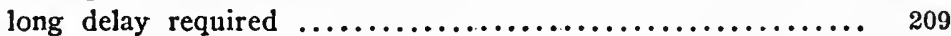

general requisites for protection $\ldots \ldots \ldots \ldots \ldots \ldots \ldots \ldots \ldots . \ldots \ldots$

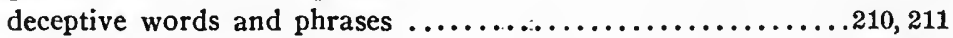

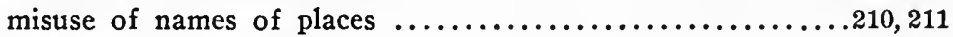

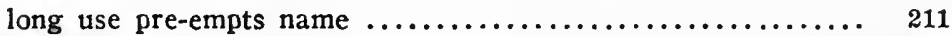

false use of name illicit ......................... 212

right to protection established $\ldots \ldots \ldots \ldots \ldots \ldots \ldots \ldots \ldots \ldots \ldots, 212$

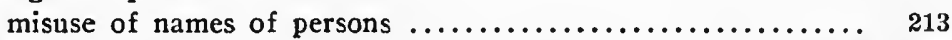

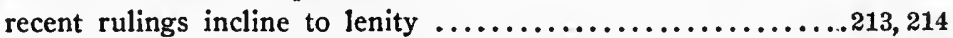

relief should fit individual needs $\ldots \ldots \ldots \ldots \ldots \ldots \ldots \ldots \ldots . \ldots \ldots . \ldots \ldots$

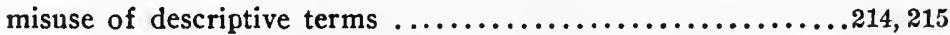

English rule now recognized and established in United States . 215

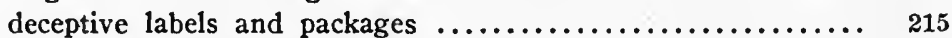

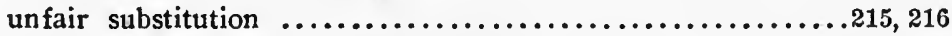

sound sense essential to just rulings $\ldots \ldots \ldots \ldots \ldots \ldots \ldots \ldots \ldots .216$

leading cases illustrative of above principle $\ldots \ldots \ldots \ldots \ldots 216,217,218$

imitators not respectors of persons ................. 217

petitioner must come with "clean hands" ................ 218

imitators display endless ingenuity $\ldots \ldots \ldots \ldots \ldots \ldots \ldots \ldots . \ldots 218,219$

absence of statutory definition of "unfair methods," explained . 218

elastic term required to meet and overcome novel forms of un-

fairness ..................................... 218

some forms of deceit enumerated $\ldots \ldots \ldots \ldots \ldots \ldots \ldots \ldots \ldots . \ldots \ldots$ 


\section{[REFERENCES ARE TO PAGES.]}

principles of fair dealing constitute sole guide ............. PAGE appropriate judicial rulings $\ldots \ldots \ldots \ldots . . . .219$ apropriate judicial rulings .........................219, 220 development of unfair competition law ................. 221 general conclusion deduced from authorities ............... 221

TRADE SECRETS:

not to be divulged by Trade Commission ...............23, 254

TRADES UNIONS: See LABOR.

equality of, and corporations, noted .................... 169

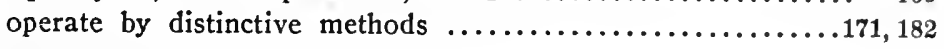

\section{TRANSCRIPT:}

of the record, filed with Circuit Court of Appeals, upon applica-

tion to enforce order to cease and desist ................ 250

similar filing required, upon review thereof by court ......... 251

for corresponding provisions of Clayton Law, see .........269, 270

TRIPP, GUY E.:

views of, on need for regulation of competition .......... 11, 12

TRUST COMPANIES: See BANKS; INTERLOCKING DiRECTORS.

TRUSTS: See MoNopoliES.

in restraint of import trade, unlawful ................. 282

in restraint of all foreign and domestic trade, unlawful .....279, 280 and monopolies, distinguished from exclusive rights of in-

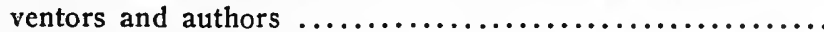

TYing ClaUSE: See Prohibitions of Clayton Law; Unfair METHODS OF CompetrTton.

contracts, etc., substantially lessening competition by tying clauses, unlawful ............................260, 261

patented and unpatented articles alike subject to .........260, 261

\section{UNFAIR METHODS OF COMPETITION IN COM-} MERCE: See CoMpeTition.

Trade Commission empowered to prevent ................ 249

problems involved in elimination of, enumerated ........... 8

myriad forms of, described ........................ 9

imitators display endless ingenuity in efforts to elude proprietor's rights in trade-marks and trade names $\ldots \ldots \ldots \ldots \ldots \ldots \ldots \ldots .218-221$ great variety of unfair methods employed in manipulations of

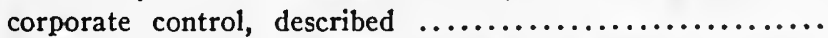
inventors and authors derive benefit from measures to pre-

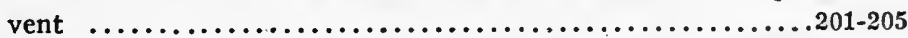

Clayton Law provides relief supplementing provisions of Sher-

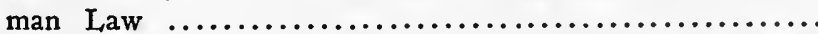

UNFAIR TRADING: See CoMpetTTION; UNFAIR MethodS of Competition; Federal, Trade Commission; Prohibitrons of 


\section{[REFERENCES ARE TO PAGES.]}

PAGE

Clayton Law; Commission or Board; Patents and Copyrights; Trade-Marks and Trade Names; Abuses of CorPORATE CONTROL.

\section{UNCONSTITUTIONALITY OF ANY PORTION OF CLAYTON LAW:}

shall not invalidate any other portion thereof $\ldots \ldots \ldots \ldots \ldots$

VANDERSLIP, F. A.:

opinion of, on needs in banking

VAN HISE, CHARLES R.:

views of, on need for regulation of competition $\ldots \ldots \ldots \ldots \ldots$

VENUE: See Circuit Court of Appeals; District Court.

\section{VERBAL ERROR:}

comma retained by mistake in Section 5, Federal Trade Com-

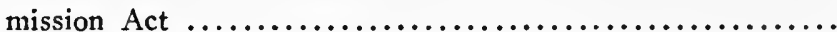

\section{VERIFIED BILL:}

or affidavit, required to show necessity for relief upon applica-

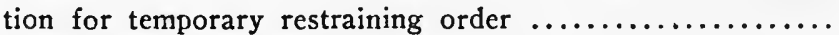

\section{WILSON TARIFF LAW:}

for text of Sections 73 to 77 , see $\ldots \ldots \ldots \ldots \ldots \ldots \ldots \ldots \ldots 28,283$ relates solely to import trade $\ldots \ldots \ldots \ldots \ldots \ldots \ldots \ldots \ldots \ldots \ldots . \ldots \ldots \ldots$ provides Anti-trust regulation of foreign trade ...........149, 150 Sherman Law Anti-trust provisions reappear in ........... 150 considered as a criminal statute $\ldots \ldots \ldots \ldots \ldots \ldots \ldots \ldots \ldots \ldots 149,150$ Section 73 thereof, not adjudicated .................. 150

WITNESSES: See Contumacy; Immunity; Rules of Practice.

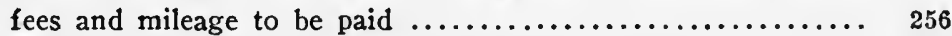

self-incrimination not to excuse failure to testify ......... 257

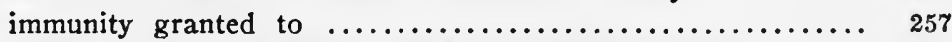

failure to testify punishable by fine and imprisonment ...... 257

may be compelled to testify ....................... 271

may be subpœnaed into other districts $\ldots \ldots \ldots \ldots \ldots \ldots \ldots \ldots 129,271$ procedure for compelling attendance of, discussed ........129, 130 falsification of, or failure to produce corporate records, pun-

ishable by fine and imprisonment ................... 257, 258

writs of mandamus authorized to compel obedience to Trade

Commission's orders and to provisions of Act ............

exemption from prosecution in Federal courts does not afford

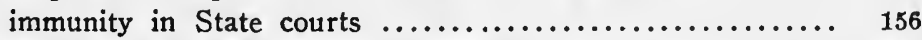

must claim privilege to obtain immunity .............. 157 proceeding must be within scope of jurisdictional powers of court or body conducting enquiry $\ldots \ldots \ldots \ldots \ldots \ldots \ldots \ldots \ldots, 158$ 
[REFERFNCES ARE, TO PAGES.]

PAGE

resistance by witness not required to secure immunity $\ldots \ldots \ldots 161,162$ decision cited holding that, when charged with contumacy, witness may secure release on habeas corpus .............. 164

WRIT OF ERROR: See APPEAL.

granting thereof stays execution and entitles defendant to be admitted to bail upon appeal from conviction in contempt proceeding instituted under Section 22 of Clayton Law ......

WRITS OF MANDAMUS: See DisTrict CourTs.

upon application of attorney general made upon request of Trade Commission, may be issued to compel obedience to provisions of Act or Commission's order ................. 




LAW LIBRARY

UNIVERSITY OF CALIFORNIA

\section{LOS ANGELES}




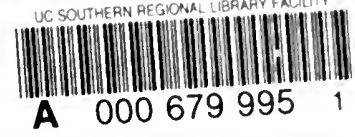

UNIVERSITY OF CALIFORNIA LIBRARY

Los Angeles

This book is DUE on the last date stamped below.

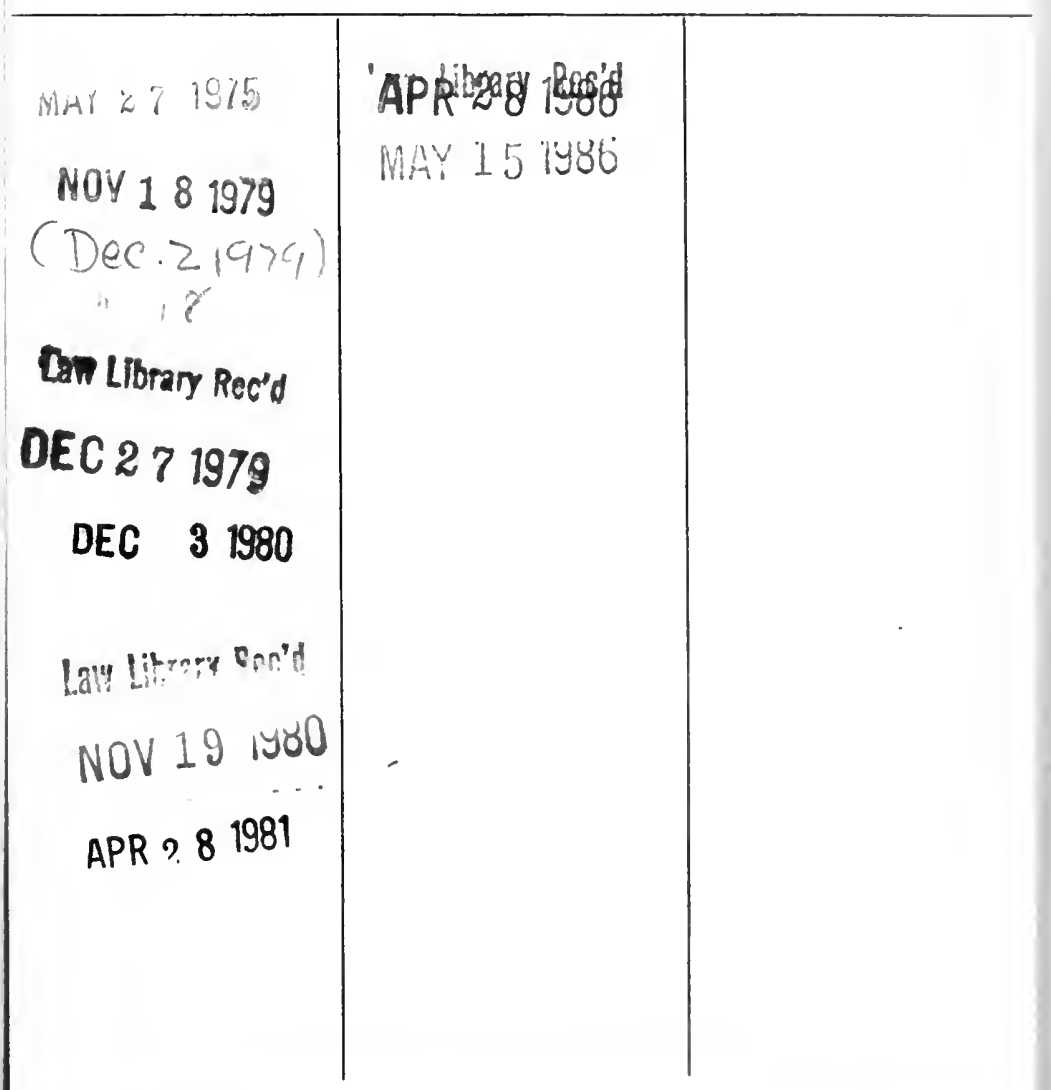

Form L9-Series 4939 
s)

if

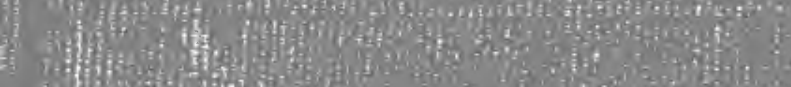

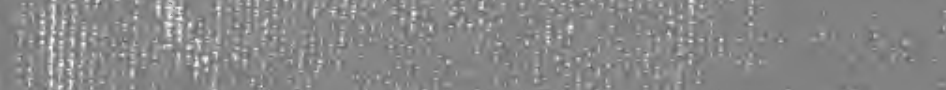

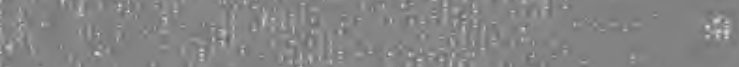

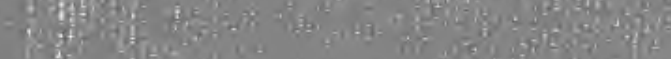
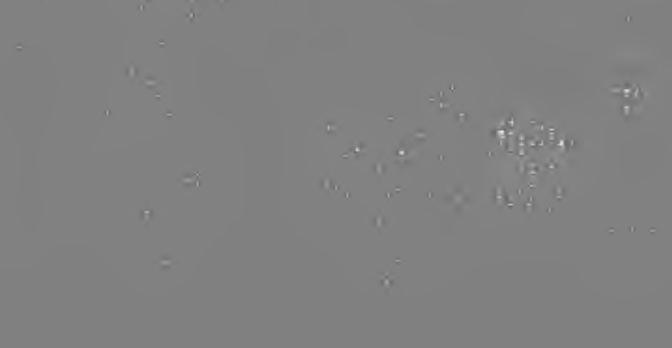

,
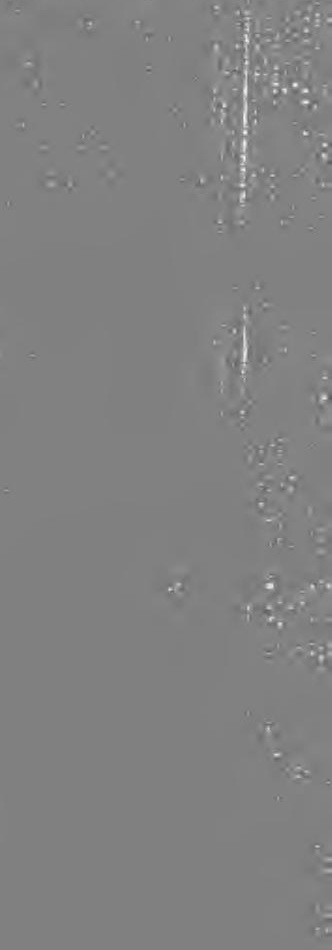